Piotr de Bończa Bukowski / Magda Heydel (eds.)

\title{
Polish Translation Studies in Action
}

Concepts - Methodologies - Applications A Reader

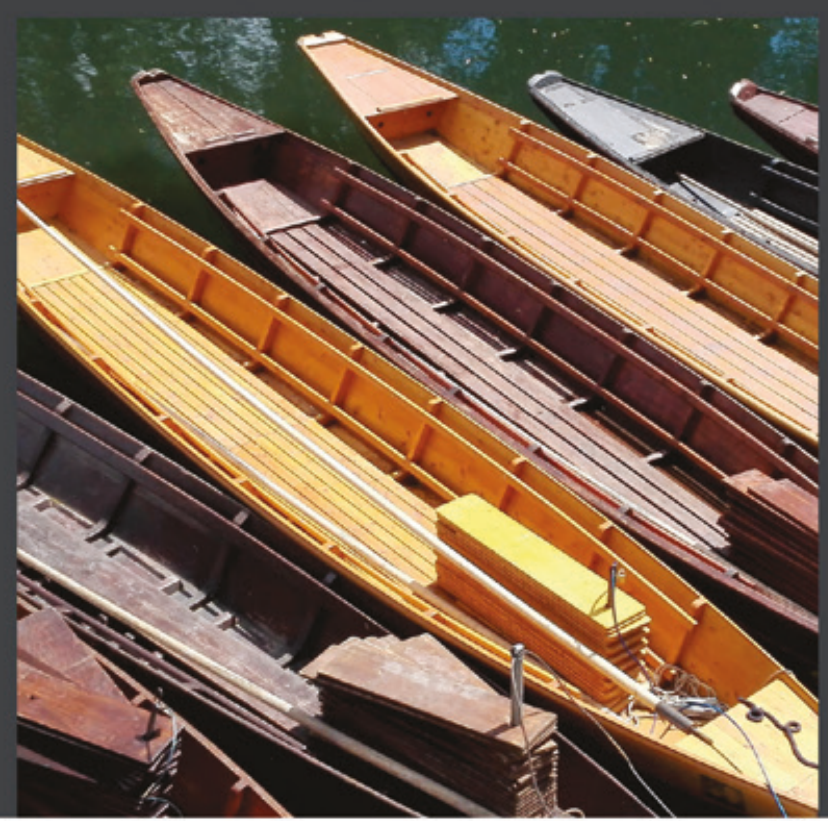


CROSS-ROADS. POLISH STUDIES IN CULTURE, LITERARY THEORY, AND HISTORY 16

\section{Piotr de Bończa Bukowski / Magda Heydel (eds.) \\ Polish Translation Studies in Action}

Translation Studies has been in action in the Polish humanities since 1930s. The book gathers the most important contributions from Polish translation scholars working in the context of Literary and Cultural Studies as well as Linguistics. The essays offer insights into the conceptualisation of translation, stylistics and poetics, history and anthropology of translation. Most of them are made available in English for the first time. The editors' introduction provides a panoramic backdrop for concepts, methodologies and applications. As part of the tendency to enlarge Translation Studies and include new contexts into its mainstream, this reader gives an overview of a rich area of translation scholarship from the centre of Europe, a crossroads of influences and traditions.

\section{The Editors}

Piotr de Bonícza Bukowski is associate professor and the head of Translation Working Group at the Institute of Germanic Studies, Jagiellonian University in Kraków. His main research interests concern theory and history of translation, hermeneutics, and literary modernism. $\mathrm{He}$ is an Alexander von Humboldt Foundation fellowship holder.

Magda Heydel is associate professor and the head of the Centre for Translation Studies at the Faculty of Polish, Jagiellonian University in Kraków. Editor-in-chief of Przekladaniec. A Journal of Translation Studies. Her work is mainly in literary translation and translation history. She is a translator of English language literature into Polish. 
Polish Translation Studies in Action 


\section{CrOSSaROa. \\ Studies in Culture, Literary Theory, and History}

Edited by Ryszard Nycz

Volume 16

\section{PETER LANG}


Piotr de Bończa Bukowski / Magda Heydel (eds.)

\section{Polish Translation Studies in Action}

Concepts - Methodologies - Applications A Reader 


\title{
Bibliographic Information published by the Deutsche Nationalbibliothek
}

The Deutsche Nationalbibliothek lists this publication in the Deutsche Nationalbibliografie; detailed bibliographic data is available in the internet at http://dnb.d-nb.de.

\section{Library of Congress Cataloging-in-Publication Data}

A CIP catalog record for this book has been applied for at the Library of Congress.

The Publication is funded by Ministry of Science and Higher Education of the Republic of Poland as a part of the National Programme for the Development of the Humanities. This publication reflects the views only of the authors, and the Ministry cannot be held responsible for any use which may be made of the information contained therein.

\author{
H. national programme \\ FOR THE DEVELOPMENT OF HUMANITIES \\ Cover image: @ Magda Heydel \\ Printed by CPI books $\mathrm{GmbH}$, Leck \\ ISSN 2191-6179•ISBN 978-3-631-67287-7 (Print) \\ E-ISBN 978-3-653-06905-1 (E-Book)•E-ISBN 978-3-631-70866-8 (EPUB) \\ E-ISBN 978-3-631-70867-5 (MOBI)•DOI 10.3726/b15794
}

\section{PETER LANG

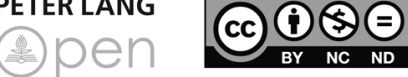

Open Access: This work is licensed under a Creative Commons Attribution Non Commercial No Derivatives 4.0 unported license. To view a copy of this license, visit https://creativecommons.org/licenses/by-nc-nd/4.0/

Copyright for the selection, introduction and editorial matter by

Piotr de Bończa Bukowski \& Magdalena Heydel

(C) Piotr de Bończa Bukowski / Magda Heydel (eds.), 2019

Peter Lang - Berlin · Bern · Bruxelles · New York .

Oxford - Warszawa $\cdot$ Wien

This publication has been peer reviewed.

www.peterlang.com 


\section{From the Editors}

The present anthology is based on the volume Polska myśl przekładoznawcza. Antologia [Polish concepts in translation studies], which we published in Polish in 2013 with the Jagiellonian University Press in Kraków. We added three essays (by Małgorzata Tryuk, Tamara Brzostowska-Tereszkiewicz and Tomasz Bilczewski) to the original table of contents. Anna Wierzbicka kindly sent us a recent paper on translatability to replace an older one we chose for the Polish publication. Elżbieta Tabakowska’s essay has also been replaced with a different piece on translation and cognitive linguistics. We also decided against including the original bibliography of Polish translation theory: instead, the bibliography at the end of this volume only lists the sources referred to in the essays. Most of them have not been translated into English, but wherever translations are available, we include them in the footnotes and the bibliography.

The footnotes in all articles have been edited for the purposes of the present publication. This is especially the case of older texts; they tended to feature extended explanatory or interpretive notes, which we saw as irrelevant or referring to context unavailable to the English-speaking reader. Some notes were also added by the editors and translators. They are marked as [editors' note] and [translator's note] respectively. In a few cases, cuts were made in the main body of essays. These are marked with [...].

For the convenience of our readers, in the main body of the text the titles of all referenced sources are given in English translation only, while the original titles are kept in the footnotes and bibliography. Polish translation studies in the 1960s and the 1970s included many references to Russian (Soviet) research. In our anthology, all quotations and titles in Russian have been transliterated. Our thanks go to Krzysztof Ozga who kindly did this for us.

We would like to thank all contributors for agreeing to become part of this anthology and for helping us with the translation and editing. We are grateful also to the copyright holders of the work of deceased scholars for kindly granting permissions to use the material. Special thanks go to Anna Legeżyńska, who generously offered to edit the chapter from her book; to Elżbieta Tabakowska, who self-translated her essay and contributed greatly to getting some of the other translations correct from the point of view of linguistic accuracy; to Jolanta Wawrzycka, who revised her translation of Roman Ingarden's essay specially for this publication; and to Małgorzata Tryuk, who checked some historical facts for us till the very last moment before publication. Kasia Szymańska had a hand 
in editing the translations of the essays by Edward Balcerzan and Stanisław Barańczak.

Our very special thanks go to Zofia Ziemann, who revised all translations in the volume. Without her knowledge, professionalism, efficiency and good humor the book would have come out lame and wobbly, and working on it would have been much less rewarding.

Piotr de Bończa Bukowski and Magda Heydel 


\section{Contents}

Copyright Note

Piotr de Bończa Bukowski and Magda Heydel

Polish Concepts in Translation Studies. Scholars - Theories - Paradigms ...

Bronisław Malinowski

The Translation of Untranslatable Words

Zenon Klemensiewicz

Translation as a Linguistic Problem

Olgierd Wojtasiewicz

Introduction to a Theory of Translation

Roman Ingarden

On Translations

Edward Balcerzan

The Poetics of Artistic Translation

Stefania Skwarczyńska

Translation and Its Place in the National Literature and Culture

Anna Wierzbicka

Translatability and the Scripting of Other Peoples' Souls: An

'International Semantic Alphabet' as a Tool of Cultural Translation

Jerzy Ziomek

Translation - Understanding - Interpretation

Jerzy Święch

Translations and Self-Commentaries

Stanisław Barańczak

The Poetic Model of the World and Problems of Artistic Translation

(Based on the Polish translations of G. M. Hopkins) 
Anna Legeżyńska

The Translator as the Second Author

Tadeusz Sławek

Calibanism: Philosophical Dilemmas of Translation 251

Seweryna Wysłouch

Film Adaptation as Intersemiotic Translation 263

Elżbieta Tabakowska

The Theory and Praxis of Cognitive Linguistics: An Oleograph and a Symphony for Two Pianos

Roman Lewicki

Foreignness in Translation and Foreignness in Culture 297

Tomasz Bilczewski

Trauma, Translation, and Transmission in a Postmemory

Perspective: From Literature to Epigenetics

Małgorzata Tryuk

You Say Nothing, I Will Interpret. Interpreting in the Auschwitz-

Birkenau Concentration Camp

Tamara Brzostowska-Tereszkiewicz

The Conceptual Art of Translation 343

List of Figures 369

Bibliography 371

Index 399 


\section{Copyright Note}

The texts and artwork reproductions comprising this volume have been reprinted from the following sources:

Stanisław Barańczak, "Poetycki model świata a problemy przekładu artystycznego." In: Wielojęzyczność literatury $i$ problemy przekładu artystycznego, ed. E. Balcerzan, Wrocław: Ossolineum 1984, pp. 207-226. Used by permission of Anna Barańczak and the publisher.

Edward Balcerzan, "Poetyka przekładu artystycznego". In his: Literatura $z$ literatury (Strategie tłumaczy), Katowice: Śląsk 1998, pp. 17-31. Used by permission of the author and publisher.

Tomasz Bilczewski, “Trauma, translacja, transmisja w perspektywie postpamięci. Od literatury do epigenetyki." In: Od pamięci biodziedzicznej do postpamięci, ed. T. Szostek, R. Nycz, R. Sendyka, Warszawa: IBL 2013, pp. 40-62. Used by permission of the author and publisher.

Tamara Brzostowska-Tereszkiewicz, "The Conceptual Art of Translation." In: Modernist Translation. An Eastern European Perspective. Models, Semantics, Functions, Frankfurt/M.-Berlin-Bern-Bruxelles-New York-Oxford-Wien: Peter Lang: 2016. Used by permission of the author and publisher.

Roman Ingarden, "O tłumaczeniach.” In his: $Z$ teorii języka i filozoficznych podstaw logiki, Warszawa: PWN 1972, pp. 132-157. Used by permission of Krzysztof Ingarden.

Zenon Klemensiewicz, "Przekład jako zagadnienie językoznawstwa." In: $O$ sztuce tlumaczenia, ed. M. Rusinek, Wrocław: Ossolineum 1955, pp. 87-97. Used by permission of Anna Turley and Jerzy Bajer.

Anna Legeżyńska, “Tłumacz jako 'drugi autor"” From her: Tłumacz i jego kompetencje autorskie. Na materiale powojennych tłumaczeń $z$ A. Puszkina, W. Majakowskiego, I. Kryłowa i A. Błoka, Warszawa: PWN 1999, pp. 11-39. Used by permission of the author and publisher.

Roman Lewicki, “Obcość w przekładzie a obcość w kulturze." In his: PrzekładJęzyk-Kultura, Lublin: Wydawnictwo UMCS 2001, pp. 43-51. Used by permission of the author and publisher. 
Zbigniew Makarewicz, tekst [1971]. In: Poezja konkretna. Wybór tekstów polskich oraz dokumentacja $z$ lat 1967-1977, ed. Stanisław Dróżdż, Wrocław: Socjalistyczny Związek Studentów Polskich 1978, p. 41.

Bronisław Malinowski, "Translation of Untranslatable Words". In his: Coral Gardens and Their Magic. A Study of the Methods of Tilling the Soil and Agricultural Rites on the Trobriand Islands, vol. 2: The Language of Magic and Gardening, London: George Allen\&Unwin 1935, pp. 11-22.

Ewa Partum, Active Poetry. Installation. Warsaw, 1971; poem by ewa. fragment W POSZUKIWANIU STRACONEGO CZASU Marcela Prousta, 1971; Text installation with music stands, National Museum, Warsaw 2001. In: Ewa Partum 1965-2001, ed. Angelika Stepken, Karlsruhe: Badischer Kunstverein, 2001, pp. 34, 37, 95; her photograph of 'Installation Metapoetry "À la recherche du temps perdu” according to Marcel Proust.' 18 Biennale of Sydney, Australia 2012. Used by permission of the author.

Stefania Skwarczyńska, "Przekład i jego miejsce w literaturze i kulturze narodowej.” In: O współczesnej kulturze literackiej, vol.1, ed. S. Żółkiewski, M. Hopfinger, Wrocław: Ossolineum 1973, pp. 287-330. Used by permission of Anna Olszewska.

Tadeusz Sławek, "Kalibanizm. Filozoficzne dylematy tłumaczenia." In: Przekład artystyczny, vol. 1. Problemy teorii i krytyki, ed. P. Fast, Katowice: Śląsk 1991, pp. 7-17. Used by permission of the author and publisher.

Jerzy Święch, "Przekłady i autokomentarze." In: Wielojęzyczność literatury i problemy przekładu literackiego, ed. E. Balcerzan. Wrocław: Ossolineum 1984, pp. 45-66. Used by permission of the author and publisher.

Elżbieta Tabakowska, "The Theory and Praxis of Cognitive Linguistics: an Oleograph and a Symphony for Two Pianos." In: Między oryginatem a przekładem I, ed. J. Konieczna-Twardzikowa, U. Kropiwiec, Kraków: Universitas 1995, pp. 31-42. Used by permission of the author and publisher.

Małgorzata Tryuk, “'You say nothing. I will interpret.' Interpretation in Auschwitz-Birkenau Concentration Camp." In: Translation and Opposition, ed. D. Asimakoulas and M. Rogers. Bristol-Buffalo-Toronto: Multilingual Matters 2011, pp. 223-243. Used by permission of the author and publisher.

Anna Wierzbicka, "Translatability and the scripting of other peoples' souls," The Australian Journal of Anthropology (2013) 24, pp. 1-21. Used by permission of the author and publisher. 
Olgierd Wojtasiewicz, "Wstęp do teorii tłumaczenia." In his: Wstęp do teorii tłumaczenia, wyd. 3, Warszawa: TEPIS 1996, pp. 10-22. Used by permission of Translegis Publishing House.

Seweryna Wysłouch, "Adaptacja filmowa jako przekład intersemiotyczny." In her: Literatura a sztuki wizualne, Warszawa: PWN 1994, pp. 157-176 and 202-206. Used by permission of the author.

Jerzy Ziomek, "Przekład - rozumienie - interpretacja." In his: Powinowactwa literatury. Studia i szkice. Warszawa: PWN 1980, pp. 159-200. Used by permission of Anna Ziomek-Miarkowska. 



\section{Piotr de Bończa Bukowski and Magda Heydel Polish Concepts in Translation Studies. Scholars - Theories - Paradigms}

\section{Early Translation Studies in Poland}

In 1918, as Poland regained independence after the period of partitions which lasted for more than a century, one of the country's leading writers, Stefan Żeromski, put forward a project for the Polish Academy of Literature. He argued that after the 123 years during which Polish identity was sustained to a large extent thanks to literature and art, the society and the state must recognize the need for an institutional patronage over authors and their work. Żeromski looked with irony at the claims, put forth by some writers, that the nation, with its material needs fulfilled, is prone to forget about the two torchlights of its development - literature and art - and for that reason is on the verge of turning into a herd of "clean, healthy, well-fed and happy livestock." ${ }^{1} \mathrm{He}$ saw compelling reasons for establishing a national institution for the development and promotion of literature. One of them was the need to broaden the scope of literary culture over "wide areas of the intelligentsia and the people."2 What Żeromski meant is simply that in order for the society to develop, citizens have to read and - he made this very clear - not just the good old books that saw Poland through the difficult political period, but also modern literature: the current international literary production. If we want to educate new generations of readers, he argued, it is necessary to produce very good, reliable and high-quality translations form many languages. He presented an overview of literature translated into Polish from major European languages, concluding that there was an urgent need for competent renditions of both the classics and the new writing. ${ }^{3}$

It is both surprising and rewarding to find such a strong voice for the promotion of translation in a funding document for a cultural institution in 1918. The fact that so early on in the history of modern Poland an eminent writer links the patriotic responsibility for literature with the broad-mindedness derived from the knowledge of international writing is a convenient starting point for

1 S. Żeromski, Projekt Akademii Literatury Polskiej, 2nd ed. (Warsaw-Kraków 1925), pp. 1-2.

2 Żeromski, p. 5.

3 Żeromski, p. 16n. 
the presentation of the history of translation studies in independent Poland. The Polish Academy of Literature and the Polish PEN (established in 1925, also thanks to Stefan Żeromski) were very active in animating the production of literary translations, as well as translator training and theoretical reflection on translation as a cultural, social and linguistic phenomenon. A number of valuable studies, both descriptive analyses of the work of eminent translators and theoretical dissertations, were published in the interwar period.

One of them was an essay by Wacław Borowy, ${ }^{4}$ a literary critic and professor of English, which was devoted to the work of Tadeusz Boy-Żeleński, the most important Polish translator of French literature (Balzac, Stendhal and Proust, as well as Moliere, Montaigne, Diderot, Rabelais, Jarry, and many others). Inspired by the aesthetics of Benedetto Croce and his claim that the same content cannot be expressed in two different forms, and hence adequate translation is impossible, Borowy formulates his own definition of translation. For him, a translation is a creative work, a new expression, to use Croce's term, remaining "close to its model." Borowy's focal point is style as a technique of "re-expression" of the original in the target language. This area of research will become central for Polish TS in the 1960s.

Also the first attempts at defining the academic identity of the study of translation are linked to literary translation and comparative literatures. In the introduction to her 1927 book on another eminent translator from French, Zenon Miriam-Przesmycki, Maria Szurek-Wisti claims that translation theory and criticism define their own methodology as "sections of literature studies". She refers to Italian and German thinkers to stress that translation research is an interdisciplinary field linked to philology, comparative literature, history and philosophy of culture and language, as well as psychology and aesthetics. ${ }^{6}$

Still, in the 1930s the research area was by no means well defined, also in the context of wider disputes within the realm of literary studies in Poland. On the one hand, Roman Ingarden was working on his phenomenological theory of literature, with its ahistorical perspective and non-linguistic poetics; on the other hand, there was Structuralism, inspired by Russian Formalists (the OPOJAZ) and the Prague Circle, postulating a close link between literary and linguistic studies. Franciszek Siedlecki, a vocal proponent of Structural thought, focused on the mediating function of language and factors of social communication. ${ }^{7}$ His

4 W. Borowy, Boy jako ttumacz (Warsaw 1922).

5 Borowy, p. 12.

6 M. Szurek-Wisti, Miriam-ttumacz (Krakow 1937), p. 5.

7 See M. R. Mayenowa, "Wersologia Franciszka Siedleckiego i jej założenia teoretyczne." In: F. Siedlecki, Pisma, ed. S. Żółkiewski and M.R. Mayenowa (Warsaw 1989), p. 49. 
work on translation ${ }^{8}$ makes this latter aspect salient: Siedlecki studies the historical, linguistic, cultural and ideological factors influencing the translator's work. This polarization will later become more visible, and the divide between phenomenological and hermeneutic research on the one hand and that of Structural and linguistic approach on the other will grow, also strengthened on the ideological plane: the Structural paradigm was regarded left-wing and progressive, naturally inspired by work done in the Soviet Union, while Ingarden, with his inspirations in the German philosophical tradition and disregard for Marxism, situated himself at the opposite pole.

Soviet (and Russian) inspirations for research in translation came to Poland much earlier than the political doctrine, implemented only after World War 2. Back in the 1930s, Korney Chukovsky's Art of Translation (1930) was read in Poland, e.g. by Julian Tuwim, a poet and translator (of Pushkin, among others), one of the towering figures in 20th-century Polish literature, author of brilliant self-analytical essays on poetic translation. ${ }^{9}$ Chukovsky claimed that the translator must aim to recreate the dynamics of the poetic style and avoid the poverty and unnaturalness of translationese. These thoughts found a vibrant resonance in the Polish literary milieu, since many of its central figures (e.g. Maria Dąbrowska, Jarosław Iwaszkiewicz, Tadeusz Peiper, Bolesław Leśmian, Leoplod Staff) translated literature (mostly from French, Russian, German and English), commented on their own translation practice, and wrote translation criticism; they were also influential in later Polish research on the poetics of literary translation.

Philosophy of language and theory of meaning provided another context for the development of translation scholarship in the 1930s. Kazimierz Ajdukiewicz worked on logical semantics and wrote on translation in the context of equivalence of utterances in different codes. ${ }^{10}$ This direction will be taken in decades to come by Olgierd Wojtasiewicz or Anna Wierzbicka, working in the paradigm of structural linguistics. On the other hand, the work of the anthropologist Bronisław Malinowski, situated within the area of pragmatic semantics, opened a path for the contextual theory of meaning, later developed by his disciple, J.R. Firth. It led to a holistic, functional theory of language, stressing its social role and close connection to culture ${ }^{11}$. This tendency in looking at language and

8 See F. Siedlecki, Pisma, pp. 645-690.

9 See J. Tuwim, “Traduttore - traditore." In: Pisarze polscy o sztuce przekładu 1440-2005. Antologia, ed. E. Balcerzan and E. Rajewska (Poznań 2007), p. 155.

10 See K. Ajdukiewicz, “Sprache und Sinn," Erkenntnis, IV, 1934, pp. 100-138.

11 See J. Lyons, Semantics, vol. 2 (Cambridge 1978), chapter 14.4. 
translation will become central to the cultural turn in Translation Studies in late 20th century.

The problem of translation is placed at the very center of Malinowski's reflection on language. His method of "participatory observation," whereby the anthropologist is for a long time deeply immersed in the community he or she studies, has an obvious connection to the experience of language. It is precisely language that gives the researcher access to the meanings of ritual, magic and everyday life. "The questions of language - Malinowski writes - are indeed the most important and central subject of all humanistic studies." ${ }^{12}$ In his study of the problem of meaning in primitive languages, Malinowski juxtaposes his own experience gained during the fieldwork in the Trobriand Islands with the theory of linguistic meaning developed by C.K. Ogden and I.A. Richards. Using numerous examples, he presents the fundamentals of the concept of word as action, immediately linked to the situational and cultural context. ${ }^{13}$ He rejects the concept of meaning as a value enclosed in an utterance, claiming that a word's meaning is an outcome of an interplay of non-linguistic factors. Language is not just "an instrument of thought and of the communication of thought." ${ }^{4}$ To regard it as such is "to take a one-sided view of one of its most derivate and specialized functions." ${ }^{15}$ The proper function of language is action. Malinowski argues that "language in its primitive function and original form has an essentially pragmatic character; that it is a mode of behavior, an indispensable element of concrete human action." ${ }^{16} \mathrm{He}$ also rejects the idea that language is a simple reflection of the extra-linguistic reality, as the relationship between them is always mediated by culture. In his later work, Malinowki makes the discovery of the close connection between language and culture his starting point for further argument.

In the passage from his Coral Gardens and Their Magic included in our anthology, ${ }^{17}$ linguistic meaning is addressed as a question of translation practice.

12 B. Malinowski, “The Problem of Meaning in Primitive Languages”. In: C.K. Ogden, I.A. Richards, The Meaning of Meaning (New York 1923), p. 298.

13 See M. Rakoczy, Słowo-działanie-kontekst. O etnograficznej koncepcji języka Bronisława Malinowskiego (Warsaw 2012).

14 Malinowski, p. 297.

15 Malinowski, p. 316.

16 Malinowski, p. 316.

17 Coral Gardens and Their Magic. A Study of the Methods of Tilling the Soil and Agricultural Rites on the Trobriand Islands, vol. 2: The Language of Magic and Gardening (London 1935), pp. 11-22. 
According to the author, the anthropological material he collected is fundamentally untranslatable, and thus the cultural reality he strives to study turns out to be unapproachable. The difficulty can be overcome by explaining the conditions of the translation process. If meaning is action in context, one cannot define translation in terms of a juxtaposition of linguistic systems. Procedures of reconstructing in your own language the meanings taken from the language of the other using philological analysis are false because they ignore the cultural and situational dimensions. The operation of translating is not an interlingual one, controllable if one establishes a set of semantic-linguistic units and rules of their mutual correspondence. It is rather a complex process of understanding the Other. Malinowski does not define any kind of formal procedure for translation - in the light of his principles this is neither possible nor useful. His concepts in translation are far ahead of their time, and can be regarded as harbingers of the Cultural Turn in Translation Studies, where translation is construed as intercultural hermeneutics, a practice where the unit of translation is neither word, nor utterance, nor text, but the entire culture.

The 1930s were an intensive time in the development of literary and translation thinking in Poland. The Second World War put a halt to much of the academic and literary activities in this field, not least because publishing in Polish was banned by the Nazi authorities. Nevertheless, the achievements of the 1930s were not wasted; research continued, and right after the war, already in 1948, two important works in the field of translation studies were published: Seweryn Pollak's "Some Problems of the Theory of Poetic Translation"18 and Stefan Szuman's On the Art and Essence of Lyrical Poetry. ${ }^{19}$

Pollak's is a theoretical study based on the author's own translation experience in 1946-47 and on his reading of Soviet theorists, mainly Chukovsky, Fedorov and Smirnoff. It is from Smirnoff that Pollak inherited both the historical model of the development of translatorial thought and the concept of adequate translation, ${ }^{20}$ which is central to his own ideas. Chukovsky made him aware of the "social attitude of the translator" and his ideological entanglements: he actually mentions a possible sociology of translation, outlined before by Franciszek Siedlecki. ${ }^{21}$ Pollak juxtaposes the Soviet translation school with the hermeneutic

18 S. Pollak, “Z zagadnień teorii przekładu poetyckiego”, Prace Polonistyczne 1948, vol. 6, pp. 191-210.

19 S. Szuman, O kunszcie i istocie poezji lirycznej (Łódź 1948).

20 Pollak, p. 194.

21 Pollak, p. 203. See F. Siedlecki, "Przekłady z poezji rosyjskiej” [1936]. In: F. Siedlecki, Pisma, pp. 663-675. 
positions rooted in $19^{\text {th }}$-century German philosophy, concentrated not on the linguistic structures as such but the "spirit of the original." Deeming the latter approach "reactionary," idealistic and even dangerous, Pollak decidedly chooses the "progressive" path. Translation, he writes, is a recreation of the original in a different linguistic material. Since a work of literature is a set of coordinated and interlinked elements, their exact recreation is usually impossible. The translator has to decide on the hierarchy of those elements and choose the most important ones, leaving what is less central behind and thus discovering the invariant. Pollak's essay is an early example of an important current in Polish Translation Studies: inspiration with Soviet concepts, discussion around invariants, problems of style, ideology in translation, and the criteria of good translation. Pollak uses the word "equivalent" - probably for the first time in the Polish tradition.

Szuman's analyses, on the other hand, seek inspiration in works from the 1930s: Roman Ingarden's theory of literary aesthetics presented in The Literary Work of Art (1931) and developed further in The Cognition of the Literary Work of Art (1937). ${ }^{22}$ According to Ingarden, a work of art is a multi-strata creation, characterized by formal unity which stems from an inner relation linking the layers of word sounds, units of sense, schematized aspects and represented objects. The structure of literary work is ordered and it differs from that of a scientific work because it includes "quasi-statements" (which give the represented objects only some aspects of reality). The literary work is schematic (it includes places of indeterminacy) and intentional, demanding concretization in the act of reception. Finally, it also includes artistic and aesthetic qualities, whose plurality creates the effect of polyphony. Szuman takes up several important elements of Ingarden's theory; by comparing poetic translations with the originals, he studies the ways of artistic reconstruction of their aesthetic effects.

In the post-war period, Ingarden himself also returned in his work to the problems of translation. His paper "On Translations" resulted from his theoretical work, but also from the experience of translating and editing classic works of philosophy. ${ }^{23}$ In the passages from this analysis included in the present anthology, Ingarden concentrates on the specificity of translating a literary work as opposed to a scientific text. Further in his essay, he discussed the problems

22 R. Ingarden, Das literarische Kunstwerk (Halle 1931). English edition: The Literary Work of Art. An Invstigation on the Borderlines of Ontology, Logic, and Theory of Literature, ed. and trans. G. G. Grabowicz (Evanston, Illinois 1973).

23 R. Ingarden, “O tłumaczeniach.” In: O sztuce tłumaczenia, ed. M. Rusinek (Wrocław 1955), pp. 127-190; later published also in: R. Ingarden, $Z$ teorii języka i podstaw filozoficznych logiki, Dzieła filozoficzne (Warsaw 1972), pp. 120-188. 
of translating philosophical discourse. Starting with his idea of the multi-strata and multiphase structure of literary work, he shows how translation consists in a process of replacement on the level of sounds, but also introduces changes into all the remaining layers. Depending on the scope and type of these changes, the work of literary art either retains or loses its individual identity. The difference between a faithful translation of a literary work and a faithful translation of a scientific text stems from the fact that in the latter case the translator focuses on using new sound material to represent in a clear manner the text's conceptual content. The literary translator, on the other hand, strives not to disturb the polyphonic harmony of the aesthetic qualities in the strata of the literary work. Ingarden's essay became an important voice in the exchange within the field of translation theory, but also an invitation for Polish philosophers to join in the debate, accepted i.a. by Jerzy Kmita and Halina Rosner.

\section{The Foundations: PEN Club Translation Seminar; Works of Zenon Klemensiewicz and Olgierd Wojtasiewicz}

The PEN Club Translation Seminar, a continuation of the pre-war efforts to recognize the importance of translators in literature, was inaugurated in 1950 with a lecture by the highly respected writer Jan Parandowski, and resulted in the publication of the 1955 volume On the Art of Translating. ${ }^{24}$ A decisive point in the development of translation thought in Poland, the book brought together contributions from writers, academics and critics. The most valuable ones were Ingarden's text discussed above and "Translation as a Linguistic Problem" by the linguist Zenon Klemensiewicz. Presented in 1953 and first published in an academic journal in $1954,{ }^{25}$ the essay is a pioneering work linking translation, so far conceptualized basically within the area of literary studies and criticism, with the domain of linguistics. Written and published independently from Jakobson, Nida or Vinay and Darbelnet's work, Klemensiewicz's essay is an attempt at creating a set of precise tools for describing the phenomenon of interlingual correspondence.

Klemensiewicz sees translation as a relation between two linguistic and stylistic systems which may be very far apart; the distance complicates the process and gives rise to various difficulties. Another set of problems stems from the fact that the language of the original is internally variegated. The author gives much attention to literary ("artistic") language as the most demanding kind. Since the

24 O sztuce tłumaczenia, ed. M. Rusinek (Wrocław 1955).

25 “Przekład jako zagadnienie językoznawstwa”, Język Polski 1954, vol. 34, pp. 65-76. 
ideal of "fidelity" is grounded in a myth and cannot be sustained, Klemensiewicz (probably inspired by Alexandr Smirnoff ${ }^{26}$ ) introduces the concept of "adequate" translation. Adequacy, according to him, is a functional equivalence (he coins a Polish noun which stands for the same concept) which requires the substitution of the linguistic elements of the original with "those elements and structures of the target language which are, as far as possible, substitutes and equivalents with the same functional capacity, suitability, and efficacy, and in this, precisely, resides their adequacy, commensurability, equality of value." ${ }^{27}$

Klemensiewicz stresses the fact that translation is a creative act and consists in the translator's own and original realization of someone else's thought. This requires affinity, a kind of kinship between the author and the translator. Seen from today's perspective, Klemensiewicz's ideas strike as shrewd and modern: he tackles on linguistic functionalism but also on hermeneutics; he underscores the creative element in translation, soon to be developed by Jiří Levý.

Soon after, in 1957, the first strictly theoretical work on translation was published in Poland: Introduction to Translation Theory by Olgierd Wojtasiewicz, ${ }^{28}$ a sinologist and linguist from the University of Warsaw. His book, whose first chapter is included in the present anthology, was a result of many years of research aiming at greater precision in the theoretical description of the problem of translation. Wojtasiewicz, whose work is situated in the context of the Leipzig school, developing in Eastern Germany since late 1950s, puts considerable stress on the "operation of translation." The use of the term "equivalent" in Wojtasiewicz's argument implies that the goal of the operation of translation is to come up with a text evoking in the recipient the same kind of reaction (the same set of associations) as the source text did in the case of the original recipients. This ensures successful communication. Parts of Wojtasiewicz's book are devoted to the question of untranslatability. He differentiates between two types of untranslatability: structural, where the structures of the languages involved differ; and conceptual, where it is impossible to evoke the same reaction. The latter type, Wojtasiewicz writes, stems from lack of equivalents or proper names in the target language and has to do with cultural aspects of translation.

Wojtasiewicz claims that the final conclusions he drew from his analyses came as a surprise: contrary to his expectations, the difficulty in translation results to a lesser extent from differences in linguistic structures than from gaps between

26 See A. Smirnoff, “Metodika literaturnovo perevoda." In: Literaturnaya enciklopedia, Vol. 8 (Moscow 1934), pp. 526-531.

27 See p. 67 in the present volume.

28 O. Wojtasiewicz, Wstęp do teorii ttumaczenia (Wrocław 1957). 
cultural traditions. The author sees this conclusion as optimistic: while linguistic structures are unlikely to converge, cultures might. These optimistic claims may sound more than a little naïve today, in the era of intercultural studies; the same is true for Wojtasiewicz's ambitions to formulate a strict scientific model for the understanding of translation. Nevertheless, his work reflects a very important stage in the development of both linguistic and cultural paths in Polish translation studies. His precise argumentation and the disciplined and linguistically grounded functional thinking link his book to Eugene Nida's work, while the role he assigns to culture and the optimistic stance towards the problem of untranslatability bring to mind Roman Jakobson's position. Wojtasiewicz's book gave very solid foundations to Polish translation theory and, in spite of criticism, it remains an important point of reference.

\section{The Dominant and the Style: Structural Paradigm of the 1960}

The work of Klemensiewicz and Wojtasiewicz already included some traits of Structuralist thought, but it was since the 1960s that Structuralism became the main driving force in Polish Translation Studies. In 1958 Roman Jakobson visited Poland for the first time and taught a series of seminars which gave a strong Structuralist impulse to Polish humanities. In linguistics it came also from the Copenhagen School (Louis Hjelmslev) and the deductive methodology which inspired Andrzej Bogusławski and Anna Wierzbicka to research universal semantic primes. Another new research area, relevant also to translation studies, concerned semantic fields (Danuta Buttler ${ }^{29}$ ). Up until 1968, Structuralism developed in Poland dynamically and the concept of translation played an important role in the new discourse, which in its turn stimulated research in translation.

The most important center of translation studies in Poland in that period was Poznań, with scholars such as Jerzy Ziomek, who combined methods inspired by Structural linguistics with his competence as a historian and theoretician of literature. In 1965 he published a monograph on two Polish poets-translators: a $16^{\text {th }}$ century classic, Jan Kochanowski and a $20^{\text {th }}$ century one, Leopold Staff: Staff and Kochanowski. An Attempt at Using Information Theory in Translation Research. ${ }^{30}$ In this pioneering study of the history of literature by means of linguistic methods, Ziomek introduces the concepts of the semantic field and the

29 D. Buttler, „Koncepcje pola znaczeniowego," Przeglad Humanistyczny 1967, Vol. 2, pp. 41-59.

30 J. Ziomek, Staffi Kochanowski. Próba zastosowania teorii informacji w badaniach nad przekładem (Poznań 1965). 
dominant, which will be later taken over and redefined by his disciples, notably Edward Balcerzan and Stanisław Barańczak. Clearly fascinated by translational linguistics and perspectives of machine translation, Ziomek principally sought to describe the style of translation in terms of mathematical stylisticstatistics and information theory. At the same time, he tried to introduce elements of stylometry, hoping that statistical methods may become a reliable way of verifying claims voiced on the basis of literary analysis.

Edward Balcerzan, the main figure of Polish Translation Studies since the 1960s, in his early text "Translation Theory and Criticism in the Soviet Union" already postulated a need for developing a precise discourse for translation criticism to replace its rather impressionistic terms. ${ }^{31}$ Inspired by Soviet research, with its technological slant, he writes: "as long as we lack a language for the description of translations, we cannot hope for any matter-of-fact criticism (criticism with no language?), and as long as we lack matter-of-fact criticism, we cannot hope to move beyond futile declarations." ${ }^{32}$ The two currents in translation studies, Balcerzan says, the literary and the linguistic, differ in their "relation to theory" (this claim, it is worth adding, turned out to be so powerful that to this day Polish scholars struggle to overcome the divide introduced here). Thus, the goal of translation scholars is to make the two meet in devising a precise language for a theoretical description of artistic translation. Chukovsky and Etkind argue that the integration of the two areas is possible within the framework of Structuralistic research in style defined as a linguistic image of the creative personality of the writer. Balcerzan stresses that a work of literature is an orderly structure, hence a good translation consists in reconstructing the relations which link particular elements within the structure, as well as their configuration within the text as a whole. "The translator has to be fully aware of the dominance of some of the elements" ${ }^{33}$ - he claims. The researcher or critic, in turn, has to be able to give account of the choices made within the act of translating.

This has implications for theorizing translation. If the literary work is defined as an intentional and organized structure, it is the entirety of the text, rather than its morphological elements, that becomes the basic unit of translation; hence the criterion of assessment for the relation between the original and the translation is

31 E. Balcerzan, “Teoria i krytyka przekładu w Związku Radzieckim”, Pamiętnik Literacki 1966, vol. 57, pp. 223-243.

32 E. Balcerzan, “Tłumacz i tłumaczenia. Wstęp." In his: Oprócz głosu. Szkice historycznoliterackie (Warsaw 1971), p. 232.

33 Balcerzan, “Tłumacz i tłumaczenia...” p. 257. 
defined as the reconstruction of the source text's structural dominant. Balcerzan's book on the bilingual work of the Polish futurist poet Bruno Jasieński, Style and Poetics in the Bilingual Work of Bruno Jasieński: Some Problems of Translation Theory, focuses on these questions. ${ }^{34}$ The author postulates a parallel between the work of the translator and the critic. Both start from an interpretative procedure defined, after Roland Barthes, as getting at meanings through "a disassembly and re-assembly of elements" 35 whereby a new semantic value is produced. An analysis of the choices made by the translator against the background of all the possibilities offered by the source text and the target language, allows a precise description and interpretation of the differences between the source and target texts, and determining the value of the "deviations". The "deviations" lose their negative connotations in this context. Balcerzan claims this process may be well described by the category of semantic fields. He defines them as ordered sets of words clustered around a focal term on the principle of similarity or adjacency. Areas of non-symmetric semantic fields across languages (e.g. lack of heteronyms or correspondences, differences of categorization) creates the so-called intermediary language. It is this intermediary language that the translator refers to while working on the translation.

The "disassembly and re-assembly" procedures are the main topic of Balcerzan's essay “The Poetics of Artistic Translation” (1968, extended version 1998) which is included in our anthology $y^{36}$. Balcerzan's superior category, informing the general poetics of translation, is the translation series, i.e. a chain of actual and potential retranslations. As opposed to original texts, a translated work always forms a part of a series, and the series is always open. The seriality of translation, a problem further developed in Balcerzan's later work, is linguisticstylistic in nature, as it is the language and style of every element of the series that expresses the particular translator's interpretation. Starting with a set of instructive (if minimalistic) examples of translation series, the author formulates a set of critical categories, a toolbox for a precise description of translation. He distinguishes the following elements of the translation process: the translator's decisions and their subject, four types of transformations (reduction, inversion, substitution, amplification), and what he calls "higher structures". These include ways of translating in relation to the translator's aims (interlinear, literal,

34 E. Balcerzan, Styl i poetyka twórczości dwujęzycznej Brunona Jasieńskiego. Z zagadnień teorii przekładu (Wrocław 1968).

35 Balcerzan, Styl i poetyka..., p. 27.

36 E. Balcerzan, “Poetyka przekładu literackiego.” In his: Literatura z literatury (Strategie tłumaczy) (Katowice 1998), pp. 17-31. See pp. 105-119 in the present volume. 
simplifying, precise, free translations) and the types of translated work in relation to the recipient (authorial, polemical and covert translations).

Balcerzan's proposition is grounded in a firm belief in the correspondence between elements of the linguistic systems involved and an unshakable tertium comparationis outside the literary work, which guarantees the existence of an invariant. The essay on poetics of translation remains highly inspirational as a point of departure for reflection on the translation process, not the least because of the wide scope of Balcerzan's research. The author gives an overview of three areas of theorizing translation: anthropological, linguistic and literary. In that sense, he takes an early step towards an interdisciplinary paradigm of translation studies. Many years later, the author himself described his position in the late 1960s as that of an ardent believer in the "scientific tendencies" which dominated the humanities at that time. Nevertheless, the methodology he proposed opened a new epoch in the history of Polish translation studies and is still used both in descriptive and theoreticalprojects. His disciples, among whom Stanisław Barańczak took central place, developed Balcerzan's concepts and found a wide spectrum for their practical applications.

\section{The Art of Translating: Literary Translation Studies in the 1970s}

Polish literary translation studies in the 1970s developed dynamically under the sign of Structuralism. In 1972 a conference on the history and theory of artistic translation brought together researchers from the universities in Kraków and Poznań, as well as Nitra (Slovakia). Published in 1974, the conference proceedings included papers by i.a. Anton Popovič ("The Model of Literary Communication and Translation"), Jerzy Święch, Jacek Baluch, Julian Kornhauser and Stanisław Barańczak. Barańczak's contribution, "Artistic Translation as a 'Self-sufficient' and 'Integrated' Object of Interpretation," ${ }^{37}$ was based on an analysis of Polish translations of Gottfried Benn's poetry. The author uses Balcerzan's method of studying the style and linguistic shape of texts in order to elicit interpretation.

37 S. Barańczak, "Przekład artystyczny jako "samoistny" i "związany" obiekt interpretacji (Na marginesie niektórych polskich tłumaczeń Gottfrieda Benna)." In: $Z$ teorii i historii przekładu literackiego, ed. J. Baluch (Kraków 1974). English translation: "Artistic translation as a "self-sufficient" and an "integrated" object of interpretation. Notes on the margins to some Polish translations of Gottfried Benn", trans. S. Gauger. In: Literature from Literature. Essays on Literary Translation, eds. K. Szymańska, M. Heydel, (Genève-Lausanne 2019). 
"Self-sufficient" translations are those designed to function without reference to the original; the "integrated" ones are to be read in juxtaposition with the original. The difference is visible already in the way translations are published: "self-sufficient" renderings would prototypically be printed on their own, "integrated" ones as bilingual editions and parallel texts. The two types of translations reflect the translator's choices on the one hand and the mode of reading on the other. The former work as original texts; they aim at maximal transfer of content, which may result in some weakening of the aesthetic qualities of the poem. Barańczak notices how the translator's choices are guided by the fact that the poems are going to be interpreted independently from the originals and how he or she may at times feel released from the duty to reconstruct the formal qualities of the text. In the case of "intergrated" translations, the emphasis is put on the artistic qualities of the text, while the potential presence of the original text serves as a kind of back-up with respect to the literal sense of the original. On the other hand, in such a comparative reading process the translator's choices are controlled and assessed.

Today, Barańczak's conclusions may seem somewhat too mechanical and imprecise; however, the way he structures his argument, combining close reading with a sharp critical sense, indicates the direction of the further development of his work. His most important essays were published in the early 1990s on the margins of his own translation practice: he used his own renderings of the masterpieces of English language literature (including twenty-five Shakespeare's plays), as authorization for his critique of other translators' work.

In the 1970s, literary translation was studied from various perspectives, although most approaches focused on literary style. In 1971, Anna Drzewicka published a monograph Some Problems of the Technique of Poetry Translation, a study of poetic individuality in translation as seen through stylistic analysis. ${ }^{38}$ Drzewicka describes two methods of translating: textual and reconstructional. The year 1975 saw another collection of translation essays published under auspices of the Polish PEN. As before, it combined scholarly dissertations, Polish and translated (Wojtasiewicz, Jakobson and Etkind were among the authors), with more personal contributions from practitioners. Seweryn Pollak, the editor of the volume, stressed the fact that literary translation, as an area of art, cannot be limited to the realm of theory.

38 A. Drzewicka, Z zagadnień techniki tłumaczenia poezji. Studia nad polskimi przekładami liryki francuskiej w antologiach z lat 1899-1911 (Kraków 1971). 
Towards the middle of the decade, Zygmunt Grosbart published a number of papers on translation between related languages (specifically Polish and Russian), paying special attention to literary translation, which he saw as the focal point of all general qualities and principles of translation at large. ${ }^{39}$ Grosbart wrote also on the psychology of translation as a creative process and the role of translated literature in the national literary system.

The latter aspect was comprehensively discussed by Stefania Skwarczyńska in her seminal paper "Translation and Its Place in the National Literature and Culture" (1973), whose first part is included in the present anthology. ${ }^{40}$ Skwarczyńska refuses to see translations as foreign texts enclosed in a new form of the target language. Such a way of thinking, she stresses, reflects the old fallacy of dualistic view on literature, where "the semantic content" is divorced from "the linguistic attire." This is additionally combined with an equally false belief in the inviolable and unique character of any literary work. Skwarczyńska argues that if, on the contrary, we accord to translations the same status in the target culture as the originals enjoy, if we concentrate on the target rather than source domain, and if we read them using the literary norms of the target domain, we gain a new perspective. First of all, we will be able to assess the translation's value in the national culture and discover that the target culture gained as many "authentic works of literature" as there were translations of any literary text. Polish literature has as many Hamlets, the author claims, as there were renditions of that play. The Polish Hamlets are Skwarczyńska's material in the analytical part of her essay, which is not included in the present book. She singles out a number of factors influencing the position of the translated text in the target literature: the moment in the history of the literature, the relation of new translations to the preceding ones, and their genetic qualities. If this brings to mind Itamar EvenZohar, the association is perfectly valid. Skwarczyńska did not know his work, but clearly her inspiration came from the same sources: the Eastern European Structuralism, not only Russian (Yury Tynianov), but also Czech (e.g. Karel Horálek). Her text opened a new vista in Polish translation studies.

39 Z. Grosbart, "Specyfika przekładu w ramach języków słowiańskich (Propozycje metodologiczne).” In: Poetyka i stylistyka słowiańska, ed. S. Skwarczyńska (Wrocław 1973), pp. 112-119.

40 S. Skwarczyńska, "Przekład i jego miejsce w literaturze i kulturze narodowej." In: $O$ współczesnej kulturze literackiej, vol. 1, ed. S. Żółkiewski and M. Hopfinger (Wrocław 1973), pp. 287-330. See pp. 121-142 in the present volume. 


\section{Translatability and Translatorics: The Linguistically Oriented Research of the 1970s}

In parallel to the literary translation research, the 1970s also saw the development of linguistically oriented studies. In 1969, Witold Doroszewski, the doyen of Polish linguists, published his work "On the Idiomatic Nature of Languages," in which he argued that the idiomatic character of language hinders translatability. Communication is possible on the level of shared experience, by arriving at the same extra-linguistic points of reference. People using different tongues cannot understand one another so they lack shared "experience related to words". According to Doroszewski, translatability entails triggering - by means of words - a reaction (a behavior) identical or similar to that triggered by the original. In the 1970s, the question of (un)translatability becomes the central point of interest for linguistically oriented Translation Studies in Poland. It is the topic of Elżbieta Tabakowska's early paper on the Polish translation of Ulysses; ${ }^{42}$ also Mieczysław Szymczak's study of "The So-called Untranslatable Linguistic Categories" ${ }^{33}$ stresses the need to research linguistic universals in translational context. This path of inquiry will be soon taken by Anna Wierzbicka in her "Translatability and Basic Semantic Units" (1978). ${ }^{44}$

Wierzbicka started working on translation-related topics already in 1963, in her PhD thesis on the style and syntax of Polish Renaissance prose. Later, when her academic interests shifted to semantics, she became fascinated by the possibilities of machine translation based on a semantic language. Her research focused on universal semantic codes resulted in the theory of NSM (Natural Semantic Metalanguage), presented for the first time in 1972 in her book Lingua Mentalis. The need to solve the problem of untranslatability, which is the essential issue of linguistic relativism, seems natural in Wierzbicka's research, as it stems above all from her interest in comparative, intercultural semantics, based on the assumption that all languages contain sets of universal, primitive terms that can be literally translated into any other language. Their exponents have the

41 W. Doroszewski, “O idiomatyczności języków”, Prace Filologiczne, 1969, vol. 19, pp. 5-22.

42 E. Tabakowska, "The Polish Translation of James Joyce's Ulysses and Some Underlying Problems", Zeszyty Naukowe UJ. Prace historycznoliterackie, vol. 24, 1973, pp. 141-156.

43 M. Szymczak, "O tzw. nieprzekładalnych kategoriach językowych.” In: Poetyka $i$ stylistyka słowiańska, ed. S. Skwarczyńska (Wrocław 1973), pp. 21-26.

44 A. Wierzbicka, "Przekładalność a elementarne jednostki semantyczne," Przegląd Humanistyczny vol. 2, 1978, pp. 53-78. 
same meaning in all languages ${ }^{45}$ Languages and cultures appose and configure these terms; still, the very existence of these in-born elementary semantic units enables intercultural communication, which is realized in translation. ${ }^{46}$

Based on the NSM theory, Wierzbicka has been developing her multidirectional, interdisciplinary research, combining semantics, pragmatics, sociolinguistics, cultural anthropology, and even psychology, ethics and theology. Wierzbicka presents the heuristic potential of her theory, while improving and universalizing her model. She proves that NSM is an effective culture-neutral tool for comparing cultures and languages, allowing to describe differences and similarities between them. Thanks to the method of semantic explication, NSM helps avoid cultural biases when translating words from one language into another.

The paper "Translatability and the Scripting of Other Peoples' Souls", which is included in our anthology, is a good illustration of Wierzbicka's method. ${ }^{47}$ The author argues that translating indigenous categories into academic English precludes capturing and understanding indigenous perspectives. This exposes the anthropologist/translator to the charge that she/he is 'scripting other people's souls' (to use Clifford Geertz's expression). Analyzing cognitive and cultural categories from Australian Aboriginal languages, usually in connection with Anglo-cultural scripts, the author shows how the thought paths encoded in these languages can be explicated from the insider's point of view, in neutral metalanguage directly cross-translatable into the indigenous languages themselves. Wierzbicka's study leads to an optimistic conclusion as to intercultural communication: "we are not imprisoned in our own modes of thinking and perception if we can rely on a shared, universal set of concepts which provide us with a common intellectual currency for 'understanding others', and indeed, for understanding ourselves." 48

At the end of the 1970s, in the light of the development of semiotics, the sharp division between literary and linguistic approaches to translation seems to blur a little. This happens due to scholars who see Translation Studies as an interdiscipline

45 W. Wojtanowska, Język kluczem do kultury. Anna Wierzbicka i naturalny metajęzyk semantyczny (Wrocław 2016), p. 32.

46 J. Bartmiński, "Droga naukowa Anny Wierzbickiej. Od składni polskiej prozy renesansowej do semantyki międzykulturowej”, Teksty Drugie 2011, no. 1-2, pp. 226-227.

47 Wojtanowska, Język kluczem..., pp. 6 and 27.

48 A. Wierzbicka, "Translability and the Scripting of Other Peoples' Souls", The Australian Journal of Anthropology 2013, vol. 24, p. 18. See pp. 143-166 in the present volume. 
anchored in the domain of semiotics. In practice, though, new research in TS was more strongly linked to linguistic paradigms, especially since it had been modified and elaborated upon by a research team at the Institute of Applied Lingustics in Warsaw. This institution became a hub for advanced research in translation teaching, as well as interpreting and specialized translation.

The main characteristics of the new school of "translatorics," as its main proponent Franciszek Grucza called it, were: a scientific approach to problems of translation, an effort to delineate a separate discipline (hence the new name), and focusing on the problems of translation competence. Grucza's programmatic paper, "Problems of Translatorics" (1976), ${ }^{49}$ defined the discipline as a science of linguistic translation, interested in the processes taking place in the translation system (construed in fact as the standard Structuralist model of the act of translation). Grucza differentiates pure and applied translatorics: the former describes and explains the system, the latter - perfects its functioning with a view to translator training. The main role in the system is assigned to the translator, who is also the focal point of translatorics, although other elements of the system also receive attention. Within the interdisciplinary framework, translatorics covers common ground with linguistics, textology, psychology and physiology; that said, linguistics remains its point of departure and reference. The field is further divided into research on "informative" vs "aesthetic" texts; the latter field remains out of the scope of Grucza's interest, which situates his work close to the Leipzig school of Translationslinguistik. Translatorics, with its conceptual unity and coherence played an important role in the practical development of translation and translator training in Poland.

\section{Multilinguality and Literature: Hermeneutics and Translation History (the 1980s)}

In 1975, Edward Balcerzan dubbed good translators "enlighteners" of foreign texts and literatures. "In the hierarchy of duties of the art of translation," he wrote, "hermeneutical goals are the most important ones." Je Jerzy Ziomek elaborated on this topic in his essay "Who's speaking?", where he asked: "Is it possible to translate without understanding?"51 By way of an answer, Ziomek recalls Friedrich

49 F. Grucza, “Zagadnienia translatoryki." In: Glottodydaktyka a translatoryka, ed. F. Grucza (Warszawa 1981), pp. 9-27.

50 E. Balcerzan, “Trudna rzecz jest jeden język drugim językiem dostatecznie wyrznąć, Teksty 1975, vol. 6, p. 5.

51 J. Ziomek, “Kto mówi?”, Teksty 1975, vol. 8, p. 55. 
Schleiermacher's idea of interpretive translation, particularly demanding as far as the translator's hermeneutic competences go. Referring also to Paul Ricoeur and Walter Benjamin, whose concepts had been present in the context of Polish translation studies, he conceptualizes understanding and subjective relations in translation in linguistic and pragmatic terms: "We translate not only in order to assimilate a text from the foreign language, but also in order to see our own language in the shaft of light from the other language." 52

The author, who had used information theory as methodology in his early translation research, now looked at translation from a different perspective, to conclude that it is more than just re-coding on the level of language. He assessed the drive towards mathematical precision in theorizing translation as caused by the "inferiority complex of humanists" impressed by the technical complication of computers. These words come from the essay "Translation - Understanding Interpretation," ${ }^{53}$ included in the present collection. Here, Ziomek revises claims stemming from the structural paradigm in TS, negates the strict division between linguistic and literary translation research, and opens up a space for the hermeneutic paradigm. He also juxtaposes interpretation seen as a way of reaching the truth with the procedure of analyzing translation shifts resulting from the difference between language systems or semantic fields, as well the translator's individual choices.

It is not language that occupies the central position in Ziomek's thinking, but rather the subject of the act of literary communication: the person who experiences the world through language and in turn introduces his or her own experience into language. Languages, Ziomek claims, carry the social experience of their users. If this is true, any text on top of its semantic contents possesses also a certain specific character, which from the external perspective is recognized as foreign. The effort of the translator goes towards overcoming or underlining this foreignness. Returning to Schleiermacher's idea of the two ways of translation, Ziomek revises the idea of fidelity (finding it actually irrelevant as a TS category) and the relation of correspondence and equivalence between utterances in two languages. He defines translation as interpretation, i.e. clarification of the meaning of the source utterance; the source serves as a model for the meaning created in the target language. In Ziomek's view, translation is liberated from the comparative domain and can be conceptualized as a process of

52 Ziomek, “Kto mówi?”, p. 55.

53 "Przekład - rozumienie - interpretacja." In: J. Ziomek, Powinowactwa literatury. Studia i szkice (Warsaw 1980), pp. 159-200. See pp. 167-190 in the present volume. 
understanding and communicating experience which is linguistic in its nature and ethical in its aims. In translation, Ziomek writes, languages reflect each other as in a mirror and shed light on each other. Translation thus is not only interpretation of a text but also of a language. Translating means "looking at one's own speech in the light of the foreign one, and at the foreign in light of one's own; it is admiration and critique, obscuring and illumination." ${ }^{54}$

Multilinguality of Literature and the Problems of Artistic Translation ${ }^{55}$ is the title of a 1984 collection of essays including a number of studies on the historical aspect of literary translation and thus marking a new opening in translation research in Poland. "We know rather well by now - its editor Edward Balcerzan writes - how to do translation theory," ${ }^{36}$ but there is a need for more descriptive and historical research. The table of contents includes interesting contributions from Zygmunt Grosbart, Michał Głowiński, Anna Legeżyńska, Stanisław Barańczak, Marek Hendrykowski and Jerzy Święch. The latter had published an essay on "Translation and the Problems of Historical Poetics" already back in $1976 .{ }^{57} \mathrm{He}$ discussed the role of translators in the communication strategies within literary tradition, with the reader occupying a central position. Swięch actually analyzed the place of translations in the system of national literature, and although he was still much attached to the concept of the "proper" function of translating - namely representation of the original - still his argument introduced a trait of a new, sociologically oriented approach, rather different form the dominant stylistic-linguistic models.

Święch revisits Balcerzan's concept of translation series as a "specific cultural code," different from the binding code of the national literature; as such it "establishes its own norms of understanding texts" and shapes "the specificity of translation communication." ${ }^{38}$ Hence, to put it in the language of contemporary TS, Swięch formulates the claim that translated literature forms a separate sub-system within the literary system in which it functions. His discussion, akin to the ideas of the Israeli School, on a different level of analysis continues and develops the propositions Stefania Skwarczyńska put forth in her text on the Polish Hamlets.

54 P. 181 in the present anthology.

55 Wielojęzyczność literatury i problemy przekładu literackiego, ed. E. Balcerzan (Wrocław 1984).

56 E. Balcerzan, “Słowo wstępne.” In: Wielojęzyczność..., p. 7.

57 J. Święch, “Tłumaczenie a problemy historii literatury.” In: Z historii i teorii przekładu artystycznego, pp. 7-24.

58 Święch, “Tłumaczenie...”. 
Primarily a literary scholar, Święch was one of the people who altered the path of Polish studies in translation and allowed them to penetrate areas outside the equivalence paradigm. His essay "Translation and Self-commentaries" (1984) is precisely such a diagonal glance across the field and its methodology. ${ }^{59}$ The author investigates the paratextual framing of translation. Even if he does not recognize the full weight of paratexts as important sources for studying the social and political history of translation, Święch underscores the question of translators' subjectivity, their specific poetic programs and ideological attitudes presented in the commentaries. He reads them as sources of knowledge about the translators' biographies, both factual and intellectual. Within the Structural paradigm, translators had been construed as textual traces, deformations introduced by interpretation. Święch, on the contrary, draws conclusions concerning the process of translating, the interpretive work and different "styles of reception," as well as the designed roles for translators and the ways of their metaphorization. In his view self-commentaries enable the study of the nature of the translation process and its product, as well as the critical and auctorial competences of translators.

Święch's essay was to a large extent based on the material collected in a groundbreaking anthology called Polish Authors on the Art of Translating, published in 1977 by Edward Balcerzan. ${ }^{60}$ It gathered comments, analytical essays and reflections on translating by writers-translators, starting with mid $15^{\text {th }}$ century, when the Polish language was being shaped as a tool for creating literature. It presents a wide array of topics, attitudes and observations - all together forming a kind of narrative on the history of translation in Polish. Święch sees a considerable growth in the genre of "translatorial explication," both in bulk and quality, which testifies to a growing self-awareness on the part of the translators. These commentaries, as he says, keep adding up to a "theory of the impossibility called translation". The essay is an early instance of academic interest in the "nonscholarly" theory, studied later for example by André Lefevere. ${ }^{61}$

Another important publication from the 1980s is Anna Legeżyńska’s book Translator and His Authorial Competences. Based on post-war translations from

59 J. Święch, "Przekłady i autokomentarze.” In: Wielojęzyczność..., pp. 45-66. See pp. 191-213 in the present volume.

60 Pisarze polscy o sztuce przekładu 1440-1974. Antologia, ed. E. Balcerzan, (Poznań 1977). An extended version of this groundbreaking anthology, co-edited by E. Rajewska, was published in 2007 [editors' note].

61 A. Lefevere, Translation/History/Culture. A Sourcebook (New York-London 1992). 
Pushkin, Mayakovski, Krylov and Blok. ${ }^{62}$ We include large portions of its first chapter, edited by the author for the purpose of the present publication. The main claim of the book is that a translated work of literature is a joint creation of the author and the translator. The methodological context for Legeżyńska's analysis comes from the Poznań School of Translation Studies, in particular with respect to the analysis and interpretation of traces of the translator's creative presence at every level of the text organization. The other theoretical context involved is the Structuralist model of literary communication proposed by Aleksandra Okopień-Sławińska, who distinguishes intra- and extratextual subjective positions present in every text (1971). ${ }^{63}$ In Sławińska’s model, every intratextual and extratextual speaking subject (literary character, narrator, the image of the author and the author as a human being) is paired with a respective receiving subject. In translation, Legeżyńska suggests, the model is doubled. For her, the position of the translator as manifested in the text of the translation is the criterion for the description and assessment of translation practice. The translator's competence in the intercultural dialogue, together with the position he or she takes in the translated text, are studied against the background of changing historical landscapes of literature and society.

Legeżyńska's book was soon followed by a work which took a further step towards the realm of the social. Wojciech Solinski's Artistic Translation and Literary Culture. Literary communication and meta-communication (1987) looked at the presence of translated literature in the target culture from the point of view of literary communication and posited it as a practice within the framework literary sociology. ${ }^{64}$ Soliński discussed questions of translators' social status, as well as translation as a problem of editing. Even if not all aspects of Soliński's study are still relevant, it was without doubt a turning point in the development of translation sociology in Poland. While Legeżyńska’s book dealt with the intratextual mechanisms of literary communication, Soliński broadened the area by including also the extraliterary as a legitimate object of translation studies.

62 A. Legeżyńska, Tłumacz i jego kompetencje autorskie. Na materiale powojennych tłumaczeń z A. Puszkina, W. Majakowskiego, I. Kryłowa, A. Błoka, 2nd edition (Warsaw 1999). For excerpts see pp. 235-249 in the present volume.

63 See A. Okopień-Sławińska, Semantyka wypowiedzi poetyckiej (preliminaria) (Wrocław 1985).

64 W. Soliński, Przekład artystyczny a kultura literacka. Komunikacja i metakomunikacja językowa (Wrocław 1987). 
Anna Legeżyńska’s book had yet another aim, namely to develop a set of tools for translation criticism. As a disciple of the Poznan School, she recognized the fact that translation scholarship must be instrumental for the critical practice based on academic principles (cf. Balcerzan's claim that without a precise language of description translation criticism is not possible), which would replace the impressionistic style of translation assessment. This topic was then undertaken by Monika AdamczykGarbowska, the author of Polish Translations of English Fiction for Children. Problems of Translation Criticism (1988) ${ }^{65}$ Her monograph was innovative on two levels. First of all, children's literature had not been a mainstream topic in Polish literary studies to date, not to mention translation studies (with a few exceptions); secondly, because the author introduced a new methodology based on Gideon Toury's 1980 book In Serach of a Theory of Translation, which had not been known in Poland until then (and which also uses examples from a children's classic, Wilhelm Busch's Max und Moritz). Adamczyk-Garbowska's book was not purely descriptive in Toury's sense, as the category of translation mistake plays an important role in her argument; also, the presentation of Toury's theory was not completely effective. Nevertheless, it is an important trace of the rising awareness of new trends in world TS.

The author whose work arguably had the greatest impact on the development of Translation Studies in Poland at that time and also triggered a huge increase in translation criticism and popular discussion around translation was the already mentioned Stanisław Barańczak. A scholar from Poznań and a disciple of Edward Balcerzan, since 1981professor of Polish Studies at Harvard, Barańczak was above all an eminent poet and one of the greatest translators of literature in the history of Polish letters. Barańczak's most famous essay on translation, "A small, but maximalist translatological manifesto Or: An explanation of the fact that one also translates poetry with the aim of explaining to other translators that for most translations of poetry there is no explanation," 66 is the best example of his critical method - essayistic, ironic, brilliant and if not really adhering to strict academic discipline, still definitely rooted in the Structuralist methodology of the Poznan School of Translation Studies. His critical and methodological texts on translation were published in a book entitled Saved in Translation (1992) ${ }^{67}$

65 M. Adamczyk-Garbowska, Polskie tłumaczenia angielskiej literatury dziecięcej. Problemy krytyki przekładu (Wrocław 1988).

66 S. Barańczak, "A small, but maximalist translatological manifesto, Or: An explanation of the fact that one also translates poetry with the aim of explaining to other translators that for most translations of poetry there is no explanation," trans. A. Lloyd-Jones. In:, Literature from Literature...

67 S. Barańczak, Ocalone w tłumaczeniu (Poznań, 1992). 
In his "Manifesto..." Barańczak offered the concept of "semantic dominant" (in his earlier works referred to as "stylistic dominant"), as well as the idea of "translation maximalism". The concept of "dominant," with its roots in Jakobson's thought, bears traces of Barańczak's early interest in Eastern European translation theories from the Structuralist paradigm, as well as Ziomek's and Balcerzan's theoretical vocabulary. A dominant, according to Barańczak, is the formal element of the original's construction which provides the key to its sense. Barańczak stresses that poetic form and content in a literary work constitute an indivisible unity and the whole of the literary text - a poem - is a meaningful structure. In Barańczak's view the translator is at the center, as an interpreter who recognizes the nature of the dominant and then takes responsibility for the decisions taken in the translation process and the quality of its final product. A literary translation should present the fullest and most convincing interpretation of the meaning encased in the fullest and most convincing re-creation of the formal shape of the original. The principle of maximalism, on the other hand, obliges the translator to an imaginative answer to the original and is a strong voice in favor of translation as a creative work and the translator as the "other/second author," whose prerogatives are quite wide. The practical advice - or rather commandments are apparently extremely simple: 1 . Never translate verse into prose; 2 . Never translate good poetry into bad poetry. Barańczak is famous for his ironic and witty style, which makes him not just an important translation scholar but also one of the most appealing critics, loved for his concepts and hated for his ruthless judgments.

The text included in the present anthology, drawing on translations from Gerard Manley Hopkins, was written before the "Manifesto," in 1984, ${ }^{68}$ and reworked several times. Hopkins was a poet close to Barańczak for many reasons and the critic underlines their spiritual kinship, a category important in his translation criticism at large. The essay on Hopkins is a lucid presentation of the concept of semantic dominant put into practical use. Hopkins's poetry, Barańczak says making use of his Structuralistic vocabulary, presents a high degree of stylistic "overorganization" (complex and intricate poetic language), which serves as an equivalent to the complex and intricate content. The author discloses the process of creating meanings by way of translational interpretation, and in this way verifies his claim that every poem is a miniature "world model" governed by a set if intrinsic rules. The rules are specific to the one text only, establishing

68 S. Barańczak, "Poetycki model świata a problemy przekładu artystycznego." In: Wielojęzyczność literatury..., pp. 207-226. See pp. 215-234 in the present volume. 
its inner harmony and producing meanings. Barańczak's essay is also a showcase of his translation criticism. Compared with the work of his older colleagues from Poznań, Barańczak's texts have a strong essayistic tone and expressive style, which earned him the image of a fierce polemist. It does not make his claims or findings less valid, just the opposite. His translations, together with their descriptions which outgrow the narrow area of academic life, radically changed the landscape for Translation Studies in Poland.

\section{The End of the Beautiful Era and New Inspirations: Linguistically Oriented Translation Studies Since the 1980s}

In the 1980s, as the influence of the Structuralist paradigm in linguistic and literary studies begins to weaken, the linguistically focused Translation Studies in Poland seem to enter a phase of crisis. 1981 saw the publication of a book by Henryk Lebiedziński, Elements of the General Theory of Translation, in which the author outlines his vision of the discipline in total abstraction from any connection with texts or cultures. Rather, he sees it as a study of "the relation between the translation and the original as dependant on the genetic relation of the original and reality." ${ }^{69}$ His work, further developed in his next book, seems nevertheless to have been too general or too eccentric to ensure a development of this line of research. Also, at that time the international environment for research in translation changed radically. Within the international TS, the notion of equivalence lost its central position as a concept organizing the field, and a more integrated approach, combining pragmatics, cognitive semantics, text linguistics and psycholinguistics began to gain more and more attention. Polish scholars in most cases were not able to take part in the new conversations within the field, partly for reasons reaching far outside academic life. In Poland and most countries of Central and Eastern Europe the 1980s and early 1990s were a turbulent period of political changes; limited access to Western sources and international collaboration on the one hand, and, on the other, the exhaustion of the sources of inspiration both from the local research centers and from former Soviet Bloc countries, resulted in slowing down the production of new concepts.

One of the exceptions was Roman Lewicki, a professor of Russian language and linguistics, who continued to work on the question of translation stylistics. In his 1993 book Connotation of the Foreign in Translation, ${ }^{70}$ he postulated a need

69 H. Lebiedziński, Elementy przekładoznawstwa ogólnego (Warsaw 1981), p. 9.

70 R. Lewicki, Konotacja obcości w przekładzie (Lublin 1993). 
for non-normative, empirical research, focused on the textuality of translation and its functions in society. Hence his interest in translation reception, especially the connotation of the foreign: the elements of translated texts which produce the foreignizing effect, bringing in associations with foreign countries, cultures, languages. Lewicki centered his empirical research around the carriers of the foreign. He tested the salience of the foreignizing elements, the level of their recognition, as well as differences in the reception of translated vs. native texts. In his 2000 work Foreigness in the Reception of Translation, ${ }^{71}$ Lewicki - revisiting early claims of Malinowski and Wojtasiewicz - stresses the fact that translation is a problem of culture, not language. In the chapter included in the present anthology, the author looks at the problem of the foreign in translation from a wider perspective, linking it with the field of cultural anthropology and intercultural communication. Based on his research, he claims that "one's attitude to foreignness in translation reception is derived from, or perhaps even is a part of one's attitude to foreignness as such, i.e. foreignness as a cultural category." ${ }^{\prime 2}$ The value of Lewicki's continually developed research consists above all in the fact that he describes one of the key notions of TS using concepts of today's culture and intercultural studies in the empirical context. This direction will prove fruitful in overcoming the temporary deadlock in Polish Translation Studies.

The 1990s in Poland witnessed a transition period. After the first partly democratic elections in June 1989, which brought a victory to the forces of democratic opposition and subsequently led to the end of Communist regimes in Central Europe, a new epoch began, with much wider opportunities also for the academic milieu. International contacts and transfer of ideas became much easier. Polish scholars got access to new sources of inspiration and joined the global discussion on translation and intercultural communication. The Structural paradigm lost its central position; research in translation stylistics was continued within the framework of cognitive linguistics, a fairy new current in the study of language developed by the American scholar Ronald Langacker and introduced to Poland by Elżbieta Tabakowska, a Kraków-based linguist and translator. As a linguist, she was especially interested in the link between linguistics and poetics, in order to devise precise descriptive tools to study language processes and phenomena at work in an interlingual literary creation. Langacker's grammar, which was an answer to the insufficiency of generative grammar for explaining the questions of meaning, alongside George Lakoff's and Mark Turner's work on metaphor,

71 R. Lewicki, Obcość w odbiorze przekładu (Lublin 2000).

72 See p. 304 in the present volume. 
inspired Tabakowska to understand the style in translation as an expression of subjectivity and to look at poetic language and its translation as two distinct but related conceptualizations of a subjective position in physical and mental spaces.

Tabakowska's work focuses on the concept of imagery understood as an ability to construe a particular scene differently depending on the ways in which linguistic tools are being deployed. As she shows on numerous examples, looking at the dimensions of imagery in language enables a precise description of the artistic shape of the original as a linguistic creation. This in turn may lead to a formulation of the translator's tasks or to a more careful assessment of translation quality. In her book Cognitive Linguistics and the Poetics of Translation (1993), ${ }^{73}$ Tabakowska claims that if the linguistic shape of a text is a function of its subject's positioning within physical and mental space, equivalence must be defined on the level of imagery in language. In this context, the unit of translation is not a word, a sentence or a text, but an image, a scene as construed by a particular conceptualizer in a particular set of conditions. A literary text in its entirety is a network of such linguistic scene construals. Equivalence in translation therefore should be studied on the level of imagery of the corresponding texts rather than on lexical or grammatical levels. Tabakowska's book, written originally in English, appeared in Polish translation only in $2001,{ }^{74}$ yet she published a fair number of papers on the tenets of cognitive linguistics (the new paradigm was also introduced by Ronald Langacker himself in a series of lectures he gave in Poland in 1993) and its implication for translation and translation studies. ${ }^{75}$

In her article "The Theory and Praxis of Cognitive Linguistics: An Oleograph and a Symphony for two Pianos, ${ }^{36}$ presented here, Tabakowska claims that a thorough linguistic analysis of a source text done from the perspective of cognitive linguistics can contribute to a fuller understanding of the translation process itself and a more adequate evaluation of its final product. The cognitive paradigm allows to initiate a dialogue with literary studies and the theory

73 E. Tabakowska, Cognitive Linguistics and the Poetics of Translation (Tübingen 1993).

74 E. Tabakowska, Językoznawstwo kognitywne a poetyka przekładu, trans. A. Pokojska (Kraków 2001).

75 See her selected papers in translation studies: E. Tabakowska, Myśl językoznawcza z myśla o przekładzie. Wybór prac, ed. P. de Bończa Bukowski and M. Heydel (Krakow 2015).

76 E. Tabakowska, "Językoznawstwo kognitywne w teorii i praktyce przekładu: oleodruk i symfonia na dwa fortepiany." In: Między oryginałem a przekładem, ed. J. KoniecznaTwardzikowa and U. Kropiwiec (Krakow 1995), pp. 31-41. See pp. 287-296 in the present volume. 
of translation based upon the notion of conceptual portrayals. According to Tabakowska, within the cognitive approach the aims of linguistics, translation theory and translation criticism converge. The point is to establish the relation between the linguistic form and the conceptual content it conveys. By analyzing a descriptive fragment of Norman Davies' Europe in the original and her own Polish translation, Tabakowska exemplifies the claim that particular dimensions of imagery have their linguistic correlates. The comparison of both texts in terms of imagery reveals differences, often subtle, in the construction of the scenes. It can therefore be said that the translator - obedient to the conventions of the target language and guided by his/her own imagination - draws the same picture with a different line, or plays the same score in her own way.

This paper is a good example of how Tabakowska combines deep theoretical insights and illustrative case studies with true virtuosity, transferring knowledge to both translation scholars and practicing translators. She was also instrumental in introducing Translation Studies into the institutional academic structures in Poland at the turn of the $21^{\text {st }}$ century: she founded and was a long-time director of the Chair for Translation Studies and Intercultural Communication at the Jagiellonian University, which brought new energy to the TS scene in Poland, becoming a hub for translation training and new research in the field. Translation Studies at the Jagiellonian have developed dynamically since the 1990s, with a number of publication initiatives, to mention only two journals: Między Oryginałem a Przekładem [Between the Original and the Translation $],{ }^{77}$ which developed from a conference and book series under the same title, and Przekładaniec. A Journal of Translation Studies ${ }^{78}$ They have been publishing TS research for more than a quarter of a century now.

Apart from cognitive linguistics, another research inspiration has been intersemiotic translation or transmutation, a concept rooted in Jakobson's tripartite division of the field of translation. With the rapid development of multimedial and multimodal communication technology, it has become one of the central issues for Polish translation scholars. With its source in Structuralist thought, research in audiovisual and intersemiotic translation has focused on film adaptations of literature within the context of semiotics. Already in 1970, Maryla Hopfinger published a paper on "Film and Literature." ${ }^{\text {S9 }}$ She saw film

77 See: http://journals.akademicka.pl/moap.

78 See: http://www.ejournals.eu/Przekladaniec/.

79 M. Hopfinger, "Film i literatura: uwarunkowania techniczne przekładu intersemiotycznego," in: Sztuka - technika - film, ed. A. Kumor and D. Parczewska (Warsaw 1970), pp. 159-182. 
adaptation as a case of intersemiotic interpretation of the literary message and if the signs used in literature and film are mutually untranslatable on the level of the artistic material itself (she calls it "the level of building blocks"), they are partially translatable on the level of semantic structures and fully translatable on the level of cultural semantics, as cultural meanings can be expressed in any sign system. The topic was taken up many years later by Seweryna Wysłouch in her paper "Film Adaptation as Intersemiotic Translation", included in the present collection. ${ }^{80}$ Wysłouch situates film adaptation in a wider perspective of the correspondence of arts. She concludes that the coexistence of iconic and literary signs may be described in terms of concretization and intersemiotic translation. Film and literary signs are mutually translatable because, being secondary sign systems superimposed over verbal and visual ones, they find equivalents in different materials and retain analogical meanings. Other authors working in this area included Wacław Osadnik ("Film Adaptation as Translation", 1995), ${ }^{81}$ who related his research to polysystem theory and suggested a shift in descriptive priorities in the study of adaptation from the concept of adequacy (faithfulness) towards acceptability, and Elżbieta Tabakowska, who wrote on intersemiotic translation in a yet another context in her "Between Image and Text, or on Intersemiotic Translation" (2009). ${ }^{82}$ Starting from the claim that every translation is an interpretation, she proposes a model analysis of the translation of visual signs into English text in the framework of cognitive theory of sign representation.

\section{New Horizons: Polish Translation Studies in the $21^{\text {st }}$ Century}

The renewed interest in TS, together with the opening of international academic world in the 1990s, gave momentum to the discipline and brought about a large number of research projects across the country. Around the turn of the 1990s and the early 2000s, there appeared a number of publications presenting a wider panorama of Translation Studies as a discipline, with a special emphasis on research in literary translation (Maria Krysztofiak's Literary Translation in

80 S. Wysłouch, "Adaptacja filmowa jako przekład intersemiotyczny." In her, Literatura a sztuki wizualne (Warsaw 1994), pp. 157-206. See pp. 263-285 in the present volume.

81 W. Osadnik, “Adaptacja filmowa jako przekład.” In: Kino wedtug Alicji, ed. W. Godzic and T. Lubelski (Krakow 1995), pp. 69-77.

82 E. Tabakowska, "Między obrazem a tekstem, czyli o przekładzie intersemiotycznym." In: Między obrazem a tekstem, ed. by A. Kwiatkowska and J. Jarniewicz (Łódź 2009), pp. 37-48. 
Contemporary Translatorics, 1996) or to recent theoretical paradigms in TS (Alicja Pisarska, Teresa Tomaszkiewicz, Contemporary Tendencies in Translation Studies, 1996). ${ }^{83}$ The Thesaurus of Translatorical Terminology (1998) edited by Jurij Lukszyn and his team was an attempt at ordering the conceptual system for the field. ${ }^{84}$ Another project with a similar agenda was undertaken in 2000 by Urszula Dąmbska-Prokop who published an edited volume entitled A Small Encyclopaedia of Translation Studies. ${ }^{85}$ Ten years later she brought out a follow-up, this time as her own book called The New Encyclopaedia of Translation Studies (2010). ${ }^{86}$ The aim of these books was to sum up and organize the relatively new research field, taking into consideration many various contexts and currents within it. Dąmbska-Prokop stresses that Translation Studies is an integrated, independent and interdisciplinary field, and although she does not include the contexts of anthropology, philosophy or postcolonial and gender studies, still the presentation she offers leaves no doubt that Translation Studies became an important element of the Polish humanities.

More recent publications, varied in terms of topics and methods, reflect the stabilization of the discipline in the country and its participation in the global exchange. The linguistic and glottodidactic current is continued at the Warsaw Institute of Applied Lingusitics. Krzysztof Hejwowski, the author of CognitiveCommunicative Theory of Translation (2006), draws on Wojtasiewicz's concept of untranslatability and ways of overcoming it. ${ }^{87}$ Jolanta Kozak, in turn, in her Literary Translation as a Metaphor. Between logos and lexis (2009) looks at translation in the philosophical framework, asking about its ontology. ${ }^{88}$ Since the 1990s, the University of Silesia has published a book series edited by Piotr Fast, presenting a wide array of methodologies and approaches to translation; it is a valuable collection of the mainstream of Polish research in translation, including works of some authors featured in the present anthology.

83 M. Krysztofiak, Przekład literacki we współczesnej translatoryce (Poznań 1996). See also her Translatologiczna teoria i pragmatyka przekładu artystycznego (Poznań 2011); A. Pisarska, T. Tomaszkiewicz, Współczesne tendencje przekładoznawcze (Poznań 1996; 2nd ed. 1998).

84 Tezaurus terminologii przekładoznawczej, ed. J. Lukszyn et al. (Warsaw 1998).

85 Mała encyklopedia przekładoznawstwa, ed. U. Dąmbska-Prokop (Częstochowa 2000).

86 U. Dąmbska-Prokop, Nowa encyklopedia przekładoznawstwa (Kielce 2010).

87 K. Hejwowski, Kognitywno-komunikacyjna teoria przekładu (Warsaw 2008); see also his Iluzja przekładu. Przekładoznawstwo w ujęciu konstruktywnym (Katowice 2015).

88 J. Kozak, Przekład literacki jako metafora. Między logos a lexis (Warszaw 2009). 
In 2009, the editors of the present collection, Piotr de Bończa Bukowski and Magda Heydel, published an anthology of essays Contemporary Translation Theories (2009), which was well received and marked an important point in Polish Translation Studies as the first comprehensive presentation of the canon of international TS in the $20^{\text {th }}$ century. In 2013, they authored another anthology, Polish Thought in Translation Studies, ${ }^{89}$ the basis of the present collection.

New contexts for Translation Studies in Poland have been provided by the development of cultural studies and the sociological framework in the humanities. This gave rise to a number of projects concentrating on intercultural communication and translation as international social practice. The Wrockawbased scholar Elżbieta Skibińska initiated a research program which resulted in studies centered around translation and international reception of the work of Polish writers (Witold Gombrowicz, Tadeusz Konwicki, Stanisław Lem). Some of the new ideas engaged philosophical and anthropological concepts. Tadeusz Sławek, a philosopher and professor of English and American literature, in his essay "Calibanism. The Philosophical Dilemmas of Translation" $(1991)^{90}$ looks at translation from the perspective of modern philosophy, especially Nietzsche and Derrida. For Sławek, translation is not a linguistic or cultural phenomenon, but belongs to the realm of understanding and interpretation, the realm of hermeneutic debate on the nature and conditions of these processes. Hence, it is not different from what criticism (in the sense given to this word by deconstruction) does: both the critic and the translator aim at destabilizing the senses in the text, and study its resistant surface: palpable, material, nonadjacent, penetrated by other texts. That surface consists of signs, the feature of a sign being that it can be repeated. In deconstruction every repetition involves change: the critic/translator repeats what has already been repeated and distorts what has already been distorted. The source, the original, is in fact always already divided, marked by difference. ${ }^{91}$

Sławek begins his essay with Nietzsche's thought on translation and claims that if history is inscribed with difference and within the space of difference between two works, the relation between the original and the translation cannot

89 Współczesne teorie przekładu. Antologia, ed. P. Bukowski and M. Heydel (Krakow 2009); Polska myśl przekładoznawcza. Antologia, ed. P. de Bończa Bukowski and M. Heydel (Krakow 2013).

90 T. Sławek, "Kalibanizm. Filozoficzne dylematy tłumaczenia." In: Przekład artystyczny, vol. 1, ed. by P. Fast (Katowice 1991), pp. 7-17. See pp. 251-262 in the present volume.

91 T. Sławek, "Vita femina. Dekonstrukcja jako styl krytyki," In: Interpretacje i styl krytyki, ed. W. Kalaga and T. Sławek (Katowice 1988). 
be described in terms of correspondence, faithfulness or treason. Firstly, the object of translation loses its outline, as we never translate a text only but also its "times;" secondly, since we are inevitably faithful to our own times, we betray the original. Hence, reflection on translation is a reflection on the present time where translation is a meta-consciousness of the present. Sławek brings forth the relationship between Prospero and Caliban in Shakespeare's The Tempest as a metaphor for translation. Kaliban symbolizes the translator, who, confronted with the Other, discovers the limitations of his own language, comes to understand the illusion of his completeness. Prospero, the figure of the author, by exercising his power over Caliban, allows him to discover worlds that are there outside the limits of his language and his world that he had thought were sufficient; Prospero shatters the peace of Caliban's own home. Caliban's reaction - rebellion and an attempted rape of Miranda - is a paradoxical answer of a translator, trying to cope with the overwhelming power of the author. The question of translation in the context of contemporary interpretation theories, particularly deconstruction, appears also in the work of Michał Paweł Markowski, a professor of literary theory, translator and author of a monograph on Derrida's interpretation theory. ${ }^{92}$ Another author working in the same area is Adam Lipszyc. His book Justice at the Tip of the Tongue (2012) ${ }^{93}$ is a reading of Walter Benjamin's philosophy, with "The Task of the Translator" as a point of departure for a wide presentation of Benjamin's concepts of the "ethics of language" or the "ethical philosophy of language", as Lipszyc names it.

Another interesting interpretive path runs through the middle ground between translation and comparative studies, the area so well described in international TS by theorists such as Susan Bassnett or Emily Apter. Polish translation scholars are well aware of the contributions from new comparative studies, which are more often than not defined in terms of translation or as translation. Tomasz Bilczewski has published two books devoted to various aspects of comparison and translation: Comparison and Interpretation: Modern Comparative Studies versus Translation (2010), in which he presents a new assessment of the historical development of the field, with a special focus on the role of translation in developing new approaches to comparative analysis and expanding the creative power of literary comparative studies, and Comparison and Translation. Comparative

92 M. P. Markowski, Efekt inskrypcji. Jacques Derrida i literatura (Bydgoszcz 1997).

93 A. Lipszyc, Sprawiedliwośćna końcu języka. Czytanie Waltera Benjamina (Krakow 2012). 
Studies Between the Anatomist's Plate and Digital Humanities $(2016)^{94}$, where he implements the category of translation and comparison to talk about narratives dealing with the experience of painful uprootedness and immersion in a world of incommensurate language and cultural realities.

In Bilczewski's analyses, Translation Studies leaves the safe but limited area of academic pursuits in literature and language; it also goes beyond the concept cultural translation in its basic sense. The scholar addresses existential, historical, political traumatic contexts, venturing into a risky ground in between, with complex identities, negotiations between the selfsame and other, and creation of communities. Bilczewski's essay included in our anthology ${ }^{95}$ places the problem of translation within the framework of psychoanalysis and discusses several examples to present ways in which the language of literature problematizes the process of working through losses and reveals the post-traumatic condition of the subject. His principal material comes from Eva Hoffman's Lost in Translation (1989), a description of forced displacement and of translating one's self, and her After Such Knowledge (2004), which reflects on the experience of exile in a perspective of inherited trauma, passed down through generations.

Problems of translation within the framework of history and traumatic memory seem to be a rich domain of study in Central Europe, marked by the experience of the Holocaust as well as decades of rule of two totalitarian systems. There is space for theorization as well as a vast scope of material to analyze, translate and interpret. One such project has been recently undertaken at the Jagiellonian University in Kraków by Research Centers for Memory Cultures and for Translation Studies; it consists in translating the actual utterances of Polish bystanders interviewed by Claude Lanzmann in his documentary Shoah. ${ }^{96}$ The new translations bring out the henceforth subdued voice of the bystanders, which was simply lost in translation, and describe the layers of meaning hidden in their form and contexts. The project, sheds light on the role of language, translation and non-translation in memory production and management.

94 T. Bilczewski, Komparatystyka i interpretacja. Nowoczesne badania porównawcze wobec translatologii (Krakow 2010); T. Bilczewski, Porównanie i przekład. Komparatystyka między tablica anatoma a laboratorium cyfrowym (Krakow 2016).

95 T. Bilczewski, „Trauma, translacja, transmisja w perspektywie postpamięci. Od literatury do epigenetyki." In: Od pamięci biodziedzicznej do postpamięci, ed. T. Szostek, R. Nycz, R. Sendyka (Warszawa 2013), pp. 40-62. See pp. 307-324 in the present volume.

96 Partial research results will be published both in Polish and English in Przekładaniec. A Journal of Translation Studies vol. 38 in 2019. 
The historical material on the translators' life and work in traumatic conditions is another huge field of research. In the anthology we present Małgorzata Tryuk's paper on interpreters working in the Auschwitz death camp. ${ }^{97}$ The author looks at testimonies on how interpreters were recruited from among the inmates, what their role and position in camp hierarchy was, and how they were treated. This shocking account of the practice of translation within the multilingual environment under extreme pressure and in inhuman conditions sheds light on the historical events themselves, the problems of memory and representation of trauma, as well as contributing an extreme case study to the field of translator studies.

The transdisciplinary nature of new developments of TS in Poland does not mean that research in literary translation as such has been abandoned altogether. The final paper in our anthology is an example of fresh and innovatory work in the area which has been the flagship of Polish translation research from its very beginning. Tamara Brzostowska-Tereszkiewicz is the author of Modernist Translation. An Eastern European Perspective - Models, Semantics, Functions (2016), ${ }^{98}$ where she proposes a typology of modernist translation in Central and Eastern Europe. In the chapter included in the anthology the author looks at a wide array of experimental forms of translation inspired by conceptual art. All of the practices she studies are avant-garde, overtly anti-illusionist and radical in their treatment of the concept of translation as construed by traditional approaches. Brzostowska-Tereszkiewicz analyses the ways in which these experiments enter into relations with visual, installation and performance art, at the same time activating aleatoric and combinatory procedures for the construction of target texts. Stressing intermediality and synesthesia, the cases she discusses introduce an inherent tension between sensory and intellectual cognition in the translation process. They also promote the translator's conceptual role in place of the traditional translational illusionism and are a strong voice for translator creativity.

Brzostowska-Tereszkiewicz's work illustrates how Polish Translation Studies combines international methodological and theoretical research framework

97 M. Tryuk, "'You say nothing; I will interpret': Interpreting in the Auschwitz-Birkenau Concentration Camp." in: Translation and Opposition, ed. D. Asimakoulas and M. Rogers (Auschwitz-Bristol-Buffalo-Toronto- 2011), pp 223-243. See pp. 325-342 in the present volume. See also M. Tryuk, Ty nic nie mów, ja będę tłumaczył. O etyce w tłumaczeniu ustnym (Warsaw 2012).

98 T. Brzostowska-Tereszkiewicz, Modernist Translation. An Easter European Perspective. Models, Semantics, Functions (Frankfurt a. Main-Bern-Bruxelles-New York-OxfordWarszawa-Wien 2016). See pp. 343-368 in the present volume. 
with the specificity of the local environment. The author looks at some interesting examples of Polish avant-garde art to read it in an enlightening way from the point of view of translation. At the same time, she makes use of the Eastern European paradigm of Translation Studies and finds the analytical tools as well as her material locally. Finally, by unpacking the translational meanings of Ewa Partum's installations, she also adds a new understanding of the visual art produced in response to the existential, political and ideological tensions of this part of Europe; hence, she also contributes to the discussion on the wider sense of translation as one of the most important cultural practices of the contemporary humanities.

Any attempt at summing up the panorama of Polish concepts in Translation Studies or generalizing about the characteristic features of research done by Polish scholars is necessarily doomed to fail. By way of a closing remark it seems apt to stress the fact that the century that passed since Żeromski's statement, a hundred years of work on theorizing and describing translation, translations and translators, brought a plethora of varied and fascinating material. The sample collected in our anthology shows Polish Translation Studies as a rich interdiscipline which has always been involved in creative dialogue with literary, cultural and linguistic studies. The growing awareness of the role translation plays in the globalized world of the future, but also in understanding the past in the cultural, social and political dimensions, allows us to expect that the work of translation scholars will develop further in the international context. 


\section{Bronisław Malinowski \\ The Translation of Untranslatable Words}

It might seem that the simplest task in any linguistic enquiry would be the translation of individual terms. In reality the problem of defining the meaning of a single word and of proceeding correctly in the translating of terms is as difficult as any which will face us. It is, moreover, in methodological order not the first to be tackled. It will be obvious to anyone who has so far followed my argument that isolated words are in fact only linguistic figments, the products of an advanced linguistic analysis. The sentence is at times a self-contained linguistic unit, but not even a sentence can be regarded as a full linguistic datum. To us, the real linguistic fact is the full utterance within its context of situation.

But still, as in all work of analysis, it does not matter very much where we begin. Since in the translation of texts we have to proceed by giving a word for word rendering, let us discuss this first. It will soon enough lead us into the apparently more complicated, but in reality more elementary, question of how to treat native texts and contexts.

Let me start with the apparently paradoxical and yet perfectly plain and absolutely true proposition that the words of one language are never translatable into another. This holds of two civilized languages as well as of a 'native' and a 'civilized' one, though the greater the difference between two cultures the greater the difficulty of finding equivalents.

Turning for a moment to more familiar European languages - anyone who has faced the difficulties of translating a novel or scientific book from Russian or Polish into English, or vice versa, will know that strict verbal equivalents are never to be found. Translation must always be the re-creation of the original into something profoundly different. On the other hand, it is never a substitution of word for word but invariably the translation of whole contexts.

It would be easy to skim the surface of any language for completely untranslatable terms. Such German words as Sehnsucht, or Sauerkraut, Weltschmerz or Schlachtfest, Blutwurst or Grobheit, Gemut or Gemeinheit are not to be equated to any word in English, or, for that matter, in any other European language. Such English words as 'sport,' 'gentleman,' 'fair-play,' 'kindness,' 'quaint,' 'forlorn' - to mention only a few from a legion - are never translated in a foreign tongue; they are simply reproduced. International currency has been achieved by many Italian words: bel canto, basta, maccaroni, diva, salami, as well as terms from music and 
painting. If we were to enquire why these, with certain French words referring to technicalities of love-making such as liaison, maitresse, au mieux, complaisance; or to culinary compositions and details of menu; to fashion or to niceties of literary craft, such as belles-lettres, mot juste, connaisseur are untranslatable the answer would be easy. In each culture certain aspects are more openly, minutely or pedantically cultivated: sport in England, good cooking and lovemaking in France; sentimentality and metaphysical profundities in Germany; music, noodles and painting in Italy.

Words referring to moral or personal values change their meaning deeply even if the form is similar: compare French honneur, Spanish honra, English 'honor', and German Ehre; or 'faith,' foi, Glaube and fe; or patrie, Vaterland, 'home,' and la peninsula. English changes east of Suez; it becomes a different language in India, Malaya and South Africa. The question whether American is English is very fruitful from the present point of view: you cannot swear in English in the U.S.A. and vice versa. You cannot order your food in an 'eat-house' nor 'get outside your drinks' by the same verbal symbols in a 'saloon' as in a 'pub'; while Prohibition has introduced words corresponding to the change of institutions and values surrounding drink. In brief, every language has words which are not translatable, because they fit into its culture and into that only; into the physical setting, the institutions, the material apparatus and the manners and values of a people.

With all this, it might appear that such words, however frequent, are but freaks or peculiarities. Surely, it will be contended, numerals, parts of the body, terms of relationship, conjunctions, adverbs, prepositions, words as ordinary as bread and butter, milk and meat, are simply, plainly, adequately and completely translated between any two languages of the Western cultures. A brief consideration convinces us that this is not so. Were we to aim merely at achieving some approximate indication of correspondence between two words, sufficient to order a meal, to bargain over the price of an umbrella or ask our way in the street, then even the linguistic instruction supplied on a few pages of our Baedecker, certainly a cheap pocket dictionary or an Ollendorf, will give adequate translations. But if in our scientific analysis we define words as devices used in a number of verbal and situational contexts, then translation must be defined as the supplying of equivalent devices and rules. This makes our point clearer: there is no simple equivalence between two languages ever to be found which could be used right through, replacing the German word by the English, or vice versa.

Let us take the simplest example, the numeral 'one,' un, ein. They correspond closely in counting. But un homme, ein Mann is not 'one man' but 'a man.' 'One man one vote' could not be translated by un homme un vote, nor is ein Mann ein 
Wort translatable into 'one man one word.' Nor is c'est un homme honnête equivalent to 'this is one honest man.' As soon as we come to derived uses, to subsidiary meanings, to idiomatic handling of words, the equivalence breaks down. Translation as an act of putting 'one'=un appears to us at once as a matter of rough, preliminary, makeshift arrangement which has to be supplemented by a long series of additional data.

Or take the parts of the human body: we have at once to face up to the fact that the conventional restrictions, euphemisms, and twists obfuscate the meaning in English to a much larger degree than in French or in German. For instance, 'belly' is not equivalent to Bauch or ventre; 'stomach' reaches almost to the knees, legs are curtailed in their upper reaches. Such words as 'breast,', gorge, sein, Brust, Busen become untranslatable. And in English again the word 'navel,' associated in a daring anatomical metaphor with an orange, shocks many a continental damsel who thinks herself absolutely protected by English prudery on this side of the Channel. 'Eye,' 'hand,' 'foot,' and 'arm,' 'mouth' and 'ears' seem so well defined and precise that here a simple $=$ might be enough. But even here some European languages, for instance Slavonic, use the term 'hand' often to embrace the 'arm', as in Polish and Russian, where instead of having 'feet' and 'legs' we have only lower extremities. Moreover, in every European language the derived and metaphorical and idiomatic uses of 'eye,' 'hand' and 'foot' are so little co-ordinated that they cannot be equated. 'My two legs' could not be set = meine zwei Beine; it would have to be meine beiden Beine. We neither eat nor sleep linguistically in the same manner: while the Englishman 'sleeps with', the Frenchman couche avec. As to eating, a Frenchman's bien manger becomes in German gut speisen, while the Englishman 'dines well'. As regards adverbs and conjunctions, no one brought up in a continental language will ever live down the absence of déjà, schon, już, uzhe, già or ya. Such German adverbs or particles as doch, nanu, also, the French mais non, mais oui - not equivalent to the German aber nein, aber $j a$ - can neither be equated nor reproduced in English.

We have now whittled down our paradox to the platitude that words from one language are never translatable into another; that is, we cannot equate one word to another. If by translation we mean the supplying of the full range of equivalent devices, metaphorical extensions and idiomatic sayings - such a process is of course possible. But even then, it must be remembered that something more than mere juggling with words and expressions is needed. When we pass even from one European country to another we find that cultural arrangements, institutions, interests and systems of values change greatly. Translation in the correct sense must refer therefore not merely to different linguistic uses but often to the different cultural realities behind the words. All the new systems of 
teaching modern languages - whether it be Toussain-Langenscheidt, Pelman or Berlitz - have in practice fully adopted this contextual theory of language and realized the untranslatability of words. In the case of words which have to be international, e.g. scientific terms, congresses have to deal with their unification; and it can only be achieved because the apparatus of science is uniform, because such arrangements as the metric system have been widely adopted and because the institutional side of scientific training, laboratory organization and academic life is sufficiently similar.

In diplomatic documents and international treaties, which must not contain any linguistic ambiguity, we are again faced with the difficulty of finding a safe and unequivocal common denominator to untranslatable words. Whether this is mainly due to the fact that diplomatic language is used to conceal thought according to the definition of one of the most famous diplomats of history or whether it honestly attempts to serve its purpose, need not be discussed here.

The translatability of words or texts between two languages is not a matter of mere readjustment of verbal symbols. It must always be based on a unification of cultural context. Even when two cultures have much in common, real understanding and the establishment of a community of linguistic implements is always a matter of difficult, laborious and delicate readjustment.

When two cultures differ as deeply as that of the Trobrianders and the English; when the beliefs, scientific views, social organization, morality and material outfit are completely different, most of the words in one language cannot be even remotely paralleled in the other.

Let us turn at once to our own special case, that of Trobriand agricultural terminology. The simplest word to be considered is 'garden'. But obviously the English term may suggest anything from a suburban plot to a park, from an allotment to a market-garden, and in none of these senses, nor yet in any of the metaphorical extensions to which this word is liable, could it be translated into Trobriand. So that at once we are faced with a serious 'gap' in the vocabulary of our Melanesian friends. For they really have no word corresponding to our general term 'garden.'

Instead they have a series of words: bagula, buyagu, tapopu, kaymata, kaymugwa, baleko, each of which describes a certain type or kind, aspect or phase of 'garden.' But to 'translate' any of these native terms by equating it to an English word would not merely be wrong, but impossible; or rather it would be impossible to find an English word exactly corresponding to any one of the native ones. Furthermore, to label the native term by even a combination of English words is at least misleading. 
What then is the correct procedure? Let me exemplify it on one of the words just mentioned - the native term buyagu - by making a methodological reinterpretation of the technique adopted in Division I ( $\$ 16-26)$ of Part V. First, we had to remind the reader of the general context of situation within which the word buyagu could be used: that is, to indicate the social, legal and technical arrangements by which a portion of cultivable soil is ear-marked for next year's gardens and recognized as 'the future gardens.'

Then I give the merely approximate but useful English label 'gardensite,' which I have used throughout the descriptive chapters in order to avoid repeating the native term constantly. But this compound term has to be immediately redefined by fuller English circumlocutions, such as 'land under cultivation at a given season,' 'the land intended for cultivation,' 'all the land within the common enclosure. These circumlocutions obviously derive their meaning from the reader's knowledge of how land is cultivated in the Trobriands; that is, tracts of land consisting of one or two fields ( $k$ wabila) are put under cultivation and a common enclosure is made round them, which converts the area into one communal garden. This meaning is illustrated in Text 3, where 'garden-site' and 'the garden as a whole' is defined by its economic as well as by its technical characteristics. In the definition of the term buyagu the reader has then to be reminded of the manner in which a garden-site is physically delimited for the natives, first by the boundary belt and later by the fence $(\$ 17)$.

Throughout its analysis we see that the word is progressively defined by reference to the ethnographic description, supplemented by additional information concerning linguistic usage. In paragraph 17 this parallelism of verbal use and real situation shows clearly: "as soon as this (i.e. the bush) is cut buyagu, 'gardensite' becomes opposed to odila, 'bush,' 'all the land outside,' also called yosewo, 'uncut bush outside the garden-site"' It is through the opposition of the word buyagu to the two words odila and yosewo and, in the sentence following the one just quoted, to the words kapopu and kaulaka that the term buyagu is more closely defined. The relation of this term to the cognate terms, bagula and baleko $(\$ 20)$, is equally important; as well as the negative fact that one of the terms for division of land, the term kwabila, is never used to describe a garden in process of cultivation. Thus, the definition of a word consists partly in placing it within its cultural context, partly in illustrating its usage in the context of opposites and of cognate expressions.

Turning to paragraphs 20-25, we see how the words buyagu, bagula, baleko are defined by placing them within a series of terms with mutually exclusive uses. It is clear that in all this the definition is partly based on the long descriptions of the main ethnographic account, but also largely on the contrast between the 
terms to be defined and their opposites, and also on the comparison between the respective area of each of the three terms.

It is interesting to note that, in his definition, the native informant himself reproduces the context of situation first: "When we clear the bush there remains the uncut scrub, there comes into being the garden-site" (Text 2). Here we have an indication that the term buyagu in its most characteristic form can be used at the clearing; that it marks the opposition between the uncut scrub and the land which is being prepared for cultivation. In the second part of this definition text: "When we stand on the boundary belt, on one side (we have) the uncut bush, on the other the garden-site," the native further defines the two terms by putting before us the concrete situation in which we can have one of the opposites on each hand. He then attaches the verbal labels to either side of the picture respectively.

The need of a clear context of situation for certain words is even more obvious in Text 3, where my informant reproduces the sociological as well as the physical context. We have an indication that strangers arriving at a garden would first enquire about the 'garden as a whole' (buyagu) and then about the 'individually owned portions' (bagula). In this text we find also the interesting grammatical feature that one word, and one word only, of the three expressions which we have roughly translated by the English 'garden' can be used verbally, and that this word bagula in its nominal form corresponds to the dynamic conception 'garden as actually cultivated'. In a full commentary on these texts a number of other grammatical points would have to be considered. For instance, the use of the possessive pronoun 'his' in Text 4 correlates a semi-economic, semi-legal claim to the whole garden site on the part of the magician with the meaning of the term buyagu, 'garden as a whole'; while the possessive 'his', referring to the individual owner, has a definite economic meaning and is connected with the synonymous use of the terms bagula and baleko.

We see then that it is impossible to define a word by mere equation. Translation in the sense of exact and exhaustive definition of meaning cannot be done by affixing an English label. Our paradoxical heading 'Translation of Untranslatable Words' is obviously based on a two-fold use of the term 'translate'. If we understand by 'translate' the finding of verbal equivalents in two different languages, this task is impossible, and the Italian adage traduttore, traditore holds good. Translation in the sense of defining a term by ethnographic analysis, that is, by placing it within its context of culture, by putting it within the set of kindred and cognate expressions, by contrasting it with its opposites, by grammatical analysis and above all by a number of well-chosen examples - such translation is feasible 
and is the only correct way of defining the linguistic and cultural character of a word.

Thus, while for practical reasons we have to adopt a certain rough and ready English equivalent for each native term - an equivalent, which functions as an aide-mémoire or rough label, but lays no claims whatever to translate the native term - the real translation is contained in the combined ethnographic and linguistic description, which we have exemplified on the one term buyagu, but which will be found illustrated in the few hundred words cited in the course of Part V.

Take, for instance, the apparently simple case of a technical implement. What do we achieve in the rendering: dayma = 'digging-stick'? A digging-stick is not an implement familiar to an English curate or clerk, even if he happens to be an amateur gardener; he has never seen one, never heard of one, certainly never used one; and even if he knows that peoples exist who break their soil and plant their seed by means of a pointed stick, he still does not understand the term unless he also realizes that the use, the type and the institutional setting of a digging-stick are not the same in every primitive culture. But to the reader the meaning of dayma has become real in that he knows something about its material, shape and size; the technical uses and economic associations, even the values and sentiments which the digging-stick derives from its daily employment and from the part it plays in magic and ceremonial. He is able to place it within the gardening scheme of the Trobriands. All he now needs is a general linguistic description of this word, of its various uses outside gardening, of the set of terms to which it belongs, and of its grammatical characteristics. All this the reader will find in Division VI (\$5).

When we translate kema by 'axe' we have to be even more on our guard, because here we are dealing with an object which also exists and functions in our culture and it is very important not to assimilate the uses, the form and the material of the native implement with those of our own. In so far as the axe is used in gardening, I have described most of its technical functions and also its magical role. And the meaning of the term kema is in the last instance to be derived, not from the substitution of 'axe' for the native word, but from our knowledge of the role which it plays within native culture, here more specifically within native gardening.

All this refers also to such words as kaylepa, 'magical wand,' kaytukwa, 'staff,' kali, 'fence,' tula, 'boundary pole'. In every case the English words merely supply a mnemonic counter, while the meaning of the native terms is given in the descriptions and through linguistic analysis. The word kamkokola I have only 
occasionally translated as 'magical prism, so far is the native word removed from anything which could be rendered by an English equivalent.

Thus, it is only because we know the world of ideas, the various activities, the economic rules of Trobriand gardening that we can grasp the linguistic side of Trobriand agriculture. It is what we might call their context of culture which supplies us with the relevant elements whereby we can translate these words. Translation then becomes rather the placing of linguistic symbols against the cultural background of a society, than the rendering of words by their equivalents in another language.

At times it is necessary in ethnographic description resolutely to go beyond the verbal and even, as we shall see, beyond the conceptual outfit of the natives. The term 'garden,' used throughout my descriptive chapters is, as we know, an example of this, for it does not correspond to any native word. At the same time, I did not use this word in its English meaning, and I trust that, especially towards the end of Volume I, the word 'garden' did not conjure up to the reader a cabbage patch with a border of geraniums or pansies, but that he saw the fence enclosing yam vines, taro, some bananas and a patch of sugar-cane.

In the same way, in speaking about 'agriculture' and 'gardening', about 'labor' or the 'organization of garden work,' about 'leadership' and 'economic dependence,' I was using abstract scientific terms which have no counterpart whatever in native speech, and yet have their meaning defined by facts belonging to Trobriand culture. The ethnographer has constantly to go beyond the native outlook and introduce certain categories which are not native. At the same time, in building up his concepts the ethnographer must never go beyond native facts. The question as to how far certain terminological lacunae, such as the absence of words for 'garden,' 'work', mana (magical force), 'crops', and so on, signify the absence of native concepts, or even the absence of sociological realities, is still to be examined (cf. Div. VII of this Part).

Returning now to the mechanism of translating words, the truth of the principle that only full ethnographic description can serve as a basis for linguistic analysis becomes very evident when we deal with sociological terms.

Kayaku, whether in its more general meaning of 'sociable reunion' or in its narrower sense 'garden council' - the German words gesellschaftliches Beisammensein approach perhaps the native idea more closely - is obviously not at all translated by either English equivalent. What really supplies us with the meaning of this native term is an account of the place which the kayaku occupies in the scheme of gardening: the character of the deliberations, the nature of the business transacted, the legal consequences of the typical harangues, and its ceremonial and magical framework. And this applies to all magical activities, all legal 
acts and all the other sociological and ceremonial phenomena which we have met with in our descriptions. Kayasa, yowota, gabu, and so on such meaning as these words have acquired has come from the description, not from the English label which we affixed to them for the sake of convenience.

We have found that the word kayaku has two different meanings: 'sociable reunion' and 'garden council.' We find a similar phenomenon in the word towosi, which signifies 'garden magician' and 'garden magic' (cf. Part V, Div. VII, $\$ \$ 10-14)$. With the term towosi a formal analysis of its structure will help us to decide which meaning is primary. Such a formal analysis, which by showing certain affinities between the word discussed and others indicates probable derivations, further demonstrates the necessity of giving a special place to the linguistics of gardening over and above mere descriptions of gardening.

Multiplicity of meanings will be found a characteristic of most native words, even of such simple terms as pwaypwaya, 'earth,' 'land,' 'soil,' 'cultivable soil,' 'economically appropriated soil'; valu, 'village,' 'place of human habitation,' 'spot,' 'home'; dakuna, 'stone,' 'coral rock,' 'stony soil'; bagula, 'area under cultivation,' 'individual garden;' or, in a verbal form, 'to garden,' 'to cultivate, or, in a compound adjectival form 'cultivated;' buyagu, 'garden enclosure,' 'garden-site,' 'cultivated land' as opposed to the bush. The detailed analysis of each will convince us beyond doubt that the natives do distinguish between these various meanings. If we were to index the sound we would find that the meaning of pwaypwaya (1) is very definitely laid down by the context in which this word occurs, and distinguished from pwaypwaya (2), pwaypwaya (3), and so on. The meaning is differentiated also by grammatical indices, by the possibility of substituting a synonymous word, by emotional tone and by circumlocutory phrases. In no case have I found any confusion in the mind of the speaker as to which of the several distinct realities he wished to indicate by the use of one homonym or another. The differentiation of meanings can be seen if we take the word, not in isolation, but in conjunction with other words, sometimes with synonyms, sometimes with opposites. Thus, as we shall see the word odila can be synonymous in certain uses with the word yosewo (Div. I, $\$ 17$ ) and then it can again be interchangeable with the word baleko (Div. I, $\$ 15$ ). In the first sense it is antonymous to buyagu, in the second sense to the body of words describing land not put under regular cultivation, words such as dumya, rayboag, kaboma, weyka, valu.

The contention that homonyms - that is, words which have the same sound but different meaning - should not be lumped, should not be represented as one word with a vague confused meaning, but rather as a series of distinguishable linguistic units, will be proved abundantly throughout the following pages. The extreme theoretical importance of doing this cannot be exaggerated. 
Carelessness in dealing with this problem, or probably a wrong theoretical attitude, has been responsible for a great deal of misleading information, sometimes on such extremely important and crucial native words as, for instance, the Melanesian word mana (magical force), kinship terminologies, dogmatic terms relating to such concepts as 'soul,' 'spirit,' 'God', and sociological appellations. To this question we shall still have to return in the course of our theoretical analysis.

We can now lay down a number of points, some theoretical and some practical, which it will be necessary to bear in mind throughout the following analysis:

(1) The mere lexical equation of an English and a native word is necessary for practical convenience but theoretically inadequate. For practical convenience it is necessary because if we used a native term wherever possible an ethnographic book would become an unreadable jumble of native and English, of native technical expressions and sociological concepts sticking out of the grammatical framework of the English language.

(2) At times it becomes necessary to use an English term with Trobriand implications, that is, a word from our own language in a native sense. For an ethnographic description must not merely reproduce the native outlook, still less confine itself to the native linguistic compass, but must operate with general sociological concepts.

(3) The correct translation of each native term, besides its rough and ready labelling, is indispensable. This is achieved by reference to ethnographic descriptions and by the placing of the word in its context of culture, in the context of cognate words and opposites and in the context of appropriate utterances.

(4) The various meanings of a homonym must be kept apart. We have to consider the use of the same sound with several distinct meanings, not as a linguistic vagueness or lumping together or confusion, but as what it really is - a series of distinct uses.

All these considerations simply mean that language is a part, and an essential part at that, of other cultural realities. The language of agriculture enters deeply into the Trobrianders' gardening activities. Unless we know how they make their gardens we can give no sense to their terms, nor meaning to their magical formulae, nor yet develop any interest in their gardening phraseology. Without this cultural foundation linguistics must remain always a house of cards. Equally true is it that without the language the knowledge of any aspect of culture is incomplete.

This is really tantamount to saying, as we did above, that language is a cultural force in its own right. It enters into manual and bodily activities and plays 
a significant part in them, a part sui generis which cannot be replaced, even as it does not replace anything else.

What this part is, however, and in what consists the placing of a word against the context of culture, we still have not defined with any precision. It is obvious that words do not live as labels attached to pieces of cultural reality. Our Trobriand garden is not a sort of botanical show with tags tied on to every bush, implement or activity. It will be our business to reconstruct what speech achieves in a primitive culture, or, for that matter, in a highly developed one.

But first it is necessary to realize that words do not exist in isolation. The figment of a dictionary is as dangerous theoretically as it is useful practically. Words are always used in utterances, and though a significant utterance may sometimes shrink to a single word, this is a limiting case. A one-word sentence, such as a command, 'come,' 'go,' 'rise,' a 'yes' or a 'no,' may under exceptional circumstances be significant through its context of situation only. Usually a oneword sentence will have to be explained by connecting it with utterances which preceded it or which follow. To start with single words - even if such words might occasionally be uttered in isolation - is the wrong procedure. But this I do not need to elaborate; for it is now a commonplace of linguistics that the lowest unit of language is the sentence, not the word. Our task is rather to show that even the sentence is not a self-contained, self-sufficient unit of speech. Exactly as a single word is - save in exceptional circumstances - meaningless, and receives its significance only through the context of other words, so a sentence usually appears in the context of other sentences and has meaning only as a part of a larger significant whole. I think that it is very profitable in linguistics to widen the concept of context so that it embraces not only spoken words but facial expression, gesture, bodily activities, the whole group of people present during an exchange of utterances and the part of the environment on which these people are engaged.

I have spoken several times of the context of cultural reality. By that I mean the material equipment, the activities, interests, moral and aesthetic values with which the words are correlated. I shall now try to show that this context of cultural reality is strictly analogous to the context of speech. Words do not live in a sort of super-dictionary, nor in the ethnographer's notebook. They are used in free speech, they are linked into utterances and these utterances are linked up with the other human activities and the social and material environment. The whole manner which I have adopted for the presentation of my linguistic and ethnographic material brings the concept of context to the fore. Not only have I tried in the definition of technical terms to show how these terms form groups of kindred entities, not only have I tried, by placing the linguistic account against 
an outline of real activities, to give them life and body; but the division of the linguistic material under headings which closely correspond to the chapters of the descriptive account keeps every word, every phrase and every text within its proper context of culture.

[1935] 


\section{Zenon Klemensiewicz}

\section{Translation as a Linguistic Problem}

Translation sparks our interest - increasingly, in recent times - above all in terms of its practical use and efficacy. It is, after all, the linguistic structure which is the means of exchange, the means of mutual transmission and assimilation of the cultural legacy of various nations. Hence its vast significance in artistic and academic literature, its socio-political importance in the propagation of the products of human thought in the most diverse fields. This aspect rises above others in planning a translation project as one of the most crucial factors affecting the cognitive, socio-political, or artistic/aesthetic stance of a given readership.

Naturally, it is a good translation that can serve these important tasks. And here is a new source of interest in translation. What should a good translation be like; what is to be done to create a good translation? Mistakes are pondered, achievements are analyzed, translation techniques are established based on positive and negative experiences, and a normative theory of translation is created as a superstructure for these strategies.

However, we can look at it from another point of view, as a linguistic problem for example, as a particular rendering of the relationship between two languages, or more precisely, two language and style systems. This point of view has not yet been considered. Henryk Elzenberg, Tadeusz Boy-Żeleński, and Wacław Borowy, ${ }^{1}$ whose works contain a great many remarks of value for translation theory, primarily call attention to translation deficiencies - their core and roots. Yet linguistic interpretation broadens the scope for proper evaluation of the difficulties and errors in translation, its desired accomplishments, and the correct approach of the translator. The aim of the present paper is to demonstrate the problematics of translation from this more general linguistic perspective.

The term "translation" has two meanings, which dictionaries outline as: 1. Translating a text from one language into another 2. A text translated into another language. We might phrase it differently: "translation" means either the act of translating, or the product of the translation act.

1 W. Borowy (1890-1950) - Polish historian, literary critic and translator; T. BoyŻeleński (1874-1941) - Polish writer, critic and eminent translator of French literature; H. Elzenberg (1887-1967) - Polish philosopher and critic. [editors' note]. 
As a result of the completed act of translation we have two parallel language products: the basis (the original) and the derivate (the translation). Their juxtaposition or comparison allows us to assess the value of the translation and provides material for constructing normative directions for translation.

From a linguistic stance, on the other hand, it is important and interesting to trace the very process of translation in its course and development, and its circumstances, which are part of the nature of human activity.

Here we have entered the field of fundamental concepts: language, thought, and their relation to reality. Objective reality comprises things, events, and phenomena. Thinking reflects this objective reality by grasping general attributes of things and isolating lasting ties and relationships between particular aspects of reality. Language is the reality of thought, it is in language that the thought becomes realized; language and thought, thought and language are inseparable. The original verbal creation (artistic, academic, journalistic etc.) is the reality of thought that reflects a fragment of the objective reality. What we mean by "thought" is not only various concepts and judgments but also their entire complexes that reflect the intricate structure of the pertinent fragment of reality. We visualize this in Fig. 1.

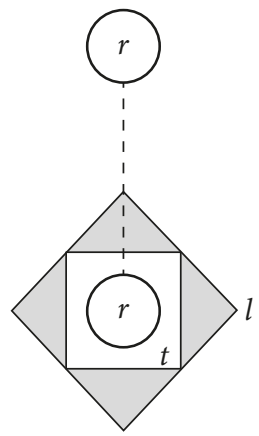

Fig. 1: An original verbal creation

There now emerges a derivative verbal creation, a translation of the original work. We depict their relationship in Fig. 2.

This means that the translator is not dealing directly with reality $(r)$, but with a thought about reality $(t)$ contained in linguistic forms $\left(l_{1}\right)$. The translator aims to communicate the thought about this reality with as much truth as the author of the original, but using different linguistic forms of languages $l_{2}, l_{3}, l_{4}$ etc. This is the essence of the linguistic act of translation. It is not creative - but what is it? 


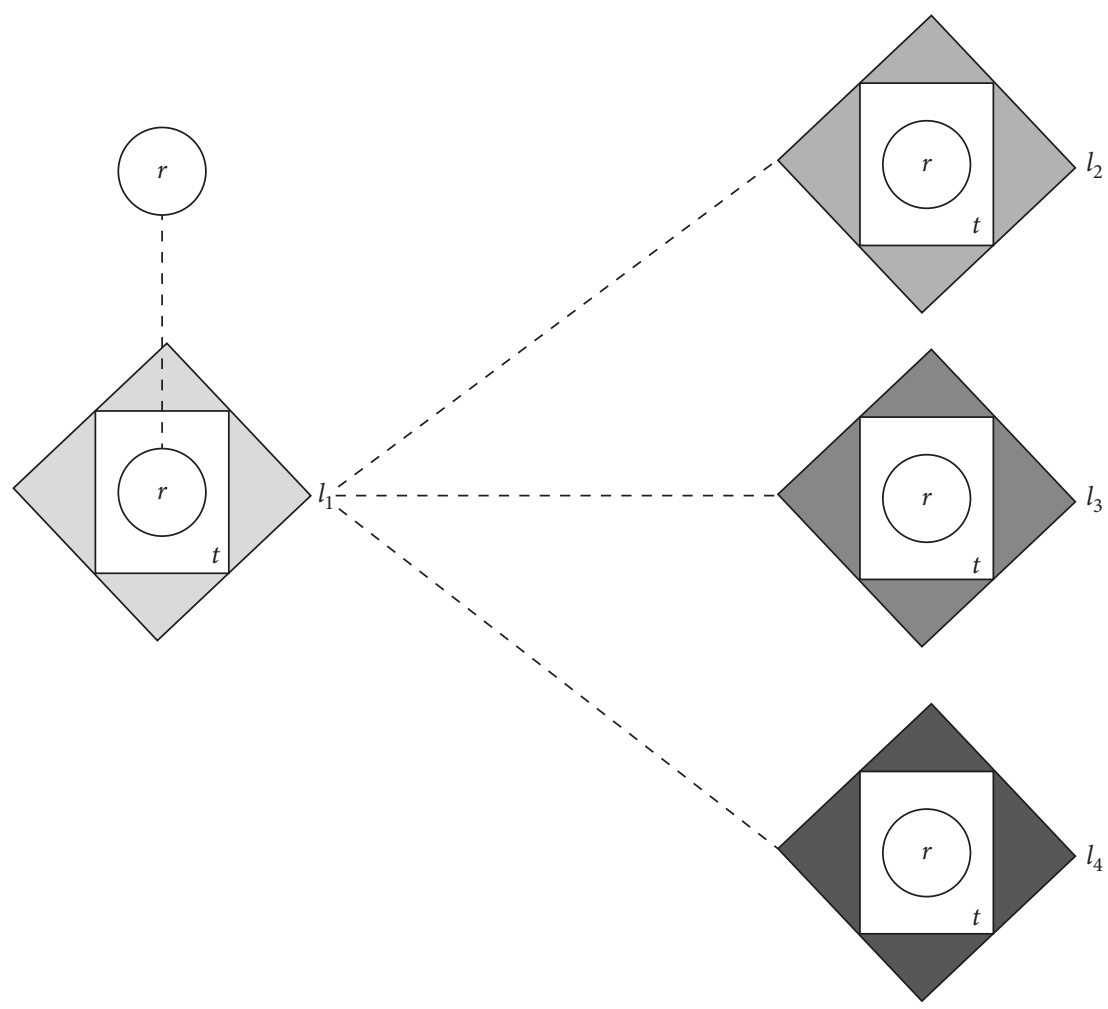

Fig. 2: A derivative verbal creation

We will arrive at an answer to this question at the end of the present discussion, when we have been made conscious of the entire course of translation in terms of linguistic facts and concepts.

For the time being, we shall content ourselves with saying that the act of translation is an instance of contact - with some deliberate exaggeration I would say: confrontation - between two languages: the language of the original $\left(l_{1}\right)$ and the language of the translation $\left(l_{2}, l_{3}, l_{4}\right)$ etc. as ways of rendering the same thought content and - let us add an aspect of major gravity and consequence - a varying degree of emotional or volitional charge.

If we are to realize the importance and consequences of this fact of linguistic confrontation, we must again provide a few linguistic definitions and descriptions. Above all: what is language? Language is a system, and as such, 
it is an internally organized structure, a grammatical and lexical construct, whose parts take a particular shape as conditioned by a certain phonetic system. Language is comprised of words which have a particular phonetic form and are associated with certain meanings which are ascribed to them; these words are arranged into meaningful sets according to the binding directives of syntax. Every national language is a singular and unique grammatical, lexical, and phonetic system; the components of this system are shaped and function according to norms specific to that language alone.

The question arises if the elements of two language systems, although varied and distinct, are somehow parallel and interchangeable, allowing for a simple substitution of an element of language $l_{1}$ for an element of language $l_{2}$. This is not so. The linguistic means of expression of thought, its shades of emotion and volition in a lexico-semantic system, the linguistic means for the grammatical use of words in sentences of various types differ across languages.

The degree of this diversity can also vary. The greatest diversity occurs in the case of typologically different languages. This is not the place to go into detail and provide examples to demonstrate the vast distance of, say, an isolating language such as Chinese, whose monosyllabic units with a lexical function have no suffixes or inflexion, while the same phonetic constructions can change their meaning through a complex system of intonations, and syntactically function through their position in the sentence - from the fusional type of language, such as Polish and other Indo-European languages, where words are inflected by means of suffixes that also express various grammatical categories: case, number, gender, person, mood, tense etc., and designate the syntactic function of the word in the sentence. There are many such different types of languages. Also, the sentence structure may be highly diverse, depending on how its three basic elements, namely subject, predicate, and object, are expressed, which of them is the sentence nucleus, and if the parts of the sentence remain autonomous, or are subject to various kinds of incorporation etc.

But even within the same language type, and moreover, in the same linguistic family, languages differ not only in sound structure, in the phonetics of words which is naturally and readily noticeable to anyone. They also differ in the scope of the lexical/semantic units, i.e. words that correspond in their basic meaning may diverge in their secondary meanings or emotional coloration, or a particular thought content can find linguistic expression in one language but not in the other. Particularly instructive here, and deserving a separate lecture, or even a series of lectures, is the problem of idiomatic phrases, i.e. fossilized phraseological groups whose meaning as a whole goes beyond the meaning of the parts, such as "Indian summer," "throw in the towel," "make tracks," etc. 
Two languages differ in their repertoire and usage of grammar: take for example the aspect, i.e. the difference between perfective and imperfective verbs, such as (in Polish) robić (IMPERF) - zrobić (PERF), pisać (IMPERF) - napisać (PERF), and siadać (IMPERF) - siąść (PERF), so crucial to the Slavic languages, but wholly absent, for instance, in German and French, whose nouns, in turn are definite or indefinite as indicated by articles der, die, das, ein, eine, ein, le, la, or une, which the Slavic languages are missing. Let us consider the usefulness of uninflected participles in building participle clauses, such as "I sat there reading," "I fell ill having left Kraków," and the impossibility of such constructions in the German language, for example. Then let us note the relative freedom in Polish word order, and its rigidity for example in German, which has a decisive effect on the way sentences are constructed, on the image of sentences. And there are many such systemic discrepancies and incompatibilities. They occur even in languages that are most closely related, e.g. two Slavic languages.

Therefore, translation cannot be conceived in the literal sense of the term, namely, that an element of thought content $X$ shaped linguistically into a form $A$ is being set free from $A$, released, extracted from it, transferred, reshaped into the precisely equivalence form $A^{\prime}$, so that as a result, $X / A$ might be equal to $X / A^{\prime}$. To some extent this correspondence exists, but there always remains a zone of some discrepancy, and the more the two languages are systemically remote, the wider this zone becomes, while the field of correspondence contracts.

This is a theoretical, linguistic rationalization of an old practical warning not to translate literally, and thus not to do things "Chinese-style," according to the anecdote of the Chinese man who, in order to paint a fish correctly, was above all intent on counting its scales. In this kind of translation the syntax, intonation, and euphony vanish, leaving only words with their general "dictionary" meaning - what gets lost is their meaning in their context, hence the national language is cruelly mangled.

This is not, however, the end of the difficulties that arise with the divergence of the language systems of the original and the translation. We must also recognize that the language of the original, i.e. whatever national language, is not a homogenous whole. There is, of course, the standard language which is taught in schools, basically used by the working intelligentsia ${ }^{2}$ (though not exclusively),

2 After the Second World War, a new kind of intelligentsia emerged in Poland, recruited mainly from workers and peasants. It was then that the term "working intelligentsia" was coined, which in fact was the equivalent of the English concept of the white-collar worker. The term "working intelligentsia" belonged to the language of the Communist state propaganda. [editors' note]. 
serving as the official language, described in grammar books, recorded in dictionaries, and regarded as representative in contacts with foreigners. There are also the regional languages, country dialects, which are geographically diverse, as well as city dialects. It is the works written in the standard language that get translated most often. But this, too, is not homogenous. The standard language in its conversational function, in its spoken (colloquial) function, differs from its written, literary variety. The vocabulary and sentence structure in free chit-chat and in a published work are different. Also, literary language may vary, depending on what needs it is meant to serve and in what particular field it functions.

Because the material of translation is, above all, literary language, we should pause for a moment to make a somewhat closer inspection of its functional varieties, which have enormous significance in the act of translation.

Let us begin with the varieties which we shall call the artistic language. Its function is to create a vivid and evocative image of reality by focusing the reader's imagination on an internal experience of the events depicted in language in as tangible a way as possible, on becoming acquainted with the characters involved, on delving into other people's emotions and aspirations, on exploring the artist's ideology contained in the work. This language has a distinct vocabulary, an abundance of concrete expressions that give it a visual and sensory impact in presenting reality. It also contains a rich vocabulary of internal states, feelings, moods, aspirations, and desires. It commands a wide range of synonyms, to express subtle shades of meaning and delicate variations of emotional coloring. Artistic language permits archaisms, dialectal and regional expressions, as long as they serve the intended style. It permits neologisms, and the use of old words in new meanings. Sentences are narrative/descriptive; there are many nominal sentences, elliptical and anacoluthic structures, due to their emotional content and power of expression, many syntactical structures found in dialogue, as well as mixed structures, where dialogue interferes with description or narrative, narrative with description, especially in free indirect speech.

Things are different when it comes to academic language. Its function is to make true statements about reality, achieved through faithful and precise description of purposefully observed facts and processes, and an explanation of these facts and processes contained in answering the question of why they have occurred, and why in such a form. There are many different sciences, but each of their languages is significantly marked with the importance of reasoning as the essential scientific procedure, i.e. the gaining of new knowledge based on the givens. Thus, the vocabulary of academic language strives toward unambiguity, toward a terminology that ensures communication and prevents multiple understandings of the same subject of investigation. In this terminology we are 
struck by the presence of foreign expressions, "learned" vocabulary, artificial to a large degree, and built on Greek and Latin roots. Academic vocabulary avoids emotional coloration, which can affect the precision of meaning; it also avoids synonyms, which blur the boundaries between sharp definitions. It does not use archaisms or dialects for style. There are, however, many neologisms, which are necessary in naming new results in the progressive cognitive investigation of reality. The syntax of academic language is also particular; its main aim is unambiguity, clarity, and precision. As such, academic sentences have the tendency to aim for exactitude, to veer away from syntactic structures loaded with emotion, preferring to use sentences that precisely express various links of the reasoning process, to stress the cognitive relations of connectivity and dependency between these links within one, often multiple-clause sentence, or between particular sentences in a tightly wrought context.

There remains the third main variety of literary language, the mixed one, of which some elements can influence the emotions and imagination of the reader, while others seek to increase the reader's knowledge with depictions ofthe life of society and the practice of human behaviour within it. This variant is applied widely, from political speeches, sermons, and journalism, to administration announcements or official documents.

Finally, we should recall the facultative professional and social varieties of language, e.g. hunting, school, or thieves' lingos.

It is evident that depending on what variety of the general national language the original belongs to, the tasks set before the translator will vary, and so will the difficulty of the translation. The greatest difficulty will indisputably be found in works written in artistic language, which are the overwhelming majority of translations. In these we find not only the special complex vocabulary and unusual syntax that we mentioned just moments ago. The difficulty increases when we acknowledge that a significant attribute of the artistic work is its being multi-systemic in terms of language and style: we have narrative language and the language of description, the language of colloquial dialogue, in which we find the peculiar linguistic features of the participants, varying due to age, temperament, gender, education, profession, class, and thus, dialects, provincial twangs, technical vocabularies, individual qualities, vulgarities, archaisms, and neologisms. A certain structural multiplicity of levels also appears in syntax. Various peculiarities and divergences from the norm of the official language may meet, alternately appear, and intermingle in the same work. They are meant to serve a particular stylistic function, which they can do only if they are authentic, i.e. if they truly exist in the language of a certain epoch, in the language of particular social circles, in the language of the people whom the writer of the original introduces into his artistic vision. 
We might add that authors also have their individual linguistic attributes, conditioned by their personal characteristics, epoch, education, class and ideological standing, the intellectual and emotional atmosphere in which their writing matures and bears fruit.

We shall only touch upon one more possible peculiarity of the artistic work, one which is expressed outside of its intellectual content and which supports its emotional, expressive and impressive charge, yet remains an independent source of aesthetic impact: the phonetic shape of its verse forms, conditioned by the prosodic resources of a given language. These include stress, vowel length, and intonation; within the framework of grammatical norms and lexical resources they permit certain verse forms, rhythmic patterns, phonological words, and stanzaic structures. Thanks to them the demands of euphony are met and onomatopoeic effects achieved.

I shall remind the reader that all these means of expression are contained in the original language in a system that is internally and organically interconnected, where each grammatical, lexical, and stylistic element has a particular function, functional capability and efficiency. I reiterate: this system cannot be replicated beyond a given language. The thought content as well as emotional and volitional load are enmeshed in the language of the original. The translator's role is to render it without diminishing its communicative or expressive-impressive power, containing it in the forms of another language system, which has different means of expression at its disposal.

Is this at all possible? And if so, to what extent? Here we come to an issue that is crucial from both practical and theoretical standpoint, including linguistic theory - the limits of translation, or translatability.

The concept and demand of "fidelity," conceived in the sense of literalness, has been sufficiently compromised in translation practice, and on certain philosophical grounds it has led to doubts as to the very possibility of full linguistic expression of thoughts or correct translation. Instead, another concept of the relation between the translation and the original has been formulated: the concept of adequacy or completeness.

The essence of adequacy can be encapsulated in the following way. The original should be conceived as a system, and not as the sum of its parts, as an organic whole, and not as a mechanical set of elements. Every element of this system, every part of the whole is given a particular communicative and stylistic function intended by the author. In the whole work, in its every section, in its every chapter, and in its every sentence - in a word, in all its dimensions - the function of the parts is executed against the backdrop of the whole, there is a constant interplay of the parts and the whole. This is the source of the work's 
effect on the reader, at the level of both the core of the content, the significance of the work, and the ideological, emotional, aesthetic charge. The task of the translation is not to copy, not to recreate, not to speak of converting the elements and structures of the original, the words, sentences, prosodic units, visual language etc., but to capture their functions and to replace the original with those elements and structures of the target language which are, as far as possible, substitutes and equivalents with the same functional capacity, suitability, and efficacy, and in this, precisely, resides their adequacy, commensurability, equality of value.

In some cases, this will entail equating the elements of the original and the translation: word for word, form for form, sentence for sentence, stylistic device for identical stylistic device, verse structure for identical verse structure and so on. In others it will mean only approximating the elements differing in form and/or meaning, though functioning identically toward the aim intended and marked out by the original writer. This may be reduced to the following formula:

$$
\begin{gathered}
a\left(l_{1}\right) \text { does not equal } a\left(l_{2}\right) \\
\text { but } \\
a\left(l_{1}\right) \text { equals } X\left(l_{2}\right)^{f=a\left(l_{1}\right)}
\end{gathered}
$$

This means that the work in the language of the translation is not a faithful and slavish reflection, a repetition of the grammatico-lexical and stylistic elements of the work in the original language; it is a carefully chosen construct of grammatico-lexical and stylistic elements in the language of the translation that can faithfully and effectively render the work's impact on the reader's psyche the author intended.

When choosing elements in the target language to render the original, one needs to bear in mind that they are not the aim of translation, they are only a means to achieving this aim: such a rendering of the whole original in the translation that will affect the reader in the same or most similar fashion as the original affected the native speaker of the language in which it was written. Sometimes, this does not occur without sacrifices, which are the inevitable effect of the confrontation of two language systems that differ to various extents. The translator's efforts should be to limit this sacrifice to an unavoidable and justified minimum.

A theoretical outline and formulation of the concept of adequacy is something new: but we must admit that this criterion has long since been met in the work of great translators. It suffices, for example, to recall the stance of Cicero, who reportedly said of his translations of Demosthenes's speeches that he rendered them not as a translator, but as an orator, giving his readers an account of the significance and the gravity of the words, and not their number. 
The degree of difficulty in meeting the demands of adequacy can vary. It is easier to achieve in academic language, owing to the properties discussed above. There are no archaisms or dialects, there are no inventive stylistic devices, there is no emotional factor, no individual hallmarks; the everyday standard language reigns, along with its intellectual content. There must be fidelity in translating the terminology and the flow of reasoning, but the latter does not suffer even if the translator departs from the syntactic structures of the original, dividing a long multipartite complex sentence, for example, into two shorter ones or more, adhering to the syntactic directives of the target language (e.g. in a translation from German).

The difficulties multiply in works composed in artistic language. Here the point is not only to communicate the specific content of the story and the description, not only to remain true to the vision, but also to ensure its effect on emotions, imagination, and the reader's volition. Here every shade of meaning, every delicate shade of emotional coloring in a word or sentence has its value which must not be underestimated. Here an archaism can characterize a person or an epoch, a dialect or technical term is a crucial factor in the artistic truth of a character or the local and social color. Here visual language - such as it is, and not otherwise - is a necessary means to render the intended evocative vision. Here the author's individual style must be respected, for it is what makes the writer distinctive and forges his stance in writing. Could one translate Proust, for instance, by reworking his characteristic complex multi-clause sentences into a series of shorter ones? In poetry the difficulties only increase, owing to the necessity of preserving the rhythmic and euphonic qualities of the original.

Are there any works that cannot be adequately translated? I believe that there are. These are works shaped in such an individual linguistic form that their translation is, for various reasons, impossible. Let us take, for example, Kazimierz Tetmajer's In Rocky Podhale; ${ }^{3}$ a translation of this work into standard language would deprive it of all the truth and charm of the people living in a distinct and peculiar land; a translation into a highland dialect of the target language, in turn, would result in an unbearable falsification of reality, caused by the clash between the particular and geographically defined linguistic framework and the realities of the life of Polish Tatra highlanders, which differ from those of inhabitants of the mountains who speak other languages. The same applies to highly archaized

3 Kazimierz Przerwa-Tetmajer (1865-1940) - Polish poet and novelist, a member of Young Poland Movement. His brilliant collection of sketches and tales In Rocky Podhale or Tales of the Tatras (1903-10) is written almost entirely in the local dialect (see: https://www.britannica.com/biography/Kazimierz-Tetmajer) [editors' note]. 
works, such as Władysław J. Dobrowolski’s Hawk's Grief or Maria BechczycRudnicka's "The Twenty Lambs of a Painter from Ravenna." Also untranslatable are Tuwim's "Słopiewnie" [Word-songs] ${ }^{4}$, though one might try to imitate them. One might say that adequate translation is possible for any work created in any standard national spoken or written language of a given epoch, which in no way precludes the use of archaisms, dialects, and other departures from the commonly accepted norm, as long as their use is stylistically motivated and systemically conditioned; where there is not yet a national language, a folk dialect can serve its function. This limitation is no threat to culture; the vast majority of writing, including some of the most outstanding works, are written in the standard national language, and these can be assimilated through adequate translation and made available to other nations. Valuable works that do not meet this condition are few in number; a person who desires to know them must do so in the original language. In any event, the finest translation could never replace all the virtues of coming in contact with the original.

From the point of view of adequacy, the translator must demonstrate the ability to accurately capture the functional value of the original's elements, using a lively, insightful, and sensitive analysis of the relationship between its parts and the whole. This is a very rigid demand.

To meet them, the translator must posses a fair number of qualities and assets, of which many have surely been already mentioned in different contexts, so I shall only give a general outline of them now. It is clear that the translator must have a perfect command of the language into which he is translating, most often the translator's native tongue, as well as the language of the original. We can be sure that neither an automatized familiarity with grammar and vocabulary nor a conversational fluency suffices in this context. Here we need a conscious, objective, reflective approach to matters of language; at least basic linguistic training would be recommended to sharpen the translator's attention, and direct an inquisitive gaze toward phenomena which often go unnoticed or undervalued.

4 W. J. Dobrowolski's (1906-1978) book Jastrzębia boleść (1938) is a "Masovian novel" written in a stylized medieval Latin. M. Becherzyc-Rudnicka's (1888-1982) story Malerza raweńskiego owieczek dwanadzieście (1937), modeled on 16th-century Italian legends was written in a language stylized as 15th-century Polish. Julian Tuwim's (1894-1953) poetry collection Słopiewnie (1921) was a language experiment based on the sound of Slavonic languages [editors' note]. 
The translator must know the reality the author picures in the original work: the people, their customs and habits, the culture, the country, its landscapes and its nature, in a word - the realities, and only this will allow the translator to fully understand the text and avoid its misinterpretation and an erroneous selection of lexico-semantic equivalents.

The translator must consciously avoid an insincere, inaccurate standpoint toward the original, which might result in seeing what was not in the author's original intention, or not perceiving what the author did in fact intend, thus misrepresenting the author for a particular reason deriving from a subjective ideological, political, aesthetic, literary-critical etc. stance. There are, after all, translations that are formally correct, free of glaring grammatical and stylistic mistakes or missteps that disrupt the reading process, but which reveal misrepresentations, distortions, or falsifications when compared more closely with the original texts.

But all these important, necessary, and rare assets are insufficient if one basic condition is unfulfilled. This is the creative attitude of the translator. As we have seen, the translator's achievement is determined by the ability to use the resources of the language of translation according to their functional equivalence with the linguistic resources used by the author of the original. The translator must deeply and independently experience, consider, and intuit the content and effect of the original, powerfully and subtly delve into and incarnate himself in the reality the author of the original experienced directly, while the translator sees it and apprehends it through the author's words. The translator must take on this standpoint in order to liberate the content and effect of the original from the unique forms of one language and bring it to life, configure it in the distinct and individual forms of another language. Neither knowledge of his own language and the original language, nor even long and in-depth experience will help if it is mechanically applied. What is necessary is the creative act; another person's borrowed idea must be rendered in the translator's own and original way, without trimming the content or the expressive-impressive effect of the original. And here we find one important warning and vital caution: the choice of author and work to translate must consider an affinity, a kinship, a congeniality between the original author and the translator.

Thus, too, we have a response to the question posed at the beginning of this paper concerning the role of the process of translation. Neither reproduction, nor transformation, but co-creation. Quod erat demonstrandum.

And if it has been even partly successful, this paper has, apart from showing the linguistic problematics of translation, served a second role I assigned for 
it: it was to be an expression of both great respect the linguist has for and great demands he sets before the translators, while fully understanding the enormous linguistic and education impact of translation on readers, and the historically proven and highly valued influence of translation as one of the driving forces in the development of the national language.

$[1954 / 1955]$

Translated by Soren Gauger 



\section{Olgierd Wojtasiewicz}

\section{Introduction to a Theory of Translation}

\section{Definitions}

Let us note that there is no precise definition of translation, either as a certain operation or as its result (the word rendering generally pertains to the outcome of an act of translation, not the act itself; this study adheres to this convention). ${ }^{1}$ Lexical definitions in various dictionaries cover this matter in a very superficial fashion. For example, let us look at several definitions from some well-known dictionaries of various languages, quoted in the original, as it would be methodologically inadmissible to use a translation to examine the definition of translation, thus using a particular operation in defining the this very operation. This is why the English renderings provided in brackets are only there to guide the reader unfamiliar with a given foreign language, and are not binding in terms of the argument; identifying whatever imprecisions they may exhibit should not undermine the conclusions we go on to draw. For the same reason, we limit ourselves to the more widely-known European languages, and shall not be supplying definitions from Chinese dictionaries, for instance, although the Chinese language will have a significant role to play in examples cited further on. Quoting the original would be futile, while supplying only the translation is impossible for the above-mentioned methodological reasons.

Polish:

Tłumaczyć - z jednego języka przekładać na drugi mowę czyją lub pismo ${ }^{2}$ [to render someone's speech or writing from one language into another]. Przełożyć, przekładać - ...3. = przetłumaczyć.

\section{Russian:}

Perevod: 1. Deystvie po glag. perevesti-perevodit'... 2. Tekst (ili ustnaya rech'), perevedennyy s kakogo-n. yazyka na drugoy yazyk.

Perevesti: 6. Perelozhit's odnogo yazyka na drugoy, Vyrazit' chto-n. (kakoy-n. tekst, ustnuyu rech') sredstvami drugogo yazyka.

1 The word rendering is used here as an equivalent of the Polish przekład, a synonym of tłumaczenie - they both mean translation [editors' note].

2 Słownik języka polskiego, Vol. 7 (Warsaw 1919), p. 69 and Vol. 5 (Warsaw 1912), p. 128. 
Perelozhit': 6. Perevesti na drugoy yazyk (ustar.) [to translate from one language into another, express something (a text or oral statement) through another language]. ${ }^{3}$

We have supplied only partial and approximate translations of the definitions. We should note that perelozhit' and perevesti are used to define each other in the above extracts from Ushakov's dictionary.

English:

Translate: 1. Express the sense of (word, sentence, book) in or into another language... ${ }^{4}$

French:

Traduction... Action de traduire, de transposer dans une autre langue... [Translation... the act of translating, of transposing into another language]. ${ }^{5}$

German:

Übersetzen, Übersetzung, Wiedergabe eines sprachgestalteten Sinngehalts mit den Ausdruckmitteln einer anderen Sprache... ${ }^{6}$ [Translate, translation - rendering the content formulated in one language using the means of expression of another language].

The above examples demonstrate that an intuitive notion of the concept of translation is widespread, even prevalent, which results in the absence of a felt need for a definition. We most frequently find attempts to formulate a definition by a circuitous route: not by establishing what is central to the act of translating, but rather by indicating what conditions should be fulfilled by its result. In these cases, "fidelity" is the most frequently raised and most strongly emphasized requirement, though it remains imprecise. Many negative statements are tied to this concept: that fidelity cannot be reconciled with the aesthetic demands of literary translation etc. It should not surprise us that circuitous attempts to define the term provide no concrete results to serve as the basis for further discussion. ${ }^{7}$

Bearing in mind, however, how much confusion the use of intuitive concepts has caused in logic and the basics of mathematics, as well as other disciplines such as physics, it would be good to limit the intuitive nature of the concepts we introduce and use.

While it may be difficult in the humanities to achieve the precision found in the hard sciences, this is no reason why the humanities should not make broad

3 Tolkoviy Slovar Russkovo Yazyka, Vol. III, eds. B. M. Volin and Prof. D. N. Ushakov.

4 The Concise Oxford Dictionary of Current English, 4th edition (Oxford 1950), p. 1357.

5 Larousse du XX-e siècle, Vol. 6 (Paris 1933).

6 Der Grosse Herder, Vol. 11 (Freiburg 1935).

7 In the author's opinion, one of the finest definitions of translation has been given by Alexander Fraser Tytler in his treatise On the Principles of Translation as far back as 1791 (London: Everyman's Library Edition, 1907), pp. 8-9. 
use of the experience of other fields, which employ greater precision and, just as importantly, use other methods. Thus, it seems appropriate to begin with a definition of translation that is annotated where needed with additional explanations; these explanations turn out to be indispensable, as the imprecise concepts of the humanities can mean that a definition will include terms that themselves require definition or, at least, clarification. I propose the following definition:

The act of translation consists in formulating an equivalent in one language of a statement previously formulated in another language.

Explanations:

1. The stress falls on the act of translating. The result ("an equivalent in one language") corresponds to what we generally call the "translation," in the sense of the action's result (and thus, a certain kind of "text").

2. The length of the original text plays no fundamental role. This can be a multivolume work or a single word. In very short texts, or single words, we ought to bear in mind that their brevity might cause the text to be polysemous, and thus impossible to translate in an unambiguous fashion. Sometimes, however, the context facilitates an unambiguous translation of even a one-word text.

3. The above-cited lexical definitions do not, of course, cover the concept of language, which is also apprehended intuitively. This is insufficient for our study.

By "language" we mean a system of signals people use to communicate in space and in time. In principle, a moment of time is always a factor, but for practical purposes we can ignore it when the passage of time between the sending and the reception of a signal plays no essential role (in direct conversation, with traffic signals, in telephone or radio communication etc.). In certain cases, when we are dealing with recorded signals, such as an encoded message, the circuit of sender and recipient can be restricted to one and the same person (a code created for the sole purposes of the writer).

We understand the notion of "signal" quite broadly here, somewhat unlike its colloquial sense, as the material aspect of an expression (to borrow Henryk Greniewski's terminology), ${ }^{8}$ and thus, a spoken or written text (regardless of its length), a road sign, an audio or optical signal in a narrower sense, a chess notation, a map, etc.

8 Henryk Greniewski (1903-1972) - Polish mathematician, logician and computer scientist, pioneer of computer technology in Poland, author of Cybernetics without Mathematics (New York 1960) [editors' note]. 
The notion that the sender ascribes certain signals to certain states of mind (or the nervous system) and that the recipient ascribes certain states of mind to certain signals plays a vital role here. It seems that this notion should be seen as primary in language theory - or at least in some of its forms.

Interpreting language as a system of signals (or signs) is familiar to linguists as well. Depending on the circumstances, a signal can serve a purely communicative function, or a communicative-expressive one (if it expresses the sender's subjective state).

The next important step is distinguishing between natural and artificial languages. Natural languages have developed spontaneously, through evolution, and serve the general communication needs of ethnic groups (nations or nationalities), and, at least in the initial phases of their development, they are closely tied to speech (what is meant here is those pictorial languages which, for various reasons, have departed from phonetic languages over time, such as "literary" Chinese, or wen-yen, Medieval Latin, etc.). Artificial languages are those which are created by adopting certain signals "all at once;" at the same time, these are usually specialist languages pertaining to fairly narrow fields, i.e. serve to describe a fairly narrow section of reality (e.g. the language of mathematical symbols, chemical formulae, road signs, various types of maps etc.), and as such, they cannot satisfy "the general communication needs of ethnic groups." In terms of this last point, the artificial languages that attempt to imitate the universality of natural languages (e.g. Esperanto) would make an exception. They differ from natural languages chiefly in that they are created in a short period of time by one person or several people, while natural languages are created over the course of long and anonymous development. It should be added that artificial languages are generally far more "codified" than natural languages, whose systems typically contain gaps that permit a certain amount of freedom in using the signals. Moreover, the rules that apply in natural languages are created ex post, through the codification of language habits, already conventionalized or in the course of conventionalization, while the rules that apply in artificial languages are created right away along with the language itself.

From the point of view of translation theory, there are four possible translation combinations: from a natural language into a natural one, from a natural language into an artificial one, from an artificial language into a natural one, and from an artificial language into an artificial one. This paper will address only translation between two natural languages. This is in accordance with the intuitive understanding of the notion of translation, also shared by the above-quoted lexical definitions, wherein "language" undoubtedly refers to "natural language." In this combination the problems are most difficult to grasp precisely because 
of the above-mentioned "slack" in codification (or formalization) of natural languages, which, in turn, precludes the formalization of the act of translation.

In terms of the remaining combinations, the matter is easier to solve, bearing in mind that the specific cases need to be analyzed. As a general rule, it is impossible to translate from a natural language into a specialized artificial one (i.e. not the Esperanto type), because the latter is only capable of describing precisely defined aspects of reality. Translating a sentence as simple as "It rained in Warsaw yesterday" into the language of chemical formulae is not possible, of course. Translating from a natural language into an artificial language of the Esperanto type is partially possible (cf. the concept of partial translatability below), but is complicated by the fact that the vocabulary and idioms of such artificial languages are generally far more limited than the vocabularies of natural languages, while expanding the vocabularies of these artificial languages (which would seem to contradict the raison d'être of these languages) would lead to the creation of complex borderline cases, in which an artificial language would begin to turn into a natural language.

Translation from an artificial language into a natural language is essentially possible, which is not to say that it is practical: a detailed natural-language description of a map of Poland from a school atlas, taking into account all the geographical features, including the delineation of the borders, the course of rivers and transportation lines, the contour lines, the location of cities and towns, mountain peaks, and lakes, the spatial relationships between various points (distances and directions according to points of the compass) etc. would surely fill a sizeable volume, while not giving the reader any mental picture. Translation between two artificial languages depends on whether these languages describe the same aspects of reality. If they do, total translatability may occur (e.g. in the translation of a mathematical decimal notation into binary and vice versa, or the translation of one system of logic symbols into another and the reverse). If they do not, however, total untranslatability may take place (e.g. the translation of chemical formulae into chess notation and the reverse). The next point addresses the existence of mixed languages. These are natural languages that, to some degree, make use of artificial languages. The first variant would be the languages of many scientific works, where, in the midst of a natural language, e.g. Polish, we find segments of an artificial language, such as mathematical notation, chemical formulae, artificially created medical terminology, botanical or zoological terminology (e.g. based on the Linnaean system) etc.

The second variant includes examples where a text originally formulated in a natural language, e.g. Polish, is transmitted or recorded in an artificial language, e.g. Morse code (in the form of light, audio, or telegraph signals), or in Braille. 
In the first variant the matter is simple, as we can easily divide the text into sections written in a natural language and an artificial language (or languages, if, for example, in a medical paper we are dealing with both medical terminology and chemical formulae). In the second variant, the matter is somewhat more complicated, though it does seem that, given the original formulation of the text in a natural language, we ought to give it pride of place, and ascribe to the artificial language merely a supporting role, all the more so in that the whole thing could be easily back-translated into the natural language in which it was originally formulated. (This is a certain simplification. In a more detailed analysis we can, and probably should, accept that, for example, reading out loud in Polish a text written in Polish means translating from the written Polish into the phonetic Polish. More complicated examples might be singing the words of a text supplied with musical notation, or reading a Polish text out loud in English etc. In this last case we are dealing simultaneously with translation in the common sense and with a transposition of a visual language into a phonetic one, which takes us beyond the limits of our present discussion).

In effect, mixed languages can be omitted in our study, as every mixed language can be reduced to parts drawn from natural and artificial languages. (The mixed languages group includes also the languages of macaronic texts, combining elements of various natural languages).

4. The above definition seems to cohere with the intuitive concept of translation, understood rather superficially. It also seems that the intuitive interpretation begins to fail us when we attempt to clarify the concept of "equivalent" in narrowing our definition. In what case ought we to acknowledge (phonetic or written) text $b$ in language $B$ as the equivalent of text $a$ in language $A$ ? To answer this question, we must introduce a supplementary definition, which in turn will require some explanation:

a. Text $b$ in language $B$ is the equivalent of text $a$ in language $A$ if text $b$ evokes the same reaction (set of associations) in the receiver as text $a$.

b. It makes little difference if the receiver is the same person (familiar with both languages) or different people.

c. The phrase "the same reaction (set of associations)" raises the most reservations and doubts. We might object that even one text (in one and the same language) evokes various reactions in different people, citing examples of various interpretations of literary texts by various people (well-known "varying" or "new" readings of texts by critics, directors, and actors), even in cases when a text does not contain passages that are debatable from the philological point of view. We might take a step further and 
cite equally familiar cases where one and the same text (e.g. a literary work, a private letter with no literary qualities etc.) evokes different responses in the same person at different moments, e.g. once read or heard at a young age, and then again at a mature or elderly age; we might thus claim that every set of associations evoked in the receiver by a given text is unique and that the above supplementary definition is worthless.

We might also cite some new formulations in the field of logic and cybernetics, i.e. the concept of relatively isolated systems. ${ }^{9}$ According to this concept, the human nervous system is a relatively isolated system, the nervous receptors being its input points and the brain (or its parts) its output point (future brain research may introduce corrections here, though these will be immaterial as far as the structure of a relatively isolated system is concerned). Effectors will not be taken into consideration here, as what interests us is the "mental" response, a certain state of the centers of the central nervous system, and not the possible further consequences, such as gestures, verbal responses, changes in blood circulation etc. Apprehending a text means creating distinguishable states in some input points. In the case of the phonetic text, the distinguishable states occur in the inputs known as aural receptors; analogously, when it comes to a written text it is the visual receptors that come into play, while with a three-dimensional text (e.g. one written in Braille), we are dealing with tactile receptors. Each output state is unequivocally defined by all present and past input states, including those which would not seem to be connected with a given text (or even any text at all). There are no sign systems based on the sense of taste, and thus there are no texts that function through taste receptors; this does not mean, however, that particular taste experiences (i.e. past distinguishable states in some input points of taste sensors) have no role to play in our response to some texts.

Given the above, we can clearly see that there cannot be two human nervous systems, or in simpler terms, there cannot be two people in whom all past and present input states were identical, if only because their nervous systems would have had to be located in exactly the same point in space. From this we also see that we cannot speak in the strict sense of the same reactions of two different people to the same text, even if it is in the same language. ${ }^{10}$

My references to concepts derived from cybernetics are probably not indispensable, but they strike me as interesting insofar as they provide an example of

9 Cf. H. Greniewski, Elementy logiki indukcji (Warsaw 1955).

10 Cf. also: S. Bogusławski, H. Greniewski, J. Szapiro, “Dialogi o cybernetyce," Myśl Filozoficzna 1954, No. 4. 
yet another "semantic interpretation" of the notion of relatively isolated systems, thus demonstrating the fecundity of this concept.

On the other hand, we face the irrefutable fact that languages do fulfill their communicative function, and as such, there is no denying that the responses evoked by a given text in different people can be quite similar, if not identical. The degree of similarity is doubtless higher when it comes to scientific prose than in the case of poetry, but in any case, it is quite considerable. Our supplementary definition thus retains its validity, though perhaps with the added reservation that the phrase "the same" ought not to be understood as defining two things that are identical sensu stricto, but is to be interpreted as signifying a very high degree of similarity.

We are dealing with a similar case in translation, or when there is a similarity in responses evoked, on the one hand, by the original, and on the other, by the translation. Despite all possible reservations, there is no denying that people largely use translation as a way of extending the communicative function of one language or another.

Here, however, we ought to make a rather important reservation: we are not concerning ourselves with purely individual reactions (or associations). As such, we shall not take into account, for instance, a man who compulsively associates the French word genou (but not the Polish kolano or the English knee, etc.) with the legs of his French governess, nor someone for whom the sight of a rose, or its pictorial representation, or the word "rose" read or heard in any language he knows, evokes a memory of eating chicken broth on a veranda. (The former example is more tightly bound with linguistic matters, as the reaction occurs based on the word, i.e. an element of language. Moreover, such a person will respond to the French text differently than to other languages and thus, in terms of the present discussion, he will have a different response to the French original and to its Polish translation, but the same response to an English original, for example, and its Polish translation. In the latter example, the stubborn association will come regardless of the language, and even as a reaction to nonlinguistic stimuli, e.g. in seeing illustrations, paintings, a film, etc.).

Leaving aside purely individual responses, triggered in every person at least in a minimal degree (this arises from the fact that there are no two people who would respond to a thing in an entirely identical fashion), takes us to accepting the concept of a certain type of group reaction, i.e. a type of reaction shared by members of a certain group. In theory this is a simplification (or, as some might prefer, a fiction), but it is a simplification confirmed by observable facts which demonstrate that languages do serve a communicative function, albeit with varying degrees of success. Since the subject of our interest is translation, 
we shall focus on group reactions characteristic of specific language groups. We must however notice it may be necessary to acknowledge within language groups also some groups distinguished according to different criteria, such as the level of education. In some cases (e.g. in academic texts) a shared reaction type conditioned, for example, by belonging to the same professional group yet different linguistic groups might prove more pivotal than a shared reaction type conditioned by belonging to the same linguistic group and different professional groups. And thus, we arrive at average types of reactions found in various social groups, allowing us to achieve a greater objectification of these reactions; their objective or intersubjective nature is, after all, a condition for communication between people.

To illustrate the foregoing, here are two examples of different reactions that arise from belonging to various linguistic groups.

In translating a poem by Nicolás Guillén about Cuba, the poet's native island, Zofia Szleyenowa ${ }^{11}$ realized at one point that the passages about God would evoke unintentionally humorous associations in the Polish reader, given the famous Polish expression Jak Kuba Bogu, tak Bóg Kubie. ${ }^{12}$ This association would probably not arise with the translation of this poem into any other language, but in the Polish translation it asserted itself so overpoweringly, contrasting with the general tone of the work, that it was necessary to replace the word "Cuba" with "island."

When translating the most common Christian prayer, "The Lord's Prayer," into the Inuit language, it was necessary to substitute "our daily bread" with a phrase that means "our daily fish" in Inuit, as the Inuit language has no word for "bread," and in this prayer, "bread" does not mean a grocery product made of flour in a certain way, but rather the most common and basic sort of nourishment. For the Inuit, this most common and basic sort of nourishment is fish. ${ }^{13}$

This attribute of Inuit vocabulary is, of course, rooted in extra-linguistic matters, which we shall cover later on, but this does not alter the fact that, in the

11 This example was supplied at a gathering of the Translation Section of the Warsaw Branch of the Polish Writers' Union.

12 "As Jacob gave to God, so God gave to Jacob." The untranslatability of this saying, which means that one can expect an adequate reaction to one's behavior, stems from the fact that the diminutive form of "Jacob" and the word for "Cuba" are identical in Polish (Kuba) [translator's note].

13 Quoted from memory, on the basis of information taken from the press before 1939. Personal communication with received in 1954 from Ewa Szelburg-Zarembina on translations of Catholic prayers into Inuit very much confirm this example. 
above respect, the group reaction that results from belonging to Inuit-language speakers is quite different from the group reaction that results from belonging to English-language speakers, for example.

5. Another note to the primary definition: the translation (equivalent) is a phenomenon that chronologically follows the original. This observation is rather prosaic, but it seeks to avoid misunderstandings that could arise with regard to simultaneous translation (translations generally performed viva voce, at congresses etc.). Here too, despite the name, the translation chronologically follows the original, though the gap that divides the production of the original from that of the translation may well be very short. ${ }^{14}$

6. With regard to the primary definition and the preceding remark, we ought to explain the relationship between the language of the original and the language of the translation, and specifically, whether this relationship involves the equality of the two languages, or the primacy of one over the other. Here too we encounter various and conflicting views. It is said that the language of the original in some way takes precedence over the language of the translation, as the original contains the primary formulation, and the translation a derivative one. On the other hand, it has been said that the language of the translation is dominant, as the wording of the translation must always remain consistent with the requirements of the target language, regardless of how the original is formulated.

It seems that two matters must be distinguished here: the relationship between the original and the translation, and the relationship between the language of the original and the language of the translation. Following our primary definition, which states that the translation is an equivalent of the original, the original and the translation are on an equal footing. Should it occur, however, that for various reasons the translation cannot be a full equivalent of the original, we ought to acknowledge the primacy of the original over the translation.

This last assumption is often confirmed in practice: in literature, the original is generally regarded to be superior over the translation, and insofar as this is possible, it is recommended that the original be read; in terms of diplomatic documents rendered in several languages, it is often accepted that, when

14 In "simultaneous" translation of a longer improvised text the beginning of the translation (as a whole) can arise prior to the creation of the end of the original (as a whole), but if we arrange juxtapose? the equivalent parts of the original and the translation, then there can be no doubt that every individual part of the original will be created prior to each equivalent part of its translation. 
doubts arise in interpretation, the text rendered in one particular language is decisive. As such, experience tells us that the translation is often not the equivalent of the original. Here we ought to distinguish between two moments: 1) the experience-based conclusion that, in practice, the translation might not correspond to the original, which might be because of circumstantial factors, such as the translator's incompetence or unfavorable conditions for properly rendering the translation (e.g. insufficient time), or 2) an impossibility owing to objective primary causes, precluding the formulation of text $b$ in language $B$ as an equivalent of text $a$ previously formulated in language $A$.

The issue of this impossibility will be examined in further chapters of the book. For the time being, we might offer a somewhat "mathematical" expression of the relationship between the translation and the original: the translation is $\leq$ the original, which means that the translation can, albeit not always does, matches (or is an equivalent of) the original.

When it comes, however, to the relationship between the language of the original and the language of the translation, our assumption is that both languages are equal. Specifically, between the language of the translation and the language of the original there is no relationship like between a metalanguage and a language, for a metalanguage is a language we use to speak of another language, while a translation is not a description of another language, but an equivalent of a formulation already existing in another language. As such, the language of a translation cannot be regarded as a metalanguage (with regard to the language of the original).

We have thus arrived at the following conclusion:

The operation of translating text $a$ formulated in language $A$ into language $B$ consist in formulating text $b$ in language $B$, so that text $b$ should evoke the same associations in the reader, or a very close approximation thereof, as those evoked in the reader of text $a$. 



\section{Roman Ingarden}

\section{On Translations}

\section{A More Precise Definition of Translation of Literary Work and the Notion of Translation Fidelity in the Scholarly Work and in the Literary Work of Art}

Considering the organic character and the structural uniformity of the literary work, it turns out that its translation is not, as it might have seemed initially, a simple exchange of the phonetic sounds of the original into the phonetic sounds of another language, with all the other strata and their interconnections remaining-automatically, so to say-untouched. Extracting just one element from this complicated organism and replacing it with another (from another language) inevitably causes changes in all other components of the work and, more importantly, in their resulting harmonic composition. These distortions sometimes reach deeply enough into the work's inner structure to cause changes so significant that an entirely new work emerges. It is hard to talk about "translation" in such cases; instead, we should really talk about paraphrasing, about writing a new but similar work, or about imitation, etc. Thus, the very notion of "translation," and especially its "faithfulness," needs to be revised and defined differently for scholarly works and for literary works of art.

Translation of a work of literature (especially of the artistic kind) is always to some degree a reconstruction, carried through by an exchange of at least (in very rare border cases) just the word sounds of the source language into those of the other language, but it is usually accompanied by manifold changes in all the remaining strata of the work, and even in the very stratum of the linguistic sound formations (as far as derivative phonetic phenomena of this stratum are concerned, such as the "melody" of the language). These changes, however, can be of such a nature that either, in spite of them, the work maintains its individual identity or this identity is violated and in "translation" we receive an entirely new work, markedly different in quality from the original. In considering the work's individual identity, resp. its identity in translation, it is highly important to separate the purely structural role of some of its components (or moments) from the perceptual-aesthetic role of often the same, but more often - different, parts of the work (that is to say, from their role as the elements and moments of the work's unique visual shape, especially in the work's aesthetic perception). 
The structural role of the work's component consists, first of all, in its participation in the composition of the work (as its element) and, secondly, in that it enables the emergence of other elements in the work. Thus, for instance, the structural role of the semantic stratum consists mainly in the fact that the meanings of words (or sentences) participate in the whole of the work, as well as in the fact that they condition both the occurrence in the work of the represented objects and their actual contents. The combining of the individual word meanings into sentences, and of sentences into larger units, brings about the occurrence of, first of all, represented objects, processes, and states of affairs, and, second, all their specific arrangements and manifold interconnections, etc. Also, the occurrence of aspects in the work, and especially in the literary work of art, is partly influenced by the elements of the semantic stratum, though these elements cannot do without the structural role and cooperation of the stratum of word sounds. But also the semantic stratum has certain structural importance for the very sounds of words, because they cease to be just "empty" sounds (purely phonetic formations), and become phonetic-language formations: on the basis of purely phonetic material, there crystalizes a typical form of the word sound, identical to manifold uses of "the same" word in spite of potential individual differences in the actual phonetic material. Also, as I tried to show elsewhere, thanks to the meaning bound to it, the word sound acquires particular secondary visual characteristics, emotional, etc.

Thus, the structural role of the semantic stratum in a work of literature, and especially in a literary work of art, is particularly important, if not decisive for the work's overall composition and its individual identity. The perceptual-aesthetic role of this stratum, on the other hand, is relatively minor, secondary, and often almost neutral. However, in this respect a considerable difference arises between scholarly works and literary works of art, and therefore this matter requires a separate discussion of both cases.

The identity of a scholarly work, both in terms of its perceptual and structural appearance, is decided by the meanings of sentences, that is to say, by the whole semantic stratum. It is the most important stratum for the perception of a scholarly work because it contains the result of cognizing of a certain reality, a process recorded in the work. Everything else in such a work, both structurally and perceptually, plays an auxiliary role. In particular, the word sounds are important only inasmuch as they determine the word meanings in a given language. Perceptually, the word sounds are important inasmuch as they allow us to recognize the meanings of the words we deal with. Besides, some properties of word sounds may facilitate either the reader's direct cognition of the objects which the work is concerned with, or the manner in which he imagines them. The 
other strata of a scholarly work, namely the stratum of aspects and the stratum of represented objects, are usually secondary if the work is used in its proper function, i.e., to convey to the reader knowledge about objects existing independently of the work, and to direct the reader's thoughts towards these objects. Similarly, any derivative properties resulting from interconnections between its strata, such as, for example, the polyphonic-harmonic qualities, are irrelevant to how the scholarly work appears before the reader engaged with it for purely cognitive purposes. They are irrelevant, that is to say, even if these new moments of the work do appear in the reader's field of vision due to various circumstances: they do not change the meaning of the sentences nor do they influence his cognition of a given segment of reality. Therefore, if those other strata of a scholarly work, or secondary properties and phenomena resulting from interconnections between them, undergo changes in translation, this does not influence the work's individual identity, as long as the semantic stratum is not altered as a result. This circumstance is decisive in considering the notion of translation fidelity in a scholarly work, which I shall address below.

[I]n the literary work of art, there occurs an important discrepancy between elements structurally significant for the work's identity and those which emerge in the process of concretization of the work (especially during its proper aesthetic perception) and which are crucial to its ultimate visual concretization. That is, in this case - as before - the structurally significant and fundamental elements are the meanings of sentences comprising the semantic stratum of the work, as well as the entire sound stratum (not only the sounds of particular words, but also their emotional character and such derivative phenomena as the rhythm, the melody of the sentence, etc.). Dependent on these two complete strata is the structural constitution of all other strata of the work and of the harmonic qualities derived from interconnections between them.

[...]

In considering problems connected with translation and its "fidelity," we have to juxtapose scholarly works and literary works of art, first of all, in their perceptual form, in order to account for the differences between them that have just been identified.

The reconstruction that accompanies translation of scholarly work retains the work's identity (or identicality) and therefore is "good" or "faithful" as long as the exchange of word sounds from one language to another alters neither the sense of the sentences in the original (as much as it is at all possible!) nor their order (resp. their logical correlations), even if, as a result of the exchange, disturbances occur in the derivative formations of the sound stratum, in the stratum of aspects and, consequently, in the whole polyphonic harmony of aesthetically 
valent qualities. In other words, if in the process of translation the so-called "literary values" of the whole work change in one way or another, then, unless the change affects the work's cognitive dimensions, it does not bear on the fidelity of translation. Translation (under these assumptions) presents the reader with the same objects as the original work and it allows him to cognize these objects in the same manner - which is exactly what constitutes the work's identity and its scholarly value. But it is not so with the translation of a literary work of art. Such a translation is "good," meaning "faithful," only when new linguistic sounds of particular words, in spite of the numerous changes of the derivative qualities they must and do introduce, do not disturb the polyphonic harmony of aesthetically valent qualities, with simultaneous preservation, if possible, of the semantic stratum of the work. Since the role of the sound stratum is much more important for the identity of a literary work of art than for a scholarly work, it is much more difficult to arrive at a "good" translation of the former than it is of the latter. In such a translation it is necessary to preserve not only the sense of sentences but also the manifold derivative characteristics of the sound stratum, as well as a number of efficacies connected with it in relation to other strata of the work and, more importantly, in relation to the polyphony of aesthetically valent qualities, and all this in spite of the exchange of word sounds. $[\ldots]$

\section{Sources of Difficulty in Obtaining a "Good” (Faithful) Translation of Scholarly Works and a Literary Works of Art}

The difficulties that stand in the way of obtaining good translations of literary works stem from the differences between the language of the original and the language of the translation. The reasons for the occurrence of such differences, in turn, lie in the relationships between the sound stratum of linguistic formations and their meanings. Let us begin, then, with the analysis of these relationships and connections between the two sides of language, first only in very general terms, applicable to any given "national" language.

There are, as we know, two opposing theories of this relationship: one, stemming from Democritus, is conventionalistic, and the other one, which can be traced back to Plato's Cratylus, is anticonventionalistic. The first proclaims no necessary connection between the word sound and its meaning, not even a "substantive" one. Therefore, if there actually occur some sounds "connected" to certain meanings, this is the result of human volition alone, and in particular a certain (tacit) agreement between people communicating with one another. In its extreme, the first theory proclaims then that every meaning can be "connected" 
with any sound we might assign to it. Now, according to the second theory, there is a certain substantive, perhaps even necessary connection between the word's sound and its meaning, regardless of our volition or agreement. Certain particular meanings occur only in connection with certain particular sounds. Both theories still have their followers. At the same time, both, in their traditional, relatively simplistic form, consider only one function of language, that which manifests itself in the process of ascribing meanings and sounds to each another. To determine their correctness or falsity, as well as the limits of their possible correctness, one has to consider all functions performed by linguistic formations, especially by words. Also, one has to consider the differences between artificial languages, created purposefully to serve certain objectives, and the so-called "natural" languages, which have emerged in the course of a long historical process, accompanied by the so far unexplained degree of deliberate efforts and decisions on the part of the members of a given linguistic community.

As far as artificial "languages" are concerned, created mainly for scientific purposes - that is, highly "symbolic" languages, which mainly use graphical symbols devoid of phonetic equivalents or only having such equivalents in the form of abbreviated phonemata that cannot really pass as full word sounds they are, indeed, created from primary symbols as a result of a number of agreements. In this case, it seems correct to claim that there is no essential connection between the primary symbol and its meaning. ${ }^{1}$ We can therefore create symbols and their sounds quite randomly, assigning them to any meanings we choose. It has to be noted, however, that artificial languages are also usually limited to fulfilling only one of the functions that linguistic formations normally perform, namely the function of ascribing certain symbols to certain objects through certain meaning (that is, the function today usually referred to, after Bühler, as the function of representation, Darstellungsfunktion). ${ }^{2}$ At first glance, it would appear that the conventionalistic theory is also correct when applied to the so-called natural languages, a fact confirmed, it seems, by the very existence of many such languages. After all, how are they different from one another if not primarily in having the same meaning assigned to often entirely different sounds? It is apparent, then, that there is no intrinsic bond between a particular sound and a particular meaning, if in another natural language the latter

1 As far as complex symbols are concerned, the difference is that the very arrangement of symbols usually exhibits some connections with the meaning of the whole formulation.

2 The identification of three functions of language presented by Bühler in his Sprachtheorie (1932) and credited to him in our country, is actually much earlier; already Twardowski was familiar with it (1894), and it was elaborated on by Husserl (1901). 
is bound to a completely different sound. A marginal question here is whether the conventionalistic theory is also correct in claiming that "the bond" between sound and meaning results from deliberate agreements or from some other cause, difficult to explain. And it seems that it is only because the assertion about the necessary connection between the word's meaning and sound is false that translation of literary works of art from one language to another is possible. On the other hand, however, it also seems that if the conventionalistic theory were fully correct, it would have been always possible to translate each work absolutely faithfully, without the manifold difficulties encountered especially while translating a literary work of art. Therefore, it should at least be accepted that not all languages were created as a result of random and purposeful agreements or that not everything in the existing languages was the effect of such processes, and that it is not in all respects that the bond between the word sound and its connotations is as loose as the conventionalistic theory has it.

To realize fully the state of these matters, let us look again at the functions that, according to contemporary views, are or can be fulfilled by words and other linguistic formations.

It is customarily accepted now, after Bühler, that the word has three functions: a) of representing certain objects (Darstellungsfunktion): the reference of a word to an object takes place through what we call the word's "meaning"; b) of expressing (Ausdrucksfunktion); and c) of informing the collocutor what the speaker has in mind (Appelfunktion). Polish linguists often refer to this as the function of "communication."3 A more detailed analysis of these issues makes it imperative, however, to introduce further differentiations.

First of all, the function of representation can be performed in two different ways, often by the same word, but in such cases usually one form of representation dominates over the other. An object can be represented either purely "notionally," entirely through thought-derived denotative intentions, ${ }^{4}$ or "imaginatively," through evoking imaginational aspects of objects designated by word

3 In our country, we often refer to this "communication" ambiguously, confusing "information" with "presentation." Moreover, it is falsely understood just what is supposed to be "communicated": the matter is presented as though the actual mental experience of the speaker were "communicated" rather than the meaning of the linguistic formation.

4 I have demonstrated elsewhere that such "meaning" of the word, too, contains various heterogeneous elements, e.g., in the name: the material content, formal content, the vector of direction, etc., but it is impossible to discuss them here; these differences, however, should also be taken into account in translation (cf. Das literarische Kunstwerk, Ch.15). 
meanings. By referring to purely "abstract" words, we usually have in mind those words whose function of representation is performed only in a "notional" manner, without the participation of imaginational factors. However, by referring to "concrete," "live," "vibrant" words, we usually have in mind those words that refer to objects not only through meaning, but also through their connection to imaginational aspects of particular objects. In everyday language, the "concrete" words are predominant, but in scientific (especially mathematical) languages there is a prevalence of words that fulfil representational function only in a "notional" manner.

To contrast just one informative function with those of representation and expression does not seem correct either, and it may be preferable to divide this seemingly one function into two. That is, "informing" someone about something would refer strictly to the function of the word or phrase that consists in awakening in the listening subject precisely the same, or at least very similar denotative (or imaginational, but in any case cognitive) intentions as those embedded in the word used by the speaking subject. This function of the word is, of course, one of the means of affecting another individual psyche through language. It is however, of a very special type. It induces the listener to co-think about the same object and in the same manner as meant by the words directed to him. ${ }^{5}$ But there is also another mode of affecting someone through language, often connected with informing, namely, that of stimulating someone to various psychological or even psycho-physical behaviors that go beyond simple co-thinking. Most often, it consists in awakening in another person the states of being moved, of wanting and of desiring, or possibly, causing psycho-physical states of readiness to act as a reaction to the words addressed to him as he understood them. "Informing" (more or less correctly understood) conditions "affecting" in this new sense; however, the latter can often occur even when "informing" is highly imperfect. It seems therefore advisable that "informing" be limited strictly to the function of evoking co-thinking and understanding (and perhaps also co-imagining of a given object), and contrasted with "affecting" in the narrower sense of inducing in others reactions of being moved, of wanting and of desiring, or the actual actions. But at the same time, as I have indicated, "informing" has to be clearly separated from "expressing." Informing occurs thanks to the word meanings being shared by collocutors. A person spoken to "understands" the meaning of words and is thus influenced to co-think about the object that the speaker

5 Thus understood, "informing" has nothing to do with the function of "expressing", which 1 will address below, although linguists often identify the former with the latter. 
has in mind and, possibly, to co-imagine it. Thus, the person does not turn to the speaker and the speaker's experiences. However, (linguistic) "expression": a) shows the psychological state of the speaker or the subject expressing his experience, and, b) it does so not through the meanings of the uttered words but through the manner in which they are uttered, in particular the tone of the utterance. Linguistic expression is but a special type of the function of expressing as such, which is usually realized in the person's behavior, facial expression, gesture, and also voice, in particular the tone. Someone who understands the other's expression turns all his thoughts (or, in broader terms, experiences) toward that person, toward his experiences and psychological states, and not toward the subject of this person's utterance. This fact differentiates clearly between the function of expressing and the function of informing through words' representational power. It does not alter the above differentiation because we often talk about our own states or experiences. In such a case, indeed, the collocutor learns about our experiences and directs his thoughts toward them, but that is possible not because of the function of expressing, but because our words refer to our experiences due to their inherent meaning.

I cannot discuss here in detail all the functions of language and their mutual relations and interdependencies. Suffice it to just ask whether the claim about a complete lack of connection between the word sound and its "meaning," that is, its "representational" function, concerns only this relationship, or whether it also pertains to other functions of the word, i.e. the relationship between the word sound and the word's expressive and informative function, as well as affecting the collocutor.

Now, with the exception of onomatopoeia, which is a rather unique phenomenon in language, it seems indeed that there is no close connection between the word sound and its purely notional meaning. However, this holds true only if by the word sound we mean a certain scientific abstraction (rather than a concrete element of everyday language): the purely phonetic side of the word sound, disregarding, first of all, the secondary moments brought about by the meaning connected to a given sound (cf. words that are "lively," "celebratory," "bombastic," "dirty" etc.), and, second, the tone (e.g., "kind," "elevated," "threatening," "sharp," "gentle," "forbearing," "tolerant," "excited," "calm," etc.) which accompanies the words in a particular utterance. However, when we consider the "word sound" in its full range of emotional appeal that stems from its meaning, and especially when we consider its contextual and situational tone, i.e., when we consider the "word sound" in the form in which it actually occurs and fulfils its functions in a living language, constituting the linguistic reality, then we must conclude that the connection between sound understood in this way and the manifold 
functions of a word is not at all as loose as proclaimed by the conventionalistic theory. First of all, the function of "imaginational" representation is closely related to certain properties of the full resonance of the word and it either does or does not occur, depending on whether a given word carries sounds equipped with some secondary characteristics capable of evoking in the listener the appropriate imaginational representation(s) of the object designated by this word (this refers not only to nouns but also, for instance, to verbs). Secondly, this function is played out differently depending on which ancillary, possibly emotional moments occur in a given word sound. There are words that are dead in this respect (e.g., "regular cuboid") and do not stimulate our imagination, and there are words that are active (e.g., "dice"). Exactly the same pertains to the relationship between the word sound and the functions of expression and affecting. In this case, however, one has to take into account not only the full word sound, along with its manifold extra-phonetic characteristics, but also the speaker's manner and the "tone" of the utterance. And here it is not only the accomplishment of these functions that depends on whether the word sound and the mode of its utterance at all contain the moments necessary to trigger said functions of the word, but there is also a close connection between the way in which the given word affects the collocutor (how it moves him, what of the inner states of the speaker it can or does express) and what the full word sound and the manner of uttering it are. Studying both living speech in conversation, especially in various conflicts of life, and the literary works of art, especially dramatic and lyrical ones, reveal beyond all doubt that such close correlations between word sounds or the tone of utterance on the hand and the word's functions mentioned above on the other do indeed exist, although it must be acknowledged that a rigorous theoretical study of the kinds of such correlations and the regularities they exhibit is still in its infancy. But the practical knowledge about them, as well as the ability to use correctly the appropriate words in appropriate, concrete life situations, or in appropriate places in literary works of art, is undoubtedly abundant and vast: on the one hand, in people who interact with others and who have polished their interpersonal skills (the activists), and, on the other, in talented artists: lyrical poets and dramatists, as well as actors. Even the informative function to some extent depends on word sound, although the most important part is played here by the word meaning. We all know from everyday life, however, from experience we gain, for instance, as teachers, that whether or not we manage through words to evoke in our listeners their co-thinking about the objects we speak about depends to some degree also on the words we use. There are words (as far as their sound is concerned) more and less easily understood, words more "convincing" to the listener and words that are "difficult to grasp". Why it is so (whether habits, 
various circumstances unrelated to language as such, or the properties of spoken language play a role here) is another question; whatever the answer, it will not alter the simple and familiar fact that some words, although they possess the same "content" as others, somehow "pass by our ear," whereas others are heard and understood "right away."

The relationship between the word's sound and its functions is therefore not as simple as the two opposing theories see it: it is neither as loose, random, and dependent on our agreement as the conventionalistic theory has it, nor as tight and necessary as the opposing theory proclaims. But precisely because this relationship is so complex and assumes such diverse forms, it becomes clear that in this respect there can and indeed do occur considerable differences between various ethnic languages. It happens that in one language certain expressions are characterized by a markedly close connection between the two elements of a word, whereas in another language expressions equivalent in meaning do not exhibit such closeness. This considerably limits the degree of fidelity that can be achieved in translation. It is the looseness of the relationship between the purely phonetic side of the word sound and its purely notional meaning that makes translation possible at all. But the difficulties that limit the degree of fidelity stem precisely from closer connections between the full sound of the word and the manner in which it fulfils all of its functions.

Before I discuss, just by way of example, certain details of these matters, first I have to stress that the differences between scholarly works and literary works of art account for the fact that these difficulties are different in scholarly works and in literary works of art. ${ }^{6}$ Limiting ourselves only to the fundamental contrast between these two types of works, we could prima facie say that in scientific works (especially of the abstract-deductive type) the most important, and in many cases the only function of language is the notional representation of objects whose cognition a given work registers and transmits. However, the function of informing is not quite insignificant here, as these works have to be

6 Naturally, it must be borne in mind that within the constraints of this brief sketch I am forced to make shortcuts and simplifications of theoretical situations. Particularly, it cannot be ignored that there are various types of science and, consequently, of scientific works, from abstract-deductive mathematics and formal logic to descriptive works on nature or history. Similarly, there are numerous types of literary works of art, from lyrical and dramatic ones to epic novels or reportage narratives. In these various types of scholarly and literary works, their language also performs different functions. Consideration of these details must lead to some modifications of the assertions that I propose here as I sketch these schematized, preliminary reflections. 
"readable" by and "understandable" to the intended reader. But in the literary work of art, all of the aforementioned functions of language play an important role, although not an equally important one in all works. For example, in purely lyrical works, the functions of expression and of affecting the reader (especially emotionally), as well as the function of imaginational representation, are all particularly important, whereas the function of purely notional representation, although undoubtedly belonging the totality of the functions of language in a lyrical work, plays a rather subordinate role. To some extent, it is similar in the case of a dramatic work. But in an epic (narrative-descriptive) work, it is the representational function in both forms that comes to the foreground, and the function of expression becomes subordinate (or sometimes vanishes), whereas the function of affecting the reader remains here equally important to the whole of the work; its efficacy determines, among other things, what we call the artistic value of the work.

However, since in the literary work of art all functions of language distinguished here play a more or less important role and since, with the exception of the function of purely notional representation which to a considerable degree remains in a conventional relationship to the phonetic side of the word, all the other functions of language strictly depending on the full word sound and its manner of utterance, it becomes clear that the replacement of concrete word sounds in a given work with the sounds of another language (with the words having approximately "the same" meaning) can, and often must, cause essential changes in the functions performed by a particular word in the original work, and thus must cause disturbances in both the particular strata of the literary work of art and in the polyphonic harmony of its aesthetically valent qualities. Because in translating a literary work of art the foremost concern is to preserve fundamental characteristics of this polyphonic harmony and the details and aesthetically valent qualities in all strata of the work, it is so much more difficult in this case to achieve translation "fidelity", which depends here on other factors than is the case with purely scholarly works. Literary works are not composed of isolated words but of multiplicities and sets of words closely interconnected with one another both in their (notional) meaning and in all their remaining functions, and even their sounds. From a number of consecutive word sounds, higher order linguistic sound formations emerge (melodies, lines, rhymes, rhythms, etc.); they become not only separate musical phenomena within the whole of the work, critical as far as its influence on the readers is concerned, but they also - it cannot be forgotten - play an important role in the realization of the expressive function, as well as in actualizing appropriate aspects of objects referred to in the work. The exchange of particular word sounds from 
one language for another only too often leads to changes in higher order linguistic sound formations. As a result, new disturbances occur in the structure of the work's strata, as well as in its polyphonic harmony I shall come back to this point.

\section{Some Differences between Languages and the Resulting Difficulties in Translation}

Precisely because the functions performed by everyday language, and also by the various types of language of literary works based on everyday speech, are much more numerous and diverse than the functions of scientific language (still varied in different types of science), a greater number of heterogeneous factors influences the development of everyday natural language than in the scholarly one. Whereas with respect to the latter, the most important considerations are only those that influence the linguistic formations' capacity to contain the results of cognition of objects in a given discipline so as to pass them on to other scholars, in the development of common language there is a great variety of circumstances that play a role. For this language not only has to fulfil much more diverse needs of the members of a much wider community, but it is also more deeply rooted in the life of an individual person. A linguistic community undergoes a number of changes itself and its development is conditioned by various factors, which results in manifold mutations of its language. The process of the formation and transformation of everyday language is very slow and long, and only to a small degree is it regulated by the active and intentional human operations (in cultural communities - through schools, the press, etc.). Changes occurring over such long periods of time are often overlooked by members of the linguistic community. The scholarly language (especially in the case of some scientific disciplines) is regulated to a much higher degree, mainly by being adjusted to the newly discovered facts in a given field, as well as by increasingly better precision in defining meanings (notions) and the ensuing terminological agreements. Similarly, the so-called "literary" language clearly undergoes the process of standardization due to research on language, the establishment of grammatical norms, the influence exerted by the works of prominent writers on their readers, etc. However, as far as the actual development of common, (ethnic) language is concerned, normalization of language has a rather secondary influence in relation to the influence of the variety of factors stemming from the psychology of the members of a given linguistic community, from social relations, from the clash of different cultures due to changes in the political situation, etc. Therefore, the differences that occur between two natural ethnic languages are 
incomparably greater and deeper than those between the respective scientific languages (e.g., within the same field, or between the languages of two different disciplines of the same ethnic language). They are not limited to the purely phonetic side of word sounds; they include especially the derivative moments of word sounds, as well as their various mutations and, moreover, the manifold spheres within the very semantic formations characteristic to both languages and of the relations between them. Let us try to identify some of these differences between languages, for they are the factors that cause the difficulties in translating literary works of art. While such works cannot utilize artificial linguistic formations found in scientific languages, they have to, despite all changes that these works introduce into the everyday language, rely on this language and avoid the artificiality that scientific or technical works can afford.

1. If we limit ourselves initially only to names, we will be struck by the fact that the names which denote "the same" in two different languages often do not mean the same. The creation of meanings of words is a derivative function of, among others, cognizing certain objects, particularly perceiving them in some kind of manner. This perception can be diverse to the extent that, for example, in looking at an object we are struck by a certain feature (e.g., color), while someone else notices some other feature and sees that object as a sub specie of that feature (e.g., sub specie of its shape or intended use; for instance, someone asks "What is it?" and the answer is "a plough," and not, say, "a chunk of steel fastened to bent wooden rod"). As a result, sometimes in the meaning of two names denoting the same thing in two languages (or two similarly named objects, if we deal with general names), there occur moments that render it through an entirely different feature, selection of features, or a different holistic moment And it may so happen that the name of an object rendered in one language through a certain feature does not find in another language a name that would render it through the same feature that was recorded in the vocabulary of the original language. In such cases, the word A in one language does not have its exact semantic equivalent in another language, although in that other language there exists the word $B$, which means the same. The word A, then, is not, strictly speaking, translatable into the other language, unless, of course, we artificially create a new word with exactly the same meaning. Such neologisms, however, are rarely accepted by language, and we always perceive them as odd coinages, even when their sound has been rendered "in the spirit" of a given language.

2. The second linguistic phenomenon that often renders faithful translation difficult if not impossible is the fact that different languages often have very 
different semantic units. This is also connected with the diverse manners of perceiving - in the broad sense of the word - the objects in the world around us: with the degree of differentiation of this world into independent objectsunits. Even within the realm of the same linguistic community, some may see two independent wholes where some others see just one. They therefore create one-word names for the units whose designation by such a name others find insufficient and use two words bound by a syntactical relationship, such as combining a noun with a verb. A similar phenomenon takes place when one language exhibits a tendency to use general names and to combine them, if needed, with adjectives that narrow the range of their meaning without having separate names equivalent to that narrowed meaning whereas in another language such names do exist and there is no need to use noun-adjective compounds to denote what is thus designated by a simple name. For instance, in one language containers that are similar but have different uses are denoted with one general name supplemented with different adjectives, whereas in other language each such container has a separate name (cf. German names for wine-glasses used for different types of wine, etc.). It may seem that it is irrelevant for the fidelity translation whether a given word is rendered through one or more words. But it is not unimportant in cases where, for example, for the sake of the rhythm of the verse we have to maintain a certain economy of words, a consideration that goes beyond the semantic stratum of the work and reaches into the structure of the sound stratum. But even purely semantically, it is not exactly the same [whether one or more words are used]. For, undoubtedly, where we use a one-word name (instead of a more general word combined with the adjective that narrows down its meaning), its meaning often denotes an object sub specie of a certain qualitative feature, whereas the compound bypasses it and renders an object sub specie of a typological moment and an isolated moment of a given feature. Therefore, the qualitative shape of an object rendered through two words is different than that rendered through one. In a scholarly work, this may not be important, but in a literary work of art, it can introduce a change that can influence the qualitative harmony of the whole work.

3. Another characteristic of the difference between two languages concerns various types of polysemy of particular words. Let us consider two names, A and $\mathrm{B}$, in two different languages, and that both are polysemous but both possess, among all the meanings connected with their sounds, a certain meaning $x$ which denotes the same thing in the same manner. Beside the meaning $\mathrm{x}$, the name $A$ also contains a sequence of meanings: $y, z$..., whereas in the name $B$, there is a partly different sequence: $y, k, 1$... In addition, the polysemy of 
the two names may not be clearly visible nor easily erased by their contexts. Under such conditions, the use in translation of the name B in place of A introduces into the text a different kind of polysemy than the one present in the original; this constitutes an instance of infidelity in translation. In the scholarly work, it is possible to remove this kind of ambiguity either through a clear definition of a given term to the exclusion of all other meanings, or through the addition of qualifiers that restore the polysemy of the original. But in the literary work of art such means are often inadmissible, be it because of the necessity to preserve the melody of the sentence or verse, or because it is generally unthinkable to supply an artistic text with clarifying definitions. Undoubtedly, however, it often happens that the change in the polysemy of a given word in translation does not matter because the context removes the meaning that does not count, so that while reading we do not even think that a given word has any other meanings.

4. It is also difficult to substitute in translation the so-called "idioms" or stock phrases common in one language (and usually having a different meaning than is suggested by the dictionary meanings of words that make them up), with the "appropriate" or equivalent idioms in another language. It is often impossible to preserve in translation the idioms characteristic of the original language. Translated "word for word", they would not only sound nonsensical $[\ldots]$ but they could introduce an entirely different meaning than that of the original idiom. But it is not always possible to find in another language a phrase equivalent to the one in the original. A given expression may simply not have formed in one language, and has to be rendered through a set of words which may ultimately mean the same, but which will not function as a stock phrase; its use may thus produce aesthetically and expressively an entirely different effect than the original phrase.

5. There are numerous fundamental differences between languages with respect to both declension and conjugation (even if we limit ourselves only to the Indo-European languages). The differences I have in mind here are exemplified by the various number of grammatical cases, morphologically formulated tenses and their functions in particular languages, etc. This causes difficulties especially in translating literary works of art, although, undoubtedly, one can always find equivalent forms, even if not quite synonymous. But, for example, German lacks a proper imperfectum, and Polish lacks various past tenses which developed in English or French; this means that, strictly speaking, some phrases of one language cannot be rendered in another, even using some additional words, which, especially in literary works of art, will always strike as incongruous, and anyway such additions are often impossible 
due to other, extra-semantic reasons. To some degree, the same also applies to substituting a simple noun in a certain grammatical case which does not exist in another language by an undeclined noun and an appropriate preposition. In a scholarly work, this usually does not matter; however, for example, in a lyrical poem, it may weaken certain artistic effects or introduce new effects, absent from the original.

6. Great difficulties in translating literary works of art are also caused by differences in the syntactic forms common in one language but non-existent in the other. Substituting them with (approximately) equivalent phrases often changes the sentence's dynamics, thus affecting the clarity or opacity of its structure, its expressiveness, etc. These are, again, important matters for preserving the "style" of the original literary work of art, yet usually secondary (though not always insignificant) in the translation of a scholarly work. Here we could also include the sentence word order, which in some languages is rigorously fixed (e.g., in German), and in others (e.g., Greek or Polish) it is quite free, or it is used in sentence structure for other purposes. For instance, the German rule of the so-called simple and reverse word order in the main clause, or of placing the verb at the end of the subordinate clause, is against the spirit of, for example, the Polish language. By obeying it while translating a text into Polish, we would produce syntactical incorrectness highly incongruous aesthetically (although there are such translations of, for example, Kant's works, or of Tacitus' Germania). These rules are also very rigid; that is, they have to be applied regardless of the actual content of subordinate clauses. Changing the word order causes grammatical error, unbearable to the German ear, and introduces no positive semantic effect in the development of the sentence's meaning. However, in other languages (e.g., in French), the transposition of a word in a sentence sometimes does alter its sense, thus playing a syntacticlogical role, and it is rather devoid of negative grammatical consequences. But retaining the shade of thought achieved in, say, French, by placing a given word in a particular position in the sentence cannot be achieved by the same means in German, because this would be inconsistent with grammatical rules. This goal, therefore, has to be achieved by other means, for example by adding certain words that do not occur in the original; then, however, the shade of thought which is indeterminate but only intimated by the whole sentence often becomes only too obviously specified - an effect really inadmissible in a literary work of art, because that which was just hinted at yet unstated now becomes stated (or else, it will not be stated at all, simply vanishing from the text). The so-called "long sentences" are used frequently in German literature even by highly acclaimed authors and great stylists (cf. novellas by Kleist, the 
late novels by Thomas Mann, etc.), and in many cases, they certainly do not constitute stylistic "errors", nor are they marked in German by the "heaviness" that their non-Germans readers or translators so often complain about. Such sentences cannot, however, be retained in Polish, or in French or English. They are simply incompatible with the linguistic habits, the style of thinking, etc. But replacing them with a number of shorter and simpler sentences, admissible and often used in translations of scholarly works, leads to an entirely different dynamics of the emerging text, an entirely different architectonics of sentences and sentence formations of the higher order, and, correlatively, also to an entirely new structure of the represented world than in the original. All these factors, although often unavoidable in translation, change the artistic shape of the work: they deprive it of certain individual characteristics and artistic efficacy embedded within and, instead, they introduce a number of new features, so that, artistically, we deal with an entirely different entity, sometimes worse, but often even better than the original. Here, then, is the locus of all the difficulties in rendering the "style" of a particular author or another language in general. In artistic prose this is often less significant, but in poetry, be it dramatic or lyrical, we run into unsurmountable difficulties precisely because the structure of the sentence determines not only its purely logical sense (that is, the function of representing certain objects in more or less complex states of affairs), but also the function of affecting others; both functions have a tremendous structural and artistic significance in poetry and drama. Particularly in drama, the words uttered by individual characters are not so much to inform the audience or the reader what these characters are going through, what they think, feel, or plan, as they are a form of the character's affecting other characters entangled in the same plot. Therefore, in drama, a change in syntax plays sometimes a crucial role, as it may change [the work's] impact. Often such a change unavoidable, because retaining the original syntax in translation would lead to just the opposite effect and to a very different impact than a given sentence has in the original. Hence, it is often impossible to slip between Scylla - a caricature of the original if its syntax is retained - and Charybdis - a complete change of the effects of utterances if new sentence syntax is introduced, one that matches the rules of the language of translation.

7. Difficulties of a new kind ensue where the necessity arises, as it does in all literary works of art, especially those written in verse, to preserve not only the same semantic units, but also all artistically and structurally pertinent features and phenomena of the work's sound stratum. In literary masterpieces, the sound stratum is structured in such a way that its qualities, especially various 
sound phenomena of a higher order, collaborate, as I said before, with the semantic stratum in constituting the stratum of aspects, in bringing about emotional qualities and other aesthetically valent qualities; at the same time, they contribute significantly to fulfilling the function of expressing the inner states of the presented characters or the function of affecting the reader. The sound stratum participates in the polyphonic harmony of the work's aesthetic values. The more excellent the work, especially a poetic one, the more profound is the role of the sound stratum in its above-mentioned capacities, and the more difficult it is to replace it, since the work, in its qualitative harmony, is a unique, unfalsifiable entity. Now, at the foundation of the sound stratum lie the individual word sounds, none among which, if taken in isolation, could likely fulfil any (or at least the majority) of the aforementioned functions; they are fulfilled only by sets of words, by their selection and their proper ordering. The exchange of these sounds for the word sounds of another language (usually entirely different from the original) results in the fact that it is extremely difficult to match these words so that, on the one hand, they carry the meaning necessary to preserve the sense of the sentences which make up the work, and that, on the other hand, they lead to the same language formations and higher order phenomena which are present in the original, and finally, that all these formations also possess the same artisticstructural efficacy in relation to the other strata of the work and to its polyphonic harmony. Just to preserve the rhythm and the melody of verse, which is connected, among others, with the order of vowels, is extremely difficult if, simultaneously, the sense of sentences is to be preserved. Dissimilar word sounds of another language, chosen because of their meaning, cannot usually be arranged into the same rhythmic formation because they introduce different sets of vowels and consonants. This results in changes in the melody of the verse, in the impossibility of creating the same rhymes as in the original, etc. Usually, we must content ourselves with formations only similar to the original, as long as the efficacy of their expression and affect, and their capacity to actualize aspects is preserved. Requirements posed by the postulate of preserving identical sense are usually at odds with those posed for translation in respect to the preserving the artistic efficacy of the sound stratum. Usually, words in two different languages have sounds that are different to such a degree that the two sets of sounds generally yield highly dissimilar formations and derivative phenomena, and thus entirely different capacities of the language sound stratum. Thus, more often than not translation either departs from the original with respect to the qualities of its sound stratum and lacks the appropriate artistic efficacy, while retaining the units 
of sense of the semantic stratum, or, conversely, it differs from the original in some details of the semantic stratum, being thus more or less unfaithful in this respect, while its sound stratum approximates the original. However, because linguistic sound phenomena of a higher order (e.g., the melody of verse) are very often qualitative features that can appear on the basis of different selectons of qualities (here: the sounds of particular words), it is not impossible, contrary to common belief, to endow the sound stratum of the translation with such word sounds that, in spite of their difference from the original, there will occur the same, or at least very similar, derivative qualitative feature, and consequently, the artistic efficacy of this stratum will be preserved in the translated work. This is a rare case, though, because beside the selection of properties of both languages, it requires a double talent on the part of the translator: first, the ability to hear in the original work all those properties of its sound stratum that determine its artistic efficacy and character, and, second, the ability to understand on which properties of the phonetic foundations of verse they all depend. On the other hand, talent is necessary in order to find in the sound material of the language of translation those words whose sound combination and succession would result in the same artistic effects of the whole stratum as in the original. Only a careful analysis of particular translations could show where and why translations, quite good in their semantic fidelity, are artistically completely disappointing in their failure to coordinate the efficacy and the artistic quality of the sound stratum with the semantic stratum and with the whole of the work. General reflections alone will not tell us any more about the matter. It only needs to be stressed yet again that all these difficulties diminish considerably in works of prose, although this also depends on the type of work. To illustrate this, we could juxtapose highly lyrically effective prose by Żeromski on the one hand and the prose by Kraszewski or Prus ${ }^{7}$ on the other. In scholarly works, however, especially in mathematics or physics, these difficulties either do not exist at all or they emerge only sporadically, mainly because some of these works might have same "literary values," which bring them closer to literary works of art and which sometimes fulfil cognitive functions and contribute to the cognitive efficacy of the work.

$[\ldots]$

7 Stefan Żeromski; Bolesław Prus - Polish writers, see editors' notes on 125 and 284 in the present volume. Józef Ignacy Kraszewski (1812-1887) - Polish novelist, historian and journalist, author of widely read historical novels [editors' note]. 
I believe that I have thus presented the most important aspects of the differences between the translation of literary and scholarly works, indicating a number of fundamental difficulties encountered in this respect. Yet I have not, of course, exhausted all problems that emerge here.

$[1955 / 1972]$

Translated by Jolanta Wawrzycka 


\section{Edward Balcerzan}

\section{The Poetics of Artistic Translation}

Many scholars see it as problematic that the poetics of translation should exist as a distinct field in the humanities. Custom dictates that we speak more of translation theory, or of the duties of translation criticism, than of poetics.

Why is this? In our present-day understanding and sensibility poetics first responds to a general question - "How does the literary work exist?" - and then offers us the tools of analysis and interpretation (of description and explication) of works that allow us to study literature on its proper ontological plane, which cannot be reduced to other planes (e.g. sociological, psychological, etc.). The poetics of artistic translation should, therefore, pose a similar question: "How does the literary work translated from a foreign language exist?" Later on, it should necessarily find evidence that, although a translation is also a "normal" literary work, although it is governed by the same structural laws, it exists differently from works of native literature. And only after uncovering this distinctiveness, after demonstrating this "differently," can it move on to developing its own research tools - its own system of concepts and terms.

It is my belief that artistic translation is subject to its own laws in addition to the universal laws of literature, and thus it exists, to phrase it with caution, somewhat differently from native-language works, and consequently, the poetics of artistic translation has all due raison dêtre. I shall confine myself to the most basic arguments. The native literary work, written "directly" in the native language, is a one-time, or, in other words, a write-once statement. The essence of the single original work is its assumed uniqueness. Even if there are two versions of the same original piece by the same author (such as the two versions of Leo Tolstoy's War and Peace), these are the exceptions that confirm the rule. In such cases, the scholar, publisher, and reader select one version which they acknowledge to be canonical. With translations, the reverse occurs. A translation of a foreign-language work is always one of many possible expressions. Multiplicity and repeatability are therefore essential attributes of translations. The same foreign-language work can serve as the basis for a whole series of translations in a given language. (For example, there are three Polish translations of The Lay

1 M. Głowiński, A. Okopień-Sławińska, J. Sławiński, Zarys teorii literatury (Warsaw 1967), p. 6. 
of the Love and Death of Christoph Cornet Rilke, five Bulgarian translations of the Polish national epic Pan Tadeusz [Master Thaddeus], four Polish versions of Mayakovsky's "Oblako v shtanakh" [A Cloud in Trousers] etc.).

Translation thus exists in a series of translations. A series is the basic form of existence for artistic translation. Such is the specificity of its ontology. Even if a foreign-language work has been translated into our tongue only once, we apprehend this translation as the beginning of a series of other translations that will or may be created in future. It is vital that both a partially realized and a potential series are open to further development. They are sequences which, for all practical purposes, are infinite; they are open sets. Thus, in an open-ended series, with its constant readiness to include new and competing solutions, every translation is, as it were, "open." It opens up in two different directions: toward the foreignlanguage original, and toward the competing components of the series. This "openness" of the translation also poses a danger. The original can question both the meaning and the poetics of a given translation. The competing components of the series can also question it, or even eliminate it from circulation.

I believe this should suffice to close the opening remarks with the comment that examining an artistic translation requires special instruments, which should be the subject of interest of a separate discipline: the poetics of translation.

\section{The Poetics of Artistic Translation in Literary History}

Even as it is taught in schools, the history of literature notes the contribution of the art of translation to the development of national literature. Grade-school students find out, for instance, that Raj duszny [Little Garden of the Soul] is a translation by Biernat of Lublin. They encounter literary protagonists of past epochs, such as Till Eulenspiegel, Aesop, or Marcolf, who have appeared in our culture thanks to translators and through translations. They are aware of the direct or indirect links to foreign-language literary traditions found in Mikołaj Rej, Jan Kochanowski, and Łukasz Górnicki. Precisely - links that are direct or indirect. Even the simplest information in this field requires that we use elementary concepts from the poetics of translation. The concept of translation alone will not suffice. On the one hand, the degree of dependence of the translation on the original, and on the other hand, the kind of innovations introduced by the translator make the variants of the translated works differ. If we call Kochanowski's Psałterz [Psalter] a "translation," we call Górnicki’s Dworzanin Polski [Polish Courtier] a "new remake," while Biernat of Lublin's Żywot Ezopa Frygi [Life of Aesop of Phrygia] is a "versified remake," etc. Nor can we deny that the more precise the set of concepts from the field of poetics the literary historian 
has at their disposal, the clearlier they can define the nature of a given work. The concepts of poetics are not there in order to satisfy someone's disinterested proclivity for "pigeonholing." The concepts of poetics of translation are there to give justice to both the original and the translation; they should describe the translator's standpoint, and finally, evaluate the role that a given translation has played in the native literature.

From this we can see that the poetics of artistic translation sees its real applicability for literary history, a subject whose practical interests lie in the development of poetics of translation. At any rate, this is how it should be; unfortunately, more often than not this is not the case. The majority of works on literary history, especially textbooks, make only occasional reference to the poetics of translation, reluctantly, as it were, limiting themselves to the two above concepts: "translation" and "remake." Or: "faithful" and "unfaithful" translation. Yet there is a vast range of intermediate variants between the "translation" and the "remake," and a dozen ways to be "faithful" or "unfaithful" to the original. It is easy to confuse these variants, particularly in attributing the so-called "influences and dependencies," which undoubtedly do exist in literatures of various languages. There is a constant exchange of artistic qualities. This is, however, an exchange in which the foreign-language text has several barriers to cross: natural languages, the literary traditions of the two different national cultures, and the rules of the art of translation binding in a given time. The diversity of the transformations that a work can undergo in the act of translation leads to more or less visible changes in its original meaning. Who and what can be the source of "influence" in such conditions? It can be the author of the original. In that case the matter is simple. It can also primarily be the translator. This also simplifies things. We receive either a "faithful translation" or an "unfaithful remake." Most often, however, the source of the "influence" is both the foreign-language writer and the native-speaking translator. Then everything becomes more complicated: we must summon the apparatus of poetics of translation in order to separate what has come from "abroad" into the native culture, and what has been produced "on site," by the translator. In the translator's workshop.

\section{"The Catcher in the Rye over a Precipice"}

The claim presented in Section One ought to be documented with a precise analysis of a series of translations of a single foreign-language work. Instead, we shall attempt the following maneuver - rather than a whole literary work, we shall take a part of it: its title. There are works in which the role of the title cannot be overestimated. It contains everything that is vital to the piece as a whole: the 
main theme, the poetic concept, the key to a stylistic code. Jerome Salinger's The Catcher in the Rye is among these. The word "catcher" is a baseball term. It is associated with "grabbing," "catching," indirectly also with "hunting." The languages into which Salinger's novel has been translated have no strict equivalent for the word "catcher." Every translation solves this problem differently. Many attempt to hold onto the metaphorical value of the title and to remain within the field of meanings marked out by the title of the original. The Finnish and Serbian titles: The Hunter in the Rye (Sieppari ruispellossa and Lovac u razhi, respectively). The Czech translation: He Who Hunts in the Rye (Kdo chytá $v$ žitě). One of German versions: The Man in the Rye (Der Mann im Roggen). The Polish version: Wanderer in the Grain Field (Buszujacy w zbożu). A Spanish translation: The Hidden Hunter (El cazador oculto). All these suggestions eliminate the moment of surprise and mystery. The contrast between the words "hunter" and "rye", or "man" and "rye", is nothing out of the ordinary. The second group of translations salvage, as it were, the drama of the original title's metaphor, introducing the motif of the precipice taken from the novel. The Estonian translation: "The Precipice in the Rye" (Kuristik rukkis). A Russian translation: "Over the Precipice in the Rye" (Nad propast'yu vo rzhi). The Korean translation: "The Precipice" (단애). The remaining translations make no attempt to render the metaphor in Salinger's title. In itself, this would not be dangerous. But these changes often mean altering the reader's expectations. "The Heart Catcher" (the French translation, LAttrape-cœurs) suggests a swashbuckling romance. "The Young Holden" (the Italian translation, Il giovane Holden) sounds like the first part of a family saga. "Savior in Time of Need" (the Swedish translation, Räddaren $i$ nöden) makes us expect a thriller with a moral at the end. "Lonely Journey" (the Dutch version, Eenzame zwerftocht) puts us in mind of adventure and travel literature. "Life of a Man" (another Italian translation, Vita da uomo) could in fact correspond to any genre.

If a single title of a foreign-language work can refract into so many translation variants, appealing to such diverse fields of meaning and to so many conventions,

2 Information on the translations of the title of Salinger's novel comes from V. Rossels's paper "B masterskoy perevodchika," Tetradi perevodchika (Moscow 1966), pp. 12-15. The list of English equivalents of respective titles was restored after Salinger's bibliography by Donald M. Fiene, originally used by Rossels as the source for his Russian translations. See: D.M. Fiene, “J. D. Salinger: A Bibliography," Wisconsin Studies in Contemporary Literature 4.1. (Winter), 1963, pp. 109-149. Having travelled in translation via English, Russian, and Polish, some of these versions may eventually differ from Balcerzan's Polish approximations [editors' note]. 
it is easy to imagine to what transformations the semantic whole of the original might succumb in the act of translation. How many "influences and dependencies" confirmed by literary history need to be questioned, reinterpreted, and redescribed.

\section{Note Added in 1997}

In the first version of this article I limited my description of the translation series to a single translation: the marvelously multiplied meanings of the title of Salinger's famous novel. Today I see that this example might provide a somewhat distorted image of the series. This is because the title of a work (be it literature or film) tends to be changed by the translators more often and emphatically than other aspects of the work, and unceremoniously so. In the truly rueful history of film title translation this is seen more sharply than in literature. Ever since the interwar period, when, for example, the Soviet comedy Vyesyoliye Ryebyata [Happy Guys] was shown to Polish audiences under the title Świat się śmieje [The World Is Laughing] - doubtless because of the idiomatic trap of the word Ryebyata - the carte blanche of translators for the silver screen has been exercised to terrifying effect. Small wonder, then, that one method of salvaging the original intention, in which the title often plays a major role, in Poland has been to entirely forgo the translation of film (and music) titles, or to publish original titles alongside their Polish translations.

The essence of a translation series is not the destruction of the meanings designed in the original, but the tension between what blasts out these meanings and what consolidates them.

To demonstrate this game, let us have a look at the (truly astonishing!) series of Polish translations of a certain very famous (and extremely succinct) text by William Shakespeare: "Why, let the stricken deer go weep..."

The diversity of the fifteen Polish translations of the famous quatrain from Hamlet simply staggers the reader. There is no agreement among translators as to the profiles or the "names" of the protagonists of the bloody forest incident. Whoever could it be? A fallow deer, a moose, a deer, a stag, a single protagonist or a collective one, a beast (an animal) with no particular characteristics - or an ill-defined mass, a wilderness? Of course, our translators are fairly unanimous in understanding what happened to this creature of many names. They say it has been wounded (hurt, struck, hit - these words are synonymous, though subtle differences emerge from the varied names. Most of the terms suggest an image of hunting, and thus man as the hunter, the culprit; but there are also those that 
indicate another sort of aggressor: an animal can be wounded by another animal, one that is stronger and predatory).

But how does the bleeding primeval forest/woods/groves-dweller act in the translations? The material gives evidence to a distressingly tangled array of possibilities. "It fell breathless," cries one. "It flees" (and thus lives), another claims. It does not yet suffer, but "goes to weep," a third interjects reassuringly. And the rest, each in their own way, say it "weeps" "sobs," "spills tears," "goes mad," "sways," "cries with pain," "chokes a roar..." Indeed, a reader could only take a doubtful approach to such a wealth of translations of a single work. What a chaotic mess! (As in Adam Mickiewicz's romantic ballad "Powrót taty" [Father's Return]: “This one said this, and that one said that..."). The more differences we find, the more intense our feeling of falsity, of the betrayal of the original. When the same thing is translated in so many various ways not all the translators can be right!

However, the moment we inquire into the overall meaning of this "Polish Shakespeare" we find that the entire series of translations retains practically the same meaning. The following construct of ideas repeats with stubborn consistency: 1. Someone suffers. 2. Someone is saved. 3. Someone's suffering saves someone else. 4. That is how things go in this world.

All the translations capture the twofold construction: thesis and illustration. First the illustration, then the thesis. From the specific to the general. This is, perhaps, more peculiar than the discrepancy in the details. After all, fifteen translators over a space of 150 years (1840-1990) understood almost the same content in the Shakespearean quatrain! Subsequent epochs, generations, ideologies, and individuals humbly took the lesson of the brilliant playwright without attempting to insert their own truths or mottoes. (Although the politically sensitive might see evidence of the epoch taking its effect in the 1953 translation, with the menacing words, "Someone sleeps, and to someone sleep has been forbidden" - highly reminiscent of the prison atmosphere of Stalinism).

The intellectual innovations, on the other hand, do command our attention. Here is one (most recent) departure from the norm sanctioned by tradition: fourteen translators found the opposition of the sacrifice and salvation in the world of living creatures, while only one (in the vein of Ecclesiastes) found it in the transformations of time ("For there is time of sleep and time to be vigilant"). But there truly are few differences in the overall understanding.

If this be the case, then why were so many translations produced? We have to return to the point of departure. To the details, be they visual, lexical, rhythmic, or in intonation. To asking which images most powerfully stir the reader's imagination: the animal "dashing through the wood," the doe that "flashes merrily through the forest," or the herd that "runs off into the 
woods"? Which phrase rings more true and more clearly illuminates the poet's theme: "This is the way of the world"? "For this is the meaning of existence"? "Thus, the world turns"?

Thus, we return to the mysteries of artistry. Every new artistic convention begs for a new translation.

And the great tournament continues - for 150 years and counting.

\section{Second Note Added in 1997}

We find the least discrepancies within a series when it comes to translations of the Bible. Identical phrases are often repeated in consecutive translations; sometimes changes are required by the obscurity of the original. As a general rule, the differences in translations are limited to subtle variations of synonyms, word order, intonation, and rhythm.

There are two reasons for the differences in the Polish translations of the fifth verse of Psalm 136. The first is the vagueness of the original Hebrew words (the collective lament of the Judean exiles says: "may my right hand forget", for which attempts have been made to replace "may my right hand be forgotten," or with more graphic images of corporal punishment: may it "die," may it "wither"). The second cause is a question of eloquence, or pure aesthetics.

Here are a few versions in translation (there are more):

Jeślibym cię zapomniał, Jeruzalem,

niech zapomniana będzie prawica moja!

[If I were to forget you, Jerusalem,

may my right hand be forgotten!]

(trans.: Jakub Wujek)

Jeśli zapomnę cię, Jeruzalem, niech zmartwieje ma prawica.

[If I forget you, Jerusalem, may my right hand die.]

(trans.: Leopold Staff)

Jeśli zapomnę cię, Jeruzalem,

niechaj zapomniana będzie prawica moja!

[If I forget you, Jerusalem,

let my right hand be forgotten!]

(trans.: Wojciech Bąk)

Jeśli zapomnę ciebie, Jeruzalem, niech uschnie moja prawica.

[If I forget you, Jerusalem, may my right hand wither.]

(trans.: Czesław Miłosz)

Jeruzalem, jeśli zapomnę o tobie, niech uschnie moja prawica.

[Jerusalem, if I forget about you, may my right hand wither.]

(trans.: Millennium Bible [collective translation]) 
The more texts that accumulate in a series (biblical or otherwise!), the more we succumb to the (cynical?) illusion that the retranslation no longer requires contact with the original or even any knowledge of the original language (or languages). All that is required is a paraphrase, an intralinguistic translation: from Polish into Polish.

\section{The Poetics of Translation in the General Theory of the Art of Translation}

The poetics of artistic translation is not merely part of a more general theory of the art of translation. This is because the general theory does not, at present, constitute a uniform whole. It crumbles into several viewpoints, it flows in several streams. It is more convenient to speak of various theoretical concepts of translation. Each of them creates a proposition of sorts for poetics, but none entirely identifies itself with poetics. We shall name three among the most active concepts: the anthropological, the linguistic, and the literary. Because some of the claims formulated in these disciplines intersect, particularly in terms of the conceptual apparatus of information theory, a "hodgepodge" of notions might easily arise; I would suggest making the basic division on the level of theoretical reflection. An anthropological approach to translation operates at the level of a "system of systems" of human culture. Anthropology is interested in all "languages" spoken by humans and thus in every act of the transfer of information. From an anthropological perspective, translation is primarily intersemiotic, i.e. it involves the transfer of a message between two sign systems, each of which exists differently and in a different substance. An example is the translation of an initiation rite into a myth. ${ }^{3}$

The translation of a ceremonial into an act of linguistic communication ( $\mathrm{T}$. Tzivyan). ${ }^{4}$ The translation of a literary work into a film or a play. Anthropology attempts to resolve a problem that is vital to us here, namely the issue of mutual translatability and untranslatability of communications belonging to various systems. The same issue pertains to various ethnic languages. A major role in anthropology has been played by Whorf's hypothesis which assumes the imposition of a vision of the world encoded in an ethnic language upon the users of this language (or, as D. Segal phrased it, "a global image of the world"5), with

3 V. Ogibenin, “Zamechaniya o strukture mifa v 'Rigvede”' In his: Trudy po znakovym sistemam (Tartu 1965).

4 T. Tsiv'yan, "K nekotorym voprosam postroeniya yazyka etiketa ..."

5 D. Segal, "Zametki ob odnom tipe semioticheskikh modeliruyushchikh sistem ..." In: Trudy po znakowym sistemam. 
rigorously set forms of perceiving reality, isolating objects, their hierarchical interrelations etc. According to an extreme interpretation of Whorf's hypothesis, ethnic languages are untranslatable, hermetic, closed to acts of complete translation. In its polemics with Whorf, anthropology seeks positive (or optimistic) solutions, in close contact with linguistics. ${ }^{6}$

From a linguistic perspective, a text produced in a language can be divided into two planes: the plane of content and the plane of expression (or the "deep" structure and the "surface" structure). In other words: into the "content" and the "form." Translation transforms the plane of expression while preserving the plane of content. According to linguists, describing the act of translation and programming it for a machine will be most effective when we can distinguish basic units of meaning on the plane of content. One of the latest projects to separate these units of meaning seeks to define the "content" of an expression through a description or a paraphrase. In communicating within a single natural language we translate the meanings of words and the significance of utterances paraphrasing them, i.e. using "other words." The same law governs interlingual communication. A foreign phrase that has no direct equivalent in our language is explained through paraphrase. The plane of expression changes. The plane of content remains unchanged.

Though the literary concept of translation borrows heavily from linguistic experience, it cannot accept its model of utterance, as it strives to resolve the translator's difficulties less on the textual level than on the level of the work, which consists of more "planes." Linguistic components of the plane of expression can constitute the main content of an epic poem or novel. The linguistic "deep structure" often reveals itself to be the "surface" of a drama or poem. In other words, in the literary work the signifier turns into the signified, and the signified becomes the signifier; "One serves as a backdrop for the other" (Yuri Lotman). Of course, paraphrase cannot be taken for a universal principle of translation. That would take us to absurd conclusions, wherein, instead of finding equivalents for the rhymes of Pan Tadeusz, the translator would describe various "units of meaning" created by various rhymes "in his own words."

Many differing definitions of literary translation orbit the notion of translation as structural reconstruction, rendered not only in a language foreign to the original, but also in the signs of a foreign literary tradition (poetics, style, genre etc.). Poetics clarifies individual aspects of literary translation theory. It

6 The anthropological aspect of the theory of translation is broadly covered by G. Mounin in Les problemes theoretiques de la traduction (Paris 1963). 
is not, as I have said, a part of literary theory, because, on the one hand, it is linked to concepts of anthropology or linguistics; on the other, it has its separate tasks, which cannot be reduced to the tasks of any of the other disciplines described here.

\section{The Poetics of the Translation Process}

The category of the speaking subject is fundamental to poetics. As I have already mentioned, the translated work most often "splits into two": one part "comes" directly, as it were, from the author of the original, and the other part comes from the translator. The poetics of artistic translation must therefore be interested in the translator's "behavior" toward the author; the point, obviously, is not in exploring what the person translating might have thought, but in determining how their decisions were captured in the text. The need to describe evident decisions of the translator has been long felt by translation theory; the traditional "moralistic" or "ceremonial" examinations of "fidelity" or "betrayal" belong to this problem area, as do issues of "compromise" and "struggle" (K. Chukovsky). ${ }^{7}$ Today's knowledge of the art of translation favors a typological description of the translator's "behavior." There objectively exist two kinds of the translation act. The first might be called "translation proper," and the second, "interpretation."

Translation proper involves a search for semantic and emotional equivalents of the original signs - among the signs of the language of the translation. The translator aims to replace the words of the original with heteronyms, e.g. "лошадь" - "horse," "drei" - "three" (Roman Jakobson). ${ }^{8}$ When there is no heteronym, the translator falls back upon the system of structural coreferences between the two languages, and between the two literary traditions. It is in this system that the translator seeks optimal solutions. This set of systemic coreferences is sometimes called an interlanguage or a "go-between language." Depending on the level of difficulty, the function of the go-between language can be served by a dictionary, grammar, or comparative stylistics, another foreign language, a third literary tradition, etc. It can also be a system of mathematical formulae programmed for a translation machine.

What can be done when it is not possible to establish systemic coreference on the plane of language? At this point, one goes beyond both language and literature. One draws directly from reality. It is precisely the search for solutions in our knowledge of reality that is an interpretation of the original. ${ }^{9}$

7 K. Chukovsky, Iskusstvo perevoda (Leningrad 1930), pp. 13-24.

8 R. Jakobson, M. Halle, Podstawy języka (Wrocław 1964), p. 119.

9 I. Revzin, V. Rozentsveig, Osnovy obshchego i mashinnogo perevoda (Moscow 1964). 
One example: "When Neruda writes: 'a muzo butterfly' we have to add 'a blue muzo butterfly', when he writes 'a marvelous jacaranda tree' we have to add: 'a violet jacaranda tree;' for the poet who on a daily basis sees the blue butterfly and the jacaranda tree covered in violet blossoms, the colors are contained in the name, while we have to explain them to our readers." 10

Neither translation proper nor interpretation ever appear in their "pure" form. (Apart from a translating machine, which is unable to resort to looking at reality.) The two types of translation activities generally intersect. Nonetheless, in certain historical translation poetics we can easily perceive a focus on one or the other way of translating. Certain schools are dominated by the cult of translation proper (Valery Briusov, Lubimov's school). In others, interpretation is programmatically applied (Enlightenment practices, Artur Sandauer). Translation proper attempts to do justice to the author of the original, to speak in his voice. The translator here contents himself with the role of an intelligent transmitter. Interpretation, in turn, makes the translator the main speaking subject. The translator retells in their own fashion the story of the world referred to in the original and existing beyond the text, or, as Ivan Kashkin phrased it, "in the beyond-text."

\section{Types of Translation Transformations}

In the translation process the original undergoes various transformations, motivated in various ways. We might speak of four fundamentally different types of transformations (familiar to Ancient rhetoric), which apply both to a text (or more precisely: to sections of texts) and to the entire work (the structural constructs of a work). These are:

1. Reduction, i.e. reducing a section of the text by certain components or removing certain properties from the stylistic construct;

2. Inversion, i.e. changing the word order, expressions, or higher-level structures;

3. Substitution, i.e. substitution of some components;

4. Amplification, i.e. supplementing the text with new components, often inferred, concealed in ellipses. ${ }^{11}$

The issue of transformative changes appears most clearly in the versification part of the translation poetics, in researching "equilinearity" (the correspondence

10 J. Iwaszkiewicz, “Słowo wstępne.” In: P. Neruda, Pieśń powszechna (Warsaw 1954), p. 7.

11 V. Koptilov, "Transformatsiya khudozhestvennogo obraza v poeticheskom perevode," Teoriya i kritika perevoda... (Leningrad 1962), p. 34. 
between the translation and the original in terms of length and numbers of lines or stanzas) and "equirhythmicity" (the correspondence between the translation and the original in terms of rhythmic structure).

\section{Ways of Translating}

More detailed taxonomies of translation are, by necessity, assembled into various configurations, as they are taken from various (sometimes contradictory) theories of translation. An interesting attempt to formalize a description of the translation process is found in the above-mentioned book by Ryevzin and Rozentzveig. The authors discriminate between a few types of translation which are fundamentally different in terms of the level of difficulty: literal, simplifying, precise, adequate, and free.

The basis for this classification involves the concept of the supercategory. Two units of translation - the smallest signifying and informative segments of the text - belong to the same supercategory if the first unit comes from the original language and the second one from the language of the translation, and if one can establish one-to-one relationships between them (e.g. "Wandzeitung" and "wall newspaper"). If it is not possible to establish a one-to-one relationship between translation units, then they belong to different supercategories, e.g. "bistro" and "diner." Within two given natural languages, $\mathrm{L}_{1}$ and $\mathrm{L}_{2}$, there is generally a certain group of units that belong to different supercategories.

Interlinear translation occurs in the sphere of units belonging to the same supercategory. This is the simplest situation, involving a simple recoding of the message. More complicated situations arise from a lack of one-to-one semantic relationships between the units of these languages.

Literal translation works as though it were possible to establish a one-to-one relationship between the units of the two languages. In terms of content, the text created through literal translation belongs to $\mathrm{L}_{2}$, while on the plane of expression it belongs to $\mathrm{L}_{1}$ (the language of the original). The authors are not interested in mistakes and oddities that result from literal translation, but rather in the very mechanism of mistakes, as a way of analyzing certain aspects of the act of linguistic communication.

Simplifying translation involves replacing a given element of $\mathrm{L}_{1}$ with another element that has a one-to-one equivalent in the language of the translation. First an intralingual translation is performed, and only then an interlingual one, most often for the translation of syntactic constructions.

Precise translation is a further extension of a simplifying translation: the translator performs an intralingual translation in the original language and 
then an interlingual translation, but he does not stop with the resulting expression and seeks in the language of the translation a one-to-one equivalent of that expression, such that might capture the meaning, and at the same time maintain the stylistic value of the original. If this operation is fully successful, if the stylistic value of the original and the section of the translation remain the same, and attaining this identical value does not infringe upon combination rules in the system $\mathrm{L}_{2}$, and does not contradict the context, then we have an adequate translation.

Finally, we have free translation, in which the rules of one-to-one relationships between elements are not taken into account.

Other scholars, such as Vinay and Darbelnet, suggest that we speak instead of variants of fragments of a translated work, in which transformative changes are of a local nature. It would seem that Vinay's and Darbelnet's chart could also be a basis for classifying entire translations. All the more so in that the categories they propose work with regard to strategies of translating single words, sentences, and phraseological units. ${ }^{12}$

These are, firstly: borrowings, or repetitions of a word or sentence from the original, such as bistro. Secondly: calques, or the mechanical replication of foreign language units, often in defiance of the norms of the target language, e.g. "He is a very sympathetic person." Thirdly: the literal translation, also known as the philological, or heteronomous translation. Fourthly: transposition. In Jerzy Ziomek's phrasing: “Transposition is what authors call a method of translation that involves replacing one expression, phrase, or term with another of related meaning." Fifthly: modulation. "Modulation is a change that involves respecting the structures of the language into which one is translating - 'modulation' is applied when a literal translation would be possible and even grammatically correct, but it would not render the spirit of the language" (Jerzy Ziomek). Sixthly: equivalence, which mainly concerns the text on a stylistic level. In this case, a shift in the meaning of the words is justified by a similarity of stylistic function. For example: Bruno Jasieński's kula śnieżna, ulegałka (snow ball, wild pear) from his poem "Słowo o Jakubie Szeli" [A Word on Jakub Szela] was translated by D. Samoylov by the "equivalent" of "apple of snow." Seventh: adaptation. Here we have a case in which the names of things or situations have no corresponding term in the target language.

12 This typology is described in detail by Jerzy Ziomek in his book Staff $i$ Kochanowski. Próba zastosowania teorii informacji w badaniach nad przekładem (Poznań 1965), pp. 24-28. 
Here the translator can use either the original name (which takes us back to "borrowing") or find an equivalent (Jerzy Ziomek). As we can see, the first six variants are linked to translation proper, while the seventh, adaptation, is a special case of translation interpretation.

I said at the beginning of this section that fragmentary solutions can dominate the whole of the translated work. In such a case, we would call the whole translation a "modulation" or an "adaptation," mindful of the quantitative, and especially the qualitative dominance of this or that translatorial strategy. Naturally, a borrowing or a calque has the least chance of being dominant. At first glance, a borrowing should not count at all here. A work where borrowing dominates would be a simple transcription of the original, not a translation. Nonetheless, there does exist a certain peculiar sort of "non-rational" poetry that suggests that the translator use borrowing as one of the important solutions. Poems of Velimir Khlebnikov, Aleksey Kruchonykh, Bozhidar, Olga Rozanova, Alargov (Roman Jakobson) and other Futurists are composed of words that are entirely new to the original language, "invented" by the poet. Here we can seek equivalents more suggestive to the recipient's "ear," though many words can simply be left intact. In Khlebnikov's poem based on the onomatopoeia of a storm:

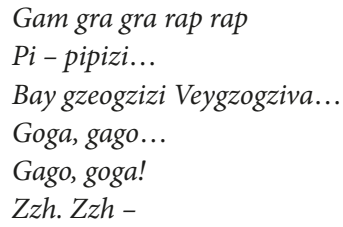

there is, of course, the option of polonizing (or anglicizing) the sound clusters ("Ho-ha, Ha-ho," for example, in place of "Goga, gago"), yet borrowing seems a crucial element in identifying the translation with the original. As such, it is the organizing principle for the whole of the translation.

The calque plays an important role in the structure of the whole translation with equal rarity. Most often it is a negative feature, creating linguistic monsters; it is a sign of the thoughtlessness of the translator; such cases are of no interest here. It seems that style might provide a chance for the calque. The emulating of foreign stylistic models, allegedly inconsistent with the spirit of native literature, can be a revolutionary act. It can be the "discovery of a style" (Efim Etkind). ${ }^{13}$ The translator who first made a calque of Faulkner's use of syntax discovered a new style in Polish narrative prose.

13 E. G. Etkind, Poeziya i perevod (Moscow-Leningrad 1963). 


\section{Variants of the Translated Work}

We obtain another configuration of variants when we ask about the real sender of the translation. Here, above all, the variant known as the authorial translation stands out, in which there is only one "sender": the author of the original has translated the work into a foreign language by themselves. We would be mistaken to suppose that the authorial translation is always closest to the original. This is not always the case. The authorial translation can just as often be a revision, as evidenced by the Russian authorial translation of Bruno Jasieński's Pale Paryż [I Burn Paris] (of 1934). Jasieński-the-translator changed the system of the literary tradition of his own original. He shifted the original Polish Pale Paryz from a Futurist code to a Socialist Realist code. The transformative changes, i.e. reduction, inversion, substitution, and amplification - involved the novel's plot, the construction of characters, and the idea of the whole work.

The role of the sender also defines the variants of polemical translations, i.e. translations made to question the value of the original. Mayakovsky's poems translated by Julian Przyboś are polemical. The Polish poet had not reconciled himself to the Expressionist flourishes of the Russian's poetics, the pathos-filled "gigantophone" of his style, and his translations put these attributes excessively on display. Hyperbolizing traits of one's opponent is, as we know, an effective polemical strategy.

Another variant of the translatorial polemics is the translation which I suggest we call "covert." The text of such covert translation has, at first glance, only one sender. The name of the foreign-language original's author has been omitted. This does not mean, however, that we are dealing with ordinary plagiarism. The covert translation is not plagiarism in that it reconstructs only fragments of a foreign-language work in a native language, generally giving them new functions and a new significance. It is not plagiarism also because it presupposes that its ties with a particular foreign-language work will be recognized. Readers must identify the encryption. Only in this manner can they decipher its polemical motivation. Bruno Jasieński’s "Pieśń o głodzie" [Song of Hunger] is a covert translation of Mayakovsky's "Cloud in Trousers." 



\section{Stefania Skwarczyńska \\ Translation and Its Place in the National Literature and Culture}

\section{1}

One characteristic of the tendencies in contemporary culture development I am taking into account the interwar period, and in particular the period following the Second World War - is the continuing ${ }^{1}$ growth of translation activity around the world, ${ }^{2}$ and the steadily rising interest in the very phenomenon of translation and its problems. These processes have already led to important changes in the situation of translation, both in terms of translatorial practice and social demands placed on it, and in terms of theoretical examinations of the subject. This change has manifested itself in various spheres of social reality, for example in the following developments: translation activity has largely moved from the hands of numerous amateurs to those of professionals aware of their multifarious responsibilities; the public opinion increasingly adds the ideal of a translation's congeniality ${ }^{3}$ to the old requirements of "fidelity" or "creative fidelity"; the old reflections on the premises, standards, and aims of translation, which used to be generally based on observation and experience, have evidently given way to academic examination of its foundations, which means a transition from an empirical interest in translation to a theoretical one. ${ }^{4}$

And it is here, in the field of theoretical investigation of translation, that a true leap has been made nowadays in the history of its modern development, which in turn signals a major increase in its international significance. Translation

1 A casual glance at the historical schools of translation yields such titles as: E. Cary, La traduction dans le monde moderne (Genève 1956); Y. D. Levin, "Ob Istoricheskoi Evolutzyi Principov Pyeryevoda" in Myezhdunarodnyie Sviazhi Russkoi Literatury: Sbornik Statyei, ed. M. P. Alexeyev, Moscow-Leningrad, pp. 5-63; cf. also F. Ross Amos, Early Theories of Translation (New York 1920) [The footnotes in the whole chapter have been edited for the present publication - editors' note].

2 Robert Escarpit mourns the fact that the translation movement is still too weak and one-sided in relation to its significance. See his: La revolution du livre (Paris 1965), pp. 100-101.

3 Cf. D. Aubry, "Préface" to Georges Mounin, Les problèmes théoriques de la traduction (Paris 1963), p. 12.

4 Aubry, "Préface", pp. 3-17. 
has gained the status of an object of academic study. ${ }^{5}$ It has in a significant way entered the sphere of linguistic research, ${ }^{6}$ as well as literary theory and philosophical studies, ${ }^{7}$ though these latter sometimes ground the discussion of translation problems in the area of cultural anthropology and cultural studies in its widest sense. ${ }^{8}$ They introduce translation into the theoretical underpinnings of their own subject of study and into their own methodology, without limiting themselves to a historical look at its previous forms, norms, and achievements,

5 Here we are most indebted to the Russian school, and to Andrei V. Fedorov in particular; cf. A. V. Fedorov, “Osnovniye Tyeorye Pyeryevodam," Voprosy Yazykoznaniya 1952, No. 5, pp. 3-22; A. V. Fedorov, Vvyedyeniye v Tyeoriyu Pyeryevoda (Moscow 1958).

6 It was above all Fedorov who discussed translation issues in the context of linguistic research, while at the same time acknowledging the relevance of literary research, as was visible in the second edition of his work (cf. note 5). Roman Jakobson laid the foundation for a theory of translation from the perspective of general linguistics, e.g. in his “On Linguistic Aspects of Translation." In: On Translation, ed. R. A. Brower (Cambridge MA 1959), pp. 232-239. In Poland this kind of research was undertaken by Z. Klemensiewicz, "Przekład jako zagadnienie językoznawstwa." In: O sztuce ttumaczenia, ed. M. Rusinek (Wrocław 1955), pp. 85-97 [see pp. 59-71 in the present volume - editors' note].

7 We should note the polemic between adherents of a strictly linguistic approach to translation (the Soviet school until 1958) and adherents of a primarily literary perspective (E. Cary, La traduction dans le monde moderne...). Today there is no shortage of translation theory from a literary theory perspective. The distinction here comes with the kind of text being translated. And thus, with regard to poetry, we have E. Etkind, Poeziya i Pyeryevod (Moscow 1963), and in Poland E. Balcerzan, "Sztuka tłumaczenia a styl" in: Studia $z$ teorii i historii poezji, ed. M. Głowiński (Wrocław 1967), series 1, pp. 33-71; E. Balcerzan, "Poetyka przekładu artystycznego," Nurt 1968, No. 3 (40), pp. 23-26 [see pp. 105-119 in the present volume - editors' note]; at the crossroads of philosophy and literary theory we have i.a. Roman Ingarden, “O tłumaczeniach.” In: $O$ sztuce ttumaczenia..., pp. 127-190 [see pp. 85-104 in the present volume, in a shortened version - editors' note]; J. Ziomek, Staffi Kochanowski. Próba zastosowania teorii informacji w badaniach nad przekładem (Poznań 1965); and in various areas of philosophy, O. Wojtasiewicz, Wstęp do teorii tłumaczenia (Wrocław 1957); E. Delavenay, La machine à traduire (Paris 1959); "Préface" to G. Mounin, La machine à traduire (The Hague 1964); I. Ryevzin, V. Rozenzveig, Osnovi Obshchevo i Mashinnovo Pyeryevoda (Moscow 1964); J. Kmita, “Z problemów semiotyki sztuki. O przekładalności dzieła literackiego," Nurt 1968, No. 8 (40), pp. 20-22.

8 Cf. i.a. E. A. Nida, "Linguistics and Ethnology in Translation - Problems," Word 1945, No. 2, pp. 194-208; Nida, "Principles of Translation as Exemplified by Bible Translating." In: On Translation..., pp. 11-31; cf. G. Mounin, Les problèmes théoriques de la traduction, p. $61 \mathrm{ff}$. 
as literary history has done for nearly half a century. Of course, the incursion of translation into these disciplines only became possible in the twentieth century, when new and groundbreaking approaches in the humanities shifted and expanded their horizons. Above all, and importantly for all humanities, structural and functional linguistics crystallized, ${ }^{9}$ then also distributional linguistics, ${ }^{10}$ as well as information theory and semiology. We should also point out the importance of the increasing collaboration of various disciplines in research practice, resulting from integrative tendencies in scholarship. To the above-listed fields we might add ethnology, social psychology, and above all sociology.

Another sign of the presently growing significance of translation around the world, apart from the place it has come to occupy in the world of modern academic research, is the well-known solicitude it enjoys by from an international institution no less than UNESCO, as well as the care for its quality and stature on the part of PEN Clubs, initiated by Poland even before World War Two. This care manifested itself in efforts to ensure a proper place for translation in literature, and a proper position for translators in the civitas litteraria.

These and other symptoms of past and present changes in the situation of translation also show an increasing awareness of the importance of translation for the development of international culture. Indeed, from the perspective of the universal ideals of fraternity, unity, and the spiritual community of all humanity, translation is one of the yardsticks and tools for bringing together various national cultures and various cultural spheres, for shaping and strengthening international or universal culture.

Could it be, then, that translation has become a tool for stripping national cultures of their identities? Should it be relegated beyond the sphere of national literatures?

The very attempt to answer this question in the affirmative would be tantamount to a fundamental misunderstanding. Above all: we do not view international consciousness and culture as emerging from an elimination or suppression of national consciousness and culture. On the contrary: the specificity, vivacity, and strong consolidation of national cultures - the cradle of a national culture being a national consciousness ${ }^{11}$ - are the most fertile soil for the international

9 For its significance in the humanities, see C. Lévi-Strauss, Anthropologie structurale (Paris 1958), especially chapt. 2: "Lanalyse structurale en linguistique et en anthropologie".

10 Cf. G. Mounin, Les problèmes théoriques de la traduction, p. $30 \mathrm{ff}$.

11 This concept lies at the basis of the cultural theory of Bronisław Malinowski, e.g. in Freedom and Civilization, (London 1947), quoted in J. Chałasiński, "Kultura i naród a 
consciousness and a requirement for development of an international culture on their foundations. As Chałasiński ${ }^{12}$ claims, citing Franz Fanon, "it is at the heart of national consciousness that international consciousness establishes itself and thrives." ${ }^{13}$

If we then extrapolate the foregoing to translation issues, we find that if translation is to serve international consciousness and international culture effectively, it must first serve the national culture. When we say "to serve," we mean a particular sense of the word - to serve the vitality of a given national culture, to energize it, deepen it and creatively expand it, not just mechanically increase the quantity of text linguistically accessible to wider circles of a national community, at best enticing them (superficially and temporarily) with the novelty or "exoticism" of a work foreign to their native soil. ${ }^{14}$

With this approach to the matter, translation problems will be clearly different depending on the spheres of culture to which a given translation belongs.

Our further investigations will strictly pertain to the translation of literary works, and thus to literature as a separate sphere of culture. But before we move on to discussing translation in the context of national literature, we shall have a few remarks on the latter.

\section{2}

We define "national literature," of course, not only as a collection of works in the language of a given national community, but as an open-ended structure, and as a mark of a particular historico-literary process. Thus, it is our assumption that every work of national literature is, from a historico-literary perspective, a link between literary tradition and the present, with its specific lines of development; that it makes live contact with the whole of the national culture, actively entering its "bloodstream" with its ideological/thought content, artistic shape, and social dynamism. This aspect of a particular literary work - and it is found in every work, born as it always is from a particular national culture - allows us to speak of its value in the national culture. This is even when, in certain historicocultural conditions and circumstances, the language of a given work is not that of

przeobrażenia świata współczesnego," in his Kultura i naród. Studia i szkice (Warsaw 1968) p. 23.

12 J. Chałasiński, “Kultura i naród a przeobrażenia świata współczesnego...," p. 11.

13 F. Fanon, The Wretched of the Earth, trans. R. Philcox (New York 2004), p. 180.

14 This issue is addressed by K. Kostyrko in "O konieczności przekładu," Nurt 1968, No. 8 (40), pp. 1-3. 
a given community (as in the case of Latin used by Andrzej Frycz Modrzewski ${ }^{15}$ ), which would seem to indicate the primacy of national-cultural value as opposed to the national language as a criterion for including a work in a certain nation's literature. Of course, with regard to national-cultural value, a typology of quality and a hierarchy of degree enters the picture, as it always does with value. For this value can differ in quality and degree, depending on the quality, dynamics, quantity, and range of functions a work serves in the national literature and culture as a whole. A reliable test of the national-cultural value of literary work should be its rootedness in the consciousness of the wider social spheres, its assimilation by society as a kind of spiritual property, with which there is a vivid emotional relationship, the creation of a permanent or long-lasting aesthetic sensitivity toward it, and a submission (more or less conscious, more or less enduring) to the ideological and philosophical suggestions and advice it proffers. Furthermore, we come to its rootedness in the literary, historical, and cultural tradition, and its bearing on the contemporary world and upon the future of the national art, culture, and history. This high national-cultural value is found in the works of our great Romantic poets (and this is also what makes them great), with Adam Mickiewicz at the forefront, as well as Cyprian Kamil Norwid's works, though society's response was belated here, and those of Henryk Sienkiewicz, Stanisław Wyspiański, and Stefan Żeromski. ${ }^{16}$

This matter of the national-cultural value of a literary work, placing it in the framework of a national literature, has a particular impact on the issue of translation. It chiefly concerns the question of whether a foreign translated work belongs to the national literature defined by the language of the translation.

15 Andrzej Frycz Modrzewski (1503-1572) - Polish Renaissance scholar, humanist and theologian, dubbed as "the father of Polish democracy," the author of Commentariorum de Republica emendanda libri quinque. [editors' note].

16 Adam Mickiewicz (1798-1855) - Polish poet, dramatist, essayist, translator, philologist, and political activist. A key figure in Polish Romanticism; author of Pan Tadeusz (1834), the Polish national epic; Cyprian Kamil Norwid (1821- 1883) - Polish poet, dramatist, painter and sculptor. He belonged to the second generation of romantics, lived abroad most of his life, and died in poverty in Paris; Henryk Sienkiewicz (1846-1916) - Polish writer, Nobel Prize laureate; author of historical novels, including the international bestseller Quo Vadis: A Narrative of the Time of Nero (1896); Stanisław Wyspiański (1869-1907) - Polish playwright, poet, painter and designer of the Young Poland generation. Author of a series of symbolic, neo-romantic drama; Stefan Żeromski (1864-1925) - Polish novelist, dramatist, and social activist, "the conscience of the Polish nation" [editors' note]. 


\section{3}

The issue of translation belonging or not to the national literature of its language is undoubtedly the main problem concerning translated work, given that its resolution has consequences in various vital fields of social practice that concern translation, including, first and foremost, research. By the same token, solving this problem is not easy, particularly within the framework of literary theory.

There is considerable resistance here in the natural discrepancy between "translation" in its most general understanding, i.e. as a foreign work dressed in the garb of the native language, and currently prevailing claims about the literary work as such. Above all, in this definition of translation we have an utterly dualistic way of thinking, sharply dividing the content of a translated work from its linguistic garb. Moreover: by this notion the foreign work, i.e. the original literary text, is divorced from its linguistic form and reduced solely to its content. The dualistic manner of thinking that informs this definition of translation and its results collides with a monistic way of thinking found in the currently prevailing definitions of the literary work, whether conceived strictly through the unique artistic organization of the language matter or through the absolute unity of the semantic content and the artistic and linguistic form. Similarly, the introduction of the genetic aspect to define a translated work stands in marked contradiction with the contemporary tendency to conceive of the literary work in descriptive or Structuralist categories.

The extent of this discrepancy is enhanced by the contradiction between the generally acknowledged fact of the uniqueness of the literary work and its inviolability, its immunity to the alteration with time, and the fact that this same literary work is subject to multiplication and variation, not only through translation into different languages, but also within any one of those languages. There are multiple variants because - quite apart from the paradoxical nature of the "transfer" of the literary work from its proper linguistic form into a foreign linguistic shape - there is no denying in our day that the ideal of total "fidelity" in translation is no more than an unattainable ideal; its attainment is blocked by four insurmountable linguistic obstacles, persuasively outlined by Georges Mounin: ${ }^{17}$

1. the differences in language structures with regard to their semantics;

17 G. Mounin, Les problèmes théoriques de la traduction... 
2. the differences in the "visions of the world" in different languages (their various ways of capturing, phrasing, and building an image of the objective reality, its fragments and aspects) ${ }^{18}$;

3. the different forms of social experience in different national collectives, while every language - which serves, after all, to facilitate communication within the respective community - corresponds to a particular structure of these experiences in a given linguistic collective;

4. the tie between every language and the geographic, civilizational, and cultural reality within its limits of its ethnic reach, which restricts and sometimes even precludes the communication of a work created elsewhere. Hence, we should not be surprised that a literary scholar looking at the literary work from the perspective of world literature has difficulty accepting that "Hamlets" in other languages, though they may function under the same title and under the name of the same author, are equal to Shakespeare's English Hamlet, as they are but various versions of the original.

And yet it might be possible to remove or at least mollify the difficulties and doubts, if, for the good of the translation, we were to agree that the literary work is a cultural fact. Here, in particular, we are taking the perspective of the national culture - since we are addressing the issue of translation belonging to the national literature of its language - and as such, the national literature. It is of fundamental importance that we establish whether translation can be attributed with national-cultural significance, the way an original work can.

We soon find there is no way to deny translation the national-cultural value. We find examples of translations of an outstanding value in every nation's literature, even when they have not been designated as "classics," as have August Wilhelm Schlegel's renderings of Shakespeare's dramas, or Baudelaire's translations of Poe. By way of proof - si licet to put side by side the names of these translators Mickiewicz's translation of Byron's The Giaour, and Józef Paszkowski's rendering of Hamlet. ${ }^{19}$

Before we attempt to argue this on the basis of analyzing some facets of Paszkowski's translation of Hamlet, we should stress that the approach of cultural studies, which basically equates translation with original work in national literature, in the pivotal category of national-cultural value, decides that it belongs

18 This is the "Neo-Humboldtian" standpoint in linguistics.

19 Józef Paszkowski (1817-1861) - Polish poet and translator, known mainly for his renderings of Shakespeare's plays (see http://internetshakespeare.uvic.ca/Library/ Criticism/shakespearein/poland12) [editors' note]. 
to the national literature, automatically dispelling doubts (more implied than voiced expressis verbis) of the part of literary theory. Representing the standpoint of cultural studies, Zofia Szmydtowa waves these doubts aside when she states:

When a translation enters the literature of its language, it is subject to the same laws as native works. Like them, it can fade away, not standing the test of time, or it can be as resilient as the great masterpieces. ${ }^{20}$

Nonetheless, it is hard to come to terms with the coexistence of two justified yet contradictory views on the same problem. As such, it is worth trying - with all due respect to the independence of either discipline - to reconcile these two positions by looking more closely at the phenomenon of translation in light of the defininions of the work of literature in literary theory.

Firstly, let us note the possibility of subduing the genetic aspect in defining the translation as a "foreign work," an aspect which is evidently opposed to more recent definitions of a work of literature in Structuralist/descriptive categories. Here the "sharpness" of the concept of "foreignness" is mollified when we recall that the subject of an original work generally bears traces of being derivative, and thus "foreign," albeit to a different extent and in a different manner, of course. We see this in how many works acknowledged as original are based on folk tales, in the way themes and motifs wind through literature, in the presently discovered patterns of adopting plot lines previously shaped in one form of art by other forms of art. ${ }^{21}$ Moreover, the definition of the literary work has not, so far, taken into consideration the theme; this includes the question of the theme being original or derivative, i.e. the question of its "foreignness." Thus, it seems that we may pass over the notion of a "foreign work" in the definition of translation, with a view to endowing the translation with full citizenship vis-a-vis the original work within the sphere of a national literature.

We might also temper the above-mentioned antinomy between "dualistic" thinking about translation and "monistic" thinking at the root of how we define a literary work. The "duality" in translation does not manifest itself in a sharp divide between the semantic content and the linguistic form. On the contrary: they are so closely connected, so intense is the cross-penetration of the "foreign" work and the native linguistic tissue (in its full historico-cultural color) that the new work achieves its own individual literary form. This is what led Boris Tomashevsky to

20 Z. Szmydtowa, “Czynniki rodzime i obce w przekładzie literackim.” In: O sztuce ttumaczenia..., p. 112.

21 Cf. e.g. T. Kowzan, Littérature et spectacle dans leurs rapports esthétiques et sémiologiques (Warsaw 1970), pp. 62-132. 
claim that, alongside the French Béranger and the German Heine, there is also a Russian Béranger and a Russian Heine. ${ }^{22}$ This intimate connection is the result of mutual and bilateral interdependencies between the foreign work and the tissue of the local language. The foreign work adopts certain attributes of a native work, and the native tissue, to a certain degree, assimilates attributes of the linguistic tissue of the original work, a tissue that works as a model here. In the translation there is a unity of "form and content," as in the original literary work. This also means that it earns the right to take an equal position in the national literature. It ceases to be a "foreign work."

If we opt to acknowledge the translation to be a literary work equal to the original, and if we look at it in terms of the literature indicated by its language and not in terms of the literature of the original, then we automatically dispense with doubts focused around the uniqueness and inalterability of the original literary work and the fact that translation yields its multiple variants. From this perspective, every translation is simply a literary work equal to an original work in the literature and national culture which it joins through language. Indeed, translation introduces to a national literature as many authentic literary works as many renditions have been made. Yes, Polish literature has as many "Hamlets" as there are translations of Shakespeare's Hamlet. And we cannot speak of a simple multiplication of the original through translation, for the original changes, and not only in terms of language: in every translation the content is crystallized differently, a content nolens volens assimilated in a new form, and somewhat altered - if only through shifts in emphasis. For this process involves interpretation and reinterpretation, sometimes extracting some deeply hidden aspects of the original. The basic difference that occurs between the original, which is oneof-a-kind and inalterable, and the translation is that in the case of the original, interpretation and reinterpretation can only be external (in criticism and literary studies), while in the case of the translation they occur within. With regard to the original, the translation is also to some degree an indicator of the translator's "critical approach."

If national-cultural value is decisive in including a work in a national literature, and if we ascribe this value to a translation, as a self-sufficient, fully-fledged literary work within a national literature, then we see no reason why conclusions derived from the theory of a literary work as a fact of a certain national culture should yield to a theory of literature that defines a work in terms of the text itself.

22 B. Tomashevsky, "La nouvelle école d'histoire litteraire en Russie," Revue des Etudes Slaves 1928, Vol. VIII, Nos. 3-4, p. 237. 
At any rate, we do not suppose - and we have tried to show it - that these two standpoints are, contrary to appearances, irreconcilable, that they turn out to diverge in a significant way. We ought better to speak of them, perhaps, as mutually complementary when we interpret their premises correctly.

The most important matter, however, as it concerns how we study the particular facets of literature, is that we cease to sidestep the question of whether translations belong to national literature. For it is more sidestepping that we are dealing with than any attempts at describing or affirming this belonging, or at denying it and thus assigning the translation a different place in the world of national literatures. The special importance of this issue manifests itself in research practice in that, despite this sidestepping, certain solutions, or tendencies toward this or that solution, are present (albeit not always consistently) in the very way the literary material is treated, how it is underscored or neglected, ordered and placed in a hiererchy. Until recently, the prevailing tendency was for more negative solutions. Only recently have we seen attempts to resolve the issue of a translation belonging to the national literature of its language.

\section{4}

The approach to translated works in overwiews of particular national literatures best shows the unclear status of translation with respect to the national literature. Here translations are generally omitted, or mentioned only in passing, as if they were second-class citizens. A certain exception is made for "classic translations," such as the above-mentioned translations of Shakespeare's dramas by Schlegel, or Baudelaire's renderings of Poe's tales. But then we must ask whether Baudelaire's congenial translations would have found their place in the greater scheme of French literature had he not been the author of Fleurs $d u$ mal - that is, if we were not "affixing" a yet another achievement - albeit a peripheral one - to the writer.

Another exception primarily concerns older translations which are in fact remakes - those in which the content of the original work was more or less thoroughly domesticated, and the linguistic tissue played a major role in the development of the native literary language and native poetics. Among these are works inseparable from the history of Polish literature, like Piotr Kochanowski's translation of Tasso's Jerusalem Delivered and Łukasz Górnicki's translation/remake of Castiglione's Book of the Courtier. ${ }^{23}$ Place of honor in this category goes to Juliusz

23 Cf. R. Pollak, “Gofred” Tassa - Kochanowskiego (Poznań 1922); R. Pollak, “Triumfy 'Gofreda’ i ścieżki cierniste 'Orlanda.’” In: Wśród literatów staropolskich (Warsaw 1966), pp. 225-241; R. Pollak, “Wstęp.” In: Łukasz Górnicki, Pisma, ed. R. Pollak (Warsaw 
Słowacki ${ }^{24}$ for his translation of Calderon's The Constant Prince, whose Polish title even departs from the original's El principe constante. ${ }^{25}$ Yet in the case of remakes, the criterion of fidelity to the original text did not apply.

As such, it would seem as though waiving the principle of translation fidelity favors the production of valuable works of national literature.

This sounds both paradoxical and alluring, but it is not altogether accurate. On the one hand this is because we need to characterize the historical poetics of the translation by demonstrating their organizing principles, and not those principles which are not relevant to them; in the present case the organizing principle is the translator's freedom with respect to the foreign text.

On the other hand - and this introduces us in medias res to the historical process determining the fickle fate of translation with regard to national literatures the concept of "waiving" suggests not only the very existence of the principle of faithful translation at the time, but also the availability of this principle to the translator. This principle has undoubtedly existed from almost the dawn of our era, but it only pertained to the translation of the Bible and liturgical texts of the Church, where it held firm. Let us recall the "College of Seventy," which Parandowski called "semi-legendary:" ${ }^{\prime 26}$ the producers of the first Greek translation of the Holy Scripture, the Septuagint; let us recall St. Jerome, the author of the Vulgate; and finally, the countless translators of the Holy Scripture into national languages. This gave the principle of fidelity a sacred dimension, so to say. Applying the same principle to secular works, therefore, would have had a touch of the profane. The first gesture of this profanation would seem to be the (rather inconsistent) attempts of Renaissance humanists and writers to apply the principle of fidelity to translations of ancient literature. Here we have in mind the outstanding translators of Ancient texts such as Etienne Dolet or Jacques

1961), Vol. 1, pp. 1-45; cf. also T. Milewski, “Główne etapy rozwoju polskiego języka literackiego," Ruch Literacki 1960, Nos. 1-2, pp. 19-27.

Piotr Kochanowski (1566-1620) - Polish nobleman, royal secretary, poet and translator. He is famous for his translations from Italian, especially Ludovico Ariosto's Orlando furioso and Torquato Tasso's Gerusalemme liberate; Łukasz Górnicki (1527-1603) Polish humanist, poet, political commentator, also royal secretary and chancellor [editors' note].

24 Juliusz Słowacki (1809-1849) - Polish poet, dramatist and translator, a key figure of Polish Romanticism [editors' note].

25 Cf. a comparison of Książe niezłomny with the original in: J. Kleiner, Juliusz Stowacki. Dzieje twórczości, Vol. 4: Poeta-mistyk (Warsaw 1927), Part 1, pp. 204-228.

26 J. Parandowski, “O znaczeniu i godności tłumacza." In: O sztuce ttumaczenia..., p. 12. 
Amyot in France. ${ }^{27}$ Yet this gesture was less aimed to eliminate the sacred in favor of the profane than to elevate Antiquity to the heights of the sacred. Each of these translators "believed in his pagan's heart" in the truly divine greatness of Antiquity.

The principle of translation fidelity was only desacralized once and for all in the eighteenth century. Small wonder that it was at this time that the first substantial (though not the first ever) treatise on translation was written based on this principle: Alexander Fraser Tytler's Essay on the Principles of Translation (1790), revived in Poland by Wacław Borowy. ${ }^{28}$ And it should come as no surprise that a translation theory was established by proponents of the principle of fidelity, the French Encyclopédistes, headed by Voltaire. The profane prevailed. From then on, the principle of translation fidelity became the basis of all translation theory, although it did not immediately subdue the popularity of translation based on a freer approach. In the Romantic period, free translation prospered (on the crest of the Baroque revival), while coexisting with the first translations that rigorously adhered to the principle of fidelity. Later, free translation was merely an offshoot of Romanticism, such as Krystyn Ostrowski's Polish translation of Hamlet, published in $1870 .{ }^{29}$

The triumph of fidelity in translation, which was also tantamount to elevating the author of the original to the place of highest importance, had vital implications for literary studies and the status of translation in national literatures.

Translation is incorporated in the sphere of the original's native literature, though in a marginal capacity; it has served as proof of the global expansion of the original work, and thus, of this work's native literature. We find testimony to this, perhaps, in the fact that scholarly competences with respect to a translated work are increasingly taken over from experts on the national literature of the translating language by experts on the native literature of the original. It is no accident that our most outstanding scholars of Polish translations of Shakespeare are experts on English-language literature: Władysław Tarnawski, ${ }^{30}$ Stanisław

27 J. Bellanger, Histoire de la traduction en France (Paris 1903); A. de Blignères, Essai sur Amyot e les traducteurs français du XVI siècle (Paris 1851).

28 W. Borowy, “Dawni teoretycy tłumaczeń.” In his: Studia i rozprawy (Wrocław 1952), Vol. 2, pp. 7-30.

29 On Polish translations of Shakespeare's Hamlet see Shakespeare in Poland: Translations, http://internetshakespeare.uvic.ca/Library/Criticism/shakespearein/poland12/ [editors' note].

30 W. Tarnawski, O polskich przekładach dramatów Szekspira (Kraków 1914). 
Helsztyński, ${ }^{31}$ alongside a Polish-literature expert who is exceptionally competent in English literature, Wacław Borowy. ${ }^{32}$ Nor should it come as a surprise from the perspective of this sovereign principle of translation fidelity - that scholars of the literary tradition of the original are among its translators: Hamlet has been translated into Polish by Władysław Matlakowski, Andrzej Tretiak, Władysław Tarnawski, and Witold Chwalewik.

Comparative studies situated translation between national literatures, or rather at their contact point, or in the field marked out by their intersection. In particular, the early twentieth-century French comparative school, which passionately examined the world dissemination of masterpieces through translations, uprooted translations from their national literatures and situated them within the radius of the shining stars and suns of the world's literary firmament. ${ }^{33}$ This was consistent with tendencies in comparative studies itself, as well as those in literature as such, which strove to topple the boundaries between national literatures in favor of a single world literature. A recent proposition by Dionýz Durišin ${ }^{34}$ that comparative studies should take over the study of translation, having placed it at the core of its research, is a logical extension of that historical standpoint in comparative studies. It also neatly crowns the tendencies to situate translation outside of national literatures.

Finally, the principle of fidelity prevailing in translation has one more consequence for its place in the world of literature. The translation research field and evaluation criteria derived from this principle have resulted in separating translations from other, original literary works. Thus, an independent department is emerging in literary and linguistic research: translation studies, in which translation is the sole object of research. We can see quite clearly groups of translation scholars forming ad hoc, in both linguistics and in literary theory. They are

31 S. Helsztyński, "Przekłady Szekspirowskie w Polsce wczoraj i dziś," Pamiętnik Teatralny, 1954, Vol. 2 (10), pp. 3-91; S. Helsztyński, "Polish Translations of Shakespeare in the Past and Today," Zeitschrift fur Anglistik und Amerikanistik, 1964, Vol. 2, pp. 183-198.

32 W. Borowy, "Przekład Shakespeare’a i teatr." In his: Studia i rozprawy..., pp. 31-54; cf. also J. Krzyżanowski, "Szekspirologia wojenna i powojenna," Nauka i Sztuka, 1948, Vol. 7, pp. 17-56.

33 This is expressed in research theory and practice, particularly in the work of F. Baldensperger, including: Goethe en France, (Paris 1904); La littérature, création, succès, durée (Paris 1913).

34 D. Ďurišin, "Woprosy srawnitielnogo izuczenija literatur i analiz pierevodcheskogo myetoda”, in: VI Mezinárodni Sjezd Slavistů v Praze 1968. Résumé, př́spěvků a sdělení (Praha 1968), s. 334. 
chiefly interested in this fidelity to the original in the translation, in various types of this fidelity, and various ways in which it is achieved.

In our day, the principle, postulate, and criterion of a translation's fidelity to the original are so deeply ingrained in the consciousness not only of the intellectual elite, but also in the society at large, that any departure from it seems impossible. It does not seem sensible either; nor necessary. On the other hand, it seems we must struggle against its extreme consequence, i.e. the separation of translations from the rest of the world of literature - so that it might be introduced into the national literature of its new language. The path toward this end seems fairly simple. It would involve applying all the same criteria to the translation as pertain to the original work, without abandoning, of course, fidelity to the original.

Naturally, if we outline the matter in this way, translation appears in a special light. It emerges as the result of a particularly difficult creative act that holds many responsibilities. It acquires dignity and greatness. In such a case, its position in the national literature cannot be marginal.

If we accept the criterion of fidelity vis-a-vis the foreign language text in evaluating the translation, yet we join this criterion to all the others for evaluating a work of original national literature, we find that fidelity fades somewhat in comparison to when it is the sole criterion for evaluating a translation. It fades in that all the other criteria have a chance to step forward, clearing room for other ways of evaluating the translation. Essentially, this scholarly strategy resembles approaches to older translations, where the translator was more at liberty. It resembles this standpoint, but never identifies with it, much as, in the eyes of the contemporary scholar, the translation sensu stricto is never identical to the remake.

We should stress that, in present-day theory, there is a growing tendency to include translation in the national literature of its new language under the above-mentioned conditions. Szmydtowa, whose approach was already mentioned, testifies to this when she stresses that, "in entering the literature shaped by its new language, the translation is subject to the same laws as the native works." ${ }^{35}$ Karel Horálek speaks in a similar vein in his paper "Literary Genres from the Standpoint of Translation Issues": “... translations are an important part of national literatures," and furthermore, "... from the perspective of the

35 Cf. Z. Szmydtowa, “Czynniki rodzime i obce w przekładzie literackim.” In: O sztuce tłumaczenia..., p. 112. 
socio-cultural function, the division between original and translated literature is of minor importance ...."36

In the nineteenth century the principle of fidelity to the original text was facilitated by the apotheosis of the creative artist, already visible in the Pre-Romantic era: the apotheosis of the poet releasing his works in volcanic eruptions of passion. Standing opposed to the Classicist concept of the poet aspiring urso labore to formal perfection, this apotheosis resulted in neglecting the work on form, demoting it to the level of craftsmanship. Thus, with regard to translation, there was a one-sided glorification of the creator of the original work and contempt for the workmanlike labors of the translator. Before this view, which outlasted the Romanticism that gave birth to it, faded out entirely, Modernism revitalized and perhaps even reinforced it with a cult of genius and originality, supported and taken well into the twentieth century by various factions of the "philosophy of life," from the Dilthey and Spranger schools to the Vitalist movements of English and French philosophy, the Bergson school, and the Croce school. Consequently, the original became absolutely central to the business of translation, and its author the omnipotent lawgiver; the linguistic substance of the translation became merely a question of the translator's greater or lesser abilities. This view ingrained itself so profoundly in the general awareness that it did not even require justification or intellectual check. This became the driving force in perpetuating convictions of the dominance of the foreign work in translation, and the source of all hesitations and academic aberrations on the subject of the translation's place in the national literature.

But there are other driving forces that have begun to oppose this force and its consequences, inspired by new directions in today's poetics and criticism. These take two approaches.

One of these is tied to the present anti-Romantic poetics rehabilitating labor, intellectual exertion, rational activity, the writer's technique, the craft of ars, téchne, in the name of an anti-inspirational concept of art. We usually see the origins of this new poetics in Ezra Pound's work and self-commentaries, then in those of T. S. Eliot. In Poland this role was played by the poets of the Krakow Avant-garde. A backlash against the cult of genius and originality in favor of fine and thoughtful work that molds the linguistic material of the literary piece was also at the heart of new movements in criticism. Here we have in mind the Russian Formalist school, then the school in Czechoslovakia, focused around the

36 K. Horálek, "Rodzaje literackie z punktu widzenia problematyki przekładowej," Zagadnienia Rodzajów Literackich, 1964, Vol. 7, Book 1 (12), p. 12. 
Cercle Lingustique de Prague. It is no coincidence that translation was examined by the Russian Formalists, and that they opposed the way it had been approached. Here, for the first time, the role of translation in the domestic historico-literary process was appreciated, and thus translation was decidedly included within the sphere of the national literature. This was expressed on the international arena by Boris Tomashevsky in his 1928 paper "La nouvelle école d'histoire littéraire en Russie," the first text to present the premises and research interests of the Formalist school to the West:

The assimilation of foreign elements is, above all, their adaptation. Translated literature should thus be studied as a constitutive part of the literature of particular nations. Alongside the French Béranger and the German Heine, there is also a Russian Béranger and a Russian Heine, adapted to the needs of Russian literature, and doubtless fairly remote from their Western namesakes. ${ }^{37}$

Undoubtedly, this concept of the original and the translation being homonyms sounds bold indeed when juxtaposed with the contemporaneous apprehensions (and misapprehensions) of the translation in literary theory.

The second approach that sustained and supported in living poetics and in criticism the new opposition toward the one-sided dominance of the foreign work in the translation is astonishing in that it accommodates (sometimes avidly) theoretical presumptions opposed to those of the first approach. This would seem paradoxical, yet it becomes natural when we understand the dialectic of the historico-cultural processes. Opposing intellectual movements sometimes join forces, and at times create a thrust that affects the historical process in a seemingly different field.

What is meant here is the living poetics' response to the call for literature to become involved in the revolutionary reconstruction of society. The history of this call dates back to the statements of the major figures in Marxism - from Marx himself and Engels to Lenin - and chimes with the call of such revolutionary democrats and critics as Vissarion Belinsky and Nikolay Chernyshevsky. It is accompanied, from a distance, by the call of "leftist" criticism of various shades, whose ideological wellspring goes back to the times of the bourgeois revolution of the eighteenth century. Consequently, even in the last quarter of the nineteenth century we find living poetics postulating a conscious, revolutionary, or at least critical stance toward contemporary life in social and political matters, whether international or national. What corresponds with this poetics

37 Cf. B. Tomashevsky, "La nouvelle école d'histoire litteraire en Russie," Revue des Etudes Slaves 1928, Vol. VIII, Nos. 3-4, p. 237. 
in literary studies is an interpretation of the work based on objective reality, with all its characteristic historical processes, be they social, class-based, or cultural, including literary. These assumptions naturally result in looking at the literary work from the perspective of cultural studies, with an understanding of culture and its processes that corresponds with these premises, of course. In Marxist literary theory, combating the cosmopolitan designs that are sometimes visible in leftist criticism, particularly in the West (in France), the issue of national culture and literature assumed a prominent place as early as the 1930s. As such, the Marxist approach could not place translation outside the framework of the national literature.

We can see that the new approach to translation took varied, though at times converging paths toward introducing it into the sphere of the national literature indicated by its language, and thus toward eclipsing the omnipotence of the original in favor of stressing the translator's ideological or artistic creative accomplishments, and thus, in favor of the national-cultural value of the translation.

And yet, as we have stressed, this new standpoint has not identified itself with that of "yesteryear," which pushed translation towards remake, as it only tones down the presence of the foreign work in translation rather that treating it as non-existent. Therefore, in translation studies of the new orientation the presence of the foreign work foists certain specific issues that need to be addressed, although they are only partly (at best in terms of the linguistic juxtaposition of the translation and the original) unrelated to the problems imposed on scholars of the original work of national literature. As such, a special sphere of research problems corresponding to the specifics of translation itself has emerged for the translation scholar.

Skimming past the close comparison of the original text with its translation (for this is a field most thoroughly explored by academia), let us turn our attention to a few aspects of these specific problems which are tied to the value of translation in national culture.

\section{5}

Foremost among the special problems that the translation scholar is faced with is that of the time of appearance of a given translation in the history of literature. This is related to the question of why this foreign work was added precisely at this developmental stage of the national literature. Did a crisis emerge in the historico-literary development, and why? Did the dominant poetics prove insufficient, so that a new one could only be grafted on, as the Russian Formalists 
observe? Did a disruption of the social and political order disqualify the literature of the times as an ideological exponent of the old ruling class, as the Marxists might have inquired? Or was it that the balance between absorption and expansion that marks the healthy development of a national culture, even if only for its own use, tilted toward absorption, thus increasing (with or without necessity) foreign import? Was the import advantageous for the development of the national culture and within it, for the development of an international consciousness, or was it irrelevant, or even harmful? What was the role of the translator's social consciousness with regard to this historical moment - his or her individuality, talent, or sense of responsibility? We might produce many more questions of this sort.

Another set of questions is related to whether the translation in question was the first rendering of the original work or one of its consecutive versions. In the former case, the scholar should be especially keen to establish if the original text had been previously known in intellectual circles, and particularly among artists. And if so, how it had been received; did this work make its mark on the native literature? In researching the first full translation of the work - whether close to or distant in time from the literary effects of this reception - it is crucial to define the relationship between the translation and the effects of the immediate reception of the foreign literary work in the native literature. This means studying the translation's roots in the native literary tradition. Shakespeare's Hamlet had already been so deeply and creatively rooted in the consciousness of our great Romantics and their work that the first full translation, coming much later on, faced a mighty Polish tradition of its reception. Is a given translation going to weave into such a tradition, becoming a living link in a chain open to the future, or not? That is the question.

If a translation of a foreign work is not the first one, but one among many, and not the last, the scholar must inquire - apart from investigating its relation to the historical moment, the needs of the national culture at a given stage, etc. - into the translation's relationship to the previous and subsequent versions. Does it make use of the earlier translations, and if so, in what way, and to what degree; and does it pass on its own achievements to subsequent renderings? We believe that the greatest expression of admiration for Józef Paszkowski's translation of Hamlet, which the critics denied the position of a "classic," 38 was Jarosław Iwaszkiewicz's confession that, upon embarking on a retranslation of

38 A position shared by all Shakespeare translations scholars: Tarnawski, Helsztyński, Borowy. 
Hamlet almost one hundred years later, he consulted only Paszkowski's translation, apart from those by the Schlegels and Boris Pasternak. ${ }^{39}$ The same goes for a gesture by Jerzy S. Sito, the most recent translator of Hamlet, whose translation includes Paszkowski's rendering of Hamlet's song from Act III, Scene 2: "Why, let the stricken deer go weep [...]," ${ }^{40}$ acknowledging it as "classic" and well-established in the shared consciousness.

At any rate, examining the ties between a given translation and earlier versions requires a particular sensitivity to the stage of the eternal sparring match in the poetics of the time between the "classical" principle of perfection and the principle of originality, of constant novelty in art. The exclusive patronage of the principle of perfection, tempting translators to use what is best in translations to date, could pose a danger to the new work of national literature (i.e. every new translation) reducing it to a mosaic and thus depriving it of unity of style.

Finally, the genre diversity of the original text foists diverse problems upon both the translator and the translation scholar. Without delving too deeply into the subtle differences between a piece of lyric poetry and a work of epic prose, we cannot sidestep the special issues that arise when it comes to drama. This complies with our theory ${ }^{41}$ of the fundamental difference between the literary art, whose genres are the lyric and the epic, and the dramatic/theatrical art, to which the drama belongs. One staple repeated anecdote is Prospér Mérimée's sarcastic observation on a translation of Gogol's Government Inspector that the translator faithfully rendered the words of the text, but did not translate the drama itself. ${ }^{42}$

A drama is designed to be viewed by an audience, which means that every dramatic text for the theater contains a "theatrical vision," ${ }^{33}$ an expression of the artist's consciously dealing with all the materials of the theatrical art, and not only the language. By the nature of things, the "vision of the stage" adheres to the theater contemporary to the playwright; and thus the "vision of the stage" in Shakespeare's dramas was shaped by the Elizabethan stage, not the Medieval or Ancient conventions. Dramatic masterpieces are marked by their wide spectrum

39 W. Shakespeare, Romeo i Julia, Hamlet, trans. J. Iwaszkiewicz (Warsaw 1954), p. 6.

40 W. Shakespeare, Hamlet, książę duński, trans. J. S. Sito (Warsaw 1968), p. 8.

41 See e.g. S. Skwarczyńska, “Zagadnienie dramatu," Przegląd Filozoficzny, 1949, Vol. 45, 1-2, reprinted in Studia i szkice literackie (Warsaw 1953), pp. 95-121.

42 G. Mounin, Les problèmes théoriques de la traduction..., p. 14, Quoted in: E. Cary, Comment faut-il traduire?, Cours polycopié de l'Université Radiophonique Internationals, 1958, p. 5.

43 Cf. e.g. I. Sławińska, Sceniczny gest poety (Kraków 1960). 
of "visions of the stage"44 (in all respects), so that they can be suitably rendered in future theaters that differ in type, style, and conventions.

Hence, the translator of the older dramatic work has the obvious task of communicating its "theatrical vision" in the translation, yet this comes with the dilemma of whether, in the name of literal fidelity to the dramatic text, it should be rendered with reference to the now-historical theater of its time, or if it should be altered in translation to fit the type and style of contemporary theater. An argument in favor of the latter solution is the fact that a drama, by its nature, is meant to have a social impact through the theater, as well as that the national culture into which the translation incorporates the foreign work expects this input from the foreign culture to have as wide an impact as possible, and thus, not only to be read, but first and foremost, to be put on stage.

Of course, the point is not for the translator to attempt to relieve or replace the play's producer. It is more a question of providing the latter with dramatic material that is as compatible as possible with the type and style of the contemporary theater. This means considering the fact that the contemporary theater makes informed use of the spoken language and all its nuances, rather than only involving a recital of a text in the written language, as, for example, in the Medieval ${ }^{45}$ and in the Classical French Theater. Also, it must be borne in mind that the contemporary principle of coordinating the utterance with the actor's movement, gesture, and behavior, the principle of pace and rhythm in a play, is incompatible with the syntactic flow of "serious" verse usually found in drama, which could serve not only a theater based on recitation, but also later theatrical conventions, where realism flexibly obliged the actors' interpretations of the internal meanderings of the phrases of this "serious" verse, particularly when enjambments could be used to give lines the flow of "realistic" prose. To this we might attribute, on the one hand, the theatrical success of Paszkowski's late-nineteenth-century Hamlet until recent times; a translation whose versification implies that the translator intended to conform the work to the Polish literary tradition, and yet to "service" the original with an equivalent versification. On the other hand, there is recent appearance of Sito's translation, which is remarkably bold in breaking with the verse form of the original and adapting

44 E. Souriau, "Les grands problèmes de l'ésthétique théâtrale," Les Cours de Sorbonne, Centre de Documentation Universitaire (Paris 1956), pp. 16-17.

45 Cf. G. Cohen, Histoire de la mise en scène dans le théâtre religieux français du moyen âge (Paris 1926). 
it to the style of present-day theater. ${ }^{46}$ Finally, the translation of an older work "geared" toward the contemporary theater must take into account that this theater is as remote as possible from the ambition of an antiquarian reproduction of older drama and theater; that their age will, at best, be signaled by allusions and stylizations. This is reflected in translation in the choice of vocabulary, selection of syntactic forms, and use of present-day language conventions.

Of course, this state of things with respect to the translation of older drama suggests a distinction between translations according to their intended social reception, or more precisely, the form and aim of this reception. We thus come to a range of translation types; in some translations, there is the possibility of two or even more types converging.

On one end of this scale we find translation intended for the academic reception of the original, and thus reflecting the present-day knowledge of the original with academic rigor; of the Polish translations of Hamlet, the renderings by Matlakowski and Chwalewik would seem to fall into this category. We might call these academic translations. They are meant to be received in reading only, and strictly from scholarly viewpoint.

The second type aims to provide the reader with a maximally faithful rendition of the philosophical and literary qualities of the work. The relevant Polish translations of Hamlet here are by Tretiak and Tarnawski. We might call these literary-philological translations.

In close proximity to the latter type we find translations chiefly aspiring to recreate the poetic virtues and puissance of the original, but based on the special capabilities of the target language with a view to evoking an aesthetic response in the reader, or the reader and the theater audience. The perception of the written text facilitates the appreciation of the beauty of the translation's language more than the theatrical reception does, owing to the fact that in the theater the audience cannot pause in the work as it moves toward the end. In our view, Paszkowski and Iwaszkiewicz are the Polish translators of Hamlet who took this approach. We might call this type an artistic literary-theatrical translation, reserving the term "artistic literary translation" for a translation intended exclusively for reading (Skłodowski's Hamlet seems an example of this).

Finally, we have a kind of theatrical translation that is strictly intended for theatrical reception; its publication makes sense only in terms of documentation

46 J. S. Sito calls it a "intonational verse," defined "both through the dramatic situation whose content it bears and through its unique intonation, inherent to a given work." "Individual parts of my verse are built based on a musical phrase...," (William Shakespeare, Hamlet, translated by J. S. Sito, pp. 7-8). 
and practical purposes of the theater. Here, we typically find that the original is adjusted to serve the needs of the contemporaneous theater and the "taste" of the theater-going public. Examples of such theatrical translations are the chronologically first and last of the Polish translations of Hamlet, by Bogusławski (based on a remake by Friedrich Schröder and the translation by A.W. Schlegel) and Sito respectively.

This classification of translations of old dramatic works according to their intended social reception, and the forms and aims of this reception, intersects with their classification based on the translator's stance toward the original, which expresses itself in a whole range of types ${ }^{47}$ from a translation which intends to be absolutely faithful to the original, to the "free" translation, to the paraphrase translation, to remakes, and those again of various kinds. This shows us the complex multi-aspectual nature of translation as a work of a national literature. This multi-aspectual nature, arising from various sources and various translation aims, leaves a profound mark on every translation, and is another research problem that exclusively pertains to translated works in a nation's literature.

Translated by Soren Gauger

47 The wide range of translation forms is covered by Edward Balcerzan in his article "Poetics of artistic translation" [See pp. 105-119 in the present volume - editors' note]. 
Anna Wierzbicka

\section{Translatability and the Scripting of Other Peoples' Souls \\ An 'International Semantic Alphabet' as a Tool of Cultural Translation}

Translatability of meanings and ideas is a key issue in linguistic anthropology. If anthropology aims at "understanding 'others' (uncapitalized and plural),"1 then obviously anthropologists must be interested in the meaning of what those 'others' say. But to understand what speakers of a language other than our own say, we need to be able to translate it, or to have it translated, into our own language. For this, we need to know what their words-especially, their cultural key words-mean. Thus, cross-linguistic and cross-cultural understanding requires translatability; and the limits of translatability place limits on crosslinguistic and cross-cultural understanding.

What are those limits, then? It has been well known ${ }^{2}$ that words generally don't match in meaning across language boundaries. ${ }^{3}$

It is less widely recognized that sentences and longer passages are even less translatable than words. For example, the well-known American translator Edith Grossman writes: "the meaning of a passage can almost always be rendered faithfully in a second language, but its words, taken as separate entities, can almost never be. Translators translate context."

In my view ${ }^{5}$, detailed comparison of almost any translated passage with the original will show otherwise. This does not mean, however, that languages are

1 C. Geertz, "Culture, Mind, Brain/Brain, Mind, Culture." In: Available Light, ed. C. Geertz (Princeton: 2000), pp. 203-217.

2 At least since Locke's wonderfully clear discussion in his Essay Concerning Human Understanding. See: L. Locke, An Essay Concerning Human Understanding (Oxford 1959), vol. 2, pp. 48-49.

3 Recall also Malinowski: "Let me start with the apparently paradoxical and yet perfectly plain and absolutely true proposition that the words of one language are never translatable into another." See p. 47 in the present volume.

4 E. Grossman, Why Translation Matters (New Haven 2010), p. 71.

5 See e.g. A. Wierzbicka, “Arguing in Russian: Why Solzhenitsyn's Fictional Arguments Defy Translation," Russian Journal of Communication 4(1/2): 2011, pp. 8-37. 
'incommensurable', as Sapir once incautiously put it: "In as much as languages differ very widely in their systematization of fundamental concepts, they tend to be only loosely equivalent to each other as symbolic devices and are, as a matter of fact, incommensurable"6. If languages were really fundamentally 'incommensurable' there would be no possibility of accurate translation and, consequently, no possibility of understanding what exactly 'others' are saying.

My own work and that of Cliff Goddard and other colleagues leads us to the conclusion that, despite the limits of translatability, languages are not incommensurable because, as evidence suggests, they share a common conceptual core-a set of fundamental human concepts and their inherent grammar. ${ }^{7}$ This is what the NSM theory of language is all about. The acronym 'NSM' stands for 'natural semantic metalanguage. The idea is that the conceptual shared core of all languages can serve as a neutral metalanguage for describing and comparing all languages and all culture-specific discourses. Furthermore, this shared core, which can be articulated by a reduced version of any language, makes accurate translation of meanings and ideas, including those encoded in cultural keywords, in principle possible.

Such accurate translation is seldom practical: in everyday communication, and in translation of written texts, shortcuts and approximations are generally far more useful than a perfectly faithful transfer of meaning from one language to another. Genuinely accurate translation can, however, be a very effective tool of cross-cultural explanations and comparisons. "Of course, comparison is both possible and necessary," Geertz admits, somewhat reluctantly. But comparison requires a common measure, in the case of conceptual comparisons, a conceptual common measure; and such a conceptual common measure requires some shared concepts. The NSM list of universal semantic primes, presented in Tab. 1, offers such a common measure.

The NSM table of universal semantic primes provides an answer to Leibniz's quest for an alphabetum cogitationum humanarum, an 'alphabet of human thoughts', which, he thought, could provide a common measure for comparing, articulating and sharing ideas across languages and

6 E. Sapir, “Conceptual Categories in Primitive Languages.” In: D. H. Hymes (ed.), Language in Culture and Society (New York 1964), p. 128.

7 See e.g. C. Goddard and A. Wierzbicka (eds), Meaning and Universal Grammar: Theory and Empirical Findings, (Amsterdam 2002); C. Goddard, Semantic Analysis, 2nd ed. (Oxford: 2011); C. Goddard., A. Wierzbicka, Words and Meanings: Lexical Semantics across Domains, Languages, and Cultures (Oxford 2013).

8 C. Geertz, “Culture," p. 138. 
Tab. 1: The NSM table of universal human concepts

\begin{tabular}{|c|c|}
\hline \multicolumn{2}{|l|}{ I, YOU, SOMEONE, SOMETHING THING, } \\
\hline PEOPLE, BODY & Substantives \\
\hline KIND, PART & Relational substantives \\
\hline THIS, THE SAME, OTHER ELSE & Determiners \\
\hline ONE, TWO, SOME, ALL, MUCH MANY, & \\
\hline LITTLE FEW & Quantifiers \\
\hline GOOD, BAD & Evaluators \\
\hline BIG, SMALL & Descriptors \\
\hline KNOW, THINK, WANT, DON'T WANT, FEEL, & \\
\hline SEE, HEAR & Mental predicates \\
\hline SAY, WORDS, TRUE & Speech \\
\hline DO, HAPPEN, MOVE, TOUCH & $\begin{array}{l}\text { Actions, events, movement, } \\
\text { contact }\end{array}$ \\
\hline BE (SOMEWHERE), THERE IS, BE (SOMEONE/ & \\
\hline SOMETHING) BELONG TO BE (SOMEONE'S) & $\begin{array}{l}\text { Location, existence, } \\
\text { specification, possession }\end{array}$ \\
\hline LIVE, DIE & Life and death \\
\hline WHEN TIME, NOW, BEFORE, AFTER, A LONG & \\
\hline $\begin{array}{l}\text { TIME, A SHORT TIME, FOR SOME TIME, MOMENT } \\
\text { WHERE PLACE, HERE, ABOVE, BELOW, FAR, }\end{array}$ & Time \\
\hline NEAR, SIDE, INSIDE & Space \\
\hline NOT, MAYBE, CAN, BECAUSE, IF & Logical concepts \\
\hline VERY, MORE & Intensifier, augmentor \\
\hline LIKE AS WAY & Similarity \\
\hline
\end{tabular}

cultures. ${ }^{9}$ At the same time, it provides a semantic analogue of the International Phonetic Alphabet, the invention of which allowed the sounds of the world's languages to be recorded in an accurate and standardized way, independent of the native language of the transcriber.

Primes exist as the meanings of lexical units (not at the level of lexemes). Exponents of primes may be words, bound morphemes, or phrasemes. They can be formally complex. They can have combinatorial variants or 'allolexes' (indicated with $\sim$ ). Each prime has well-specified syntactic (combinatorial) properties.

It is largely because it permits a standardized transcription of meanings in a system independent of the language and culture of the investigator that NSM can

9 See A. Wierzbicka, "The Common Language of All People: The Innate Language of Thought," Problemy peredachi informatsii/Problems of Information Transmission 47(4): 2011, pp. 380-99. 
be an effective culture-neutral tool for the translation of meanings and ideas and thus, for 'understanding others'. Furthermore, since this 'International Semantic Alphabet' can be accessed, and used, through a trimmed-down version of any natural language, it allows the meanings of cultural 'others' to be transcribed 'in their own words', without letting the investigator's own language (e.g. English) come between the indigenous meanings and the conceptual world of the investigator.

The analogy between NSM and the IPA is far from perfect, if only because the latter is, to some extent, arbitrary (there could be alternative systems of transcription), whereas NSM, which is the result of empirical cross-linguistic investigations, is not. Thus, the key difference is that the IPA was invented whereas NSM was gradually discovered (over many years of empirical, as well as analytical investigations). Both systems, however, provide a method of standardization and a stable, neutral framework for the transcription of 'raw material': in one case, sounds and in the other, meanings.

Conventional interlinear glosses formulated in English (or whatever the language of the investigator happens to be) do not provide a neutral framework for semantic 'transcription', since more often than not they cannot be translated, with exactly the same meaning, into other languages. In this, they differ profoundly from NSM explications, whose hallmark is their cross-translatability.

The metaphor of an alphabet, with its historical antecedent in Leibniz's thought, should not deceive anyone into thinking that NSM offers a universal mental lexicon without outlining at the same time a universal grammar. Meaning and ideas cannot be compared and explained through words alone; they can only be compared and explained through sentences, that is, through words arranged into meaningful sequences. No one understood this better than Leibniz, who aimed at establishing a lingua mentalis rather than just a mental lexicon. NSM, too, is a mini-language: along with a mini-lexicon of 65 universal primes (matching the empirically established lexical common core of a large sample of natural languages) it includes also a mini-grammar (also matching the empirically established grammatical common core of a large sample of natural languages).

For example, the lexicon of NSM English represents a radical reduction of the full English lexicon, and the grammar of NSM English represents an equally radical reduction of full English grammar. At the simplest level, grammar can be thought of as a matter of what can be combined with what. In this sense, semantic primes have their own grammar, which is the same in all languages. For example, in all languages specifier primes (THIS, THE SAME, OTHER ELSE) can be combined with the universal 'substantives' SOMEONE, SOMETHING, PEOPLE, and KIND, as will be evident in NSM texts presented in sections 3 and 4 . 
Taken together with their associated grammar, semantic primes constitute the shared semantic-syntactic core of all human languages. Now that its structure is substantially understood, this shared core can be used-and is being used-as an analytical metalanguage for the exploration of the full lexicons and grammars of individual languages. It provides a non-arbitrary standard tertium comparationis (common measure), which is free from any English-specific terminological bias.

The same metalanguage can also be used for exploring ideas, values, emotions, social norms, ethno-biology, and so on, allowing an integrated approach not only to lexicon and grammar, but more broadly to language, culture and cognition. Hundreds of explications have been published, including, i.a., nouns for body parts, kin relations, artefacts, and natural kinds; verbs for physical acts and activities, speech-acts, and emotions; adjectives (property words) for physical qualities, dimensional properties and colors; and discourse particles and interjections as well as morphological categories and syntactic constructions.

This is the larger mission of linguists in the NSM paradigm, who, in addition to their studies into conceptual universals in language, have published numerous studies into language-specific and culture-specific aspects of individual languages. The NSM program has the most productive record in crosslinguistic and cross-cultural semantics on the contemporary scene. ${ }^{10}$

Calling NSM an effective culture-neutral tool is not tantamount to claiming that it is perfect and that there is no room for further improvement. But the effectiveness of NSM as a standardized framework for comparing and explaining meanings across languages and cultures does not depend on its perfection or even on the absolute universality of the primes.

On this point, too, it is worth invoking Leibniz, who wrote of his projected universal language:

Although this language depends on true philosophy, it does not depend on its perfection. That is to say, this language can be established even if the philosophy is not perfect: as our knowledge grows, this language will also grow. In the meantime, it can marvelously help us to use what we do know, to see what is lacking, and to invent the means for getting there, and especially to resolve controversies in matters which depend on reasoning. ${ }^{11}$

10 A bibliography and downloads are available at: www.griffith.edu.au/humanitieslanguages/school-languages-linguistics/research/ natural-semantic-metalanguagehomepage.

11 Qtd. after L. Coutrat, Opuscules et fragments inédits de Leibniz, (Paris 1903), p. 78. 


\section{The Hawaiians, the Dangs, and the Anglos}

Richard Collin notes that in his short story, "El idiomaanalitico de John Wilkins" Jorge Luis Borges "imagines an artificial language invented to permit the expression of any human thought." ${ }^{\prime 2}$ Using for this purpose Umberto Eco's term 'effable, ${ }^{13}$ Collin comments: "some linguists believe that all natural languages possess what is awkwardly called effability." ${ }^{14}$

The 'effability' of all existing natural languages (in Eco's sense) is clearly an illusion, but the NSM texts presented in this paper (and elsewhere in NSM literature) suggest that, in contrast to natural languages as such, reduced versions of natural languages (known as their 'NSM versions') are indeed-at least within certain limits-'effable' (and ipso facto, cross-translatable): whatever can be expressed in one of them can be expressed in any other, without addition, subtraction, or distortion of meaning.

Geertz writes:

Over the past twenty-five years or so, the post-everything era (post-modernism, structuralism, colonialism, positivism), the attempt to portray "how the 'natives' think" (or thought), or even what they are doing when they do what they do, has come in for a good deal of moral, political, and philosophical attack. ${ }^{15}$

Although Geertz evidently wants to distance himself from the spirit of the 'posteverything' era, he does seem to be sincerely skeptical about any attempts to portray "how the 'natives' think". In my view, such skepticism is misplaced. How could we possibly seek to understand others if we didn't try to grasp 'how they think? "The days of simple 'the Dangs believe, the Dangs don't believe' anthropology seem truly over," Geertz says. But without some further comment, this statement can be misleading. As I see it, questions like 'how do the Dangs think?', 'what do the Dangs believe?' are, in principle, legitimate, and indeed necessary, if we wish to come close to 'understanding others'. But they are only legitimate on certain conditions. I will list four.

The first condition is that we ask such questions not only about 'Dangs', but also about our own speech communities, and in particular, about 'Anglos'. As

12 R. Collin, "Moving Political Meaning across Linguistic Frontiers," Political Studies 2012, p. 2.

13 U. Eco, The Search for the Perfect Language (Oxford 1995), p.23.

14 Collin, Moving, p. 2.

15 C. Geertz, “Culture," p. 102. 
I have discussed in many publications ${ }^{16}$ while there are many 'Englishes' in the world and many cultural worlds associated with them, there is also a cultural world associated with what Braj Kachru calls "the English of the Inner Circle"17 and what I have called 'Anglo English.'18 Denying this usually leads to taking cultural norms and assumptions associated with 'Anglo English' for the human norm. An NSM perspective helps to free us from the blind Anglocentrism of such a position and allows us to recognize that, alongside Dangs, Hawaiians, Russians, and all the other human cultural groups (changeable, of course, and fluid, but nonetheless recognizable), there are also 'Anglos'.

The second condition is that we interpret these questions as applying to ways of thinking, and ways of understanding, shared by many rather than by all members of a given speech community. Obviously, it is not the case that all Anglos-or all Dangs-think the same (about anything). This doesn't mean, however, that there are no shared cultural assumptions among many Anglos, or many Dangs.

The third condition is that when we attribute widely shared assumptions and understandings to either Anglos or Dangs, we provide direct linguistic evidence for such attributions, and that this evidence is presented (inter alia) in their own words. For example, the existence, and high frequency, of the words 'fair' and 'unfair' in English (Anglo English), and the common forms of discourse based on these words (e.g. starting a sentence with the words 'to be fair..., or commenting: 'this is unfair') provide evidence for the generalization that many 'Anglos' often think about human relations in terms of the conceptual categories 'fair' and 'unfair'. Mutatis mutandis, the same condition applies to attributing assumptions to 'the Dangs.'

The fourth condition is that when we attribute shared understandings and cultural knowledge to a group of people we try to posit only beliefs that they could, in principle, express in their own language. The language of the investigator can

16 See e.g. A. Wierzbicka, English: Meaning and Culture, (New York 2006); A. Wierzbicka, "Anglo Scripts against 'Putting Pressure' on Other People and Their Linguistic Manifestations." In: C. Goddard (ed.), Ethnopragmatics: Understanding Discourse in Cultural Context (Berlin 2006), pp. 31-63; A. Wierzbicka, Experience, Evidence and Sense: The Hidden Cultural Legacy of English (New York 2010).

17 B. Kachru, "Standards, Codification and Sociolinguistic Realism: The English Language in the Outer Circle." In: R. Quirk, H. Widdowson (eds), English in the World: Teaching and Learning the Language and Literatures (Cambridge 1985), pp. 11-30.

18 A. Wierzbicka, English. 
be used for convenience as a shorthand for indigenous ideas but it cannot be the only medium in which those ideas could be expressed.

Geertz writes:

The mere claim 'to know better' which it would seem any anthropologist would have at least implicitly to make, seems at least faintly illegitimate. To say something about the forms of life of Hawaiians (or anybody else) that Hawaiians do not themselves say opens one to the charge that one is writing out other peoples' consciousness for them, scripting their souls. ${ }^{19}$

To my mind, there is nothing inherently wrong with the claim 'to know better', because someone who has studied a subject deeply may indeed 'know better' than someone who has never studied it at all. This applies not only to 'knowing others' but also to knowing one's own community. For example, most 'Anglos' are not aware of the existence or the exact nature of Anglo cultural scripts, and indeed many Anglophone linguists and anthropologists reject the proposition that there are any such scripts associated with 'Anglo English. ${ }^{20} \mathrm{I}$ believe that to know better, Anglo scholars need to study 'Anglos', in a way that is on a par with studying Hawaiians or 'Dangs.'

In principle, then, I don't see anything wrong with saying something about Hawaiians (or anybody else) that they themselves do not say. But to say something about Hawaiians (or anybody else) that Hawaiians could not themselves say (in their own words, because they have no such words) indeed opens one to the charge that one is 'writing out other peoples' consciousness for them, scripting their souls'.

\section{'Loyalty' vs. 'Sharing Goods with Kin'}

Consider, for example, the following passage from a book entitled Language and Culture in Aboriginal Australia:

19 C. Geertz, “Culture," p. 102.

20 See e.g. Wierzbicka, English; Wierzbicka, "Anglo Scripts”; C. Goddard, "Not Taking Yourself too Seriously in Australian English: Semantic Explications, Cultural Scripts, Corpus Evidence," Intercultural Pragmatics 6(1): 2009, pp. 29-53; A. Wierzbicka, “Early interactions' in Australian English, American English, and English English: Cultural Differences and Cultural Scripts." In: M. Haugh, K. Schneider (eds), (Im)politeness in English: Journal of Pragmatics, Special Issue 2012, pp. 1038-1050. 
Another cultural value which is important in non-traditionally oriented Aboriginal societies, as in traditionally oriented societies, is loyalty to kin. Aboriginal people expect each other to be loyal to a wide extended family. ${ }^{21}$

But as far as I have been able to ascertain, there is no word for 'loyalty' in Australian Aboriginal languages, and so if one attributes to people in Australian Aboriginal societies a belief in the value of 'loyalty to kin', one is, in my view, open to the charge of 'scripting their souls.'

The concept embodied in the English word loyalty (or French loyauté) comes from a European cultural tradition. The historical roots of this concept can be gleaned from the following definition offered by the Oxford Australian Dictionary: "loyal: steadfast in allegiance; devoted to the legitimate sovereign or government of one's country." 22 Other dictionaries of English offer similar definitions. For example, The Longman Dictionary of the English Language (1984) defines the word 'loyal' as "unswerving in allegiance" and the Collins Cobuild English Language Dictionary (1991) states that "Someone who is loyal remains firm in their friendship or support for someone or something, e.g. Most Tories remained faithful to the Government."

What these definitions either state or imply is a continuity in a person's support for someone else ('steadfast', 'unswerving', 'remains') and their undertaking not to 'betray' the other person's legitimate expectation of support and to stay 'on their side.'

These are, of course, only approximations, but clearly they are not approximations which would correspond to a way of thinking common in Australian Aboriginal societies. Judging by the literature on Australian Aboriginal cultures, and especially, on kinship-based requests and demands, one could venture the following approximation as closer to the norm that Diana Eades really has in mind:

THE 'WALYTJA' NORM

many people think like this:

"if someone is my 'kin' (walytja) it is good if I do good things for this someone when this someone says to me: "I want you to do something good for me" it will be good if I do it, it will be bad if I don't do it"

21 D. Eades, "Language and the Law: White Australia vs Nancy." In: M. Walsh and C. Yallop (eds.), Language and Culture in Aboriginal Australia (Canberra 1993), p. 188 (emphasis added).

22 B. Moore (ed), The Australian Oxford Dictionary (Melbourne 1999). 
Thus, consider the examples offered in the entry for walytja (roughly, 'kin') in Goddard's Pitjantjatjara/Yankunytjatjara to English Dictionary:

walytja

one of the family, a relation, a kinsman. Someone you care for, and who cares for you ... Paluruwalytjatjutakuwatjilarinyi. He’s pining for his relations./Papulankunytjawiya. Nyuntumpawalytjapalatja Don't stare at her. That's one of your relations (e.g. to a young child). Ananguwalytjangkapalkunangatjiningi, palungurpatjamantinyuntu. I thought I was asking of a relation, but I guess you must be a stranger to me (i.e. a reproach to someone unwilling to give).$^{23}$

The same norm is further highlighted by the entry on the verb ngatjini (roughly, 'ask for something in the name of kinship'):

ngatjini

ask, demand, request to be given something. Usually in connection with implied right to expect results, on account of kin obligations. (Person asked takes locative ending-la/-ngka, etc.): Palurutungunpungkulangatjiningi, kana putupainu. He really pressed his request, and I couldn't get rid of him. /Naipakungatjintjikitja-nayananyi, karatjikutu. I'm going to the garage to get someone to give me a knife. /Palurungalyapitjalangayulangatjinu. He came and asked me (for something).

Clearly, this is not about 'loyalty' but about the norm that one should do something good for a relation (e.g. give them something they want), especially when one is asked to do so. The key point is that 'loyalty' is, essentially, about not doing something bad to someone else (the person to whom one is being 'loyal'), whereas the Aboriginal norm is, essentially, about doing something good for someone else (a person to whom one is related). Roughly speaking, a person who is described as 'disloyal' is not someone who doesn't help someone else, or doesn't share resources with him or her, but someone who 'betrays' another person, against all expectations.

Using NSM, we could explicate loyalty more accurately along the following lines:

loyalty

it can be like this:

someone thinks like this about someone else:

"I know that at some times after this time

some people can do some bad things to this someone

if this happens, I will not do these things with these people

I can't do it, I don't want to do it

this someone can know this"

23 C. Goddard, C. Pitjantjatjara/Yankunytjatjara to English Dictionary, 2nd ed. (Alice Springs 1993). 
because this someone thinks like this,

when at some times after this some people do bad things to this other someone

this someone doesn't do these things with these people

it is good if it is like this

This is only an approximation, but it helps us to make the key differences between loyalty and the walytja norm more transparent: the contrast between 'not doing bad things to someone else' and 'doing good things for someone else', and the role of 'continuity' in loyalty ('remaining steadfast').

It is interesting to note that in his classic essay "Of cannibals" (written in 1578-80 and directed against European moral ethnocentrism), Montaigne cited 'loyalty' as an example of a moral absolute. ${ }^{24}$ Thus, he wrote famously: "Each man calls barbarism whatever is not his own practice; for indeed it seems we have no other test of truth and reason than the example and pattern of the opinions and customs of the country we live in" (I: 30). This didn't stop him, however, from extolling the 'courage' and 'valor' of 'South Sea' cannibals, and of expressing horror at 'treachery', 'disloyalty', 'tyranny' and 'cruelty,' which, he says, "are our ordinary vices" (I: 30).

For Montaigne, then, these are examples of moral absolutes: 'courage is good', 'cowardice is bad', 'disloyalty is bad', 'cruelty is bad', 'valor is good. Or, more precisely: desloyauté, cruauté, and lacheté are bad, courage and vaillance are good. Most of the examples cited by Montaigne translate reasonably well from (modern) French into (modern) English (although lacheté doesn't mean the same as 'cowardice, and implies 'a lack of moral fibre' in general rather than, specifically, 'cowardice').

Needless to say, the fact that loyauté in present-day French appears to match the present-day English 'loyalty' does not mean that the same was the case in the sixteenth or seventeenth centuries. In fact, the definitions provided by Antoine Furetière's (1690) dictionary of French suggest that there may have been some changes here, as well as continuity. Thus, in the entry for loyauté we read: "Quand on fait homage d'une terre au Seigneur dominant, on lui promet foi and loyauté. On prometen se mariant, une foi et loyauté reciproque."25

24 Cf. R. A. Shweder, “Relativism and Universalism.” In D. Fassin, (ed.), Companion to Moral Anthropology (Chichester 2012), pp. 85-102.

25 "When a vassal pledges allegiance to his lord he promises him fidelity and loyalty. In marriage, one promises reciprocal fidelity and loyalty," Le Dictionnaire Universel d'Antoine Furetière (Paris 1978) [1690]. 
The material cited by Furetière in this and related entries suggests that in the sixteenth and seventeenth centuries the meaning of loyauté may have been closer to 'pledging allegiance' (and being faithful to that pledge) than it is now and may have been closer to the formula below:

loyalty/loyauté (an older meaning)

it can be like this:

someone says to someone else at some time:

"I know that some people can do some bad things to you at some time after this time

I want you to know that when these people do these things, I will not do these things with these people"

because this someone says this,

when at some time after this some people do bad things to this other someone,

this someone doesn't do these things with these people

this someone thinks like this at that time:

"I can't do things like these, I don't want to do things like these"

it is good if it is like this

Whether or not Montaigne's virtue of loyauté corresponds exactly to the meanings of the present-day words loyauté and 'loyalty' is a point which would require further investigation. In any case, however, it seems clear that these words don't have exact semantic and cultural equivalents in Australian Aboriginal languages. ${ }^{26}$

Linguistic and ethnographic evidence suggests that in Australian Aboriginal cultures, if someone violates norms like the walytja norm this is seen as a case not of 'disloyalty' but of something like 'selfishness'. In Pitjantjatjara/Yankunytjatjara, the relevant words are ngurtju and its derivates, glossed in Goddard's dictionary as follows:

ngurtju

selfishly, greedily, without sharing: Nyuntukukaungkunytjawiyangkungurtjungkungalku $\underline{n} u$. You selfishly ate all the meat, without giving any to anyone else.

ngurtjuringanyi

be or act selfishly, keep something to yourself: Maini ngalya-uwa, ngurtjuringkuwiyangku.

Give me some food, don't be selfish.

ngurtjunytju

selfish person, thinking only of yourself: Anangungurtjunyungkukutjupakungalturingku laungkunytjawiya. A selfish person doesn't feel for and give to others.

26 For a wealth of data on the moral lexicon of one of them, Warlpiri, see L. Hiatt, "The Moral Lexicon of the Warlpiri People of Central Australia," Australian Aboriginal Studies 1 (2007), pp. 4-30. 
The strength of the norm 'to do good things for one's relatives when they ask' is well illustrated in an Aboriginal story from north-western New South Wales about the Durupa people discussed recently by Luise Hercus:

The Durupa came down from Mabu Crossing on the Cooper.

They came here (i.e. to Tibooburra)

There was a big mob here, all those people in a big heap (of stones) here now.

They ask for rain-stone and they won't give to them.

A little boy was sent over by the Durupa, but they wouldn't give it to ' $m$.

There used to be plenty of grass seed, nardoo, oh plenty. Pig weed. some were camped out, some coming in.

"Alright you can all go away tomorrow but this little boy can stay."

This little boy was running about call them uncle. People [said?] "That's not your uncle, they're strangers,"

They wouldn't give them rain-stone, only red ochre.

All went away hunting next morning. The Durupa made big clouds. Some were coming back with weeds, some with meat.

Hailstones came and killed them all. That's how those stones here. ${ }^{27}$

In her commentary on this story, Hercus writes:

This is a common theme of traditional stories: when someone asks for something, even if it is a very precious possession, as this rain-stone was, one can try to fob them off with other just slightly less precious things, like red ochre ... But one ultimately has to give away one's treasure. The local people would not give it even to the little boy who claimed kinship with them. That is why the locals got killed.

Clearly, this is not a story about disloyalty. Concepts like ngurtju and 'disloyalty' are very different. The difference between them highlights the disparity between norms like the walytja norm and the Anglo cultural scripts associated with the word loyalty.

\section{Translating Social Categories from Dalabon into English}

Presumably, by describing the Aboriginal cultural norm in terms of 'loyalty' rather than 'kinship obligations', as it is more commonly done, Diana Eades was trying to make it sound like something that her readers could identify with, and be in sympathy with, and one can appreciate that. Her aim was no doubt to validate an unfamiliar cultural norm-an understandable and in itself valuable project. Nonetheless, the cost to cross-cultural understanding is, in my view, too high.

27 L. Hercus, Languages and Storylines at the Crossroads 2011, unpublished. 
The same applies to Nicholas Evans's attempt (in his splendid book Dying Words) to offer English readers a glimpse of the social world of the speakers of the Australian language Dalabon. The cognitive category that Evans is trying to explain is usually referred as 'disharmonic'. Evans glosses this element of meaning as "the two of them, who are in odd-numbered generations with respect to one another" and he puts this gloss in the first person, as if it represented the speaker's perspective. To quote:

To round this chapter ["Social Cognition in Grammar"] off, let us put together some of these themes by seeing how all the socially relevant dimensions of experience we have touched on go into building a single inflected word in Dalabon, a language that makes you attend to rather different social categories from what English grammar directs you to. (Dalabon is a polysynthetic language, ... which condenses into a single word what would take a sentence in English.) Here is the word:

Wekemarnûmolkkûndokan.

"I'm afraid that the two of them, who are in odd-numbered generations with respect to one another, might go, with consequences for someone else, and without a key person knowing about it; by choosing the form of words I do, I hereby indicate that one of those carrying out the action is a mother-in-law of mine or equivalently respected relative."

... Intricate as it is, this one-word example only scratches the surface of how languages use their grammars to construct and update their speakers' ever-unfolding dossier of the social universe they move in. ${ }^{28}$

But strictly speaking, this cannot be how the native speakers of Australian languages think because their culture has no concept of 'odd number' and their languages have no words for it (not even for 'number', let alone 'odd number'). As I wrote in my Semantics, Culture and Cognition, "terms such as ... 'oddnumbered generations' ... useful as they are as an analyst's shorthand, cannot represent native speakers' meaning." ${ }^{29}$

Of course, Evans did not invent the term 'odd-numbered generations'. It is a traditional technical term in Australian linguistics, which can be found, i.a., in Ken Hale's classic paper "Kinship Reflections in Syntax: Some Australian Languages." ${ }^{30}$ What is novel about Evans's use of this term is that he puts it in the mouth of a Dalabon speaker, in an attempt to enter the Dalabon speakers' mental world and to present their social cognition from an insider point of view.

28 N. Evans, Dying Words: Endangered Languages and What They Have To Tell Us, (Chitchester 2010), pp. 77-79 (emphasis added).

29 A. Wierzbicka, Semantics, Culture and Cognition (New York 1992), p. 358; see also A. Wierzbicka, "Semantics and the Interpretation of Cultures: The Meaning of 'Alternate Generations' Devices in Australian Languages”, Man 21 (1986), pp. 34-49.

30 Word 22 (1986), pp. 318-24. 
This is a bold move for which I believe Evans should be applauded. If in this 'post-everything' era one still wants to try to understand 'how the natives think' one must make that move and try to speak, sometimes, in the first person.

By explicating the Dalabon speaker's meaning in a first-person mode, Evans is, of course, not implying that the Dalabon speakers carry the knowledge of their social categories in their heads in a propositional form and could easily articulate it themselves. He is evidently trying to explicate the tacit knowledge of a Dalabon speaker-knowledge that is unconscious but which, in Sapir's words, could in principle be 'dragged to the light' of one's consciousness.

Articulating one's tacit knowledge in propositional form may not be a traditional cultural practice in an Aboriginal society. This does not mean, however, that if it is articulated, empathetically, by a linguist or anthropologist it cannot be assessed by a native speaker as something that 'rings true', or not-provided, of course, that it is articulated 'in their own words'-or in the words of their second language (such as Aboriginal English) which match 'their own words.'

As I hope to show in a moment, we can try to enter the mental world of speakers of a language like Dalabon by relying on indigenous conceptual categories such as 'father' and 'mother', but not on technical terms such as 'harmonic' and 'disharmonic,' 'odd-numbered,' and 'even-numbered.'

No one was more aware of the unconscious character of grammatical categories than Franz Boas, who wrote of the concepts encoded in them that "although they are in constant use, they have never risen into consciousness." ${ }^{31}$ At the same time, in writing his grammars of American Indian languages Boas strove to treat "the inner form of each language ... as though an intelligent Indian was going to develop the forms of his own thoughts by an analysis of his own form of speech." ${ }^{2}$

To pursue Boas's mental experiment further, we may ask: in what language could a Dalabon speaker develop the forms of his (her) own thoughts encoded in the grammatical categories of his (her) own language? Presumably, in his (her) native language, not in English (and if in English, then not in Anglo English molded by Anglo culture and history but in that inner core of English which is shared with other languages).

But would the indigenous languages have the necessary resources for their speakers to be able to articulate the forms of their own thoughts? Sapir, for one, had no doubt that they would, for while he too believed that languages are

31 F. Boas, "Linguistics and Ethnology." In: D.H. Hymes (ed), Language in Culture and Society (New York 1964), p. 19.

32 Boas, "Linguistics," p. 123. 
unconsciously patterned, he also firmly held that "the content of every culture is expressible in its language." ${ }^{33}$

An interpretive formulation like 'odd-numbered generations' radically distorts the indigenous perspective, by relying on the culturally alien concept of 'odd number'. Moreover, it oversimplifies and distorts the social model implicit in the indigenous perspective-a model evidently based on prototypes (which can be articulated through indigenous words like 'father' and 'mother') and on provisions for extensions.

Clearly, what lies at the heart of the 'disharmonic' category is the contrast between parents and their children, whereas the 'harmonic' one is modeled on the relationship between two people who have the same father and mother (i.e. siblings). These are the focal categories, lost in the 'odd-numbered generation' approach. Since for speakers of a language like Dalabon the social universe is divided into two categories, based on those focal relationships, the prototypical 'harmonic' and 'disharmonic' categories can be extended to many other interpersonal configurations, both 'vertical' and 'horizontal'. But a characterisation that denies the key role of those focal points distorts the structure of the indigenous socio-cognitive model.

In fact, this is how anthropologist A. R. Radcliffe-Brown in his classic 19301931 work The Social Organization of Australian Tribes first described the feature of Australian kinship systems which later came to be linked with technical terms such as 'harmonic' and 'disharmonic' or 'even' and 'odd-numbered generations':

Another important principle of the Australian system is connected with the relations between persons of different generations. The relationship of generation has its origin in the family in the relation of parents to children. It becomes of importance in general social life because social continuity requires that the body of tradition possessed by the society shall be handed on by one generation to the next, and this handing on of tradition entails a relation of superiority and subordination as between one generation and the next. The generation of parents must have authority over the generation of children ... As between persons who are separated by an intervening generation a new situation arises. If we call the generations 1, 2 and 3, then those of generation 1 exercise authority over those of 2 and those of 2 over those of 3 , but ... persons of 1 and 3 are brought together

33 E. Sapir, "Language," in: D. Mandelbaum, ed. Selected Writings of Edward Sapir in Language, Culture and Personality (Berkeley 1949), p. 10. 
into a different kind of relationship which, in spite of the difference in age, links them together on terms of familiarity and almost of equality. ${ }^{34}$

Thus, as Radcliffe-Brown envisaged 80 years ago, it is the relationship between parents and children which provides a conceptual anchor for the distinction in question-or, more precisely, the relationship between children and their mothers and fathers.

In his 1982 study of the 'alternating generations' phenomenon in Dalabon, linguist Barry Alpher records a revealing comment on the 'disharmonic' category offered by a native Dalabon speaker, Don Bununhoa: 'like mother and father. ${ }^{35}$ As this comment shows, from an insider's perspective, 'mother' and 'father' are the focal categories, and this is what is lost in the 'odd-numbered generation' approach. Since for speakers of a language like Dalabon the social universe is divided into two categories, based on those focal relationships, the prototypical 'harmonic' and 'disharmonic' categories can be extended to many other interpersonal configurations, both 'vertical' and 'horizontal.' But a characterization that obliterates the key role of those focal points-'mother' and 'father'-distorts the structure of the indigenous sociocognitive model. To do justice to the indigenous perspective we need to account for both the prototypes and the extensions. By proceeding in this way, we can ensure both the predictive power of our analysis and its psychological reality and, at the same time, we can avoid putting our own words into other people's mouths and our own concepts into their heads.

Trying to provide a characterization of the cognitive categories in question that would be more faithful to the indigenous perspective I would propose, first, two explications based on the prototypes indicated above, and second, several 'cultural scripts' for extending these prototypes to other relationships. ${ }^{36}$ Thus, for

34 A.R. Radcliffe-Brown, The Social Organization of Australian Tribes (Sydney 1973), pp. 432-33.

35 B. Alpher, "Dalabon Dual Subject Prefixes, Kinship Categories, and Generation Skewing," in: J. Heath, F. Merlan, A. Rumsey, eds., Languages of Kinship in Aboriginal Australia (Sydney 1982), p. 21.

36 'Cultural scripts' are statements which are framed entirely or largely in the metalanguage of semantic primes and which articulate norms and understandings shared by people of a given speech community. These statements may relate to different aspects of thinking, speaking and behaviour. The theory of 'cultural scripts' (as the term is used here) is a sister-theory to NSM semantics. The first explicit statement of this theory can be found in my 1994 article "'Cultural scripts': A semantic approach to cultural analysis and cross-cultural communication.” In: L. Bouton, Y. Kachru, Pragmatics and Language Learning (Urbana-Champaign 1994), pp. 1-24. Since then, this approach has been developed jointly by Cliff Goddard and myself, and has been applied in many 
the 'disharmonic' aspect of the Dalabon word cited by Evans I would propose an explication based on the contrast between parents and their children:

disharmonic

I think about these people like this:

"they are not people of the same kind

they are like two people are if one of them is the father of the other one,

they are like two people are if one of them is the mother of the other one"

It could be said, of course, that a characterization of the 'disharmonic' category phrased in terms of 'odd-numbered generations' in Evans's gloss, is only a placeholder for the speaker's meaning. But if so, then the question must be asked: what is the speaker's meaning that this phrase is a place-holder for? The explication above purports to answer this question. This explication does not claim that only parents and children are treated as 'disharmonic'. On the contrary, the use of the word 'like' indicates that these two categories are regarded as prototypes for a much wider range of relationships.

The same kind of conceptual structure based on a prototype can be found, I believe, in the 'harmonic' category, as the phrasing of the formula below shows:

harmonic

I think about these people like this:

"they are people of the same kind

they are like two people are if the father of one of them is the father of the other one, they are like two people are if the mother of one of them is the mother of the other one"

publications by many NSM researchers. See in particular: C. Goddard, A. Wierzbicka, eds. Cultural Scripts: Special Issue of Intercultural Pragmatics 1(2): 2004, pp. 153-166; C. Goddard, ed., Ethnopragmatics: Understanding Discourse in Cultural Context (Amsterdam 2006). The 'cultural scripts' approach shares some of its basic assumptions with a number of other approaches in linguistic anthropology, especially those developed by Dell Hymes, "The Ethnography of Speaking." In: J. Fishman, ed., Readings of the Sociology of Language (The Hague 1968), pp. 99-138; Roy D’Andrade, The Development of Cognitive Anthropology (Cambridge 1995); R.A. LeVine, "Preface: Japan as Front Line in the Cultural Psychology Wars." In: H. Shimizu and R. A. LeVine, eds. Japanese Frames of Mind: Cultural Perspectives on Human Development (Cambridge: 2001), pp. xi-xxii, Naomi Quinn, "Universals of Child Rearing," Anthropological Theory 5(4): 2005, pp. 475-514; “The Self," Anthropological Theory 6(3): 2006, pp. 365-87) and Richard Shweder, Thinking Through Cultures: Expeditions in Cultural Psychology (Cambridge, MA 1991). Its crucial and unique feature is a reliance on the metalanguage of universal semantic primes - a feature which makes NSM-based cultural scripts cross-translatable into the languages of the people whose cultural norms are being portrayed. 
These explications have been formulated in words which are known to have exact equivalents in many Australian Aboriginal languages ${ }^{37}$ and so they have a claim to psychological reality that formulations like 'odd-numbered generations' cannot have. By themselves, however, they do not have sufficient explanatory power to predict that, for example, a person's grandparents will be placed in the 'harmonic' category, and great-grandparents in the 'disharmonic' one. To account for this, we need to combine the explications with 'cultural scripts' which would show who is to be treated as someone of the same kind as the speaker (or the person spoken of). I would propose several such scripts, formulated in the same metalanguage of simple and universal human concepts as the explications. Since the phenomenon of 'alternating generations' is widespread in Australian languages, ${ }^{38}$ these scripts appear to apply right across Australia and are by no means restricted to Dalabon. The foundational one is a script which lies behind what anthropologists and linguists call 'generational moieties':

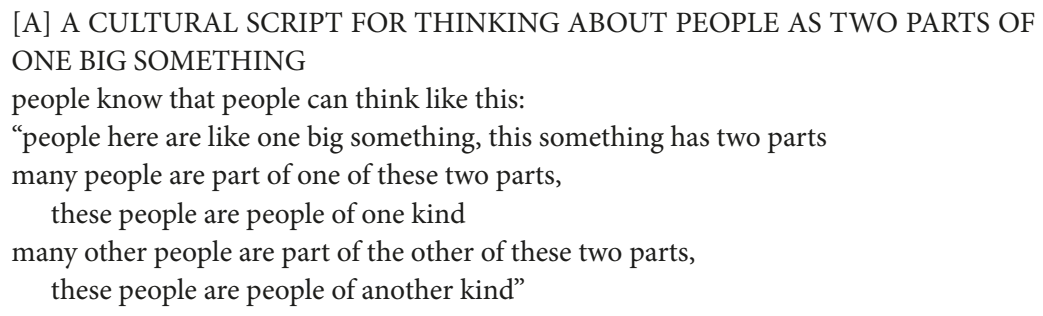

This script outlines the basic social structure of an indigenous group, as seen from an indigenous perspective: the overall unity, the division into two halves, the resulting categorization of people as people of two kinds, depending on the membership in (belonging to) one half or the other. On this foundational script [A] another very general script is based-a script for categorizing other people in relation to oneself:

37 Cf. C. Goddard, "Lexical Primitives in Yankunytjatjara." In: C. Goddard, A. Wierzbicka, eds. Semantic and Lexical Universals: Theory and Empirical Findings (Amsterdam 1994), pp. 229-62; J. Harkins, D. P. Wilkins, "Mparntwe Arrernte and the Search for Lexical Universals." In: Goddard, Wierzbicka, Semantic and Lexical Universals, pp. 285-310; E. Knight, "Hyperpolysemy in Bunuba, a Polysynthetic Language of the Kimberley, Western Australia." In: C. Goddard, ed. Cross-Linguistic Semantics (Amsterdam 2008), pp. 205-24.

38 As noted already by Radcliffe-Brown in: Social Organisation and A. P. Elkin in: The Australian Aborigines (Sydney 1938). 


\section{[B] A CULTURAL SCRIPT FOR THINKING ABOUT OTHER PEOPLE IN TWO WAYS}

people know that everyone can think about other people in two ways they can think about some people like this:

"I am someone of one kind, these people are people of the same kind" they can think about some other people like this:

"I am someone of one kind, these people are not people of the same kind"

Apart from ethnographic evidence discussed in the anthropological literature, this script is also supported by linguistic evidence discussed in dictionaries and grammars of Australian languages. For example, Alpher writes:

The Dalabon language ... spoken in south-central Arnhem Land, obligatorily marks the person and number of the subject of the sentence by means of a prefix to the predicate word ... If the subject is dual (two in number), the choice of prefix further marks a feature of the kinship relationship of the two referents: darruhgobarrah-bon 'two brothers go', but be-go geh-bon 'a father-and-son pair go,' both with -bon 'go' (present), but with distinct 3Du prefixes barrah- and geh-. Similarly, for first person dual exclusive (1DuEx) subject, there are two prefix forms, yarrah- and ngeh-, as in ngeh-bon 'my father and I go.' For the subject of a transitive verb, the distinction is maintained ... The feature that is marked is, in general, 'same alternate-generation level' vs. 'different alternate-generation level' (i.e. the set of generations including ego's own and those of his/her grandparents and grandchildren vs. the set of generations of ego's parents and children). ${ }^{39}$

In their Dalabon dictionary, Evans et $a .^{40}$ expand on Alpher's description with revealing contextual information:

compared to the 'free pronouns' and possessive pronouns, there's another group hereabbreviated 'dis' for 'different sides' or 'disharmonic'. These are used of people belonging to odd-numbered generations, or who are on different sides of a location (e.g. opposite sides of a river, or hunting an animal or burning off from opposite sides), or who are seen as in opposing groups (e.g. enemies in a story). Compare barrah-bon 'they two go

39 B. Alpher, "Dalabon Dual Subject", p. 19. In his study of Dalabon kinship grammar, Alpher notes that 'anomalous dyads' such as a European travelling with a European, are treated as disharmonic (p. 73). This supports, I think, both the psychological plausibility of the component 'someone of the same kind' and the validity of the reference to how people can think about other people. The possibilities of social manipulation of the harmonic/disharmonic distinction discussed in this and other papers in Heath et al. (Languages of Kinship) also support the relevance of the reference to 'thinking,' and not just to biological relations between people.

40 N. Evans, F. Merlan, M. Tukumba (comp.). A First Dictionary of Dalabon (Ngalkbon) (Maningrida, NT 2004). 
(same sides, or relation in even-numbered generations like brother or grandparent and grandchild)', keh-bon 'they two go (opposite sides, or relations in odd-numbered generations like parents and children)'.

From the general script $[\mathrm{B}]$ it follows that everyone in the community will be able to think of many other people as being someone 'of the same kind as me.' This is stated in the masterscript [C]:

[C] A CULTURAL SCRIPT FOR IDENTIFYING WITH MANY OTHER PEOPLE people know that everyone can think like this about many other people:

"I am someone of one kind, this is someone of the same kind"

As foreshadowed in the explication of the so-called 'harmonic' category, the prototype for classifying people as being 'of the same kind as me' lies in a person's relationship with the people who have the same mother and father (that is, with people who in English would be described as one's siblings). This can be articulated in script [D]:

[D] A CULTURAL SCRIPT FOR IDENTIFYING WITH PEOPLE WHO SHARE ONE'S MOTHER AND FATHER

people know that someone can think like this about someone else if it is like this:

this someone's father is this other someone's father,

this someone's mother is this other someone's mother

The prototype for the opposite category, i.e., for those with whom a person cannot identify, lies in a person's parents. This is articulated in script [E]:

[E] A CULTURAL SCRIPT FOR CONTRASTING ONESELF WITH ONE'S MOTHER AND FATHER

people know that it is like this:

someone can't think like this about someone else

if one of them is the father of the other one

someone can't think like this about someone else

if one of them is the mother of this other someone

The cultural scripts based on the opposing prototypes of siblings [D] and parents [E] can be projected onto numerous other people in the community on the basis of two very simple principles: one can identify with all the people with whom one's parents cannot identify, and conversely, one cannot identify with anyone with whom one's parents can identify. These two simple principles can be articulated by means of cultural scripts $[\mathrm{F}]$ and $[\mathrm{G}]$ :

[F] A CULTURAL SCRIPT FOR IDENTIFYING ONESELF WITH PEOPLE WITH WHOM ONE'S FATHER AND MOTHER CAN'T IDENTIFY

people know that it is like this: 
someone can think like this about someone else

if this someone's father can't think like this about this other someone

someone can think like this about someone else

if this someone's mother can't think like this about this other someone

[G] A CULTURAL SCRIPT FOR CONTRASTING ONESELF WITH PEOPLE WITH WHOM ONE'S FATHER AND MOTHER CAN IDENTIFY

people know that it is like this:

someone can't think like this about someone else

if this someone's father can think like this about this other someone

someone can't think like this about someone else

if this someone's mother can think like this about this other someone

At this point we need to note that the scripts presented so far may not be sufficient to account for the relationship between a person and this person's grandchildren. We know (or can deduce) how the grandchildren will think about their grandparents as being people 'of the same kind' but nothing has been said so far about how the grandparents will think about their grandchildren.

To account for the ways the 'upward' perspective (from children to their parents' parents) is complemented by a 'downward' one (from parents' parents to their grandchildren) we need to posit an assumption of mutuality: if I can think of you as being someone of the same kind as me, then you can think about me as someone of the same kind as you. Conversely, if I can't think of you as being someone of the same kind as me, then you can't think like this about me either. These assumptions, which are a basis for a vast network of links between people, both vertical and horizontal, can be articulated in cultural script $[\mathrm{H}]$ :

[H] A CULTURAL SCRIPT FOR MUTUAL IDENTIFICATION WITH OTHERS people know that it is like this:

if someone can think like this about someone else, then this other someone can think like this about this someone

if someone can't think like this about someone else, then this other someone can't think like this about this someone

This script explains, to some extent, why great-great-grandparents can be thought of in the same way as grandparents (and great-great-grandchild in the same way as grandchildren) whereas great-grandparents (and great-grandchildren) cannot, because the relationship between persons who see one another as being people of the same kind is presented as transitive. Thus, if I can think about my grandmother as someone of the same kind as myself, and she can think like this about her own grandmother, then I can think like this about my grandmother's grandmother, and the same applies 'downwards' 
The idea that people would think of those in the fourth ascending (or descending) generation in one way and those in the third in another because three is an odd number and four an even one, seems bizarre. Attributing such an idea to Aboriginal people (as Evans' formula may seem to do) exoticises them unnecessarily. ${ }^{41}$

The identification of children not only with their siblings but also with their grandparents may at first also seem strange to many Anglo Australians, but on reflection they probably can perceive a certain logic in this: if the children are contrasted with the parents, and parents with their own parents, then it is not beyond comprehension that the children and the grandparents may fall into one category and the parents into another. But this can make sense in terms of a contrast between children and their parents, not in terms of some magic of even and odd numbers. ${ }^{42}$ Evans says that "until you have the concept of 'harmonic' vs. 'disharmonic' generations you cannot make even ... the unavoidable move of using Dalabon subject correctly." ${ }^{\$ 3}$ But while he highlights the importance of this concept, he doesn't explain what this concept is. He also says, quite poignantly, that when a language like Dalabon dies "no one's mind will again have the thought-paths that its ancestral speakers once blazed." ${ }^{44}$ But if so, it is all the more important to try to understand those thought-paths as best we can; and I don't think we can understand them through academic English. ${ }^{45}$

Describing 'how Aboriginal people think' in terms of English phrases such as 'odd-numbered generations' or 'disharmonic' is, in my view, misleading and indeed open to the charge that one is 'writing out other people's consciousness for them.' It does not follow from this, however, that we cannot try to understand what the shared modes of thinking and shared cultural scripts of Aboriginal people are, and that we have to accept the sterile and self-defeating intellectual fashions of which Geertz wrote:

Postmodernists have questioned whether ordered accounts of other ways of being in the world-accounts that offer monological, comprehensive, and all-too-coherent

41 Cf. R. Keesing, Kin Groups and Social Structure (New York 1975).

42 It would be easy to devise several more cultural scripts referring, specifically, to one's father's father, father's mother, mother's father and mother's mother. Whether or not these more specific scripts would allow us better to explain what Evans calls the Dalabon speaker's "ever unfolding dossier of the social universe they move in" is a matter for further investigation.

43 Evans, Dying Words, p. 159.

44 Evans, Dying Words, p. xviii.

45 See Wierzbicka, Imprisoned in English (Oxford 2013). 
explanations-are credible at all, and whether we are not so imprisoned in our own modes of thought and perception as to be incapable of grasping, much less crediting, those of others. ${ }^{46}$

As I hope the explications and cultural scripts presented in this paper demonstrate, we are not imprisoned in our own modes of thinking and perception if we can rely on a shared, universal set of concepts which provide us with a common intellectual currency for 'understanding others', and indeed, for understanding ourselves.

Again, I do not claim that either the explications or the scripts posited in this paper are perfect just as they are and that there is no room for improvement. I do not believe, however, that they can be improved by shifting back from indigenous categories like 'father' and 'mother' to non-indigenous ones like 'odd numbers' and 'even numbers.' Geertz's point about the value of trying to understand other people's conceptual worlds through 'their own words' stands.

\section{Acknowledgment}

The explications and scripts in this chapter have been extensively discussed with Cliff Goddard.

46 Geertz, “Culture”, p. 102. 
Jerzy Ziomek

\section{Translation - Understanding - Interpretation}

1

Based on our intuition and the common meaning of the word "interpretation," it is easy to agree that a translation is an interpretation: we interpret when we are explaining something that is not comprehensible to someone who does not understand, using the means of comprehension available to that person. In this sense the translator-Hermeneut $(\mathrm{H})$ who knows two natural languages (L1 and L2) explains the meaning of the Utterance (U1) made by the Sender (S) in L1, by presenting it as $\mathrm{U} 2$ to the uninitiated Novice reader $(\mathrm{N})$, who is only familiar with L2.

At a first glance we already see that this approach to translation as interpretation does not entirely concur with the understanding of "understanding" in hermeneutics (a), with scientific explanation (b), or with some definitions that have taken root in translation theory.

(a) Ricoeur says that "Interpretation ... is the work of thought which consists in deciphering the hidden meaning in the apparent meaning, in unfolding the levels of meaning implied in the literal meaning."' If the first part of this definition could, with certain reservations, apply to translation (the meaning invisible to the Novice), the second, which speaks of "unfolding levels of meaning," cannot be applied here (except in freely translated variations on a theme taken from the original work).

(b) If the utterance in the original language (U1) is considered the explanandum, and the utterance in the language of the translation (U2). is the explanans, then the translation from one natural language to another (be it applied or artistic) meets few requirements of proper explanation, and above all, it does not meet the condition specified by the rule that the "explanans should not be identical to the explanandum in terms of the information it contains, and it should not contain the explanandum as one of its parts."2 Furthermore, if

1 P. Ricoeur, The Conflict of Interpretations, trans. D. Ihde (London/New York 2004), p. xiv.

2 Y. Nikitin, Wyjaśnienie jako funkcja nauki, trans. S. Jędrzejewski and Z. Simbierowicz (Warsaw 1975), p. 40. 
we accept that "a condition vital for a given sentence that is the explanandum to be explained by a given conjunction of sentences known as the explanans" is the circumstance that "the explanandum derives from the explanans," then translation is not, of course, a scientific explanation. ${ }^{4}$

Nonetheless, I believe that translation is a certain kind of interpretation, which deserves our attention owing to more general methodological issues. Before we investigate ways of understanding translation and understanding through translation, we should clear up a terminological misunderstanding that makes the rounds of translation theory, namely categorizing "interpretation" as a type of translation.

Due to a dispute between two orientations in translation theory - "linguistic" and "literary" - we have come to distinguish between two types of translation: the "ordinary" translation and the translation that is an interpretation, ${ }^{5}$ or, in other words, the linguistic (logical and contextual) and the situational (referential, extra-linguistic) translation. "Ordinary" linguistic translations (including machine-made ones) are limited to understanding the form and the information about the message's linguistic parts. The situational (referential, extra-linguistic) translation, on the other hand, aims to understand the essence of the message, to gain knowledge of the referential subject (the referent).

3 J. Kmita, Z metodologicznych problemów interpretacji humanistycznej (Warsaw 1971), p. 18.

4 I am leaving aside the highly complicated, not to say sensitive question: What is science? No one doubts that mathematics is a science. If so, perhaps we ought to trust Danuta Gierulanka's arguments on mathematical cognition? She distinguishes three forms of understanding: 1) understanding the meaning or intention (sender-oriented? - J.Z.), 2) understanding the structure, and 3) understanding the role (a pragmatic orientation? - J.Z.). In each of these cases understanding consists in moving from what is directly given to what is ultimately grasped. See D. Gierulanka, Zagadnienie swoistości poznania matematycznego (Warsaw 1962), pp. 61-64. To understand a text means to intellectually grasp something of the field to which it pertains. But in understanding through the text, the meaning of the text itself is sometimes not used to the full (p. 83). I should stress the word "used" because this approach lets us see the text not as an obstacle, but as a certain value. This value appears to varying degrees depending on the disciplines - least of all in mathematics, where the text is "disregarded" to an extent incomparable to any other science (p. 150). We generally call this "disregard" for the text "transparency," which, depending on one's point of view, might be an advantage or a shortcoming.

5 V. R. Rozenzveig, I. I. Ryevzin, "K Obosnovaniyu Tyeorii Pyeryevoda," Voprosy Yazikoznaniya 1962, No. 1. 
Alexander Ludskanov writes that one can understand and translate the Russian sentence Krivizna tryekhmyernovo prostranstva (K) oznachayet poetomu nalichiye dyefekta ili izbitka u treugol'nikov without identifying the referent of the phrase krivizna prostranstva. To understand the form (allegedly) "I need not understand the essence of the phrase krivizna prostranstva at all [...]. It suffices that I see (or establish) - i.e. obtain information about this linguistic (signifying) means which will tell me that - that krivizna prostranstva means 'spatial curvature' in this context."

There are many reasons why we cannot accept this distinction. Firstly, the example is convenient because it uses formalized language, which is the language of science insofar as it guarantees precise correspondence between the signifier and the signified in two texts in different languages. Secondly, the understanding of "spatial curvature" is gradable: without the knowledge of mathematics this concept cannot be fully understood, but partial understanding, i.e. the understanding of the components alone (curve, curvature, space), is, after all, an understanding "of sorts." Thirdly, Ludskanov's argument that a digital machine can accurately translate this phrase (this statement, or set of statements), and thus understands this phrase, is flawed, because a digital machine that renders krivizna as "curvature" or Krümmung, and prostranstvo as "space" or Raum in the context of krivizna prostranstva, i.e. "spatial curvature" or Raumkrümmung, understands nothing, because the understanding of concepts and their relationships and the corresponding linguistic symbols have been previously determined by the human programmer of the computer's actions.

What Rozenzveig and Revzin, and Ludskanov in their wake, have called linguistic translation is a certain form of imperfect routine "rough" or "raw" translation, a form known for ages, sometimes inaccurately called a "philological translation." Today it has become a major methodological issue due to the inferiority complex of humanists, impressed by the technical complexity of how computers work. Friedrich Schleiermacher, a classic figure of hermeneutics, used the term das Dolmetschen (as opposed to das Übersetzen) with regard to translation in which the translator (be it a person or a computer) uses a facilitated program that frees him from the need of continual recursion from the sign to the concept and the referent. ${ }^{7}$

6 A. Ludskanov, Tłumaczy człowiek i maszyna cyfrowa, trans. K. Leski, A. Naumow (Warsaw 1973), pp. $80 \mathrm{ff}$.

7 F. Schleiermacher, "Über die verschiedenen Methoden des Übersetzens" (1813). In: Sämmtliche Werke, Abteilung 3, Band 2 (Berlin 1838), pp. 207-213, or in: H. J. Störig (Hrsg.), Das Problem des Übersetzens (Stuttgart 1963), p. 38n. 
The Polish language has no equivalents for dolmetschen and übersetzen, and we shan't provide any ad hoc attempts here. ${ }^{8}$ We shall be using the term "translation", as we are chiefly concerned with how far understanding is involved in translation, and the gradation of an understanding translation. ${ }^{9}$ For there are not merely two translation variants (situational and linguistic), though there does exist the extreme option of translating without understanding the referents: this is how a digital machine translates (at a high speed and capacity), and so too (probably in an incompetent way) does a person who is unfamiliar with either language, but who possesses the relevant dictionary and grammar book. ${ }^{10}$ From the extreme of "zero-referential" translation in practice we move on to translations in which an the understanding of the "essence" increases or decreases depending on the type of text, but never ceases to be necessary.

\section{2}

Let us take utterance $\mathrm{U} 1$ articulated in language L1 (e.g. Je vais à la maison), and then utterance U2 articulated in language L2 (e.g. "I'm going home"). The Novice does not understand U1. For him, the transformation of U1 into U2 is an act that makes the incomprehensible comprehensible; it is the explanation of someone's verbal behavior pertaining to situation $\mathrm{R} 1$ (the shared referent) known to both the Addresser who produced $\mathrm{U} 1$ and to the translator $(\mathrm{H})$ with a command of L1 and L2, as well as the Novice, who only has a command of L2.

8 Olgierd Wojtasiewicz [see pp. 91-107 in the present volume - editors' note] suggests (all too arbitrarily, I believe) that we call a translation an action, and a rendering the outcome of this action.

9 "All understanding is interpretation [Auslegen], and all interpretation takes place in the medium of a language that allows the object to come into words and yet is at the same the interpreter's own language." This claim of Hans-Georg Gadamer (Truth and Method, trans. J. Wiensheimer and D. G. Marshall, London 2013, p. 407) is quoted by Werner Koller (Grundprobleme der Übersetzungstheorie (Bern and Munich 1972, p. 65) as an argument supporting the thesis contained in the chapter title "Translation as the Production of Comprehensibility" [Übersetzen als Herstellung von Verstehbarkeit]. The following chapter is called "Translation as Interpretation and Creation [Neuschöpfung]." Here the author apprehends interpretation as imitation or reconstruction, recreation.

10 The example of the possibility of a translation from one language to another rendered by a person familiar with neither language but with the relevant lexical/grammatical instructions (just as a computer has a program to use) is provided by Zinovij Rovenskij, Avenir Uyemov, and Yekaterina Uyemova (Filozoficzny zarys cybernetyki, trans. M. Niewęgłowski, Warsaw 1963, p. 52). 
In such a case, I would say that the translation is an interpretation, because it elucidates the meaning expressed in L1 by building a model for this meaning in L2. $\mathrm{U} 2$ is thus a model of $\mathrm{U} 1$.

We have tacitly assumed that $\mathrm{U} 2$ is an adequate model of $\mathrm{U} 1$, because $\mathrm{U} 1$ is also a model for $\mathrm{U} 2$, and because the referent we are speaking of is identical and known to all three participants in the communication act $(\mathrm{A}, \mathrm{H}, \mathrm{N})$. We have thus performed the optimization we need as a point of departure for an analysis conducted in hypothetically sanitary laboratory conditions.

In practice, the correspondence between the two utterances walks a fairly thin tightrope. Though in colloquial terms we immediately understand and translate Je vais à la maison as "I'm going home," which in turn we render as Ich gehe nach Hause, which becomes Idu domoi, and then back to Je vais à la maison, after a moment's reflection we begin to doubt if we can indeed treat the relationships between these phrases as reflexive, symmetrical and transitive, i.e. equivalent. ${ }^{11}$ For what if we try to add not a final clause to the phrase je vais, but an adverbial of manner: Je vais (en auto)? It then turns out that the speaker fährt, and not geht. And if a Frenchman says je vais à cheval then an Englishman will now be "riding a horse," and a German can only reiten, not gehen or fahren.

If our means of transportation is the subway, things get even more complicated. The Berliner has his $U$-Bahn, the Parisienne her métro, and the Londoner the underground. What will the Pole in Warsaw do when he finally has this means at his disposal? Will he travel by metro or SKM [szybka kolej miejska, fast city train]? I suspect it will be metro, and in this way the history of our knowledge of means of transportation will be expressed. At any rate, our Pole in Warsaw of the future or today's Paris pojedzie metrem (is going to travel by metro, from the infinitive pojechać) or wsiadzie do metra (is going to board the metro, from the infinitive wsiaść), but never weźmie (is going to take, from the infinitive wziać) the metro, as a Frenchman does (prendre le métro). Nor does a Pole ever bierze autobus (take the bus, from the infinitive $b r a c ́$ ), though he does sometimes happen to brać taksówkę (take a taxi).

For the time being, I intend to support the claim that texts cannot be produced without access to extralinguistic information, ${ }^{12}$ that is to say, that translation is more than a re-coding on the linguistic level. ${ }^{13}$ The world, experience,

11 On the notion of "equivalence" [równoważność], see: T. Micewicz, Zarys teorii przekładu (Warsaw 1971), p. 54.

12 In other words: extralinguistic information is necessary to gain access to the deeper structure. Cf. T. van Dijk, Beiträge zur generativen Poetik (Munich 1972).

13 A. Popovič, "Teoria przekładu w systemie nauki o literaturze." In: Konteksty nauki o literaturze, ed. M. Czermińska (Wrocław 1973). 
and language - these are the three apexes that demarcate the terrain explored by translation theory. In experiencing the world, the speaking and receiving subject, and in translation also the intermediary subject, takes it in through speech. A game is played between the world, the speech, and the speaker - as such, between the world and the speech, or between the world and the language, there is no relationship of "mapping:"

To be sure, what comes into language is something different from the spoken word itself. But the word is a word only because of what comes into language in it. Its own physical being exists only in order to disappear into what is said. Likewise, that which comes into language is not something that is pregiven before language; rather, the word gives it its own determinateness. ${ }^{14}$

This can be empirically ascertained by investigating the possibility of translation into an artificial language (not a formal one, but one that imitates a natural language - e.g. Esperanto). If a group of Esperanto speakers were to find themselves on a desert island and were to use only that language, after some time Zamenhof's creation would become less "aseptic," because it would come to contain social experience. For the time being, Esperanto is only a dictionary with a grammar, affiliated with European languages (chiefly Romance, partly also Slavic); it has neither past nor future.

\section{3}

One of the classic translatological misunderstandings concerns the literalness of translations. Arguments in favor of translating sense for sense, and not word for word, endorsed by Cicero (non verbum pro verbo necesse habui reddere; "De Inventione"), Horace (Nec verbo verbum curabis reddere fidus Interpres; "Letter to the Pisos", V 1313), and St. Hieronymus (Non verbum e verbo, sed sensus exprimere sensu; "De optimo genere interpretandi," Letter 57 to Pammachius), ${ }^{15}$ are seemingly so natural to accept that they hide a number of traps. St. Hieronymus, in fact, was less opposing a word-for-word approach than calling attention to the fact that the sensus might lie in units of various length - from a word to a fragment,

14 Hans-Georg Gadamer, Truth and Method, Second, revised edition, Translation revised by J. Weinsheimer and D.G. Marshal (London-New York 2004), p. 470.

15 The reader will find some interesting remarks on the ancient theories of translation in: K. Dedecius, Notatnik tłumacza, trans. J. Prokop (Krakow 1974), pp. 100-101. 
sentence, parable, book, or the whole of the Holy Scripture. ${ }^{16}$ Today we would say that Hieronymus and Horace were opposed to acknowledging a word (every word) as a finished text, and so they were essentially examining the issues of textual delimitation and coherence. Only this rewording of the issue clarifies the subsequent development of the debate on translation accuracy. Diderot claimed that he got down to translating having read a book once, twice... and having closed it. ${ }^{17}$ Novalis permitted or even recommended a similar tactic, though with an opposite justification - he called such translations mythical (unlike grammatical and modifying translations). "Adhering to the tastes of the Romantic era, he viewed mythical translations as maintaining 'the highest style, as while they might not render the actual work, they do transmit its ideal." ${ }^{\prime 8}$ Perhaps we would not be incorrect in seeing Diderot's and Novalis's concepts as an avant la lettre conviction that there is a deeper overall structure of a work, reconstructed or rearticulated in translation. The difference between two languages and the possibility of their correspondence is another prevailing classical issue in the history of translation theory. The questions raised by the greatest of practitioners and theorists are: Is translation transparent? Should it be transparent? Should the original be recognizable in the translation? Or rather, as Cazamian opines, comprendre c'est unifier, wherein unifier means "to unify, reconcile," but also "to level"? ${ }^{19}$ Ghazar Parbeci, a fifth-century Armenian poet, is said to have claimed that words pass through the gate of translation as foreigners, then as guests, then as acquaintances, and finally as relatives. ${ }^{20}$ This is a very beautiful turn of phrase, but it is not entirely apt. In a less evocative but more accurate manner, we might say that, entering through the gate of a translation as foreigners, words sometimes acquire the citizenship of the city they visit, but sometimes, on the contrary, they impose their presence and their foreignness upon their hosts.

These are two schools, or at least two methods of translation. One aims to make the color of the original vanish in the translation, and the other permits

16 St. Hieronymus stressed that the meaning (or mystery) of the Holy Scripture can be contained in both the longer sequences of the text and in a single word or series of words (Patrologia latina, Vol. 22, Col. 431).

17 Cf.: V. Ogniev, “Czas syntezy," trans. M. Zagórska. In: Przekład artystyczny. O sztuce tłumaczenia ksiegga druga, ed. S. Pollak (Wrocław 1975), p. 225.

18 Novalis, "Blüthenstaub," Athenaum 1798. Quoted in: K. Dedecius, Notatnik tłumacza..., p. 111.

19 With reference to R. S. Crane, Critical and Historical Principles of Literary History (Chicago 1967), p. 51.

20 V. Ogniev, Czas syntezy..., p. 20. 
the translation to be tinted by the original, and even appreciates the effect of foreignness. Already Luther himself grappled with this problem, but as a great artist, he put forward a flexible solution: sometimes he spent weeks searching for a German equivalent, and when none was forthcoming, he relied on Hebrew or Greek borrowings:

Thus for the dignity of this study and the tranquility of the conscience these words should be kept and assimilated, and thus the Hebrew language should be admitted where it serves better than our German language would be capable. ${ }^{21}$

This meant that either the original is "moved toward the reader" or that the reader bends toward the original.

Luther's dilemma lost none of its relevance in more than four centuries. Schleiermacher believed that speech has a certain malleability (Biegsamkeit), thanks to which the boundaries between a foreign and a native language can shift. A good translation from, for example, Latin into German, is a text that is composed as if written by a Roman with a perfect command of German. ${ }^{22}$

Wilhelm Humboldt took a different approach, finding the workings of a special force he called enérgeia in language; it was active and fruitful only in the translator's native tongue. "A clear recognition of diversity," he said, "requires a third component, a simultaneous consciousness of both one's own linguistic form and a foreign one."23

This contention between the effect of foreignness and the assimilation effect (if we might thus universalize the German terms Verfremdung and Eindeutschung) continued into the twentieth century. In 1930, Walter Benjamin, with reference to Rudolf Panwitz's Krisis der europäischen Kultur (1917) and Goethe's West-East Divan, wrote:

Our translations, even the best ones, proceed from a wrong premise. They want to turn Hindi, Greek, English into German, instead of turning German into Hindi, Greek, English. Our translators have a far greater reverence for the usage of their own language than for the spirit of the foreign works. [...] The basic error of the translator is that he

21 M. Luther, Summarium über den Psalter und Ursachen des Dolmetschens [1533], qtd in: R, Kloepfer, Die Theorie der literarischen Übersetzung (Munich 1967), p. 37 [translation by S. G.].

22 R. Kloepfer, Die Theorie der literarischen Übersetzung..., p. 53; F. Schleiermacher, Über die verschieden Methoden des Übersetzens (1813)..., p. 219; H. J. Störig (Hrsg.), Das Problem des Übersetzens..., p. 48.

23 W. von Humboldt, Uber die Verschiedenheit des menschlichen Sprachbaues (1828-1829), Vol. 6, Berlin 1903-1920, p. 121. Qtd in: Rolf Kloepfer, Die Theorie..., p. 51; cf. R. M. Mayenowa, Poetyka teoretyczna, Wrocław 1974, pp. 62-70. 
preserves the state in which his own language happens to be instead of allowing his language to be powerfully affected by the foreign tongue. ${ }^{24}$

"Powerfully affected by the foreign tongue!" Does this mean that the concept of fidelity is of not much use in translatology? The joke about translations and women who are faithful and ugly or unfaithful and beautiful, though merely a joke, has its academic worldview - a Crocean one. Such a worldview hardly befits a linguist, so Zenon Klemensiewcz wrote quite (though not entirely) rightly:

The essence of adequacy can be encapsulated in the following way. The original should be conceived as a system, and not as the sum of its parts, as an organic whole, and not as a mechanical set of elements. [...] The task of the translation is not to copy, not to recreate, not to speak of converting the elements and structures of the original, the words, sentences, prosodic units, visual language etc., but to capture their functions and to replace the original with those elements and structures of the target language which are, as far as possible, substitutes and equivalents with the same functional capacity, suitability, and efficacy, and in this, precisely, resides their adequacy, commensurability, equality of value..$^{25}$

Indeed, it is true that we ought to speak of reproducing the function of the original and not of copying its elements and structures. Our doubts are raised by something else: by the excess of terms to explain the meaning of adequacy: capacity, suitability, efficacy, commensurability, and equality of value. Klemensiewicz used these terms as near-synonyms to present what he believed to be the most crucial property of the translated work, which "it is a carefully chosen construct of grammatico-lexical and stylistic elements in the language of the translation that can faithfully and effectively render the work's impact on the reader's psyche the author intended."26

A different formulation of the concept of semantic equality was proposed by Olgierd Wojtasiewicz in the supplement to his Introduction to Translation Theory (1957). He encapsulates his definition of translation inthe following logical formula:

$$
b=\mathrm{T}_{i j}(a)<=>\left[\left(a \in \mathrm{L}_{i}\right) \wedge\left(b \in \mathrm{L}_{j}\right) \wedge(a \approx b)\right]
$$

which reads as: " $b$ is the translation of text or word $a$ from one language into another" means that " $a$ belongs to language $\mathrm{L}_{i}, b$ belongs to language $\mathrm{L}_{j}$, and $b$ is semantically equal to $a$," wherein $\mathrm{T}_{i j}$ indicates the operation of translation from

24 W. Benjamin, Illuminations, trans. H. Zohn (New York 1969), pp. 80-81.

25 Z. Klemensiewicz, "Przekład jako zagadnienie językoznawstwa." In: O sztuce tłumaczenia, ed. M. Rusinek (Wrocław 1955), p. 93 [see pp. 59-71 in the present volume - editors' note].

26 Klemensiewicz, p. 88 in the present volume. 
$\mathrm{L}_{i}$ to $\mathrm{L}_{i}<=>$ denotes equivalence, $\in$ symbolizes belonging to a set, $\wedge$ symbolizes logical conjunction (more or less corresponding to the conjunction "and"), and $\approx$ symbolizes semantic equality (this formula is somewhat simplified, but sufficient to represent the problem that interests us here). ${ }^{27}$

Thus, we are dealing with two ways of understanding semantic equality: one is naively psychological, the other logical and scientific, and thus reductive, and, to make matters worse, it is imprecise.

Equality of value (understood in logical terms) is achieved when two sentences result from each another. This also pertains to equality of value in the semantic sense. Semantic equality (in logical terms), is, in turn, a relationship of equal value that occurs between expressions with the same meaning. Semantic equality is generally conceptualized as a stronger relationship than equality of value. ${ }^{28}$

Wojtasiewicz is aware that, given the commutativity of conjunction, the above definition ought to be reversible, i.e. that not only $b=\mathrm{T}_{i j}(a)$ etc. but also $a=\mathrm{T}_{i j}$ (b) etc., and that as a result we might falsely conclude the symmetry of the relationship. Therefore, he adds that translation is not a fully symmetrical process, as "the rules of translating from one language to another are not a simple reversal of the rules of translation from the second language to the first one (only the relationship of semantic equality is symmetrical)."29

It is not only that the relationships between two texts are not fully symmetrical - worse, they are hardly ever symmetrical. In fact, we would have to abandon the terms "equality of value" and "semantic equality" altogether if we were to use them in the sense accepted and rigorously followed in logic.

Since the term "equivalence" (equality of value) is frequently used in translatology, however (and since equating the terminology of literary theory with that of logic does more harm than good), I shall hereafter use the term "equivalence" in a slightly different, less precise sense. I will be using "equivalence" to describe the optimal relationship of correspondence ${ }^{30}$ of a translated text to the original. I am using the concept of "optimal" here in the sense approximating

27 O. Wojtasiewicz, "Wybrane zagadnienia z teorii przekładu." In: Przekład artystyczny..., p. 347.

28 Cf.: Mała encyklopedia logiki, ed. W. Marciszewski (Warsaw 1970), pp. 259 ff.

29 Wojtasiewicz, "Wybrane zagadnienia," p. 348.

30 "For the science of translating the term equivalence is a core concept," Katharina Reiss asserts, adding that "corresponding target language expressions may be considered optimally equivalent." See: Translation Criticism: The Potentials and Limitations. Categories and Criteria for Translation Quality Assessment, trans. E. F. Rhodes (London-New York 2000), p. 3. 
its application in game theory: "The best solution from the adopted point of view, bringing the greatest gains with the minimal losses."

We do not know (and we should rather doubt) if we might find two utterances, U1 and U2, belonging to two contacting languages, L1 and L2, of which one (U1) appears in L1 always and only when the other statement (U2) appears in L2. As such, U1 and U2, appearing together with sufficient frequency, ought to be considered equivalent in the translatological sense. I can say, for example, that "brother" is equivalent to the French frère and the German Bruder, though I cannot be certain if in all the French or German equivalents of English statements containing the word "brother" we will use frère or Bruder.

Using the concept of the "equality of value" as an optimal concept does not release us from coming up with a definition of an ideal equality of value.

Presupposing that a sign is to be considered in three relations: to reality, to the user, and to other signs, i.e., dividing semiology into semantics, pragmatics, and syntactics, I would propose the following terms for the postulated ideal equivalence of two statements belonging to two languages: 1) semantic equality, when we are dealing with a semantic relationship, 2) equality of value, when we are dealing with a pragmatic relationship, and 3) equality of form, when we are dealing with a syntactic relationship. ${ }^{31}$

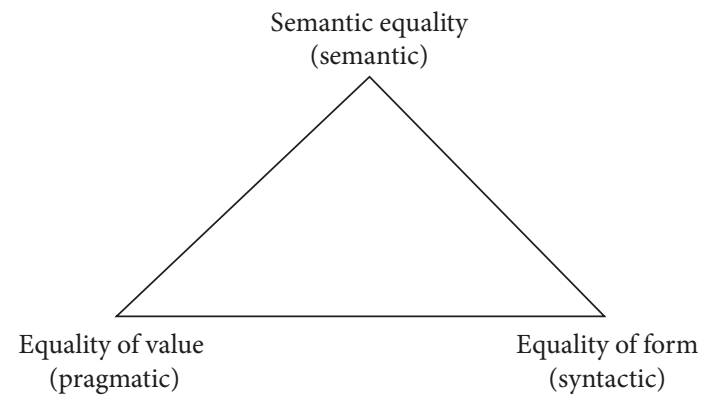

31 Jerzy Pelc uses slightly different terminology, calling the relations between signs (of the same language or various languages) substitution: "Two signs substitute each other when one can take the place of the other without altering the logical value or sense of the statement .... It the first case, equivalent signs substitute each other and the substitution occurs salva veritate. In the second case, the signs that substitute each other are also semantically equal and then the substitution occurs salva sensu." See J. Pelc, "Zastosowanie funkcji semantycznych do analizy pojęcia metafory." In: Problemy teorii literatury, selected by H. Markiewicz (Wrocław 1967), p. 97. 
Thus, we will say that $\mathrm{U} 1 / \mathrm{L} 1$ is the ideal equivalent of $\mathrm{U} 2 / \mathrm{L} 2$ when it is also precisely semantically equal, equal in value, and in form.

Languages are constructed from differently delineated semantic fields. This is a home truth and no one apart from a novice might suppose that an acquired foreign language is richer and more flexible than his native tongue: we all know that his is only an immediate, superficial impression, when one senses the inflexibility of one's own language and admires the exactitude and precision of another.

Let us imagine a language that makes no distinction between "buy" and "sell," which has a single term for both these actions. We might jump to the conclusion that such an imprecise language is primitive, that it reflects primitive trade customs in the society that uses this language. There is nothing more misleading than drawing conclusions on the segmentation of the image of reality based on the segmentation of surface structures. On the other hand, it can be dangerous to underestimate the seemingly passive resistance of language on the surface level, i.e. the level of terms. When an Englishman learns that, in Polish, pożycz mi swój długopis means "lend me your pen," he is only getting half the story, because the Polish verb pożyczyć can mean either "lend" or "borrow," depending on the immediate grammatical context, analogous to our example of "sell" and "buy."

We can also easily come up with examples of reverse situations, where an English word offers a wider range of meanings, such as the verb "to go." The Polish equivalent of this, depending on the means of locomotion and the frequency of travel, parses into iść, chodzić, jechać, and jeździć - leaving aside the prefix-generated variants of these verbs and their perfective forms. Yet nobody suspects English-speaking people of not being able to tell these meanings apart, just as nobody suspects that Polish speakers might get confused about the direction of the transaction when using pożyczyć for both "lend" and "borrow."32

This problem is widely known, not to say trivial. And yet in translation practice, various scopes of semantic attribution lead to the most frequent sorts of mistakes, caused not by the translator's incompetence in a given language, but by a certain pressure of automatism exerted by the surface structure.

32 The examples quoted above have been modified in order to make them more relevant for the English-speaking reader [editors' note]. 
For example, the protagonist of a brilliant English novel, rendered by a fine translator, is found to be working in a (public) library nocami (INSTR pl. of noc, "night"). Indeed, the original does say that he is working "nights." The error comes from the fact that the English "night" signifies the period between dusk and dawn, and thus "day + night" fulfills the condition of the additive function, which means that their sum covers the meaning of the concept rendered by the Polish doba (a twenty-four-hour period). The English language does, of course, have the word "evening," which corresponds to the Polish wieczór, but "evening" is a facultative name for one part of the "night."

Thus, our protagonist in fact worked wieczorami (INSTR pl. of wieczór, "evening") in the library. He could have stated this more precisely, but he didn't have to. The English "day" and "night" have a different distribution from the Polish dzień and noc.

\begin{tabular}{|l|l|l|}
\hline \multirow{2}{*}{ day } & \multicolumn{2}{|c|}{ night } \\
& evening & \\
\hline dzień & wieczór & noc \\
\hline
\end{tabular}

It is true that in Polish we say dniami i nocami [by days and by nights], noce $i d n i$ [nights and days], dni i noce [days and nights], and dzień i noc [day and night], but this is when we are less concerned with a strict measurement of time than with signaling its rhythm and flow.

With this example we encounter the next problem in interlingual relationships: hyponymy. The physical universe accessible to the speaker's experience is divided differently in various languages not only into surface segments (horizontally), but also into "levels" (vertically). This vertical division is known as hyponymy (and its reverse: hypernymy). As such, the Polish dzien [day] and noc [night], regardless of how we delimit the range of their denotators, are hyponyms of the superordinate term doba [24 hours], which has no equivalent in English, German, or French. Thus:
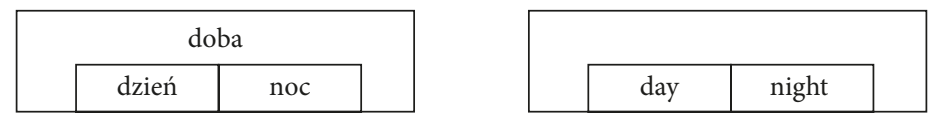

This issue, of course, is not limited to nouns - it is only for the sake of clarity that we have provided examples with distinctive denotates.

The above-described phenomenon, familiar to both theorists and practitioners, actually has no widely accepted expert term. We speak of varying objective collocability characteristic of a given language, of semantic attribution 
and segmentation. None of these terms, however, strike me as sufficiently accurate. Because behind this terminological dispute there is a consequential philosophical one, we must choose a term that would not predetermine the result of the discussion.

The subjective-objective universe creates a continuum that is consistent. As a dictionary and grammar, language is a collection of discreet or granular units of irregular distribution or granulation. Every natural language has a different granular distribution on the surface level of its structure; this is the basic translatological difficulty.

This difficulty is usually illustrated by the names of colors, because the semantic field of colors is relatively limited and because the spectrum of colors is identical for all language users, and can be measured and described fairly precisely. But are colors identically perceived? Does a speaker of Polish, with several words (niebieski, modry, błękitny, granatowy...) for the German blau and the French $b l e u$, see this band of the spectrum more clearly?

Having analyzed the semantic fields of color, parts of the body, and plants, Bertil Malmberg suggests that "there are no concepts independent of language and determined only by 'reality." ${ }^{33}$ Alfred Gawroński disagrees with this conclusion, quite rightly seeing in Malmberg's claim a continuation of the dispute over universals - the naive nominalist's fight against the realist who is also naive, or put in a naive situation. Gawroński writes:

Let us note that the argument whose clear model is offered by Malmberg tacitly supposes only one alternative: the choice between two monisms, the nominalistic and the realistic monism. Given this alternative, we must either accept that semantic categories are a reflection of pre-existing categories of reality (a thesis combated by nominalism) or that it is solely man who, through language, conjures reality's divisions and categories into existence. ${ }^{34}$

Indeed, the most difficult and most interesting problem of language is its equivocal status as a product and a producer. Language is created by human beings, but it only submits to ad hoc interventions to a minimal degree. The speaker is both a creator and a user; the group of people using what we call a "national language" pass on their experience to this language, but it is also through this language that they experience the world.

33 B. Malmberg, Nowe drogi w językoznawstwie, trans. A. Szulc (Warsaw 1969), p. 214. Cf: New Trends in Linguistics: An Orientation (Lund 1964).

34 A. Gawroński, "Język a filozofia (3). Między świadomością a światem," Znak 1975, No. 248, p. 198. 
Differences in the granulation of various languages are not homological in terms of the experience and knowledge of various groups of users. Continuing his polemic with Malmberg, Gawroński writes (and he has a point):

The division of the whole semantic field through vocabulary itself should be understood less as a closed and finished process than as the first step of categorization, which is completed at a higher, syntagmatic level (i.e. at a sentence level), where certain regularly repeating sets of words play the same role as certain individual words play on other levels. ${ }^{35}$

This means that languages are either imprecise or extravagant. After all, why ought we to discriminate between an elder brother and a younger brother (in Hungarian, báty and öccs)? Why distinguish a maternal from a paternal uncle (in Polish, wujek and stryjek), or the wife's mother-in-law, i.e. the mother of her husband, from the husband's mother-in-law, the mother of his wife (Polish świekra and teściowa). We might respond that a need to introduce such distinctions reflects social relationships (the importance of types and degrees of kinship in a given culture), while the disappearance and impoverishment of certain nomenclatures shows changes occurring in these relations. However, this would explain only a small fraction of changes in a language's vocabulary, mainly and primarily nomenclature changes whose examples are easiest to find. Languages are sometimes imprecise, sometimes extravagant. Translation and all kinds of bilingualism reveal this quality of natural languages. Translation does not only interpret a text. Translation also interprets language. Translating means looking at one's own speech in the light of the foreign one, and at the foreign in light of one's own; it is admiration and critique, obscuring and illumination.

\section{5}

Generally speaking, translation theories bemoan the untranslatability or incompatibility of languages, and the efforts of translation theorists and practitioners are directed towards effacing or at least reducing this punishment for building the Tower of Babel. Let us take a different course, however, and try to see the difference between languages as a virtue rather than a flaw. It is a truism that language is a system. Language is also irrational, disorderly, and unpredictable. In language, order (i.e. death) struggles with disorder (i.e. life). Because order and disorder are variously distributed in them, languages can see one another in the mirrors of other languages.

35 Gawroński, “Język," p. 203. 
Understanding of one language in light of another entails continuous confrontation and ascertainment of capabilities: of referential semantic equality, syntactic equality of form, and subjective equality of value. We already know that only if all three conditions are met, ideal equivalence of the two texts occurs, while if none of them is met, the meanings of the texts are completely different.

When I say that a door "leads out into the garden" I see nothing very peculiar in this expression until I try to translate it into French. It then turns out that doors don't have legs and thus cannot "lead" us anywhere. I should use the expression La porte donne sur le jardin and wonder that a door should "give" me anything. I say in Polish that something is ważne (important/valid) and, perhaps, I do not sense the ambiguity of to ogłoszenie jest ważne (this announcement is important/valid), which is resolved when I translate it into German. Ważne becomes wichtig when we mean that something is of high importance and gültig when we mean it is legally binding or valid. As such, the Polish notice can be ważne in two ways. I say in English that something is "ready" and that someone is "ready," and I might not register the ambiguity of the word. For example, "my lecture is ready" means mein Vortag ist fertig in German, while "I am ready to give the lecture" means that ich bin bereit den Vortrag zu halten.

These examples would be trivial if their aim was to illustrate, once again, the above-described phenomenon of polysemy and "heterogranularity" of languages. But I evoke them to make a different point: I want to say that translation difficulties involve not only unearthing the deep structure of polysemous expressions, but also in establishing connections in the surface structure that can sometimes be hard to perceive. From this perspective, the astonishment of the German who learns that wichtig and gültig are identical in Polish is crucial. This identical appearance is a sign of a commonality, of a hidden similarity that one misses at a first glance: "readiness" as a cause and "readiness" as effect.

Now let us take a reverse example. The German brechen means "to break," and in the vast majority of texts I will most likely find it thus translated indeed. But brechen can also mean "to clear the way" (die Bahn brechen), "to pick" flowers, "to plow" a field, "to fold" a letter (einen Brief brechen), or "to vomit." The polysemy of the word brechen (and the accidental homonymy) creates, or rather unveils connotations that are partly shared: clearing (the way), picking (flowers), plowing (a field), folding (a letter, a sheet of paper), even vomiting. Indeed, each of these English expressions has to do with destroying or finishing, but also with a kind of a new beginning. [...] In one instance the German brechen overlaps precisely with the English "break" in die Spalte brechen, to break columns in print. It could be that this meaning is a German borrowing - at any rate, it is an apt Germanism. 
Can there be an apt Germanism (or Latinism, or Russicism)? Of course. It can be useful and beautiful, particularly in idiomatic phrases. Usually, foreign borrowings, whether in the form of proper loans or calques, indeed disfigure a language; on the other hand, however, purism, that bastard child of national complexes, undoubtedly impoverishes it.

\section{6}

To steer clear of sensitive matters, let us try to illustrate the illuminating role of translation with emotionally neutral examples. [...] The noun $d z i e c k o$ is a relatively exact match for the German Kind, the French enfant, and the English "child" (or sometimes "baby"), and nobody would think that this word holds its own kind of ambiguity, depending on whether we say "they have children" or "the teacher guides children." In the former case, we mean "children" in the sense of "offspring," while in the latter "children" means "people young of age."

If someone were to tell us that there was a language which does not discriminate between "son" and "daughter," we might find it to be fairly primitive or we might all too hastily search for cultural/anthropological reasons why this granulation is so thick.

In Swahili, which has an ancient written tradition and its own contemporary translation of the Bible, and thus could hardly be seen as a primitive language, mwana can mean either "son" or "daughter;"36 but at the same time, Swahili has the noun mtoto, which connotes the "person's age" and not the kinship relation. This might be depicted graphically as follows:

\begin{tabular}{|c|c|c|}
\hline English & child & daughter, son \\
\hline Swahili & mtoto & mwana \\
\hline
\end{tabular}

This means that the "baby" the Three Magi seek (Luke 1:76) is a mtoto, while the "Son of God" (Mark 1:1) is Mwana wa Mungu. When it is absolutely necessary to indicate the gender of a child, however, as in the story of Jairus, whose daughter Jesus resurrected (saying in the Aramaic, which survived in the Greek text of the Gospel of Mark, talitha kumi!), the Swahili Bible keeps the Aramaic quote in the original form, calling the daughter kijana (girl), where the English translator would use either "child" or "girl." Meanwhile, in the Book of Genesis (11:11), where it says that Shem lived five hundred years and had "sons" and "daughters,"

36 I base this on the dictionary of Swahili by Roman Stopa and Bolesław Garlicki: Mały słownik suahilijsko-polski i polsko-suahilijski (Warsaw 1966), p. 37 (entry: Mwana), p. 93 (entry: Córka), p. 116 (entry: Syn). 
East-African Bible scholars say that he had waume na wake, which means "men and women." ${ }^{37}$

The examples, lists, and tables we have mentioned can be infinitely multiplied; what we actually do here is employ stylistic comparison or comparative stylistics, or at least we ought to, as so far there have been very few attempts at stylistic/ comparative syntheses of two languages ${ }^{38}$ not to speak of multilingual syntheses. But our deliberations are not meant as a contribution to a future synthesis, but rather as a thesis that can be encapsulated in the statement that translation is a comparative activity and that the translated text is an interpretation of the original. It is an interpretation in the sense that it explains the meaning of utterance U1 expressed in L1 by building a model of this meaning (U2) in language L2. As such, U2 is a model of U1.

The conclusion we are slowly approaching requires certain modifications and specifications. Translation is an attempt to create a model of the original statement: in this attempt, doomed to error and tempted by the possibility of clarification, it is a special case of interpretation, which is interesting because it allows us to observe how the interpretandum is distorted by the interpretans under the pressure of the interpreter's knowledge/ignorance and the target language's structure. Language is looking at its own reflection in another language, text in text, experience in experience. To use more precise terminology: in translation we observe the work of three variables - reality, the subject, and language. The dispute between linguistic and literary translation theories is barren in that it lacks complementarity: linguistic theories are chiefly interested in syntactic relationships in language, neglecting (sometimes programmatically and provocatively) semantic and pragmatic relationships, while literary theories are often not even theories, but merely an assortment of cliches about the kinship of spirit between author and translator.

My thesis requires that we construct a proper concept of "the reader" who contrary to popular custom - would read the translation as a translation, and not as a surrogate for the original. This reader might be called the "scholarly reader"39 and amateur reader, and might be treated as either virtual or empirically real. $\mathrm{He}$ may be an idealization of sorts, or he may be a bookstore customer in search of editions with multi-language parallel texts.

37 All Swahili examples are taken from the Bible: Maandiko Ma-takatifu Ya Mungu Yaitwayo Biblia Yanni Agano La Kale Na Agano Jipya (Nairobi 1970).

38 E.g.: J.-P. Vinay, J. Darbelnet, Stylistique comparée du français et de l'anglais. Méthode de traduction (Paris 1958).

39 See: E. Balcerzan, Przez znaki (Poznań 1972), pp. 60-61 ff. 
Translation is a peculiar art because it must strive for identification with the original, while it profits from the impossibility of fulfilling this task.

As a result, translatology cannot simply view untranslatability as a drawback, a flaw, a contaminant that makes it difficult to take measurements and introduce order. By nature, translatology is a study of heresy and schism: it studies translations as texts written by dissenters. Traduttore - traditore: the translator as a traitor? Not at all! The translator is not a traitor if treachery means abandoning one's duties or breaking a natural or otherwise sanctioned relationship. He is, however, a heretic in his passionate striving for truth and his sinful erring.

To clarify our argument, we should add that we are not interested in intentional and conscious dissent. In other words - the four transformation types in poetry translation listed by Victor Koptilov ${ }^{40}$ (condensation, supplementation, restructuring, and substitution) should be regarded as operations that preface (in the logical, though not necessarily genetic sense) the translation proper. It seems, at any rate, that these sorts of transformations appear not only in between texts of various languages, but that they are variants of a wider sort of paraphrase, even occurring within a single language. Either way, we are dealing here with the very nature of necessary deviations and distortions. To speak of necessary distortions, we shall have to accept the premise that the essence of all translation activity is a utopian effort to make two texts correspond exactly. The result of this utopian pursuit, however, brings a certain real optimization of this correspondence. The optimal state of similarity between text U1, built in target language L2, to text U1, built in original language L1, has been called equivalwence here. The relationship of equivalence is always unidirectional in translations from one natural language to another (it is not reversible, symmetrical, or transitive), which means that text $\mathrm{U} 1$ is rewritten by text $\mathrm{U} 2$, but not the other way around, and that $\mathrm{U} 2$ is the equivalent of $\mathrm{U} 1$, but not the other way around. I stress this in order to take a polemical stance against terminologies that view equivalence as a subcategory of correspondence. ${ }^{41}$

40 V. Koptilov, “Transformatziya Khudozhestviennovo Obraza v Poeticheskom Pyeryevodye." In: Teoriya i Kritika Pyeryevoda, ed. B. A. Lari (Leningrad 1962), p. 34. Qtd after: E. Balcerzan, Styl i poetyka twórczości dwujęzycznej Brunona Jasieńskiego. Z zagadnień teorii przekładu (Wrocław 1968), p. 38.

41 J.-P. Vinay, J. Darbelnet, Stylistique, p. 55. 


\section{7}

All unidirectional correspondence between two texts articulated in two languages is equivalence; but since, as it has been said, pragmatic, semantic, and syntactic relationships can compete, or, in game-theory terms, they are antagonistic, the systematics of equivalence must take into account differences in how the two languages are used by two speaking subjects, to whom similar knowledge about a given objective-conceptual reality (shared or not) is (or is not) available. To simplify our systematics as far as possible, let us distinguish four varieties of equivalence: transliteration, transcription, description, and loan. To facilitate our task, our first example will be less a translation from one language to another than the notation of a single language into two different alphabets. In this sense the reality which we hope to communicate is the phonetics of an ethnic language, while the code is the relevant alphabet. Let us compare a Bulgarian word written in the Cyrillic and the Latin alphabet. Let us take a word with an international sound and meaning, but one that has an old-Slavonic ultra-short semivowel that survived in Bulgarian: the hard or back yer. For the clarity of the example, the remaining sounds should be similar to English in all their relationships (including, and above all, syntactic). ${ }^{42}$ Let us therefore take a name of a measurement, metzr. The ultra-short vowel $r$ does not exist in English and the Latin-based English alphabet offers no equivalent for it. As a result, an Englishman with the code of the Latin alphabet at his disposal will find no way to transliterate the Bulgarian $z$ in his phonic experience. For transliteration means rendering letter for letter so that, as far as possible, one letter does not represent two sounds, or that one sound does not require two letters - so that the system of both alphabets is perfectly equivalent. Transliteration, therefore, is only possible after applying the international phonetic alphabet, and this means the use of a new language - a lingua universalis of sorts. If I do not know this alphabet, I can do something else - I can search for a vowel in the English experience (in the English speech apparatus) that approximates and the $r$ sound and render it with the short "i," such as we find in the word "bit." This adaptive approach, which respects differences of experience, we call transcription. If it should prove necessary, in certain cases I can also forgo transcription and settle for what we call description: "a short, central, neutral vowel." When description is inconvenient,

42 We should note here that the example of a translation from one alphabet to another merely serves as a convenient introduction to the issue. Transliteral equivalences on the level of the alphabet differ from translation proper in that they are always reversible, symmetrical, and transitive. 
transcription imprecise, transliteration impossible, and we should like to avoid confusion, then we abandon all attempts at assimilation and simply borrow the z symbol for the Latin alphabet, writing: metzr, Petzr, etc.

\section{8}

A translation is always an instance of "being for..." and "being for the sake of..." The distinction between transliteration and transcription, description and loan, forms the systematics of rules for achieving equivalence according to the degree in which the speaking subject assimilates the world. For transcription, in a sense, is a hidden comparison - unfamiliarity with an object, its exotic nature, or its altered customary function causes substitution. Description, in turn, is a metalingustic operation. ${ }^{43}$ A loan comes in tandem with the assimilation of a foreign concept and an object of foreign origin, most often a product of civilization. ${ }^{44} \mathrm{~A}$ loan is sometimes replaced by a neologism and then removed from the language (as automobil in Polish became samochód), or sometimes coexists alongside the native word but has a narrowed, more specific meaning (as in the Polish wygoda and komfort pair).

Incidentally, all the above-named varieties of equivalence could and should be signaled in popular bilingual dictionaries by means of qualifiers. For instance, das Tor is correctly transliterated in German-English dictionaries as "gate" and "goal" (in football), but der Mundschenk rendered as "cupbearer" requires a qualifier that would indicate this equivalent as a transcription, because in both languages we are dealing with a title that pertains to official and customary relationships, which are comparable, though untranslatable (untransliterable). On the other hand, the Polish gazda [a farmer in the Tatra mountains] would be erroneously translated as the German der Gebirgsbauer except with a qualifier

43 Roman Jakobson (“On Linguistic Aspects of Translation.” In: On Translation, ed. R. A. Brower, New York 1959) distinguishes between three varieties of translation: 1) intralinguistic, 2) interlinguistic and 3) intersemiotic translation. This division strikes me as logically flawed, given that re-editing is both intralinguistic and interlinguistic. Thus, the word "teach" can be "re-edited" using the phrase "a pejorative term in student slang, meaning 'teacher"' This word should be explained in a bilingual dictionary in the same fashion, so that an English-German dictionary would read: teach - verächtlich im Schülerjargon): Lehrer. This would be an example of re-editing in a terminology we call "description," as distinct from a kind of transcription from "teach" to Arschpauker.

44 Despite all appearances, the situation of the language loan is complicated: it can be a transliteration if it is assimilated or resemble a calque when it is new (e.g. in translations of proverbs). 
that would categorize it as a description. A lack of such qualifiers is felt by all dictionary users. Das Tor, der Mundschenk, and gazda all "signify differently." In other words, they have different relations of equivalence with their dictionary counterparts; they are equivalent in different ways.

We arrive at some interesting observations through analyzing ways of achieving equivalence in onomastic and toponomastic terms.

Let us take the French name Jacques. We will normally translate this into Polish as Jakub, presupposing that, in a certain sphere of civilization, this name is ordinary, widespread, and shared. If we apply the Polish familiar form of the name, Kubuś, then we have a transcription, for all hypocorisms are not universal, but characteristic and local (it is, for example, significant that Kubuś appears in the Polish title of Diderot's Jacques the Fatalist). Jacques will still be called Jacques, as a loan word, if the fact that he belongs to French culture is an integral part of the text (or the literary genre). We do not take into account description when it comes to translating names (it is possible only in explaining telling names). We do translate, that is transliterate, the names of widely known cities. We say Rome, Florence, Vienna, and Moscow, but Bologna, Rostock, and Nizhny Novgorod. In this case it is exceptionally clear that the choice of equivalence depends on the genre convention and cultural factors. For instance, a contemporary realist novel often defies translation when it comes to the transliteration of proper names, whereas the common language custom requires us to transliterate places names. As such, the sentence Vittorio e stato invitato a Roma would be translated as "Vittorio was invited to Rome," and not "Victor was invited to Roma."

There are cases, however, where historical or political reasons oblige us to replace a correct transliteration with an erroneous loan. In a certain period, the Warsaw Radio began its program for Germans with the words Hier spricht Warszawa instead of Hier spricht Warschau. We can understand why this peculiarity was invented, but the error remains an error, whose dimensions we can imagine by reversing the formula: Tu mówi [here speaks] München or - distancing ourselves from the conflict zone - Tu mówi [here speaks] Athína, etc.

It does sometimes happen, however, that transliteration and loan are equally justified, a situation which expresses an uncertainty as to the degree of assimilation of the name, which is proportionate to the general knowledge about the referent. Ought one to say Cracow or Krakow, for instance? Loans are undoubtedly there in order to avoid confusion when it comes to international transportation timetables and information. I take the train from Stockholm to Rome, but on the signboard I read: Sassnitz - Szczecin - Wrocław - Praha - Wien Roma. Although rare, examples of toponomastic transcription do occur: in an eighteenth-century novel adaptation that gave the reality a Polish flavor, though 
the original plot-line and intrigue is kept, Paris could be equivalently replaced with Warszawa. ${ }^{45}$

The Russian $d u b$ [oak] should, of course, be transliterated into Polish as dąb. Plant names should present no problem. And yet with a change of context, the Russian $d u b$ may cease to be a Polish $d a b$. I might only recall the well-known difficulties Julian Tuwim had in translating a passage from Pushikin's Ruslan and Ludmila: U lukomorya dub zyeloniy ("By an arc of sea a green oak stands" in Roger Clarke's translation). In Tuwim's Polish version, the tree becomes a "green sycamore by the bay." The transcription of $d u b$ as jawor [sycamore] is justified by the connotations of tree names in the folklores of the respective nations (in Polish folk songs: "sycamore, sycamore, sycamore people" and "why are you standing under that sycamore, girl?").

The doubts that come with the choice between transliteration and transcription have often been discussed by translators. Jerzy Zagórski, for example, pleads guilty -unnecessarily, as I shall presently attempt to prove - to having once "too hastily" translated the phrase mi figue - mi raisin as pół figi - pół rodzynki [half fig - half raisin] instead of correctly (!?) offering ni pies, ni wydra [neither fish nor fowl $].{ }^{46}$ We ought to come to his defense against himself. While pót figi - pót rodzynki is a calque, ni pies, ni wydra is a transcription. In translating proverbs and phraseological expressions, a calque is not blameworthy; on the contrary, it often has more assets than a transcription.

Let us take the proverb (proverbial phrase) robić $z$ igly widty [lit. "to make a pitchfork out of a needle," fig. "to make a mountain out of a molehill"] and try to translate it into German. Preserving the moral sense (making a big deal out

45 In translating place names, we ought to take into account the complications that arise from a special addresser/addressee relationship, and their relationships to the language and to the referent: the peculiarity of these relations lies in the fact that all the elements participating in the communication act here are "of a certain nationality." If $A$ (of nationality $a$ ) talks with $B$ (of nationality $b$ ) in language $c$ (because $A$ does not know $b$ and $B$ does not know $a)$, then they must decide between them what language $(a, b$, or $c)$ they will use to name a place that lies in country $A$ (or $B$ ). Let us suppose that, due to historical circumstances, all three languages have their own names for a given place: for example, a Pole speaking German with a Slovak hesitates before asking: Wohnen sie in Pressburg?, but will also feel uncertain whether to say Wohnen sie in Bratysława or in Bratislava? This is a problem at the crossroads between stylistic and social norms. On a similar topic, see: T. Pretnar, "Nazwy geograficzne i ich odpowiedniki rzeczywiste. Na marginesie polskiego przekładu Symultanki Ingeborg Bachmann," Literatura na Świecie 1977, No. 1.

46 J. Zagórski, “Tłumaczenie testów do muzyki.” In: Przekład artystyczny ..., p. 354. 
of something small or trivial) and respecting German usage, we will say: aus der Mücke einen Elefanten machen (to make an elephant out of a moskito). And conversely: we render the German (though probably borrowed) aus der Mücke... as the Polish robić $z$ igty widly, when the context permits or demands that we make the expression and the surrounding circumstances Polish. This procedure would be a transcription. But let us now check the opportunities for creating a calque with these proverbs and let us write robić $z$ komara słonia in Polish and aus der Nadel eine (Heu)gabel machen in German. Of course, just as the Poles do not say pót figi - pót rodzynka, they do not say robić $z$ komara słonia, but it is not an error if these phrases are used in a translation. ${ }^{47}$

To transcribe or to calque? That is a genological question. All this brings us back to the dilemma of Luther and Goethe. Are we to "Polonize" Shakespeare, or to subject the text designed for a Polish actor to a mild English stylization that could be seen though the perfectly correct Polish grammar (as Jerzy S. Sito manages to do)? In a fairly essayistic tone, we might rephrase the question: Is English the language of Shakespeare, or is it the language of Hamlet, King Lear, and Othello? There is no doubt that English is the language of Hamlet in a different sense than French is the language of Gargantua and of Jacques the Fatalist, and different again from how English is the language of Winnie the Pooh. ${ }^{48}$ The identification and distinction of the language of the protagonist from that of the author, or rather their differing relationships to a given ethnic language, which is also the language of the work - this remains one of the most interesting and practically unexplored problems in translation studies.

[...]

I have quoted all the above examples to emphasize again that interpretation in translation is a special case of confrontation between two kinds of competence. My initial claim that translation is interpretation through modelling can be now summarized as follows: since the modelling is performed in various kinds of material, the text and language of the translation and the original text and language can mutually explain each other.

$[1979 / 1980]$

Translated by Soren Gauger

47 Some phraseological collocations are untranslatable (recte: which defy transliteration).

48 Cf.: S. Barańczak, "Rice-pudding i kaszka manna. O tłumaczeniu poezji dla dzieci," Teksty 1975, No. 6 . 


\section{Jerzy Święch}

\section{Translations and Self-Commentaries}

\section{1}

The history of the art of translation, in Poland as elsewhere, abounds in translators' statements. These are appended to their works as various sorts of "extras," as prefaces, afterwords, glosses illuminating "obscure" passages of the original text, and remarks pertaining directly to the act of translation itself, which, as we know, is a custom that has been practiced by translators since Antiquity. These are not infrequently testimonies of major importance for understanding the art of translation, and the postulate that "the history of the development of translation should begin with compiling inventories of [translators' -J.S.] abundant statements on these matters" ${ }^{\prime \prime}$ is all too correct. Fortunately, we now have such compilations; special attention should go to two important publications released under the patronage of the Translation Section of the Polish PEN Club: On the Art of Translation (1955) and Artistic Translation: On the Art of Translation, Volume Two (1975), as well as an anthology edited by Edward Balcerzan, Polish Writers on the Art of Translation, 1440-1974 (1977). ${ }^{2}$ Such writing on strictly translation-oriented problems, the work of the translators themselves, has had a checkered history, as the aims of the translators/self-commentators have changed over the centuries; here, however, it is not our task to discuss this historical (if fascinating) issue. The present consideration shall be based almost exclusively on contemporary material, as our aim is to determine what is the place in the present-day translation research of statements by practicing translators, who, we might add, have no ambitions whatsoever to act as translation theoreticians or critics.

Every recorded statement, of whatever form or type, that bears the mark of authorial signature is important, relevant, necessary, indispensable, etc. and should thus be analyzed as carefully as possible - insofar as the scholar's

1 P. Grzegorczyk, "Problematyka tłumaczeń. Szkic bibliograficzny." In: O sztuce tłumaczenia, ed. M. Rusinek (Wrocław, 1955), p. 445 [further on quoted as: OST].

2 Przekład artystyczny. O sztuce tłumaczenia księga druga, ed. S. Pollak, (Wrocław 1975) [further on quoted as: PA]; Pisarze polscy o sztuce przekładu 1440-1974. Antologia, ed. E. Balcerzan (Poznań 1977) [further on quoted as: PP]. [An extended version of the anthology, co-edited by E. Rajewska, was published in 2007 - editors' note]. 
competence and insight permits. Given that alongside, or on the margins of translations, so to say (though they need not be marginal in the pejorative sense) there appear the translators' own statements devoted to translated texts, we need not ask to what extent they are important, relevant, or necessary. Since they exist, it is clearly in order to play a more-or-less important role with regard to the primary text, to fill a gap in the work which might dissatisfy the translator in certain respects, driving him to clarify or supplement it, or turn the reader's attention to alternative translation solutions disregarded in the main text, etc. The translator can be his or her own censor, editor, and reviewer. A translation commentary provides what for a multitude of reasons could not appear in the translation itself. It tells the reader what the main text is unable to communicate, at least not in an explicit fashion. ${ }^{3}$ The translator is sincerely concerned for the correct reading of the text's intentions, particularly when the translation itself does not unambiguously give instructions to this effect. We might well doubt if the reader would glean all of the translator's intentions embedded in the main work without this considerable assistance. Thanks to the translator's direct statements we discover, for example, that the translation of a piece by a little-known American poet, W.S. Merwin, "Corps de ballet," was created "to demonstrate the powerful present-day tendency to address various problems directly, that is, to rebuild the poem's logical structure." ${ }^{\prime}$ When the translator's comments take the form of a more personal confession, they have yet different weight. "This time I did not intend to create an anthology of Russian poetry as such. I chose authors and works that spoke to me on the deepest emotional level." ${ }^{5}$

Or in a similar vein: "I set out to translate something [...] that could match my twentieth-century bitterness: The Kohelet, or: Ecclesiastes."

3 It also sometimes happens that a commentary is embedded in the text. "When Neruda writes 'the morphocypris butterfly' [mariposa de muso], we have to add 'the blue morphocypris butterfly;' when he writes 'the marvelous jacaranda tree,' we have to add 'the violet jacaranda tree,' as for the poet, who knows the bright-blue morphocypris butterfly and the jacaranda with its violet blooms from everyday life, the colors are contained in the names themselves, whereas we have to explain them to our readers. Of course, such elaborations are possible only in a small number of cases" (J. Iwaszkiewicz, "Przekłady z Pablo Nerudy," quoted from: OST, pp. 247-248). "The only solution is to translate and explain all at once, including a commentary into the text." See: A. Sandauer, "Wstęp." In: Arystofanes, Żaby (Warsaw 1956), p. 11.

4 C. Miłosz, Kontynenty (Paris 1958), p. 359.

5 J. Łobodowski, U przyjaciół (Lublin-Warsaw 1935), p. 126.

6 C. Miłosz, Ogród nauk (Paris 1979), p. 227. 
The personal and sometimes even intimate (as in the above examples) nature of statements from translators, who reveal the deeper reasons for their interest in a given work, aims to convince the reader that translations are always born of particular inner needs and motifs that the readers do not and cannot know, for they have no direct access to them. Balcerzan correctly observes that selfcommentary "reveals the biography withdrawn from the text of the translation, transparent within it, and reduced to the role of an instrument."' Today's translator (things once were different) does not wish to be relegated to a nonsubjective medium; in phrasing his other, more personal statement $a$ part, he wants to sanction his right to speak in the first person as "myself," and not only as the "representative of the author," i.e. the person whose work he translates. "A real translation is transparent; it does not cover the original, does not block its light, but allows pure language, as though reinforced by its own medium, to shine upon the original all the more fully." Translator statements indicate the fiction of the "pure language" Benjamin mentions; the translator's biography is not, and never can be "transparent" in the work. It is in the translators' statements that this truth is articulated. Thus, their intention, apart from purely personal aims, is to counteract the falsity of seeing translations as "pure" and "transparent" representations of foreign works.

It is easy to see, then, that translators' commentaries serve as a sort of metatext to the main text, describing the work, the finished product; regrettably, they do so in the same language as the translation itself. Like every metatext, they concern "either a set of sentences in a creative statement, or the rules governing this statement." Thus, the aim of the translator is to reveal his hidden work method, to "tally" his mistakes with both the reader and his fellow translators, to give account of both necessary and arbitrary compromises that were made etc. The translator's statement $\dot{a}$ part questions this attribute of the given work which is indisputable when it comes to all original works: its completion. Translators do not generally describe their finished products if they seek to find the readers' (and scholars') understanding for their decisions - this is done by focusing attention on the various stages of their work, on the various phases of progress, in a word, by concentrating on the work in statu nascendi. "The following remarks are an attempt at almost stenographically recording the course of work on the

7 E. Balcerzan, "Wstęp" PP, p. 6.

8 W. Benjamin, “The Task of the Translator." In: Illuminations, trans. H. Zohn (New York 2007), p. 79.

9 K. Bartoszyński, "Pogranicza krytyki literackiej.” In: Badania nad krytyką literacka, ed. J. Sławiński (Wrocław 1974), p. 98. 
translation of the first four lines of the introduction from Pushkin's epic poem Ruslan and Ludmila," wrote Julian Tuwim in his now-famous "translator's confession," titled "Working on a Quatrain."10 An exceptional example comes from a relatively recent publication by Maria Kurecka, Devilish Troubles, covering, step by step, the dauntless and truly Benedictine labor of rendering in Polish one truly remarkable book: Thomas Mann's Doctor Faustus. ${ }^{11}$ The inner imperative that made the author comment on her own work, showing the whole world the enormous scale of this effort, no smaller than the one needed to create the original work, must have been considerable indeed, given that the "supplement" to the translation is a whole book in itself!

It is the ambition of today's translators to present by means of such a creative self-commentary another version of the original; these are not, therefore, mere meta-statements on the main text, on the "first-degree" statements, but rather competing partner texts that rival the previous version. At the heart of these secondary statements lies a sense of insufficiency, of the inadequacy of the work he has managed to produce, albeit not in a form that he finds fully or partly satisfactory. How often we find in translators' confessions that works and authors they had once thought overcome now torture their mind. After many years they return to their translations, finding passages which, they believe, could sound "better" (which could mean either more "Polish," or, on the contrary, more faithful to the original). Such was the case with Nerval's beautiful sonnet "El Desdichado," which, once translated, was a source of nagging doubt for the translator, ${ }^{12}$ or one line from Baudelaire's "The Balcony:" Nous avons dit souvent d'impérissables choses. This was the only line in his work that later struck the translator (Czesław Miłosz) as less successful, which is why he tried to alternate the rendition. ${ }^{13}$ It is an old home truth that poetry translation means sacrificing some things for others, privileging certain aspects of a work (e.g. rhythm) at others' expense; it should not surprise us, then, that poetry translators, aware of their losses and failures, should try to do things over. They feel driven to do this

10 "Czterowiersz na warsztacie," first printed in Wiadomości Literackie 1936, No. 47; reprinted in: J. Tuwim, Pegaz dęba, czyli panopticum poetyckie (Warsaw 1950) and PP, pp. 280-294.

11 M. Kurecka, Diabelne tarapaty, Poznań 1970. [Kurecka's translation of Doctor Faustus, made in collaboration with her husband, Witold Wirpsza was published in 1960 - editor's note].

12 A. Ważyk, "Przygody i doświadczenia," PA, pp. 331-332.

13 C. Miłosz, Ogród Nauk, p. 177. 
by the unchanging rules of the art, which hold that the translation should sacrifice as few of the original's attributes as possible.

It seems that this motivation of translators' commentaries first came to the fore in the Romantic era, though those translators owed a great deal to their predecessors from the Enlightenment. At that time both amateurs and masters of translation were increasingly coming round to the idea that there was not, and could not be a perfect translation, that every translation could only be an attempt to wrestle with a foreign work - and this alone justifies its existence in the literary culture; that it could never bring satisfaction to those who would seek to see it as a faithful and exact recreation of the author's "thoughts" and "feelings," a meticulous rendering of the content and form (let us also bear in mind that in those days there were far more bilingual readers, who were able to translate the work on their own and were thus all the more capable of assessing the translator's achievement). A translation is only one of many possible versions of a foreign work, a version created through a range of utterly random circumstances, and thus, if other "parameters," occurred, the results of the translator's work could be entirely different. The more adamantly and vociferously the "fidelity" of the translation to the original is postulated, the more clearly translators see other competing projects, which hence cannot be considered singular and final, as it was once assumed. ${ }^{14}$

This is why, in translators' commentaries of that epoch, a ready and finished translation was sometimes furnished with a whole web of dubious and unhealthy suspicions that it was incomplete, in need of improvement, that it was the product of compromises in which the original author probably lost more than he gained. This made the urge to write a commentary all the stronger. Cyprian Kamil Norwid, who also in this respect had a viewpoint very much like today's translators, advised against "providing the translation alone" - he was thinking of translations possibly "profitable for the present time," as he was convinced that two parallel versions of the same work, a translation in the strict sense and a critical translation, need not be mutually exclusive. On the contrary, they could coexist on equal terms, alongside each other. "If I were to translate Childe Harold's Pilgrimage I would write a separate version alongside, in critical prose."15 Today this truth is considered patently obvious among poetry translators (largely aspiring to be called professionals and experts in a field we have come to call

14 J. Ziętarska, Sztuka przekładu w pogladach literackich polskiego Oświecenia (Wrocław 1969).

15 C. Norwid, "O tłumaczeniach z Byrona (written in 1865)," PP, p. 169. On Norwid see note 16 on page 171 in the present volume. 
the art of interpretation or "close reading"), who believe that the premise of all translation is experimentation, i.e. a trial, including critical, "commentary-like" rendering of a foreign work that has already been attempted by a translator. This kind of rendering only increases the range of possible solutions and, like all other versions, whether actual or potential, does not aspire to a greater "compatibility" with the original. Increasingly, the standpoint of the contemporary translator, as far as we can recreate it on the basis of the self-reflective statements, encourages us to think of the translation process in terms of a game. The game has replaced the old metaphor of a fight, a duel, in which rigid codes of honor held sway; the combatants (the translator and his author) had to respect these rules, and so there could be only one victor in this duel. The one who succumbed to his rival was defeated by "superior weaponry and an exhausted treasury of vocabulary." ${ }^{16}$ In a freer game, meanwhile, there are no victors nor losers; the results of the rivalry between the translator and the author are increasingly difficult to predict, and the rules of the game are always changing, for they are established anew on every occasion. As Maria Kurecka notes (following Ortega y Gasset), a game involves utterly free activity, unhampered by the restrictions of life; its repetitiveness, etc. ${ }^{17}$ Furthermore, "poets and translators of various movements write their own rules of the game [...], which become relative, open to constant change." 18 This corresponds with the view that a translation's proper "form of existence" is the series. "Even if a foreign-language work has been translated into our tongue only once, we apprehend this translation as the beginning of a series of other translations that will or may be created in future. It is vital that both a partially realized and a potential series are open to further development. They are sequences which, for all practical purposes, are infinite." ${ }^{19}$

\section{2}

The superordinate category that embraces the actual multiplicity of the translator's roles in the translation process is that of the interpreter of the literary text (in the musical sense of the word; it is not by chance that the authors of commentaries devote so much attention to the analogy between a translator and a musician who the plays a melody according to the score). In the course of

16 L. Osiński, “O potrzebie, ważności w literaturze i warunkach przekładów," PP, p. 111.

17 Kurecka, Diabelne tarapaty, pp. 52-54.

18 A. Ważyk, "Przygody i doświadczenia," p. 333.

19 E. Balcerzan, “The Poetics of Artistic Translation" [1968]. See pp. 105-119 in the present volume. 
his work, the translator also executes a great many "commissions," feeling that none can be disregarded, that while he has various obligations toward his supposed readers (to whom he supplies knowledge of the world, as an experienced guide through its sprawling labyrinths, sometimes called upon to be an adviser, teacher, and moral authority, at other times a promoter of new literary phenomena), he is primarily obliged to the translated author. All the aforementioned roles must be acknowledged as secondary to his primary function as a reader, an interpreting critic, an insightful exegete, and a scholar. Translators' statements demonstrate in a fine way the stages of designing and carrying out a work plan, illustrating the translator's ever-changing self-perception as a "reader," "critic," "scholar," etc. This means that he simultaneously identifies himself with each of these self-designed roles, seeking to attain the optimal result, the best one possible. The optimization of the translation process through the adoption of such self-suggestions or working hypotheses is the first important information to be gained by the the scholar and the critic from a patient reading of these texts. An initial remark: none of the translator's experimental trial versions should be disregarded; we ought to remember that the finished translation is the fruit of many individual interpretations, which leave an invisible mark on the whole text (the skill is in the concealing of mastery!). The translations are sometimes done by heart. "I eyed the quatrain. I have known it by heart for perhaps thirty years. ${ }^{20} \mathrm{~A}$ poem stored in the memory and often repeated (like a folk rhyme) or rather recited "for oneself," situated in the realms of auto-communication, where each time it is enriched by a new network of associations, becomes, as it were, an organic element of the translator's life. We might say that we are dealing here with a Mallarmesque metaphor of Life woven around the Book. We generally tend to treat the translators' statements as their private documents; but the autobiographies of translators that emerge from their "confessions," even when at their most personal, are evidently constructed biographies; after all, "the life of the author is a kind of a text itself, its legibility and meaning derived from its connection to the world of literature." ${ }^{21}$ Let us not be misled by the private and confessional titles, such as: "Tyetradi Pyeryevodchika," "Notizbuch des Übersetzers," "Some Reflections on the Difficulty of Translation," etc. ${ }^{22}$ In all these examples

20 J. Tuwim, Czterowiersz na warsztacie, PP, p. 281.

21 J. Sławiński, "Myśli na temat: biografia pisarza jako jednostka procesu historycznoliterackiego." In: Biografia - geografia - kultura literacka, ed. J. Ziomek, J. Sławiński (Wrocław 1975), p. 15.

22 L. S. Barkhudarov, Tyetradi Pyeryevodchika, (Moscow 1964); K. Dedecius, Notatnik tłumacza, trans. J. Prokop (Kraków 1974); A. Fang, "Some Reflections on the Difficulty 
the translator's biography has its own logic, which is by no means the logic of real life. The internal rhythm of this biography is created by the ebb and flow of a fascination with a given work; it is composed of phases of feverish work followed by rest, or in-depth study and then an entirely disinterested reading etc. Unquestionably, the only part of the translator's life that has significance for him is what is directly linked with the work kept in his memory and often recreated. All the rest is meaningless chaos.

The work recreated in the memory is an endlessly paraphrased text in the most basic sense of the word: paraphrasing means saying the same thing, but in a different way. The impulses for internally recoding these texts through memory are supplied by the translator's life itself, made meaningful by many years of acquaintance with the same work, which reveals a new, unfamiliar, and unexpected horizon of significance each time around. Thus understood, the translator's life is the first, hugely important interpretive framework for the original work; it is a screen, as it were, which the work gradually crosses. In speaking of himself, the translator isolates certain "segments" of his biography. This biography is diacritical, so to speak: every segment is deeply rooted in "its own" time, which indicates not only that the translator's consecutive interpretations of a work are not only chronologically restricted and that the various interpretations accumulate, but also that they are always qualitatively different. Years later, translators are not certain if works signed with their names are really their own: "[...] I am far from certain if that is my translation, or merely the recollection of someone else's translation that was lost and somehow survived in some corner of my memory." ${ }^{23}$ Naturally, this is a tactic, a game, mere autosuggestion, but it is significant for the translator's work, in his constant progress from one stage of his writerly biography to the next. The translator is truly content not with "corrected" works but with utterly new ones, executed in a radically new fashion. The abovementioned book by Maria Kurecka is an instance of self-created biography (of two translators). Another fine example is Roman Brandstaetter's Biblical Circle, a brilliant depiction of life in a close relationship with the Bible, a work he carried “inside him" for many years. ${ }^{24}$ Karl Dedecius' Translator's Notebook ${ }^{25}$ has a clearly

of Translation.” In: A. Fang, R.A. Brower, eds, On Translation (Cambridge, MA 1959), pp. 111-133.

23 A. Ważyk, "Przygody i doświadczenia," p. 334.

24 R. Brandstaetter, Krag biblijny (Warsaw 1975). [Roman Brandstaetter (1906-1987), a Polish-Jewish writer and journalist, translated into Polish selected books from the Old and New Testament - editors' note].

25 Dedecius, Notatnik tłumacza. 
biographical character. Mieczysław Jastrun, Adam Ważyk, and Czesław Miłosz have also left us extremely valuable testimonies. ${ }^{26}$

\section{3}

Translators' statements record their reading experiences; sometimes they give evidence, for example, of having read the original text out loud. The translator of Sophocles' Antigone recalls that he recited the tragedy in the original Greek so as to "hear the rhythm of the internal melody and render this rhythm in the phrase of Polish poetry." ${ }^{27}$ Many equally interesting remarks on a similar topic can be found in the relevant chapters of Kurecka's book, which cover her work on the "musical" passages in Doctor Faustus. ${ }^{28}$ The translator first reads the text for himself, producing for private purposes, as it were, the fiction of the original reader of the work, and then in turn becomes the interpreter of the now different melody, and finally, its listener, gauging the sound of the text he created just moments before etc. "I heard those choruses of Sophocles in my translation [...] and I assure you, they made a powerful impression." ${ }^{.29}$ Indeed, the translator is a Protean persona, transforming from the "quiet" reader to the "loud" interpreter, then into the composer of a different melody, and finally into an adoring listener! Every reading is a performance of the work; we might say, in the most general terms, that the translator is bound by the principle of an inordinately scrupulous reading, wherein it would be a sin to lose sight of the text even for a moment. It must be always at hand. This fact is frequently stressed in translators' statements.

The above-cited Ludwik H. Morstin argues that "no one gets to know the work like its translator; no one is so intimately acquainted with the author." 30 Translation, as another author tells us, is "the art of minute details." ${ }^{31}$ Indeed, in his quiet or vocal dialogue with the author, the translator is justified in believing himself initiated into rules of the poetic art that are hidden from ordinary readers. We might say that such reading always sets a new boundary between the

26 M. Jastrun, Między słowem a milczeniem (Warsaw 1960); Poezja i rzeczywistość. Eseje i szkice (Warsaw 1965); Walka o słowo (Warsaw 1973); A. Ważyk, Kwestia gustu (Warsaw 1966) and Wybór przekładów (Warsaw 1979); Czesław Miłosz, Kontynenty, Prywatne obowiązki (Paris 1972), Ogród nauk (Paris 1981).

27 L. H. Morstin, Moja praca nad przekładem utworów Sofoklesa, Horacego, Lope de Vegi, Calderona i Goethego, OST, p. 281.

28 Kurecka, Diabelne tarapaty pp. 121-154.

29 Morstin, Moja praca, p. 281.

30 Morstin, Moja praca, p. 279.

31 M. Jastrun, “O przekładzie jako o sztuce słowa," PA, p. 129. 
spheres of text and non-text (a semiotic mechanism of experiencing the text). Over the course of reading, the translator accesses what is normally inaccessible, or seldom accessible, to the ordinary reader: the poet's individual language. Jastrun writes that "this language [he is referring to Mallarmé, Hölderlin, and Rilke - J.S.] is, in a sense, untranslatable, and the translator must combine his awareness of this fact with audacious and resilient persistence." 32 For today's poet, translation becomes a measure of the poetic character of the utterance itself; attention has decidedly shifted from peripheral issues to, so to speak, the linguistic heart of poetry, the center of poetic speech, which is most difficult to define in other terms. Therefore, it is quite accurate to say that "poetry translation, as it is understood and practiced at present, is a relatively recent phenomenon." ${ }^{33}$ At every turn, then, we are dealing with a type of interpretation reserved for "authorities" and "experts," or readings that are seldom accessible to the ordinary reader, if at all.

We might say, therefore, that translators' statements create a testimony of various "reception styles" prevailing in a given epoch, and they have been rightly studied from this angle in the past. The translator's choices are indicative not only of his conscious decisions, "they reveal not only his literary taste, but also indicate the ways of reading characteristic of the epoch when the translation was made." ${ }^{34}$ Here we are interested in another issue, namely the translator's conscious and intentional reading projections, that is the instructions, contained in the text, on how to read and correctly interpret it. We may repeat Głowiński's claim that the translator's reading always follows or departs from the reading standards dominant in the society (though these might be quite diverse, as we have indicated above). The translator projects the reader that is suggested to him as most appropriate through a certain "style" of reading; the whole strategy of his game with the reader depends on this projection, whether it is an "ordinary" reader, an "expert," or a "disciple." The translator should facilitate and not hinder the chosen reader's understanding of the text. At any rate, in the game involving two, it is not translatability that is at stake, but the originality of the translation. The reader should not be aware that he is dealing with a translation. "A poetry translation is only worthy, and can only be considered when the reader does not sense that he has a translation in front of him."35

32 Jastrun, “O przekładzie”, p. 130.

33 A. Kamieńska, "Pochwała niemożliwości," PA, p. 134.

34 M. Głowiński, Style odbioru. Szkice o komunikacji literackiej (Kraków 1977), p. 122.

35 A. Ważyk, "O pracy nad Onieginem," OST, p. 377. 
As we know, however, there is another way of reading assumed in texts, when they are attributed with the features of secondary texts, of a certain kind of quotations. Crucially, in both cases we have a projection of the reader as an active co-interpreter of the work. The translator cannot work without the hypothetical reader, as this is how he checks his steps against the presupposed presence and participation of someone who is fully entitled to be reckoned with and not to be ignored in tallying the gains and losses which, from there on, will be their shared work. "It is only proper, Gentle Reader, that I inform you in advance what has guided us here in retranslating these sacred tomes after their initial translators, from Krakow and Brzesko." With these words one of our oldest and worthiest translators, Szymon Budny, arranges the game with his assumed audience in the preface addressed to "the pious reader." ${ }^{36}$ In this respect, nothing has changed over the years. In the past, the translator appealed to the reader's bilingual capabilities. There would have been no real partnership between the reader and the translator in this game for a better understanding of the original text if the latter had denied the former the ability to transform parts of the source language into parts of the target language. In later periods the partners' unequal language competencies caused conflicts to arise in the reception of the translated work in two different languages. In the projection of today's reader, in turn, it is pivotal that he knows the two languages to a lesser degree than readers of times past, and thus his co-interpretation will be of an utterly different kind. The reader, "that third person in the dispute between the original and the translation, hardly knows the original, does not know the principles of the foreign language, nor does he know anything about the differences between Polish and Russian, between the structure of the Russian poem and the Polish one." Consequently, this reader "wants a beautiful Polish work, trusting that it is the equivalent of a foreign work in form and content." ${ }^{37}$ A vast shift has occurred: the old bilingual reader has been replaced by a new one who accepts on faith that the translation is "faithful" and "accurate."

Making a translation sound "pleasant to the Polish ear" - and this is the undying wish of our translators - is an element of "bad faith," of an unwritten agreement between the translator and the reader, in which the latter commits to pretending to read the work as if it was written in Polish, to "interpret" the text in reading just as he would read and interpret an original work. This explains the repeated attempts at measuring the "naturalness" of translation, as mentioned

36 Biblia, to jest ksiegi Starego i Nowego Przymierza (1572), PP, p. 44.

37 P. Hertz, "O tłumaczeniu ksiąg," OST, p. 215. 
by translator Gabriel Karski, who urges us to read "our text as though it were an original work." 38 This statement testifies to a sort of unaware "performance" that the translator introduces in his work, to a game played with himself, which then must be replicated by the reader: the act of reading the translation as if it were an original work. The history of the art of translation, as Edward Balcerzan asserts, has seen a clash between "two concepts of translated literature [...]: on the one hand, an effort to retain the memory of the work's two-phase (bilingual, biauthorial) history, and on the other, attempts to sanction a kind of amnesia (an invalidation of this history)." ${ }^{39}$ This has always created a range of communication tensions between the translator and reader. In their self-commentaries, translators either seek to justify the choices that could potentially generate conflicts with the reader's habits, or to voice approval for existing reading habits. A translation that is consciously created as native version, as the translation of a foreign-language work, does not "fit" readers' expectations. Sometimes, so to say, there is no place for it whatsoever in the repertoire of literature decoding techniques. The "quotational" nature of translations can be seen as a sign of a "falsely understood accuracy" (an accusation Kazimierz Kumaniecki levied at translators of classical Roman literature).$^{40}$

\section{4}

It is a common view among translators that it is they, and not scholars-theorists, who are the best critics of their own translation work. The creators of true translations are themselves poets who, "as one might assume, owe nothing to translation theory." ${ }_{11}$ "No weakness of the author can be concealed from his translator, particularly when the latter is a writer himself," ${ }^{42}$ which obviously leads us in practice to some dangerous and slippery conclusions - that the translator is "better" and "wiser" than the original author. As such, the translator's brand of criticism ought to be called active, creative, unafraid to boldly meddle with the text of the original work, a criticism that justifies the right to experiment, to make trial, provisional, auxiliary interpretations. ${ }^{43}$ For the translator, as

38 G. Karski, “Kłopoty tłumacza,” OST, p. 258.

39 E. Balcerzan, "Wstęp" to: PP, p. 21.

40 K. Kumaniecki, "Nad prozą antyczną," OST, pp. 99-109.

41 A. Międzyrzecki, "O przekładach," PA, p. 179.

42 Morstin, Moja praca, p. 289.

43 See: E. Balcerzan, Styl i poetyka twórczości dwujęzycznej Brunona Jasieńskiego. Z zagadnień teorii przekładu (Wrocław 1968), pp. 38-39. 
we have mentioned, ruthlessly reveals all the "weaknesses" and "insufficiencies" of the work - he shows how, in his view, the work "really" ought to look. As a critic, the translator always uses the concept of perfect and ideal solutions, which need not indicate his anachronistic Classicist impulses, but rather his conscious search for an abstract model to illuminate all the qualities of the work being translated. At any rate, his critical acumen reaches above and beyond what is found in the work itself, into what necessarily determines its final shape. We might say that it is indeed as a critic that the translator competes with the author for a finer reproduction execution, a reconstruction of the world model that a given work achieves in a limited capacity. "The translator must understand the model of the world of the poet he is translating," a theorist ${ }^{44}$ has opined; for our part, we would add that this model is describable in general semiotic categories. Thus the "fidelity" of the translation depends on how accurately and in what detail the model has been reconstructed. In essence, it boils down to an old debate - whether to translate the "spirit" or the "letter" of the text.

In light of translators' commentaries, this phenomenon acquires particular importance. The translator works with models, which, in our day, so evidently likens his abilities as a critic of the text to those of a scholar, an expert. And thus, conscious departures from the original are justified by the hypothesis of the work as a whole, as a "body" or an "edifice," whose overall meaning cannot be reduced to the sum of the meanings of its parts; it is a certain quality that overrides them and is given directly, in its visible aspect. This is why, as we find out, the translator of poetry has no choice but to translate a poem in its entirety, or not at all. "A statement that contains a discursive thought can be transformed," Ważyk writes. "Where there is no discursive thought, there are no variants." ${ }^{45}$ Tertium non datur. "One does not sit down with the intention of translating phonemes or morphemes. One sits down to translating the poem as a whole. [...] A work of poetry is a whole. Nerval's line Où sont nos amoureuses? is such a whole, too; one can either translate it entirely, with its trembling emotion and tightly packed semantic and phonetic space, or not translate at all." ${ }^{36}$ An either/or situation, no other way out (we are not concerned, at present, to what extent translation practice goes against this theory of translation; we are interested here in the hypothesis of the work as a whole, conditioning the translator's later work on the text). Translators' experience confirms the aptness of a claim that gest effectively

44 E. Etkind, "Swoboda tłumacza jako konieczność uświadomiona," trans. E. Siemaszkiewicz, PA, p. 45.

45 Ważyk, "Przygody i doświadczenia," p. 331.

46 A. Międzyrzecki, “O przekładach," PA, p. 179. 
defended today by one of the most influential branches of the art of interpretation, i.e. close reading: the guarantee of a "faithful" or "good" translation is to grasp the organic unity of a work, its character as a coherent text, as a sign. We ought to translate "not the parts, but the whole, take as a point of departure not the individual words, but the character of the poem." ${ }^{37}$ This opinion derives from translation practice, not from theory.

What do we translate anyway? Does a text as an object of interpretation maintain its full identity and integrity in the act of translation? Should the translator respect those meanings that are communicated directly, regardless of the interpreter's changing tastes and predispositions (here we have in mind the "coefficient of the translator's individual understanding and experiencing of the text" ${ }^{48}$ )? Does the translator face the work in its only and final shape, sanctioned in this very unique form by the author's will (the translator is then its guardian and defender), or does he only deal with a figment of his own imagination? What, then, is being critiqued and interpreted - the author's intention hidden in the text and explicitly formulated in various statements, or the immanent expression of the work, justifying the postulate of "objective interpretation" ${ }^{\prime 9}$ ? The work "in itself" or its various concretizations (in reading, criticism, translations), piling up over the centuries, over the epochs, which the work itself does not contain? Is the object of interpretation the work as it was understood by its contemporaries, or, given the evident impossibility of reproducing its original historical meanings, ought it to be seen in a "contemporary" light? Where, then, to use the language of today's hermeneutics, is the border between the inner and outer horizons of the work ${ }^{50}$ ? Throughout these questions posed by translators there is a correspondence to the claims of hermeneutic, including the risky one about the translator/interpreter's identification with the author: "the translator should try to think and feel like the poet he is translating." ${ }^{51}$ The identification concerns "personae," not "shadows," that is, the translator's conscious ego: the art of translation is mastered by those who "possess the invaluable ability to conquer their egos and to incarnate themselves with the highest degree of artistry as the author they are translating." ${ }^{52}$

47 A. Sandauer, “Troski tłumacza," OST, p. 344.

48 S. Pollak, “Granice swobód,” PA, p. 272.

49 E. D. Hirsch, “Objective Interpretation,” PMLA, Vol. 75, No. 4 (Sept. 1960), pp. 463-479.

50 Hirsch, "Objective Interpretation."

51 A. Stern, "Nad Majakowskim," OST, p. 349.

52 K. Chukovsky, Vysokoye Iskusstvo (Moscow 1964), p. 47. 
The author as a "persona," the translator as his "double," and the work as a structure ("organism," "construction") are all just examples of model projections that appear in the act of translation. Translators mention them in their confessions. Another aspect at play here would be the concept of perfect bilingualism, fully symmetrical, categorized typologically as "creative bilingualism." 53 Space restrictions do not permit us to explore this matter, however important it may be. Undoubtedly, the most important model the translator uses in his work is the model of language as an instrument assisting the process of understanding and interpretation. Translator statements reveal the range of linguistic assessments they perform. Between two different ethnic languages, carrying their own traditions, a network must be established, or rather, a complicated system of mutual relationships, a tally of differences and similarities ("Every language has its own sphere of strengths. Sometimes the spheres of two languages partially overlap, and then they have a common sphere in which a good translation is attainable" $\left.{ }^{54}\right)$. Ongoing comparison is required; the "sphere of strength" etc. must be established for each language. This is why in operations of this sort a mediating sphere comes to being, one that corresponds to no one particular linguistic reality (neither of the source nor the target language) - it is a sphere of pure potentiality. Understanding involves establishing equivalence between the units of the two codes. The ability to understand statement "S" formulated in language " $L$ " is measured by the degree of an individual's capacity to paraphrase it, to "translate" it, whether within the same code (intralingual translation) or into a foreign code (interlingual translation). The transformational theory of translation deals with these phenomena in detail. ${ }^{55}$

Yet translators explore them as well. Mere knowledge of the language in which a text has been written is insufficient; it is also necessary to be competent in the rules by which the information contained in statement " $\mathrm{S} 1$ " is equivalent to the information carried in "S2." The equivalence of these two pieces of information and two statements can only be achieved through applying the correct rules of transformation - the recoding of language "L1" into language "L2." The mediating sphere in the act of translation - the auxiliary language or the "interlanguage" - covers the sum of these transformational rules. If, in a self-reflective commentary, the translator returns to the phase in which the work was being created ("I proceed [...] from the finished poem, crystallized as it were in its fame,

53 Balcerzan, Styl i poetyka..., pp. 11-14.

54 Milosz, Ogród nauk, p. 176.

55 V. N. Komissarov, Slovo o pyeryevodiye (Moscow 1973), pp. 37-42. 
back to its nascent state," Paul Valéry confessed on the margins of his translations of Virgil's Eclogues ${ }^{56}$ ), then he performs an act of understanding and, simultaneously, translating the work through a whole range of paraphrases, from the most primitive and "content-oriented" to far more complicated ones, respecting the formal (artistic) properties of the original. The sum of these paraphrases, the selection made among them, determines the final form of the translation.

We do not want to ascribe to translators the accomplishments that are surely more deserved by scholars; yet it is a fact that their observations can often supply valuable inspiration to theory. The above-mentioned issue of the metalanguage, for instance, appears in the reflections of many translators today. If saying that translation is "looking at one's own speech in the light of the foreign one" ${ }^{\text {"57 }}$ is apt (and compelling), then this act - carried out without the translator's awareness occurs only upon distancing oneself from one's own language, which then plays an auxiliary role as a linguistic tool (it does indeed find its application in translator commentaries). Based on a critical assessment of both languages (source and target), an "interlanguage" of sorts is created, resulting from the translator's compromise in attempting to address two contradictory postulates: "adequacy" (the translation should be read as the original) and "naturalness" (the translation should be read as an utterance in the target language). ${ }^{58}$ The "interlanguage" is not merely an invention of scholars; it indeed emerges during the translation process, wherein the translator always plays the role of a comparative linguist, and thus, the creator of a metalinguage. The essence of all translatorial interpretation is that "it elucidates the meaning expressed in L1 by building a model for this meaning in L2. U2 is thus a model of U1." ${ }^{59}$ And here is how things look in a translator's reflections: "Something like an empty space is created in my mind, or more accurately, a frame that can be meaningfully filled depending on double critical reflection: on both the original language and the language of the translation. These two languages critique each other, but on a neutral ground, as it

56 P. Valéry, "Variations on the Eclogues," trans. D. Folliot. In: J. Biguenet, R. Schulte (eds.), Theories of Translation: An Anthology of Essays from Dryden to Derrida (Chicago 1992) p. 120.

57 J. Ziomek, "Przekład - rozumienie - interpretacja," in: Zagadnienia literaturoznawcze interpretacji, eds. J. Sławiński, J. Święch (Wrocław 1979), p. 57. See p. 261 in the present volume.

58 G. Toury, "Interlanguage and Its Manifestations in Translation," Meta 1979, Vol. 24, No. 2, pp. 223-231.

59 Ziomek, "Translation - Understanding - Interpretation," p. 171 in the present volume. 
were, through a language of empty signifiers." ${ }^{60}$ The translator/critic has to constantly overcome his own resistance against everything which he tends to perceive as "foreign," "not ours," "hostile," etc., as a result of his image of the world being determined by linguistic categories. The "foreign" is more often described, and thus evaluated, from the perspective of the user of a given language, who, consciously or not, privileges "our" point of view, than from the opposite perspective, which requires tolerance for all that is "foreign." In reflections on translation, ethnocentrism and xenophobia are far from rare. Our language, which has been ascribed with noble ancient kinships, ${ }^{61}$ was best qualified to "assess, weigh, and compare the words and turns" of a foreign language. ${ }^{62}$ The translator of yore had still to adhere to the mandatory division into "better" and "worse" languages, that is, those which were allegedly more advanced in their development, and those which, in comparison, were underdeveloped, less capable and refined, both as tools of communication and as means of artistic expression. A confrontation of two ethnic languages, with all respect for their distinctiveness, brought about a much greater chance of creating an "interlanguage" than in times previous - and in particular one that stood a chance of taking root in the native culture and literature. Such translators as Roman Brandstaetter and Czesław Miłosz have fought for the equal status of the biblical style in contemporary Polish.

Linguistic production of this sort can only be created when one has a perfect command of both languages. The observation that translation is "learning about one's own language, testing its capabilities and incapabilities, its strengths, its limits" ${ }^{33}$ requires some elaboration. The translation process means, to a no lesser degree, delving into the "strengths" and "limits" of a foreign language, to make the cost of importing foreign attributes into the native system lasting and advantageous. Here we come upon the above-mentioned issue of bilingualism, which the statements by practicing translators also show from a slightly different angle than translation theory does. Obviously, the translator was and is expected

60 W. Wirpsza, "Parę aktualnych czynników współczesnego przekładu poetyckiego," Poezja 1976, Vol. 6.

61 "If any living language," wrote Warsaw University professor and translator Ludwik Osiński in 1824 in all seriousness, "can claim to have a closer affinity with the Classical speech of the Greeks and Romans, then this honor surely belongs to the Polish language.” L. Osiński, “O tłumaczeniach z obcych języków, PP, p. 112.

62 A.K. Czartoryski, "Myśli o pismach polskich, z uwagami nad sposobem, pisania w rozmaitych materiałach" [1801], PP, p. 91.

63 A. Kamieńska, "Pochwała niemożliwości," PA, p. 136. 
to have a perfect command of two languages to the same extent, one of which is his native tongue, and the other a learned language. A translator deserves to be called "good" only if he acquired and permanently assimilated the ability to use the two languages actively; as a postulate this causes no controversy among authors, though we know that in everyday translation practice "the decisive factor is the creative skill in the native language," ${ }^{64}$ and not both. This is true, though obviously, we read a great deal about the necessity of the translator "getting intimate" with the foreign language, which is meant to safeguard him from making overhasty correspondences between the two languages, from the temptation of succumbing to false analogies etc. "It is only through long, daily engagement with another language," writes Maria Kuncewiczowa, "that the translator can be an author's co-creator." ${ }^{65}$ Thus, the translator ought not to be seduced by the "close kinship of languages, the contrasting opposition of the aural fabric, the differences and deceptive similarities of form." ${ }^{\circ 6}$ "Creative bilingualism" appears everywhere as a postulate, a condition sine qua non, upon which the profession depends. Translators commenting on their own work thus confirm Roman Jakobson's observation that "a faculty of speaking a given language implies a faculty of talking about this language." ${ }^{67}$ "Functional bilingualism" in turn, is a matter of translation practice.

Examining translators' statements, we see that the concept of "creative" bilingualism plays an important role in their writing strategies as an auxiliary working hypothesis. To execute their task as well as the author, or perhaps even better (what translator does not dream of this in the depths of his soul!) - this must imply entering the author's sovereign territory, the realm of his own culture, literature, and above all, language. It is only upon gaining deep insight into the possibilities that once or presently stand open to the author, upon, let me reiterate, the hypothetical "adoption" of the role of the consumer and, at the same time, producer of the work created in the original language, can the translator point out the author's errors and inconsistencies - and duly avoid them. In the phase of planning and executing the translation work, over whose course the translator dons several masks, plays several roles at once, he must, at least for a moment, feel "more at home" in the author's own language, as though executing his role better than the author himself. If the translator wants to be an attentive

64 J. Pilař, Trzy aspekty przekładu artystycznego, trans. J. Bułakowska, PA, p. 261.

65 M. Kuncewiczowa, "Inne języki," PA, p. 163.

66 Ważyk, "Przygody i doświadczenia," p. 336

67 R. Jakobson, “On Linguistic Aspects of Translation.” In: A. Fang, R.A. Brower, eds, On Translation (Cambridge, MA 1959), p. 234. 
and just critic of the original, he must acquire and master the rules and principles of the author's code - in a word, he must consider himself an equal executor of the same tasks and commissions, and to this end, he requires the competencies provided by creative bilingualism: parallel and equally valuable creativity in two languages. For only the truly bilingual writer can write literary works of value in both languages. Translators' commentaries, therefore, constitute an interesting addendum to the matter of bilingualism - such as becomes a component of the writer's roles.

\section{5}

In the game of translation, the image of the author is usually made in the translator's likeness, and interestingly enough, in this theatre of language, the more the original author is sure of his right to speak in his own voice, the more strongly he goads the translator, now fully aware of all the author's shortcomings and assets, individual tendencies and mannerisms, into taking a polemical stance. And conversely: there is no polemic - or at least not one that would bring artistically fertile results - without acknowledging the artist's full autonomy. After all, one of the most important articles in the unwritten contract between the translator and the author is the recognition of translator's independence, a respect for all his distinctiveness. This is one of the most enduring and least disputed conditions for starting the game. What does this full creative autonomy mean for the translator? In a nutshell, each partner plays according to his own rules of the game. It is telling that a translator of a sonnet by Mallarmé utterly ignored the author's commentary to the poem, considering it to be "non-binding," preferring his own reading, thus disregarding what the author wanted to say "on his own behalf." ${ }^{68}$ Both here and elsewhere the dialogue with the author shifts from a "personal" level to a field where the sovereign rules of poetic game reign. Whether approval or dissent - always with full respect for the autonomous rules of the art.

But what art? The literary art, of course; after all, in every epoch translations have been a response to some social need, meeting (to a greater or lesser degree) the expectations and hopes of a (larger or smaller) target audience, though both these "needs" and these "expectations" strictly concerned literature (poetry). Translations have always appeared as a result of the translator's more or less keen assessment of the literary situation at a given moment, which he could, for a

68 Ważyk, “Przygody i doświadczenia," pp. 344-345. 
variety of reasons, regard as unfavorable. They were a response to the condition and opportunities that seemed, at the time, insufficiently explored by the native literature. In brief, they were born from a sense of excess (oversaturation) or deficit in the native writing. Evaluations of the current situation occupy considerable space in translators' monologues; they do not forget for an instant that their true vocation as producers of valuable literary works is to constantly probe the opportunities and verify the condition of literary communication at a given time. A certain system, of style, versification, or genre, may seem thoroughly exhausted, and thus affords no tension whatsoever between the author and the reader. For this reason, translations aim to monitor, so to speak, the "capacity" of a convention; as we know very well, they strive to be an active factor in literary evolution. ${ }^{69}$ The translator has always aspired to the title of a discoverer of novelties; translations were to stimulate change in literary communication. He wanted to open before the reader perspectives of unprecedented artistic solutions and achievements. He wants to be the first to acquaint the reader with something new to his aspirations and expectations. The translator promises the reader an adventure he has never embarked on, because writers have never before provided the opportunity. If, by way of generalization, we say that in every literary synchrony the role of the translator gravitated toward either the pole of "archaist" or "innovator" (we seldom deal with such polarizations in the art of poetry), then nowadays it has swung toward the latter - or so it would appear based on statements by translators themselves.

As such, it would be hard to speak of translators' commentaries on their own work without mentioning their significance in learning the tastes, habits, and aspirations expressed in the "current" literary production, as well as projects for future, now merely intimated solutions. Translators' confessions often give us a basis to speak of an outline of a literature that has yet to exist, a literature which, perhaps, in the near future, will emerge through the concerted effort of writers and translators, equally concerned for the future of their country's literature. Compared to such aspirations, translation practice must always involve compromises; even the most realistic projects never have a chance of fully coming about, though this does not detract from their significance as fascinating visions of the literary future. The same goes for the view of the literary past, for with the advent of translation projects in the form described here, the vision of tradition changed considerably as well. We are well aware that, like any memory, tradition is not "solely a synthesis of either synchronic or diachronic parts; it is a

69 A. Popovič, Preklad a výraz (Bratislava 1968). 
whole made up of both at once." ${ }^{\prime 7}$ Every new translation reorganizes this whole, much like every new literary translation project establishes a new relationship between "dead" and "active" layers of tradition. If finished translations do not always indicate this with sufficient clarity, translators' statements undoubtedly aid them in this respect.

The significance of these important documents also derives from the fact that they show an awareness of the standards and rules of the art of translation, to which every translator should remain true if he does not want to be accused by his colleagues of shoddy craftsmanship, all sorts of blunders and sloppiness, one-sided succumbing to the rules of the market etc. As a critic of others' achievements and inadequacies, the translator always stands up as a guardian of the good name of his profession. He defends the autonomy of an art which demands that every novice respect its firm and eternal principles. These rules hold to varying extents: the universal ones are obligatory to the highest degree, while a lower degree involves the time-honored national habits in translation practice (e.g. the Polish tradition of translating poetry in verse, whereas in France a poem is rendered in prose). Translators' monologues can also be an articulation (sometimes polemical) of rules that were shaped at a certain time and treated as binding because of the prestige of a particular accomplishment. We know, for example, that the Polish Shakespeare canon, which is now fiercely contested as a translation standard, was created in the nineteenth century and is the work of such translators as Józef Paszkowski, Leon Urlich, and Egbert Koźmian. ${ }^{71}$ The canonical "Polish Conrad" is, as we know, established in the translations of Aniela Zagórska etc. It is the same translation practice, rather than prescriptions, that produced rules which proved advantageous up until a certain point in time, and then lost their significance. Following one's predecessors for some time one could achieve fine results, but then these solutions ceased to hold people's interest. "Leo Belmont's old translation of Onegin is now no more than a respectable historical document."72 It is important, however, that both in accepting and rejecting the experiments of times past, the translator treats his predecessors as autonomous partners, participants in the game.

70 C. Znamierowski, Oceny i normy (Warsaw 1957), p. 89.

71 S. Skwarczyńska, "Przekład i jego miejsce w literaturze i kulturze narodowej (Na przykładzie “Hamleta” w wersji Józefa Paszkowskiego)." In: O współczesnej kulturze literackiej, eds. Stefan Żółkiewski and Maryla Hopfinger, Vol. 1 (Wrocław 1973), pp. 287-330. See pp. 121-142 in the present volume.

72 Ważyk, O pracy nad Onieginem, p. 377. 


\section{6}

In conclusion, let us return to the question posed at the outset: What significance do translators' statements, those more-or-less personal monologues, have for today's reflections on the art of translation? There can be no doubt that this genre of "explicatory" writing has only evolved on a wider scale in our day, and is, to a considerable degree, a product of the "academicization" of the translation profession. The translator's faith in his intuition diminishes steadily, and now he maintains that "the results of his work can be picked apart with a lancet and a pair of pincers." ${ }^{\prime 3}$ The infiltration of academic concepts and terms into this seemingly strictly subjective field is tangible. It suffices to compare the two publications which have supplied the majority of our quotations: On the Art of Translation and The Artistic Translation. The twenty-year period that separates them shows that the standards of professionalism, the sui generis translator's academic slant, have developed to a considerable extent. In our day, the translator shows increasing assurance in using analytical tools heretofore reserved for initiated specialists. The result has been a split in his personality, the definitive division of two roles, each of which is articulated differently: the writer and the scholar/observer. Where the translator focuses on the translation process itself, the understanding of a foreign text, and gives a glimpse behind the scenes of his work, he always speaks to the reader as "someone else" - as a self-critic, selfcensor, and self-corrector. He undermines his own work in its ready and definitive form, now presenting it in statu nascendi, and thus supplying an alternate version of the original work. He appears now as a critic, interpreter, or scholar, and not as a translator.

Translators' commentaries increasingly, therefore, betray their own ambitions; they aspire to being creative statements, that is, other renderings of the text, using different, more private devices. These new "interpretations" of the original work tap into the possibilities which the translator had failed to perceive, or consciously ignored. For all the trust that today's translator has in "hard" academic expertise, there is much to indicate his loneliness and abandonment. He finds no assistance in dictionaries and encyclopedias, for he explores regions that have yet to be appropriated by academia. What seems to him crucial in achieving his desired effect remains entrusted to his own intuition, and thus to the "feelings" and not to the "glass and the eye."

73 Tuwim, “Czterowiersz na warsztacie," p. 283.

74 Allusion to a famous quote from Adam Mickiewicz's ballad "Romanticism": "Feelings and faith speak more to me/than the wise man's glass and eye" [translator's note]. 
where institutionalized academia is said to still be ineffectual, which it has yet to assimilate and conceptualize in its system of notions and terms. In a word, today he often seems to venture into the margins (of a culture, a language, of customs) which have yet to enter the scope of academic paradigms. This is why the translator's thoughts on the art of translation constitute a sphere of new theory, a study that stands up for the impossibility called translation. This theory has its own hypotheses and projections, and thus own ways of pursuing the truth, against whose backdrop the dispute between the "linguistic" and "literary" concept of translation, intractably forced by expert theories, can only lose significance. Speaking of the role of translation in contemporary literary culture, therefore, we cannot overestimate the value of these documents. 

Stanisław Barańczak

\section{The Poetic Model of the World and Problems of Artistic Translation}

\section{(Based on the Polish translations of G. M. Hopkins)}

The premise of the present article is the simple statement that artistic translation - if indeed it is to deserve this name -must be a reconstruction of the model of the world implied in the original text.

Of course, this statement in itself is nothing particularly new: phrased in slightly different terms, it has carved a niche for itself in contemporary translatology, and especially in its subfield that studies problems of poetry translation (among Polish scholars Edward Balcerzan puts special focus upon this question). My task involves using Polish translations of the poems of Gerard Manley Hopkins as a series of concrete examples to indicate the multiplicity of translation methods that attempt to access this model of the world; the various understandings of the essence of the original text's model of the world in contemporary translatorial practice; and finally, the sources and mechanics of the resulting misunderstandings and failures.

The "model of the world" concept might well seem too general and imprecise, and thus we ought to begin our observations with a definition. According to semioticians Ivanov and Toporov, a "model of the world" is:

a behavioral program for individuals and groups defining the repertoire of operations for interacting with the world, as well as the rules of their application and the motivations behind them. A model of the world can be enacted in various forms of human behavior and in the products of this behavior (e.g. in language texts, social institutions, cultural monuments); [...] we call every such enactment a 'text.'

Moving on to poetry and the poetry texts to be analyzed here, we immediately note two important consequences of this universal definition. Firstly, it presupposes that a "model of the world," as a "behavioral program" inscribed

1 To the best of our knowledge, this is a paraphrase from: V.V. Ivanov, V.N. Toporov, Slavianskiye jazykovyie modielirushchiye semioticheskiye sistemy (Moscow 1965), p. 5. The author does not provide a reference here [editors' note]. 
in a text, is enacted in certain sociological categories, in the social micro-model called the "internal communication situation" of the poetry text. From this we draw a key conclusion: a reconstruction of a model of the world requires less an analysis of directly formulated worldview statements than an analysis of the "internal communication situation," the system of tensions between the poetic "I" and the "You" (singular or plural), the (external) "World," "Language," and ultimately the "Text" itself. And secondly, poetry is special in that its language (perhaps most of all) is in itself a project and a reflection a "model of the world." If we see poetic language as a "special organization of natural language, dictated by a specific concept of the world" (Jerzy Faryno), then it is clear that this definition could well be upended, i.e. that we could try to decode a "specific concept (resp. model) of the world" through analyzing the laws of linguistic organization in a given poetry text.

Thus, to encapsulate this introductory and most general stage of our argument, we shall state that the reconstruction of a poetic model of the world must be rendered not only through examining the work's concrete philosophical, religious, moralist, or social statements, but also through analyzing the "intratextual communication situation" and the organizing principles of the poetic language since a model of the world is reflected in both these fields on the basis of a particular homology. (Of course, this presupposition applies to an ideal state of things - it concerns maximally "poetic" poetry, so to speak. On the other hand, we can raise a whole gamut of examples - drawn from "philosophizing," propagandistic, didactic, or devotional poetry, for example - where the language is relatively transparent in terms of its significance, and where its organizational principles betray no particularly precise or meaningful homologies $v i s-a$-vis the overriding model of the world. Yet in addition, such writing in a way is fundamentally disloyal to the essence of poeticness and the autonomy of poetry, occupying the margins, as it were, of the genre of poetry).

So far, we have discussed the "reconstruction of the poetic model of the world" in general terms. But what are its rules when such a reconstruction is attempted not by a scholar or an ordinary reader, but by a translator - that special interpreter for whom the reconstruction is only an initial stage in creating the work itself, the translation, i.e. in transfiguring a given model of the world into the substance of another ethnic language? It is common knowledge that the poetry translator who seeks to replicate the model of the world from the original text as faithfully as possible is sometimes faced with insuperable difficulties. This resistance chiefly derives from the objective differences between two language systems and then the objective differences between two systems of literary tradition with differing principles and organization, including the poetic language. If 
the translator apprehends the essence of a model of the world in a primitive and simplistic fashion, as a set of one-to-one worldview statements appearing in the text - and this unfortunately occurs with remarkable frequency - then their task is obviously a relatively simple one. However, poetry translations of this sort are most often regarded as translatorial mistakes. What remains in them is the "bare" content of the worldview, while what vanishes is the peculiar poetic grasp of the worldview. Meanwhile, the ideal would be to communicate both these values at once. This is, naturally, an extremely difficult task, and one that involves a whole array of semantic compromises and substitutions that do not always render the full significance. Yet the more "poetic" the poetry (in the above-described sense), the more a translator is required to choose the most challenging method of translation: delving into the original's "model of the world" by analyzing its intratextual communication relations and forms of organization in the poetic language, and then organizing the structure and language of the translation according to homological principles.

\section{2}

It seems that Gerard Manley Hopkins might serve as a particularly instructive case here. His work is, above all, an example of highly "poetic" poetry, i.e. with a maximal degree of linguistic structuring of the language, and at the same time strongly rooted in a particular worldview, in this case religious and philosophical. Additional difficulties arise for every translator in the peculiar place of this poetry in its native literary tradition: chronologically it belongs to the Victorian era, though its innovations in style and worldview look far into the future - it is no accident that Hopkins is widely regarded to be the forefather and precursor of modern English language poetry, much as Cyprian Norwid is in Poland. ${ }^{2}$ This comparison is also appropriate in that Hopkins - and this is another attribute that makes the translator's work difficult - is a "dark" poet, whose work often has layers of cryptic meanings. This quality of his work, combined with its stylistic innovation, made Hopkins an utterly unknown poet during his own lifetime, one who was "discovered" almost thirty years after his untimely death. English literary history likes to recall the astonishing paradox - a memento in the spirit of Norwid's "None knows the paths to posterity..." - of the posthumous and lifetime fame of two poets: Hopkins and his close friend, Robert Bridges. They were peers, hailing from a similar intellectual environment, yet the first died at

2 Cyprian Norwid (1821-1883) - Polish poet. See footnote 15 on p. 125 in the preset volume [editors' note]. 
the age of forty-five, not having managed to publish a single poem, and the latter lived to the ripe age of eighty-six, releasing numerous books and receiving the greatest honor in the English literary world of his day - the title of Poet Laureate. Today, the former is considered a genius and a groundbreaking innovator, while the latter is recalled on occasion, though primarily as a publisher of Hopkins's works... Nota bene, in releasing a selection of poems by his prematurely deceased friend in 1918, Bridges - even then! - felt compelled to note in the introduction that, in his view, this was a poetry full of "rare masterly beauty", though not free of "oddity," "obscurity," "affectation," and "faults of taste."

If we add to this all of Hopkins's attributes that make him such an individual and difficult poet, isolated from his own epoch, we can hardly be surprised that the vast majority of Polish translations of his poetry - which are not, at any rate, numerous - make for a textbook series of translatorial failures. These failures are worth examining up close - not only to provide facile criticism (I should like to avoid this accusation by proposing my own counter-solution in each case), but because they are, through negation, as it were, instructive examples of the vital importance of the translator's ability to reconstruct the original's "model of the world."

Before we proceed to our translatological investigations, however, we shall require a longer digression on the problematics of Hopkins's worldview. To delve into the latter, we ought to begin by recalling the basic biographical facts. Hopkins was not, essentially, a poet of autobiographical confession, yet following the paths of his life is crucial to appreciating the gravity of certain elements of his worldview.

The poet was born in Stratford, Essex, in 1844, as the son (the eldest of eight children) of a higher functionary, a wealthy man of wide-ranging scientific and literary interests. A religious atmosphere (in the Anglican spirit) reigned in the home, yet there was a free cultivation of artistic interests. Hopkins graduated from Highgate School with excellent marks (showing the first signs of a budding poet), and in 1863 he began studies in Classical Literature at Balliol College in Oxford. His fellow student was the above-mentioned Robert Bridges, and his instructors were such famed figures as Walter Pater, John Ruskin, and Matthew Arnold - the leading minds in England during the period. Hopkins, theretofore an Anglican and a fierce advocate of the "Oxford movement," which strove for the spiritual restoration of Anglicanism, soon came under the powerful influence of John Henry Newman, a famous thinker who, twenty years previous, had converted to Catholicism (later becoming a cardinal). In 1866 Hopkins decided to follow his example, and after graduating, he joined the novitiate of the Jesuit order in 1868. 
This is one of only two truly pivotal dates in his brief life. Pivotal also for his poetry since, upon entering the order, Hopkins set fire to his entire collection of poetry manuscripts (only four juvenile poems survived, without his knowledge), resolving "to write no more, as not belonging to my profession, unless by the wishes of my superiors." He began a nine-year study period (at St. Beuno's College in Northern Wales), preparing for the priesthood. For Hopkins, this was a period of spiritual ripening, formative for his worldview, whose first outlines were sketched in his early youth.

An extremely interesting journal of the future poet survives; it was kept in the period from 1866 to 1875 . What catches our eye in these pages is an abundance of observations, of detailed notes and reflections on the natural world. Delving into the essence of beauty found in a tree, a knoll, or a cloud, Hopkins gradually constructs his view of the outer reality, in which every object is individual and unique, containing a peculiar quality characteristic to itself alone; at the same time, this is what makes it a tangible reflection of God's presence in the world. To define this inner quality of an object, Hopkins used the neologism "inscape" in his journals, a term most difficult to translate. It signifies an object's specificity and uniqueness composed of sensory data, making up its internal unity; the term "instress," in turn, signifies the complementary concept of existential energy, which defines and animates the inscape. These two terms play a central role not only in shaping Hopkins's concepts of the natural world, but also in shaping the outlines of his poetry theory.

The latter emerged only several years later, in 1872 to be precise, when Hopkins, who was studying Medieval philosophy, came across the writings of Johannes Duns Scotus and - by his own admission - "was flush with new stroke of enthusiasm." As a later biographer, W. H. Gardner, phrases it (with perhaps a touch of exaggeration), the influence of Duns Scotus's thought was decisive in that "this theologian seemed to give him [i.e. Hopkins - S. B.] a sanction for doing as a Christian poet what, as a Jesuit priest, he could not possibly do, that is, assert his own individuality." Ignatius of Loyola's Spiritual Exercises remained a signpost for the future poet, of course - as was soon to be demonstrated in the dazzling sonnet “The Windhover." Yet Duns Scotus's categories gave this ascetic religiousness a new dimension. Doctor Subtilis, as the philosopher was called by his contemporaries, attached great importance to the principle of the unique individuality of people and things, which he called "thisness" or haecceitas. Haecceitas is Hopkins's "inscape" - the "inner form" of the object, as it were, which makes it precisely what it is, rather than something else. While St. Thomas of Aquinas, the "official" philosopher of Catholicism, maintained that, unlike the "universal," the "individual" is essentially unknowable to human mind, Duns 
Scotus stressed that it was precisely individuality that can be known directly, through the senses and the intellect combined. It is only the retroactive process of abstraction that allows the mind to travel from the "particular" to the "general."

For the time being, the philosophy of the Medieval thinker (to whom Hopkins pays tribute in the sonnet "Duns Scotus's Oxford") only formed the general outlook of the young Jesuit: soon, however, it would also affect the shape of his entire poetics, the incomparable sensory aspect of his work, and his concrete vision of the outer world. As already Bridges so aptly phrased it, Hopkins's poetry is "the naked encounter of sensualism and asceticism" - and however improbable this combination might seem, Hopkins did indeed manage to join a unique "selfhood" of the things of the world seen with the mind's constant attempt to rise to the aims of the supernatural world.

Let us return to Hopkins's biography, to the second pivotal date: 1875. In December of that year he broke his seven years' vow of silence at the urging of his rector, and in an outburst of pent-up creative energy he wrote his greatest work: the brilliant long poem "The Wreck of the Deutschland." This is an occasional poem: it was a tribute to the memory of five German nuns who drowned in a widely-reported sea disaster off the coast of England. But Hopkins puts everything into the work all at once: his Christian notion of human fate, his complex thoughts on the paradoxical nature of God, his Scotus-inspired philosophy of nature and language, his new poetic style, even an innovative approach to verse rhythm. In this first work after his long-past juvenile attempts, he shows himself to be a fully mature poet - and one who was so original that he did not fit into any of the contemporaneous molds. Small wonder that the Jesuit journal The Month rejected the poem, and his closest friend, Bridges, was unable to conceal his distaste after a first reading.

Hopkins was embittered, but he did not abandon poetry. In 1877, when he entered the priesthood, he created a series of marvelous "sonnets of nature": "God's Grandeur," "The Starlight Night," "Spring," "Hurrahing in Harvest," and others. Their only reader remained Bridges, and later two of Hopkins's other close friends, R. W. Dixon and Coventry Patmore, with whom the poet corresponded, tirelessly explaining to them the principles of his theory and creative work.

Until 1881, Hopkins served as a preacher and missionary in various towns in England and Scotland; he particularly worked in many of the poverty-stricken neighborhoods of the large industrial centers, which took a depressing toll and weakened his already frail physique. The observations he took from the working class environments also brought about the swift radicalization of his social views. This combination of factors made the monastery authorities withdraw Hopkins 
from the priesthood and steer him toward university work. From 1882 to 1884 , the poet taught Latin and Greek at Stonyhurst College in Blackburn, then taking the chair of Classical Literature at the University College Dublin. Yet his health was quickly fading, the tragic spiritual dilemmas were multiplying, and his creative powers were also at a low ebb. A compelling testimony to this are the "dark sonnets" of 1885, or the final poems: "Thou art indeed just..." and "To R. B." $\mathrm{W}$. H. Gardner is correct in stating, however, that even in these poems there is more heroic acquiescence to his fate than barren moping about, more faith in man, "that immortal diamond," and in "the comfort of Resurrection," than doubt and helplessness. This, at any rate, serves as the triumphal coda of one of the most outstanding poems of the last period, "That Nature Is a Heraclitean Fire and of the Comfort of the Resurrection:"

I am all at once what Christ is, since he was what I am, and

This Jack, joke, poor potsherd, patch, matchwood, immortal diamond,

Is immortal diamond.

In 1889 , Hopkins fell into a typhoid fever, complicated by peritonitis. After a brief struggle with the illness, the poet died on 8 June.

\section{3}

Were he only a philosopher poet, a Christian artist pondering God, nature, and mankind, this would have been enough to make Hopkins, with his insightful sensitivity and depth, a remarkable poet. As it stands, he is a doubly remarkable poet in that, during the Victorian Era, in a time of didacticism and verbose rhyming philosophizing, he discovered that a poem should give the reader reflections upon the world in its own private way. It should less instruct the reader, directly supply them with information or didactic postulates, than focus their attention upon what is central to poetry: the language. Poetry is the art of the word. As such, it should govern the word and the sentence so that the very manner of their formation give the reader certain information - albeit in need of decoding. Furthermore: language should be a miniature model of the world the poem describes.

It is an extraordinarily difficult task to tear away from the conventions of the epoch in order to harness all the elements of a style to do poetic work, beginning with the tiniest atoms of speech. What is fundamental for Hopkins from the outset - from "The Wreck of the Deutschland" - is to choose stylistic operations which would bring to language what derived from Scotus's "thisness" in the poet's philosophy. If the intellect learns primarily what is singular, individual, 
and unto-itself through the senses, if in everything we can perceive its inscape, i.e. that what makes it what it is, and not something else, then the language of the poem (which is, after all, the discovery of the individual uniqueness of the things of this world) must be marked by an analogous drive toward the concreteness and uniqueness of names. "Down to the least separable part [a poem should have] an individualizing touch," as Hopkins worded his creative credo in a lecture.

This tendency begins, of course, with the choice of vocabulary. Hopkins's poetical lexicon abounds in unusual expressions, rare ones used once only, yet immediately striking in their concreteness, their semantic targeting of the crucial attribute of an object; often such words are additionally emphasized because of their placement in a rhyme scheme (see, for example, the remarkable rhyme of "billion - sillion - vermilion" in the "The Windhover"). Hopkins's commentaries to his own works in essays or, more directly, in letters to his friends, bear testimony to his persistence in seeking words to render most precisely the sensory qualities of an object, as in the unexpected use of "foil" (whose meaning might seem rather too technical for poetry) in the second line of "God's Grandeur:"

The world is charged with the grandeur of God.

It will flame out, like shining from shook foil;

The poet copiously justifies the choice in a letter to Bridges, stating that he was chiefly after a lighting effect created by gold foil when shaken - a flash that resembles lightning. He similarly corrected his correspondent when the latter, in the midst of a polemic, misquoted a passage from "Duns Scotus's Oxford:" it was not "airy between towers," Hopkins protested, but "branchy between towers," as Oxford, as his memory informed him, was most striking for its thick foliage between its towers, and the poet felt the change of "branchiness" to "airiness" upset the "inscape" of the view he described. Seeking expressions with the most of an "individualizing touch," Hopkins does not shirk from colloquial speech, or even from dialects ("God rest him all road ever he offended" from "Felix Randal"); through context he mobilizes peripheral meanings of words; and finally, he creates neologisms - an utter horrendum for the English poetry of the time - or multi-word compounds. "I have invented a number of new words," he explains in a letter, "I cannot do without them." Indeed: at the core is the necessity of individualizing naming, extracting the "inscape" of the things described this end justifies violence to the stylistic conventions of the epoch, and even the grammatical and dictionary rules of the language.

And thus, the precision in names, and by the same token, the precision in image. Even when tackling the most abstract issues, Hopkins always translated 
them into a language of concrete, tangible visions. This was not only to avoid a rhetoric that was hollow and diluted; it was also because such a seemingly abstract problem as the presence of God in the world manifested itself to the poet through a range of extremely concrete phenomena and images, through the existence of those countless things "swift, slow; sweet, sour; adazzle, dim" in the poem "Pied Beauty:"

Glory be to God for dappled things -

For skies of couple-color as a brinded cow;

For rose-moles all in stipple upon trout that swim;

Fresh-firecoal chestnut-falls; finches' wings;

Landscape plotted and pieced - fold, fallow, and plow;

And all trades, their gear and tackle and trim.

All things counter, original, spare, strange;

Whatever is fickle, freckled (who knows how?)

With swift, slow; sweet, sour; adazzle, dim;

$\mathrm{He}$ fathers-forth whose beauty is past change: Praise Him.

Perhaps, the poet's most outstanding expression of an analogy between the nature of the world and the nature of language is the sonnet "As Kingfishers Catch Fire, Dragonflies Draw Flame." Let us have a look at the text in the original and in an attempted Polish translation:

As kingfishers catch fire, dragonflies draw flame;

As tumbled over rim in roundy wells

Stories ring; like each tucked string tells, each hung bell's

Bow swung finds tongue to fling out broad its name;

Each mortal thing does one thing and the same:

Deals out that being indoors each one dwells;

Selves - goes itself; myself it speaks and spells,

Crying What I do is me: for that I came.

I say more: the just man justices;

Keeps grace: that keeps all his goings graces;

Acts in God's eye what in God's eye he is -

Christ - for Christ plays in ten thousand places,

Lovely in limbs, and lovely in eyes not his

To the Father through the features of men's faces.

I ważek wartkie wrzenia, zimorodków zimne

Ognie; i krągła studnia, gdzie kamień rzucony

Brzmi echem; i ton struny tkniętej, i skłon dzwonu,

Co swą szeroką mową głosi własne imię -

Wszelka rzecz tego świata czyni to jedynie:

Wydziela z siebie wnętrze swe, tkwiąc w nim jak w domu;

Trwa sama w sobie - i swe ja rzuca nam do nóg, 
Krzycząc Po tom powstała: by być tym, co czynię.

Więcej powiem: człek prawy sobą prawo tworzy;

Łaska jest w nim - i w tym, co czynić mu się zdarzy;

Tym chce się Bogu wydać, kim jest w oczach Bożych -

Chrystusem - bo w tysiącach miejsc Chrystus się jarzy

Blaskiem, co ciała cudze prześwietla i oczy,

By Pan mógł dostrzec światłość w rysach ludzkich twarzy.

Here again we can make out, above all, the complete - and discursively presented - theory of "inscape." Everything of this world, Hopkins tells us, possesses a "self" that distinguishes it from other things. This "self" is a kind of inner essence of things but at the same time the thing as if extracts its "self" from itself, manifesting it through its work perceptible to the senses ("What I do is me").

Yet there is something even more important worth noting here. Hopkins not only lays out his theory of reality in his poem discursively; his poetic speech also constructs its parallel reflection or illustration. An object manifests its "self" by acting on our senses - thus, let us not only describe, but also demonstrate this phenomenon through what is both the building matter and the tool of poetry: through language. And thus the "bell" in this poem indeed "is what it does," because the words referring to it ("hung - swung - finds - tongue - fling"), monosyllabic and based on nasal phonemes, onomatopoeically imitate the ringing of a bell. The kingfishers "catch fire" and the dragonflies "draw flame" not only because these metaphors have a sound visual basis, but also because each of them is based on alliteration, creating, as it were, an extra bond between the parts of the metaphor. The link between the internal "self" of the object and its external sensory effect, including its name, is "proven" through language alone.

Thus, we come to the second fundamental problem in the relationship between the model of the world and poetic language. The second basic component of Hopkins's philosophy is his conviction that the visible world reflects the Divine harmony of all things. Many poems - such as the above-cited "Pied Beauty" or "God's Grandeur" - speak of this directly. But all of the poet's works, even the most tragic and internally at odds, document this conviction in an indirect manner: through molding the poetic language to be a model and tangible proof of the harmony of Creation. First of all, this is the harmony between word and thing: as we have seen, the name selected by the poet is never accidental. It not only needs to define a sensory aspect of the object accurately, but, insofar as possible, it also has to be an aural equivalent of this aspect. This accounts for the great quantities of onomatopoeia in Hopkins's verses, sometimes borrowed from a language outside of poetry, but more frequently foisted upon words through 
the poetic context. It is as if the task of the poet were to prove that, contrary to everyday experience, one can perceive a natural motivation and necessity in the relationship between the name and the thing.

However, the harmony of all things must find its reflection not only in the link between word and thing, but also among words themselves. This explains, in turn, the true orgy of alliteration and other means of phonological orchestration that Hopkins's contemporaries found excessive, while we tend to find it striking and delightful, as a show of remarkable poetic virtuosity that serves defined aims. The phonological orchestration, in the forms of alliteration, echolalia, and internal rhymes, has an important semantic effect in these works: it links expressions, makes us seek a certain hidden necessity in their combination, a certain deeper similarity or kinship (in such cases we might speak of the use of paronomasia or pseudo-etymology). There is also a constructive effect, as the aural similarity extracts integrated structures from the words of the poem, thus more highlighting the inner architecture of the work. The poem as a whole becomes a reflection of the concealed plan according to which the harmony of the world was created; in both reality and in the poem, everything is necessary and exists in interrelation.

Hopkins would not have been a great poet, however, if this harmony lacked its opposite. The philosophy of this poetry is anthropocentric, and as such, it must contain an element of tragedy; unlike the harmonious world of nature, the human being is condemned to irreconcilable contradictions, to an awareness of the paradoxical nature of one's own existence. As early as "The Wreck of the Deutschland" we find the conviction that God is the Creator of harmony, but also a harsh and punishing Father; that man's lot is not only happiness, but suffering as well. These contradictions are both focused and resolved in the figure of Christ and the phenomenon of Incarnation: yet even for a Christian of such profound faith as Hopkins, the tragedy of human existence on Earth could never be a problem to be resolved with a gesture.

Such an important component of Hopkins's "model of the world" must have found its analogy in the language of his poetry and its organizing principles, to highlight this point for the third time. Everything we might call "grating" in the poet's style reflects the paradoxes and anxieties of human existence - and here we mean not only grating phonically, but also grammatically, syntactically, and semantically. Tactics so contrary to the ideal of harmony such as the seemingly arbitrary grammatical and lexical experiments, the defiance of word order hardly ever found in English, the oxymorons and antitheses that govern the poetic semantics, and finally, the general tendency to pile up the ambiguities and semantic surprises - it all seems explicable only through the fact that, 
in making his style, Hopkins sought an indirect means to communicate his understanding of human fate as dramatic and inherently contradictory to the extreme.

I would give a similar explanation for the unique phenomenon in Hopkins's work - the poetic rhythm. Undoubtedly it has many roots: following the explanations of the poet himself, we might perceive, for example, an attempt to make versification more flexible, to make it close to the prosody of colloquial speech; we can also see the genesis of this concept of rhythm in the archaic forms of Medieval Anglo-Saxon poetry, as some scholars have suggested. Yet most important is the fact that the "Sprung Rhythm" invented by Hopkins is dynamic, restless, and dramatic. It juxtaposes the idea of regularity (a steady number of accents in a line) with a radical irregularity and freedom (varying syllabic spread of the lines), resulting in a singular tension, with enormous capacity for modulation and intensification.

"Sprung Rhythm," Hopkins's great and entirely independent discovery, is a rhythm of stormy emotions: euphoric delight (as in "Hurrahing in Harvest"), doubt and despair (as in "Carrion Comfort"), profound human sympathy and supernatural illumination (as in "The Wreck of the Deutschland"). This "explosive rhythm" (as we could translate the English term, choosing from many possibilities,) combines, by the poet's own admission, "opposite and, one would have thought, incompatible excellences, markedness of rhythm - that is rhythm's self - and naturalness of expression." It is significant that even those poems which Hopkins wrote in "standard rhythm," i.e. in syllabic or syllabotonic verse, have a powerfully dramatic flow, artfully produced through enjambments, disrupted word stress patterns, leaps of intonation etc. Sprung Rhythm facilitates the same in much greater intensity and with a much greater number of variants. Hopkins recommended that poems with this rhythm be read aloud, to make audible the "explosive" clashes of accents and the ecstatic accelerations of tempo in places where several unstressed syllables are clustered. The appearance of his original texts in manuscript form is characteristic: they recall musical scores, with masses of complicated markings pertaining to accent, intonation, and other aspects of prosody.

Yet it ought to be repeated that the musical drama of the rhythm, like the other stylistic devices of analogous functions, is not an end unto itself: it also reflects in poetic language a philosophical concept of human fate, strung between the poles of ecstasy and despair, happiness and suffering. If Hopkins's style were to have stopped at harmony, the philosophical layer of this poetry would not have gone beyond an uncomplicated, ecstatic pantheism. Only the element of the tragic dilemma - introduced in part through style - made Hopkins a Christian 
poet: Christ appears in these poems as an ever-present link between the world of Divine harmony and human suffering.

\section{4}

For the translator, one basic conclusion emerges from all these observations on Hopkins's poetry: as in the original, the stylistic dominant for the translation should be the constant clash between harmony, regularity, and similarity on the one hand and interference, irregularity, and contrast on the other. These values should coexist in mutual balance, in a dialectic interplay of forces that is never entirely resolved.

Let us take a simple example. In the first lines of "The Wreck of the Deutschland," the translator finds the apostrophe:

Thou, mastering me

God! giver of breath and bread.

The translator must realize that the words breath and bread contain their literal meanings, but of equal importance is that these terms are clasped together by clear alliteration, and with this link they come together to render a new significance. At the same time, the regularity and similarity (a paronomastic link between two words) thus created is juxtaposed in these two lines with a strong aspect of contrast and surprise (a sharp enjambment). Thus, the rendering by a Polish translator (Janusz A. Ihnatowicz):

Władający mną Boże, dawco chleba i tchu, [Mastering me God, giver of bread and breath $]^{3}$

albeit philologically correct (something which cannot be said, alas, for the remainder of the translation), strikes me as utterly wrong-headed as a translation of poetry. It has lost both the aspect of similarity (the translator has omitted the alliteration) and that of contrast (the enjambment has been eliminated); the tension and dramatization of the initial apostrophe have vanished, leaving the "literal" information, albeit made mundane and colorless; there is only the "thematic information" with none of the "implied information." We might argue that salvaging these two types of information intact in another language is impossible (particularly bearing in mind that the quoted beginning of the stanza is continued,

3 Back-translations of selected Polish renditions were added in this edition [editor's note]. 
requiring additional - rhyming, rhythmic, and semantic - adaptations in the initial couplet). Indeed, this is true, yet with some compromises or substitutions of secondary importance - practically inevitable in translating poetry - we can salvage the main principle that governs the original text. A solution, for example, might be:

$$
\begin{aligned}
& \text { Władco mój, Boże, } \\
& \text { który karcisz i karmisz. } \\
& \text { [Ruler mine, God, } \\
& \text { you who punish and feed]. }
\end{aligned}
$$

This is not a "literal" translation, of course, but, in a sense, it is more faithful. The necessity of rhyming with a subsequent line of the stanza means foregoing the sharp enjambment here; yet the aspect of contrast that it contained has been shifted, as it were, to a different field, namely to the sphere of semantic relations between the words karcisz [you punish/rebuke] and karmisz [you feed], which are key to this couplet. The phonetic similarity is juxtaposed with a semantic opposition; the basic stylistic principle of Hopkins's poetry is salvaged. Though there has been a substitution of meaning ("you punish and you feed" in place of "bread and breath"), it does not disturb the intratextual communicative relationships of the poem, nor the premises of its worldview; on the contrary, it even reinforces and emphasizes them, as the contrast between the severity and mercy of God, which is constitutive for the human fate, serves as the main theme of "The Wreck of the Deutschland."

To translate in such a way as to reconstruct the model of the world as implied by the stylistic form of the original text: this is, of course, a remarkably difficult task, and a risky one at that. As such, there is a notable trend of Polish translations of Hopkins's poetry following the line of least resistance and settling for halfway measures.

We might observe two models for such solutions: in either of them the "halfbaked" reconstruction of the original's model of the world involves something different. The first model, perhaps the most frequently chosen, is a translation that "lists" toward irregularity, abandoning the means and stylistic maneuvers which can balance off this irregularity with their considerable internal organization. Possibly the most extreme example of this sort of solution (so extreme that it deserves to be called a translatorial experiment, albeit a failed one) would seem to be a rendering of the sonnet "Felix Randal" by Jerzy S. Sito. The two initial stanzas will serve to explicate our point:

Felix Randal, the farrier, $\mathrm{O}$ is he dead then? My duty all ended, Who have watched his mould of man, big-boned and hardy-handsome, 
Pining, pining, till time when reason rambled in it and some Fatal four disorders, fleshed there, all contended?

Sickness broke him. Impatient he cursed at first, but mended Being anointed and all; though a heavenlier heart began some Months earlier, since I had our sweet reprieve and ransom Tendered to him. Ah, well, God rest him all road ever he offended!

Feliks Randal, od koni, ach, więc umarł? cóż, moje zadanie spełnione; Kto go znał, grubokostnego, ho, ho, w ramionach szeroki, chłop jak dąb, wiatr od niego wiał, kiedy tak młotem po kładziwie, młotem, aż się potem, sadzą uwalał i w zapamiętaniu, w kuciu, rozsądek i wszystkie zmysły w puch porozwalał i zaniemógł; ciekawe? nie mógł zwalić choroby, więc go choroba zwaliła.

Klął, lecz kiedy go świętym olejem i ten... wydobrzał; choć serce zanielało już pierwej, odkąd to ja, nasze słodkie zabieranie darowanie mu przyniosłem. Ha, niech go Bóg pocieszy, jeśli co i zgrzeszył.

This translation calls our attention with its absolute nonchalance with regard to the literal meaning of the original text. The majority of the first stanza (from the words wiatr od niego wiat [the wind blew from him] up to choroba zwalita [the illness knocked him down]) has nothing in common with the meaning of the original, and is a fully self-willed addition by the translator. We might merely call it a failed translation, probably arising from an insufficient examination of the complex and ambiguous lines of Hopkins's sonnet; this supposition would seem to be confirmed by the fact that Sito has not included this verse in any subsequent reprints of his Hopkins translations. The matter is not quite so simple, however. The chaotic and free-form structure of the translation is, at least in part, the result of a conscious translation approach. We can see that Sito was quite careful to ensure that his translation retained all those (indeed striking and unusual) attributes of the original text marked by irregularity, dissonance, surprise, and contrast. As such, he has salvaged the sharp enjambments. He retains the intralinear leaps in intonation resulting from the use of embedded questions or exclamations, and the contrast between long and short sentences. Finally, he also saves the original's lexical/stylistic dissonance created through the deliberate use of colloquialisms, interrupted sentences ("being anointed and all" - lecz kiedy go świętym olejem $i$ ten... [but when they with the holy oil and, well...]), and dialect ("all road ever he offended" - jeśli co i zgrzeszy $z$ [if he even sinned something]).

Yet even if this is a conscious concept, it is a half-baked measure. In calling so much attention to the stylistic irregularity, Sito has failed to perceive that the poetic puissance draws from the contrast with the equally pronounced factor of regularity. This is represented in the original text, above all, by the versification 
(the use of Sprung Rhythm, the deep and sophisticated abba abba ccd ccd rhyme scheme, the sonnet's consistent stanzas), and the phonetic instrumentation (a whole gamut of alliteration, as in the second line: "mould of man," "big-boned," "hardy-handsome"). Salvaging both of these contrasting stylistic aspects was not possible, of course. Here is one translation possibility:

Feliks Randal, kowal, och, więc umarł? nie moja już moc go wskrzesi,

Kto się przyjrzał grudzie gliny, grubym gnatom, upartej urodzie,

Kto go widział, jak marniał i marniał, jak w dal jego umysł uchodzi,

Aż cios cierpień poczwórnie potwornych na wskroś jego ciało przeszył?

Choroba go zwaliła. Z początku buntował się, klął i złorzeczył,

Potem, po namaszczeniu i tym wszystkim, ścichł; zresztą z niebem w ugodzie

Był od paru miesięcy, od kiedy dostarczałem mu ulgi ubogiej

Swą służbą. Cóż przebacz mu Boże, jeśli jakoś tam nawet pogrzeszył!

An analogous "half-baked" concept is found in translations by Janusz A. Ihnatowicz. Here we have the same choice of a stylistic dominant; Ihnatowicz's translation takes those qualities of Hopkins's poetry which boil down to contrast, obscurity, and irregularity. This is how he translated "The Wreck of the Deutschland," for instance: what takes place in this translation, the omission of the rhymes (appearing here in a defined structure that repeats in all thirtyfive stanzas), the steady rhythmic structure of the stanzas, to say nothing of the remarkably rich and abundant instances of phonetic instrumentation, coinage, syntax, facilitates the task at hand, but it also upsets the whole model of the world implied by the language of the poem. Instead of a vision of a world that is tragic, though obedient to the unbending rules of God, we have a vision of the world as total chaos and absurdity. This is particularly true in that the language is structured to an even lesser extent than a reasonably correct colloquial statement would require. Ihnatowicz seems to purposefully pile on the methods for loosening syntactic structures - even where nothing of the sort can be found in the original - making unexpected ellipses and inversions, disregarding grammatical, and choosing "wrong sounding," anti-euphonic solutions (consonant clusters, and a too-frequent masculine cadence of lines and sentences):

Uwielbiony wśród ludzi

bądź, Troisty bycie, Boże;

skrusz buntownika, co się czai w norze,

pożogą i burzą ludzką złość.

Nad wypowiedzenie słodki, ponad siłę słów,

tyś błyskawica i miłość, tyś zima i żar;

ojcze i miłośniku serc, któreś zgniótł: masz

ciemne swe zstępowanie i najlitościwszyś wtedy. 
This is one of the relatively less chaotic stanzas of Ihnatowicz's translation, and yet even here nothing remains of the organization and regularity so evident in the original:

Be adored among men,

God, three-numbered form;

Wring thy rebel, dogged in den,

Man's malice, with wrecking and storm.

Beyond saying sweet, past telling of tongue,

Thou art lightning and love, I found it, a winter and warm;

Father and fondler of heart thou hast wrung:

Hast thy dark descending and most art merciful then.

Any translation of this stanza that would aim at a most basic fidelity to the stylistic virtues of the original would have to aim to salvage what is unquestionably the main dominant of the original text, i.e. the numerous parallelisms achieved through the work of alliteration, versification, and syntax, which seem to join forces. One solution might be the following:

Niech będzie pochwalone

Twe imię, troisty Boże;

Bunt i grzech ludzki skrusz burzą i gromem,

Jak zwierza, co zjeżył się w norze.

Nie wysłowi słodyczy Twej słowo, nie wyjawi jedności język,

Błyskawicą i błogosławieństwem jesteś - wiem - miłością i mrozem;

Ojcze i opiekunie serc, któreś skruszył, uwięził:

$\mathrm{Z}$ mroku do nas przyszedłeś i trwamy w miłosierdzia Twojego ogromie.

The model for translation solutions we have described here on the basis of a few examples might be called "half-baked measures" in that, during the translation, it is only the stylistic aspect of non-regularity, dissonance, or chaotic tumultuousness that remains, at the expense of the contrasting aspect of regularity, harmony, and organization. The "half-bakedness" of the second model involves something else entirely. The second path often taken by Polish translations of Hopkins involves a total, or almost total dismissal of "implied information" in favor of "thematised information"; it involves an attempt to transpose the literal information contained in the linguistic signs while neglecting the external formation of those signs and how they are organized, though this often carries a more pivotal set of messages than the literal meanings. In the previous solution the literal meanings of words and sentences were often considerably distorted (let us recall once more the first stanza of "Felix Randal" in Sito's translation), while the translators attempted to salvage at least some of the stylistic qualities of the original text (the non-regularity, dissonance etc.). In terms of the solution which we 
presently aim to describe, the meanings of the words and sentences of the original text are translated in a way that is full and correct - such translations in their extreme forms approach "philological translations" - yet the translator disavows any attempt to reconstruct the stylistic attributes of the original in advance, as it were. In this way, almost all the "implied information" is amputated.

Here we should note that there is no clear and invariable line between these two models of how translators approach Hopkins's poetry. It happens that the same translator has recourse to one method and then the other in rendering various pieces; it also happens that within the space of a single work the accepted model of translation has an "enclave" within which another sort of "half-baked" translation seems to hold sway. This is the case with "The Wreck of the Deutschland" as rendered by Ihnatowicz, which is essentially an example of the first model, though in certain fragments of the poem the translator seems more concerned with a literal rendering than with communicating the aspect of stylistic tumult (one example might be the above-quoted initial couplet of "The Wreck..."). In other translations, the same Ihnatowicz decidedly opts for the latter "half-baked" model. Such is the case in the translation of the poem "Carrion Comfort," whose striving for philological literalness forces the translator to eschew all forms of poetic language structure: one result of this is the necessity to lengthen the work, which has twentytwo lines in the translation, while the original - being a sonnet - has fourteen, of course. Amplification of text is, in general, a common phenomenon in translation solutions of this sort, partly due to the necessity to make a clear articulation of the meanings of certain ambiguous passages of the original, and partly from the abandonment of a poetic form of textual organization, whose devices can permit a maximum concision of statement with a maximum multiplicity of meanings.

With regards to Hopkins's poetry, the second type of translatorial "halfbakedness" would seem as insufficient as the first. In this respect, it seems worth analyzing the translations of Adam Czerniawski in particular, which most frequently correspond to the model of scholarly literalness, while eschewing the poetic information. Such is the case in the first couplet of one of the "dark sonnets," "No Worst, There Is None:"

No worst, there is none. Pitched past pitch of grief,

More pangs will, schooled at forepangs, wilder wring.

In Czerniawski's translation, we have a colorless statement:

Końca temu nie ma: poza obrębem

Nieszczęścia ból bólem spłodzony przebieglej rwie.

[There is no end to this: outside the limits

Of misery the pain-begotten pain shoots more cunningly] 
What vanishes here is substantial amount of "implied information," which in this couplet is particularly found in the clear phonetic/rhythmic organization of the incipit, or to be precise, the second hemistich. "Pitched past pitch of grief," with the persistence of the plosive "p" (echoed in pangs and forepangs in the second verse) and the equally explosive cluster of accents, is the phonetic indicator of the emotional temperature of the work, an aural image of the torment and thoughts in conflict addressed in the poem. A denial to make even a substitute rendering of this stylistic attribute in the translation is a semantic error tantamount to mistaking the Polish meaning of one of the words. Objective linguistic differences make it difficult to achieve an effect as pronounced as that of the original, yet it is possible to salvage the poetic information in part:

Nie ma dna udręk. Miota się za metą męki

Męka gorsza: przez tamtą szkolona i świeża.

[No bottom to torment. Beyond the finishing line of ordeal thrashes about A worse ordeal: schooled by the other one and fresh]

And one more example, this time courtesy of Czerniawski in the translation of “That Nature Is a Heraclitean Fire...":

Cloud-puffball, torn tufts, tossed pillows | flaunt forth, then chevy on an airBuilt thoroughfare

Obłoków purchawki, rwane, podrzucane pęki-jaśki | tańcują, harcują, gonią powietrza gościńcem

[Puffballs of clouds, torn, tossed up bundles-pillows dance, caper, run along the road of air]

The image of a piece of nature in Hopkins is generally supported by a vivid onomatopoeia. Such is the case in this excerpt: the clouds that "chevy on an airbuilt thoroughfare" are not only metaphorically compared to "torn tufts" and "tossed pillows," but this image is backed with equal vigor in a whole range of onomatopoeia (first in a "natural" onomatopoeia - puffball - then in poetic onomatopoeias), chiefly grounded in the recurring "p," $t$," and " $f$ " sounds. Little remains of all this in Czerniawski's translation; indeed, almost nothing. Meanwhile, if we make only minor departures from philological fidelity (exchanging, for example, the obtoki for chmury, i.e. the more for the less poetic Polish equivalent of "cloud", admittedly somewhat less apt in this context), we can achieve an analogous series of onomatopoeias, derived (as in the original) from the natural onomatopoeia contained in the word purchawka [puffball]: 
Chmur purchawki, puch darty, poduchy | porwane przez paradny huragan Gonią górnym gościńcem.

[Puffballs of clouds, torn dawn, huge pillows | blown away by pageant gale Run along the upper road]

Apart from the two "half-baked" translation models we have described here, we should also find space for adequate solutions, which do not neglect the aspect of stylistic organization in favor of chaos, and which do not disregard the "implied information" in favor of the "thematic information." When it comes to Hopkins, however, there are few such good examples (at most we might find a few examples geared in this direction - I have in mind some of Pietrkiewicz's translations and some of Sito's - though on closer inspection even these ultimately raise too many objections and critical observations). There is a more general tendency at work here; it turns out that what frequently gives the translator the greatest problems, what forces him to resort to "halfway" solutions, is the particular essence of poetic language that involves communicating a model of the world in an indirect and often ambiguous fashion: through a specific organization of the linguistic level, one that purposefully juxtaposes incongruous stylistic aspects. We might say that, much as reflecting upon the essence of poetry is invaluable for the translator in making his interpretive and creative decisions, the reverse is also true translators' failures are valuable in that they help us to understand the special way in which a model of the world is made present in a poetic text. 


\section{Anna Legeżyńska \\ The Translator as the Second Author}

The phenomenon of translation arose from the need for communication between societies, languages, and cultures. The basic function of translation is to mediate between nations, epochs, and areas. Translation is "one of the rarest of missions, because it does good service to two different nations at the same time," as Karl Dedecius has phrased it. And he adds: "If the Webster definition of culture is correct when it says that culture preserves the traditions and ideas that constitute the background of a given society, then we might say that, as a facet of culture, literary translations show to the linguistic community which they address the background of the linguistic community about which they testify."

If translation is communication, all practical and theoretical translation problems should be addressed with the special conditions of this communication in mind. It follows a different path than in the case of an original work:

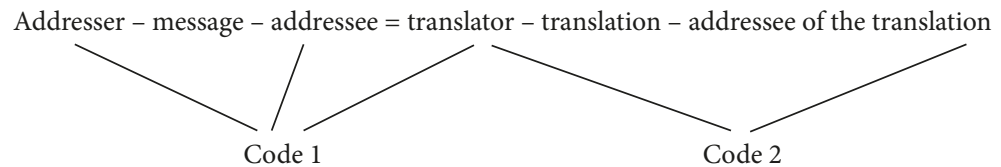

This very simple formula shows the relationships between the addresser and addressee in the original and the translated work. It has been constructed by doubling Roman Jakobson's famous model of linguistic communication; there would be no need to present it here were it not for the fact that we must outline the differences in the addresser/addressee circuits in these two types of text.

A translation is a literary utterance based on another work. It is built from a different linguistic substance and addressed to a different reader. Its addressee also inhabits a reality unlike that of the reader of the original. The author and the addressee of the original use the same language. They also occupy the same (or similar) geo-cultural space. As such, they are essentially of the same language

1 K. Dedecius, Notatnik tłumacza, trans. J. Prokop (Kraków 1974), pp. 49 and 120. 
(we are still speaking of communication through a single literary work). The translator is among the addressees of the original, but his competencies are broader, for he must be a bilingual reader (with the exception of the atypical cases of translating from "pony" translations, that is literal renderings prepared by other translators). The difference between the virtual addressee of the original and the translator lies in their different degrees of engagement, as the latter must not only carry out the reading program inscribed in the work, but then also record this act of reading in the form of a text in another language: the translation. (The literary critic is in a somewhat similar situation; however, the critic and the author both use the same language system). What makes the translator's communication situation unique is the accumulation of roles: he acts as the reader, expert, critic, and "second author" of the text.

The translator acts as a reader when he selects the text. "The translator has a wide choice. He chooses the language, theme, idea, and epoch; he selects the author, the work, the space, the form, the interpretation, and the meaning: he has as many possibilities as he cares to use."2 And so we see that that the translator's knowledge of literature and its context is extensive enough for us to call him an expert. ${ }^{3}$ At this stage of work the translator, like the reader, assesses, selects what he "likes" (though, obviously, there may be other motivations to translate: a polemic with, rather than celebration of, the original; the requirements of the current translation policies, the literary market, or simply material incentives). The overlap with the critic's role comes in the interpretation phase, when the translator establishes the implied meanings of the work, interprets it holistically, seeking its structural dominant. This is also the phase when the overall poetics of the translation is decided; it is for good reason that translation is often called the "art of interpretation." The translator becomes a critic when he dismantles the original, comparing the meanings of lexical units, establishing the equivalents and activating further contexts - biographical, historical, sociological etc. Finally, he creates a new text, signaling his presence in an overt and conventional fashion, with the traditional phrase "translated by X." His presence, however, is also felt indirectly in the manner of translation. He becomes another "addressing function," which the reader is ready to see as the direct causal power behind the (original) work. The addressee of the translation might, of course, be a bilingual reader, and if he has the original at his disposal (in a bilingual edition, for example), then he is fully aware of the text's origins. Usually, however, the translatorial nature of the

2 Dedecius, Notatnik, p. 26.

3 In the sense given to this term by J. Sławiński in: "O dzisiejszych normach czytania (znawców)," Teksty 1974, No. 3, p. 9. 
work is concealed and only indicated by the information "translated from the...". Subsequently, the reader experiences the translation as he would a self-sufficient text. He faces no additional requirements; on the contrary, the translator wants to give the reader the illusion of reading an original work.

Alerting the reader, turning his attention to the text's origin as a translation, can be the result of the translator's incompetence, or it can be an intentional device, part of the translation strategy. The basic "signals" of the text's "foreignness" include retaining proper names in their original form, syntactic structures that clash with the rules of the language of the translation, and exotic cultural phenomena. These can never, however, be seen as unequivocal signs of a work being a translation, because they also sometimes occur in self-sufficient works. As such, the translation cannot have any features that could reliably attest to its genesis in a foreign language. (Even the information "translated from the..." on the front page could be a false lead, a device used in a self-sufficient work in order to conceal the authorship.) The translatorial nature of the text only appears in context: in juxtaposition with the original, in a series of other translations of the same work, in a translator's commentary, in reviews etc. It must be confirmed by another statement.

Anton Popovič writes: "Translation is a matter of style." Indeed, it is the art of skilled stylistic transformations. But the translatorial nature of a work manifests itself beyond style and beyond the work, and if it can sometimes be deduced in the structure of the translation, then this is at the level of "large semantic figures." ${ }^{5}$ This is also why translation criticism (properly understood, that is) rejects the analytical method of juxtaposing microstylistic components of the original and the translation. A comparison of this sort can only be a point of departure and should lead to describing the poetics of the translation as a whole. This has been understood since translators of old, beginning with St. Jerome and his famous formulation: non verbum e verbo, sed sensum exprimere sensu.

The relationships between the translation personae are arranged somewhat differently from the self-sufficient work. They become more complicated, as illustrated by the following table (based on Aleksandra Okopień-Sławińska's well-known model) ${ }^{6}$

4 A. Popovič, “Teoria przekładu w systemie nauki o literaturze," trans. M. Papierz. In: Konteksty nauki o literaturze, ed. M. Czermińska (Wrocław 1973), p. 137.

5 I understand "large semantic figures" here to be the higher units of signification, constructed by sentences and utterances that can hold autonomous meaning (characters, the narrator, phenomena in the presented world).

6 A. Okopień-Sławińska, “Relacje osobowe w literackiej komunikacji." In: Problemy socjologii literatury, ed. J. Sławiński (Wrocław 1971), p. 109. 


\begin{tabular}{|c|c|c|c|}
\hline & $\begin{array}{l}\text { Addressing } \\
\text { functions }\end{array}$ & $\begin{array}{l}\text { Addressee } \\
\text { functions }\end{array}$ & $\begin{array}{l}\text { Communication } \\
\text { levels }\end{array}$ \\
\hline \multirow[t]{3}{*}{$\begin{array}{l}\text { Intratextual } \\
\text { relationships }\end{array}$} & $\begin{array}{l}\text { Speaking } \\
\text { protagonist }\end{array}$ & $\begin{array}{l}\text { Listening } \\
\text { protagonist }\end{array}$ & $\begin{array}{l}\text { Quotation (from the } \\
\text { translation) }\end{array}$ \\
\hline & $\begin{array}{l}\text { Narrator (the } \\
\text { speaking I) }\end{array}$ & $\begin{array}{l}\text { Addressee of the } \\
\text { narrative (or poem) }\end{array}$ & $\begin{array}{l}\text { Translation } \\
\text { narrative }\end{array}$ \\
\hline & $\begin{array}{l}\text { Internal author }+ \\
\text { the image of the } \\
\text { translator }\end{array}$ & $\begin{array}{l}\text { Virtual addressee } \\
\text { of the original }+ \\
\text { addressee implied } \\
\text { in in the translation }\end{array}$ & $\begin{array}{l}\text { The work (entire } \\
\text { translation) }\end{array}$ \\
\hline \multirow[t]{2}{*}{$\begin{array}{l}\text { Extratextual } \\
\text { relationships }\end{array}$} & $\begin{array}{l}\text { The addresser of the } \\
\text { work (the subject } \\
\text { of the creative act) } \\
+ \text { the subject of the } \\
\text { translation act }\end{array}$ & $\begin{array}{l}\text { Ideal reader of the } \\
\text { translation }\end{array}$ & $\begin{array}{l}\text { Convention of } \\
\text { the original }+ \\
\text { Convention of the } \\
\text { translation }\end{array}$ \\
\hline & $\begin{array}{l}\text { Real life author }+ \\
\text { real life translator }\end{array}$ & $\begin{array}{l}\text { Real life addressee } \\
\text { of the translation }\end{array}$ & $\begin{array}{l}\text { Biography + } \\
\text { translator's } \\
\text { commentary }\end{array}$ \\
\hline
\end{tabular}

In the case of translation, literary communication grows more complicated at the higher levels, where the "internal author" and the "image of the translator" appear as the work's subject. We ought not to suppose that the two categories exist autonomously; they are linked, and can only be separated in an academic critical analysis of a translation. The subject of the original artistic endeavors is manifested in translation through the translator's stylistic operations. Depending on the type of translation (which is, in turn, conditioned by the translation conventions of a given epoch, the genre, and the individual poetics of translation), one of these profiles - the author's or the translator's - is more foregrounded. The closer we come to the para-translation genres, with their "nostalgic poetics" (re-workings of all kinds), the more visible the translator. Examples include Łukasz Górnicki’s Dworzanin [Courtier], ${ }^{7}$ Hertz's fables, ${ }^{8}$ or

7 See note 23 on p. 131 in the present volume [editors' note].

8 Benedykt Herz (1872-1952) - Polish writer, satirist and journalist; author of several collections of fables; translator of Ivan Krylov's fables [editor's note]. 
some translated works for children that appear to have been authored by one person. In Who is Happy in Russia?, ${ }^{9}$ The Bronze Horseman or Eugene Onegin, ${ }^{10}$ (read in Polish), the authorship is never in doubt, because in these works the translator conceals his presence, he "covers his tracks" of creative involvement.

The category of the addressee undergoes similar transformations. The reader implied in the translation might be equipped with the same competencies as the addressee of the original; on the other hand, he might be given additional or different tasks. The reading conventions are never the same for the original and the translation, though they do overlap (in general terms) when we are dealing with "translation proper" and when the translated work (the original) comes from a related cultural circle. The translations of Dante's Divine Comedy in European literature activate similar addressee programs. Translated into Japanese, The Divine Comedy would be addressed to a reader utterly unlike the addressee of the original. Similarly: the literature of contemporary Latin American writers translated into European languages is appreciated within conventions unlike those implied the original. These differences are the result of the discrepancy between cultural contexts. The latter example further proves that conventions or, as Michał Głowiński would say, styles of reading foreign to the translator's literature can be "grafted on" thanks to translation, generating further reading programs already in a given literature (at one point, Julio Cortazar's structurally complex works Hopscotch and 62: A Model Kit served this function for Polish literature).

The virtual addressee of the original and the implied reader of the translation coexist in the translated text, much as the intratextual images of the author and translator. The translator establishes the relationships between the two reading programs, yet he takes into account and favors "his" reader, the reader of the translation. "We might say that such a reader determines the structure of the translator's gambits: he stimulates the 'meta-creative' act which brings about a new text," Anton Popovič writes. ${ }^{11}$

The mechanism of guiding the addressee can be explained through analyzing the interpretation inscribed in the translation. Additional guidelines come from translators' comments of all varieties, which also pave the way for

9 A poem by Nikolay Nekrasov (1821-1878). Translated into Polish by Julian Tuwim [editors' note].

10 Narrative poems by Alexander Pushkin (1799-1937). Translated into Polish by Julian Tuwim [editors' note].

11 A. Popovič, "Rola odbiorcy w procesie przekładu literackiego," trans. J. Sławiński. In: Problemy socjologii literatury..., pp. 208-209. 
the reading program; they explain to the reader the principles of translating a given text, and also facilitate its understanding. Clear examples of a total subordination of the translation to the expectations and capabilities of the potential addressee are translations for children; on the opposite end of the spectrum we find translations that are maximally faithful to the reading program of the original. Thus, we ought to qualify the above-quoted remark by Anton Popovič: the translation's virtual reader indeed is a norm for the translator; however, this norm is subject to gradation.

The expectations of the presupposed addressee of the translation determine the translator's methods on various levels (in various layers) of the work. The particularly frequent and marked "concessions" to this reader can be observed in the make-up of the presented world. [...]

The tension between the visibility of the author and the anonymity of the translator is always there in a translated work, though it is tempered by the genre and conventions. Also the tension between the competencies of the reader implied in the original and the virtual reader of the translation appears in every translated work. It can be nearly eliminated; it can also be greatly enhanced when the translator "corrects" the author, reinterprets the meanings of the original, and encourages the reader to perform tasks not intended by the original. This phenomenon is most visible in translations where worldviews and ideologies collide, and the addressee is forced to perform axiological actions.

In terms of extraliterary communication, the dual roles of the addressing functions of translation show in the context of two types of testimonials: biography of the author, and self-commentaries and criticism concerning the translator. The context of the translator's biography is very seldom introduced. Whereas the life of the author may cast light on his work, the biography of the translator strikes us as rather dispensable in interpreting the translation (the exception that proves the rule might be Artur Sandauer's "theory of equivalents" and his translation of Mayakowsky's Good, whose form was largely determined by the translator's living situation during the war - the necessity of remaining in hiding and summoning the original text from memory).

It would seem that the duality of addresser/addressee categories of the translation does not pertain to the lower levels of intratextual communication. Nonetheless, in a translation the protagonist and narrator (or the speaker in poetry) are also hybrid categories. Their ontology is conditioned by the nature of the translated text. In the translation, the character, as well as other "large semantic figures," are signs of the model of the world designed in the original. They do exist, however, and manifest themselves through the language of the translation, which in turn reflects the extralinguistic reality of the translator, and 
not of the author. Thus, the protagonist (also the narrator), exists on the border between two presented worlds ("invented" in the original and "articulated" in the translation), and on the border between two creative consciousnesses: the author's and the translator's. And again, the hybridity of the figures can be unevenly distributed, like the duality of the subject of the creative act. For example, in Julian Tuwim's translation of Who is Happy in Russia? by Nikolay Nekrasov, the protagonists inhabit the social reality of Czarist Russia, they bear Russian names, but they often speak in a Polish local dialect. In translations of Ivan Krylov's fables for adults, the fictional character attains maximum cultural autonomy; in translations of his works for children, the protagonists are adapted to the intellectual capacities of its virtual addressee and the context of the Polish culture. When the characters in a fictional world become primarily signifiers of a foreign cultural reality, this enhances the cognitive function of the world created in the translation.

The way the characters (and the narrator) speak is of prime importance not only for reconstructing the worldview of the original, but also for describing the translator's strategy. This is why, in the following analyses, some questions are reiterated: Who is speaking? And how are they speaking? A comparison of the rules shaping an utterance in the original and in the translation allows us to see the mechanisms of translation transformations and isolate its dominant, to reveal the range of options discarded by the translator, the range of potential variants of the poetic language of the original.

Literary communication in translation is, as we have said, doubled; at least doubled: it would be more accurate to speak of multiplied communication. We ought to consider the fact that a translation is not always directly relative to the original. The "dialogue" between the translation and the original can also be indirect. This is true, firstly, in a literal sense, when the translation is created through a "philological translation" developed in a different language (this is common practice in translations from Asian languages into European ones). The premise of a philological translation is to achieve maximum precision in communicating the meanings of the original, bypassing (or diluting) its linguistic over-organization. In other words, the aim is to preserve the referential, and not structural meanings. Still, as the philological translation is made by a person using a natural language, its "transparency" (let us thus call the zero-degree subjectivity of the translator) would seem impossible, at least for statements composed of several sequences. We might translate the Russian Otyetz ponyat' yevo nye mog as "father could not understand him," but a more complex sentence, like Otyet zponyat' yevo nye mog I zemlyi otdaval $w$ zalog might have at least two variants: "Father couldn't understand him and mortgaged his land" or "Father couldn't understand him and 
mortgaged the villages." In the verse translation of Eugene Onegin that contains this line, we find a third option "His father never understood/And mortgaged all the land he could." ${ }^{2}$ Here, the translator in-between would have to choose from the range of meanings of the word ponyat' (understand, conceive, grasp), zemlyi (land, village, property), and otdavat' $w$ zalog (to mortgage, to give up for mortgage). He would also need to choose a syntactic variant, with or without subjectverb inversion. The choice from the range of translation options depends on the individual understanding of the nuances of meaning in the translated text and the translator's stylistic preferences. As such, the philological translation retains the "image of the translator" superimposed on the "image of the author." When on the basis of this translation another foreign-language translation is rendered, three different languages collide within it, and three models of reality: that of the author, that of the first translator, and that of the second translator. Another variant of an intermediate "dialogue" between the translation and the original is translations that exist in a series. If the translation of work $\mathrm{X}$ is created in a given language as a successive one, the law of competition prevails, but also that of "repetition," as Franciszek Siedlecki says: "often, a crucial stimulus for a retranslation is the previous translation." 13 This means that the new translation questions the structural variant of the original put forward in earlier translations, as it seeks to be superior. It cannot be, however, an absolute negation; it retains the "memory" of previous solutions, repeating the same heteronyms and images at the microstylistic level, and sometimes also repeating the interpretation of the work as a whole. Like a parallel mirror, it reflects the devices and communication models constructed in the previous translations. [...] We ought to add that this bears on a fundamental question: the translation's form of existence ${ }^{14}$ (not in Ingarden's sense of the phrase). The original work is singular. Of course, there is no such thing as total innovation in literature; every literary work is immersed in tradition, it draws upon ideas, motifs, and a vast repertoire of artistic strategies from the dawn of literary history, either endorsing or negating them. We ought to understand innovation as a unique combination of elements of a repertoire; in this sense, a work's uniqueness is linked to a "minimal innovation of the system." ${ }^{15}$ In the

12 A. Pushkin, Eugene Onegin: A Novel in Verse, trans. J. E. Falen (New York 2009), p. 8.

13 F. Siedlecki, "Przekłady z poezji rosyjskiej" In: Siedlecki, Pisma, pp. 663.

14 The seriality of translation is discussed by E. Balcerzan in his essay "The Poetics of Literary Translation" [see pp. 105-119 in the present volume].

15 J. Sławiński, "Synchronia i diachronia w procesie historycznoliterackim.” In his: Dzieło. Język. Tradycja (Warsaw 1974), p. 17. 
literary art, repetition means derivativeness - i.e. plagiarism. The literary system cannot produce a work that is literally analogous and written by another author. Various versions, remakes, and reinterpretations are permitted. Plagiarism is not. The uniqueness of a work is thus gauged by its originality. Works that allude to existing literature always differ from the original, at least to a minor degree. In the case of translation, the opposite is true. A translation seeks to be as close as possible to its original; similarity is the idea behind every translation. It may be conceived differently in various epochs, conventions, and genres, but the aim is always similarity. A translation does not aim to be either "better" or "worse" than the original. The criterion for evaluating translations is the concept of optimality, not originality. ${ }^{16}$ The translation series results from the failure to achieve this optimal similarity to the original, and repeated efforts to do so. The history of literature has seen "congenial" translations, ones that could not be improved. But even this concept is historically relative. Ever since Julian Tuwim's translation of Alexander Pushkin's The Bronze Horseman, no translator has tried to retranslate the poem. Thus, Tuwim's version stands as optimally similar to the original. This does not mean, however, that it has closed the series, and that this optimum will never change. In more extensive series, the impetus for development is precisely the inability - or difficulty - to achieve optimality, which need not result from the artistic quality of the original but can also come be conditioned by factors external to the work: the degree of kinship between the languages, the intercultural relations, or the translators' competencies.

It is these basic differences between the original and the translation, and their relationship to the literary system, that give rise to limitations in the translator's space of creative activity. The translator adopts a role different to that of the author. According to translators themselves, it is a role that is sometimes inferior, sometimes equal. Miguel Cervantes de Saavedra famously said that Translating from one language to another is like looking at Flemish tapestry from the back: the figures are visible but covered by threads that obscure them, devoid of the smoothness and color of the front of the tapestry. Franciszek Ksawery Dmochowski:

If you doubt the power of your pen

Or your wit or the breadth of your ken,

That you might in writing bring forth your own fruit;

16 This category was introduced to translation theory by J. Ziomek in his essay: "Kto mówi?", Teksty 1975, No. 6, p. 44. 
Waste not time, why practice when you can loot Foreign works, by making them Polish. ${ }^{17}$

Valery Bryusov: "In translating poems, you succumb, time and again, to bouts of artistry, one might say, 'you create,' and thus you lose the capacity to critically evaluate what you write as a "translation"" (193). Nikolai Gumilov: "Here is the ideal situation - translations ought not to be signed with the translator's name" (189). This is the view of people for whom translation should supplement to the original, rather than fighting for equal rights. Others see the roles of the author and the translator on a par. Ignacy Krasicki: "Translating books is a nobler art than one might suppose at first glance; in order for it to be properly proclaimed, then, we ought to free from error all those who call translators, be it of older or contemporary books in foreign tongues, and their valuable work, craftsmanship and not the labor of the intellect" (76). Vasily Zhukowsky: "The translator of prose is a slave, the translator of poetry - a rival."18 Natalia Modzelewska: "For understanding the author's method is an indispensable condition for the co-creating that translation ought to be."19 Karl Dedecius: "Art presupposes freedom. Translation limits this freedom, yet it demands art" (385).

Translation supplies implied information about translators. This is information about how they use the language. Only a dual-text analysis (of the translation and the original) reveals the competencies of the translator in the original language, along with information on how he has transferred meanings from one message to the other. A description of the language of translation also enables us to establish the translator's temporal and spatial location, as well as allowing to characterize his idiolect, his individual stylistic attributes. Less frequently, the translation holds topical information, which can appear in footnotes and commentaries to the main text. Usually, these concern the translation process itself, the impossibility of rendering certain fragments of the text, the necessity of substitution or interpreting the meaning of the original etc. A dual-text analysis increases the scope of this information to include neglected options (potential translatorial solutions). The two texts might be further supplemented by other versions of the translation (rough drafts, notes) made by the same translator;

17 Quoted from Balcerzan's Pisarze polscy, p. 88. Unless otherwise indicated, the quotations in this chapter are from this anthology, with page numbers in parentheses. Translations by S.G. [editors' note].

18 Quoted from E. Balcerzan, “Tłumacz i tłumaczenia. Wstęp." In: E. Balcerzan, Oprócz głosu. Szkice historycznoliterackie (Warsaw 1971), p. 232.

19 N. Modzelewska, "Refleksje tłumacza." In: Przekład artystyczny. O sztuce tłumaczenia. Księga druga, ed. S. Pollak (Wrocław 1975), p. 190. 
this makes the description of the translation process fully reliable. ${ }^{20}$ The pool of implied information on the translator decidedly outweighs the topical information. The latter might appear in an accompanying text, outside the presented reality. The implied information, on the other hand, can be found throughout the text, from the title onward. The title of the translation gives us our first signal as to the poetics of the translation; in a sense, it introduces the "program" of the work..$^{21}$ It is no accident that the translation of titles has been studied by critics, ${ }^{22}$ and it often allows us to infer the global interpretation of the original. In a self-sufficient work, hidden information about the author allows us to reconstruct his image as the "arbiter of the linguistic rules." ${ }^{23}$ Based on a translation, we are able to say not only how the translator has used language, but also how he reads another text. This is the chief difference between the "image of the author" and the "image of the translator"; the translator exists in the translation both as a subject creating a literary statement and as a subject interpreting a foreignlanguage text. This latter function emerges, however, only in a description of the dual-text. When reading only the translation, the reader encounters the translator-as-interpreter as an implied, and not overt category.

As we have already said, both figures - the "external author" and the "image of the translator" - co-inhabit the text as a kind of alternating interference. The author is the addresser, usually seen by the reader as the sole and ultimate one. Simple reading experience tells us that one generally recalls the name of the author of the translated work, and far more seldom the name of the translator. If we managed to reverse the publishing convention and foreground the name of the translator over that of the author, however, it would probably turn out that the reader would blame all the work's shortcomings on the incapability of the translator. This might be done by an addressee who is conscious of the text being a translation, but does not compare it with the original. It is thus that the addressee as though separates the spheres of presence of these two categories: to the author he attributes the effort of creating a fictional reality and everything that occurs within it, while the translator is held responsible for the linguistic form of this reality. In rhetorical terminology, we might speak here of the plane

20 One example might be Julian Tuwim's rough draft of the first stanza of Chapter Seven of Eugene Onegin, commented upon by Juliusz Wiktor Gomulicki in the review " $\mathrm{Z}$ rosyjskiego Juliana Tuwima," Twórczość 1955, No. 2. p. 37.

21 Cf.: A. Popovič, "Rola odbiorcy," p. 215.

22 E.g. K. Chukovsky, Vysokoye Iskustvo (Moscow 1964).

23 J. Sławiński, “O kategorii podmiotu lirycznego. Tezy referatu.” In: Wiersz i poezja, ed. J. Trzynadlowski (Wrocław 1966), p. 55. 
of invention and disposition as the author's hegemony, and the plane of elocution as the translator's territory. To some degree, this is accurate; the model of the world contained in the original is reflected in the translation. But since we must not separate the fictional reality from the language through which it exists, the translator can only be regarded as its co-creator. This issue only emerges differently in non-artistic translations, such as scientific ones, in which the linguistic composition is not a primary genre marker of the text. ${ }^{24}$

The "image of the translator" thus emerges on all levels of the text, much like the "image of the author." The relationship between them, however, is re-established anew in every translation. In the above-quoted views the images of the ideal translation were quite varied: from overtly signaling the translator's participation in the "creation" of the work, to utter anonymity of the translation, using only the author's signature. The intratextual "original author - translator" relationship was modified by the literary conventions of particular epochs.

In every translation there is a tension between the visibility and anonymity of the translator. It can be alleviated by the genre of the original. Highly codified genres (e.g. fairy tales) set limits on expression. Non-codified forms help strengthen the "voice" of the translator, because they are more open and "individual." (This can be observed in many contemporary translations, such as Maciej Słomczyński’s rendering of Finnegan's Wake).

Yet translators also have complexes. These concern the radically unequal creative contributions of the author and the translator, or the issue of "limited freedom." They are expressed in translators' abundant commentaries on their own work. We do not find that many statements by writers who have felt the need to justify their need to create literature and reveal the quandaries of the creative process. They are far fewer, at any rate, than statements by translators justifying the existence of the translation and showing the limits of the creative act. The translator's statement arises from the eternal need to appreciate the role of the translator and to reveal his position as a subject.

The historical shifts in the translator's degree of visibility in the text are linked to varying notions of the nature and role of translation in the system of native literature. In the Pre-romantic era translations are chiefly a way to bolster its development. In the Post-romantic era translation is increasingly seen as serving

24 See: R. Ingarden, “O tłumaczeniach.” In: O sztuce tłumaczenia, ed. M. Rusinek (Wrocław 1955), p. 127. See pp. 85-104 in the present volume. 
to represent another culture. ${ }^{25}$ The beginnings of translated literature are born of the need to supplement the native culture, and thus there is a more powerful imperative to naturalize the translated work. After all, it is significant that in older Polish literature there are no extensive translation series. A once-translated work did not inspire rival retranslations, as the artistic status of the translation mattered less than the fact of the introduction of the foreign-language work into the domestic literary system. In the Post-romantic era the poetics of translation was a vital issue not only because of the wealth of existing literary conventions, but also because the dilemma of what and whom the translation ought to be representing emerged in all its intensity. Is it the foreign literature and the foreign writer, or the translator and the literature into whose bloodstream the text is injected? From these two opposing perspectives come a variety of concepts of translation technique, as well as various ways of seeing the translator's status, which nonetheless generally aspire to elevate the art of translation. [...]

The translators' statements that have emerged over the space of centuries to illuminate the role and nature of language, the craft of translation, the reproduction of the original, the poetic genius required to create correct translations, and finally, fidelity, the relationship between the original and the translation, and the translator's creative competencies and their limitations, constitute material for studying the translation concepts binding in various epochs. These statements lay out the general rules of translation; they co-create the system of translation norms which I call the formulated poetics of translation. They reveal the translators' convictions that mark the limits of creative freedom. And yet apart from these norms (which, after all, are not always respected in practice), there are also the limits of the translation's sovereignty determined by the features of the original's genre. The "image of the translator" and the degree of its visibility in the translated work primarily depends on the genre. As I have mentioned, "open" genres strengthen the translator's voice. Highly conventionalized forms weaken this voice. Moreover, a great role is played by the position of the genre form of the translated work within the literary tradition that the translator represents. For the translation can be the genre equivalent of the original when the translator appeals to the genological awareness of his reader and uses conventions preexisting in his native tradition. If these conventions are foreign or underdeveloped, however, the translation might serve to introduce a genre that is far

25 The thesis on the Romantic caesura in the history of translation is formulated by E. Balcerzan in his paper "Sztuka przekładu jako przedmot badań literackich," Pamiętnik Literacki 1980, Vol. 1, p. 3. 
from assimilated, or even entirely new. (Such was the case in Polish with Nikolay Nekrasov's digressive epic poem Who Is Happy in Russia?).

In terms of reception, the translator is the "second author" of the text when his presence is noticed by the reader. (Although, as I have already argued, the reader must fulfill certain conditions: he must know the language of the translation and the original, and make a comparison of the two artistic messages). Reading the translation alone, the addressee is unable to establish the functions and the consequences of the translator's operations. One exception to this rule might be in reading a translation that has already been the object of critical attention (such as Maciej Słomczyński's translation of Joyce). Here the reader might not know the original or its language, yet he can be aware that the work expresses the translator's personality. The same goes for the reception of translations that are tangibly archaic, emphatically burdened with mannerisms (such as Goethe's Faust in Emil Zegadłowicz's translation). A hint of the translator's intervention remains in every translation, but it seems that among the translatorial transformations we can distinguish between the necessary and the redundant ones. Necessary transformations are those which serve to transfer the meanings of the poetic message; here the translator regards the original as a system of directives that should generate equivalent semantic fields in the foreign-language text (the translation). Redundant transformations modify the original structure and most often appear in the prevalence of two types of non-neutral translation approaches: amplification and reduction. We can distinguish between the two kinds of translation interventions using the criterion of congruency of styles of the original and the translation. When the author's style ceases to be recognizable in the translation, the "image of the translator" as the creator of the literary work appears most vividly. The translation must show a relative balance in the "participation" of the author and the translator. Should the scales tip, and the author's style be entirely eliminated, the work shifts from translated literature to paratranslation.

Redundant transformations can pertain to various areas of the text; but when they become the rule in the immanent poetics of the translation, we are dealing with the maximum subjectivity of the translator. In artistic translation practice we equally seldom encounter zero-degree and maximum translator visibility. The entirely absent translator and the omnipresent translator are merely model translation situations that are aspired to or derided in various translation conventions. In the main, a translation has two authors and is heterophonic, with the voices of the author and the translator creating a sort of counterpoint. In research practice we observe cases where this heterophony is disrupted in order to show boundaries that the translator cannot cross, lest he annihilate the 
text-as-translation, and beyond which he ceases to co-create the work and begins to usurp the rights of the author.

The category that appears most frequently in [...] descriptions of the translation process is "selection." As I have mentioned a number of times already, this selection has two aspects. The translator selects elements of style and convention from his native linguistic/literary paradigm, but simultaneously makes choices within the semantic field of the original. The author selects only from the former system, since he is creating an original work, for which there is no prototype (provided, of course, that we ignore the issue of genre rules). Thus, we could say that the translator's selection is wider and more alternative. And yet this is a factor that limits the translator's "freedom" rather than increasing it: "In the simplest of terms, the translator has no creative freedom in his choice of means and ways of speaking [...]. In all circumstances the translator's message simplifies the ambiguity of the original; it gravitates naturally toward the unambiguous," claims Anton Popovič. ${ }^{26}$ "The other's" voice and "one's own" words in a translation are the result of the creative work of two authors. When the words of the translator prevail over the style of the original author, this interferes with the principle of reproduction. Then translation becomes a creative work in the sense of a process and a product. The "subjective truth" of the author is replaced by the truth of the translator, and thus the text becomes, to a greater or lesser degree, the work of a single author.

In translation practice we seldom find such extreme interference with the translation convention. We usually observe the translator's dramatic oscillation between humility and the desire to communicate "the other's" voice, and the intention of leaving something of his own "image" in the text.

[1986/1999/2013]

Translated by Soren Gauger

26 Popovič, Rola odbiorcy..., p. 214. 



\title{
Tadeusz Sławek \\ Calibanism: \\ Philosophical Dilemmas of Translation
}

\author{
To refuse translation is to refuse life. \\ Jacques Derrida, The Ear of the Other, trans. Peggy Kamuf
}

In the eighty-third aphorism of The Gay Science, Friedrich Nietzsche addresses the subject of translation. This is the most substantial piece devoted to translation in his oeuvre. Briefer remarks can be found in his early lectures On the Future of Our Educational Institutions, where he speaks of translation exercises as "splendid" (herrlichen) and the "most beneficial" (heilsamste) means of "fertilizing" (befruchten) native speech, in The Wanderer and His Shadow, and Beyond Good and Evil, where Nietzsche points out the difficulties in translating signifiants, speaking of the impossibility of rendering the "pace" of the original language. It was in the above-mentioned passage from The Gay Science, however, that he laid the framework of his translation theory and gave it a wide philosophical context. To Nietzsche, translation is closely linked to history, or, quite significantly, to the historical sense (historische Sinn): "The degree of historical sense of any age may be inferred from the manner in which this age makes translations and tries to absorb former ages and books."

This does not just mean that every translation is grounded in some past, but also, and perhaps primarily, that the relationship between the original text and the translation is not a simple correspondence, for history writes itself through the differences and in the space of difference between the two works. Hence, speaking of the historical sense, we inscribe the art of translation into the interdependencies between what constitutes the generally unperceived aura around my body and what encompasses phenomena such as language, writing, and ideology (in The Genealogy of Morals Nietzsche says that thanks to the "historical sense" we can easily deduce what values a given society lives by), and the

1 F. Nietzsche, The Gay Science, trans. W. Kaufmann (New York 1974), pp. 83-84. All subsequent quotes from this edition and will be marked GS with the page number. 
body itself (in the concluding sections of The Gay Science, the philosopher calls "historical sense" the "sixth sense").

In other words, translation, which has been traditionally subject to the demand of a dual fidelity - a fidelity to the original and a fidelity to its own present day (for is it not by now a classical belief that every epoch must have its own Homer?) - is in a highly suspect situation, for, as we find from Nietzsche's analysis, the fidelity to one's time consists precisely in betraying the original. The books the philosopher mentions are "bygone," as are the times (vergangene Zeiten und Bücher). Thus, the translation is (theoretically) meant to be faithful to something that belongs to the sphere of imperfectum, to something that once was, and whose contours are imprecise: it is not books that one translates, but books and times (Zeiten und Bücher). The translation, therefore, is to be faithful to something that is unfaithful to itself: the text is not defined by contours, but always "spills over" into times, changing its scope; it is always "the text and the times." And if the original is not loyal to itself, not faithful to itself, it is "the text and the times," so it is the text only at times, only at times is it the thing we are to translate -what is it that the translator should be faithful to? The only fidelity in translation is the fidelity to yet another form of betrayal.

Do we even have any basis for speaking of fidelity and betrayal? Is there a point beyond sequences of betrayal and loyalty from which we might establish precise criteria of truthfulness, fidelity, love for the text? Can we conclusively state: this is a faithful translation, this is an unfaithful translation? This is a translation free from sin, untouched, virginal, beyond the danger of violation? And, above all, why this list of questions inscribing translation into the themes of the body and sin, the erotic and transgression, sensuality and passion? There are two reasons: firstly, because the "historical sense" is our "sixth sense," and thus is inevitably linked with the nature of our corporeality; secondly, because this is the rhetoric of the knowledge which Nietzsche calls "joyful"(or "gay").This knowledge (or "science") sees translation as "assimilation," or rather "incorporation" (einverleiben), "taking possession," a "conquest" (bemächtigten), "forcible taking hold of" (gewaltsomlegtees seine Hand auf...). As such, the "historical sense" is the historical figure of sensuality; if we translate the German term historischer Sinn acoustically into English, we get "historical sin." Historischer Sinn = historische Sünde.

In the age of Corneille and even of the Revolution, the French took possession of Roman antiquity in a way for which we would no longer have courage enough - thanks to our more highly developed historical sense. And Roman antiquity itself: how forcibly and at the same time naively it took hold of everything good and lofty of Greek antiquity, which was more ancient! How they translated things into the Roman present! (GS, 84) 
The sin chiefly consists in our belief that we can stand outside the series of distortions and transformations, and pass judgments on the translation's degree of accuracy; in other words, we believe that we can attain a point which is beyond sin and thus beyond sensuality and beyond history, beyond the body. Nietzsche argues that this is impossible. The course of history is a sequence of perspectives, and therefore a sequence of errors; its limit cannot be ascertained. As Jacques Derrida has noted, the limit can only appear in the succession of differences and fissures:

The limit [la limite] has the form of always different faults [failles], of fissures whose mark [trace] or scar [cicatirce] is borne by all the texts of philosophy. ${ }^{2}$

In Nietzsche's aphorism, the series of distortions goes as follows: In the seventeenth and eighteenth centuries the French "conquer" the Romans, who in turn had appropriated Greek heritage, and thus in fact Corneille is translating a whole mosaic of Greek texts mediated through the Roman poets, and he is not even aware of this. Thus, translation is an exponent of the "historical sense," i.e. the individual and social ways of appropriating the world. Nietzsche calls this appropriation "absorption" or "incorporation" (einverleiben). This term deserves our attention; with it, translation becomes part of politics and (again) the body. We "incorporate" the original text into our own culture much as an independent city or state is incorporated into the empire. Nietzsche clearly recognizes this imperialistic aspect of translation, drawing parallels between the work of a translator and the politics of the "great Roman Empire." This point of view alters the dependency between the text of the work that is being translated and the text of the translation. So far, this relationship has borne all the hallmarks of a master/ slave relationship: the translator was to carry out the author's commands. The text of the translation was merely a to-do list left by an absent employer. The situation changes with the introduction of the concept of "incorporation": the translator/slave is suddenly put in a position in which, firstly, he is forced, as it were, to compete with the author/master, and, secondly, this competition inevitably leads to a subversive ending: the servant will overpower his or her master. In the traditional translation model which prevails in Western culture, the author's idea, message, the signifié reigned supreme over the signs of the text, the body of the work, and the body of the author. The classical instruction declared that the translator should render the thoughts, not the words, the signifié, not the signifiant; completely devoted to his or her work, the translator remained celibate, as

2 J. Derrida, Positions, trans. A. Bass (Chicago 1982), p. 57. 
it were, eliminating him/herself and his/her desires for the sake of the author's thoughts, restricting his/her own presence to but a shadow of the author's divine presence. It was no accident that in Medieval Europe monks were the masters of translation; nor was it by chance that their actual names remained hidden behind monastic names or faded into oblivion. Nor is it by accident that translations have yet to enter the classical literary canons of the languages into which they are translated. The translator under the rule of the author, the body governed by the spirit, the significant at the mercy of the signifie - these are the foundations of the philosophy of translation.

Nietzsche however uses the term "incorporation" (einverleiben), and this concept changes everything. "Incorporation" presupposes resistance, or at the very least, the solid, material nature of both elements: the incorporating and the incorporated. "Incorporation" means entering the body and becoming its part, functioning within its sphere. What is corporeal and material, and keeps appearing on the horizon of the spirit-possessed translation, is the TEXT. With the politics and erotics of "incorporation," the physically absent (yet spiritually omnipresent) author, ruthlessly though discreetly surveilling the translator's actions, and the equally "disembodied" translator, always retreating from his own presence and his own desires, are called to order by the appearance of the TEXT.

As we know from Roland Barthes, TEXT differs from work in that it is a methodological field rather than the sum total of cautions and completed forms; in that it is paradoxical, for it is located beyond the sphere of doxa; and in that it is a multiplicity of languages irreducible to a single langue. In a word, TEXT is where the pleasure principle is enacted. This means that the stakes of translation are in regaining the pleasure of the TEXT. This pleasure is Barthes' jouissance and Nietzsche's frohliche Wissenschaft, and the main battlefield is the relationship between ourselves, the past, and the foreign. In his meditations, Nietzsche writes that the Romans

did not know the delights [Genu $\beta]$ of the historical sense; what was past and alien was an embarrassment for them; and being Romans, they saw it as incentive for a Roman conquest (das Vergangene und Fremde war ihnen peinlich, und als Römern ein Anreiz zu einer römischen Eroberung). (GS, 84)

The pleasure of history (let us note the erotic rhetoric of the whole sentence) consists in the fact that the past must remain past and foreign, which means that it is not subject to translation to the extent that the translator's work focuses on the translation of "bygone times" into our times and of the foreign language into (his own) national language. And yet translation does not cease, as it is a condition of history (and not only literature). Without translation other times would 
remain foreign to us, and thus incomprehensible; history would become a sphere of impenetrable gloom or even total oblivion. As such, the translator translates what must be both translated and left untranslated if it is to be understood: history must cease to be foreign, it must speak my language, but if it is to be history as a source of pleasure, it must contain what is foreign, it must continue to speak in a language I do not quite understand. This is precisely how Roland Barthes describes what his theory calls a text of bliss (text de jouissance), which gets me out of my comfortable rut of perceiving of the world, revealing the world as foreign, history as a space of non-continuity, and language as a domain of an epistemological crisis.

Succumbing to the text as jouissance, the translator alters the course of his work: now the translation is meant to reveal the fact that the translated past is a construct of the present, and thus it must rely on the paradoxical assertion that the translated text is not translated completely, for we only translate it at all because it contains what must remain "bygone and foreign." Translation reveals what is untranslatable not because of syntactic or lexical incompatibilities, but for a far more serious reason: the structure of human temporality. Let us note, above all, the play of numbers: the translation is always an attempt to translate times past (vergangene Zeiten) into the language of some other time, though it must inevitably be reductive, as the original was also created in the aura of its present time and spatial topography. But a text is not and cannot be entirely "original" for, as Nietzsche reminds us, it is the domain of "private things," and thus must inevitably be a "translation" of other texts, not necessarily literary ones. The text is inextricably entangled in the intertextuality of the world: the private nature of the text is a translation of the world's gestures, whose language, for Nietzsche, is the primary text of existence, upon which consecutive layers of translation are inscribed. This explains his apologia, in Ecce Homo, for the physiology of existence, for that pre-semiotic state of being where translation begins:

You must know the size of your stomach. Inadvisable for the same reason are those longdrawn-out meals which I call sacrificial feasts with intermissions [...]. - No snacks, no coffee: coffee makes you gloomy. Tea beneficial only in the morning. A little, but strong; tea is very harmful and makes you feel sickly all day if it is just slightly too weak. [...] In a very agaçant climate it is inadvisable to begin with tea: one should lead off with a cup of thick, oil-less cocoa an hour beforehand. - Sit as little as possible; do not believe any idea that was not born in the open air and of free movement - in which the muscles do not also revel. All prejudices emanate from the bowels. - Sitting still (I said it once already) - the real sin against the holy ghost. ${ }^{3}$

3 F. Nietzsche, Ecce Homo, trans. D. Large (New York 2009), p. 21. 
What we consider the beginning and an absolutely present moment, i.e. the "original" text, turns out to be a complex structure, or as Nietzsche puts it, "the languages of gestures and glances." "To examine the problem of translation must mean contemplating the substance of the present; even though it seldom occurs to us, translation is an awareness of the awareness of "now," a meta-awareness of the present. According to the philosopher, in translating the Greeks into the Roman present, the Roman poets exchanged the multiplicity and diversity of the past for the homogeneity of "now." Nietzsche writes:

How deliberately and recklessly they brushed the dust off the wings of the butterfly that is called moment!

(Wie verwischten sie absichtlich und unbekümmert den Flügelstaub des Schmetterlings Augenblick!) (GS, 84)

Therefore, translation is a deliberate, inevitable loss. The essence of this loss is the removal - double removal - of the "present" moment. This movement has two phases. First, the translator acknowledges the inadequacy of full self-realization "now" in the "original" text, presented in Nietzsche's aphorism as dust raised by the wings of a butterfly, and then he recognizes that the work of the translator also (and intentionally - absichtlich) wipes away the traces of the "now" moment. Thus, like it or not, translation is a meditation on the impossibility of capturing and actualizing the "now" referred to as Augenblick.

In a manner of speaking, Augenblick is a pre-semiotic element, and all the work of the writer of the "original" text (now we must place the word in inverted commas as evidence of our mistrust for it) already is a translation, as it consists in entrusting to signs the stuff of experience (Nietzsche asks: "What was it to them [the translators] that the real creator had experienced this and that and written the signs of it into his poem?" [GS, 84]), and the signs, too, have their own pasts, and, consequently, they can only efface the original, unique, irreplicable nature of the moment of Augenblick.

Hidden in Nietzsche's beautiful phrase is an atmosphere of death: the butterfly has flown away, and all traces of its presence have been carefully and deliberately removed. The "original" text is a place of mourning ritual, as it were (the Augenblick butterfly vanished or was caught and pinned, as suggested by the last aphorism in Beyond Good and Evil: "Alas, always only birds that grew weary of flying and flew astray and now can be caught by hand [...]. We immortalize what cannot live and fly much longer"5). The "original" text is doubly dead: it is

4 F. Nietzsche, The Will to Power, trans. W. Kaufmann (New York 1968), p. 422.

5 F. Nietzsche, Beyond Good and Evil, trans. W. Kaufmann (New York 1989), p. 237. 
dead for its own time (it cannot render the Augenblick moment) and dead for the future, which will have to breathe its own life into it (Nietzsche phrases the Roman translator's question as: "Should we not have the right to breathe our own soul into this dead body? For it is dead after all" [GS, 84]).

As we can see, translation is an attempt to animate a creature which is seemingly the incarnation of life and creative energy; yet Nietzsche does not entertain the slightest of hopes when it comes to the efficacy of this undertaking. The translator begins his work in the face of the death encoded in the sign, but the life which he intends to bestow on the breathless being, is nothing but the multiplication and intensification of that mortality: the translator pursues the mysteries of the text's life, rummaging among the monuments of death, like Dr. Frankenstein.

As Nietzsche argues, the Roman translator (and every translator shares this fate) gives his own life to the text, which is a political death (what perishes is the independence and autonomy of the work, which now becomes part of the empire) and the death of the present (the Augenblick of the translation is just as dead as the Augenblick of the translated work). Yet despite the whole gravity of death, translation is an activity that manifests what Nietzsche would have called "the will to power." Through its constant confrontation with death, it opens up to hope for the future. Considering the futility of efforts to breathe life into something dead, to assimilate what is foreign (and what could be more foreign and untranslatable into any other language than death), the translator asserts the need for corrections, revisions - the interventions of the future. The translator is particularly focused on the future. He uncovers the truth fundamental for his work: that true historicity is not about seizing and animating the past, but, on the contrary, about admitting death to the realm of times past and present, about activity based on what is untranslatable, but which the future shall attempt to translate anyway. The movement of translations, therefore, not only monumentalizes the past or traces it back in the antiquarian mode; it is also an act that looks critically at the past (we are borrowing the terms for the three schools of historical thinking in Nietzsche's Untimely Meditations) in order to preserve it as "past" and "foreign." In order to "faithfully" preserve the past, to give the past to the present to understand, translation, as an attempt at considering the past, rendering it in the language of "now," must demonstrate the "foreignness," or the untranslatability of the past. To translate is to constantly reveal the limits of translatability. The translator is someone who, consciously or not, ensures that the work always speaks a language that is ultimately "foreign." Translating is existence in an eternally self-renewing difference.

The past, foreignness, death - three elements that provoke translation and three concepts describing what is untranslatable, but which conditions the 
translator's efforts and serves as their patron. Yet Nietzsche speaks of "incorporation" (einverleiben). How are we to understand these acts that imply enlargement, enhancement, expansion, if the translation's context is set by the past, foreignness, and death?

We have said that the stereotype of the translator is the very model of the servant's behavior toward the master, of Caliban toward Prospero: the translator is "conquered" by the author, taught his language, and discipline compels him to carry out the tasks he is given. The master is life, and the servant lives by the grace of his superior. Let us bear in mind that Prospero, the master, author, director, omnipotent God on the small island of the text where wondrous things can happen, is also the guardian of morality, of the purity of his offspring. Caliban is outcast into the periphery of the island and the text, as (according to Prospero's accusation) he attempted to "violate the honor of [his] child" (Act I, Scene 2).

The author, Prospero, tends to the purity of his art and the virginity of his daughter: in a word, he increases the obstacles for those who should seek to possess either one or the other. The daughter and magic weave into one: they are a product of Prospero's actions, they are his book. As such, the assault on Prospero's authority must be a violent conflict with his authorial language of structure and order. Rebelling against Prospero, Caliban first attempts to relinquish his speech:

You taught me language, and my profit on 't

Is I know how to curse. The red plague rid you.

For learning me your language!

(Act I, Scene 2)

Later, when the rebellion becomes open, he advances on Prospero's house repeating two phrases: to destroy the books and sate himself on Miranda's beauty (Act III, Scene 2). Prospero deprives Caliban (as the author does the translator) of the sanctuary of his own speech; before Prospero's arrival on the island, his language was speech that ensured a seemingly harmonious existence in the world. This harmony was only apparent, as it was reduced to the immediate surroundings; it made the world a home, but this home proved to be vulnerable, permeable, even only apparent. Harmony guaranteed a non-confrontational relationship with the world, which became just like a toolkit; and in this manner, it domesticated the world, which responded confidently to every question and satisfied all our needs. The foreign language, the speech of a newcomer from distant shores and the "abysm of time" (Act I, Scene 2) shatters homeliness by demonstrating the limited nature of the domestic topography: Caliban functions within his immediate surroundings, but has no relationship with the sun and the 
moon. Prospero disrupts the seemingness of native speech, so obvious and automatically taken for granted, by "calling in" the heavens into the native tongue. We might say that the speech in which and for which a man is born cannot make him aware of the power of language that calls the most remote beings into speech. The intervention of a foreign tongue will show that what we accept as evident - so evident that it scarcely seems to be speech or a sign, it is simply the world - in fact contains vast spaces of namelessness. It seems to us that the native tongue exhausts the world in the perfection of naming, yet a foreign language reveals the inexhaustibility of the world with regard to the capacities of language. Prospero, the author, the defender of purity, teaches Caliban to name the Sun and the Moon. When asked what naming things is, Heidegger once responded:

The naming call bids things to come into such an arrival. Bidding is inviting. It invites things in, so that they may bear upon men as things. ${ }^{6}$

If what belongs to the "sky," "day," and "night" is to appear in the consciousness of the native language, it will appear through a foreign element. This lies at the basis of both the phenomenological (Heideggerian) and deconstructive (Derridean) methods, choosing translation and the processes involved in it as the primary fields of philosophical inquiry. Answering a question about the meaning of the word bauen, Heidegger resorts to translation into Old English and Upper German, and, in an etymological game, combines bauen with the verb "to be" (ich bin) and the Latin noun cultura, in order to demonstrate that bauen means "to dwell," a meaning which belongs to the sphere of silence in the shadow of the dictionary meaning of bauen as "to build."

Heidegger's procedure involves three instructions:

1. every meaning is a translation, an idea well rendered in the word play between the Polish expressions "tłumaczyć/przetłumaczyć/wytłumaczyć" [translate, explain IMPERF/translate PERF/explain PERF]; or the double meaning of the English "interpreting".

2. every translation goes through many languages and associative territories;

3. translation does not establish the truth once and for all, but merely unveils it for a brief moment, gives it a voice, and then silence falls.

The truth of translation is truth conceived as aletheia, not homoiosis - i.e. we understand it as an oscillation between what has suddenly been unveiled and the murky sphere that conceals many other meanings. The truth of translation must recall the silence that resounds in every word that is spoken' this silence

6 M. Heidegger, Poetry, Language, Thought, trans. A. Hofstadter (New York 2013), p. 197. 
is inhabited by other recollections and other words. Heidegger's English translator, William Lovitt, reminds us of this constantly. Here is one of his cautions regarding the term das Ge-stell:

Stellen embraces the meanings of a whole family of verbs: bestellen (to order, command; to set in order), vorstellen (to represent), sicherstellen (to secure), nachstellen (to entrap), verstellen (to block or disguise), herstellen (to produce, to set here), darstellen (to present or exhibit), and so on. In these verbs the various nuances within stellen are reinforced and made specific. All these meanings are gathered here in Heidegger's unique use of the word that is pivotal for him, Ge-stell (Enframing).?

Even a proper name is included in the translation game; translation opens it to the workings of a pun that can only be preserved in the native language: take $\mathrm{Mr}$. Choakumchild from Dickens's Hard Times, who appears in an older Polish translation as pan Dławibachor, ${ }^{8}$ which keeps the linguistic associations contained in the English original, but at the same time it interferes with the author's intention (the translator presumes that this surname is not accidental, that it alludes to the character's personality).

A proper name is something that presupposes familiarity, knowledge, and the confidence of possession: a proper name excludes presence, and thus eludes translation. But the translator listens to the calls resounding in words. He defends foreignness. For the translator, even a proper name is foreign, as language ceases to be an expression of human thought, a cognitive tool, as Heidegger as demonstrated, and begins to speak for itself. The translator listens to the language, not the author speaking.

At the opening of his bizarre, multilingual book Glas, Jacques Derrida includes his deliberations on Hegel, but he begins them (or does he really "begin," given that Glas, like Finnegans Wake, has no "beginning" or "end," and begins with a lowercase letter) with a question: Qui, lui? Is the answer "Hegel"? Who would even hazard a comprehensive answer, if the philosopher's surname, which ought to be doubly beyond the possibility of translation (as a proper name and as a part of a science called philosophy, synonymous with wisdom), has already been translated, and doubly at that (from a proper name to a common one, and from German to French). Through a game of signifiants, Derrida's jouissance has changed Hegel into a parody of the Nietzschean figure of the eagle soaring

7 M. Heidegger, The Question Concerning Technology, trans. W. Lovitt (New York 1977), p. 15.

8 This remark appears in a footnote to Apollo Korzeniowski's 1866/1867 translation. Qtd from: C. Dickens, Ciężkie czasy (Warsaw 1955), p. 20. 
through the icy mountain air: the Derridean eagle seems encased in a block of ice.

"His name is so strange" (Son nom est si étrange), Derrida writes. Small wonder, given that the French pronunciation (another translation - from semantics to phonetics) turns Hegel into aigle and gel.

From the eagle it draws imperial or historic power. Those who still pronounce his name like the French [à la française] (there are some) are ludicrous only up to a point: the restitution (semantically infallible [...]) of magisterial coldness and imperturbable seriousness, the eagle caught in ice and frost, glass and gel [laigleprisdans la glace et le gel]. ${ }^{9}$

With this image of the eagle encased in frozen water, trapped in ice, the eagle of philosophy resting in an ice-cold crypt, we return in somewhat parodistic form to the Nietzschean concept of einverleiben. The translation "incorporates" the "original" text. It devours and consumes it, feeds on it (this meaning lives in the German reflexive form of sich einverleiben, "to eat or drink something," as well as in the noun Genuß, which Nietzsche used in the same passage). At the same time, given the still active notion of the author as the highest sanction, quasidivine presence, this act of consuming the "original" text is a ritual act, in which a totemic animal is sacrificed. According to Freud's interpretation of the totem, this concept brings together all the attributes of an author: paternal authority and the ambivalent feelings toward him.

The totemic animal, as Freud states in his Totem and Tabu (1913), echoing Robertson Smith, can be sacrificed to the gods with which it is identified. Translation, therefore, is a sacrifice of the "original" text in place of the author, whose text is his child, a totemic animal.

Another restriction concerning the totem (the first, let us recall, prohibits acts of aggression against the father/author) is the taboo on relationships with women belonging to the same totem. We have seen how, in The Tempest, Caliban - the figure of the translator stripped of the certainties of existence by Prospero's foreign language - is punished for attempting to rape Miranda.

In the context of this Freudian analysis, the translator's situation thus emerges as follows: he competes with the father/author by whom he has been, to some extent, created, for the text/daughter (Miranda in The Tempest), which plays the object of desire. Thus, incorporation (einverleiben) is a form of sacrifice made in order to reconcile oneself with the father, the author, God; and simultaneously, it is a substitute burial of this many-headed creature, so that the translator can seize the text in his name alone (one "struck out the name of the poet and replaced it

9 J. Derrida, Glas, trans. J. P. Leavey, R. Rand (Nebraska 1990), p. 1. 
with one's own - not with any sense of theft," Nietzsche writes in the last sentence of his meditation on translation).

Incorporation now becomes a combination of the act of putting the text in the crypt of another language and a mourning ceremony, an act of grieving. The "original" text, cannot, as it were, be abandoned to its own fate and its own language like other "normal" statements in the native language; the text that was the object of conflict between the author and the translator; the text that played the role of pharmakon and a totemic animal. In their enactment, these roles inevitably lead to death; the text is absorbed by the language of the translation, surrounded by other sounds and words, which, at the same time, are the words that bemourn the death of the text. The text is laid into the coffin of the translator's native language.

When I read a text in the "original" it is dissolved, as it were, internalized through my work as a reader. When I do the work of a translator I begin to ask the text questions that reaffirm it as an object; but at the same time, in face of the aura of death that surrounds this object, they make the answers come as voices "from beyond the grave." Then I have to deposit or bury ${ }^{10}$ the text in order to perform a mourning ceremony through the gesture of translation. The text returns, naturally, animated by questions (much as repressed experiences return through a psychoanalyst's questions), summoned by other texts; it returns as a "foreigner," as an "alien body," a "living dead."

Translated by Soren Gauger

10 Untranslatable play on words in Polish: przechować (store, deposit) and pochować (bury) [translator's note]. 
Seweryna Wysłouch

\section{Film Adaptation as Intersemiotic Translation}

The ties between literature and film have often been considered from various points of view. Over the last fifty years, film has struggled for autonomy, freeing itself from literature's hegemony; this has changed the views on the mutual relationships between these two arts. Initial assertions about influences and genetic dependencies, and then about film's structural and functional links with literature ${ }^{1}$ have given way to the opposite thesis, emphasizing film's role as an inspiration for the avant-garde movements of twentieth-century art. $^{2}$ In the panorama of film theory, there are also exponents of the parallel development of the two art forms $\mathrm{s}^{3}$ and even tentative suggestions of the mutual relationships and conditioning of literature and film in European culture. ${ }^{4}$ One aspect of this broad subject area concerns film adaptations of literary works.

A great deal has already been written on adaptations, from both the historical and the theoretical perspective. Apart from the longer or shorter articles ${ }^{5}$ our literature also boasts two monograph books: Władysław Orłowski’s From Book to Screen ${ }^{6}$ and Maryla Hopfinger's Film Adaptations of literary works.

1 See: M. Marcjan, M. Salska-Kaca, “Koncepcja 'przyliterackości' filmu w teorii Bolesława W. Lewickiego.” In: Dzieło filmowe - zagadnienie interpretacji, ed. J. Trzynadlowski (Wrocław 1987).

2 A. Hauser, "Pod znakiem filmu." In: Społeczna historia sztuki i literatury, trans. J. Ruszczycówna, Vol. 2 (Warsaw 1974). Following Hauser's lead, the filmic provenance of contemporary narrative techniques was underscored, in particular the shaping of time (I have written about this in Problematyka symultanizmu w prozie (Poznań 1981), pp. 152-154). On the influence of film on the work of the Polish avant-garde of the 1920s, see: W. Banaszkiewicz, W. Witczak, Historia filmu polskiego, Vol. 1 (1895-1929), Warsaw 1966.

3 A. Jackiewicz, "Proces literacki a film." In: Proces historyczny w literaturze i sztuce. Materiały konferencji naukowej, ed. M. Janion, A. Piorunowa (Warsaw 1967).

4 M. Hopfinger, Adaptacje filmowe utworów literackich. Problemy teorii i interpretacji (Wrocław 1974), pp. 26-68.

5 These are listed in the bibliography compiled by Andrzej Gwóźdź: "Polski film fabularny $\mathrm{w}$ relacjach z innymi sztukami. Wybór polskich publikacji z zakresu metodologii, teorii, estetyki I krytyki filmu z lat 1945-1977, dotyczących powojennej kinomatografii polskiej (bibliografia)." In: Film polski wobec innych sztuk, eds. A. Helman, A. Madej (Katowice 1979).

6 W. Orłowski, Z książki na ekran (Łódź 1974). 
Theory and interpretation ${ }^{7}$ which treats film adaptation as intersemiotic translation. Today, we can already observe a certain exhaustion with the issue of adaptation and "literature-centrism," as the juxtaposition of works of film and literature seems to privilege the literary-theory perspective, and breaks little new ground. Edward Balcerzan has postulated the alternative of studying the literary origins of film, i.e. tracing the transformations of themes and motifs

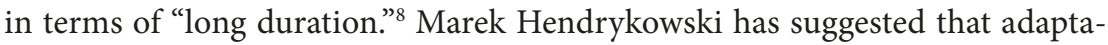
tion is only one of many possible variants for dialogue between film and literature, and that the correspondences should not be studies on the level of the text itself, but the whole of literary culture. ${ }^{9}$ Yet the most comprehensive attack on "adaptology" has come from Alicja Helman. ${ }^{10}$ In her view, the fact of adaptation does not determine anything; the value and rank of the literary work does not translate into the value of the film, whose quality is independent of the model it is based on - films polemical towards their literary sources are often successful. Furthermore, an adaptation in no way differs from an original film; it does not have its own poetics, it can only be recognized as an adaptation if one knows the literary source. Essentially, then, it is the viewer's knowledge that is all-decisive. ${ }^{11}$ According to Helman, "film does not adapt literature but uses it." 12 Given the difference in material, this use cannot be covered by a universal model. There are no principles of transcription or equivalence between literary and film signs, and so we cannot speak of intersemiotic translation. This undermines the theoretical approach to adaptation once and for all. Nonetheless, I should like to return to it, because adaptation is a convenient point of departure for juxtaposing literary and film signs, and it should provide an answer as to whether sign translation is possible, and whether we can speak of intersemiotic translation in this case.

7 Hopfinger, Adaptacje filmowe utworów literackich.

8 E. Balcerzan, "Gdy film rozstaje się z literaturą." In: Kręgi wtajemniczenia (Krakow 1982).

9 M. Hendrykowski, "Zagadnienie kontekstu literackiego filmu (na przykładzie polskiej szkoły filmowej)." In: Film polski wobec innych sztuk, pp. 44-60.

10 A. Helman, "Modele adaptacji filmowej. Próba wprowadzenia w problematykę," Kino 1979, No. 6.

11 Helman elaborates on this in "Adaptacje filmowe dzieł literackich jako świadectwo lektury tekstu" (a lecture delivered at the Semiotics of Literary Culture conference, IBL, Warsaw 1984).

12 Helman, "Modele adaptacji filmowej," p. 28. 


\section{The Phenomenon of the Plot}

That the arts employ plot is beyond dispute. It is plot - the fictional characters and events - that seems to link literature, film, and even painting. Jerzy Ziomek has claimed that there is something like a class of plot-based arts that oppose the class of poetic arts. ${ }^{13}$ The universality of plot comes from its non-linguistic nature. Plot is a higher semantic figure ${ }^{14}$ formed beyond the material; it can be articulated in various languages. It is reconstructed by the viewer/reader through integrating lower-level units. A well-known film theorist, Christian Metz, initially even ascribed the central role in films to plot, claiming that the essence of cinematic language is the narrative structure; he sought syntactic rules at the level of the plot. ${ }^{15}$

Let us ask, then, how adaptation shapes the original plot. As an example, we shall take a passage from Maria Dąbrowska's Nights and Days: ${ }^{16}$

One time, during an outing, our whole group were resting on a knoll by the river. Part of the riverbed was overgrown with blossoming water lilies, which Miss Barbara admired greatly.

'What a shame,' she said, 'that we cannot pick them. Józef Toliboski looked at her and, saying nothing, without so much as a smile, as if it were less a whimsical joke than a grave testimonial of his readiness for anything, waded into the river up to his elbows, and returned with a handful of heavy white flowers. The others on the riverbank spent the whole while jesting, doubled over in laughter, and Barbara wept. After this event she was all the more pleased when Józef was among the guests. ${ }^{17}$

13 J. Ziomek, "Powinowactwa przez fabułę." In his: Powinowactwa literatury. Studia i szkice (Warsaw 1980), pp. 10-11.

14 J. Sławiński, "Semantyka wypowiedzi narracyjnej." In: Dzieło, język, tradycja (Warsaw 1974).

15 C. Metz, "Zagadnienia oznaczania w filmach fabularnych (Przyczynek do semiologii filmu)" trans. M. R. Pragłowska, KulturaiSpołeczeństwo 1967, Vol. 11, No. 1. Metz later withdrew from this view and stressed a multitude of codes; see: C. Metz, Langage et cinéma (Paris 1971).

16 Maria Dąbrowska (1889-1965) - Polish novelist, playwright, essayist and journalist. Author of the historical epic and family drama Nights and days (Noce i dnie, 19321934). The film based on Dąbrowska's novel was nominated for an Academy Award For Best Foreign Language Film in 1977 [editors' note].

17 M. Dąbrowska, Noce i dnie, Vol. 1 (Warsaw 1975), p. 15. Hereafter NiD with page number. Translated by S.G. 
This laconic episode with water lilies appears only once in Nights and Days. This is not the case in the film adaptation by Jerzy Antczak (1975). ${ }^{18}$ The terse discourse is translated into an impressionistic image that is a visual concretization of this scene. Not only the protagonist's gesture is important, but also his garb: his snow-white suit sacrificed for Miss Barbara's whim emphasizes his determination. This vivid image shows the beauty and poetry of the moment, and is far more expressive than its literary source. As such, the plot is "the same," yet not "the same." Not only has it been transposed from literature to film, but also modified in a special way, and this modification is inevitable: it has nothing to do with translation "fidelity" or "infidelity," but results from the very nature of the film medium. The term "transcription" is quite suitable here, as it is used in linguistics, cartography, or music - recording a phenomenon in a sign system different from the original's "native" one, presupposing inevitable transformation.

The term "transcription" has found its way into translation theory as well. Jerzy Ziomek defines it as "adaptive approach, which respects differences of experience," and sees it as one of four types of equivalence (alongside transliteration, description, and loan). Its aim and ideal is correspondence on each of the sign's three levels of meaning: 1. correspondence of semantic relations (semantic equality), 2. correspondence of syntactic relations (equality of form), and 3. correspondence of pragmatic relations (equality of value).$^{19}$

Are there any rules for plot transcription? We could theoretically transfer all the novel's episodes and motifs to the screen, but the plot needs to be transformed further to accommodate the limited duration and the viewer's endurance. Its supralinguistic nature means that these transformations occur in terms of the rhetoric, not the "grammar." We can thus distinguish four basic rhetorical operations that modify the plot to achieve the adaptation's semantic equality, equality of form, and equivalence with respect to the original. These are:

1. detraction (the reduction of parts)

2. permutation (the inversion of parts)

18 Noce i dnie: Part I "Bogumił i Barbara," Part II "Wiatr w oczy." Scriptwriter and director: Jerzy Antczak, cinematography: Stanisław Loth, music: Władysław Kazanecki, featuring: Janina Barańska (Barbara), Jerzy Bińczycki (Bogumił), Karol Strasburger (Józef Toliboski), Elżbieta Starosiecka (Teresa Kociełłowa), Stanisława Celińska (Agnieszka), and others. Kadr Group 1975. Antczak also filmed a thirteen-episode TV version of Nights and Days (based on a different script), which I am not analyzing here.

19 J. Ziomek, "Przekład - rozumienie - interpretacja." In his: Powinowactwa literatury, pp. 185. See pp. 167-190 in the present volume. 
3. substitution (the exchange of parts)

4. addition (the supplementation of new parts)

Translation theorists see these operations as transformations resulting from systemic differences between the languages of the translation and the original, as well as differences between the artistic languages and individual styles. ${ }^{20}$ All these modifications can be easily explained using any example of film adaptation; they always raise the greatest controversies among critics. They oscillate between two extremes: "fidelity" to the text and interpretive "freedom." Reduction and inversion veer closer to the extreme of fidelity, while substitution and, above all, addition, suggest a freedom of approach to the subject.

Works on adaptation prove convincingly that methods of literary plot transcription are historically defined. In her overview of Polish film adaptations up to 1967, Maryla Hopfinger distinguished several phases: 1919-1929, 1930-1939, 1947-1955, 1956-1961, and 1962-1967. ${ }^{21}$ These periods were marked by certain choices in the literary works (preferred themes and poetics), ways of using the literary text (the role of interpretation), and above all, the selection of cinematic language (the word-based verbal type or the audiovisual type). Although external factors (e.g. cultural politics or literary movements) indisputably have an impact, we might speak of adaptation conventions in which the type of plot transformation plays an important role.

We should add that apart from the plot, the novel's dialogue is also transcribed; it must be adapted to communicate information through film, becoming a cinematographic event. ${ }^{22}$

But even the most faithful plot transcription does not guarantee that the adaptation will capture the "spirit of the original." This was demonstrated by Władysław Orłowski, who analyzed the TV adaptation of The Office (1963, dir. Andrzej Szafiański) and the film versions of The Shared Room (1960, dir. Wojciech Has) and Stanisław Dygat's The Farewell ${ }^{33}$ (1958, dir. Wojciech Has). The reason is that a novel is not just the plot alone; even where it seems to be the constitutive

20 See: E. Balcerzan, Styl i poetyka twórczości Brunona Jasieńskiego (Wrocław 1968), p. 38, and Oprócz głosu (Warsaw 1971), p. 243.

21 Hopfinger, Adaptacje filmowe.

22 See: M. Hendrykowski, "Słowo w tekście filmowym." In his: Słowo w filmie (Warsaw 1982); cf. W. Orłowski, Z książki na ekran, pp. 78-87.

23 Orłowski, Z książki na ekran. The Office (Urzą, 1960) - psychological novel by Tadeusz Breza (1905-1970); The Shared Room (Wspólny pokój, 1932) - roman à clef by Zbigniew Uniłowski (1909-1937); The Farewell (Pożegnania, 1948) - satirical novel by Stanisław Dygat (1914-1978) [editors' note]. 
element, the way its events are narrated also suggests important meanings (e.g. the metaphorical significance of the office in Breza's novel, or Dygat's irony). The problem, therefore, is the substance of language, the discourse, which cannot be mechanically translated into images. ${ }^{24}$ Hopfinger calls this part of the work the level of building material; it determines the specifics of the art form and is untranslatable, unlike the building material-semantic level, which is partly translatable, and the semantic-cultural level, which is translatable. ${ }^{25}$

But every translator knows that if something has no direct equivalent in another language, and is untranslatable in the literal sense, he must find a different suitable equivalent. How does this work in film adaptation ${ }^{26}$ Can we set any rules for the equivalence of signs? Before we answer this question, we ought to hone our concept of the sign in literature and in film.

\section{The Literary Sign - The Cinematic Sign}

As Roland Barthes once put it, literature is a parasitical system that feeds on language. It uses language signs as a raw material, sparking a wealth of connotations. What serves as a sign (signifiant + signifié) in a natural language suddenly becomes part of another structure - the literary work - and serves as a signifier (signifiant), opening a field of new meanings (artistic, ideological, philosophical). ${ }^{27}$

The concept of literature as a second-order system allows us to focus on how it differs from language - on its own special means of expression. Yuri Lotman has phrased this most aptly:

To say that literature has its own language, one which does not coincide with its natural language but is superimposed on that language, is merely another way of saying that literature possesses an exclusive, inherent system of signs and rules governing their combination which serve to transmit special messages, not transmittable by other means. ${ }^{28}$

24 Władysław Orłowski tried such an experiment, attempting to translate a few pages of the novel Wspólny pokój into the language of film.

25 Hopfinger, Adaptacje filmowe.

26 I am only considering film adaptations. According to scholars, TV adaptations, which prefer the code of language, are closer to the spirit of the original than film adaptations (Orłowski, $Z$ ksiażki na ekran, p. 237). The television series, taking a more pious approach toward the literary text, has opened a new chapter of relations between cinema and literature (W. Wierzewski, "Ekranizacje rodzimej klasyki literatury w powojennej twórczości filmowej.” In: Film polski wobec innych sztuk, pp. 36-37).

27 Roland Barthes showed this process based on the example of another second-order system - the myth; see his Mythologies, trans. A. Lavers (New York 1972).

28 J. Lotman, “The Language of Verbal Art.” In his: The Structure of the Artistic Text, trans. R. Vroon (Ann Arbor 1977), p. 21. 
Literary signs are, therefore, second-order signs. They are created from linguistic signs organized in a special artistic fashion. This means that not every language sign is a literary sign (e.g. a single word). It becomes one only when it is marked, loaded with extra meaning (e.g. an opaque poetic word). The literary sign can be built of many language signs and be a higher semantic figure, like the speaking "I," time, or space.

Can literary signs undrerstood in this way be compared with film signs? And what is a film sign anyway?

The sign in film has been the subject of much debate, because it is closely linked to the concept of film construction. The status of the basic unit depends on what the scholar considers to be the essence of the work. This is why the thesis of the multi-code structure of film (combined with a critique of the linguistic standpoint) led Christian Metz to negate the very concept of the film sign. According to Metz, there is no such thing as a signe cinématographique, ${ }^{29}$ because there is no one sovereign code in film. Numerous codes weave together, and we can only speak of minimal units that are parts of particular codes, and have various shapes and dimensions depending on the code's specifics. For example, the smallest unit of language is the phonem; of myth, the character or motif; and the smallest unit of the technological code is the photogram. Minimal units link up like shingles: tightly fitted, they overlap. ${ }^{30}$

Seeing film as a multi-code phenomenon, Metz immeasurably multiplied the number of codes, and abandoning the concept of the sign, he relegated the issue of connotation to the background. ${ }^{31}$

Can we, therefore, speak of film signs? Adopting the general concept of the sign as an object that serves a semantic function, Łukasz A. Plesnar has proven that we can. ${ }^{32}$ But the conceptual layer of film that he proposed is based on the

29 Metz differentiates between the adjectives filmique and cinématographique. The latter refers to the properties of the code (or codes), while the former is a broader concept, including all the specific and non-specific attributes of filmic expression (the signifiant of the message). See his Langage et cinéma, pp. 33-36.

30 Metz, Langage, pp. 139-156.

31 Metz speaks, for instance, of an identification code for objects, audiovisual composition, sound composition, perceptual analogy, expression, mechanical images, montage, iconic nomination, content, movement etc. Later, influenced by psychoanalysis, Metz addressed the issue of the signifiant. See A. Helman, Stownik pojęć filmowych, Vol. 1 (Wrocław 1991), pp. 91-92.

32 See Ł. A. Plesnar, Semiotyka filmu (Krakow 1990). 
perception of sensory data, ${ }^{33}$ which inevitably highlights denotation, neglecting the specific nature of cinema.

What should we see as a film sign? The smallest unit of the narrative code, i.e. the film sequence (as Metz once suggested), or a moving iconic sign, as Umberto Eco preferred ${ }^{34}$ Neither of these solutions is satisfactory. The narrative sequence is too large a unit, and the icon so small that the path from a single sign to an entire film seems impossibly long. Hanna Książek-Konicka’s reflections contained in Semiotics and Film ${ }^{35}$ are interesting and instructive in this respect. They are based on Eco's analyses of the icon, challenging its "natural" character and its "similarity" to the signified object, and showing that recognizing the icon as a sign depends on the addressee's knowledge and ability to "read" signs, i.e. on our culture's codes of perception and recognition. ${ }^{36}$ The matter is important, because it determines the concept of the icon: whether it should be seen not only as having a motivated referential meaning, but also a high connotative potential.

Hanna Książek-Konicka expands on Umberto Eco's thoughts, drawing from psychological laws and descriptions of the phenomena of visual perception. She sees the sign as non-identical to the object it designates or the image that appears on the retina, because this image undergoes double correction: by the sensory experience of the individual and by the brain's correctors, which decode and revises even faulty images as representations of reality (e.g. sensory illusions). Thus, Książek-Konicka writes, "the icon is not the result of a simple reproduction of the visual form of an object, but comes from a translation of the total content of the sensory experience concerning this object into visual signals." ${ }^{37}$

This translation is executed through perceptual patterns in the brain that contain selected attributes of the model; this ensures the universal comprehensibility of signs:

Dictionaries of icons are unnecessary, because these signs, firstly, enact a subsystem of perceptual patterns, whose "card catalogue" $[\ldots]$ is found in the gnostic field of the

33 Plesnar distinguished between the following layers in film: representing (the set of visual and audio stimuli), recorded (the reconstructed reality), represented (the fictional universe), and communicated (the meaning). See Ł. Plesnar, Semiotyka filmu, Sposób istnienia i budowa dzieła filmowego (Krakow 1990).

34 Views on the film sign are more widely discussed in H. Książek-Konicka, Semiotyka i film (Wrocław 1980); A. Helman, Stownik pojęć filmowych, Vol. 1, Język, znak, denotacja - konotacja, identyfikacja.

35 Książek-Konicka, Semiotyka i film.

36 U. Eco, Pejzaż semiotyczny (Warsaw 1972).

37 Książek-Konicka, Semiotyka i film, p. 119. 
brain of every person with perceptual capacity and ability. This means that a practically unlimited number of possible enactments, facultative variants on the pattern, does not impede their recognizability. ${ }^{38}$

According to Książek-Konicka, individual icons connect to form a "pictorial syntagma," which contains objective and extra-objective perceptual patterns, and has its own rules of combination. Pictorial syntagmas, in turn, can create a "multi-image utterance"; examples include photo novels, comics, and film.

We can raise one basic objection to this concept: it misses the essence of the art of film. The motion of the iconic sign in film, which distinguishes it from the other visual arts, vanishes here, becoming theoretically irrelevant. The proposed rules function in every pictorial utterance; it is not by chance that the author cites reference literature on drawing and photography. How is film unique in this approach? Because the pictures are linked? Have we returned to Metz's theory, criticized before?

I believe that Książek-Konicka, rather than describing the filmic code, spoke of the visual code, whose nature is entirely unlike that of (verbal) language but which, like language, is a primary system. For there is no reason to claim that verbal language is the only primary system and the sole basis for the development of other communication systems. There are far more arguments for the claim that at least two basic primary systems developed in the process of social progress, based on different receptors and using different signs: verbal and visual. The secondary systems feed on the primary systems, using the connotative potential of signs. Literature is a secondary language-based system, while film, in turn, is a secondary system based on the visual code.

Film is unique in that it is based on moving images and multiple codes, i.e. using other codes (e.g. language or music), which, however, are not equal or equally important: the basic (visual) code prevails.

The systemic nature of the film code can be seen as opposed to "ordinary" visual perception, to the convention of the visual code. It includes the rules for the mutual relations between codes involved in the utterance, that is the "grammar" of film language, the particularly shaped ways of "film speaking". This approach allows us to highlight connotation and provides a theoretical basis for making comparisons between the arts.

38 Książek-Konicka, Semiotyka i film, p. 229. The author's views converge with 1980 theses of Italian semiotician Paul Bouissac, who, based on the psychophysiology of sight, regards the icon as a genetically programmed selective tool. See P. Bouissac, "Iconicity and Pertinence." In: Iconicity, ed. P. Bouissac et al. (Tübingen1986), pp. 193-213. 
Both film and literature are second-order utterances, then, but based on a different primary system. Consequently, the film sign, like the literary one, is a second-order sign, a special organization of visual signs that, without losing their signifying functions within the utterance, mean more: they acquire additional psychological, philosophical or metaphysical connotations. This, too, is how Roland Barthes conceived of the nature of film, as creating "the third meaning," beyond the symbolic and cultural meaning. ${ }^{39}$

The ontology of film signs is thus the same as in the case of literary signs: they are built onto a primary system and they are rich in meaning, resulting from semantic, syntactic, and pragmatic references. They differ in the material and the structuring rules inherent to every art. Is it possible to translate signs? And how? Let us consider this issue using several examples.

\section{Narrative Distance}

Zofia Woźnicka thus characterizes storytelling in film:

Another special attribute of film storytelling is that film is generally a narrative with a hidden narrator. Unless there is an off-screen commentary, even when the entire work or some of its parts are in some way attributed to particular narrators, the sphere of the narration and the narrated world are not clearly distinguished or juxataposed; the narrator's personality is not clearly outlined, and the narrative distance diminishes. The photographic, reproductive nature of the representations, which foregrounds the concreteness of the "presented world,", creates a sense of things happening now, making visions and recollections seem real. ${ }^{40}$

The narrator, the narrative distance, and time - the basic categories of epic literature, which determine the way in which phenomena are presented and assessed, the anticipation of the future and the disintegration of the past - are foreign to the nature of film. Most significant of all is the treatment of time. Language is capable of creating temporal oppositions, and the literary work uses this capacity in a variety of ways. Film is different. The visual code has nothing that could serve as analogous to verb forms, ${ }^{41}$ which is why there is a consensus among film theorists that the presented events seem to be happening in the present. ${ }^{42}$ So how does film show the basic temporal oppositions?

39 See R. Barthes, "Le troisième sens." In his: L'obvie et l'obtus. Essais critiques III (Paris 1982).

40 Z. Woźnicka, Problemy kreacji i reprodukcji w filmie (Wrocław 1983), p. 227.

41 Książek-Konicka, Semiotyka i film, p. 223.

42 See S. Kracauer, "Interlude: Film and Novel." In his: Theory of Film (New YorkOxford 1960), pp. 232-244; A. Laffay, “Opowiadanie, świat, kino," trans. S. Kowalski, 
Let us return to the example of Dąbrowska's Nights and Days and Antczak's film adaptation of this novel. The plot is narrated from a considerable chronological distance and covers the history of the whole generation following the Uprising. ${ }^{43}$ But the novel's narrator does not foreground the narrative situation; on the contrary, it is concealed, so that the opposition between the present and the past is blurred. ${ }^{44}$ Such a narrative situation seems convenient for a film adaptation; nevertheless, Antczak radically changed it, introducing a narrative frame that destroys the chronology of the novel and creates a sharp distance between "then" and "now": fleeing from burning Kaliniec in the first days of the war, Barbara reminisces about her life. The frame opens and concludes each of the two parts of the film and recurs in the course of the film, emphasizing the distance from the past. Why? Is this device justified?

The blurring of time contrasts in the novel's narrative does not mean that its chronology is one-dimensional; not with Dąbrowska's narrative style, sententious discourse, and aphorisms shaped as universal truths. In the words of Janusz Sławiński:

Through the generalizing formulations which, scattered throughout the narrative, allude to this hidden sphere, the concealed dualism of the epic performance is momentarily revealed. The narrative situation emerges from its hiding. To be more precise, a part of it emerges which we might call the work's "super-consciousness." We have in mind the plane of rules and ethical values professed by the narrator and treated as directives of the presented world, as norms of selection, combination and evaluation of the narrated events, in a word: the "metalanguage" of the book, its system of moral principles, with respect to which the protagonists' experiences are only one possible world, one of its probable manifestations, not the sole or ultimate manifestation. ${ }^{45}$

This narrative manner thus produces a special type of distance from the presented world, facilitating general, philosophical and moralistic reflections. However, Antczak ascribed this narrative superconsciousness and reflexivity to Barbara. Her words after Uncle Klemens's death: "I don't understand why all this goes on, passes..." (NiD, p. 60) are key to the film, ${ }^{46}$ justifying the narrative frame that

Pamiętnik Literacki 1975, Vol. 2; J. Lotman, Semiotics of Cinema, trans. M.E. Suino (Ann Arbor 1976).

43 The January Uprising (1863-1864) - a Polish insurrection against the occupation by the Russian Empire [editors' note].

44 See J. Sławiński, "Pozycja narratora w Nocach i dniach Marii Dąbrowskiej.” In: Pięćdziesiąt lat twórczości Marii Dąbrowskiej, ed. E. Korzeniewska (Warsaw 1963), p. 96.

45 Sławiński, "Pozycja narratora," p. 85.

46 The director mentioned this in an interview (D. Karcz, "Odwołuję się do sfery uczuć. Rozmowa z Jerzym Antczakiem”, Kino 1975, No. 12, pp. 12-17). 
makes us aware of the transience of people, things, and the world. As Ryszard Matuszewski put it:

A screen adaptation of a great epic work, whose main virtues lie in the author's reflexive commentary and the psychological nuance of the prose that lazily meanders among gray and ordinary people and events, is undoubtedly more hazardous than most film adaptations of literary masterpieces.

But here we had a heartening surprise. [...]

Director Jerzy Antczak clasped the sprawling plot of the book Nights and Days with the compositional brackets of the novel's concluding episode: World War One breaks out, Kaliniec is burning, and with it, the entire world of Nights and Days, while Barbara, clattering along in old Szymszel's cart, sees and contemplates all her past life. A simple, splendid idea, giving the whole thing the dimensions it requires - a sense of the epic, a view of life from afar that one gets in recalling things that are remote and finished. ${ }^{47}$

The narrative framework that reverses the chronology of events and shows the protagonist at the end of her life becomes a film sign equivalent to the narrative structure of the novel and its philosophical meanings. In a filmic manner, it reproduces the syntactic relations between the literary signs and thus fills the condition of equality of form and semantic equality (it does not go beyond the plot). ${ }^{48}$

\section{Narration}

Like every epic work, Nights and Days communicates many events, and especially mental experiences, in a discursive fashion. Barbara's quandaries and complexes, her romantic disappointment in early years, which weighed on her psyche and to which she continually returns in her mind, are scrupulously detailed by the narrator. During Barbara's stays in Warsaw and in Krępa (this fills only half of the novel's first volume) the narrator signals Toliboski's "returns" of eight times:

[...] Bogumił came for her the following day in a remarkably beautiful, glistening sleigh. They sat in together on frozen navy-blue cushions amid the tinkling of bells, nestling their legs in between the locks of a gorgeous cloth-lined sheepskin. The sleigh gave a soft jerk, making them tilt backwards, and off they glided along the sparkling silver road with a swish. Barbara earnestly regretted that J. T. was not there to see her. (NiD, p. 33) Sometimes she tried, on this or that occasion, to think: Why hadn't he turned out to be like this, the one I had loved in vain for eight years? Or the contrary, she would see how

47 R. Matuszewski, "Filmowe Noce i dnie." In: Z bliska. Szkice literackie (Krakow 1981), pp. 339-340.

48 Antczak abandoned the narrative frame in the television adaptation. 
impoverished Bogumił's words of love were compared to the things that Józef Toliboski knew how to say. (NiD, pp. 73-74)

She took a look around. Oh, how she missed that pair of steel-gray eyes, cool yet caressing, and the black hair, and the black beard that ringed the naughty, scarlet lips. (NiD, p. 100; cf. pp. 30-31, 42, 89, 101, 107.)

These nagging memories of the old amour become significant on the psychological and characterological level, which means the adapter had to find a way to work them in. He did so by translating discourse into images, giving it the status of a film sign. Two images featuring Józef Toliboski are extraordinary enough, and so incessantly recurring, that they rise to become film signs. One of them is the picking of the water lilies, the other has Toliboski dashing into the Niechcics' miserable dwelling in Krępa. The vision-like quality of this latter image is suggested by a sharp montage and an unnatural shot repeated several times (Toliboski running straight at the camera).

These signs are the equivalent of the discourse: they brilliantly render the semantic and syntactic relations of the novel's narrative. They only differ in pragmatic terms. Dąbrowska's transparent narration does not stir emotion in the reader; the Toliboski motif does not impose itself so insistently. In fact, it can even go unnoticed, as was the case with Stefan Otwinowski, who said: “The 'Toliboski refrain' in the novel is barely sketched out. Dąbrowska does not return to it so clearly and so frequently as the film's director. But this 'correction' of Dąbrowska is necessary for the film's structure." ${ }^{49}$

It was due to the pragmatic virtues of the sign that the critics preferred the Toliboski motif in the film to its literary source. Włodzimierz Maciąg commented:

$[\ldots]$ in my view, the Toliboski motif emerges as far more interesting and vivid on screen, where it is one of the main subplots. [...] I believe that Antczak's repetitions were quite necessary, for example the motif of Toliboski entering Barbara's house recurs at least a dozen times, each of which gave me aesthetic pleasure..$^{50}$

As with Barbara's recollections, Antczak found a purely filmic equivalent for the story about Piotruś, the Niechcics' first child. The images and sounds eliminated the words: filmed in an impressionist landscape, the scenes of playing with the child need no dialogue - they "signify" unlimited parental love and contrast with the later image of the cemetery dusted with snow and the recurring motif of Barbara at her son's grave. The meaning of the signs on the semantic and

49 "W rodzinie... w społeczeństwie... w historii... O Nocach $i$ dniach rozmawiają S. Balbus, W. Maciąg, M. Malatyńska, S. Otwiński," Życie Literackie 1975, No. 43, p. 5. 50 "W rodzinie..." 
syntactic level remain intact, only the means of expression change, determining the pragmatic aspect and evoking different responses in the audience.

\section{Poetic Language}

Jerzy Ziomek has contrasted "narrative literature" with "poetic literature." The former focuses on representing things and events; it strives for language transparency and imperceptible narration. The latter foregrounds the linguistic form, which becomes the source of additional, non-referential meanings. "The extreme of narrativity is the maximum transparency of language (or the code in general) with respect to the narrated events, while the extreme of poeticness is the minimum transparency, which results from the language being focused on its autonomous and egocentric organization in the text." ${ }^{1}$

Nights and Days falls on the narrative side of the spectrum; we might even join Julian Przyboś in acknowledging it as the very center of transparent Polish language..$^{52}$ The problems posed by translation of the plot and the narrative into the language of film are characteristic of adaptation - we might only say that they were solved with a varying degree of success. The "plot-based unity" have led many an adapter astray because, typically, it is traditional novels, in which the plot plays a major role, that have usually been adapted. ${ }^{53}$ This is why attempts to adapt works whose language is far from transparent, but which becomes a source of new meanings, seem all the more interesting. According to Edward Balcerzan, it is adaptations of this sort that provide a chance for contemporary cinema to revive film language and means of expression. In 1977, Balcerzan postulated the adaptation of works by Stanisław Ignacy Witkiewicz, Witold Gombrowicz's Ferdydurke, Miron Białoszewski's A Memoir of the Warsaw Uprising, and Edward Redliński's Konopielka. Witkiewicz, Konopielka, and Ferdydurke have already been done, so it is high time we considered the problem of translating "poetic literature." It is all the more complex in that, at the "building material level," it concerns internally diverse (one "poetic language" or many languages?) and inherently untranslatable literature. How is the adapter to deal with non-transparent language? Can he substitute it with film language? How? And to what effect? I will examine this issue on the basis of two successful

51 Ziomek, "Powinowactwa przez fabułę," pp. 10-11.

52 J. Przyboś, “Centrum polszczyzny." In: Pięćdziesiąt lat twórczości Marii Dąbrowskiej.

53 Władysław Orłowski points this out in $Z$ książki na ekran, p. 25. Edward Balcerzan has criticized the adaptors' traditionalism ("Gdy film rozstaje się z literaturą"). 
screen adaptations by Witold Leszczyński: Konopielka $(1981)^{54}$ and Siekierezada (English title: Axiliad1986)..$^{55}$

Edward Redliński's Konopielka ${ }^{56}$ fascinated audiences and critics with its "Rabelaisian language" 57 and unique take on reality. Maria Janion wrote:

Thumbing his nose at 'avant-gardism' and 'traditionalism,' reversing values so as to make the progressive seem backwards and the backwards quasi-progressive, and in general muddling concepts, emotions, and deeds that we ordinarily consider clear and unequivocal, Redliński presented his encapsulation of the 'peasant question' in Poland in a way never seen before, giving our literature an entirely new 'image of the peasant' and 'image of man. ${ }^{58}$

This encapsulation took place chiefly through the choice of the novel's artistic language. The work is one long monologue by the protagonist, an inhabitant of the village of Taplara for many generations, Kaziuk Bartoszewicz. This monologue is remarkable not only because it is stylized to resemble a dialect of the Polish-Belorussian broderland, but also because it expresses the peasant mindset and world of values, which is entirely different from the worldview of contemporary readers of literature.

The speaker reacts emotionally to the world, so the narrative is expressive, full of exclamations, calls, and questions, immediately recording everything that the protagonist thinks, sees, and feels (this explains the frequent use of the present tense and iterative forms):

54 Konopielka. Scriptwriter (based on the novel by Edward Redliński) and director: Witold Leszczyński; dialogues: Edward Redliński; cinematography: Zbigniew Napiórkowski; music: Wojciech Karolak. Featuring: Krzysztof Majchrzak (Kaziuk), Anna Seniuk (Handzia), Joanna Sienkiewicz (teacher), Jerzy Block (father), Franciszek Pieczka (grandfather, God), and others (see: Filmowy Serwis Prasowy 1982, No. 10).

55 Siekierzada. Scriptwriter (based on the novel by Edward Stachura) and director: Witold Leszczyński; cinematography: Jerzy Łukaszewicz, music: Antonio Vivaldi ("Amen" from Stabat Mater) and Jerzy Satanowski. Featuring: Edward Żentara (Janek Pradera), Ludwik Pak (Peresada), Danial Olbrychski (Michał Kątny), Krzysztof Majchrzak (Kaziuk), Franciszek Pieczka (ranger), Magdalena Żentara (Apple Tree Branch), and others (see: Filmowy Serwis Prasowy 1986, Nos. 18-19).

56 Konopielka (Konopielka, 1973), novel by Edward Redliński (b. 1940) belonging to the so-called "peasant current" in Polish literature, created by writers of rural origin and touching upon rural themes [editors' note].

57 A term used by Michał Sprusiński in Między prawdą a zmyśleniem (Krakow 1978), p. 41.

58 M. Janion, "Ludowość rozdwojona." In her: Odnawianie znaczeń (Krakow 1980), p. 298. 
She [Handzia - S. W.] went out milking, and till she gets back you can have a good sit, let your mind roam. I sit by the stove, nodding off or not, thinking or not, so sweet. The day begins all by itself, everything goes the way it should, like yesterday, like long ago, as it was in the beginning, is now, and ever shall be, world without end, amen.

But now:

But now footsteps and shouts from the yard: Raba's calved, come on Kaziuk, hurry up! Calved? How could she calve when Advent has only just began, she was in heat before St Adalbert's, she's due before the Christmas.

What are you babbling about, woman, I say, Raba's got almost a month left to go! [...] I make for the yard with long strides, peek into the trough, and sure enough: something black's lying in the straw, but under the fence that separates the cow from the mare, so that I see both both the cow and the mare licking it! What the devil's this freak show? ${ }^{59}$

Kaziuk's consciousness has no past nor future, everything happens "now" and will always be happening. Every action has been passed down for centuries and revived multiple times by the members of the community, with whom the protagonist has a strong family and neighborly bond. There is no place here for change or innovation. Yet Kaziuk's archaic, mythologized consciousness undergoes dramatic transformations in the novel. He is tempted by the "new" and, despite his resistance, he succumbs to it, which leads to conflict with the village. His monologue shows his quandaries in an ambiguous fashion, far from primitive moralizing, mainly thanks to the narrative style and the linguistic form. In an interview, Redliński confessed: "Language is philosophy, a worldview. When, after several years of attempts, I finally found the language or, more broadly speaking, the form for the content I wanted to communicate, the novel wrote itself, the work went quickly and was hugely enjoyable."60

How to translate such a monologue into the language of film? How to show the protagonist's inner self, an archaic way of seeing and experiencing the world, if the camera sees him from the outside? Witold Leszczyński suggested Kaziuk's primitive consciousness in the film's opening sequence. Making an inversion of the plot, he showed the protagonist's dream about meeting God and the Virgin Mary on the border between fields. Naturally, they treat him kindly and want to make his dreams come true... The plot inversion seems intentional; it introduces

59 E. Redliński, Konopielka (Warsaw 1974), pp. 12-13. Translated by S.G. Hereafter K with a page number.

60 "Raczej krowy na wygonie niż kossakowski koń...," Edward Redliński in conversation with Teresa Krzemień, Kultura 1977, No. 35, p. 5. 
a fairy-tale atmosphere, but also creates some narrative distance from the protagonist, a naive simpleton.

The plot of Konopielka is transposed to the screen with minor cuts that serve to "tone down" the mood, ${ }^{61}$ but it is handled differently. In the novel the events are less important than the protagonist's mythical consciousness created through language. In the film, however, a significant shift occurs: the whole weight of the situation rests on the plot, which reveals itself to be fast-paced and lively.6. Something is always going on, and the protagonists experience all events as dramatic: things big and small, an egg being crushed and the arrival of the "teach," a luncheon in town and swamp draining. The village community is shown in a few collective scenes, directed in such a way as to evoke uncertainty and tension, later released in torrential carnivalesque laughter. The opening scene is a telling example; it builds on the laconic information from Kaziuk's monologue:

[...] everyone was falling over themselves when the clerks came and the women and children gathered round the machine sitting on the water like they were coming to a wedding.

They'd never seen a boat like that before: like a ferry, but with a quarter-deck on the front, glass windows, and behind the glass sits a soldier in a cap, munching on an apple. (K, p. 44)

Kaziuk describes the boat that astonished him; the director, in turn, uses this moment to "describe" the people of Taplara. The camera shows the rugged peasant faces gaping at the soldier eating his apple. In the end, the soldier lobs the core into the water and all the eyes follow the path of the projectile for a moment, until there is the splash, echoed seconds later by a rude physiological noise, an ironic accompaniment that eases the tension and makes the crowd erupt in hearthy laughter. The other collective scenes are constructed on the same pattern: congregating in town hall and digging up treasure, and the concluding Gombrowiczean "heap". These scenes acquire the status of signs, characterizing Taplara's inhabitants and their emotional and childish reactions $s^{63}$ that disarm their opponent. They are a semantic equivalent of the sociological content of

61 Apart from the motif of Gregor, which is only loosely connected with the action, the director omitted one flashback with an entirely comic flavor (a matchmaking scene), and a naturalistic episode (the death and burial of an infant).

62 Leszczyński did not want the film to be "folksy," so he shot it in black-and-white (see "Ład utracony. O filmie Konopielka mówi reżyser, Witold Leszczyński," Film 1982, No. 14).

63 See K. Nowosielski, “Ludowy i ludzki widnokrąg. O Konopielce Edwarda Redlińskiego," Pamiętnik Literacki 1982, vols. 1-2, p. 142. 
Kaziuk's monologue. Yet the atmosphere of this monologue vanishes because the protagonist's individual, colorful language is limited to the dialogues (written by Redliński). As a full-blooded filmmaker, Leszczyński saw language as an auxiliary tool, as a filmic subcode that was utterly subordinated to a vividly directed plot. He openly admitted this in an interview: "I believe the language-based material and the problems it may cause are not the most important. The basic issue is whether the work gives you a profound experience, whether it deeply stirs the imagination as it should." ${ }^{64}$

Thus the film's dialogues only accentuate the protagonists' social standing, their "backwardness" and distinctness from literary culture. The director consciously subdued the regional dialect and its phonetic peculiarities.

How did Redliński view the film adaptation of his novel? The director says: "After watching the finished film, Redliński said I had found my way back to the spirit he was in before writing the book. And that I had used the resources of film to express what he had said through literature." ${ }^{55}$

Redliński was accurate in regarding the screen adaptation as a return to the plot before it had been clothed in language, which was enacted and directed so that it could support the socio-psychological content of the novel. But let us be clear: this only pertains to the socio-psychological meaning. It is unable to render the exotic language and mythic sense of time. This is a different Konopielka Leszczyński’s Konopielka.

The film adaptation of Siekierezada ${ }^{66}$ has its own history. The script was written with Edward Stachura already in 1972, but did not make it to the stage of filming. Leszczyński recalls that this offended Stachura; nevertheless, over a decade later, he stands by this administrative decision:

Now, years later, I can confidently say that that wasn't a good script. It was very amorphous, not cinematic enough. Stachura kept close to his prose, which cannot be translated into the language of film in a literal way. I worked toward concrete images, toward reality. How to show the fog that envelopes Janek Pradera on screen? And what is that fog? The onset of madness? A kind of poetic rapture?67

64 "Ead utracony."

65 "Lad utracony."

66 Axilliad (Siekierezada, albo zima leśnych ludzi, 1971), psychological, partly autobiographical novel by Edward Stachura (1937-1979).

67 “Siekierezada," ed. B. Zagroba, Filmowy Serwis Prasowy 1986, Nos. 18-19, p. 14. 
The problems that arose in writing the script have to do with translating poetic language, finding an adequate equivalent for Stachura's lyrical prose. Here is an excerpt:

But when you are happy then you want everyone to be happy. That's how it is and what's wrong with that? That's how I enjoyed the new day, which I felt tangibly on my eyes, on my eyelids, on my hands, all over my skin, on my chest and on my back beneath my shirt, sweater, jacket and coat, because I was dressed warm, I had a pile of clothes on. Winter. So I enjoyed the new day, which I felt spontaneously and tangibly all over my skin, as if there were ants crawling all over me, but not biting, only skittering about with their multiple legs, and that was pleasant, pleasantly tickling, and I couldn't wait till Nikodem would finish skidding the trees so that I could get to work. I enjoyed the new day and I wanted everyone to enjoy it as I did, because when you are sad you don't want everyone to feel sad, not at all, but when you are happy, you want everyone to be happy and what's wrong with that ${ }^{\text {68 }}$

[...] now I fell in, I sank in that cloud, but I didn't want to, I was very afraid of it; so first the feet, then the fog came up to my ankles, then to my knees, and crawled up higher over me, then I was up to my waist, in the fog in the fog, now up to my chest, in the fog in the fog, I threw my hands up like a drowning man, because the fog was now up to my mouth, my mouthful of fog, it was already over my eyes, eyes full of fog, my poor head was drowning, in the fog in the fog, and the fog climbed higher still, over my raised arms, from my elbows to my wrists and to the tips of my pointer fingers, but pointing at what? Pointing at whom? (S, p. 44)

[...] a mountain of that smoke blew down on him, that fog that fog, but it didn't hurt him, not at all, on the contrary: he somehow felt good, very good even, nice even, intoxicated even, he wanted to sleep and that was what surprised him, because a nerve of his consciousness that sliced through the thick layers of fog that engulfed him figured out that it was only noon, no later, and so that surprised him [...] and so on from nerve to nerve, from thread to thread, he pressed on, he wound up into a ball, which he was, he saw himself as a ball, and right thereafter saw himself as a human ball, and right thereafter saw himself as an attacked human ball, he reached as far, over the nerves, over the threads, and it was only as far as he reached, to the human ball under attack, because he did not reach what he was attacked by, nor to whom and where he was, and what he was doing here, here, where he is, he only reached as far to the fact that he was a human ball under attack [...]. (S, p. 72)

A fascination with the beauty of the world is expressed in the constant repetitions and paraphrases. Whole sentences, phrases, and single words repeat even in short passages. We might compare Stachura's style to Peiper's "blossoming

68 E. Stachura, Siekierezada (Warsaw 1975), pp. 36-37. Translated by S.G. Hereafter: S with a page number. 
poem" ${ }^{\prime \prime 9}$ - every repetition is also an extension, an expansion, and a clarification of the first impression: "I felt [it] tangibly on my eyes, on my eyelids, on my hands, all over my skin," "I felt spontaneously and tangibly all over my skin, as if there were ants crawling all over me"; "he saw himself as a ball, and right thereafter saw himself as a human ball, and right thereafter saw himself as an attacked human ball," etc. All this is in order to delve into the sensations of the "I." For in the center of everything is the cognizant "I" which becomes aware of the limits of human cognition every step of the way, and expresses this through rhetorical questions: "and the fog climbed higher still, over my raised arms, from my elbows to my wrists and to the tips of my pointer fingers, but pointing at what? Pointing at whom?"

How to translate Siekierezada into the language of film?

Above all, Leszczyński attempted to create a story with metaphysical meanings. He abandoned all references to the student rebellion of the 1960s, he dropped Stachura's realistic background of the events (the plot takes place in the so called Recovered Territories in Western Poland, inhabited by a non-integrated Polish, Ukrainian, and Belarussian population transferrd there after World War 2; conflicts break out constantly etc.). He even rendered the Apple Tree Branch unreal, which the novel's narrator remembers as a girl of flesh and blood, and in the film she becomes an apparition in exotic scenery. The limitation of referential meaning is meant to emphasize the sphere of the final things: of love and death.

The dialogues play an important role in this film. They often concern existential experiences, and even metaphysics, e.g. the conversation about "all the brightness" or about "our boys" (from the November Uprising) called in for help during the dance at the fire station. But not only the subject matter is important there. The protagonists' dialogues are not simple exchanges of opinions between interlocutors; they have subtexts, they reveal the characters' secret dramas. Their presentation makes them ambiguous, endows them with a metaphysical dimension. The best example of this is Kątny's lighthearted conversation with the ranger, in which the former admits to having attempted suicide, eliciting the following comment from the novel's narrator: "neither the ranger nor his wife thought of anything else, only I saw the possibility that this here person with a smile on his lips, who also puts smiles on other people's lips, slowly plunges a knife in his heart" (S, p. 166).

69 Polish Avant-garde poet Tadeusz Peiper (1891-1969) claimed poems should develop like living organisms. "The first paragraph would contain everything that will happen, the poem would be a further development of the content of the first paragraph, the last one would give us a full, wide-spread flower" (T. Peiper, Nowe usta, 1925) [editors' note]. 
In the film this conversation adopts a different tone. The camera uses closeups to show only the face of the speaker and to suggest his inner experience. It also shows that the ranger has intuited the protagonist's mood and understands his situation. The conversation becomes ambiguous for both its participants and the viewers.

The dialogues in the film version of Siekierezada have no dialogical tension. The interlocutors are generally filmed en face, they speak slowly, with emphasis, more to themselves than to the other - this is true for the conversations between Pradera and Peresada, or between Pradera and Kątny. The way the dialogue is rendered suspends referentiality and stresses its "poeticness."

The lyricism and emotionality of Stachura's prose finds an equivalent in the moody landscapes and soundtrack of the film. The beauty of the forest, shown at all times of day and night, ${ }^{70}$ the music and singing (Jerzy Satanowski used a fragment of Vivaldi's Stabat Mater) create the film's poetic ambiance. It concludes with Stachura's song "Is it worth it," whose lyrics appear on the screen, as if the director did not trust the viewer's sense of hearing and had to reinforce it with visual perception.

Semantic meanings have been limited in the film, in favor of syntactic and pragmatic ones, i.e. the suggestion of metaphysical significance and the emotional impact on the viewer. In the latter respect, the director's concept played a crucial role; he read the novel as autobiography and made some significant modifications, introducing the motif of suicide on the railroad tracks twice (the film begins with Kątny's attempted suicide and ends with Pradera throwing himself under a speedily approaching locomotive). Thus, Siekierezada confirms the form of "life-writing" "11 and reinforces Stachura's legend.

The novel's non-transparent, lyrical language found its filmic equivalent in the moody scenery, the soundtrack, and the special handling of the dialogues. We might say that all the film codes - image, sound, and speech - have been harnessed to influence the viewer's emotions and communicate secondary meanings.

Time for some conclusions.

70 Siekierezada is Witold Leszczyński's first color film - the use of color motivated the monotony of the black-and-white winter landscape (see Filmowy Serwis Prasowy).

71 A term coined by Henryk Bereza in "Życiopisanie," included in: E. Stachura, Fabuła rasa. $Z$ wypowiedzi rozproszonych (Warsaw 1982). 
There is no reason to question the translatability of literary and film signs. Built onto (verbal and visual) primary systems, these signs can find equivalents in other material and preserve analogous meanings.

The laws that govern the adaptation of a literary work are the same as those that govern linguistic translation. As with translating from one language to another, adaptation must overcome three obstacles: different material, cultural distance and the resulting differences in the addressee's expectations, and the narrative styles contemporary to the director, which can limit his choices in the translation process. ${ }^{72}$

The principles of translating signs are also analogous to the rules of translatology. As in translation, we ought to speak of modifying operations and principles of equivalence. The language of film can find equivalents for both epic and poetic signs, but the translation of poetic language involves an especially strong activation of film codes: image, music, and speech. As in linguistic translation, full equivalence is seldom achieved. But characteristically, most differences in equivalence involve pragmatic meanings. Film offers different sorts of aesthetic experiences to the viewer and works more powerfully on the emotions than the written word. The basic difference concerns the rules of perception of verbal and visual language, and is thus in the sphere of reception.

The outcome of this process - the finished adaptation - also functions like the translation in that it is a link in a series. While the literary work has its canonical form, it is singular, there can be infinitely many adaptations. There are already a good number of parallel screen adaptations of the Polish classics: two versions of Boundary, two of The Doll, two of The Promised Land... ${ }^{73}$

The rules that govern adaptation and the ways in which it functions thus allow us to speak of intersemiotic translation, which, overcoming the resistance of different codes, aims to achieve full equivalence of the semantic, syntactic, and pragmatic meanings.

How, then should we treat adaptations that are not fully equivalent or, worse, which diverge from the "spirit of the original"? ${ }^{74}$ We can find an answer to this,

72 All these barriers are brilliantly demonstrated by Anna Legeżyńska in Tłumacz i jego kompetencje autorskie, (Warsaw 1986). See pp. 235-249 in the present volume.

73 Boundary (Granica, 1935) - psychological novel by Zofia Nałkowska (1884-1954); The Doll (Lalka, 1887-1889), the most prominent Polish realistic novel, written by Bolesław Prus (1847-1912), The Promised Land; (Ziemia obiecana, 1897-1898) novel by Władysław S. Reymont (1867-1925) with the plot set in the city of Łódź [editors' note].

74 Various suggestions have been put forth. Władysław Orłowski postulated abandoning the work's original title ( $Z$ książi na ekran, p. 236) and generally supported "loyalty" 
too, in translation theory. Jerzy Ziomek once said: "Translation is a peculiar art because it must strive for identification with the original, while it profits from the impossibility of fulfilling this task."75

[1994]

Translated by Soren Gauger

to the original. Andrzej Kijowski, on the other hand, argued that the strength of the adaptation consists not in slavishly repeating old concepts, but in offering a new treatment of the subject (Dedal, "Film, czyli literatura na nowo," Twórczość 1970, No. 3).

75 Ziomek, "Translation," p. 182; cf. E. Balcerzan, "Poezja jako semiotyka sztuki." In his: Kregi wtajemniczenia, pp. 142-143. 



\author{
Elżbieta Tabakowska
}

\title{
The Theory and Praxis of Cognitive Linguistics: An Oleograph and a Symphony for Two Pianos
}

Numerous speculations and opinions concerning translation in general, and literary translation in particular, can be divided into three basic categories, which are defined by the particular role that the translator is supposed to play in the process.

The first category is represented by proponents of the "stainless pane" theory: it is assumed that in the process of translation the translator should remain invisible; the degree to which he or she manages to do so becomes the ultimate criterion of success. This is the measure used mainly by literary critics and the so-called "common readers", that is, by people who in general have neither theoretical knowledge about language nor, as it happens, comprehensive practical knowledge of the language in which the text had originally been written.

The second theoretical position is based upon opposite assumptions. It allows the translator to enjoy rights that are almost equal to those belonging to the original author: the rights of a creative artist, for whom the work written in a foreign language is mainly - or perhaps even exclusively - a source of inspiration. This principle, which in the literature of the subject is associated with the notion of les belles infideles, was quite popular in earlier epochs; in contemporary translation theory it does not find too many followers.

The third category includes opinions of theorists who believe that there exists a direct analogy between the translator and the copyist of a work of art. According to this view, a translation is a copy of an original - just as an oleograph is a reproduction of a painting. The measure of success is therefore the degree of fidelity to the model - just as in the case of sculpture or painting. In other words, what is measured is equivalence, the notion that has been subject to the theorists' renewed attempts at creating an adequate definition. The task is taken up especially by those who would prefer to construct a theory of translation based upon a theory of language rather than a theory of literature. ${ }^{1}$

1 Cf. N. de Lange, "Reflections of a Translator," In Other Words, vol. 3 (1994). 
It is not my aim to carry out at this point a detailed analysis of advantages or disadvantages of these three theoretical positions. However, I am inclined to favor the last one - in my capacity as a practicing translator, a critic of translation and a theorist of both translation and language; I would like to indicate how linguistic analysis can contribute towards a more comprehensive description of the process of translation and to a fairer assessment of its final product. In earlier decades attempts at adapting the rigid framework of transformational generative grammar to the requirements of authentic texts (not necessarily belonging to any of the literary genre) have in general ended in frustration. ${ }^{2}$ It seems, however, that the recent dynamic development in American and European linguistics of the theory of language known as Cognitive Linguistics (inspired by American structuralism but based upon fundamentally different assumptions) will make it possible to offer more successful ways of bridging the gap between linguistics on one hand and linguistic theory and the theory of translation on the other.

All the three domains, that is, cognitive linguistics, poetics and translation theory (especially of the "copyist variety" defined above), use the same fundamental metaphor based upon the notion of "image." In literary theory "imagery" is generally associated with what is called "poetical language" - figurative language of similes and metaphors. In a wider sense, it is sometimes defined as the use of language to represent objects, activities, feelings, mental states and experiences. ${ }^{3}$ It is precisely in this sense that the semantics of the word "image" becomes almost identical to the meaning that the term acquires in the model of language proposed by Ronald W. Langacker, the most prominent theorist of the cognitivist persuasion. In Langacker's work, "imagery" is language users' ability to construe particular situations in different ways, selecting different linguistic means and different images, in order to think and to express their feelings and emotions. ${ }^{4}$ This ability is available to all speakers of all languages, and the idea of alternate construals - the notion which underlies all theoretical assumptions of Cognitive Linguistics and at the same time justifies its practical applications finds an obvious parallel in the consecutive stages of the work of a painter creating an artistic image.

2 Cf. E. Tabakowska, Cognitive Linguistics and Poetics of Translation (Tübingen 1993), pp. $6-20$.

3 Cf. e.g. J.A. Cuddon, Dictionary of Literary Terms and Literary Theory (London 1991), pp. 442-443.

4 R. W. Langacker, “An Introduction to Cognitive Grammar," Cognitive Science, vol. 10 (1986), pp. 1-40. 
Thus, both the person who wants to construe a linguistic message and the artist who wants to paint a picture have to begin with organizing the particular representation of a fragment of reality which they had chosen to deal with in their own, particular way (in other words, they have to begin by "selecting the topic"). The selection depends crucially upon the perspective and the point of view of the observer - most frequently it will be that of the speaker or the painter themselves, although other choices are also possible. In linguistic messages such departures from the prototype are more frequent than in painting, the classical example being the narration in a novel, with the point of view of the narrator not necessarily being that of the author.

To refer to the fragment of reality selected as a particular topic of the verbal message Cognitive Linguistics uses the term "scene"; in agreement with the general understanding of the word, a scene has its participants and its setting. After the selection of the subject has been made and the organization of the scene accomplished, both the speaker and the painter have to decide on the way in which the picture should be framed. The frames designed for a depiction of a scene delimit its scope in much the same way as the frames of a verbal message delimit the scope (of predication) of the content intended by the speaker. Thus, when a still life is painted, the painter can set the limits of the scene along the edges of the table on which the objects have been arranged, but they can also include the interior in which that table stands. Similarly, when someone says: "there is a red apple on the plate", they can consciously ignore the fact that next to the apple there lies a fruit knife. The selection of scope, which in Langacker's model constitutes a crucial dimension of imagery, is related to the choice of yet another aspect: the level of specificity, which once again can be found both on a painter's canvas and in the discourse of a language user. Both are obliged to decide how detailed their representation of the scene is to be. It can be just a sketchy drawing (for instance, when one smells burning and says: "somebody must have burned something"), but, alternatively, it can become as rich in details as its author chooses it to be (for instance, when I say "my next door young neighbor must have burned her roast beef"). Finally, when painting a scene, both the painter and the language user have to decide which constitutive elements of that scene are to be given most prominence, and thus perform the function of figure(s) (or constitute the painting's foreground), and which have to be demoted and serve as the ground (or become what the painters call staffage).

There is one more aspect of construal that should be mentioned at this point. A most fundamental experience of the person who observes the surrounding world is that of physical objects moving through physical, three-dimensional space. But this elementary motion becomes the source of inspiration and the 
starting point for innumerable notional extensions, which underlie and condition conceptual metaphors and thus make it possible to grasp highly abstract and/or complex phenomena. The proponents of the cognitivist theory of language consider this type of extension, which they call abstract motion, as the very gist of human understanding of the phenomenon of change. When one says: "John fell in love", the metaphorical "falling" represents John's rapid passage (in a metaphorical sense) from one emotional state to another. Moreover, like physical motion in physical space, metaphorical motion can be given a direction. When one says "the street runs parallel to the beach", a message is construed which is considered meaningful (sensible) just because the verb "run" includes the metaphorically extended notion of "following something with one's eyes"; the listeners' imagination makes it possible for them to "follow with their eyes" two parallel lines - one representing the street, and the other representing the coastline. This type of motion can of course occur when watching an image created by a painter.

According to the cognitivist theory of language, every dimension of imagery has its correlate (or correlates) in the resources of a given language, and every choice made on the level of concept making (conceptualization) conditions a subsequent selection of element(s) that build up the repertoire of a given language at its speakers' disposal. This can be a single word (for instance, the pronoun "something" as opposed to the phrase "roast beef"), but it can also be a grammatical structure (for instance, in the sentence "John fell in love" the positioning of the noun "John" in subject position predetermines that its designate should play the role of figure). The association of a given dimension of imagery with a particular linguistic device that corresponds to it is sanctioned by the convention of a given language. Cognitive Linguistics aims at providing a description and an explanation of precisely those conventions, while an analysis of differences between them, which can be seen when comparing different natural languages, is the subject matter of contrastive studies. The theory of translation makes use of the achievements of both types of linguistic study, and treats them as its ancillary disciplines.

The aims of this kind of linguistics, which consists in establishing the relation between the linguistic image and the linguistic form, are thus the same as the aims of both translation theory and translation criticism. However, there is an important difference: while for the linguists the relation constitutes the object of study, a translator, a theorist of translation or a translation critic make use of it ex post - in order to describe the original and to assess its translation. This is precisely the approach that I wish to illustrate further in this essay. 
We all keep creating images painted with words, because imagery is the essence of the process of construing verbal images. One could then assume that at this point the parallelism between painting things and talking about things breaks down: evidently, not all of us are painters. But each of us could paint a picture if we wanted to or if, for some reason, it should become necessary (as is speaking). It is just that most of those paintings would be bad paintings. We all speak, but not everyone is a poet. And bad poetry abounds.

Ultimately, the difference between a literary text and a non-literary text is only quantitative: it involves the degree of conventionalization of the image and the level of technical skills required for its creation. A good poem employs structures that are less conventional than those which appear in a press report. It is less trivial - like a good painting compared to one which has been pronounced poor by viewers and art critics. The parallel does not become meaningless.

The text presented below, selected as an example of an analysis carried along the lines described above, is an extract from a description of the royal chapel of Charlemagne in Aachen. ${ }^{5}$ Its author, the British historian Norman Davies, is a superb stylist. In the present context this simply means that he has mastered the ability to construe a scene with available linguistic devices (as described by Langacker and summarized above) to the degree which enables him to paint pictures that a sophisticated reader would intuitively consider as "good". It follows, of course, that his translator has to do work that we would be inclined to classify (once again intuitively) as "artistic translation". The passage runs as follows:

The decoration of the chapel is heavy with the imperial symbolism which Charlemagne and his successors had revived in a new and naive Christian setting. A mosaic inside the Dome represents the Adoration of the Lamb. The ambo or 'pulpit' is encrusted with fragments of Roman pottery, glass and an eagle cameo. Egyptian columns in green and rose porphyry support the second tier of arches. The pala d'oro or 'altar panel' portrays the Passion in classic Roman relief and in solid gold. The Lotharkreuz or "Cross of Lothar", is a magnificent Christian ornament of beaten gold with antique gems. It is surmounted by a central portrait cameo of Emperor Augustus. The Imperial Throne, cut from simple slabs of white marble, looks down from the first-floor gallery as it did during all the thirty-two coronations of seven hundred years. The message is clear. The Empire, which Charlemagne launched, thought of itself both as Holy and as Roman. ${ }^{6}$

5 For details, see E. Tabakowska, "Linguistic Expression of Perceptual Relationships: Iconicity as a Principle of Text Organization (A Case Study)." In: Form Miming Meaning, ed. M. Nänny and O. Fischer (Amsterdam/Philadelphia 1999), pp. $409-422$.

6 N. Davies, A History of Europe (Oxford 1996), pp. 220-221. 
It was translated into Polish as follows:

W dekoracji wnętrza kaplicy uderza bogactwo elementów symboliki cesarstwa, którą Karol Wielki i jego następcy przywrócili do życia w nowym i naiwnym chrześcijańskim kontekście. Tematem mozaiki we wnętrzu kopuły jest Adoracja Baranka. Ambona jest inkrustowana kawałkami rzymskiej ceramiki, szkłem i kameą z orłem. Drugi rząd łuków wspierają egipskie kolumny z zielonego i różowego porfiru. Pala d’oro, panel głównego ołtarza, przedstawia Mękę Pańską; jest to klasyczna rzymska płaskorzeźba w litym złocie. Lotharkreuz, czyli "Krzyż Lothara”, wspaniałe dzieło sztuki zdobniczej o tematyce chrześcijańskiej, wykonane ze złotej blachy i wysadzane starymi klejnotami, wieńczy umieszczona centralnie kamea z portretem cesarza Augusta. Tron Cesarski, wykonany z prostych płyt białego marmuru, spogląda w dół z wyżyn galerii pierwszej kondygnacji - nieodmienny świadek wszystkich trzydziestu dwóch koronacji. Przesłanie jest jednoznaczne: cesarstwo, które założył Karol Wielki, uważało się za Święte, ale i za Rzymskie. $^{7}$

The general "topic" of the description is what art historians call "Carolingian renaissance". This, of course, must influence the interpretation of individual lexemes. For instance, the fact that the mosaic as a decorative technique was developed in Rome, and only later was taken over by early Christian art, belongs to an encyclopedia rather than to a common dictionary of both English and Polish languages. Similarly, the knowledge that the eagle (mentioned in the third sentence of Davies's paragraph) was an important symbol revered in ancient Rome and that an eagle was a decorative ornament on Charlemagne's cloak, is encyclopaedic in character; however, to those in the know it is evoked by the English word eagle and the Polish word orzet. Yet in their context both elements are important: they occupy a particular place within a series of juxtapositions, built according to the schema "Roman vs. Christian". In a context-free constituent analysis this feature of the text would be classified as connotative and left out of consideration. In contrast, in an analysis carried out in the cognitivist vein, the context would be seen as making this feature salient, and thus crucial for semantic interpretation.

In order to activate the encyclopedic elements of meaning the text has to use particular linguistic devices. In English the function is performed by the indefinite article (as claimed by all standard textbooks of English, the phrase a mosaic defines the referent as a "mosaic" without, however, allowing for its identification, which would require the definite article: the mosaic), as well as placing the phrase an eagle cameo at the end of the series and thus making the

7 N. Davies, Europa. Rozprawa historyka z historia. trans. E. Tabakowska (Kraków 1998), pp. 338-340. 
referent maximally salient (cf. the principle of "end focus"). The latter case was not problematic for the translator, since Polish has an analogous convention: the last element in a sentence tends to carry sentence stress, which makes it semantically salient: in the Polish text, kamea $z$ orkem becomes kamea $z$ ORŁEM. On the other hand, the translator's modification of the sentence which describes the mosaic has most probably resulted from her intention to emphasize the semantic contrast, otherwise weakened because of the lack of equivalent linguistic means.

The contrast between the Roman and the Christian designates the frame of the picture: out of the many decorative elements in the chapel the original author only "notices" those that make this contrast most clearly visible. Moreover, the perspective is not that of a tourist visiting the chapel, but rather of a narrator, who organizes ex post the fragments of the overall picture - such as were observed earlier. The organization follows a particular idea. From the formal point of view, this is just the kind of perspective which justifies the use of definite articles: the ambo, the pala d'oro, the Lotharkreuz, the Imperial Throne. Similar definite phrases could also appear in a guidebook, which characteristically assumes the perspective of a tourist. For instance, the expression the Imperial Throne (as used by Davies) means "the particular Imperial Throne that both of us are able to identify - I can do it because I know (about) it, and you can do it because you are just looking at it". However, in the passage quoted above the Imperial Throne is "this particular Imperial Throne that I know can be found in the royal chapel of Charlemagne in Aachen". This egocentric character of the description is emphasized by the particular ordering of individual images that constitute the description of the chapel. The kind of iconicity typical for tourist guidebooks ${ }^{8}$ would require the ordering corresponding to the direction and consecutive stages of the tourist route: elements of reality are represented linguistically in the same order in which they occur in space and time. But in Davies's text the iconicity occurs on a higher conceptual level: the description "progresses" from symbols that are peripheral from the point of view of the history of Christianity to one which is central: the dome (of a chapel) - the ambo - the altar - the cross.

On the level of conceptualization, the sentence which mentions the cross differs from the others. This highest symbol of Christianity is adorned with antique gems, but on the other hand the description looks as if it came straight from a guidebook; it brings relatively detailed information about the craft, and a kind of tribute to less sophisticated viewers - the only element of evaluation in

8 See e.g. N. E. Enkvist, “Experiential Iconicity in Text Strategy," Text 1981, vol. 1, pp. 97-111. 
the whole text: the word magnificent. The next sentence brings an iconic reconstruction of what is (in the context provided) a normal course of events; it is only when the observer looks up that he or she will notice the cameo with the portrait of Emperor Augustus - the missing element of the contrast that builds up the leitmotif of Davies's text. But in this particular text it is at the same time an instance of metaphorical iconicity. In the case of the cross such a "notional confusion" comes as a surprise: one might wish to put the metaphorical full stop and thus end the metaphorical sentence a bit earlier: before Emperor Augustus appears on the stage. According to the fundamental assumption that underlies Cognitive Linguistics, syntax directly symbolizes the content. And this is precisely why translating an image that the original author meant to be incoherent as a simple (though well-developed) sentence should be considered as an error on the part of the translator.

As a part of the overall image, the sentence which mentions Egyptian columns seems a poor fit. It lacks the marshalling description of the semantic contrast. However, it displays the second kind of "textbook iconicity:" the direction "from bottom up," which is imposed by general sensuous experience. Thus, the visitors to the cathedral first classifies the columns as "Egyptian columns in green and rose porphyry", and only afterwards, when they look up, they notice that these columns "support the second tier of arches". It will be noticed that the translator has "put the description in order": egipskie kolumny z zielonego i różowego porfiru (NB. in the original they are given indefinite determination: "Egyptian columns", analogous to the earlier expression "a mosaic") are shifted to sentence end position. In this way the text gained in salience (the property of being "antique" has been promoted semantically), but on the other hand some of the original iconicity has been lost.

While the "textbook sentences" suggest the Langackerian directionality motivated by perceptual experience, the direction "from top to bottom" is directly included in the English phrasal verb "looks down". At the same time this is the only verb in the text that refers to active interaction between scene participants; it has no direction and no timeless static reference, which is present in all the remaining verbs: " $x$ represents $y$ ", " $x$ is encrusted with $y$ ", "x supports $y$ ", " $x$ portrays $y$ ", " $x$ is surmounted by $y$ ". The Imperial Throne - like a living creature endowed with free will or the emperor who used to sit upon it - looks down upon its/his chapel, the other symbol of the Holy Roman Empire. In view of the "semantic activity" which constitutes part of the meaning of the verb "look" the contrast between grammatical tenses, the present and the past (looks down ... as it did) builds up the timelessness of the relation. In the Polish translation, this is rendered by the introduction of the adjective nieodmienny ("indeclinable", 
"invariable"). The personification, which in the original is marked only by the choice of the verb (look), in the Polish translation shows somewhat more care for detail. The Throne spoglada $w$ dół $z$ wyżyn galerii and is świadkiem ("a witness") of historical acts of coronation. However, the original image seems more illuminating: the throne looking down upon the chapel is - in terms of Cognitive Grammar - a figure that provides the foreground. Everything else serves as the ground against which it is shown - even the slabs of white marble of which it is made. The original author creates this effect by demoting the sentence "[was] cut from simple slabs of white marble" to a reduced subordinate clause. ${ }^{9}$ The Polish świadek is an additional, somewhat competing, figure, which breaks the compositional unity of the whole image.

In passive voice constructions or in structures with verbs which express timeless relations the function of the figure is performed by grammatical subjects of sentences, that is, elements that are objects of the relations. ${ }^{10}$ In Davies's text those figures are nouns or nominal phrases which are grammatical subjects of successive sentences: a mosaic, the ambo or 'pulpit', Egyptian columns, the pala d'oro or 'altar panel', the Lotharkreutz. In the sentence which includes the description of the Imperial Throne the figure is, as was said above, the relation between two things: the throne which looks down upon the chapel. Thus the chain of parallel structures is broken, which adds to the ultimate effect.

It seems that making use of instruments provided by the notional setup of Cognitive Linguistics makes it possible to provide a description of a linguistic image which is more precise than that based solely upon the intuition and the sensibility of a mindful researcher. And this is precisely the ultimate aim of Cognitive Linguistics; it makes no claim to new discoveries. Its only goal is to give the form of a coherent theory to intuitions, and its main assumption, which one might think is right and well justified, is that a description of language must ultimately become a description of human cognition. And so must the process of translation itself, which - like the prime process of conceptualization that underlies the process of construing an expression - is in its very nature a process of interpretation of the represented world and things that are found in it.

The Polish translation of Davies's description of the royal chapel in Aachen is - like the English original - a description of the royal chapel in Aachen. The

9 More on the function of subordinate clauses in the construal of ground in L. Talmy, "Figure and Ground in Complex Sentences." In: Universals of Human Language, ed. J.H. Greenberg (Stanford 1978), pp. 627 - 649.

10 Cf. R. W. Langacker, Foundations of Cognitive Grammar, vol. 2: Descriptive Application (Stanford 1991), p. 297. 
main topic remains the same: the Carolingian renaissance. But, as we could see, the translator makes it stand out in relief, more than the original does. One could say that the picture is drawn with as thicker line. Or perhaps it would be better to say that the translator plays the same score in her own way. In fact, the comparison of the translator and the musician who plays someone else's score is not new at all. ${ }^{11}$ It was beautifully explained by the same historian-artist whose text was the subject of the above analysis: "Every translator has the right to be an artist. A history that was written in English and then translated into Polish is like a symphony in A-flat major, which was transcribed into F-sharp major, for two pianos." 12

[1995]

Translated by Elżbieta Tabakowska

11 Cf. e.g. De Lange, "Reflections of a Translator."

12 N. Davies, Boże igrzysko, vol 1, trans. E. Tabakowska (Kraków 1989), p. 17. 


\section{Roman Lewicki}

\section{Foreignness in Translation and Foreignness in Culture}

One of the more important motifs in academic translation studies to date is the observation that translations are texts of a specific sort, that they differ from other texts, i.e. from non-translations. Initially (and to this day) the translation was essentially perceived only in relation to the original, i.e. the text on which it was based, against which it can be defined and evaluated. According to this approach, the translation exhibits smaller or greater differences compared to the original; we might investigate what causes them, whether they are objectively inevitable or result from a translation strategy, or, finally, from the translator's erroneous decisions due to insufficient professional competence. This is the approach that informs translation concepts we might call "equivalence-oriented," as they take translation equivalence to be the fundamental category; as such, their reference point is the original text, with its language (more or less) as its backdrop. In our day, these concepts unquestionably dominate translation research. They consider equivalence, i.e. the relationship to the original, as the defining feature of translation.

The specificity of the translation, based on its relationship to the original, is thus perceived as a similarity or parallelism with the source text. Let us note that this is due to the fact that the translation is a derivative text, resulting from and based on the original. It is thus to the original that the scholar refers in establishing or analyzing equivalence.

The linguistic derivativeness of the translation means that many of its features stem from its "attachment" to the original and to the language in which the original was created. Sometimes these features are visible, sometimes hidden; regardless of how well visible they are in reading the translation, however, there is always some probability that the reader might recognize them, seeing them as a certain departure from the target-language linguistic norms, typical verbal behaviors, or customary usage. Because of this departure, we may say that reading a translation involves activating the category of foreignness.

This means that foreignness appears in translation as a feature of its reception, or in other words, as a feature of the translation's functioning. Placing the translation in the communicative situation in which it operates gives the scholar a different optic. For this situation is not identical to that in which the original 
text operates. Above all, the translation functions as a text in the target language, among other texts in this language which are not translations. Its reader is usually unfamiliar with either the original text or the original language (this is, after all, why he has chosen the translation), and thus equivalence is, for him, practically irrelevant. This last statement is by no means too categorical; it suffices to mention examples of translations deeply rooted in the culture and literary circulation whose equivalence to the original leaves much to be desired (such as Winnie the Pooh translated into Polish by Irena Tuwim as Kubus Puchatek). ${ }^{1}$ This phenomenon unambiguously indicates the irrelevance of equivalence for how the translated text functions. Since translations operate independent of the original, equivalence is not a factor determining the reception of the translated text.

Thus, when it comes to foreignness in translation, we might conclude that although it does appear as a feature of reception (and, consequently, of the translation's functions), its roots are in the linguistic derivativeness of the translation: in its relationship to the original and the source language.

A translation is a derivative text by its very definition. This derivativeness is primarily rooted in language, though, as we have long been aware, it often also involves cultural derivativeness, as a result of the original text being designed to function in its native society. Only a handful of texts, written from the outset with their subsequent translation in mind, are entirely free from this intended purpose. Another translation feature that activates the category of foreignness in the course of reading is connected with the parallelism between the world presented in the texts and the language in which those texts were written. In non-translations this is a typical situation; the only time it is infringed upon is in texts that concern other countries, foreign customs etc. In translation, this kind of parallelism is, by their very definition, limited; although the realities depicted in the texts have many shared attributes (this makes translation at all possible), they also have differing features, so that the presented reality must be described in the translation using the resources of another language, i.e. one originally meant to describe another reality. It often happens that the contradiction between the translation's presented world and its language comes to the fore - although it is a matter of convention, it does exist. And it is the existence of this contradiction that constitutes the second feature of translations "responsible" for the relevance of the category of foreignness in their reception. Both the above-named translation features indicate that foreignness must be important in

1 On this topic see: M. Adamczyk-Garbowska, Polskie tłumaczenia angielskiej literatury dziecięcej. Problemy krytyki przykładu (Wrocław 1988), pp. 53-54, 113-116, 127. 
the reception of translations, because it arises from their very nature as derivative texts in terms of culture and language. As we might imagine, then, the foreignness of an old text to a contemporary reader or the foreignness of jargon to a reader unfamiliar with it, for example, are not vital in the study of translation. At the basis of examining translations in terms of their foreignness lies their linguistic and cultural derivativeness. This foreignness results from the derivative nature of the text, and thus, from the very essence of translation, and it manifests itself as a feature of translation reception.

Let us examine how thus understood foreignness surfaces in translation, and how it relates to foreignness as a broad cultural category.

The traditional notion of foreignness in culture involves its various facets; given that culture as such is a human creation, however, the category of foreignness is first and foremost applied to people, whether individuals or entire groups. In culture, pride of place is taken by an individual's self-identification and self-definition through the fact of belonging to a group. This explains the importance of the "familiar/foreign" opposition, which has been alive since the time of traditional societies to the present-day, also in developed societies. In the traditional approach, the differentiation between familiar and foreign often involves value judgments: the familiar is good, the foreign is bad, despicable. The perception of people and groups as foreign has multiple causes, which can be summarized as a set of characteristics that distinguish these people from the group that evaluates them. These characteristics, in turn, are not selected arbitrarily or at random; they must in some way be integral for defining the group. Finally, the third crucial aspect of perceiving people and groups as foreign is that the above-mentioned set of their characteristics is defined from the evaluators' perspective, and not by those to whom foreignness is ascribed, nor by any external authority. In short, we might say that foreigners are those who, in our view, differ from us in some appreciable way. The perception of other people as foreign is thus determined by a set of significant characteristics of the evaluated people or groups, which distinguish them from the evaluators. Specifically, these are (according to a classification by Alina Cała): linguistic difference, religious (and, consequently, axiological) difference, difference of custom and the group's social organization, difference in the activities, and thus, in the way of life. ${ }^{2}$

If we examine the category of foreignness in terms of the social perception of the products of human culture, including texts, we will see a partial parallelism

2 A. Cała, Wizerunek Żyda w polskiej kulturze ludowej (Warsaw 1992), p. 12. 
with this set of relevant characteristics that activate the social and individual sense of foreignness.

The set of characteristics that are significant to the perception and evaluation of foreignness in translation somewhat varies from the one pertaining to the foreignness of a group of people. Comparing the translation characteristics that generate a sense of foreignness with those listed above, we might say that among Cała's characteristics that refer to social relations, the foreignness experienced in translation reception is based on:

- the linguistic difference of particular expressions used by the translator, regarded as atypical, unusual, strange, incomprehensible, or not quite clear;

- cultural difference that consists in the difference between the situations described and those the reader knows from personal experience, or in a different interpretation and evaluation of particular phenomena;

- religious and axiological difference.

Undoubtedly what most differentiates a translation from a non-translation is various manifestations of linguistic difference; they are also the most visible characteristics, especially in incompetent translations. This explains the old requirement to adapt the translation to the norms of the target language. As it has been pointed out, ${ }^{3}$ in order to be accepted the translation must be correct. And yet a complication emerges here: research shows that even if translations do not give the impression of being incorrect, they exhibit an essential difference in their use of linguistic forms, and treat the target norms more freely than non-translated texts. ${ }^{4}$ This is not only a question of linguistic correctness, but also of adherence to the textual conventions dominant in the community of the translation's addressees. The reception of translations involves their evaluation, as in this society they are (generally, though not always, of course) assessed on an equal footing with other, non-translated texts. ${ }^{5}$

Relatively visible is the difference of the presented world, including in religion, customs/morals, and so forth. Less immediately apparent is the axiological standpoint of the author; it can sometimes be hidden in the use of vocabulary

3 See: e.g. A. V. Fyodorov, Osnovy obshchey teorii perevoda (Moscow 1968), p. 151.

4 See: e.g., K. Klaudy, "Empirical Research in Translation Studies." In: Translatologica Pragensia VI. Ed. M. Hrala, Praha: Univerzita Karlova, 1998, pp. 19-25; A. V. Okladnikova, Issledovanie v oblasti yazyka perevodov (problemy normy i uzusa) (Moscow 1980).

5 V. N. Komissarov, Slovo o perevode (Moscow 1973), p. 159. 
and its emotional overtones. The axiological stance of the original author can also be incongruent with what the reader is used to. It seems, then, that in spite of some differences, translation foreignness is not accidental, for it is "built into" the category of foreignness that exists in culture. As such, investigating translation foreignness presupposes that translation should be regarded as a cultural phenomenon. This approach to translation research has been particularly visible in recent years; many works have appeared where translation is viewed as a record of the reception of cultural difference, a testimony to how the culture of a given society treats a foreign culture. In this context, we speak of assimilation, of the concept of overcoming cultural barriers. Thus, translation is seen as combining the familiar with the foreign to form a new, complex cultural text. ${ }^{6}$ Yet we ought to point out that these works, while undoubtedly valuable for positing the problem of translation as a cultural phenomenon and describing the various manifestations of intercultural confrontation in translation, draw exclusively on literary material. Meanwhile, it would seem that translation is a cultural phenomenon regardless of whether it pertains to a literary text or not. In the former case, it ought to be seen in the context of artistic culture, satisfying our cognitive/philosophical, ethical, and aesthetic needs; in the latter, it also partly belongs to culture, if not artistic, then at least spiritual (e.g. translations of photo books or travel guides, academic or popular science literature), and partly to material culture, or, to be precise, to the "maintenance services" of material culture (translations of practical texts: documents, manuals, advertisements). Consequently, foreignness is perceived not only in the reception of literary translations, but also in other sorts of texts, though the characteristics that evoke it may differ in various sorts of texts; similarly, the type of a text may determine the reader's response to perceived foreignness in general and the foreignness

6 See especially: A. Tippner, Alterität, Übersetzung und Kultur. Chechovs Prosa zwischen Rußland und Deutschland (Frankfurt a. M., 1997). Some works devoted to the "intercultural" approach to translation are: L. K. Latyshev, Perevod: Problemy teorii, praktiki i metodiki prepodavaniya (Moscow 1988), p. 86 (here see the concept of the cultural barrier in translation, though insufficiently separated from the language barrier); Translation as Intercultural Communication. Selected Papers from the EST Congress, eds. M. Snell-Hornby, Z. Jettmarová, K. Kaindl (Prague 1995); Übersetzung als Repräsentation fremder Kulturen, ed. D. Bachmann-Medick (Berlin-BielefeldMunich 1997); H. W. Dreschner, Transfer: Übersetzen - Dolmetschen - Interkulturälitat (Frankfurt a. M., 1997); Cultural Functions of Translation, eds. C. Schäffner, H. KellyHolmes, (Clevedon-Philadelphia-Adelaide 1995); Differente Lachkulturen? Fremde Komik und ihre Übersetzung, eds. T. Unger, B. Schultze, H. Turk (Tübingen 1995). 
of individual translation solutions. This is why it would seem appropriate and promising to embark upon a comprehensive scholarly investigation of foreignness in translation reception, without restricting ourselves to a single variety of texts. Of course, this in no way means we ought to ignore significant typological differences, which, however, ultimately result from the communication intentions of both the original author and the translator.

The linguistic features of a translation that foreground its foreign origin are subject to linguistic description based on an analysis of the linguistic resources; this analysis will likely reveal not only features visible to the reader (insofar as this is a perceptive, well-read and sophisticated reader), but also those that are invisible to this "normal" perception, but which, following a linguistic analysis, could "expose" the text as a translation. Such analyses have been attempted in the past, with varying degrees of success. The reader's perception of the linguistic features in question - whether we speak of the reader assumed by the translator, potential and general, i.e. the "addressee" in the translation model, or the real, individual reader - depends on his perception of foreignness as such, as well as the foreignness of particular cultural and linguistic features. In other words, the perception of the translation features that arise from its foreignness depends on the reader's sensitivity to this category. Furthermore, the reader can react to or evaluate the aspects of the text he perceives as foreign in different ways: without getting into detail here, we might say that he can accept them or reject them. This means that his perception of the translation features derived from its foreignness also depends on the reader's attitude towards foreignness as a cultural category. If the unusual nature of the text is accepted, with its non-standard qualities, the presence of proper names and other culturally unfamiliar elements, the foreignness of the translation is seen as a value. If the unusual aspects are rejected, they are viewed as simply bizarre; the reader is irritated by the incomprehensibility of parts of the text, the difficulty in correctly reading the names etc. In this latter case, foreignness is not a value for the reader; he sees a value in the text being shaped in a recognizable way, being easy to read and familiar. With such a form, let us note, the derivativeness or "translatedness" of the text becomes invisible. Yet this readability and familiarity, as Piotr Fornelski has aptly observed, is a "concession to the fear of a mythologized foreignness, [...] a search for shelter in an equally mythologized community: in what is your own, familiar, homey."

7 P. Fornelski, "Kontekstualizacja przekładu. Między mitem wierności a zdradą." In: Między oryginałem a przekładem, Vol. I, eds. J. Konieczna-Twardzikowa and U. Kropiwiec (Kraków 1995), p. 29. 
Indeed, this expectation contains a paradox: it would be hard to expect something that is "your own, familiar, homey" in a linguistically derivative text. Nonetheless, readers do often declare that they expect such things of a translation. The fear of foreignness is all the more paradoxical in the reader of a translation in that, as we have mentioned, the linguistic derivativeness of a translation is evident to him; the reader is aware of it; he knows that he is making contact with a text that speaks of another cultural reality. We might say that reading translations inevitably bears the risk of a culture shock.

A rejection of translation foreignness could be the sign of an instinctive, and thus unconscious urge to shelter oneself amid familiar things; this, I believe, is a normal manifestation of the human striving for a sense of security (evidently including verbal or communicative security). The unusual or atypical nature of some aspects of communication thus stand as a threat: the threat of not understanding the text, but also of a disrupted sense of the stability of the surrounding world, the sense of its familiarity. At the same time, there is an opposite endeavor: to get to know new things, to encounter a world that differs from the everyday and familiar. We observe this attitude in readers who accept foreignness in a translation. The foreign traits of the text intrigue them; they are perceived as original and interesting. Curiosity about the world is generally the charactersitic (of people, and this also of readers) that makes them reach for a translation. This testifies to a certain cognitive alertness of translation readers. This is perhaps why the degree of tolerance for foreignness is relatively high in the reception of translations, as is shown by experimental research. ${ }^{8}$ At any rate, for now, in our general considerations of foreignness in translation reception, we can say that it is the tension between the two poles of a person's cognitive standpoint - striving for communicative security and a curiosity for the world, or a striving to discover its diversity - that determines the importance of foreignness for the translation reception in a society.

Regardless of the cognitive attitude of the readers, we see that - as with the foreignness of social groups - it is not the author of the original who decides upon the foreignness in the translation, nor the language of the original, nor an external authority (i.e. the translation scholar), but the reader, who identifies those characteristics that distinguish the translation from other texts and make it foreign. It is the reader who admits carriers of foreignness found in the translation, i.e. tolerates them or even deems them desirable, or rejects them outright. Hence the importance of the reader figure in researching the category of

8 R. Lewicki, Obcość w odbiorze przekładu (Lublin 2000), pp. 94-97, 153-157. 
translation foreignness, as well as the individual manifestations of this foreignness, i.e. particular translation strategies and devices.

Activation of the category of foreignness in translation reception is thus not unlike its activation in the perception and evaluation of other people and groups. I believe we can say that one's attitude to foreignness in translation reception is derived from, or perhaps even is a part of one's attitude to foreignness as such, i.e. foreignness as a cultural category.

We can quite easily see that the perception of foreignness of people or groups is linked to the presence of useful social contacts between the evaluators (as a society) and the evaluated. Similarly, the reception of translation foreignness depends on the contacts between the two societies; they condition the knowledge of the foreign culture, which results in a "limited biculturalism" of the translation's reader, and the knowledge of the foreign language, most often involving a knowledge of only some of its facts: particular expressions, linguistic behaviors in certain typical communication situations ("microtexts"), proper names, and so on, resulting in the reader's "limited bilingualism." Both these phenomena are of crucial significance for the existence of foreignness in a translation and its evaluation.

The limited biculturalism of a reader of translation means that there is one more significant fact in translation reception: the awareness that the text is a translation, as a result of which the reader anticipates the presence foreign elements, such as proper names. ${ }^{9}$ This is why the partly expected foreignness of the translated text is a crucial marker of the reading convention for translations, shaping the translation norms, which is not identical to the norm for nontranslations. Anna Legeżyńska is right when she categorically states that "the reading conventions are never the same for the original and the translation"10

9 Many of the above-listed studies of the intercultural situatedness of translation, however, do not presuppose a description of the text of the translation in its culturally conditioned functioning (as in A. Tippner's Alterität, Übersetzung und Kultur...; Cultural Functions of Translation, ed. Ch. Schäffner, H. Kelly-Holmes), but rather a description of the translation process as intercultural transfer, e.g. Translation und interkulturelle Kommunikation, ed. J. Albrecht (Frankfurt a. M. 1987); Ubersetzungswissenschaft. Eine Neuorientierung, ed. M. Snell-Hornby (Tübingen 1986); Tradition und Translation: zum Problem der interkulturellen Übersetzbarkett religiöser Phänomene, ed. C. Elsas (Berlin 1994), and earlier works: Vinogradov, Leksicheskie voprosy perevoda khudozhestvennoy prozy (Moscow 1978), pp. 85-108. Of course, such a description must necessarily be based on two texts (the original and the translation), i.e. it is impossible to study the translation without reference to the original.

10 A. Legeżyńska, Tłumacz i jego kompetencje autorskie (Warsaw 1986), p. 15. See p. 239 in the present volume. 
These conventions can, of course, approximate each other, but this depends on the above-mentioned contacts between the two societies and not, as is sometimes supposed, on the affinities between the two languages. ${ }^{11}$

Speaking of the limited biculturalism of translation readers, we have to bear in mind that the distance between two given cultures fluctuates in time, as it is a function of their current positioning in respect to one another, the state and intensity of their mutual contacts, their historical sensitivities and resentments, and the mutual interest and fascination. This fact has already been pointed out. ${ }^{12}$ We might only add that it also partly depends on the current aims of a given society (nation) in a given time: in the life of a society, there are ages of greater openness and ages of intensified striving for self-identification and accentuating difference. There are epochs of greater or lesser sensitivity (sometimes even oversensitivity) to foreignness. If we accept this point of view, the dynamic, i.e. chronologically changing nature of foreignness becomes clear. Thus the connotations of foreignness will have a different reach in the reception of texts in various epochs (even in the reception of the same text). Readers' habits also undergo constant change; this causes historical shifts in the acceptance of translation foreignness and its various manifestations.

This suggests that, as with the perception of people, the category of foreignness in the reception of translations is historical in nature (it changes over time). In terms of the activation of the category of foreignness, translation reception undergoes constant changes; ultimately, it depends on the state of contacts between the target language and other languages, and more broadly speaking, contacts between the receiving culture and other cultures. Consequently, the translator's tendency to use particular translation solutions, including features of foreign derivation, is also historically changing. And so is the readers' acceptance of each of these solutions, and the acceptance of any textual features of foreign provenance in a translation.

11 It is easier to agree with Legeżyńska's thesis that both reading conventions "overlap (in general terms) when [...] the translated work (the original) comes from a related cultural sphere" (p. 239). Yet in my opinion, a more crucial factor is the contact between cultures, and not their proximity in belonging to the same sphere.

12 E.g., A. D. Shviyetzer, "Sotsiolingvisticheskie osnovy teorii perevoda," Voprosy Yazykoznaniya 1985, No. 5, p. 21. 
All these qualities should be taken into account in attempting to describe translation reception in terms of foreignness. The results bear testimony not only to the preferences of translation readers at a particular time and place, but also to their cultural awareness with regard to foreignness as such.

$[2000 / 2002]$

Translated by Soren Gauger 


\section{Trauma, Translation, and Transmission in a Postmemory Perspective: From Literature to Epigenetics}

\section{A Displaced History}

Pertaining to a mental or somatic injury suffered as a result of experiencing an event with an extraordinary impact power, the category of trauma has been known to psychiatry and psychoanalysis since the latter half of the nineteenth century. More recently, it has been readily employed in many fields of the humanities as helpful in diagnosing the condition of the (post)modern subject, struggling with the burden of extreme experiences of twentieth-century history and the overwhelming excess of stimuli produced by the progressing modernization. ${ }^{1}$ At first glance, however, it seems that for a long time this category did not receive due attention from translation studies. Yet, seen in the context of cultural-linguistic transfer, it could well back up many efforts to explain those aspects of (post) modern history that resist swift comprehension or various mechanisms of representation, and conventions of textualization or depiction. If we are reminded today that history is experienced as trauma when "it returns as transmission and translation," ${ }^{2}$ the categories of trauma, translation, and transmission deserve all the more to be discussed together in a postmemory perspective.

So much for the first glance. But if we look more carefully at the development of translation studies over the last two decades, we see that at least two currents that have been gaining ground - feminist and postcolonial TS - have very often referred to traumatic experiences in building their narratives. Rape, injury, violence, and anxiety are key words in their lexicons. Translating highly experimental literary texts, revising fundamental myths and narratives or simply exposing mechanisms that have led to the marginalization of women translators, feminist TS scholars have shown in their most radical attitudes and projects the necessity to confront the painful effects of patriarchal authority and linguistic and cultural oppression. In her influential piece titled "Gender and the

1 K. Bojarska, “Trauma.” In: Wydarzenia po Wydarzeniu. Białoszewski - Richter Spiegelman (Warsaw 2013), pp. 247-289.

2 Bojarska, “Trauma”... p. 251. 
Metaphorics of Translation,"3 Lori Chamberlain attacked George Steiner's model of step-by-step translation hermeneutics, which he described, i.a., as an act of invasion and aggression, penetration and appropriation.

Numerous feminist rewriting strategies, aiming to achieve the redistribution of discursive power and often built on the premises of deconstruction, have echoed the ambitions of postcolonial translation studies, perhaps even more rigorous in tracing how injuries reflected in particular acts of translation and translation strategies are worked through. With even greater determination, perhaps, postcolonial translation scholars explore the various geographies and histories of hegemonies, painfully experienced invasions, conquests, and religious conversions. ${ }^{4}$

I am not going to describe here the numerous forms that this working through process has taken; I would like to pause, however, on the field of psychoanalysis, chiefly because it is conducive to the efforts to show the traumatic and at the same time translational dimension of the experience of (post)modern history, and in particular those of its traces which we are not (or not fully) conscious of, ${ }^{5}$ and which affect, to a greater or lesser extent, the construction of our individual or collective memory, challenging to the epistemic frameworks we use to view the past.

Andrew Benjamin, who has examined Freud's uses of the term "translation" (Übersetzung), states that two related contexts are of prime importance for psychoanalysis: one pertains to the role of the analyst as a translator and interpreter, and the other to translation as a component of the subject's mental life. Involving the active participation of both the patient and the therapist, translation is linked to the fundamental movement that transfers what is repressed into the consciousness. This process occurs on two levels, which are best revealed in the interpretation of dreams: what happens here is that the latent content is connected to the manifest content, and then the manifest content is translated into the language of the conscious. This movement pertains to both the interpretation of dreams and the concept of "afterwardsness" (Nachträglichkeit), which bears mention, as it places the process of translation, fundamental to Freudian

3 L. Chamberlain, "Gender and the Metaphorics of Translation." In: Translation Studies Reader, 3rd edition, ed. L. Venuti (London-New York 2012), pp. 254-268.

4 For detailed discussion see T. Bilczewski, Komparatystyka i interpretacja. Nowoczesne badania porównawcze wobec translatologii (Kraków 2010).

5 C. Bollas, The Shadow of the Object: The Psychoanalysis of the Unthought Known (New York 1988); G. Schwab, "Words and Moods: The Transference of Literary Knowledge," SubStance 1997, No. 3, pp. 107-127. 
psychoanalysis, in the light of a traumatic experience, and also indicates other (also translational) contexts for the reception of psychoanalysis. The excerpt that introduces all these contexts is Freud's famous letter to Wilhelm Fliess of 6 December 1896, in which he speaks of the mechanism of repression, referring to its workings as die Versagung der Übersetzung. Following Andrew Benjamin, let me quote the key sentence, in which Freud defines repression as a refusal or failure of translation: "Die Versagung der Übersetzung, das ist das, was klinisch 'Verdrängung' heisst." ${ }^{6}$ Throughout its interpretive history, this passage first of all drew attention to the translation difficulties it presented. The translations of die Versagung der Übersetzung led readers in somewhat different semantic directions, as we can see through juxtaposing the English "failure of translation" with the French refusement de traduction (rather suggesting "refusal," through the neologism refusement). ${ }^{7}$ Secondly, already in Freud's letter itself we are dealing with an intralingual translation of sorts in Verdrängung, borrowed from clinical language. Thirdly, if repression is defined as a failure or refusal of translation, we might well ask what was to be translated - what was the source or the original.

In both Translation and the Nature of Philosophy and in an article that develops the psychoanalytical motifs discussed in that book, Translating Origins: Psychoanalysis and Philosophy, Andrew Benjamin shows the complex, relational, and ontologically problematic status of the source as an event, its entanglement in the act of repeating what has occurred, and its involvement in the process of creating something new, which has significant consequences not only for the anatomy of translation, but also for the mechanisms of repression and afterwordness. Benjamin points out the necessity of rethinking the view of the relationship between the original and the translation as a relation of an interior to a stable exterior. He argues that the past event does not demand total replication, or an "intact presence," from the translation, but rather a repetition carrying the potential to transform the past into the "here and now." Benjamin links the displacement of the source through space and time ${ }^{9}$ - as it ceases to be

6 A. Benjamin, "Translating Origins: Psychoanalysis and Philosophy." In: Rethinking Translation: Discourse, Subjectivity, Ideology, ed. L. Venuti (New York-London 1992), p. 19.

7 See: Benjamin, “Translating Origins," p. 20.

8 A. Benjamin, "Psychoanalysis and Translation." In: Translation and the Nature of Philosophy: A New Theory of Words (New York-London 1989), pp. 109-150.

9 On the category of time in Lacan and Freud in the context of early trauma and the two concepts of the subject's narrative identity see: A. Bielik-Robson, "Słowo i trauma: czas, narracja, tożsamość," Teksty Drugie 2004, No. 5, pp. 23-34. 
apprehended as arché, the origin of something identical, and reveals its complex and always already translational nature, which allows the old to be situated within a new order and a new network of relationships through repetition - to Freud's description of hysteria, where the event itself resonates less than its later memory. In hysteria, Freud says, memory is repressed, and when it returns it becomes trauma. ${ }^{10} \mathrm{He}$ tried to describe and investigate this mechanism on many occasions. It presumes the existence of two moments: the subject's first confrontation with the event, the repression of the content connected with it, and its return or activation through a later event, which is the "actual" experience of trauma. It is only retroactively that the first scene of the confrontation can be understood, possibly introduced to the symbolic system, textualized, visualized and comprehended. In a dissertation on childhood neurosis, ${ }^{11}$ Freud pointed out that this first moment does not bring symptoms of an illness, which only appear later on. Adam Lipszyc explains this special duality as follows:

Although Freud himself does not state things so radically, we could probably say that the remarkable circular dialectic of Nachträglichkeit essentially has two complementary aspects: first, the later event lends a traumatic nature and agency to the earlier event; second, it is only the later event that creates an image of the earlier event, though itself it is, of course, an echo of the previous event! ${ }^{12}$

As Freud wrote in Beyond the Pleasure Principle (1920), a work that is seen as the seminal statement in his theory of trauma, the image of hysteria approaches that of traumatic neurosis through a gamut of similar motor symptoms, the difference being that the latter surpasses hysteria

in its strongly marked signs of subjective ailment (in which it resembles hypochondria or melancholia) as well as in the evidence it gives of a far more comprehensive general enfeeblement and disturbance of the mental capacities. ${ }^{13}$

The characteristics of traumatic neurosis was here placed in a particular historical context: it came about as a result of

10 Bielik-Robson, "Słowo i trauma," p. 30.

11 S. Freud, From the History of an Infantile Neurosis, trans. J. Strachey, in: The Standard Edition of the Complete Psychological Works of Sigmund Freud, Volume XVII (19171919), pp. 1-124.

12 A. Lipszyc, "W.G. Sebald: W noktoramie niepamięci." In his: Rewizja procesu Józefiny K. $i$ inne lektury od zera (Warsaw 2011), p. 145.

13 S. Freud, Beyond the Pleasure Principle, trans. J. Strachey (New York 1989), p. 10. 
severe mechanical concussions, railway disasters and other accidents involving a risk to life $[\ldots]$. The terrible war which has just ended gave rise to a great number of illnesses of this kind. ${ }^{14}$

In this essay, I will focus on traumatic neurosis tied to the experience of the Holocaust, and particularly on the mechanisms behind its intergenerational transmission, which I want to consider in conjunction with the experience of emigration, a state of "suspension," and a journey between languages. Although the link between psychoanalysis and translation deserves further investigation, particularly in terms of the French reception of Freud's work and the more recent theories attempting to diagnose the condition of the (post)modern subject using the category of trauma, ${ }^{15}$ here I would like to recall only one work, which will guide my further argument, and in which translation and psychoanalysis illuminate each other.

I have in mind Paul Ricoeur's late text, Sur la traduction. Returning to Walter Benjamin's "The Task of the Translator," the author considers the problem of translation in terms of the double meaning Freud gives to the word "work:" in one essay it pertains to the work of memory, and in another to the work of mourning. ${ }^{16}$ This meaning reveals a modus operandi characteristic of translation, wherein the aim is lossless repetition, salvaging and retaining, but at the same time there is the necessity to reconcile oneself to loss. The logic of this operating mode comes from the translation's ontological status of belonging to both the source and target cultures, as well as from its economy and politics, which shapes, on the one hand, the conviction that there cannot be two originals, which means emphasising the secondary, inferior, and subordinate nature of the copy, which more or less faithfully approximates the original, and on the other, the dream of a second original so perfect that even the well-armed eye and ear would be incapable of detecting its flaws and betrayals. Among the various expressions of a longing for the perfect translation, Ricoeur singles out two: the project of creating a total library born in the Aufklärung circles, the idea of a book collection as an infinite network of translations of all works into all languages, and a teleological vision of a pure language, which every translation contains as a "Messianic echo." Both forms, pan-translation and the coming of the saving reign of reine Sprache, express the desire

14 Freud, Beyond....

15 See: K. Bojarska, Wydarzenia po Wydarzeniu..., pp. 247-289.

16 P. Ricoeur, On Translation, trans. R. Kearney (New York 2006). 
that translation would gain, gain without losing. It is this very same gain without loss that we must mourn until we reach an acceptance of the impassable difference of the peculiar and the foreign. ${ }^{17}$

This mourning would lead every time to working through the loss resulting from the departure of the ideal of the absolute translation, and to drawing joy from its dialogical nature and a "rational desire of translation."

Meanwhile, I would suggest moving on from the work of translation described in psychoanalytical terms to a literary perspective, in order to see how the language of literature problematizes the issues signaled above, and how it represents the post-traumatic condition of the subject.

\section{Traveling the Cracks There and Back}

Although the issues I shall discuss could emerge from a mosaic of many texts from various cultural-linguistic traditions (the works of Wilhelm Dichter, Magdalena Tulli, Lisa Appignanesi, W.G. Sebald etc.), I will be focusing on Eva Hoffman's 1989 book Lost in Translation, ${ }^{18}$ as it makes the above anatomy of translation the basis of its composition in the context of psychoanalysis and inquiries into what happens to the subject at the moment of a painful shift from one linguistic image of the world into another. The three parts of this book, "Paradise," "Exile," and "The New World," mark the stages of a real-life journey of the nearly-thirteenyear-old Ewa Wydra, who was forced to leave her hometown of Krakow with her parents in the 1950s amid growing anti-Semitic moods. Sailing out from Gdynia, the ocean liner Batory brings Ewa to Montreal, where, following the painful uprooting, she faces the prospect of acculturation into a new and wholly unfamiliar world. ${ }^{19}$ The translation process, and thus, in accordance with the etymology of the Latin transfero, the transfer from one place to another, can be observed here in two closely interlocking aspects: on the one hand, the longterm feeling of having left home, losing one's possessions and oneself, the slow parting from language, perceived as an agony, and, on the other the necessity of coming to terms with a foreign geography and making one's home in a new language.

17 Ricoeur, On Translation..., p. 9.

18 E. Hoffman, Lost in Translation: A Life in a New Language, (New York 1989); hereafter: LiT followed by the page number.

19 See: B. Karwowska, “Tożsamość postmigracyjna. Przypadki (między innymi) Evy Hoffman i Czesława Miłosza." In her: Druga płeć na wygnaniu. Doświadczenie migracyjne w opowieści powojennych pisarek polskich (Krakow 2013), pp. 17-48. 
As images flash before the reader's eyes of the protagonist's happy childhood in Krakow, in a Jewish family that had moved from a small Ukrainian shtetl after the war in search of new opportunities in a big-city environment and to distance themselves from the difficult past, as we get a glimpse of young Ewa's private world immersed in the communist reality of the 1950s, iconically represented by the colorful life of the house at 79, Kazimierza Wielkiego Street, "full of talk, visits, and melodrama," we begin to comprehend the scale and intensity of her shock. It suffices to juxtapose two images:

I pick up a reddish brown chestnut and suddenly, through its warm skin, I feel the beat as if of a heart. But the beat is also in everything around me, and everything pulsates and shimmers as if it were coursing with the blood of life. Stooping under the tree, I'm holding life in my hand, and I am in the center of a harmonious, vibrating transparency. For that moment, I know everything there is to know. I have stumbled into the very center of plenitude, and I hold myself still with fulfillment [...]. (3)

It is April 1959, I'm standing at the railing of the Batory's upper deck, and I feel that my life is ending. I'm looking out at the crowd that has gathered on the shore to see the ship's departure from Gdynia - a crowd that, all of a sudden, is irrevocably on the other side - and I want to break out, run back, run toward the familiar excitement, the waving hands, the exclamations. We can't be leaving all this behind - but we are. I am thirteen years old, and we are emigrating. It's a notion of such crushing, definitive finality that to me it might as well mean the end of the world. (41-42)

And thus, the Eden of childhood, in which the girl experiences the compatibility of language and experience and which constitutes the "original" of life, begins to fall apart with the trauma of displacement, adopting a very physical dimension. During a train journey from Montreal to Vancouver, both Ewa and her sister experience a physical pain of immersion in a foreign, majestic space. Their response is many hours of numbness, fever, and refuge in sleep. The translation machine that Ewa had discovered in childhood, which allowed the musically talented girl to transfer the score written in her mind to the physical movements of her fingers, breaks down. ${ }^{20}$ "The verbal blur covers these people's faces, their gestures with a sort of fog. I can't translate them into my mind's eye" (LiT, p. 108). Apart from the language of emotions and images that reproduce the state of exile from the childhood paradise, from a world that is losing not only its meaning, but also colors and shades, there appears the work of the intellect, a conviction that "the signifier has become severed from the signified." As in other parts of this book, Freud always looms large:

20 The musical motifs of a "life in translation" recur in Hoffman's Appassionata (New York 2008). 
The worst losses come at night. As I lie down in a strange bed in a strange house - my mother is a sort of housekeeper here, to the aging Jewish man who has taken us in in return for her services - I wait for that spontaneous flow of inner language which used to be my nighttime talk with myself, my way of informing the ego where the id had been. Nothing comes. Polish, in a short time, has atrophied, shriveled from sheer uselessness. Its words don't apply to my new experiences [...]. In English, words have not penetrated to those layers of my psyche from which a private conversation could proceed. (LiT, p. 107)

As in every act of translation, loss also pertains to the space of acculturation; it becomes most visible when most of what Ewa reads is lost in a flood of misunderstood words. From here on we accompany her in the process of building a whole architecture of language; we observe how a dramatic suspension in a transitional zone triggers in her new waves of melancholy, a feeling once linked to beauty, and now closer to the Freudian category of the "empty subject." Increasing nostalgia and longing grow to the proportions of a sickness, of a devastating sense of loss called a "phantom pain" (LiT, p. 115). This is halted, however, by the narrator's decision to turn from Ewa to Eva, to enter the mourning phase, which, as Freud would say, facilitates the transfer of libidinal energy to a new object, a new language. Beginning the work of transfer, Eva starts to write a diary, to let English into her private world, treating her first language as a part "of the untranslatable past" (LiT, p. 120). The attempt to establish a voice that seems "tight, thin, and mat - a voice without the modulations," without the "dips and rises it had before" (LiT, p. 122), the attempt to inhabit a new home proves to be a constant struggle, the agonic task of the translator, who must overcome the double resistance of unwanted separation and difficult acceptance: "each language modifies the other, crossbreeds with it, fertilizes it" (LiT, p. 273). Each makes the other relative. "Like everybody," Hoffman writes, "I am the sum of my languages - the language of my family and childhood, and education and friendship, and love" (LiT, p. 273). The zones of incompatibility in between them become a window through which the world shows its diversity, and the subject builds the multidirectional consciousness that allows to understand that there is no one center, that we are constantly being dislocated, and various topographies compete for our attention. The geography of displacement demands that we seek various points of reference, established by the dialectic clash of the familiar with the foreign, which Hoffman calls a triangulation process:

we need to triangulate to something - to the past, the future, our own untamed perceptions, to another place - if we're not to become creatures of ephemeral fashion. (LiT, p. 276) 
This process does not ensure, however, a return to the lost paradise; the wholeness of childhood cannot be recreated. A new subject is born in the experience of displacement, as a result of the work of memory and mourning; the writing inscribed in translation becomes a kind of therapy, a "talking cure," the medicine of the second language:

For me, therapy is partly translation therapy, the talking cure a second-language cure. My going to a shrink is, among other things, a rite of initiation: initiation into the language of the subculture within which I happen to live, into a way of explaining myself to myself. But gradually it becomes a project of translating backward. [...] It's only when I retell my whole story, back to the beginning, and from the beginning onward, in one language, that I can reconcile the voices within me with each other; it is only then that the person who judges the voices and tells the stories begins to emerge. (LiT, pp. 271-272)

But in my translation therapy, I keep going back and forth over the rifts, not to heal them but to see that I - one person, first-person singular - have been on both sides. [...] And so, while therapy offers me instruments and the vocabulary of self-control, it also becomes, in the long run, a route back to that loss which for me is the model of all loss, and to that proper sadness of which children are never really afraid. (LiT, pp. 273-274)

The translation process which Hoffman's writing inaugurates with the international success of Lost in Translation has been divided into stages marked by her subsequent books. Each of which also marks a new stage in the work of memory and mourning. Especially After Such Knowledge $e^{21}$ makes us realize that the experience of exile from one's native land and language is part of a broader perspective on translation, tied to the experience of trauma passed down through generations. It is probably no accident that the scene of the ship leaving port in the debut volume of the recollections is accompanied by a memory of the parents' pain, inherited by both sisters, the elder of whom bears the name of her grandparents, and the younger, Alina, her aunt, who had suddenly turned gray and had to dig her own grave before she perished in a gas chamber. The younger child stirs constant feelings of sympathy and anxiety in her mother, which she shares with Ewa: "I inherit some of this fear and look on my sister as a fragile, vulnerable creature who needs all my love and protection" (LiT, p. 7). Ewa notices a sea of pain and death surrounding her; she realizes that her "true origin" is the war. Years later, in New York, having met in a café a woman who remembered her parents and life in the Ukrainian shtetl, she confesses that her parents' pain is the place of her beginning.

21 E. Hoffman After Such Knowledge: A Meditation on the Aftermath of the Holocaust (London 2004). 


\section{Postmemory: Psyche and Somatics}

After Such Knowledge reminds us about two main areas of interest in the translation of the effects of boundary experiences connected with the Shoah. First, there is the medical focus, with an extensive reference literature. Including the noteworthy contribution of Polish psychiatrists, who, as Maria Orwid has often mentioned, for many years had been unable to present their research results at international forums because of the Iron Curtain. ${ }^{22}$ Second, there is the cultural studies focus, examining mainly postmemory, the artistic expression of the experience of the "second generation" of survivors, who suffer recurring nightmares, anxiety or panic attacks, and a sense of persecution. ${ }^{23}$ They have not lived through the Holocaust like their parents, but it works its way into their experience in a different way (as I shall explain momentarily), leaving traces in the mental and somatic spheres.

Works of the latter sort, among which the most well-known are by Marianne Hirsch, ${ }^{24}$ draw from the intergenerational theory of trauma inheritance devised by Nicolas Abraham and Maria Torok; this theory reveals the existence of an inaccessible mental crypt, which, it is often claimed, throws a wrench in the gears of the narrative mechanism or calls attention to a painful "secret." The mental effects of the crypt are called the "phantom"; it is active in the field of postmemory as a

figure of a transitive intergenerational anxiety, passing from the parents' unconscious into the children's unconscious [...]. According to Nicolas Abraham, the phantom is marked by a modality that resembles the dynamic of repression: its insistent, periodic returns are not part of the symptom, conceived as a return of the repressed: "it

22 Mainly work inspired by S. Kłodziński and A. Kępiński, picked up by M. Orwid, A. Teutsch, A. Szymusik, R. Leśniak, J. Mitarski, then continued by a team which included: M. Dominik, J. Gątarski, Z. Ryn, K. Pietruszewski, J. Zadęcki, E. DomagalskaKurdziel, E. Czaplak, R. Izdebski, M. Kamińska, K. Szwajca, K. Prot, Ł. Biedka, J. Bomba, M. de Barbaro, M. Szaszkiewicz, and B. Treger. The team investigated transgenerational transfer, asthenia, and emotional anesthesia. See: M. Orwid, Trauma (Krakow 2009); M. Orwid, Przeżyć... i co dalej? Rozmawiaja Katarzyna Zimmerer i Krzysztof Szwajca (Krakow 2006).

23 N.P.F. Kellerman, "Epigenetic Transmission of Holocaust Trauma: Can Nightmares Be Inherited?" Israel Journal of Psychiatry and Related Sciences, 2013 No. 50/1, pp. 33-39.

24 See, e.g: M.Hirsch The Generation of Postmemory. Writing and Visual Culture after the Holocaust, (New York 2012); E. van Alphen, "Second-Generation Testimony, Transmission of Trauma, and Postmemory," Poetics Today 2006 No. 27/2, pp. 473-488. 
constantly operates [...] like a ventriloquist, like the voice of a stranger (foreigner) in the subject's mental topography."25

This phantom and this secret are at the forefront in Hoffman's writing. The former returns in the opening fragments of Lost in Translation as an identified figure ("My own sister is named after this person who exists like an almost concrete shadow in our lives" LiT, p. 7), while the latter is most evidently explored in The Secret ${ }^{26}$ where the seventeen-year-old protagonist, Iris, senses that a dark mystery is lurking behind her bizarre family situation, her unsettling relationship with her mother and the absence of her father. She makes the startling discovery that she has been cloned, and takes off on a journey of self-discovery, to flee her mother and to seek her grandparents. We get the impression that the themes of existence and translation so present in Hoffman's debut have returned here in the form of different voices: in the questions about the clone's chance for her own, independent life, the ties that bind the original and the copy, and the border between repetition and uniqueness.

We can easily see that, through the returning phantoms of ancestors and the family secrets, Hoffman's writing evokes the experiences of replacement children, recorded extensively in numerous works of literature, of which perhaps the most famous is Art Spiegelman's hybrid Maus (whose origins go back to the 1970s) and Philippe Grimbert's 2004 bestselling novel Un Secret ${ }^{27}$ (based on which Claude Miller made a film under the same title). The latter is the story of a Parisian psychoanalyst who, feeling lonely as an only child, grows up believing that he is constantly accompanied by an imaginary brother, visiting his dreams and possessing everything he lacks: strength, endurance, and the love of his father. Over time, Louise, his confidante and a family friend, reveals a secret he

25 B. Dąbrowski, "Postpamięć, zależność, trauma.” In: Kultura po przejściach, osoby z przeszłościa, ed. R. Nycz (Krakow 2011), p. 268; In the same volume see also: A. Szczepan, Polski dyskurs posttraumatyczny. Literatura polska ostatnich lat wobec Holokaustu i tożsamości żydowskiej, pp. 239-256; M. Żółkoś, Tworzenie pamięci. O powieściach autobiograficznych Ewy Kuryluk, pp. 271-282; A. Mach, "Polska kondycja posttraumatyczna - próba diagnozy," pp. 217-238. These texts comprehensively describe the ways of understanding the category of postmemory, the differences between the second-generation and third-generation experiences, and the role of objects that establish a relationship with the past (Roland Barthes' and Marianne Hirsch's category of "punctum," Bożena Shallcross's "precarium”), or the imagination (Dominick LaCapra's “acting out").

26 E. Hoffman, The Secret. A Fable for our Time (London 2001).

27 Ph. Grimbert, Un secret (Paris 2012). 
long suspected: Philippe had Jewish ancestry, and he also had a brother, Simon, who was born from his father's first marriage and perished in Auschwitz. This is the most important, but not the last family secret; others concern the relationship between the father and his first wife, Hannah, and Philippe's mother, Tania. The narrator's story of discovering a family secret is an experience that changes his entire life; it records an attempt to understand his painful relations with his parents, his own obsessions, his astonishment at the fact that his "imaginary," strong, and nearly perfect brother (who also appears in Spiegelman - let us recall that a photograph of this phantom, "unbeatable" rival was allegedly found in the parents' bedroom) suddenly turns into a real figure from the past, and not a mere phantom created through the language of scenes enacted between the narrator and his parents.

This tale shows the mechanisms that lodged the deceased child in Phillipe's psyche: a crypt inhabited by a living corpse. At the same time, we see how descending to the crypt becomes part of the narrator's rebirth, of a mourning process which aims to stop the intergenerational transmission of trauma. Gabriele Schwab, the author of Haunting Legacies: Violent Histories and Transgenerational Trauma, ${ }^{28}$ shows that here the mourning process consists in the gradual transfer of emotions connected with the dead brother and that it is made up of many symbolic gestures, both personal and political (Philippe travels to Serge and Beate Klarsfeld's archive in Paris, where he discovers the details of the family's deportation to Auschwitz; the decision to write a memoir is made at a dog cemetery, which turns out to be owned by the daughter of Pierre Laval, the politician responsible for the deportations). Referring to Jacques Derrida's Archive Fever, Schwab also shows how writing and archive research become the reverse of the destructive effect of the crypt, and the attempt to counteract the influence of the family secret acquires a communal aspect.

Recent Polish prose features many motifs which could illuminate from various angles the experiences of the boy described by Grimbert. Born back during the war, Roma Ligocka depicts a difficult mother-child relationship in the shadow of war trauma in The Good Child.$^{29}$ She is aware of the mechanisms of the post-traumatic syndrome and her resulting vulnerability to anorexia in a home where there is a language of silence, a language of shared depression, gestures attesting to emotional disorders and difficult contact with the others.

28 G. Schwab, "Replacement Children: The Transgenerational Transmission of Traumatic Loss." In: Haunting Legacies. Violent Histories and Transgenerational Trauma (New York 2010), pp. 118-150.

29 R. Ligocka, Dobre dziecko (Krakow 2012). The passage translated by S.G. 
We find similar awareness in the second-generation narrative of Ewa Kuryluk, who long struggled with family secrets pertaining to her mother's Jewish roots. In Frascati, the protagonists read Trio for the Hidden together, which leads to the following conversation:

'The next sentence sticks in my throat, I'm afraid of choking, my dear daughter', she complained. 'Is it easier to write than to read?' 'I think so, Mama.' 'An injury is like a taboo,' she complained, 'it passes from mother to child, from generation to generation.' 'I know.' 'But it can't last forever,' she waved her hands, 'no one wants to sit under the floorboards until she dies!' 'That's true, Mama.' 'Read me this sentence aloud, starting from "I like how Carol keeps transforming"' 'Softly', she mumbled, 'so that they can't hear you. 'I like how Carol keeps coming transforming,' I read in a whisper, 'from the Jewish girl who wants to hide into the Jewish girl who wants to give herself away, because she feels guilty for having survived. ${ }^{30}$

Another second-generation narrative, Magdalena Tulli's Italian Stilettos - which strikes me as interesting also because it situates the personal landscape of postmemory in the perspective of bilingualism, translation, and functioning in at least two different worlds - takes us into an atmosphere of tensions shaping the life of an Italian-Polish family, vented in "scenes of aggression and humiliation:"

We were too young to know what past events were causing our suffering, sixteen years after the war was lost. Eighteen years after Yalta, where our fate was sealed, in advance, even before we were born. Eighteen years was an eternity for us [...]. Stalin was already dead. But Hitler was still alive and kicking. He sent over Germans who, in the mornings at breakfast, set the tone of our minor frustration, nurtured by a deep and wider frustration, omnipresent as groundwater, or as streams of bile hidden beneath the surface. ${ }^{31}$

Feeling cut off from the environment, haunting dreams ("Sometimes I dreamed about the Germans"; WS, p. 20), the recurring absence of the father and the trying presence of a cold mother - "a beautiful woman with a sad gaze that held a mystery" (WS, p. 26), fleeing from the past and losing her memory (WS, p.32), who, during her illness, seemed like a character plucked from a concentration camp, seeking a mysterious child and recalling relatives the daughter never knew - then struggles with apathy, powerlessness, and a sense of being overwhelmed by an excess of the past: all this is a way of paying an inheritance tax of sorts, a payment that extends "to the end of one's life, if not longer:"

30 E. Kuryluk, Frascati. Apoteoza topografii (Krakow 2009), p. 136. The passage translated by S.G.

31 M. Tulli, Włoskie szpilki (Warsaw 2011), p. 8. Hereafter quoted as WS followed by a page number. Translated by S.G. 
The protagonist of this story would like the war to finally end for her as well. But once the war starts, it has no end. Not for everyone, at any rate. [...] And for civilians the silent, invisible war is still underway. They bleed in it day after lonely day, night after night, year after year. To the end of their days, and some much longer. War, like bankruptcy assets, is passed on to one's descendants. (WS, pp. 64-45)

Replacement children, children of families crippled by Holocaust trauma, growing up in an atmosphere of tension and anxiety, full of disturbing secrets, and realizing their inadequacy with regard to their parents' expectations, more or less consciously grapple with the consequences of the intergenerational transfer, in which, as Gabriele Schwab writes, the parents establish an affective economy of fantasy, where living and dead children become indistinguishable. At the same time, it is interesting that the "replacement" with which the child is burdened need not be limited to a single dead person; it can be all those who have passed. ${ }^{32}$ The economy of the phantom's haunting can operate not only at the level of the individual, but also collectively. Moreover, it affects perpetrators as well as victims. ${ }^{33}$ As the parents maintain their silence, their flow of uncontrolled emotions or emotional frigidity, and frequent mood swings, the child experiences something like cumulative trauma, ${ }^{34}$ losing a sense of stability, dealing with serious identity issues, and becoming someone who is not fully him/herself, an embodiment of memory.

Meanwhile, lest we confine the issue of intergenerational transmission of trauma to the unconscious, or the reception of uncontrolled behavior and gestures, it is time to focus on the somatic side of traumatization. This requires references to the most recent findings in biology and medicine, which I mentioned in the introduction. Although these fields are far from offering a precise explanation of the mechanisms of the intergenerational transmission of trauma, the findings of biologists exploring the structure and mechanisms of the human genome cast new light on this problem. This is particularly true of the flourishing field of epigenetics, which explains changes in the expression of genes unconnected with the modification of DNA sequences, but resulting from methylation of double helix fragments, modification of histones, or the RNA interference (Andrew Z. Fire and Craig C. Mello received the Nobel Prize in medicine and

32 See: G. Schwab, Haunting Legacies... p. 125; see in particular the chapter Haunting Legacies. Trauma in Children of Perpetrators, pp. 67-91.

33 Schwab, Haunting Legacies... p. 126.

34 M. Khan, “The Concept of Cumulative Trauma," Psychoanalytic Study of the Child 1963 No. 18 , pp. 286-306. 
physiology for this discovery in 2006). To replace the extensive conceptual apparatus with a metaphor (justified by relevant footnotes), we might say that epigenetics uncovers the mechanisms of "cellular memory," which activates or dampens the process of gene transcription and mRNA translation into a chain of amino acids when affected by environmental factors, for example. Methylation plays a key role here: the joining of methyl groups to the relevant fragments of a DNA chain, in a reaction caused by enzymes. The main premise of the new field of epigenetics is that genes have a kind of memory, or, as it was phrased in the description of a BBC documentary: "that the lives of your grandparents - the air they breathed, the food they ate, even the things they saw - can directly affect you, decades later, despite your never experiencing these things yourself." ${ }^{\prime 3}$ Studies on the mechanisms behind this sort of transfer also incorporate various fields of medicine, including psychiatry, in the hopes of not only understanding certain physiological processes, but also discovering new forms of therapy. ${ }^{36}$

In terms of postmemory, the most interesting aspect would of course seem to be the findings concerning the impact of traumatic experiences on epigenome modifications and their intergenerational transmission. For example, it was demonstrated that sexual damage incurred in childhood impacts the functioning of the "stress axis," ${ }^{37}$ and Canadian researchers have shown the repercussions of pregnant women's mental disorders on how this axis functions in their children. ${ }^{38}$ Special note should be made of work on Posttraumatic Stress Disorder (PTSD), ${ }^{39}$ which is classified as a mental disorder resulting from painful events of unprecedented impact (involving death, a threat to life or personal integrity), combined with an experience of fear and evoking terror or a deep sense of helplessness. ${ }^{40}$

35 See: www.bbc.co.uk/sn/tvradio/programmes/horizon/ghostgenes.shtml (access: 16.08. 2013). The Ghost in Your Genes, dir. by N. Paterson, BBC 2005.

36 See: J. David Sweatt, "Experience-Dependent Epigenetic Modifications in the Central Nervous System,” Biological Psychiatry 2009 No. 65/3, pp. 191-197.

37 P. O. McGowan et al., "Epigenetic Regulation of the Glucocorticoid Receptor in Human Brain Associates with Childhood Abuse," Nature Neuroscience 2009 No. 12/3, pp. 342-348.

38 T. F. Oberlander et al., "Prenatal Exposure to Maternal Depression, Neonatal Methylation of Human Glucocorticoid Receptor Gene (NR3C1) and Infant Cortisol Stress Responses," Epigenetics 2008 No. 3/2, pp. 97-106.

39 In the late 1960s, this was called KZ syndrome, concentration camp syndrome, or Holocaust syndrome. See: A. Kępiński, “The KZ syndrome," in his: Rytm życia (Kraków 2012) pp. 106-123; M. Orwid, Trauma.

40 See: The ICD-10 Classification of Mental and Behavioural Disorders, Diagnostic Criteria for Research, WHO, Geneva, F43.1. 
The causes of the mental dysfunctions of Holocaust victims - described in literature and memoirs, as well as in works that draw from psychoanalysis, psychodynamic theories or socio-cultural communication models - for some years have been researched by Rachel Yehuda, a psychiatrist and neurobiologist from The Mount Sinai Medical Center in New York. ${ }^{41}$ Yehuda and her coworkers have broadened their initial scope of inquiry to include the traumatic experiences of not only the second generation, but the third one as well, adding observations of the effects of the attack on the World Trade Center in women who witnessed it during pregnancy. ${ }^{42}$ Their research shows the impact of shock on epigenetic programming, making us realize that trauma has a wider resonance than we have suspected, affecting not only the mind, but also the biological sphere. This opens new avenues for therapy, creating opportunities for combining psychotherapy and pharmacotherapy more effectively. ${ }^{43}$

Future research on genome structure and the workings of epigenetic mechanisms could eliminate many doubts on the process of intergenerational transfer, and not only when it comes to trauma, casting new light on the interpretation of problems raised by Eva Hoffman and other authors, such as Ewa

41 R. Yehuda et al., "Maternal, Not Paternal, PTSD Is Related to Increased Risk for PTSD in Offspring of Holocaust Survivors," Journal of Psychiatric Research 2008 No. 42/13, pp. 1,104-1,111; T. B. Franklin et al., "Epigenetic Transmission of the Impact of Early Stress Across Generations," Biological Psychiatry 2010 No. 68/5, pp. 408-415; R. Yehuda, "Current Status of Cortisol Findings in Post-Traumatic Stress Disorder," Psychiatric Clinics of North America 2002 No. 25, pp. 341-368; R. Yehuda, L. M. Bierer, "Transgenerational Transmission of Cortisol and PTSD Risk," Progress in Brain Research 2008 No. 167, pp. 121-135; R. Yehuda, L. M. Bierer, “The Relevance of Epigenetics to PTSD: Implications for the DSM-V," Journal of Traumatic Stress 2009 No. 22(5), pp. 427-434; R. Yehuda et al., "Ten-Year Follow-Up Study of PTSD Diagnosis, Symptom Severity and Psychosocial Indices in Aging Holocaust Survivors," Acta Psychiatrica Scandinavica 2009 No. 119/1, pp. 25-34; R. Yehuda et al., "The Role of Genes in Defining a Molecular Biology of PTSD," Disease Markers 2011 No. 30/2-3, pp. 67-76.

42 R. Yehuda et al., "Gene Expression Patterns Associated with Posttraumatic Stress Disorder Following Exposure to the World Trade Center Attacks," Biological Psychiatry 2009 No. 66/7, pp. 708-711; R. Yehuda et al., "Transgenerational Effects of Posttraumatic Stress Disorder in Babies of Mothers Exposed to the World Trade Center Attacks during Pregnancy," The Journal of Clinical Endocrinology \& Metabolism 2005 No. 90/7, pp. 4,115-4,118.

43 S. M. Stahl, "Psychotherapy as an Epigenetic 'Drug': Psychiatric Therapeutics Target Symptoms Linked to Malfunctioning Brain Circuits with Psychotherapy As Well As with Drugs," Journal of Clinical Pharmacy and Therapeutics 2011 No. 37, p. 249-253. 
Kuryluk, Piotr Paziński, Andrzej Bart, Anda Rottenberg, Magdalena Tulli, Bożena Keff, Piotr Szewc, Marek Bieńczyk, Mieczysław Abramowicz, Agata Tuszyńska, and Igor Ostachowicz: on the translation work of memory and mourning as a way of dealing with historical shock. The rise in the social significance of postmemory issues is signaled by the significant growth of literature that problematizes mechanisms of intergerational trauma transmission, which is naturally linked to the present historical situation; witnesses to the Holocaust are passing away, and the memory of this event must now be constructed in their absence. The growing alignment of postmemory perspectives and questions of translation, in turn, is linked to the increasing significance of the ability to adapt to a "life in translation," which has become an important modus vivendi of (post) modernity, our age of global flow and migration. The categories of trauma and translation transfer from the optic established by attempts at dealing with the consequences of the Shoah to the optic focused on the effects of injuries inflicted through torture, colonialism, slavery, and contemporary conflicts. These effects arise in a different geography of memory, which we can see in Gabriele Schwab's aforementioned book, in which the phenomenon of intergenerational transmission is seen in the context of two works representing Māori culture: Witi Ihimaera's The Whale Rider and Patricia Grace's Baby No-Eyes. This tendency is confirmed by the developments in translatology in the past decade: apart from a book devoted to the work of Primo Levi, ${ }^{44}$ in which recurring images of translation are a tool for dealing with the (in)expressibility of the experience of the Shoah, and a project under the patronage of Derek Attridge and Susan Bassnett, ${ }^{45}$ which brought, i.a., Piotr Kuhiwczak's inspiring study (based on translations and pseudo-translations of Władysław Szpilman's The Pianist) on how the knowledge of painful wartime events is shaped by cultural-linguistic mediation, we also find attempts to show the translational aspect of boundary experience. One such example is Bella Brodzki's juxtaposition of a narrative by the French Holocaust survivor Claude Morhange-Bégué with the postcolonial novel of the Nigerianborn writer T. Obinkaram Echewa. ${ }^{46}$

44 L. N. Insana, Arduous Tasks: Primo Levi, Translation, and the Transmission of Holocaust Testimony (Toronto-Buffalo-London 2009).

45 Tradition, Translation, Trauma. The Classic and the Modern, eds. J. Parker, T. Mathews (New York 2011). See also: P. Kuhiwczak, Mediating Trauma. How do we Read the Holocaust Memoirs?, pp. 283-298.

46 B. Brodzki, "Scenes of Inheritance: Intergenerational Transmission and Imperiled Narratives." In her: Can These Bones Live? Translation, Survival, and Cultural Memory (Stanford 2007). 
The importance of literature that strives to uncover and work through the wounds and obsessions arising from traumatic past events passed down through intergenerational transmission comes from the fact that it allows us to delve into unconscious or barely conscious realms of individual and shared history; that it can serve as a "transformational object," to borrow a term from Christopher Bollas, a catalyst that allows us to reassess the past, to understand and change our lives. In other words, the language of literature provides a chance to gain missing knowledge about the ties that bind us to the historical events of our times, ${ }^{47}$ filling gaps in other discourses, including the language of the natural sciences. The latter has been included here in order to present the issue of intergenerational trauma transfer from another angle. It would seem that both languages used in this essay mark out separate territories of knowledge and imagination, but there is no reason to limit ourselves to one of them in a world where translation is gaining significance, to forsake attempts at moving freely between them, even if this kind of "translation" should prove risky.

[2013]

Translated by Soren Gauger

47 S. Felman, D. Laub, Testimony: Crises of Witnessing in Literature, Psychoanalysis, and History (New York-London 1992), p. XX. 
Małgorzata Tryuk

\section{You Say Nothing, I Will Interpret. Interpreting in the Auschwitz-Birkenau Concentration Camp}

\section{Introduction}

Community interpreting is the type of interpreting which takes place in the public service sphere to facilitate communication between officials and lay people: at the police station, immigration departments, refugee and social welfare centers, medical and mental health offices, schools, and other institutions of this kind. This type of interpreting is bi-directional and carried out consecutively. It covers interpreting in face-to face situations and is probably the most common and the oldest type of interpreting in the world. Sometimes it is performed by volunteers, untrained bilinguals, friends or relatives, and even by children.

The role of an interpreter is as vital to successful communication in community interpreting as it is in any other type of interpretation. Involvement in faceto-face interaction emphasizes the interpreter's function as both language and social mediator. Nowadays the interpreter also plays a crucial and complex role in the process of integration in society, often acting as a coordinator, a cultural mediator or even a censor.

The fact that interpreting takes places in different institutional contexts, involving various aspects such as empowerment, equity and access to social capital, makes it necessary to also examine interpretation from a historical perspective.

Accounts of the work of interpreters in extreme situations - critical situations which are important and difficult in their human aspect for all the main participants (i.e. the involved parties and the interpreter her/himself) - have been presented on numerous occasions in the writing on interpreting, both those of an empirical, observational, and interactive character and those more analytical and theoretical in nature. These accounts include reports on interpreting at the trials of the Nazi war criminals in Nuremberg ${ }^{1}$ or at Eichmann's trial in Jerusalem, ${ }^{2}$ as

1 D. Bowen, M. Bowen, "The Nuremberg Trials (Communication through Translation)," Meta Vol. 30, No. 1, 1985, pp. 74-77; F. Gaiba, The Origins of Simultaneous Interpretation: The Nuremberg Tria (Ottawa, 1998).

2 R. Morris, "Court Interpretation: The Trial of Ivan Demjanjuk. A Case Study," The Interpreters' Newsletter, 2, 1989, pp. 27-37. 
well as more recent reports on the role of interpreters at the hearings conducted by the Commission of Truth and Reconciliation in South Africa ${ }^{3}$, at the UNO peace missions in Lebanon and the countries of former Yugoslavia ${ }^{4}$, and the humanitarian missions of NGOs in Iraq or Afghanistan ${ }^{5}$. Equally extensive has been the research on interpreting at public prosecutors' offices and at all stages of court hearings and interrogations. Researchers of both empirical and theoretical aspects of court-based community interpreting have tried to reveal the ethical norms binding on an interpreter in her/his work. ${ }^{6}$ These norms are deontological, sui generis, and include: reliability, morals beyond reproach, linguistic competence and expertise, faithfulness in interpreting, impartiality and neutrality, acting in an unassuming way, awareness of social and cultural peculiarities, high resistance to stress and observance of the rules of professional ethics. Among all the norms described, impartiality and/or neutrality are usually assigned primary importance; most studies emphasize that, above all, a court interpreter is expected to be accurate and impartial. This means the interpreters are expected to be neutral with regard to the people and discourse they interpret.

In all the studies on community interpreters, there has so far been very little research into the work of the interpreters in the concentration camps and at Gestapo interrogations during World War II. Interpreters were needed in those extreme conditions, as is evidenced in the diaries, the memoirs and records of the former concentration camp inmates. These might have been ex officio interpreters who over-zealously joined these functions with other policelike duties, or, not infrequently, prisoners themselves like the camp Schreiber/in ('registrar') or Läufer/in ('messenger').

The aim of the present research is to study the records of the AuschwitzBirkenau concentration camp in order to trace the recollections of and about camp interpreters, their work and their attempts to ease the hardships of other prisoners, often risking their own lives in the process. It is also my intention to show that the generally accepted norms applicable to interpretation in courts,

3 Ch. Wiegand, "Role of the Interpreter in the Healing of a Nation: An emotional view." In: The Critical Link 2: Interpreters in the Community, eds. R. Roberts, S.E. Carr, D. Abraham, A. Dufour (Amsterdam-Philadelphia 2000), pp. 207-218.

4 R. Thomas, "United Nations Military Observer Interpreting in a community setting." In: Carr et. al., The Critical Link, pp. 249-257.

5 M. Szymczukiewicz, "L'inteprétation communautaire dans l'armée. Etude de cas: missions polonaises de paix." Unpublished M.A. Thesis, University of Warsaw, 2005.

6 M. Tryuk, Linterprétation communautaire. Des normes et des rôles dans l'interprétation (Warsaw 2004); M. Tryuk, Przekład ustny środowiskowy (Warsaw 2006). 
police stations, jails and holding cells were not applicable to concentration camps, and that different norms were adopted, which were highly justified by the circumstances.

This work is based on the collection of testimonials and recollections of former concentration camp inmates, which is held at the Auschwitz-Birkenau Memorial and Museum Archives. The collection includes 134 volumes of recorded statements (3,000 separate items), 200 volumes of recollections $(1,000$ reports), and 76 volumes of the trial of the General Commandant of the Camp, Rudolf Höss. ${ }^{7}$ This material is a unique example of the ontological narratives referred to by Mona Baker. ${ }^{8}$ It relates the experiences of the victims of the Nazi regime and presents an account of their arrest, their life in the camps, their relationships with other prisoners and their expressions of fear of the SS men and other camp officials. An important strand which is evident to the careful reader is that many accounts mention 'the good chap' who would help one survive, who would be willing to share his meager rations as well as any information he has obtained. The "good chap" could also be the interpreter. Despite the massive amount of material, it should be noted that references to interpretation are rather scant, and when they do occur, they tend to be random, brief and laconic, usually consisting of dry facts. Moreover, inmates often offer differing versions of the same event. For these reasons, obtaining an objective, empirical account of events is virtually impossible. This chapter focuses mainly on the profiles of the official camp interpreters, the Lagerdolmetscher.

\section{Why Were Interpreters Needed in the Concentration Camps?}

In each Nazi concentration camp, the inmates represented between 35-40 different national or ethnic groups, each having their own language. All the inmates lived in extreme conditions. The communication, if any, with the German Kapo had to be in German, the ever-present language, and if any postal services were allowed at all, all the paperwork had to be in German, too. In the barracks and work blocks all rules, orders, and directions were delivered in German. In Konzentrationslager (KL) Auschwitz the use of Polish, Russian or Italian was forbidden. ${ }^{9}$ The General Commandant of the Camp, Rudolf Höss, issued an order

7 Throughout the paper the quotations from the Auschwitz-Birkenau Memorial and Museum Archives are marked as APMA-B with the relevant volume and page numbers in brackets.

8 M. Baker, "Narratives to and on translation," Skase Journal of Translation and Interpretation 2005, Vol. 1, No. 1, pp. 4-13.

9 A. Gunia, "Język obozów koncentracyjnych," Języki Specjalistyczne 2006, vol. 6, p. 51. 
on July 30, 1940, forbidding the camp staff to use any foreign language they might know, in particular forbidding the use of Polish or Czech. This order was directed to the Silesians and Volksdeutsche ('ethnic Germans) who performed various function in the camps. In addition, every inmate was required to memorize some basic phrases in German: their concentration camp number, their barrack number, and the texts of songs they were required to sing for the amusement of their guards. Only in a few instances were certain signs posted in both German and Polish, for example "Halt! Stój!”. Concentration camp German was, however, of a specific nature. Michael Cronin defined it as follows: "German, in this instance, is a language not of requests but of orders." ${ }^{10}$ Survival in the concentration camp without some knowledge of German was practically impossible. Primo Levi notes that:

The greater part of the prisoners who did not understand German - that is, almost all the Italians - died during the first ten to fifteen days after their arrival: at first glance, from hunger, cold, fatigue, and disease; but after a more attentive examination, due to insufficient information. If they had been able to communicate with their more experienced companions, they would have been able to orient themselves better: to learn first of all how to procure clothing, shoes, illegal food, how to avoid the harsher labor and the often lethat encounters with the SS, how to handle the inevitable illnesses without making fatal mistakes. I don't mean to say that they would nor have died, but the would have lived longer and had a greater chance of regaining lost ground ${ }^{11}$.

Further on, he writes about French prisoners (Alsatians or German-Jewish or Polish-Jewish emigres to France, knowing German or Yiddish):

They were our natural interpreters: they translated for us the fundamental commands and warnings of the day, "Get up," "Assembly." "Line up for bread," "Who's got broken shoes?" "By threes," "By fives," et cetera. (DS, p. 83)

In essence, however, two languages were used in the camps: German and the 'unofficial' language, that is Polish or its sociolectal variety, so-called Lagersprache. ${ }^{12}$ Polish was used owing to the dominating number of Polish inmates. Lagersprache was created out of Polish, Yiddish, Silesian dialects, and Hungarian. It was a camp slang - a way for the inmates to communicate among themselves in the camp, although it also occurred that some German functionaries and even SS troops took some expressions from Lagersprache. It is noteworthy that there were two

10 M. Cronin, Translation and Identity (London - New York 2006), p. 77.

11 P. Levi, The Drowned and the Saved, trans. R. Rosenthaler (New York 2017), p. 80. Hereafter marked DS with a page number.

12 Gunia, "Język obozów." 
varieties of this sociolect: a different Lagersprache was in use in the men's camps and in the women's camps. Reflecting on the role of Polish for inmates coming from other countries and nationalities, Levi writes:

To this day I remember how one pronounced in Polish not my registration number but that of the prisoner who preceded me on the roster of a certain hut [...]. As a matter of fact, in that hut the soup dispenser and the greater part of the prisoners were Polish, and Polish was the official language; when you were called, you must be there ready, holding out your bowl in order not to miss your turn and, so as not to be caught by surprise, it was a good idea to jump when the companion with the immediately preceding registration number was called. (DS, p. 80-81)

Levi also notes that another 'language' was frequently used in the camp: "All Kapos gave beatings; it was [...] their more or less accepted language. After all, it was the only language that everyone in that perpetual Tower of Babel could truly understand [...] like the Tower of Babel, beating was the one language understood by all" (DS, p. 60). Similarly, presenting the profile of Karl Broch, the sadistic Unterscharführer from the Politische Abteilung ('Political Section') in the Auschwitz-Birkenau camp, Lore Shelley recalls that he had a 'saying' that Die Peitsche ist der beste Dolmetscher, sie spricht alle Sprachen ('the whip is the best interpreter; it speaks in all languages') ${ }^{13}$ The camp inmates' first contact with an interpreter occurred during their interrogation by the Gestapo. Janusz Karwacki recalls: ${ }^{14}$

Here I have to explain that the way of interpreting the message didn't really reflect the form in which we prisoners were addressed. I came to understand it much later, when there were no interpreters and we were addressed directly in German. We were always addressed as Sie. It was equally true of common talk, orders, commands, abuse or ridicule. Always Sie was used. It was a dismal farce. You were civilly addressed with Sie. You were selected to be transported to the gas chamber with Sie, you were abused and punished with Sie. You were downtrodden in what remained of your human dignity, so stubbornly defended, with Sie. Everything with Sie.

I think that inherent in it was an additional perfidy of making the victim break down psychologically. Due to this Sie, every utterance involved a hidden sneer: sneer at a Sir in rags and in total degradation, the state to which anyone can be brought as a result of undernourishment, overwork and permanent life in fear of what other kind of anguish is to follow.

13 L. Shelley, Secretaries of Death. Accounts by Former Prisoners who Worked in the Gestapo of Auschwitz (New York 1986), p. 363.

14 All quotations form the former inmates narratives are my own translation - M.T. 
Interpreters for the Gestapo did not understand the full significance of the sneer involved in this form of address and translated it as 'you' This gave them the delusive feeling of superiority over the prisoner. ${ }^{15}$

An equally dramatic picture of the interpreter during the Gestapo interrogation is given by Jerzy Mostowski, as detailed in the memoirs stored in the AuschwitzBirkenau Memorial and Museum Archives:

I asked for an interpreter, since I wasn't confident in my knowledge of German. I only knew some German from my school lessons, and knew that I was bound to encounter expressions which were completely foreign to me. But when I finished the session with my interpreter - of Silesian origin - I felt as though I'd gotten less than nothing from him. I was not beaten by the German officer conducting the interrogation and asking the questions; nor was I beaten by the underofficer taking down the protocol; but this greasy and obese interpreter went out of his way to insult and humiliate me [...]. (APMA-B vol. 20: 11-14)

Just like in any other multilingual social situation, interpreters were needed in the concentration camps. Auschwitz-Birkenau was no different. Upon arrival in the camp a number of inmates listed their profession as Dolmetscher. These declarations can be found in the registration documents of new arrivals to the death camps. In the majority of cases persons declaring themselves to be interpreters were Jews born in Poland or Russia, often transported to the camps from France or Belgium. Very few of them survived.

\section{Who Were the Interpreters?}

It is not easy to present a profile of those persons choosen to act as interpreters in the concentration camps. From the memoirs held in the Auschwitz-Birkenau Memorial and Museum Archives, it follows that they belonged to a very specific type with multilingual competencies but with German as the dominant language. In the Auschwitz-Birkenau camp three groups of persons acting as interpreters can be distinguished.

The first group consisted of the SS men from the Politische Abteilung ('Political Section'), often Volksdeutsche or Silesians fluent in Polish and employing Polish during the initial interrogation. Shelley names the following SS members: Klaus Dylewski, Gerard Lachman, who most likely joined the French Foreign Legion after the war, Johann Schindler from Łódź, Joseph Stetnik, a Pole from Silesia, Karl Broch, Alois Lorenczyk, a Volksdeutscher

15 J. Karwacki, Życie wśród śmierci (Warsaw 1981), p. 15. 
from Rybnik, Joseph Pach from Silesia, as well as the Volksdeutsche Witold Witkowsky and Georg Woznitza. ${ }^{16}$ The SS guard Lachman also assumed the function of Lagerdolmetscher. ${ }^{17}$

The second group consisted of female prison inmates working in the Politische Abteilung. These were mostly Slovakian or Hungarian Jews, Schreiberinnen ('registrars') or Läuferinnen ('messengers), for example Mala Zimetbaum, working in the following sections:

- Registratur ('Registry, Document section'). Among the persons working there was one Hella Cougno, a Greek from Thessaloniki, who later described here arrival at the camp as follows: "My mother's number was 38911, mine 38912 - and work began. We were assigned as interpreters." When the transport of inmates from Greece ceased, Ms. Cougno writes that: "My mother and I were no longer needed as interpreters. We were therefore dispatched back to Auschwitz, to the Politische Abteilung." 18

- Schreibstube ('Secretariat'). Shelley worked here. She recalls: "I also served as secretary for out-of-town Gestapo officials who came to interrogate camp prisoners. [...] Frequently, one of the girls of my commando served as interpreter for Polish, Ukrainian or Russian prisoners." ${ }^{19}$

- Vernehmungsabteilung ('Interrogation section')

- Standesamt ('Civil section')

- Rechtsabteilung ('Legal section')

- Aufnahmeabteilung ('Reception')

- Erkennungsdienst ('Photographic section').

The third group of interpreters were those prisoners who declared that they knew German (or another language necessary in the camp). They were singled out as camp interpreters, that is Lagerdolmetscher. The rest of the present chapter is devoted to this group of inmate interpreters.

Stanisław Skibicki writes: "The camp commanders communicated with us using interpreters as intermediaries" (APMA-B vol. 149: 99). The interpreters often had to perform this function in addition to the other murderous work activities forced upon them like all the other inmates. Their interpretation work did not guarantee them any privileges in terms of how they were treated; for

16 L. Shelley, Secretaries of Death.

17 See Pilecki's statement (APMA-B, vol. 97: 190).

18 Shelley, Secretaries of Death, p. 47.

19 Shelley, Secretaries of Death, p. 97. 
example, they received no additional rations. Nor did it guarantee them survival. Their knowledge of German did, however, give them access to information, and enabled them to communicate better with other inmate functionaries, and in addition simply allowed them to help others.

Camp interpreters wore an armband on their striped prison uniforms like the other functionaries in the camp. Jerzy Poźmiński recalls it as a white armband with black letters reading 'Dolmetscher' (APMA-B, vol. 82: 2). Tadeusz Paczuła, however, writes that the "Lagersdolmetscher wore a black armband" (APMA-B vol.111: 155).

The function of the camp interpreter was fulfilled by the following persons:

- Władysław Baworowski

- Leonard Belewski

- Franciszek Galus/Kalus

- Józef Baltaziński/Balasiński

- Kurt Machula

- Egbert Skowron

- Eugen/Łukasz Łukawiecki, who was the last interpreter in AuschwtizBirkenau left until the final evacuation of the camp.

\section{Władysław Baworowski}

Władysław Baworowski was assigned concentration camp number 863 . He was born on 10 August 1910 in Germakówka and was among those transported to Auschwitz from Kraków and Tarnów on 20 June 1940; he died from exhaustion and hunger on 1 June 1942. Former Auschwitz camp inmates remember Baworowski as one of the first camp interpreters.

Stanisław Skibicki writes:

As I remember the camp interpreter was Franciszek Kalus, who arrived with the first Silesian transport ( $\mathrm{nr}$ 1000), because Baworowski - who also should be mentioned was then only an assistant interpreter. Kalus was really a nerd, but I have to admit that he was useful, wrote different letters and petitions for the inmates and was always willing to help. (APMA-B vol. 149, p. 99)

Kazimierz Zając notes:

I was taken to what was then barrack building nr 5, where Józef Baltaziński was designated as the barrack interpreter. He was a bad man. He was very afraid of the Germans and carried out all their orders with zeal. On more than one occasion was I abused by him. He came from the same area where I was born, from Jasień near Brzesko. [...] He spoke very good German and immediately had a better position than others in the 
camp. Together with Baworowski he first became an interpreter, and later advanced to barrack interpreter. (APMA-B vol. 136, p. 192)

In the recollections of the former inmates, Władysław Baworowski usually interprets the 'welcoming' speech given the inmates by the Camp Commandant Rudolf Höss or his assistants. Czesław Rychlik writes:

First there was a speech by the Commandant of the camp. His speech was translated by Baworowski. Pointing to the crematorium chimney, he explained to us that that was the only way out of the camp. Whether we lived longer or shorter depended on how hard we worked and our strict obedience to camp regulations. (APMA-B vol. 26a: 97)

Baworowski was present and interpreted a number of punishments and sentences handed out to the inmates Zdzisław Wiesiołek recalls:

After two months, during evening roll call, eleven of us were escorted to the front of the roll call area. In the presence of the other inmates gathered there Fritzsch [the Lagerführer] read out our death sentence. It was translated from German by the inmate Baworowski, who explained to us that Fritzsch, in the exercise of his pardon powers, was reducing our sentence to five years of hard labor in the stone quarries and 25 lashes. (APMA-B vol. 33: 29)

Henryk Król writes:

Following the escape of a prisoner, the interpreter - Baworowski - translated to us the punishment announced by the Camp Commandant: "You will remain standing for three days and three nights - without food or water." (APMA-B vol. 76: 199)

Władysław Baworowski was treated even worse than others by the SS men on account of his origins and his pronunciation in German using the characteristic French "r". As Alojzy Drzazga recalls:

During the installation of the inmates in the barracks, the most beaten inmate was Baworowski, later a camp interpreter, who was initially beaten on every occasion, accompanied by shouts of Graf [Count]. (APMA-B vol. 33: 47)

This same inmate writes about the first night in the camp, in a stuffy room without a bunk: "The person who suffered most at the time was the Lagerdolmetscher Count Baworowski, against whom the SS guards had the greatest resentment." (APMA-B vol. 86: 71)

Jan Zdebik notes:

Those persons in charge of supervising us, either SS guards or German criminal inmates, were characterized by a high degree of sadism. All their sadistic acts seemed to give them great pleasure. In particular they singled out Count Baworowski. He had a strange pronunciation and his lifestyle was also different from the other inmates. Generally speaking he was quite a fine man. He didn't survive the camp. (APMA-B vol. 139: 90) 
The most dramatic recollections of Baworowski's suffering is given by Henryk Król, who describes how the SS made him eat faeces (APMA-B vol. 76, p. 199). This incident also shows up in a number of statements by other former inmates. The humiliation of this individual greatly moved the other inmates and gave them an indication as to what might await them at the camp.

Among others, Janusz Walter writes of Baworowski's death:

I also recall the matter of Count Baworowski, who before the war was a person with a title and fortune and had great influence in various governing circles. During his early days at the Auschwitz Camp he carried out the function of interpreter [Lagerdolmetscher] and enjoyed respect of the SS authorities. It is even said that he once ate supper with the Commandant of the camp. Over time however he sunk to a lower and lower rung in terms of his standing at the camp, sinking to a point where the German inmates made him sit up like a dog begging for food in order to obtain his bread ration. And he agreed. Baworowski was waiting for a release from the camp, and had swelled up like a Muselman (weighing almost $200 \mathrm{~kg}$ ) and then died. Shortly afterward his release papers came through. (APMA-B vol. 74, p. 133)

Bronisław Cynka writes:

None of the inmates were ever certain of surviving the day, or even the hour. Some died from stupidity or lack of will power. For example Baworowski, upon being dismissed as a camp interpreter, deteriorated to such an extent that he went rooting through the garbage in search of food scraps. (APMA-B vol. 75, p. 87-88, 95)

\section{Józef Baltaziński/Baltasiński}

Concentration camp number 749, later released from the camp, Baltaziński/ Baltasiński performed various functions in the camp, for example, block interpreter and block supervisor. He zealously carried out all the orders of the Germans. His inhumane treatment of young inmates, beating them and kicking them out in the snow, is recalled by Stanisław Hantz (APMA-B vol. 88: 163-165), Andrzej Rablin (APMA-B vol. 50: 6), Kazimierz Brzeski (APMA-B vol. 35: 38), Kazimierz Zając (APMA-B vol. 136: 189). As Baworowski has done, Baltaziński also interpreted the 'prison welcoming ceremonies.' Włodzimierz Borkowski writes:

These ceremonies were very disorganized and inefficient, for many in the audience didn’t understand the commands. It wasn’t until Józef Baltaziński approached individual columns and started giving the commands in Polish - Bacznośc! W prawo - zwrot! Naprzód - marsz! (Attention! Right-turn! Forward - march!) - that the columns began to move in an orderly fashion. (APMA-B vol. 115: 5) 


\section{Kurt Machula}

Concentration camp number 12355, born on 1 May 1913 in Katowice, transported to Auschwitz on 17 April 1941 from Katowice, Kurt Machula fulfilled the function of camp registrar and interpreter. He was released in 1944. As far as possible, he tried to help the inmates. Adam Cyra writes:

My father, rest his soul, was also fortunate thanks to the intervention of one of his acquaintances, from the days prior to his capture, from Katowice, a man who ran a optic's shop on Świętego Jana Street, who remembered my father from times when he changed camera film for him, and was known in the camp as an "old inmate" and worked in the canteen as Kurt Machula [...], who became a Lagerdolmetscher. When we were "received" into barrack building 23 he wrote down the number of my father and tried to obtain work for him in DAW - Deutsche Ausrüstungswerke Holzbüro, and my father worked as a registrar until that fateful day on 28.10.1942. It makes one think - just how much good one can do in order to help another. (APMA-B vol. 133: 228)

Roman Nawrot notes, however:

Unfortunately, there were also some of us who helped others in the hope of securing a debt of gratitude in the future. One such man was the inmate Kurt Machula from z Bytom, an optician by trade. Supposedly he belonged to an SS formation and in September entered Silesia together with Hitler's army. His homosexual inclinations (so it is said) landed him in the concentration camp, from which he was released in 1944. I don't know his post-war history. In any case this Machula, when helping other inmates, scrupulously recorded their personal data, counting on future rewards upon the end of the war. (APMA-B vol. 80: 107-8)

Elsewhere in his memoir, he writes: "In 1942 I became ill with typhus and was taken to the hospital. I managed to get out early and escaped the gas chamber. I learned about my fate from Kurt Machula - a camp interpreter." (APMA-B vol. 65:137).

The function of an ad hoc interpreter was fulfilled by any inmates, but only those referred to in the present chapter wore the 'Lagerdolmetscher' armband, hence it seems appropriate to refer to them as 'official' interpreters.

\section{How Were the Interpreters Recruited for the Job?}

Camp interpreters were either assigned ex officio, or selected from the groups of prisoners. We have little hard evidence of the process of choosing camp interpreters, only individual recollections, such as the following by Józef Kret:

I remember during my stay in the Auschwitz camp that in the early days of October there was an announcement during roll call for all inmates knowing Russian and German to 
gather in front of barrack building nr. 25 following the roll call. About 100 inmates showed up and were organized into a line, after which they were led in, several at a time, to one of the rooms in the building. There they were examined in German and Russian by a committee consisting of the Lagerdolmetscher, two inmates and one SS officer.

When the exam was over the results were announced and 25 inmates, including me, were deemed to have 'passed'. We were told to remain in the camp. During this time I heard that we were to join the transport of Russian prisoners of war and act as interpreters. (APMA-B vol. 4: 431-433):

\section{What Were the Language Combinations?}

In the camp there were primarily German-Polish interpreters and a group of young multilingual Jewish girls (in the Politische Abteilung) who interpreted during the interrogations of Polish, Slovakian, and Hungarian inmates, Russian and Ukrainian prisoners of war, and so on. Inasmuch as the predominant numbers of inmates were Polish, the primary need was for interpreters working from German into Polish. Nevertheless, a review of the recollections also reveals references to other language combinations, for example from German into French. Stanisław Lagus writes:

A large number of French worked in the Weberei. I should point out that they were not French Jews, but maquis, many of whom were well-educated. Because I had a good knowledge of French (having studied in France before the war), I spoke with these French inmates. The Untercapo Bogdan - I can't recall his last name - who was from Czechoslovakia noticed this and informed the Obercapo. Thanks to this coincidence the Obercapo assigned me to the French as an interpreter - hence I was given a relatively easy job. (APMA-B vol. 78: 171-172)

There was also a need for interpretation from German into Czech. Karel Stransky recalls:

During our stay in barrack no. 11 a transport of criminal prisoners from Czechoslovakia arrived. The group, about 200 to 300 men, had previously been interned in the Prague's Pankrac prison. During their intake registration the Germans were unable to communicate with them, hence they used me as an 'interpreter', since as a long-time worker in Czech I knew their jargon. As a sign of recognition of my services the barrack supervisor gave me a piece of bread and sausage. (APMA-B vol. 84: 54)

Owing to the large number of Russian prisoners of war there was a need for interpreters from German into Russian. Jakub Jan Szegidewicz/Jakub Sehyd writes: "As soon as the Russian prisoners of war arrived in the camp I was sent to barrack building $\mathrm{nr} 22 \mathrm{a}$ as a German interpreter. I carried out this task until the liquidation of the prisoner of war camp in Auschwitz." (APMA-B vol. 45, p. 37-42) 
Service as a camp interpreter as well as knowledge of the functioning of the camp was sometimes useful following the liberation:

On May 4, 1945 the Red Army took control of the area where I hid out. I came out of the woods, and owing to my looks the Russians took me for a spy and wanted to shoot me. However, one of the Russian soldiers who had been a prisoner of war in the Auschwitz camp during the time I served as interpreter intervened to save my life. (APMA-B vol. 45: 41)

\section{Ludwik Kończal notes:}

A month later I returned to barracks building no. 5 as a registrar and Russian interpreter, as there were then Russian prisoners of war in the barracks. This was just two weeks after they gassed the first transport of prisoners of war from barrack no 13. (APMA-B vol. 75, p., 76)

\section{What Were the Duties of the Interpreters?}

As indicated earlier, the interpreters' duties included assisting at the hearings, acting as camp Schreiber or Läufer and some others duties. Above all all the interpreters were required to be active during the arrival at the camp of new prisoners, at times when punishment was inflicted and during the 'management' of inmates. Jan Janicki writes:

I remember that during my first days of imprisonment at the KL Auschwitz all the prisoners were escorted onto the roll call area to watch a public hanging of an entire family: father, mother and daughter, as punishment for the escape of their son from KL Auschwitz (as explained to us by the interpreter). (APMA-B vol. 94: 162)

Nikodem Pieszczoch recalls: "They were brought to Blockführerstube, where the interpreter, Count Baworowski [...] dictated to the candidates for the orchestra a letter they were to send to their families with a request for musical instruments." (APMA-B vol. 72: 14)

\section{Jakub Orlik writes:}

The head of the camp, SS-Obersturmführer Karl Fritzsch, screamed at the stuttering prisoners: "Why are you bandits, you Polish dogs, barking and bothering us?!" The interpreter (Dolmetscher) was Count Baworowski from the Poznań area. He read out all the names on the transport list and acquainted us with the rules of the camp. Violation of any regulation was punishable by death. No complaints or appeals could be addressed to the SS authorities. (APMA-B vol. 94: 179)

The SS troops needed interpreters during their interrogations. Maria Karawacka remembers: 
That same day the messengers from Schreibstube came with the order that the following day we were to report to the Politische Abteilung. [...] My trance of fear was broken by the call of my number. I entered the chamber. They told me to approach the desk. The initial questions concerned my personal data. I answered them only after the questions were translated from German into Polish by a female inmate. I addressed my answers to her rather than to the camp official seated behind the desk. An SS guard stood beside me. He appeared upset that I had directed my answers to the interpreter. He hit me, and as a result I didn't hear the next question, and thus didn't know how to answer. He then beat me repeatedly. I lost consciousness and awoke in the corridor, completely covered in blood, with my blood-smeared clothes sticking to my body. (APMA-B vol. 46: 92)

\section{Wanda Sawkiewicz writes:}

Mandel [the head of the female camp in Birkenau] led me to one of the buildings where the functionaries were German women; both the barrack supervisor as well as four Kapo. The only inmate whose name was mentioned, Hania Łukasiewicz, was the acting interpreter. [...] After Mandel left, the barrack supervisor called me over to her and asked me who I was, how old I was, and what I was arrested for [...] Our talk was interpreted by Hania Łukasiewicz. [...] Later I met once again with Hania Łukasiewicz in barrack no. 11, where she gave me her sweater. (APMA-B vol. 88: 145)

\section{Józef Kret notes:}

Along the entire length of the loading ramp stood a long train with boxcars. The boxcars doors were closed. It was explained to us that the boxcars contained Russian prisoners of war and that we were to translate into Russian the orders given by the SS troops. [...] An SS guard told us as interpreters to organize them into lines of 100 persons. [...] The next day we went to the first floor of building no. 24, where our Schreibstube was - there we sat at tables and registered the prisoners of war who were gathered in lines in front of us. (APMA-B vol. 4: 431-433)

\section{Interpreters also engaged in other "tasks." Stanisław Cienciała writes:}

An alarm sounded [following the escape of a prisoner], we stood and waited until our work crew returned. Lagerältester Franz immediately pulled us out of line. He knew our numbers. It appears that he was the new interpreter, the one who replaced Baworowski. We stood in front of the Lagerführer, a man with a pockmarked face who stood in front of us with his crooked legs spread and his hands on his hips. The inmates singled out stood around him, and the columns returned to barracks. The question arose: Why didn't you escape? Quite surprising! The interpreter wanted to interpret (Idzikowski and I had earlier agreed that I would do the speaking) when I said, in German: "I don't need an interpreter!" Knowing the mentality of the SS, I hollered out like I was in a platoon, more or less as follows: "We live in the third barracks. We didn't know Kutscher. He lived in the Kutchers' barracks." I tried to speak in a soldier-like voice; loud, quick and decisive. [...] Fritzsch answered with a hand signal: to the left, that meant to our barracks, 
to the right, that meant to barrack no. 11 [the death barrack]. He signalled to the left. (APMA-B vol. 87: 37)

Girls from the Politische Abteilung also took part in the interrogations as interpreters. Hermine (Herma) Markovits (nee Hirschler) writes:

Erber employed me frequently as an interpreter for the Polish and Czech prisoners, although he himself, being a Czech citizen, probably understood just as much of what they said as I did. On these occasions I tried to frame the answer to favor the defendants. "Is your translation accurate?" Erber once suddenly asked me.

"As far as I understand Polish it is. I am Czech, not Polish," I answered. He looked at me, frowning. "Your translation is incorrect. So shut your mouth."20

Further on, she writes:

In the Politische Abteilung one could help only in the way I did, by making intentional typographical errors or interpretations in favor of the accused. With Brose this was not necessary. He himself changed the interrogations to the advantage of the inmates as much as possible ${ }^{21}$.

These examples show how the camp interpreters not only fulfilled the normal roles of an interpreter but also tried to divert the fate of their fellow inmates.

\section{How Did They Perform Their Duties, What strategies and Techniques Did They Employ and What Were the Roles of Interpreters?}

In light of the sparse data available, we know little about the techniques employed by the interpreters. Kazimierz Hałgas writes: "Lagerführer Fritzsch spoke to us from the steps of our barracks. His words were translated word for word by Count Baworowski" (APMA-B vol. 89: 174). None of the accounts explain precisely what is meant by the phrase "translated word for word". Most likely this referred to translation sentence by sentence of military-like orders, which were short and to the point. In Primo Levi's recollection of his arrival at the camp, an inmate by the name of Flesch steps forward and announces he will be interpreting the SS guards' welcome' into Italian. As Michael Cronin comments,

The Italian writer is struck by the physical toll of the interpretation task on the interpreter. Flesch is used as an instrument, a mouthpiece, but the mouth that utters the words also expresses its revulsion, the expressive and alimentary functions of the same

20 Shelley, Secretaries of Death, p. 120.

21 Shelley, Secretaries of Death, p. 125. 
organ combining to articulate the distress of the interpreter who becomes a hostage of his own skills. ${ }^{22}$

Sometimes it happened in the camp that the interpreter's help was invaluable, even to the point of saving other inmates' lives. Alfred Wilk writes:

The day after Christmas Eve (or maybe it was another day) an inmate appeared at the gate, wishing to speak with the Lagerführer. The interpreter who was present, the inmate Baworowski - quickly realized that the matter was of great importance. He tried to get the inmate to explain to him why he so badly wished to see the Lagerführer. The inmate did not want to reveal his reasons; he even became threatening. I don't know what arguments Baworowski used, but in the end he learned the truth of the matter. The inmate was wandering around near the kitchen on Christmas Eve and heard other inmates singing the Polish national anthem - and this is what he wanted to tell the Lagerführer. He was counting on a favor in return. When Baworowski learned the truth, he told the appropriate person and the denunciator was finished off during the night by Brodniewicz (the Lagerältester) or the Kapo Arno. It was a very sad incident, and if Baworowski had not intervened, many inmates would have lost their lives, not excluding such prominent camp functionaries such as Brodniewicz and the Kapos Arno and Diego. (APMA-B vol. 78: 1078)

\section{Zygmunt Kędziora remembers:}

When I appeared in front of the Lagerführer, the interpreter present, an inmate with fair hair, whose name I cannot remember, told me: "You say nothing, and I'll interpret." I knew a bit of German, but I understood from his offer that he wanted to help me. The interpreter, turning to Aumeir [the Lagerführer] said that my matter was one of the "radio matters." He added that one of the participants in that matter had been released from the SK [Strafkompanie, i.e. 'punishment corps'] several days earlier. The interpreter handled the entire conversation with great skill and presented the matter such that the Herr Lagerführer understood everything completely and considered it obvious that I should also be released from the punishment corps. (APMA-B vol. 83: 263)

\section{Zygmunt Jankowski recalls:}

For some period of time a certain Olpiński - a camp squealer and traitor - worked in DAW. I knew him from the pre-war period. [...] In the camp he told the inmates that he was arrested because he refused to agree to serve as Prime Minister in the Nazi puppet Quisting government. In this way he earned the trust of the inmates. We later learned from Ms Dąbrowska, who was an interpreter in the Politische Abteilung, that he passed all his information along to the SS [...]. That's why we had to get rid of him. We gave him a beautiful English sweater with lice infected with typhus. When he became infected, no one in the hospital took care of him and he died. (APMA-B vol. 65: 174)

22 Cronin, Translation and Identity, pp. 77-78. 


\section{Concluding Remarks}

An interpreter in the Nazi prison camp was not simply "a disembodied container of others' messages," ${ }^{23}$ as we can see. The recollections of the former inmates illustrate the complex role a camp interpreter had to assume, faced with tasks which went far beyond the neutral transfer of information. The picture of the interpreter presented above also illustrates the role of ethical norms in interpretation. In court/police interpreting, the prevailing norms have been described in detail. The ideal picture of interpreters is that they do not demand any space of their own, but function as unobtrusive recorders or translation machines from one language into the other, conveying messages between speakers. A commonly held belief is that the interpreters are only conduits of information and as such have little impact on the communicative situation. Several studies have demonstrated that this ideal does not hold up when confronted with real-life interpreting interactions between humans in various institutional settings. The interpreter's role is certainly not that of a passive conduit, but active, governed by their social and linguistic knowledge of the entire communicative situation, including not only competence in the appropriate ways of speaking, but also in the management of the intercultural interpreting event.

Particularly in extreme situations, such as interpreting during an interrogation, the role of an interpreter may be compared to that of a facilitator, an assistant to one of the parties, life-saver, informer and so on. ${ }^{24}$ It is through the interpreters that, often for the first time, those who until that moment have not had the opportuity to present their opinions and talk about their suffering, tortures and persecutions are finally given a voice, a rare occurrence in a concentration camp. The numerous examples quoted here show the interpreters tried to divert tragic lives of other inmates. Basing his observations on Levi's recollections of interpretation in the camps, Cronin describes the role of the Lagerdolmetscher as follows:

The fact of Flesch [an interpreter] having a body situated in place and time not only means that his body will give expression, voluntarily or involuntarily, to his world-view. His embodied agency also means that he is immediately aware of the consequences of his interpreting activity. Not only as a speaking body is he affecting the bodies of the other deportees but as an embodied agent he is uniquely vulnerable to torture and worse should he fail to discharge his duties to the satisfaction of his superiors. ${ }^{25}$

23 C. Wadensjö, Interpreting as interaction (London, New York 1998), p. 279.

24 Tryuk, L'interprétation communautaire....

25 Cronin, Translation and Identity p. 78. 
The Lagerdolmetscher found himself at the heart of the crisis, in the center of the interaction which likely changed his life as well as that of his fellow inmates. What he need to translate impacted on his life, as has been illustrated by the history of Władysław Baworowski, as well as other personal narratives quoted in this chapter. Camp interpreters were not, and could not, remain unbiased, neutral observers of the reality which they were required to interpret. In no other situation has an interpreter played such a deeply human role. By reflecting on their works, the complexities of interpreting and the dilemmas the interpreters have faced can be seen in new light.

[2011]

The author would like to express her gratitude to Dr. Piotr Setkiewicz, the head of the Auschwitz-Birkenau Memorial and Museum Archives in Oświęcim, for making the materials held in the Museum available to her. 


\title{
Tamara Brzostowska-Tereszkiewicz \\ The Conceptual Art of Translation
}

\author{
All that's left is pattern ${ }^{\star}$ (shoes?). \\ *doubtful reconstruction \\ Armand Schwerner, Tablet 1, 1999: 13
}

Departing significantly from the rigid rules of translational illusionism, ${ }^{1}$ a considerable number of twentieth-century writers and performers recognized the art of translation as being essentially conceptual. In many respects, their artistic experiments deserve the title of 'conceptual translations', deriving as they do their creative impulses from the neo-avant-garde's most radical artistic current, which has come to be known as conceptual art, Kunst-im-Kopf, art-as-idea, or post-object art, also depicted as mental, dematerialized, theoretical, uncreative, and impossible. When considering conceptual artists, it is important to acknowledge them as the inheritors of the discoveries and interpretations made by historical avant-gardes, who had succeeded in self-consciously expanding the boundaries of artistic language. Conceptual translation, as an experimental and innovative mode of writing, has been quick to elaborate upon the artistic strategies and techniques of Dada, Cubism, Futurism, Constructivism, Abstract Expressionism, concrete poetry, Letterist hypergraphics, and Oulipian poetics, among others, and has put itself at the extreme end of this historical continuum. In this respect, there is a certain continuity with Cubist translation. ${ }^{2}$ Yet while the

1 I refer to Jiří Levýs classical distinction between illusionist and anti-illusionist translations in: J. Levý, The Art of Translation [1963], trans. by P. Corness, ed. Z. Jettmarová (Amsterdam-Philadelphia 2011), pp. 19-20. Illusionist methods of translation, akin to the conventions of illusionist theatre and the realist novel, serve to build up an illusion of providing direct access to the reality of the original, whereas antiillusionist methods play on the fact that they are offering the audience a mere imitation of the original's universe of discourse by various means of alienation (for example, ingenious language conceits and personal or topical allusions directed towards the intended target reader).

2 For background and further discussion, see T. Brzostowska-Tereszkiewicz, Modernist Translation. An Eastern European Perspective. Models, Semantics, Functions (Frankfurt/M.-Berlin-Bern-Bruxelles-New York-Oxford - Wien 2016), pp. 128-160. 
latter rotates the source text "through a sequence of potentially multidimensional angles, of different spaces and times"3 in order to explore the formal devices of historical avant-garde languages in a pastiche-like manner, and celebrates the unexpected blending and collision of mutually distant conventions, styles, and forms of literary production, the conceptual translator exploits the avant-garde achievements of the past as an effective framework for exhibiting the mental processes behind his/her artistic project.

First theorized by Clive Scott, a vigorous advocate of the "creative turn" in translation studies, ${ }^{4}$ translation as a conceptual art is informed by the assumption that "the product is in many ways inadequate evidence of the conceptual processes, ambitions and potentialities which the particular translation project has activated and developed, that, in short, the artistic concept is in striking excess of the artistic object." 5 The notion that conceptual art recognizes the primacy of intellectual inquiry and reflection over physical representation is expressed by Lucy Lippard: "the idea is paramount and the material is secondary, lightweight, ephemeral, cheap, unpretentious, and/or dematerialized."' It might be said that the conceptual translator does not actually produce a material target text; instead, (s)he produces the means for the target text's production, i.e. "sets up a concept-machine that possesses the potential for a myriad of material creations." In many cases, translation is reduced to the most simplified scheme and becomes merely the concept of translation. The idea behind this mode of artistic experiment, Carolina Martes explains, is to establish "the possibility of conceptualism as a democratic space (a place where artist, spectator, and translator can converse since they all share the knowledge of the means of the work's production)."

3 C. Scott, Translating Rimbaud's Illuminations (Exeter 2006), p. 252; C. Scott, “Translation and the Spaces of Reading." In: Translation and Creativity: Perspectives on Creative Writing and Translation, eds. E. Loffredo, M. Perteghella (London 2006), p. 39.

4 See E. Loffredo, M. Perteghella, "Introduction.” In: Translation and Creativity: Perspectives on Creative Writing and Translation.

5 Scott, Translating Rimbaud's Illuminations, p. 257.

6 T. Godfrey, Conceptual Art (London 1998), p. 14; qtd in C. Scott, Translating Rimbaud's Illuminations, 311-2.

7 C. Martes, “Translation in Conceptual Writing," UC Berkeley Comparative Literature Undergraduate Journal, Vol. 2, No. 1, 2012; online: http://ucb-cluj.org/2571-2/ (access: 02.02.2013).

8 Martes, "Translation in Conceptual Writing." 
Along with its economy of artistic means, conceptual translation provides an opportunity to reflect on its own possibilities, conditions and constraints, and, concomitantly, for examining the methodological capacities of translation studies. Inevitably self-referential and self-reflexive, it may be referred to as "metatranslation," although in a sense which is not necessarily fully compatible with the Structuralist meaning of that term as introduced by Anton Popovič, where " $[\mathrm{t}]$ ranslation is a metatext within the system of literary communication." Nor is it completely parallel to the newly revived meaning of metatranslation as the "conscious and thoughtfully designed practice of making the translating subject visible,"10 as outlined by the feminist literary theoretician Luise von Flotow. For what is at stake here is neither the visibility of the translator nor the derivative (or "second-degree") character of translation practice, ${ }^{11}$ but rather the idea of a "metatranslative self-reflection when translation observes its own operations and the factors conditioning those operations." 12 In Theo Hermans's The Conference of the Tongues, conceptual translation becomes embroiled in the problem of "representation playing on the idea of representation," as the target readers are invited to

consider not so much the way in which the translation re-enacts its donor text, but the way it interacts with existing translations and with expectations about translation. The self-referentiality of translation is raised to self-reflection when the translative act itself is rehearsed within a translation, when the form - translation as a form distinct from other forms - re-enters the form and the translation contract is renegotiated within the text. This happens when the performance of translation is thematised in a translation itself and metatranslation invades the translated text. ${ }^{13}$

The 1971 installation Active Poetry created by the feminist performance and installation artist Ewa Partum, who represented the first generation of the conceptual avant-garde in Poland in the 1960s and the 1970s, is particularly revealing in this context. An eloquent example of metatextual discourse, it also

9 Qtd. in: Routledge Encyclopaedia of Translation Studies: 1st Edition, ed. M. Baker (London-New York 2001), p. 256.

10 M. Minier, "[...] the translatress in her own person speaks: A Few Marginal Notes on Feminist Translation in Practice, in Creative Writing and in Criticism." In: Identity and Cultural Translation: Writing Across the Borders of Englishness. Women's Writing in English in a European Context, eds. G. Macedo, M. E. Pereira (Bern 2006), pp. 40-41.

11 G. Genette, Palimpsests: Literature in the Second Degree, trans. Ch. Newman and C. Doubinsky (Lincoln \& London 1997).

12 T. Hermans, The Conference of the Tongues (Manchester 2007), p. 51.

13 Hermans, The Conference of the Tongues, p. 42. 

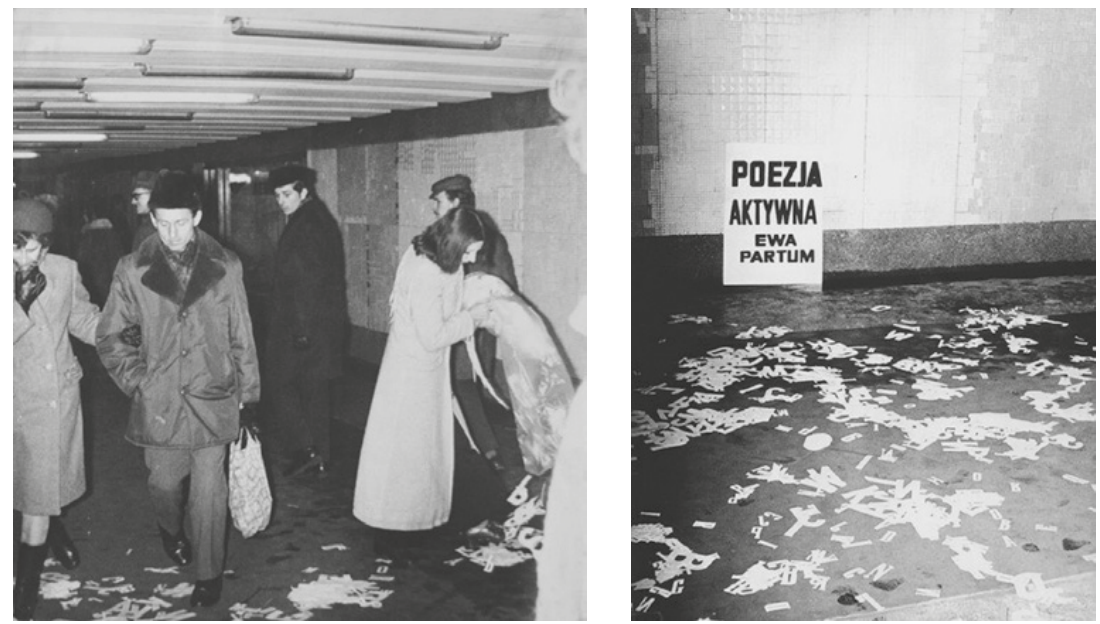

Fig. 1 and Fig. 2: Ewa Partum, Active Poetry. Installation. Warsaw 1971. Reprinted by permission of Ewa Partum. A. Stepken, "Monograph," trans. from the German by I. Balfour. In: Stepken A. (ed.) Ewa Partum 1965-2001, p. 34.

demonstrates that the phenomenon of conceptual translation is by no means restricted to a single domain of verbal art, but rather operates across other media and forms of artistic utterance. The ephemeral Active Poetry public space intervention consisted in scattering in a pedestrian underpass (beneath the junction of two central streets in Warsaw) large white cardboard letters that used to be mass-produced in socialist states for propaganda slogans which emblazoned the walls of public buildings during the communist party's official ceremonies. The set of letters had been selected from a one-page extract of Maciej Słomczyński's 1969 rendition of James Joyce's Ulysses. ${ }^{14}$ Apart from being an act of subversion of the official socialist ideology, like a number of Partum's other conceptual poems and installations (though not primarily intended as experimental translations), this act has implications for translation theory.

14 G. Nabakowski, “Apprehension and Masquerade. Letter Millionaire - Ewa Partum's Path to Conceptual Poetry and Feminist Gender Theory," trans. from the German by O. Kossack. In: Ewa Partum 1965-2001, ed. A. Stepken (Karlsruhe 2001), pp. 131-2. The Polish 1969 translation of Ulysses was an important moment in Polish literary life of the early 1970s; see J. Wawrzycka, "The Reception of James Joyce in Poland." In: The Reception of James Joyce, Vol. 1: Germany, Northern and East Central Europe, eds. G. Lernout, W. van Mierlo (London-New York 2004), pp. 219-229. 
The randomly scattered letters freed from the restraints of grammar and syntax, "devoid of political message and as if restored to the state of innocence,"15 were made openly accessible to passers-by who (accidentally or on purpose) moved them about on their shoe soles, creating diverse semantic and visual arrangements. As a result of this performance, Joyce's Ulysses could "fan out into multiple versions of itself, not just interpretations of its meaning, but performances of the experience of reading,"16 kinesthetically re-creating its collational formula and mosaic structure. ${ }^{17}$ What is particularly important regarding Partum's conceptual, alternative retranslation of Ulysses is the fact that it was generated aleatorically from "ready-made" materials. As the cardboard letters wore out, the site-specific target text practically ceased to exist in its material sense.

A "tautologically" similar artistic action took place forty years later at the $18^{\text {th }}$ Biennale of Sydney "All Our Relations" (2012), where Partum presented her "Installation Metapoetry À la recherche du temps perdu according to Marcel Proust." In a private communication, the artist reported that she used forty thousand letters conscientiously selected from the first eleven pages of Tadeusz BoyŻeleński’s 1937 Polish translation of the first volume of Proust's À la recherche du temps perdu: Du côté de chez Swann. These were scattered around the Prison Courtyard on Cockatoo Island. In this clearly self-repetitive gesture, ${ }^{18}$ Partum invited the biennale visitors to collect the random cardboard letters and form new words and phrases in an act of "linguistic liberation."

Partum's interactive metapoetry installations can be construed as target texts which struggle "to maximise linguistic materiality" and "to incorporate the creative sensibility of the translator and the receptive sensibility of the reader, in a word, to achieve a maximum of actualization." 19 They appeal to multiple sensory

15 G. Dziamski, "Ewa Partum - od konceptualizmu do feminizmu," Odra 2006, Vol. 11, No. 539 , p. 89.

16 See the formula of synesthetic translation: C. Scott, "Intermediality and Synaesthesia: Literary Translation as Centrifugal Practice," Art in Translation 2010, Vol. 2, No. 2, p. 155.

17 On Joyce's mosaic narrative technique see e.g. K.M. Booker, Joyce, Bakhtin, and the Literary Tradition: Toward a Comparative Cultural Poetic (Ann Arbor 1995), p. 86.

18 The installation and performance with the text of the Polish translation of Joyce's Ulysses were repeated at the "Collected Views from East or West" exhibition (Generali Foundation, Vienna, 2005), at the Turbine Hall Tate Modern in London (2006), Tate Modern in London (2012), during the opening of the retrospective exhibition "Nothing Will Stop the Idea of Art" at the Museum of Art in Łódź (2014) and as part of the "Umjetnik na odmoru u Valamaru" event in Poreč in the Croatian Istria (2015).

19 C. Scott, Translating Rimbaud's Illuminations, pp. 258-9. 


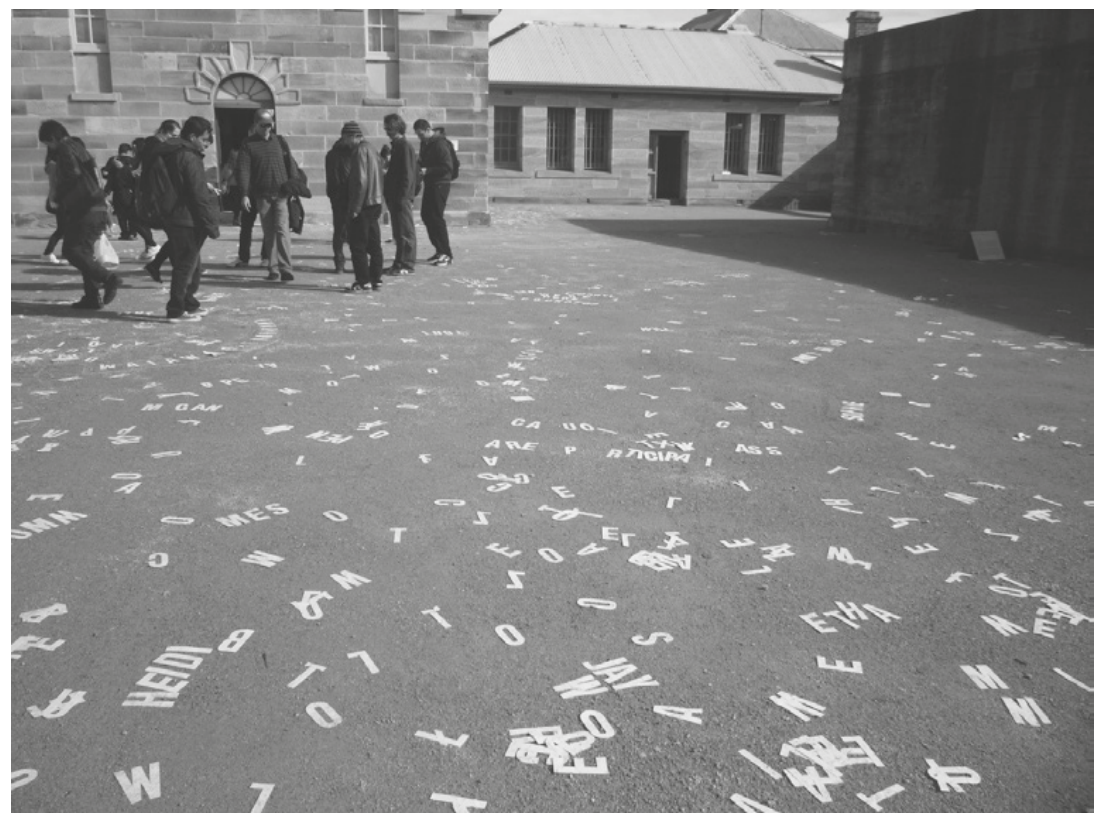

Fig. 3: Ewa Partum, "Installation Metapoetry À la recherche du temps perdu according to Marcel Proust". 18 Biennale of Sydney, "All Our Relations", Australia 2012. Copyright (c) 2012 by Ewa Partum. Reprinted by permission of Ewa Partum.

modalities simultaneously. Besides sight (white letters on a contrasting grey/red ground), hearing (the rustle of letters under the feet), touch (letters as tangible objects), and smell (waterlogged/dust-covered cardboard), the conceptual "active translations" incorporate a sense of proprioception and kinesthesia. They strengthen the sensation of bodily movement in and through urban/open space. The target reader's multisensory perception of the material serves to reinforce his or her assumed engagement with the translator's conceptual process. In Partum's translations "concept functions as the prosthetic extension of percept. ${ }^{20}$ At this point it is important to emphasize that conceptual translation tends to be not only intermedial, but also "synaesthetic" in the sense explained by Clive Scott:

20 C. Scott, "Intermediality and Synaesthesia: Literary Translation as Centrifugal Practice," p. 155. 
Intermedial translation [...] is not primarily to be conceived of as a process of transfer from one medium to another; it is the translation of one medium out of itself into multisensory, or cross-sensory, consciousness; put another way, it is the translation of one medium back into whole-body experience. ${ }^{21}$

The Sydney "Installation Metapoetry À la recherche du temps perdu according to Marcel Proust," together with the Proust metatranslations that Partum presented in other locations, ${ }^{22}$ can themselves be considered "tautological" repetitions of one of her earlier self-referential and self-reflexive works from poems by ewa (1971-1972), entitled fragment W POSZUKIWANIU STRACONEGO CZASU Marcela Prousta [An Excerpt from IN SEARCH OF LOST TIME by Marcel Proust; capitalization in the original]. This poem can be considered a conceptual translation of the opening lines of $\grave{A}$ la recherche $d u$ temps perdu. Technically speaking, it was again a retranslation of the initial section of Tadeusz Boy-Żeleński’s 1937 Polish rendition of the French original. In this work, one of the most celebrated texts of European Modernism was decomposed into single letters dispersed arbitrarily over a sheet of paper in a manner reminiscent of both Dada and Concrete poetry. ${ }^{23}$ The artist used Letraset fonts (see Fig. 4 below).

It is interesting to note that Partum's conceptual poem with its "constellational", centripetal pattern, resembles in its layout Heinz Gappmayr's concrete poem ohne Titel (1986). Waltraud "Wara" Wende wrote about Gappmayr's work that its "letters are presented topologically no longer as a closed composition of a word, but as a typographical phenomenon with signs concentrated around a centre."24 Moreover, both visual texts share the theme of time, which binds them together in a relation of interdependence, and are practically unreadable without the

21 Scott, "Intermediality and Synaesthesia: Literary Translation as Centrifugal Practice," p. 154.

22 E.g., the installation and performance with the text of the Polish translation of Proust's À la recherche du temps perdu: Du côté de chez Swann at the "Formes breves, autres 25" exhibition (Frac Lorraine, Metz, France, 2012).

23 Partum's early visualizations of semantic material are closely influenced by the works of Kurt Schwitters, Louis Aragon, and Polish avant-garde poets: Julian Przyboś, Jan Brzękowski, Stanisław Młodożeniec, and Stanisław Dróżdż (see: A. Stepken, "Monograph," p. 17).

24 W. Wende, "Sehtexte - oder: Vom Körper der Sprache." In: Über den Umgang mit der Schrift, ed. W. Wende (Würzburg 2002), p. 310. 


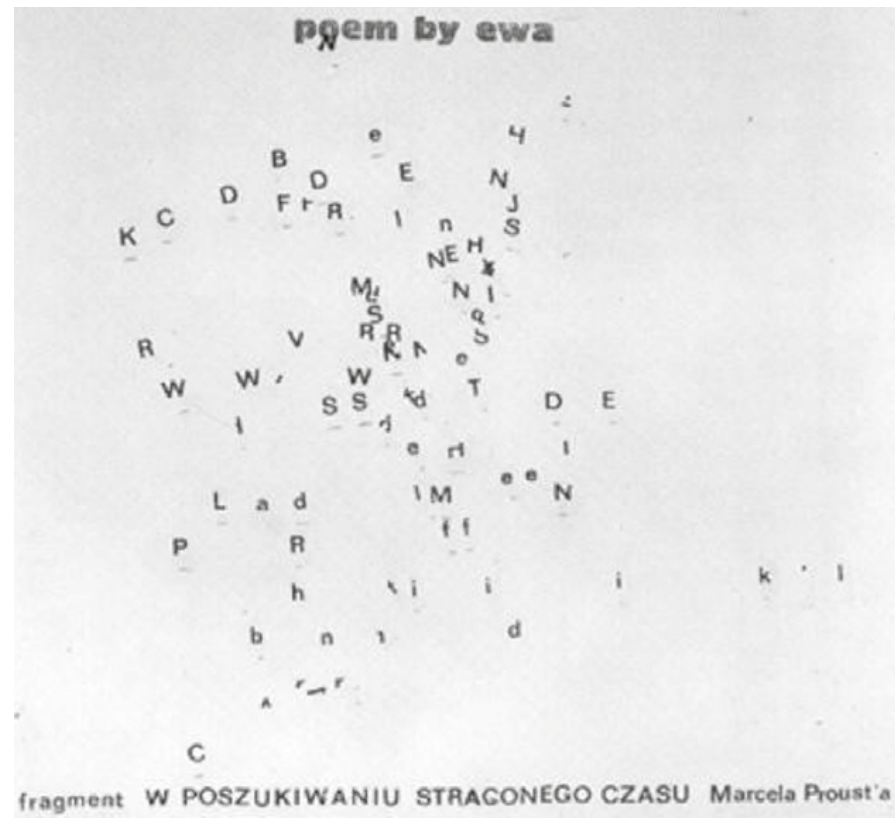

Fig. 4: Ewa Partum, poem by ewa. fragment W POSZUKIWANIU STRACONEGO CZASU Marcela Prousta, 1971. Sig. Nationgalerie, Staatliche Museen zu Berlin. Reprinted by permission of Ewa Partum. A. Stepken, "Monograph," p. 37.

awareness of this intertextual relation. The irregular, multi-linear configuration of discrete letters and their occasional collisions serve to picture the "lost time" and to visualize its potential connotations, such as movement, momentum, dislocation, inconstancy and transience. However, while the randomly mixed letters of Gappmayr's poem can be easily integrated into the German word for time $z e i t$ - the dispersion of letters in Partum's work does not allow for a reconstruction of the opening lines of $\bar{A}$ la recherche du temps perdu. The verbal language is dissected into its smallest visual signs which gain an aesthetic validity of their own and allow for unlimited reconfigurations. One might even, with Gislind Nabakowski, see Partum's conceptual metapoetry as a visualization of the poststructuralist division of the signifier from the signified, where "meaning is not immediately present in a sign," but is "scattered or dispersed along the whole chain of signifiers: it cannot be easily nailed down, it is never fully present in any 


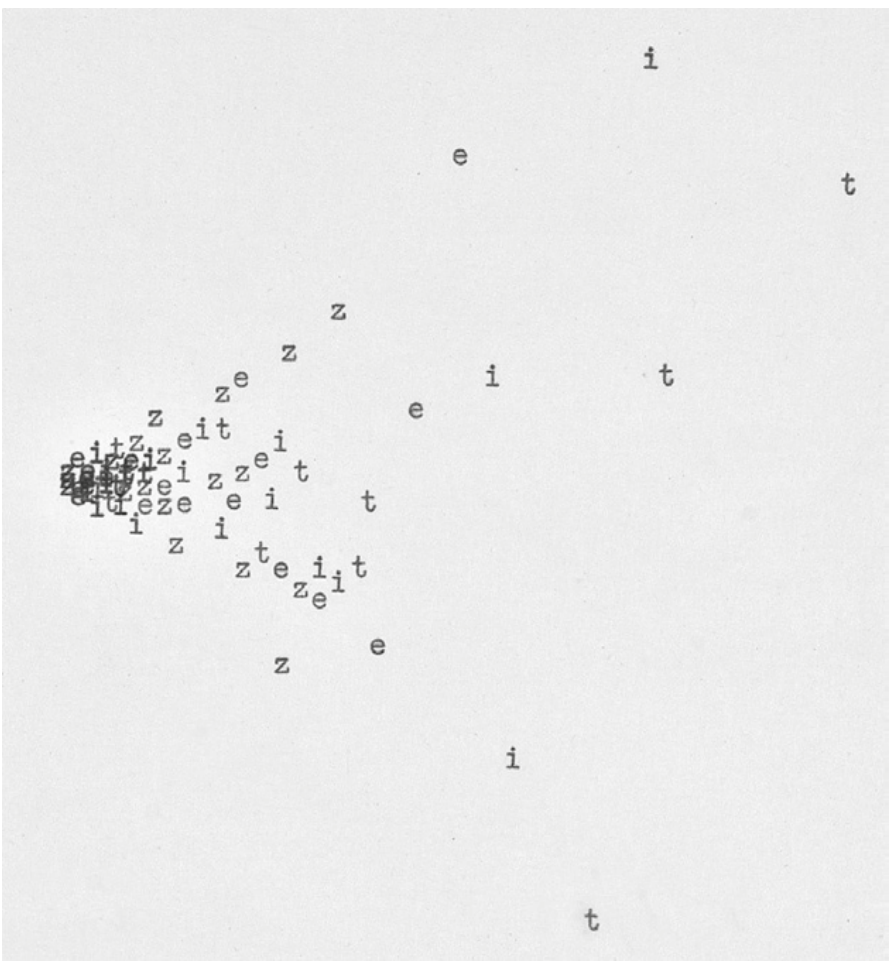

Fig. 5: Heinz Gappmayr, ohne Titel, 1986. J. Linschinger, ed., TEXTBILD/BILDTEXT, mit einem Vorwort von Peter Weiermair und einer Einleitung von Eugen Gomringer (Piesport 1990), p. 17.

one sign alone, but is rather a kind of constant flickering of presence and absence together."25

Finally, Partum's multiple and essentially self-repetitive versions of fragments of Proust's quasi-autobiographical novel on remembrance of things past are tautological (self-referential and self-reflexive) in the sense that they might be regarded as an autobiographical statement by the artist herself: in her 1984 Pirouette performance Partum proclaimed playing with ideas of representation, substitution, and authenticity: "what passed and what was important to

25 T. Eagleton, Literary Theory. An Introduction (Minneapolis 2008), p. 111; see G. Nabakowski, "Apprehension and Masquerade. Letter Millionaire - Ewa Partum's Path to Conceptual Poetry and Feminist Gender Theory," p. 131. 
us connects with us in a way the mirror's reflection connects with its original."26 This thread has continued throughout her career. Since the early 1970s, the artist has been analogously rewriting excerpts from Kafka's Journal, Camus' The Plague and Goethe's Faust, ${ }^{27}$ using their Polish translations.

The choice of literary works and excerpts as conceptual sources of Partum's metatextual practices was not accidental. As the artist herself explained, insofar as the works were drawn from the core canon of European literature and were firmly located in the mental spaces of the target recipients, they could resist the most radical attempts at distorting their canonical form. ${ }^{28}$ As Nabakowski observes, Partum's conceptual appropriations of masterpieces from world literature did not "entail contaminating or destroying, but rather reshaping them in liberal variations." ${ }^{29}$ These ostentatiously synecdochic translations of European classics were exhibited in juxtaposition with the originals. As often in the case of conceptual translation, the juxtaposition of source and target texts - whether in the spectator's mental space or in the physical space of a gallery/museum - appears to have been a necessary condition for revealing the full semantic potential of the artist's intervention into the original's universe of discourse. In an allusion to the Cageian notion of notation, Partum exhibited the source texts on music stands, while the conceptual target texts were hung on the wall (see Fig. 6 below).

The significance of the juxtaposition of the source and target texts in the domain of conceptual art was reinforced in Partum's 1997 Aussage Pur - Goethe in Goethe installation in Berlin-Charlottenburg. The action consisted in scattering over two thousand letters from Feliks Konopka's Polish translation of Faust's monologue (Tragedii część I, Noc) [Part I, The Night] along Kurfürstendamm and Fasanenstraße, while a choir performed the text. Conducted by the artist, the choir-members declaimed Faust's monologue of Goethe's tragedy in several languages simultaneously. As one critic commented, Partum's metapoetry provides "signs of a language without words, symbols of an international script that requires no translation." 30 The artist's emancipating textual practices are an

26 See E. Partum, Pirouette, Galerie Dialog, West Berlin, online: Filmoteka Museum http://www.artmuseum.pl/filmoteka/?id=1274\&l=1 (access: 23.01.2011).

27 M. Ławrynowicz, "Ewa Partum’s Metapoetry” [1980]. In: Ewa Partum 1965-2001, p. 143.

28 I draw here on a private conversation with Ewa Partum (February 8, 2013).

29 G. Nabakowski, "Apprehension and Masquerade. Letter Millionaire - Ewa Partum's path to conceptual poetry and feminist gender theory," pp. 129-139.

30 A. Stepken, “Monograph," p. 17. 


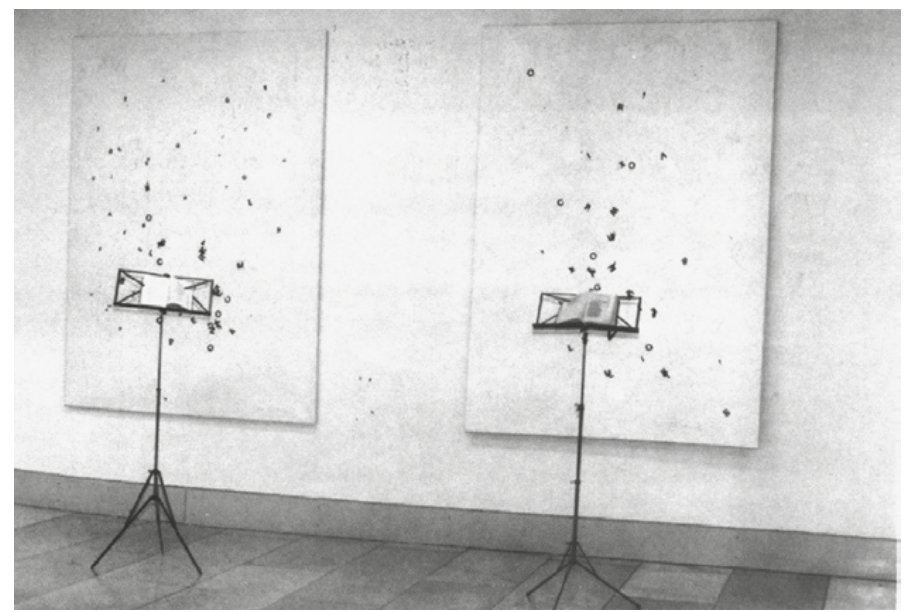

Fig. 6: Ewa Partum, Text installation with music stands, National Museum, Warsaw 2001. Reprinted by permission of Ewa Partum. A. Stepken (ed.), Ewa Partum 1965-2001, p. 95.

attempt to create a kind of common mental space or a conceptual Esperanto, which could operate beyond the cultural and linguistic differences of its target recipients.

Interestingly, Proust's $A ̀$ la recherche $d u$ temps perdu also became the source text for Michael Maranda's Marcel Proust: All the names in "In Search of Lost Time" (2006). This work belongs to a sizeable number of conceptual translations that reduce the material presence of the originals to the point of their complete erasure, through the substitution of extra-verbal (graphic) features for the source text. The Parasitic Ventures retranslation of Proust's novel retains only proper names. All other words are replaced with a series of dots while the punctuation is left intact: ${ }^{31}$

31 See Against Expression: An Anthology of Conceptual Writing, ed. C. Dworkin, K. Goldsmith (Chicago 2011), p. 471. 


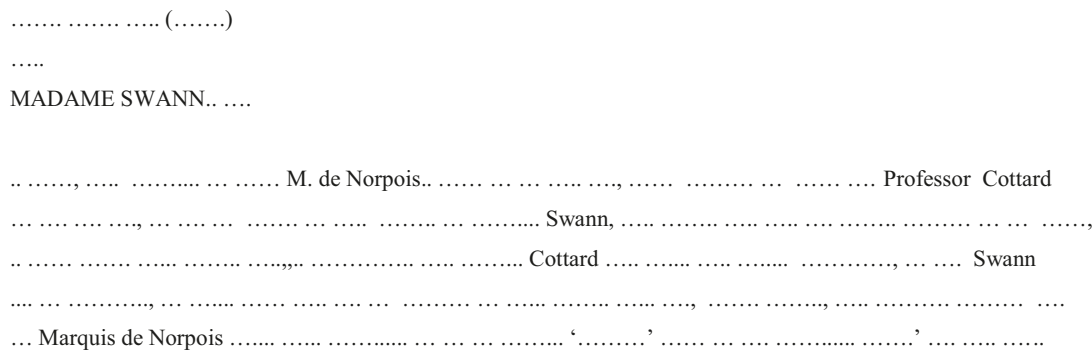

An excerpt from Michael Maranda, All the Names in "In Search of Lost Time" (2006)

Through Maranda's conceptual gesture, the Modernist stream of consciousness novel is turned into a complex visual poem reminiscent, as Craig Douglas Dworkin and Kenneth Goldsmith remark, of "Cageian writing-through"; but whereas John Cage "used proper names as a way to begin composing mesostic poems, for Parasitic Ventures, the name is the end point, an indexed reduction, parasitically feeding off a primary text." ${ }^{32}$

In a very similar way, the graphic equivalent of a text became the constructive principle of Timur Kibirov's metatextual Ekvivalent teksta (a to uzh slishkom mnogo pro lubov) [Equivalent of the text (which is already too much about love)]. This was presented as a counterpart to Alfred Edward Housman's LII lyrical ballad Far in a western brookland and published in a bilingual edition na poliakh "A Shropshire Lad" [in the margins of $A$ Shropshire Lad] (2007):

-LII$-52-$

EKVIVALENT TEKSTA (a to uzh slishkom mnogo pro lubov)

Far in a western brookland

That bred me long ago The poplars stand and tremble

By pools I used to know.

32 Against Expression: An Anthology of Conceptual Writing, p. 472. 
There, in the windless night-time,

The wanderer, marvelling why, Halts on the bridge to hearken

How soft the poplars sigh.

He hears: no more remembered

In fields where I was known, Here I lie down in London

And turn to rest alone.

There, by the starlit fences,

The wanderer halts and hears My soul that lingers sighing

About the glimmering weirs.

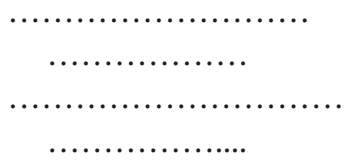

Kibirov's poem functions both as an interlingual translation and as an extraverbal (graphic) substitute for the poetic text, a phenomenon first theorized by Yuri Tynianov in his Problema stikhotvornogo iazyka (1924) [The Problem of Verse Language, 1981]. The Moscow postconceptualist almost preserves the verse structure of the traditional ballad quatrains and mimics their visual internal organization as if a verse form could exist outside language. Retaining merely the visual metrical contour underlying Housman's poem, Kibirov provides nothing but a geometric scheme of a mimetic metapoem in the sense explained by James Holmes in an algebraic formula:

$$
\mathrm{F}_{P} \sim \mathrm{F}_{M P}
$$

where $\mathrm{F}_{P}$ designates the verse form of the original poem, $\mathrm{F}_{M P}$ that of the metapoem, and $\sim$ fundamental similarity. ${ }^{34}$

The Russian poet was apparently mocking the approach of the translator who "looks squarely at the original poem when making his choice of verse form, to the exclusion of other considerations." ${ }^{35}$

In a certain respect, in his mock-mimetic translation Kibirov managed to achieve absolute agreement between the metrical patterns of the translation and

33 T. Kibirov, na polakh "A Shropshire Lad" [2007]. In his: Stikhi o lubvi (Moscow 2009), 742-3.

34 J. Holmes, Translated! Papers on Literary Translation and Translation Studies. Introduction by R. van den Broeck, 2nd ed. (Amsterdam [1972] 1988), p. 26.

35 J. Holmes, Translated! Papers on Literary Translation and Translation Studies, p. 26. 
the original, which is virtually unattainable between source and target texts. ${ }^{36}$ In line with Tynianov's ideal, the metrical energy of the original is certainly communicated through the translation. ${ }^{37}$ Kibirov's gesture of mock-equimetrical translation thus seems to encode a critique of the "fanatical interest in preserving the metrics of the original" that formed a basic principle of Symbolist translation..$^{38}$ Moreover, the semantic potential of Kibirov's conceptual metatranslation could be said (although again with some irony) to be greater than that of the original. For, as Tynianov asserted, "the phenomenon of equivalents does not signify a lowering or a weakening, but rather the pressure and tension of unspent, dynamic elements." 39 The target reader is presented with

an uncertain text (the uncertainty of which, however, is quite limited and semi-revealed), but the role of an uncertain text (of any text in the semantic aspect), instilled into the continuous construction of verse, is immeasurably greater than the role of a definite text. The feature of this partial uncertainty is filled with the maximum tension of the missing elements, of that which is potentially given. ${ }^{40}$

Irony is a common feature of such graphical translations, in relation both to the original and to the activity of translating.

Ekvivalent teksta can further be seen as a materialization of Sergey Eisenstein's idea of the "invisible text as a universal equivalent." ${ }^{11}$ According to the Russian director, only a decomposition of a form reduced to a bare scheme can guarantee equivalence, the interaction of two texts and their mutual substitution. Kibirov inspects the original with X-rays and preserves exclusively its metrical skeleton, which functions as a synecdoche of Housman's ballad. Kibirov's dots could be conceived of as a momentary solidification of what Mikhail Iampolski calls the "invisible inner text," "graphic memory," "third text," structural invariant, "hidden equivalent" of reality, ${ }^{42}$ allowing a comparison of the

36 See L. Pszczołowska, Wiersz polskich przekładów poezji Puszkina. In: "Słowiańska metryka porównawcza," Vol. IV: Wiersz przekładu. Mickiewicz i Puszkin, eds. L. Pszczołowska, D. Urbańska (Wrocław-Warszawa-Kraków 1992), p. 145.

37 See Y. Tynianov, The Problem of Verse Language [1924], ed. and trans. M. Sosa, B. L. Harvey (Ann Arbor 1981), p. 44.

38 See M. Wachtel, Russian Symbolism and Literary Tradition: Goethe, Novalis, and the Poetics of Vyacheslav Ivanov (Madison 1994), p. 184; A. Wanner, Baudelaire in Russia (Gainesville 1996), pp. 78, 98-99, 108.

39 Y. Tynianov, The Problem of Verse Language, p. 44.

40 Tynianov, The Problem of Verse Language, p. 44.

41 M. Iampolski, The Memory of Tiresias: Intertextuality and Film (Berkeley 1998), p. 221.

42 Iampolski, The Memory of Tiresias: Intertextuality and Film, pp. 221, 242-243. 
two texts: Housman's Far in a western brookland and its possible illusionist translation. ${ }^{43}$

When viewed against Russian Ego-Futurist experiments in poetry, Kibirov's poem reveals its paradoxical stage potential. One can imagine a performance of Kibirov's non-acoustic Ekvivalent teksta as a mini-pantomime, comparable to Vasilisk Gnedov's kinesthetic performance based on his aphonic Poema kontsa [The Poem of the End] (1913), which consisted of the title and a blank page. Adrian Wanner describes the following scene: 'Gnedov would raise his arm and then quickly let it fall in a dramatic gesture, eliciting stormy applause from the audience. ${ }^{34}$ In Gnedov's stage experiment, it was not the word but the movement of a body part ('gesture as such') that became the most important means of poetic expression and the ultimate goal of poetry. Kibirov seems to follow this Ego-Futurist idea of kinesthetic writing in his translation of Housman's poem.

An interesting combination of the four distinctive features of conceptual translation mentioned above (its performance method, the introduction of a graphic equivalent of a verbal text, aleatorical methods for target text construction, and the utilization of "ready-made" materials) can be found in Jackson Mac Low's 1955 collection of 5 biblical poems. The first four sections of 4.5.10.11.2.8.4.2., the 2nd biblical poem read as follows:

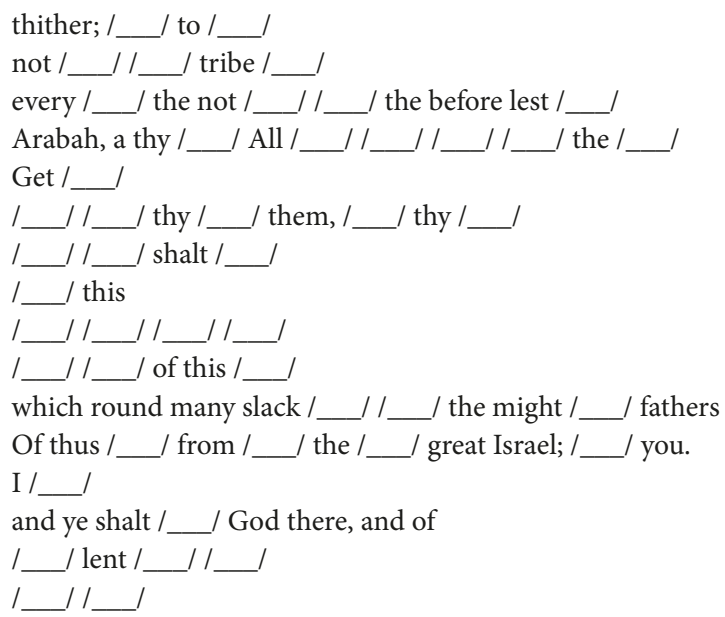

43 Cf. R. Shusterovich's Russian translation: V kraiu ruchev dalekom, http://raf-sh. livejournal.com/522561.html (access 03.08.2015).

44 A. Wanner, Russian Minimalism: From the Prose Poem to the Anti-Story (Evanston, Illinois 2003). 


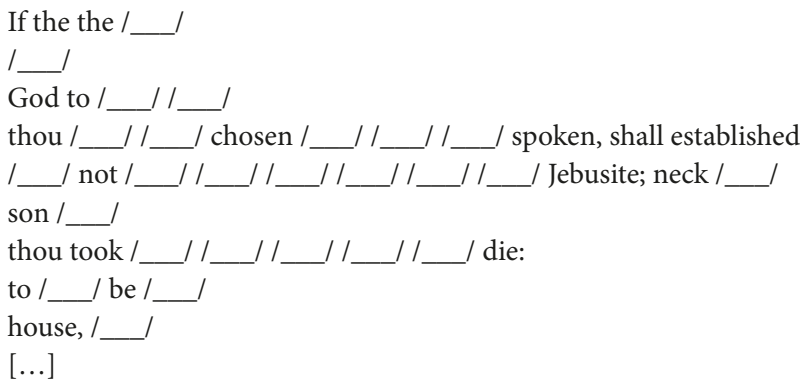

Numbers 35: 6-Judges 5: $27^{45}$

Mac Low translated the Jewish Publication Society's Hebrew Bible into sequences of words and ellipses by a random-selection system utilizing a single die. The outcomes of successive throws of the die "determined both the structure and the contents of the poems: the number of lines and stanzas, the number of 'events' in corresponding lines of each stanza, and the nature of each event in each line: whether they are words (or names) from the Hebrew Scriptures or silences (each silence is represented in the text by a 'box')." ${ }^{6}$ The "hollowed" text provides the basis for its realization in an acoustic performance. Ellipses are to be read as temporal gaps equal in duration to any word the reader chooses. ${ }^{47}$ Barrett Watten writes of 5 biblical poems:

In what appears to be a reenactment of the textual project of romantic hermeneutics, the horizon of the text's 'original' meaning can thus only be realized in the historical act of the poem's reinterpretation in a way that fuses the horizons of the original language of the Old Testament, the interference of the printed version, and the contemporary meanings of what has now been rendered as a neutral and pseudo-objective poetic vocabulary. ${ }^{48}$

Mac Low's biblical poems, in a way similar to all conceptual translation, become both an abstracted model of translation activity and a critique of translation theory. They may be understood not only as a realization of the hermeneutic fusion of horizons in translation, but also as an algorithm for translation conceived of as a game, "a decision process: a series of a certain number of consecutive

45 J. Mac Low, Thing of Beauty: New and Selected Works, ed. A. Tardos (Berkeley 2008), pp. 39-41.

46 J. Mac Low, qtd. after N. Zurbrugg ed., Art, Performance, Media: 31 Interviews (Minneapolis 2004), pp. 255-6.

47 Mac Low, Thing of Beauty: New and Selected Works, p. 39.

48 B. Watten, The Constructivist Moment. From Material Text to Cultural Poetics (Middletown 2003). 
situations - moves, as in game - situations imposing on the translator the necessity of choosing among a certain (and very often exactly definable) number of alternatives." ${ }^{39}$ According to Jiři Levý, the process of translating "has the form of a GAME WITH COMPLETE INFORMATION - a game in which every successive move is influenced by the knowledge of previous decisions and by the situation which resulted from them (e.g. chess, but not card-games)." ${ }^{\prime 50}$ Chancederived translation determined by throws of a die encodes a critique of a translation theory that posited that "it should be possible to apply to translation the formal methods of GAME THEORY." ${ }^{11}$ However, while Levy emphasizes the translator's responsibility and decision-making role, Mac Low clearly seems to strive to eliminate the translator's subjectivity from the translation process, testing the possibilities of an "unintentional poem." 52

Inter- and intrasemiotic transfer ${ }^{53}$ can take the form of the sign of a transfer, as in the case of two conceptual translations of Christian Morgenstern's Fisches Nachtgesang [Night Song of a Fish], from his 1905 book of poems Galgenlieder [Gallows Songs]. This work has been hailed as a unique example of iconic minimalism, a proto-form of Concrete poetry and the "crowning achievement of all sound poetry, for it represents sounds emanating from a mute creature." ${ }^{54} \mathrm{It}$ is composed of alternating sequences of symbols used in ancient vowel lengthbased metrics for determining the long and short syllables within the foot, but here they are isolated and arranged in such a way that they resemble no known metrical scheme. Leo Spitzer recognizes them as iconic signs of open and closed

49 J. Levý, "Translation as a Decision Process." In: To Honor Roman Jakobson. Essays on the Occasion of his Seventieth Birthday, 11 October 1966, vol. II (The Hague-Paris 1967), p. 1171.

50 Levý, “Translation as a Decision Process." p. 1172.

51 Levý, "Translation as a Decision Process." p. 1172.

52 Mac Low, Thing of Beauty, p. xxxiv.

53 In Gideon Toury's terminology. See G. Toury, Translation. A Cultural-Semiotic Perspective. In: Encyclopedic Dictionary of Semiotics, vol. 2, ed. T.A. Sebeok (BerlinNew York-Amsterdam 1986), p. 111. Interestingly, Toury points to the possibility of a translation without the participation of any linguistic code.

54 A. Liede, Dichtung als Spiel: Studien zur Unsinnspoesie an der Grenze der Sprache (Berlin 1963), p. 292, qtd. in J. White, "Forms of Restricted Iconicity in Modern Avant-Garde Poetry." In: Insistent Image, eds. E. Tabakowska, Ch. Ljungberg, O. Fischer (Amsterdam-Philadelphia 2005), p. 133. 


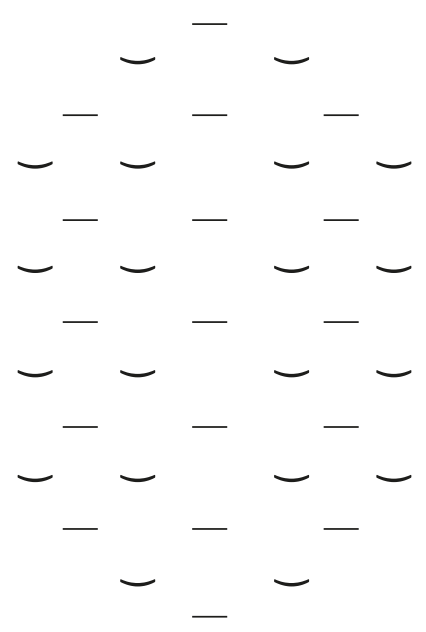

Fig. 7: Christian Morgenstern, Fisches Nachtgesang, 1905. Reproduced from the public domain.

fish mouths. ${ }^{55}$ Other critics have seen the poem's graphic shape as resembling the contours of a fish and the signs for short syllables representing fish scales. ${ }^{56}$

Apart from the conventional translation in verbal signs of the poem's title: Fisches Nachtgesang - Fish's Night Song, the transfer is marked by a reversal of metric symbols. Remarkably, these changes were enough for Knight's version to be recognized as translation in the target culture or, as Andrew Chesterman put it, as a text which "fall[s] within the accepted range of deviance defined by the target-culture product norm 'translation." ${ }^{57}$

The possibility of a graphic translation of the "textual equivalent" (in Tynianov's terms) has not generally been considered in translation studies. ${ }^{58} \mathrm{In}$

55 L. Spitzer, "Zur Interpretation Christian Morgensternscher Gedichte," Euphorion 1921, 23, pp. 96-7, qtd. in J. White, "Forms of Restricted Iconicity in Modern Avant-Garde Poetry," p. 133.

56 See: J. Drucker, “Visual Performance of the Poetic Text." In: Close Listening: Poetry and the Performed Word, ed. Ch. Bernstein (New York 1998), p. 150.

57 A. Chesterman, "Hypotheses about translation universals." In: Claims, Changes and Challenges in Translation Studies, eds. H. Gyde, K. Malmkjær, D. Gile (AmsterdamPhiladelphia 2000), p. 59.

58 See: e.g. E. Balcerzan, Tłumaczenie jako "wojna światów” (Poznań 2009), pp. 91-2: "Graphic creations should not be taken into consideration by the theory of interlingual translation since they are neither translatable nor untranslatable." 


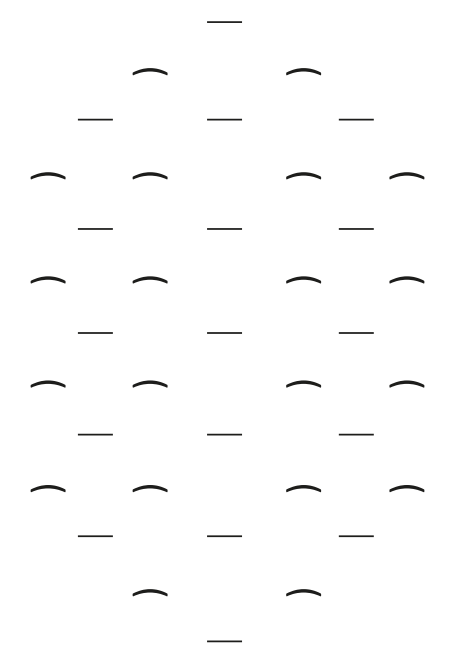

Fig. 8: Christian Morgenstern, Fish's Night Song. Trans. Max Knight. Ch. Morgenstern, The Gallow Songs/Galgenlieder. A Selection, trans. by M. Knight (Berkeley and Los Angeles) 1963, p. 31.

an illusionist translation, the graphic is simply reproduced in its original form, as in the case of Marian Hemar's 1936 Polish translation of Morgenstern's poem, Rybi śpiew nocny [Night Song of a Fish].$^{59}$ However, conceptual translations urge us to revise what has hitherto been considered as a "zone of untranslatability." 60 What is at issue here is not the question of the (un)translatability or otherwise of a poem's graphic devices, but the "textual equivalent" as a method of conceptual translation.

In a bilingual concrete poem by Zbigniew Makarewicz (1971), ${ }^{61}$ a traditional interlingual translation of the formula of Symbolum Nicaenum Constantinopolitanum [The Nicene-Constantinopolitan Creed] - visibilium omnium et invisibilium [of things visible and invisible] with the end of the last word cut off, hiding what should be visible, is accompanied by the transformation of the original into a textual equivalent:

59 See: M. Hemar, Koń trojański (Warszawa 1993), p. 189.

60 E. Balcerzan, Tłumaczenie jako “wojna światów,” p. 86.

61 Makarewicz's work is referred to in Balcerzan's study as an example of "bilingualism made visible in a translation." See E. Balcerzan, "Jedno - oraz dwu(wielo)języczność literackich "światów”. In: Kultura w stanie przekładu: translatologia - komparatystyka transkulturowość, eds. E. Kraskowska, W. Bolecki (Warszawa 2012), p. 85. 


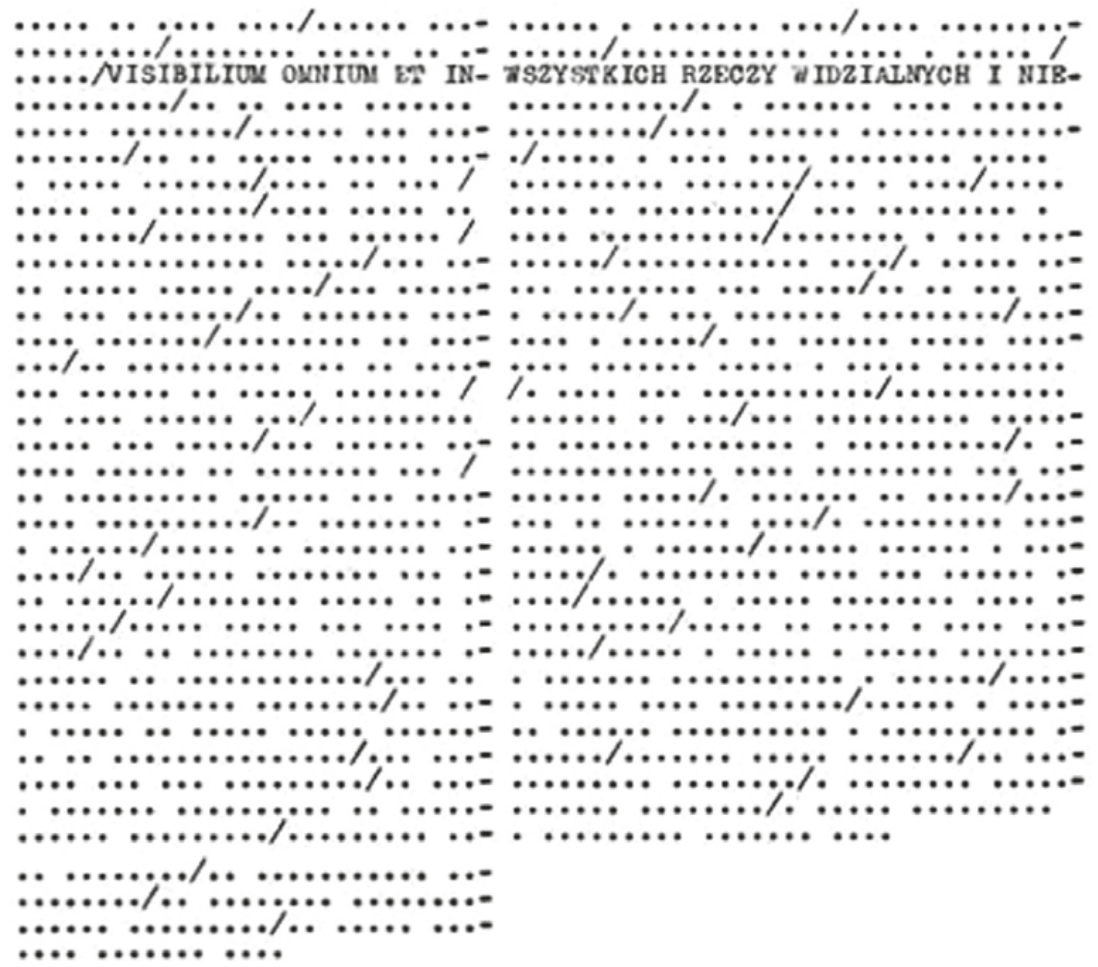

Fig. 9: Zbigniew Makarewicz, tekst, 1971. Reprinted by permission of the author. S. Dróżdż, ed., Poezja konkretna. Wybór tekstów polskich oraz dokumentacja z lat 19671977 (Wrocław 1978), p. 41.

The left-hand side textual equivalent is a graphic substitute of Symbolum Nicaenum Constantinopolitanum, while the right-hand side replaces the Polish version of the Creed.

The juxtaposition of the two differently-sized and variously-structured texts, which may remind the reader of stone tablets, makes one aware of the inevitably transformational nature of translation - even of the interlinear, literal translations historically associated with the hermeneutics of sacred texts, which set the translational norms for "all texts in almost all languages" 62 from Late

62 S. Brock, "Translation in Antiquity." In: A History of Ancient Greek: From the Beginnings to Late Antiquity, ed. A.-P. Christidis (Cambridge-New York 2007), p. 877. 
Credo in unum Deum, Patrem omnipotentem, factorem caeli et $t$ errae, visibilium omnium et invisibilium. Et in unum Dominum Iesum Christum, Filium Dei unigenitum, et ex Patre natum ante omnia saecula. Deum de Deo, Lumen de Lumine, Deum verum de Deo vero, genitum non factum, consubstantialem Patri; per quem omnia facta sunt. Qui propter nos homines et propter nostram salutem descendit de cae1is. Et incarnatus est de Spiritu Sancto ex Maria Virgine, et homo factus est. Crucifixus etiam pro nobis sub Pontio Pilato, passus et sepultus est, et resurrexit tertia die, secundum Scripturas, et ascendit i$\mathrm{n}$ caelum, sedet ad dexteram $\mathrm{Pa}-$ tris. Et iterum venturus est cum gloria, iudicare vivos et mortuos, cuius regni non erit finis. Et in Spiritum Sanctum, Dominum et vivificantem, qui ex Patre Filioque procedit. Qui cum Patre et Filio simul adoratur et conglorificatur: qui locutus est per prophetas. Et unam, sanctam, catholicamet apostolicam Ecclesiam. Confiteor unum baptisma in remissionem peccatorum. Et expecto resurrectionem mortuorum, et vitam venturi saeculi. Amen.
Wierzę w jednego Boga, Ojca Wszechmogacego, Stworzyciela nieba i ziemi, wszystkich rzeczy widzialnych i niewidzialnych. I w jednego Pana Jezusa. Chrystusa, Syna Bożego Jednorodzonego, który z Ojca jest zrodzony przed wszystkimi wiekami. Bóg z Boga, Światłość ze Światłości, Bóg prawdziwy z Boga prawdziwego. Zrodzony, a nie stworzony, wspókistotny Ojcu, a przez Niego wszystko się stało. On to dla nas ludzi i dla naszego zbawienia zstapil z nieba. I za sprawą Ducha. Świętego przyjął ciało z Maryi Dziewicy i stał się człowiekiem. Ukrzyżowany równiez za nas pod Poncjuszem Piłatem został umęczony i pogrzebany. I zmartwychwstał trzeciego dnia, jak oznajmia Pismo. I wstapił do nieba; siędzi po prawicy Ojca. I powtónnie przyjdzie $w$ chwale sadzić żywych i umarłych, a królestwu Jego nie będzie końca. Wierzę w Ducha Świętego, Pana $i$ Oźywiciela, który od Ojca i Syna pochodzi. Który z Ojcem i Synem wspólnie odbiera uwielbienie i chwakę; który mówił przez Proroków. Wierzę w jeden, święty, powszechny $i$ apostolski Kościół. Wyznaję jeden chrzest na odpuszczenie grzechów. I oczekuję wskrzeszenia umarkych $i$ życia wiecznego w przyszłym świecie. Amen.

Fig. 10: Reconstruction of the double text: Symbolum Nicaenum Constantinopolitanum and its Polish translation [T.B.-T.].

Antiquity through the European Middle Ages into the Renaissance. Despite the obvious differences in size and structure, the (left-hand) target text retains all the verse markings of the Latin Creed and supports its perception as an organized structure. The pair of texts in the Polish concrete poet's work are the product of an intersemiotic translation (transmutation), i.e. an interpretation of verbal signs by means of nonverbal sign systems. ${ }^{63}$ Within Makarewicz's tekst [text], the target (left-hand) column exhibits extreme formal equivalence: the number of dots in both text equivalents (right- and left-hand) closely mirrors (maps)

63 See: R. Jakobson, “On Linguistic Aspects of Translation.” In his: Selected Writings, Vol. 2: Word and Language (The Hague and Paris 1971), p. 261. 
the number of letters in the words of the The Nicene-Constantinopolitan Creed (respectively: Latin and Polish). Interlingual verbum e verbo translation is thus accompanied by a faithful translation of verbal signs into signs from the nonverbal sign system. At the same time, Makarewicz's concrete poem has an iconic character - the invisible poetic text corresponds to "things invisible."

The graphic textual equivalent is the constructive principle behind Armand Schwerner's poem The Tablets (1968-1991) which sets itself up as a translation of Sumero-Akkadian clay tablets from more than four thousand years ago. Schwerner's The Tablets is a sophisticated translational mystification in the tradition of James Macpherson's The Poems of Ossian, the Son of Fingal (1799) or Václav Hanka’s Rukopis královédvorský [The Queen's Court Manuscript] (1817). The graphic textual equivalent serves as a means of stylization after the original. The Scholar/Translator meticulously records all the gaps and blanks due to the supposed physical degradation of a Mesopotamian monument, as well as the lack of sufficient knowledge of its archaic (and, in fact, fictitious) language: dots of ellipsis [...] stand for untranslatable passages, plus-signs enclosed in circles for missing ones, question marks (???) for variant reading, and square brackets for comments supplied by the Scholar/Translator. For example, Tablet $X$ begins in the following way:

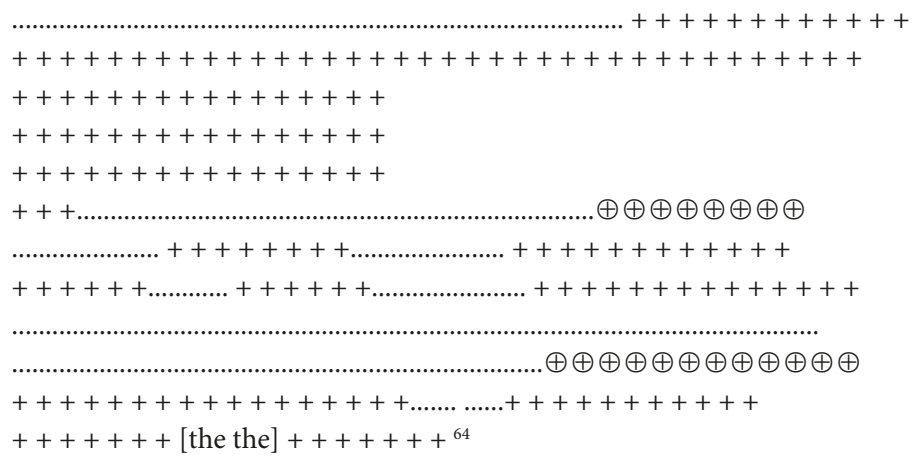

The apparatus of non-alphabetic signs mimics the symbols used in authentic scholarly editions of historical sources. The text equivalent is not only an example of translational mystification, but above all, strongly dynamizes the structure of the poem, increasing the "sensing of form," its pure movement, caused by the interaction of structural factors. In Tynianov's terms, its “'unfinishedness' becomes an aesthetic fact." 65 "Instead of verbal matter, there is a dynamic sign

64 A. Schwerner, The Tablets (Orono 1999), p. 35.

65 Y. Tynianov, The Problem of Verse Language, p. 70. 
pointing to it. Instead of a definite semantic weight, there is an indefinite, enigmatic semantic hieroglyph, which serves to complicate and semantically impede the following stanzas and lines." ${ }^{\prime 6}$ The construction of Schwerner's "apocryphal translation" rests on the assumption that "no matter how compelling (artistically) the omitted stanza, it is weaker than the sign of omission and the dots." ${ }^{67}$ Thus, poetic translation acquires the status of a self-model of translation activities, a reflection on the possibilities of performing translation and the efficiency of translation studies. The Tablets becomes an archaeology of translation, a pastiche of scholarly discourse and palaeographic archaeological research.

The introduction of the graphic equivalent of a text in the target poem changes the translation into a methodology of translation..$^{68}$ Metatranslations that make use of the graphic equivalent of a text as an artistic device are not only a veritable literary/translational laboratory, they are also an area with considerable laboratory significance for verse and translation scholars, in that they foreground the technical aspects of translation. In a way similar to Constructivist translation, ${ }^{69}$ they ostentatiously disclose the constructive factor of the original, for example through implementing the principle of equimetricity, agreement between the metrical patterns of the translation and the original, and equilinearity (e.g., Kibirov's Ekvivalent teksta). Conceptual target poems tend to parody translation as a rule-governed activity. They lay bare the transformational and inevitably manipulative nature of translation. They demonstrate the extreme consequences of understanding translation as a game involving a sequence of choices from a limited repertoire of elements. They make the reader aware of the multivariant character of translation, calling into question the dogma of the infallibility of the interpreter. They undermine the idea of the translator's invisibility and

66 Y. Tynyanov, "On the Composition of Eugene Onegin." Trans. S.S. Hoisington. In: Russian Views of Pushkin's "Eugene Onegin", ed. S.S. Hoisington (Bloomington 1988), p. 78.

67 Tynyanov, "On the Composition of Eugene Onegin," p. 78.

68 To paraphrase M. Głowiński’s formula describing "the novel as a methodology of the novel." See his: "Powieść jako metodologia powieści." In his: Intertekstualność, groteska, parabola. Szkice ogólne i interpretacje (Kraków 2000), p. 122. For a detailed discussion of various realisations of "translation as a methodology of the translation", see: T. Brzostowska-Tereszkiewicz, "Przekład jako metodologia przekładu.”In: Reguły gier. Między normatywizmem a dowolnością w przekładzie, eds. P. Fast, T. Markiewka, J. Pisarska (Katowice 2016), pp. 8-29.

69 For background and further discussion, see: T. Brzostowska-Tereszkiewicz, Modernist Translation. An Eastern European Perspective. Models, Semantics, Functions, pp. 113-128. 
non-intentionality. In terms of Andrew Chesterman's "translational memetics," the graphic equivalent of a text in translation allows the researcher to lay bare the "translation supermemes," such as the idea of the directionality of translation (source-target), the transformational nature of translation, the supermemes of equivalence and untranslatability, the binary opposition between free and literal translation, and finally, the assumption that any writing is a translation. It highlights the evolutionary variability of translation norms which ossify into translation memes and seem to be ineffaceable. Most importantly, it gives translation scholars "new knowledge of the patterns, and patterns of patterns, which helps us to make sense of what we are looking at."

The graphic equivalent of a text turns it into an intermodal translation. It involves a change of the sensory channel through which the original message is received by the target reader. An acoustically realized text becomes a visual/kinesthetic statement. The graphic equivalent of a text restitutes the dynamics of the relationship between the source and the target texts and leads to deautomatization of the target reader's perceptual habits. These estranging functions can be performed not only by interlingual translations in which the graphic equivalent of a text plays an important structural role (although, it is often these examples that seem most eloquent), but by conceptual translations in general, which employ various paratexts and metatexts typical of illusionist translations in order to evoke particular responses in their audiences.

Having surveyed the various sensual and intellectual strategies used by artists to undermine translational illusion, one may say that, while it may be difficult to delineate specific characteristics of all conceptual translations - from dense constellations of Proustian letters to the graphic equivalent of a verbal original in Kibirov's experiments - they always tend to lean towards visual, installation, and performance art. They are likely to be marked by an intense preoccupation with intermediality, the multisensory reception of artistic endeavor, and synaesthesia. The inherent tension between sensory and intellectual cognition or, as Clive Scott put it, the "aiding of percept by concept," ${ }^{\text {"11 }}$ is particularly important in the translation process. As a rule, conceptual translations also introduce "the idea of the ludic, of jouissance, or playfulness" which Susan Bassnett diagnosed as

70 A. Chesterman, "Hypotheses about translation universals." In: Claims, Changes and Challenges in Translation Studies, p. 11.

71 Scott, "Intermediality and Synaesthesia: Literary Translation as Centrifugal Practice," p. 155. 
"the missing element in so much writing about poetry and translation."72 In the framework of Scott's theory of synaesthetic translation, conceptual translations are distinctive for their "centrifugal" rather than "centripetal" attitude to the source text:

On the one hand, I am imagining a centripetal attitude to text, a continual return to a source text (ST), which believes that this ST fully possesses itself in its linguisticity; that the literary is a stable constant within it; that what one must gather from it is its meaning, by interpretation. On the other hand, my hand as it were, is the centrifugal practice of text, which believes that the text is constantly in search of itself; that it does not comprehend itself; that it has yet to fulfill itself, in paralinguistic realizations, in synaesthetizations; that it does not own its literariness, but that this literariness is unstable, continually reinventable, always at the text's widening periphery. ${ }^{73}$

What is particularly relevant here is the conceptual translators' focus on conceptual "pirouettes" rather than illusionist representations of the original. Indeed, conceptual translation as an experimental mode of literary production may not, at first, even be recognized or appreciated as translation in the target context. Clive Scott, who himself turned Rimbaud and Apollinaire translations into conceptual experiments, asserted:

to call translation a conceptual art is ... to presuppose that translation constantly questions assumptions about translation, about what translation needs to be in order to be translation, and implies that there are ways of achieving its ends which are much more 'economical. ${ }^{74}$

The conceptual art of translation actively sets out to be controversial, insofar as it seeks to encourage a revisionist understanding of what the target audience tends to take for granted in the domain of interlingual and intercultural communication. It makes creative use of graphic/urban space as a structural factor and as a means of conveying the translator's idea. Rediscovering and mingling the techniques and strategies of historical avant-gardes, conceptual translation places a special emphasis on the materiality of signification (sound, shape, texture, layout) and the constructedness of the target text. It also privileges aleatoric and combinatory procedures in the construction of target texts. The utilization

72 S. Bassnett, "Translaplanting the Seed. Poetry and Translation." In: S. Bassnett, A. Lefevere, Constructing Cultures: Essays on Literary Translation (ClevedonPhiladelphia 1998), p. 65.

73 Scott, "Intermediality and Synaesthesia: Literary Translation as Centrifugal Practice," pp. 154-5.

74 Scott, Translating Rimbaud's Illuminations, p. 257. 
of "ready-made" materials (e.g. cardboard letters, a Biblical lexicon) is particularly significant in the context of the further evolution of literary translation, which eventually leads to postmodernism.

[2016]

The author would like to thank the following individuals and organizations for permission to reproduce copyright material:

Ewa Partum for permission to reproduce images of some of her artworks for the purposes of criticism: Active Poetry. Installation. Warsaw, 1971; poem by ewa. fragment $W$ POSZUKIWANIU STRACONEGO CZASU Marcela Prousta, 1971; Text installation with music stands, National Museum, Warsaw 2001 (from Angelika Stepken ed., Ewa Partum 1965-2001 (Karlsruhe 2001), pp. 34, $37,95)$ and for her photograph of 'Installation Metapoetry "À la recherche du temps perdu” according to Marcel Proust.' 18 Biennale of Sydney, Australia 2012.

Zbigniew Makarewicz for permission to reproduce his concrete poem tekst, 1971 (Stanisław Dróżdż, ed. Poezja konkretna. Wybór tekstów polskich oraz dokumentacja z lat 1967-1977. (Wrocław1978), p. 41. 


\section{List of Figures}

Zenon Klemensiewicz, Translation as a Linguistic Problem

Fig. 1: An original verbal creation ............................................................... 60

Fig. 2: A derivative verbal creation ............................................................. 61

Tamara Brzostowska-Tereszkiewicz, The Conceptual Art of Translation

Fig. 1 and Fig. 2: Ewa Partum, Active Poetry. Installation. Warsaw 1971.

Reprinted by permission of Ewa Partum

Fig. 3: Ewa Partum, "Installation Metapoetry À la recherche du temps perdu according to Marcel Proust". 18 Biennale of Sydney,

"All Our Relations", Australia 2012. Copyright ( 2012 by Ewa

Partum. Reprinted by permission of Ewa Partum

Fig. 4: $\quad$ Ewa Partum, poem by ewa. fragment W POSZUKIWANIU

STRACONEGO CZASU Marcela Prousta, 1971. Sig.

Nationgalerie, Staatliche Museen zu Berlin. Reprinted by

permission of Ewa Partum

Fig. 5: Heinz Gappmayr, ohne Titel, 1986 .............................................. 351

Fig. 6: Ewa Partum, Text installation with music stands, National

Museum, Warsaw 2001. Reprinted by permission of Ewa

Partum

Fig. 7: Christian Morgenstern, Fisches Nachtgesang, 1905. Reproduced from the public domain .................................................................. 360

Fig. 8: Christian Morgenstern, Fish's Night Song. Trans. Max Knight ......... 361

Fig. 9: Zbigniew Makarewicz, tekst, 1971.Reprinted by permission of the author 362

Fig. 10: Reconstruction of the double text: Symbolum Nicaenum Constantinopolitanum and its Polish translation [T.B.-T.] 



\section{Bibliography}

Adamczyk-Garbowska, Monika. Polskie ttumaczenia angielskiej literatury dziecięcej. Problemy krytyki przykładu. Wrocław: Ossolineum, 1988.

Ajdukiewicz, Kazimierz. “Sprache und Sinn.” Erkenntnis 1934, Vol. IV, pp. 100-138.

Albrecht, Jörn, ed. Translation und interkulturelle Kommunikation. Frankfurt a. M.: Peter Lang, 1987.

Alphen, Ernst van. "Second-Generation Testimony, Transmission of Trauma, and Postmemory." Poetics Today 2006, Vol. 27(2), pp. 473-488.

Alpher, Barry. "Dalabon Dual Subject Prefixes, Kinship Categories, and Generation Skewing." In: Languages of Kinship in Aboriginal Australia. Eds. J. Heath, F. Merlan, A. Rumsey. Sydney: Sydney University Press, 1982, pp. 19-30.

Aubry, Dominique. "Préface." In: Les problèmes théoriques de la traduction. Ed. G. Mounin. Paris: 1963, pp. VII-XII.

Augé, Claude, ed. Larousse du XX-e siècle. Paris: Larousse, 1933.

Bachmann-Medick, Doris, ed. Übersetzung als Repräsentation fremder Kulturen. Berlin-Bielefeld-Munich: E. Schmidt, 1997.

Baker, Mona, ed. Routledge Encyclopedia of Translation Studies.1st edition. London - New York: Routledge, 2001.

Baker, Mona. "Narratives To and On Translation." Skase Journal of Translation and Interpretation 2005, Vol. 1(1), pp. 4-13.

Balbus, Stanisław et al. "W rodzinie... w społeczeństwie... w historii... O Nocach i dniach." Życie Literackie 1975, Vol. 43, p. 5.

Balcerzan, Edward. “Teoria i krytyka przekładu w Związku Radzieckim." Pamiętnik Literacki 1966, Vol. 57, pp. 223-243.

Balcerzan, Edward. "Sztuka tłumaczenia a styl." In: Studia z teorii i historii poezji. series 1. Ed. M. Głowiński. Wrocław: Ossolineum, 1967, pp. 33-71.

Balcerzan, Edward. Styl i poetyka twórczości dwujęzycznej Brunona Jasieńskiego. Z zagadnień teorii przekładu. Wrocław: Ossolineum, 1968.

Balcerzan, Edward. Oprócz głosu. Szkice krytycznoliterackie.Warsaw: PIW, 1971.

Balcerzan, Edward. "Trudna rzecz jest jeden język drugim językiem dostatecznie wyrznąć.” Teksty 1975, Vol. 6, pp. 1-7 and 23-43.

Balcerzan, Edward, ed. Pisarze polscy o sztuce przekładu 1440-1974. Antologia. Poznań: Wydawnictwo Poznańskie, 1977. 
Balcerzan, Edward. "Sztuka przekładu jako przedmiot badań literackich." Pamiętnik Literacki 1980, Vol. 1, pp. 3-7.

Balcerzan, Edward, Kręgi wtajemniczenia. Kraków: Wydawnictwo Literackie, 1982.

Balcerzan, Edward, ed. Wielojęzyczność literatury i problemy przekładu literackiego. Wrocław: Ossolineum, 1984.

Balcerzan, Edward. "Słowo wstępne." In: Wielojęzyczność literatury i problemy przekładu literackiego. Ed. E. Balcerzan. Wrocław: Ossolineum, 1984, pp. 7-8.

Balcerzan, Edward. "Poetyka przekładu artystycznego," Nurt 1968, Vol. 3(40), pp. 23-26; or in: E. Balcerzan, Literatura $z$ literatury (Strategie tłumaczy). Katowice: Śląsk, 1998, pp. 17-31.

Balcerzan, Edward. Tłumaczenie jako "wojna światów." Poznań: Wydawnictwo Naukowe UAM, 2009.

Balcerzan, Edward. "Jedno- oraz dwu(wielo)języczność literackich światów." In: Kultura w stanie przekładu: translatologia - komparatystyka - transkulturowość. Eds. E. Kraskowska, W. Bolecki. Warsaw: IBL, 2012, pp. 71-90.

Baldensperger, Fernand. Goethe en France. Paris: Librairie Hachette et Cie, 1904.

Baldensperger, Fernand. La littérature, création, succès, durée. Paris: Ernest Flammarion, 1913.

Banaszkiewicz, Władysław, Witczak, Witold. Historia filmu polskiego, Vol. 1 (1895-1929).Warsaw: Wydawnictwa Artystyczne i Filmowe, 1966.

Barańczak, Stanisław. "Przekład artystyczny jako "samoistny" i "związany" obiekt interpretacji (Na marginesie niektórych polskich tłumaczeń Gottfrieda Benna).” In: $Z$ teorii i historii przekładu literackiego. Ed. J. Baluch. Kraków: Uniwersytet Jagielloński, 1974, pp. 47-74.

Barańczak, Stanisław. "Poetycki model świata a problemy przekładu artystycznego." In: Wielojęzyczność literatury i problemy przekładu literackiego. Ed. E. Balcerzan. Wrocław: Ossolineum, 1984, pp. 207-226.

Barańczak, Stanisław. "Mały lecz maksymalistyczny manifest translatologiczny." In: Ocalone w tłumaczeniu. Poznań: a5, 1992, pp. 13-63.

Barańczak, Stanisław. Ocalone w tłumaczeniu. Poznań: a5, 1992.

Barkhudarov, Leonid S. Tyetradi Perevodchika. Moscow: Izdat. Meždunarodnye Otnošenija, 1964.

Barthes, Roland. Mythologies. Trans. A. Lavers, New York: Farrar, Strauss and Giraux, 1972.

Barthes, Roland. "Le troisième sens." In: Lobvie et l'obtus. Essais critiques III. Paris: Seuil, 1982, pp. 43-58. 
Bartmiński, Jerzy. "Droga naukowa Anny Wierzbickiej. Od składni polskiej prozy renesansowej do semantyki międzykulturowej." Teksty Drugie 2 011, Vol. 1-2, pp. 218-238.

Bartoszyński, Kazimierz. "Pogranicza krytyki literackiej." In: Badania nad krytyką literacka.. Ed. J. Sławiński. Wrocław: Ossolineum,1974, pp. 95-120.

Bassnett, Susan. "Transplanting the Seed. Poetry and Translation." In: Constructing Cultures: Essays on Literary Translation. Eds. S. Bassnett, A. Lefevere. Philadelphia: Multilingual Matters, 1998, pp. 57-75.

Bellanger, Justin. Histoire de la traduction en France. Paris: Alphonse Lemerre, 1903.

Benjamin, Andrew. "Psychoanalysis and Translation." In: Translation and the Nature of Philosophy: A New Theory of Words. New York-London: Routledge, 1989.

Benjamin, Andrew. “Translating Origins: Psychoanalysis and Philosophy." In: Rethinking Translation: Discourse, Subjectivity, Ideology. Ed. L. Venuti. New York-London: Routledge, 1992, pp. 18-41.

Benjamin, Walter. “The Task of the Translator." In: Illuminations. Trans. H. Zohn. New York: Schocken, 2007, pp. 62-82.

Bereza, Henryk. "Życiopisanie." In: Edward Stachura. Fabula rasa. Z wypowiedzi rozproszonych. Warsaw: Czytelnik, 1982, pp. 445-465.

Bielik-Robson, Agata. "Słowo i trauma: czas, narracja, tożsamość." Teksty Drugie 2004, Vol. 5, pp. 23-34.

Bilczewski, Tomasz. Komparatystyka $i$ interpretacja. Nowoczesne badania porównawcze wobec translatologii. Kraków: Wydawnictwo Uniwersytetu Jagiellońskiego, 2016.

Bilczewski, Tomasz. Komparatystyka i interpretacja. Nowoczesne badania porównawcze wobec translatologii. Kraków: Universitas, 2010.

Blignères, Auguste de. Essai sur Amyot e les traducteurs français du XVI siècle. Paris: Auguste Durand, 1851.

Boas, Franz. "Linguistics and Ethnology." In: Language in Culture and Society. Ed. D. H. Hymes. New York: Harper and Row, 1964, pp. 15-26.

Bogusławski, Stanisław, Greniewski, Henryk, Szapiro, Jerzy. "Dialogi o cybernetyce." Myśl Filozoficzna 1954, Vol. 4, pp. 158-212.

Bojarska, Katarzyna. "Trauma." Wydarzenia po Wydarzeniu. Białoszewski Richter - Spiegelman. Warsaw: IBL, 2013, pp. 247-289.

Bollas, Christopher. The Shadow of the Object: The Psychoanalysis of the Unthought Known. New York: Columbia University Press, 1988.

Bończa Bukowski, Piotr de, Heydel, Magda, eds. Polska myśl przekładoznawcza. Antologia, Kraków: Wydawnictwo Uniwersytetu Jagiellońskiego, 2013. 
Booker, K.M. Joyce, Bakhtin, and the Literary Tradition: Toward a Comparative Cultural Poetic. Ann Arbor: University of Michigan Press, 1995.

Borowy, Wacław. Boy jako tłumacz. Warsaw: Instytut Wydawniczy Bibljoteka Polska, 1922.

Borowy, Wacław. "Dawni teoretycy tłumaczeń." Studia i rozprawy. Wrocław: Ossolineum, 1952, Vol. 2, pp. 7-30.

Borowy,Wacław. "Przekład Shakespeare’a i teatr." Studia i rozprawy. Wrocław: Ossolineum, 1952, Vol. 2, pp. 31-54.

Bouissac, Paul. "Iconicity and Pertinence." In: Iconicity. Eds. P. Bouissac et al. Tübingen: Stauffenburg, 1986, pp. 193-213.

Bouissac, Paul. "Ikoniczność i stosowność." Trans. M. Witkowski. In: Semiotyka dziś i wczoraj. Wybór tekstów. Eds. J. Pelc, L. Koj. Wrocław: Ossolineum, 1991, pp. 117-135.

Bouton, Lawrence, Kachru, Yamuna. Pragmatics and Language Learning.Urbana - Champaign: University of Illinois Press,1994, pp. 1-24.

Bowen, David, Bowen, Margareta. "The Nuremberg Trials (Communication Through Translation)." Meta 1985, Vol. 30(1), pp. 74-77.

Brandstaetter, Roman. Krag biblijny. Warsaw: PAX, 1975.

Brock, Sebastian Paul. “Translation in Antiquity." In: A History of Ancient Greek: From the Beginnings to Late Antiquity. Ed. A.-P. Christidis. Cambridge - New York: Cambridge University Press, 2007, pp. 873-886.

Brodzki, Bella. Can These Bones Live? Translation, Survival, and Cultural Memory. Stanford: Stanford University Press, 2007.

Brzostowska-Tereszkiewicz, Tamara. "Przekład jako metodologia przekładu." In: Reguly gier. Między normatywizmem a dowolnościa w przekładzie. Eds. P. Fast, T. Markiewka, J. Pisarska. Katowice: Śląsk, 2016, pp. 8-29.

Brzostowska-Tereszkiewicz, Tamara. Modernist Translation. An Eastern European Perspective. Models, Semantics, Functions. Frankfurt/M.-BerlinBern-Bruxelles-New York-Oxford-Wien: Peter Lang, 2016.

Bukowski, Piotr, Heydel, Magda, eds. Współczesne teorie przekładu. Antologia. Kraków: Znak, 2009.

Buttler, Danuta. "Koncepcje pola znaczeniowego., Przegląd Humanistyczny 1967, vol. 2, pp. 41-59

Cała, Alina. Wizerunek Żyda w polskiej kulturze ludowej. Warsaw: Oficyna Naukowa, 1992.

Cary, Edmond. La traduction dans le monde moderne. Genève: Librairie de l'Universite, Georg\&Cie, 1956. 
Cary, Edmond. Comment faut-il traduire? Cours polycopié de l'Université Radiophonique Internationals, 1958.

Chałasiński, Józef. “Kultura i naród a przeobrażenia świata współczesnego.” In: Kultura i naród. Studia i szkice. Ed. J. Chałasiński. Warsaw: Książka i Wiedza, 1968.

Chamberlain, Lori. "Gender and the Metaphorics of Translation." In: Translation Studies Reader. Ed. L. Venuti. 3rd edition. London and New York: Routledge, 2012, pp. 254-268.

Chesterman, Andrew. Memes of Translation. The Spread of Ideas in Translation Theory. Amsterdam-Philadelphia: John Benjamins, 2000.

Chesterman, Andrew. "Hypotheses About Translation Universals." In: Claims, Changes and Challenges in Translation Studies. Eds. H. Gyde, K. Malmkjær, D. Gile. Amsterdam-Philadelphia: John Benjamins, 2004, pp. 1-13.

Chukovsky, Korney. Vysokoye Iskusstvo. O Principakh Khudozhestvennogo Perevoda. Moscow: Iskusstvo, 1964.

Cohen, Gustave.Histoire de la mise en scène dans le théâtre religieux français du moyen âge. Paris: Champion, 1926.

Collin, Richard. "Moving Political Meaning Across Linguistic Frontiers," Political Studies 2012, pp. 1-19.

Coutrat, Louis. Opuscules et fragments inédits de Leibniz. Paris 1903. Reprint: Hildesheim: George Olms Buchhandlung, 1961.

Cronin, Michael. Translation and Identity. London-New York: Routledge, 2006.

Cuddon, John Anthony. Dictionary of Literary Terms and Literary Theory. London: Penguin Books, 1991.

Davies, Norman. Boże igrzysko.Vol. 1. Trans. E. Tabakowska. Kraków: Znak, 1989.

Davies, Norman. A History of Europe. Oxford: OUP 1996.

Davies, Norman. Europa. Rozprawa historyka z historia. Trans. E. Tabakowska. Kraków: Znak, 1998.

Dąbrowska, Maria. Noce i dnie. Vol. 1. Warsaw: Czytelnik, 1975.

Dąbrowski, Bartosz. "Postpamięć, zależność, trauma." In: Kultura po przejściach, osoby z przeszłością. Ed. R. Nycz. Krakow: Universitas, 2011, pp. 257-270.

Dąmbska-Prokop, Urszula, ed. Mała encyklopedia przekładoznawstwa. Częstochowa: Educator, 2000.

Dąmbska-Prokop, Urszula. Nowa encyklopedia przekładoznawstwa. Kielce: Educator, 2010. 
De Lange, Nicholas. Reflections of a Translator. Cincinnati: University of Cincinnati, 1993.

Dedecius, Karl. Notatnik tłumacza. Trans. J. Prokop. Kraków: Wydawnictwo Literackie, 1974.

Delavenay, Émile. La machine à traduire. Paris: Presses Universitaires de France, 1959.

Der Grosse Herder. Freiburg: Herder \& Co., 1931-1935.

Delavenay, Émile. "Préface." In: La machine à traduire. Ed. G. Mounin. The Hague: Mounton, 1964.

Derrida, Jacques. Positions. Trans. A. Bass. Chicago: University of Chicago Press, 1982.

Derrida, Jacques. Glas. Trans. J. P. Leavey, R. Rand. Nebraska: University of Nebraska Press, 1990.

Dickens, Charles. Ciężkie czasy. Trans. A. Korzeniowski. Warsaw: Czytelnik, 1955.

Doroszewski, Witold. “O idiomatyczności języków." Prace Filologiczne 1969, Vol. 19, pp. 5-22.

Dreschner, Horst.W. Transfer: Übersetzen - Dolmetschen - Interkulturälitat. Frankfurt a. M.: Peter Lang, 1997.

Dróżdż, Stanisław, ed. Poezja konkretna. Wybór tekstów polskich oraz dokumentacja $z$ lat 1967-1977. Wrocław: Socjalistyczny Związek Studentów Polskich, 1978.

Drucker, Johanna. "Visual Performance of the Poetic Text." In: Close Listening: Poetry and the Performed Word. Ed. Ch. Bernstein. New York: Oxford University Press, 1998, pp. 131-161.

Drzewicka, Anna. Z zagadnień techniki tłumaczenia poezji. Studia nad polskimi przekładami liryki francuskiej $w$ antologiach $z$ lat 1899-1911. Kraków: Uniwersytet Jagielloński, 1971.

Dworkin, Craig, Goldsmith, Kenneth, eds. Against Expression: An Anthology of Conceptual Writing. Evanston: Northwestern University Press, 2011.

Dziamski, Grzegorz. "Ewa Partum - od konceptualizmu do feminizmu." Odra 2006, Vol.11(539), pp. 87-91.

Ďurišin, Dionyz. "Voprosy srawnitielnogo izučenija literatur i analiz pierevodcheskogo myetoda." VI Mezinárodni Sjezd Slavistů v Praze 1968. Résumé, příspèvků a sdělení. Praha: Academia, 1968.

Eades, Diana. "Language and the Law: White Australia vs Nancy." In: Language and Culture in Aboriginal Australia. Eds. M. Walsh, C. Yallop. Canberra: Aboriginal Studies Press, 1993, pp. 181-190. 
Eagleton, Terry. Literary Theory. An Introduction. Minneapolis: University of Minnesota Press, 2008.

Eco, Umberto. Pejzaż semiotyczny. Trans. A. Weinsberg. Warsaw: PIW, 1972.

Eco, Umberto. The Search for the Perfect Language. Oxford: Blackwell, 1995.

Elkin, Adolphus Peter. The Australian Aborigines. Sydney: Angus \& Robertson, 1938.

Elsas Christoph, ed. Tradition und Translation: zum Problem der interkulturellen Übersetzbarkeit religiöser Phänomene. Berlin: de Gruyter, 1994.

Enkvist, Nils Erik. "Experiential Iconicity in Text Strategy." Text 1981, Vol. 1(1), pp. 97-111.

Escarpit, Robert. La revolution du livre. Paris: Presses Universitaires de Paris, 1965.

Etkind, Efim. "Swoboda tłumacza jako konieczność uświadomiona." Trans. E. Siemaszkiewicz. In: O sztuce tłumaczenia. Ed. M. Rusinek. Wrocław: Ossolineum, 1955, pp. 35-50.

Etkind, Efim. Poeziya i Pyeryevod. Moscow: Sovetsky Pisatel, 1963.

Evans, Nicholas. Dying Words: Endangered Languages and What They Have To Tell Us. Chitchester: Wiley-Blackwell, 2010.

Evans, N., F. Merlan, M. Tukumba (comp.). A First Dictionary of Dalabon (Ngalkbon). Maningrida: NT, 2004.

Fang, Achilles. "Some Reflections on the Difficulty of Translation." In: On Translation. Eds. A. Fang, R. A. Brower. Cambridge: Cambridge UP, 1959, pp. 111-133.

Fanon, Frantz. The Wretched of the Earth. Trans. R. Philcox. New York: Grove Press, 2004.

Fedorov, Andrey V. Osnovi Obshchey Tyoryi Pyeryevoda. Moscow: Vysša škola, 1968.

Fedorov, Andrey V. Vvyedyeniye v Tyeoriyu Pyeryevoda. Moscow: Izdatel'stvo literatury na inostrannikh yazykakh,1953.

Fedorov, Andriey V. “Osnovniye Tyerye Perevoda.” Voprosy Yazykoznaniya 1952, Vol. 5, pp. 3-22.

Felman, Shoshana, Laub, Dori.Testimony: Crises of Witnessing in Literature, Psychoanalysis, and History. New York-London: Routledge, 1992.

Fiene, Donald. M. “J. D. Salinger: A Bibliography." Wisconsin Studies in Contemporary Literature 4.1. (Winter), 1963, pp. 109-149.

Fornelski, Piotr. "Kontekstualizacja przekładu. Między mitem wierności a zdradą." Między oryginałem a przekładem, Vol. I. Kraków: Księgarnia Akademicka, 1995. 
Fowler, Henry W., ed. The Concise Oxford Dictionary of Current English, 4th edition, Oxford: Calderon Press, 1950.

Franklin, Tamara B., Russig, Holger, Weiss, Isabelle C., Gräff, Johennes, Linder, Natacha, Michalon, Aubin, Vizi, Sandor, Mansuy, Isabelle M. "Epigenetic Transmission of the Impact of Early Stress Across Generations." Biological Psychiatry 2010, Vol. 68(5), pp. 408-415.

Freud, Sigmund. From the History of an Infantile Neurosis, Trans. J. Strachey, In: The Standard Edition of the Complete Psychological Works of Sigmund Freud. Vol. XVII. London: The Hogarth Press, 1917-1919, pp. 1-124.

Freud, Sigmund. Beyond the Pleasure Principle, Trans. J. Strachey. New York: Norton,1989.

Gaiba, Francesca. The Origins of Simultaneous Interpretation: The Nuremberg Trial. Ottawa: Universeity of Ottawa Press, 1998.

Geertz, Clifford. "Culture, Mind, Brain/Brain, Mind, Culture.” In: Available Light. Ed. C. Geertz. Princeton: Princeton University Press, 2000, pp. 203-217.

Genette, Gerard. Palimpsests: Literature in the Second Degree. Trans. Ch. Newman, C. Doubinsky. Lincoln-London: University of Nebraska Press, 1997.

Głowiński, Michał, Okopień-Sławińska, Aleksandra, Sławiński, Janusz. Zarys teorii literatury. Warsaw: PWN, 1967.

Głowiński, Michał. Style odbioru. Szkice o komunikacji literackiej. Kraków: Wydawnictwo Literackie, 1977.

Głowiński, Michał. “Powieść jako metodologia powieści.” In: Intertekstualność, groteska, parabola. Szkice ogólne i interpretacje. Ed. M. Głowiński. Kraków: Universitas, 2000, pp. 122-154.

Głowiński, Michał. Intertekstualność, groteska, parabola. Szkice ogólne i interpretacje. Kraków: Universitas, 2000.

Goddard, Cliff. Pitjantjatjara/Yankunytjatjara to English Dictionary. 2nd edition. Alice Springs: Institute for Aboriginal Development, 1993.

Goddard, Cliff. "Lexical Primitives in Yankunytjatjara." In: Semantic and Lexical Universals: Theory and Empirical Findings. Eds. C. Goddard, A. Wierzbicka. Amsterdam: John Benjamins, 1994, pp. 229-262.

Goddard, Cliff. "Ethnopragmatics: A New Paradigm." In: Ethnopragmatics: Understanding Discourse in Cultural Context. Ed. C. Goddard. Amsterdam: John Benjamins, 2006, pp. 1-30.

Goddard, Cliff. "Not Taking Yourself Too Seriously in Australian English: Semantic Explications, Cultural Scripts, Corpus Evidence." Intercultural Pragmatics 2009, Vol. 6(1), pp. 29-53.

Goddard, Cliff. Semantic Analysis. 2nd edition. Oxford: Oxford University Press, 2011. 
Goddard, Cliff. "'Early Interactions' in Australian English, American English, and English English: Cultural Differences and Cultural Scripts.” In: (Im) politeness in English: Journal of Pragmatics, Special Issue. Eds. M. Haugh, K. Schneider. 2012, pp. 1038-1050.

Goddard, Cliff, Wierzbicka, Anna, eds. Meaning and Universal Grammar: Theory and Empirical Findings. Amsterdam: John Benjamins, 2002.

Goddard, Cliff, Wierzbicka, Anna, eds. Cultural Scripts: Special Issue of Intercultural Pragmatics 2004, Vol. 1(2).

Goddard, Cliff and Wierzbicka, Anna. Words and Meanings: Lexical Semantics Across Domains, Languages, and Cultures. Oxford: Oxford University Press, 2013.

Godfrey, Tony. Conceptual Art. London: Phaidon Press Limited, 1998.

Goethe, Johann Wolfgangvon. Dramatic works: Comprising Faust, Iphigenia in Tauris, Torquato Tasso, Egmont. Trans. A. Swanwick and Goetz von Berlichingen trans. by Sir W. Scott, carefully revised, London: Henry G. Bohn, 1850.

Goethe, Johann W. Faust. Trans. F. Konopka. Warsaw: PIW, 1977.

Gomulicki, Juliusz Wiktor. “Z rosyjskiego Juliana Tuwima." Twórczość 1955, Vol. 2, pp. 172-179.

Greniewski, Henryk. Elementy logiki indukcji. Warsaw: PWN, 1955.

Greniewski, Henryk. Cybernetics without Mathematics. New York: Pergamon Press, 1960.

Grimbert, Philippe. Un secret. Paris: Grasset, 2012.

Grosbart, Zygmunt. "Specyfika przekładu w ramach języków słowiańskich (Propozycje metodologiczne)." In: Poetyka i stylistyka słowiańska. Ed. S. Skwarczyńska. Wrocław: Ossolineum, 1973, pp. 112-119.

Grossman, Edith. Why Translation Matters. New Haven: Yale University Press, 2010.

Grucza, Franciszek. "Zagadnienia translatoryki." In: Glottodydaktyka a translatoryka. Ed. F. Grucza. Warsaw: UW, 1981, pp. 9-27.

Grzegorczyk, Piotr. "Problematyka tłumaczeń. Szkic bibliograficzny." In: O sztuce tłumaczenia. Ed. M. Rusinek. Wrocław: Ossolineum,1955, pp. 445-477.

Gunia, Anna. "Język obozów koncentracyjnych." Języki Specjalistyczne 2006, Vol. 6, pp. 56-60.

Gwóźdź, Andrzej. "Polski film fabularny w relacjach z innymi sztukami. Wybór polskich publikacji z zakresu metodologii, teorii, estetyki i krytyki filmu z lat 1945-1977, dotyczących powojennej kinomatografii polskiej (bibliografia).” In: Film polski wobec innych sztuk. Eds. A. Helman, A. Madej, Katowice: Uniwersytet Śląski, 1979. 
Hale, Ken. "Kinship Reflections in Syntax: Some Australian Languages." Word 1986, Vol. 22, pp. 318-24.

Harkins, Jean, Wilkins, David P. "Mparntwe Arrernte and the Search for Lexical Universals." In: Semantic and Lexical Universals. Eds. C. Goddard, A. Wierzbicka. Amsterdam: John Benjamins, 1994, pp. 285-310.

Hauser, Arnold. "Pod znakiem filmu." In: Społeczna historia sztuki i literatury, Trans. J. Ruszczycówna, Vol. 2, Warsaw, 1974, pp. 363-390.

Heidegger, Martin. The Question Concerning Technology. Trans. W. Lovitt, New York: Harper Torchbooks, 1977.

Heidegger, Martin. Poetry, Language, Thought. Trans. A. Hofstader, New York: Harper Modern Classics, 2013.

Hejwowski, Krzysztof. Kognitywno-komunikacyjna teoria przekładu. Warsaw: PWN, 2008.

Hejwowski, Krzysztof. Iluzja przekładu. Przekładoznawstwo w ujęciu konstruktywnym. Katowice: Śląsk, 2015.

Helman, Alicja. "Modele adaptacji filmowej. Próba wprowadzenia w problematykę." Kino 1979, Vol. 6, pp. 28-30.

Helman, Alicja. Słownik pojęć filmowych. Vol. 1, Wrocław: Wiedza o Kulturze, 1991. Helsztyński, Stanisław. "Polish Translations of Shakespeare in the Past and Today." Zeitschrift fur Anglistik und Amerikanistik 1964, Vol. 2, pp. 183-198.

Helsztyński, Stanisław. "Przekłady Szekspirowskie w Polsce wczoraj i dziś." Pamiętnik Teatralny 1954, Vol. 2(10), pp. 3-91.

Hemar, Marian. Koń trojański. Warsaw: Burchard Edition, 1993.

Hendrykowski, Marek. "Zagadnienie kontekstu literackiego filmu (na przykładzie polskiej szkoły filmowej)." In: Film polski wobec innych sztuk. Eds. A. Helman, A. Madej. Katowice: Uniwersytet Śląski, 1979, pp. 44-60.

Hendrykowski, Marek. "Słowo w tekście filmowym.” In: Słowo w filmie. Warsaw: PWN 1982, pp. 83-106.

Hercus, Luise. Languages and Storylines at the Crossroads. 2011, unpublished.

Hermans, Theo. The Conference of the Tongues. Manchester: St. Jerome, 2007.

Hertz, Paweł. “O tłumaczeniu ksiąg.” In: O sztuce tłumaczenia. Ed. M. Rusinek. Wrocław: Ossolineum, 1955, pp. 206-230.

Hiatt, Lester. "The Moral Lexicon of the Warlpiri People of Central Australia." Australian Aboriginal Studies 2007, Vol. 1, pp. 4-30.

Hirsch, Edward D. “Objective Interpretation." PMLA 1960, Vol. 75(4), pp. 463-479.

Hirsch, Marianne. The Generation of Postmemory. Writing and Visual Culture after the Holocaust. New York: Columbia University Press, 2012. 
Hoffman, Eva. Lost in Translation: A Life in a New Language. New York: Penguin, 1989.

Hoffman, Eva. The Secret. A Fable for our Time. London: Secker \& Warburg, 2001. Hoffman, Eva. After Such Knowledge: A Meditation on the Aftermath of the Holocaust. London: Secker \& Warburg, 2004.

Hoffman, Eva. Appassionata. New York: Other Press, 2008.

Holmes, James. Translated! Papers on Literary Translation and Translation Studies. Amsterdam: Rodopi, 1988.

Hopfinger, Maryla. "Film i literatura: uwarunkowania techniczne przekładu intersemiotycznego." In: Sztuka - technika - film. Ed. A. Kumor, D. Parczewska. Warsaw: Wydawnictwo Artystyczne i Filmowe, 1970, pp. 159-182.

Hopfinger, Maryla. Adaptacje filmowe utworów literackich. Problemy teorii i interpretacji. Wrocław: Ossolineum, 1974.

Horálek, Karel. "Rodzaje literackie z punktu widzenia problematyki przekładowej.” Zagadnienia Rodzajów Literackich 1964, Vol. 7, Book 1, pp. 5-13.

Iampolski, Mikhail. The Memory of Tiresias: Intertextuality and Film. Berkeley: University of California Press, 1998.

Ingarden, Roman. Das literarische Kunstwerk. Halle: Max Niemeyer Verlag, 1931. (Polish edition: O dziele literackim. Warsaw: PWN, 1960; English edition: The Literary Work of Art. Trans. G. G. Grabowicz, Evanston: Northwestern University Press, 1973).

Ingarden, Roman. O poznawaniu dzieła literackiego, Lwów: Ossolineum, 1937. (New edition: Warsaw 1976; English edition: The Cognition of the Literary Work of Art, Trans. R. A. Crowley, K. R. Olson, Evanston: Northwestern University Press, 1973).

Ingarden, Roman. "O tłumaczeniach." In: O sztuce tłumaczenia. Ed. M. Rusinek. Wrocław: Ossolineum, 1955, pp. 127-190; or in: Z teorii języka i podstaw filozoficznych logiki, Dzieła filozoficzne. Warsaw: PWN, 1972, pp. 120-188.

Insana, L. N. Arduous Tasks: Primo Levi, Translation, and the Transmission of Holocaust Testimony. Toronto-Buffalo-London: University of Toronto Press, 2009.

Iwanov, Wiaczeslav, Toporov, Wladimir. Sławianskije jazykowyje modieli ruszczije semioticzeskije sistiemy. Moskva: Izdatel'stvo Nauka, 1965.

Iwaszkiewicz, Jarosław. "Przekłady z Pablo Nerudy." In: O sztuce tłumaczenia. Ed. M. Rusinek. Wrocław: Ossolineum, 1955, pp. 245-253.

Jackiewicz, Aleksander. "Proces literacki a film." In: Proces historyczny w literaturze i sztuce. Materialy konferencji naukowej. Eds. M. Janion, A. Piorunowa.Warsaw: PIW, 1967. 
Jakobson, Roman. "On Linguistic Aspects of Translation." In: On Translation. Ed. R. A. Brower, Cambridge: 1959, pp. 232-239; or in: R. Jakobson, Selected Writings, vol. 2: Word and Language. The Hague and Paris: Mouton, 1971, pp. 260-66.

Janion, Maria. "Ludowość rozdwojona." In: Odnawianie znaczeń. Krakow: Wydawnictwo Literackie, 1980.

Jastrun, Mieczysław. Między słowem a milczeniem. Warsaw: Czytelnik,1960.

Jastrun, Mieczysław. Poezja i rzeczywistość. Eseje i szkice. Warsaw: Czytelnik, 1965.

Jastrun, Mieczysław. Walka o słowo.Warsaw: Czytelnik, 1973.

Jastrun, Mieczysław. “O przekładzie jako o sztuce słowa.” In: Przekład artystyczny. O sztuce tłumaczenia księga druga. Ed. S. Pollak. Wrocław: Ossolineum, 1975, pp. 117-131.

Kachru, Braj. "Standards, Codification and Sociolinguistic Realism: The English Language in the Outer Circle." In: English in the World: Teaching and Learning the Language and Literatures. Eds. R. Quirk, H. Widdowson. Cambridge: Cambridge University Press, 1985, pp. 11-30.

Kamieńska, Anna. “Pochwała niemożliwości." In: Przekład artystyczny. O sztuce tłumaczenia księga druga. Ed. S. Pollak.Wrocław: Ossolineum, 1975, pp. 133-136.

Karcz, Danuta. “Odwołuję się do sfery uczuć. Rozmowa z Jerzym Antczakiem.” Kino 1975, Vol. 12, pp. 12-17.

Karłowicz, Jan, Kryński, Adam, Niedźwiedzki, Władysław, eds. Słownik języka polskiego. Warsaw: Kasa im. Mianowskiego, 1900-1935.

Karski, Grzegorz. "Kłopoty tłumacza." In: O sztuce tłumaczenia. Ed. M. Rusinek.Wrocław: Ossolineum, 1955, pp. 255-278.

Karwacki, Janusz. Życie wśród śmierci. Warsaw: Serwis multimedialny Sp. z o.o., 1981.

Karwowska, Bożena."Tożsamość postmigracyjna. Przypadki (między innymi) Evy Hoffman i Czesława Miłosza." In: Druga płeć na wygnaniu. Doświadczenie migracyjne $w$ opowieści powojennych pisarek polskich. Krakow: Universitas, 2013, pp. 17-48.

Keesing, Roger. Kin Groups and Social Structure. New York: Holt, Rinehart and Winston, 1975.

Kellerman, Natan P. F. "Epigenetic Transmission of Holocaust Trauma: Can Nightmares Be Inherited?", Israel Journal of Psychiatry and Related Sciences 2013, Vol. 50(1), pp. 33-39.

Kępiński, Antoni. "KZ-syndrom.” In: Rytm życia. Kraków: Wydawnictwo Literackie, 2012, pp. 106-123. 
Khan, Masud. "The Concept of Cumulative Trauma." Psychoanalytic Study of the Child 1963, Vol. 18, pp. 286-306.

Kibirov, Timur. "Na polakh 'A Shropshire Lad"' In: Stikhi o lubvi. Ed. T. Kiborov. Moskwa, Vrema, 2009, pp. 742-743.

Kijowski, Andrzej (Dedal). "Film, czyli literatura na nowo." Twórczość 1970, Vol. 3, pp. 131-134.

Klaudy, Kinga. "Empirical Research in Translation Studies." In: Translatologica Pragensia VI. Ed. M. Hrala, Praha: Univerzita Karlova, 1998, pp. 19-25.

Kleiner, Juliusz. Juliusz Słowacki. Dzieje twórczości. Vol. 4., part 1. Warsaw: Gebethner i Wolff, 1927.

Klemensiewicz, Zenon. “Przekład jako zagadnienie językoznawstwa." Język Polski 1954, Vol. 34, pp. 65-76; or in: O sztuce ttumaczenia. Ed. M. Rusinek. Wrocław: Ossolineum, 1955, pp. 85-97.

Kmita, Jerzy. "Z problemów semiotyki sztuki. O przekładalności dzieła literackiego." Nurt 1968, Vol. 8(40), pp. 20-22.

Knight, Emily. "Hyperpolysemy in Bunuba, a Polysynthetic Language of the Kimberley, Western Australia." In: Cross-Linguistic Semantics. Ed. C. Goddard. Amsterdam: John Benjamins, 2008, pp. 205-24.

Komissarov, Vilen Naumovich. Slovo o pyeryevodiye. Moscow: Mezhdunarodnie Otnosheniya, 1973.

Koptilov, Victor. "Transformatziya Khudozhestviennovo Obraza v Poeticheskom Pyeryevodye." In: Teoriya i Kritika Pyeryevoda. Ed. B. A. Lari. Leningrad: Izd-vo Leningradskogo Universiteta, 1962.

Kostyrko, Krzysztof. “O konieczności przekładu.” Nurt 1968, Vol. 8(40), pp. 1-3.

Kowalczyk, August. Refren kolczastego drutu. Cieszyn: Wojewódzkie Towarzystwo Opieki nad Oświęcimiem, 2001.

Kowzan, Tadeusz. Littérature et spectacle dans leurs rapports esthétiques et sémiologiques. Warsaw: PWN, 1970, pp. 62-132.

Kozak, Jolanta. Przekład literacki jako metafora. Między logos a lexis. Warsaw: PWN, 2009.

Kracauer, Siegfried. Theory of Film. New York-Oxford: Oxford University Press, 1960.

Krysztofiak, Maria. Przekład literacki we współczesnej translatoryce. Poznań: Wydawnictwo UAM, 1996.

Krysztofiak, Maria. Translatologiczna teoria ipragmatyka przekładu artystycznego. Poznań: Wydawnictwo UAM, 2011. 
Krzyżanowski, Julian. "Szekpirologia wojenna i powojenna." Nauka i Sztuka 1948, Vol. 7, pp. 17-56.

Książek-Konicka, Hanna. Semiotyka i film.Wrocław: Wydawnictwo PAN, 1980.

Kuhiwczak, Piotr. "Mediating Trauma. How do We Read the Holocaust Memoirs?" In: Tradition, Translation, Trauma. The Classic and the Modern. Eds. J. Parker, T. Mathews. New York: Oxford University Press, 2011, pp. 283-298.

Kumaniecki, Kazimierz. "Nad prozą antyczną." In: O sztuce ttumaczenia. Ed. M. Rusinek.Wrocław: Ossolineum, 1955, pp. 99-109.

Kuncewiczowa, Maria. "Inne języki." In: Przekład artystyczny. O sztuce tłumaczenia księga druga. Ed. S. Pollak. Wrocław: Ossolineum, 1975, pp. 161-165.

Kurecka, Maria. Diabelne tarapaty. Poznań: Wydawnicwto Poznańskie. 1970.

Kuryluk, Ewa. Frascati. Apoteoza topografii. Kraków: Wydawnictwo Literackie, 2009.

Laffay, Albert. "Opowiadanie, świat, kino." Trans. S. Kowalski. Pamiętnik Literacki, 1975, Vol. 2, pp. 175-209.

Langacker, Ronald Wayne. "An Introduction to Cognitive Grammar." Cognitive Science 1986, Vol. 10, pp. 1-40.

Langacker, Ronald Wayne. Foundations of Cognitive Grammar, Vol. 2: Descriptive Application. Stanford: Stanford UP, 1991.

Lange, Nicholas de, "Reflections of a Translator." In: Other Words 1994, Vol. 3.

Latyshev, L. K. Pyeryevod: Problemy tyeorii, praktiki i myetodiki pryepodavaniya. Moscow: Prosveschenie, 1988.

Le Dictionnaire Universel d'Antoine Furetière. Facsimile edition. Paris: SNL-Le Robert, 1978.

Lebiedziński, Henryk. Elementy przekładoznawstwa ogólnego. Warsaw: PWN, 1981.

Lefevere, André. Translation/History/Culture. A Sourcebook. New York-London: Routledge, 1992.

Legeżyńska, Anna. Tłumacz i jego kompetencje autorskie. Na materiale powojennych tłumaczeń z A. Puszkina. W. Majakowskiego, I. Kryłowa, A. Błoka. Warsaw: PWN, 1999.

Leszczyński, Witold. “Ład utracony. O filmie Konopielka mówi reżyser.” Film 1982, Vol. 14.

Levi, Primo. I sommersi e i salvati. Torino: Guilio Eimaudi editore, 1986.

Levi, Primo. The Drowned and the Saved. trans. R. Rosenthal. New York: Simon\&Schuster, 2017 [1988]. 
Levin, Yuri. "Ob Istoricheskoi Evolutzyi Principov Perevoda." In: Myezhdunarodnyie Sviazhi Russkoi Literatury: Sbornik Statyei. Ed. M. P. Alexeyev, Moscow-Leningrad: Izdatel'stvo Akademii Nauk SSSR, 1963, pp. $5-63$.

Levý, Jiři. “Translation as a Decision Process." In: To Honor Roman Jakobson. Essays on the Occasion of his Seventieth Birthday.Vol. II, The Hague-Paris: Mounton, 1967, pp. 1171-1182.

Levý, Jiři. The Art of Translation [1963]. Trans. P. Corness, Ed. Z. Jettmarová, Amsterdam-Philadelphia: John Benjamins, 2011.

Lewicki, Roman. Konotacja obcości w przekładzie. Lublin: Wydawnictwo UMCS, 1993.

Lewicki, Roman. Obcość w odbiorze przekładu. Lublin: Wydawnictwo UMCS, 2000.

Lévi-Strauss, Claude. Anthropologie structurale. Paris: Plon, 1958.

Liede, Alexander. Dichtung als Spiel: Studien zur Unsinnspoesie an der Grenze der Sprache, Berlin: DE Gruyter, 1963.

Ligocka, Roma. Dobre dziecko. Krakow: Wydawnictwo Literackie, 2012.

Linschinger, Joseph, ed. TEXTBILD/BILDTEXT, mit einem Vorwort von Peter Weiermair und einer Einleitung von Eugen Gomringer. Piesport: Ottenhausen Verlag, 1990.

Lipszyc, Adam. "W.G. Sebald: W noktoramie niepamięci." In: Rewizja procesu Józefiny K. i inne lektury od zera. Warsaw: Sic!, 2011, pp. 133-173.

Lipszyc, Adam. Sprawiedliwość na końcu języka. Czytanie Waltera Benjamina. Kraków: Universitas, 2012.

Locke, John. An Essay Concerning Human Understanding. Vol. 2, Oxford: Clarendon Press, 1959.

Loffredo, Eugenia, Perteghella, Manuela, eds. Translation and Creativity: Perspectives on Creative Writing and Translation, London: Continuum 2006.

Lotman, Yuri. Semiotics of Cinema. Trans. M. E. Suino. Ann Arbor: University of Michgan Press, 1976.

Lotman, Yuri. The Structure of Artistic Text. Trans. R. Vroom. Ann Arbor: University of Michgan Press, 1977.

Lukszyn, Yuri, et al. eds. Tezaurus terminologii przekładoznawczej. Warsaw: PWN, 1998.

Lyons, John. Semantics. Vol. 2. Cambridge: Cambridge UP, 1978.

Ławrynowicz, Marek. “Ewa Partum’s Metapoetry” [1980]. In: Ewa Partum 19652001. Ed. A. Stepken. Karlsruhe: Badischer Kunstverein, 2001, pp. 142-144. 
Łobodowski, Józef. U przyjaciót. Lublin - Warsaw: Biblioteka Poetycka Dźwigarów, 1935.

Mac Low, Jackson. In: Thing of Beauty: New and Selected Works. Ed. A. Tardos. Berkeley: University of California Press, 2008, pp. 39-41.

Mach, Anna. "Polska kondycja posttraumatyczna - próba diagnozy." In: Kultura po przejściach, osoby z przeszłością. Ed. R. Nycz. Krakow: Universitas, 2011, pp. 217-238.

Malinowski, Bronisław. "The Problem of Meaning in Primitive Languages." In: The Meaning of Meaning. Eds. C. K. Ogden, I. A. Richards. New York: Harcourt, Brace \& Company, 1923, pp. 297-336.

Malinowski, Bronisław. Coral Gardens and Their Magic. A Study of the Methods of Tilling the Soil and Agricultural Rites on the Trobriand Islands, vol. 2: The Language of Magic and Gardening. London: George Allen \& Unwin, 1935.

Malinowski, Bronisław. Freedom and Civilization. London: George Allen \& Unwin, 1947.

Maranda, Michael. "All the Names in In Search of Lost Time" [2006]. In: Against Expression: An Anthology of Conceptual Writing. Eds. C. Dworkin, K. Goldsmith. Chicago: Northwestern University Press, 2011, pp. 472-475.

Marcjan, Maria and Salska-Kaca, Mirosława. "Koncepcja 'przyliterackości' filmu w teorii Bolesława W. Lewickiego." In: Dzieło filmowe - zagadnienie interpretacji. Ed. J. Trzynadlowski. Wrocław: Wydawnictwo Uniwersytetu Wrocławskiego, 1987, pp. 29-57.

Markowski, Michał Paweł. Efekt inskrypcji. Jacques Derrida i literatura. Bydgoszcz: Homini, 1997.

Martes, Carolina. “Translation in Conceptual Writing.” UC Berkeley Comparative Literature Undergraduate Journal 2012, Vol. 2(1), online: http://ucb-cluj. org/2571-2/ (accessed: 02.02.2013).

Matuszewski, Ryszard. "Filmowe Noce i dnie." In his: Z bliska. Szkice literackie. Krakow: Wydawnictwo Literackie, 1981, pp. 339-340.

Mayenowa, Maria Renata. "Wersologia Franciszka Siedleckiego i jej założenia teoretyczne.” In: Pisma. Ed. F. Siedlecki, S. Żółkiewski, M. R. Mayenowa. Warsaw: PIW, 1989, pp. 45-72.

McGowan, Patrick O., Sasaki, Aya., D’Alessio, Ana C., Dymov, Sergiy, Labonté, Benoit, Szyf, Moshe, Turecki, Gustabo, Meaney, Michael J., "Epigenetic Regulation of the Glucocorticoid Receptor in Human Brain Associates with Childhood Abuse." Nature Neuroscience 2009, Vol. 12(3), pp. 342-348.

Metz, Christian. "Zagadnienia oznaczania w filmach fabularnych (Przyczynek do semiologii filmu).” Trans. M. R. Pragłowska, Kultura i Społeczeństwo 1967, Vol. 11(1), pp. 141-150. 
Metz, Christian. Langage et cinéma, Paris: Larousse, 1971.

Międzyrzecki, Artur. “O przekładach.” In: Przekład artystyczny. O sztuce tłumaczenia księga druga. Ed. S. Pollak. Wrocław: Ossolineum, 1975, pp. 177-183.

Milewski, Tadeusz. "Główne etapy rozwoju polskiego języka literackiego." Ruch Literacki 1960, Vol. 1-2, pp. 19-27.

Miłosz, Czesław. Kontynenty. Paris: Instytut Literacki, 1958.

Miłosz, Czesław. Prywatne obowiązki. Paris: Instytut Literacki, 1972.

Miłosz, Czesław. Ogród nauk. Paris: Instytut Literacki, 1981.

Minier, Marta. “[...] the Translatress in her Own Person Speaks': A Few Marginal Notes on Feminist Translation in Practice, in Creative Writing and in Criticism." In: Identity and Cultural Translation: Writing Across the Borders of Englishness. Women's Writing in English in a European Context. Eds. G. Macedo, M. E. Pereira. Bern: Peter Lang, 2006, pp. 39-54.

Modzelewska, Natalia. "Refleksje tłumacza." In: Przekład artystyczny. O sztuce tłumaczenia ksiega druga. Ed. S. Pollak. Wrocław: Ossolineum,1975, pp. 185-196.

Moore, Bruce, ed. The Australian Oxford Dictionary. Melbourne: Oxford University Press, 1999.

Morgenstern, Christian. The Gallow Songs/Galgenlieder. A Selection. Trans. M. Knight. Berkeley and Los Angeles: University of California Press, 1963.

Morris, Ruth. "Court Interpretation: The Trial of Ivan Demjanjuk. A Case Study." The Interpreters' Newsletter 1989, Vol. 2, pp. 27-37.

Morris, Ruth. "Justice in Jerusalem - Interpreting in Israeli Legal Proceedings." Meta 1998, Vol. 43(1), pp. 110-118.

Morstin, Ludwik Hieronim. "Moja praca nad przekładem utworów Sofoklesa, Horacego, Lope de Vegi, Calderonai Goethego." In: O sztuce ttumaczenia. Ed. M. Rusinek. Wrocław: Ossolineum, 1955, pp. 279-298.

Mounin, Georges. Les problèmes théoriques de la traduction. Paris: Editions Gallimard, 1963.

Nabakowski, Gislind. "Apprehension and Masquerade. 'Letter Millionnaire' Ewa Partum's Path to Conceptual Poetry and Feminist Gender Theory." Trans. O. Kossack. In: Ewa Partum 1965-2001. Ed. A. Stepken. Karlsruhe: Badischer Kunstverein, 2001, pp. 129-139.

Nida, Eugene A. "Linguistics and Ethnology in Translation - Problems." Word 1945, Vol. 2, pp. 194-208.

Nida, Eugene A. "Principles of Translation as Exemplified by Bible Translating." In: On Translation. Eds. A. Fang, R. A. Brower. Cambridge: Cambridge University Press, 1959, pp. 11-31. 
Nietzsche, Friedrich. The Will to Power. Trans. W. Kaufmann. New York: Vintage Books, 1968.

Nietzsche, Friedrich. The Gay Science. Trans. W. Kaufmann. New York: Vintage Books, 1974.

Nietzsche, Friedrich. Beyond Good and Evil. Trans. W. Kaufmann. New York: Vintage Books, 1989.

Nietzsche, Friedrich. Ecce Homo. Trans. D. Large, New York: Oxford University Press, 2009.

Nowosielski, Kazimierz. "Ludowy i ludzki widnokrąg. O Konopielce Edwarda Redlińskiego." Pamiętnik Literacki 1982, Vols. 1-2, pp. 125-143.

Oberlander, Tim F., Weinberg, Joanne, Papsdorf, Michael, Grunau, Ruth, Misri, Shaila, Devlin, Angela M. "Prenatal Exposure to Maternal Depression, Neonatal Methylation of Human Glucocorticoid Receptor Gene (NR3C1) and Infant Cortisol Stress Responses." Epigenetics 2008 Vol. 3(2), pp. 97-106.

Ogibenin, W. “Zamechaniya o strukture mifa v Rigvede," Trudy po znakovym sistemam. Tartu: Tartuskij Gosudarstvennyj Universitet, 1965.

Okladnikova, A. V. Issledovanie $v$ oblasti yazyka perevodov (problemy normy $i$ uzusa), PhD candidate's resume, Moscow, 1980.

Okopień-Sławińska, Aleksandra. "Relacje osobowe w literackiej komunikacji." In: Problemy socjologii literatury. Ed. J. Sławiński.Wrocław: Ossolineum, 1971, pp. 109-125.

Okopień-Sławińska, Aleksandra. Semantyka wypowiedzi poetyckiej (preliminaria). Wrocław: Ossolineum, 1985.

Orłowski, Władysław. Z książki na ekran, Łódź: Wydawnictwo Łódzkie, 1974.

Orwid, Maria. Przeżyć... i co dalej? Rozmawiaja Katarzyna Zimmerer i Krzysztof Szwajca, Kraków: Wydawnictwo Literackie, 2006.

Orwid, Maria. Trauma. Kraków: Wydawnictwo Literackie, 2009.

Osadnik,Wacław. "Adaptacja filmowa jako przekład." In: Kino według Alicji. Ed. W. Godzic, T. Lubelski. Kraków: Universitas, 1995, pp. 69-77.

Parandowski, Jan. “O znaczeniu i godności tłumacza." In: O sztuce tłumaczenia. Ed. M. Rusinek. Wrocław: Ossolineum, 1955, pp. 11-20.

Parker, J., Mathews, T. eds. Tradition, Translation, Trauma. The Classic and the Modern. New York: Oxford University Press, 2011.

Partum, Ewa. Pirouette, Galerie Dialog. West Berlin, online: Filmoteka Museum http://www.artmuseum.pl/filmoteka/?id=1274\&l=1 (accessed: 23.01.2011).

Paterson, Nigel, dir. The Ghost in Your Genes. BBC 2005. www.bbc.co.uk/sn/ tvradio/programmes/horizon/ghostgenes.shtml (access: 16.08.2013). 
Pilař, Jiři. "Trzy aspekty przekładu artystycznego." Trans. J. Bułakowska, In: Przekład artystyczny. O sztuce tłumaczenia księga druga. Ed. S. Pollak. Wrocław: Ossolineum1975, pp. 261-270.

Pisarska, Alicja, Tomaszkiewicz, Teresa. Wspótczesne tendencje przekładoznawcze. Poznań: Wydawnictwo UAM, 1996.

Plesnar, Łukasz A. Semiotyka filmu. Krakow: Uniwersytet Jagielloński, 1990.

Plesnar, Łukasz A. Sposób istnienia $i$ budowa dzieła filmowego. Kraków: Wydawnictwo Literackie, 1990.

Pollak, Roman. “Gofred” Tassa - Kochanowskiego. Poznań: Gebethner \& Wolff, 1922.

Pollak, Roman. "Wstęp.” In: Łukasz Górnicki, Pisma. Ed. R. Pollak. Warsaw: PIW, 1961, Vol. 1, pp. 1-45.

Pollak, Roman. “Triumfy ‘Gofreda’ i ścieżki cierniste 'Orlanda.” Wśród literatów staropolskich. Warsaw: PWN, 1966, pp. 225-241.

Pollak, Seweryn. “Z zagadnień teorii przekładu poetyckiego." Prace Polonistyczne 1948, Vol. 6, pp. 191-210.

Pollak, Seweryn, ed. Przekład artystyczny. O sztuce tłumaczenia księga druga. Wrocław: Ossolineum, 1975.

Pollak, Seweryn. "Granice swobód." In: Przekład artystyczny. O sztuce tłumaczenia ksiegga druga. Ed. S. Pollak. Wrocław: Ossolineum, 1975, pp. 271-284.

Popovič, Anton. Preklad a výraz. Bratislava: SAV, 1968.

Popovič, Anton. "Rola odbiorcy w procesie przekładu literackiego." Trans. J. Sławiński. In: Problemy socjologii literatury. Ed. J. Sławiński.Wrocław: Ossolineum, 1971, pp. 205-219.

Popovič, Anton. “Teoria przekładu w systemie nauki o literaturze." Trans. M. Papierz. In: Konteksty nauki o literaturze. Ed. M. Czermińska. Wrocław: Ossolineum, 1973, pp. 107-126.

Popovič, Anton. “Translation as Communication." In: Komparatistika a preklad. Ed. P. Petrus. Acta Facultatis Philosophicac Universitatis Šafarikanae. Literárnovedný zborník. Vol. 6, Bratislava: SPN, 1980, pp. 5-23.

Przyboś, Julian. "Centrum polszczyzny." In: Pięćdziesiąt lat twórczości Marii Dąbrowskiej. Ed. E. Korzeniewska. Warsaw: PIW, 1963, pp. 21-31.

Pszczołowska, Lucylla. "Wiersz polskich przekładów poezji Puszkina." In: Słowiańska metryka porównawcza. Eds. L. Pszczołowska, D. Urbańska. Vol. IV, Wiersz przekładu. Mickiewicz i Puszkin. Wrocław-Warsaw-Kraków: Ossolineum, 1992, pp. 133-188.

Pushkin, Alexander. Eugene Onegin: A Novel in Verse. Trans. J. E. Falen. New York: Oxford World's Classics, 2009. 
Radcliffe-Brown, Alfred R. The Social Organization of Australian Tribes. Sydney: Oceania Monographs, 1973, pp. 432-33.

Rakoczy, Marta. Słowo-działanie-kontekst. O etnograficznej koncepcji języka Bronisława Malinowskiego. Warsaw, 2012.

Redliński, Edward. Konopielka. Warsaw: LSW, 1974.

Ricoeur, Paul. On Translation, Trans. R. Kearney. New York: Routledge, 2006.

Ross Amos, F. Early Theories of Translation. New York: Columbia University Press, 1920.

Rossels, Vladimir, "B masterskoy perevodchika." In: Tetradi perevodchika. Moscow 1966: Mezhdunarodniye otnosheniya, pp. 12-15.

Rusinek, Michał, ed. O sztuce tłumaczenia. Wrocław: Ossolineum, 1955.

Ryevzin, Isaak, Rozenzveig, Wiktor. Osnovy obshchey teorii perevoda. Moscow: Vysšaâ škola, 1964.

Sandauer, Artur. “Traski tłumacza." In: O sztuce tłumaczenia. Ed. M. Rusinek. Wrocław: Ossolineum, 1955, pp. 343-346.

Sandauer, Artur. "Wstęp." In: Aristophanes, Żaby. Trans. A. Sandauer. Warsaw: PIW, 1956.

Sapir, Edward. "Language." In: Selected Writings of Edward Sapir in Language, Culture and Personality. Ed. D. Mandelbaum. Berkeley: University of California Press, 1949, pp. 7-31.

Sapir, Edward. "Conceptual Categories in Primitive Languages." In: Language in Culture and Society. Ed. D. H. Hymes. New York: Harper and Row, 1964, p. 128.

Schaffner, Anna Katharina. "How the Letters Learnt to Dance: On Language Dissection in Dadaist, Concrete and Digital Poetry." In: Avant-garde/Neoavant-garde. Ed. D. Scheunemann. Amsterdam-New York: Rodopi, 2005, pp. 149-172.

Schäffner, Christina, Kelly-Holmes, Helen, eds. Cultural Functions of Translation. Clevedon-Philadelphia-Adelaide: Multilingual Matters, 1995.

Schwab, Gabriele. "Words and Moods: The Transference of Literary Knowledge". SubStance 1997, Vol. 3, pp. 107-127.

Schwab, Gabriele. "Replacement Children: The Transgenerational Transmission of Traumatic Loss." Haunting Legacies. Violent Histories and Transgenerational Trauma. New York: Columbia University Press, 2010, pp. 118-150.

Schwerner, Armand.The Tablets. Maine: The National Poetry Foundation, 1999.

Scott, Clive. "Translation and the Spaces of Reading." In: Translation and Creativity: Perspectives on Creative Writing and Translation. Eds. E. Loffredo, M. Perteghella. London: Continuum, 2006, pp. 33-46. 
Scott, Clive. Translating Rimbaud's Illuminations. Exeter: University of Exeter Press, 2006.

Scott, Clive. "Intermediality and Synaesthesia: Literary Translation as Centrifugal Practice." Art in Translation 2010, Vol. 2(2), pp. 153-169.

Segal, Dimitrij M. "Zametki ob odnom tipe semioticheskikh modeliruyushchikh sistem", Trudy po znakovym sistemam, Tartu: Tartuskij Gosudarstvennyj Universitet, 1965, pp. 12-14.

Shakespeare, William. Romeo i Julia, Hamlet. Trans. J. Iwaszkiewicz. Warsaw: PIW, 1954.

Shakespeare, William. Hamlet, książę duński.Trans. J. S. Sito. Warsaw: PIW, 1968.

Shelley, Lore. Secretaries of Death. Accounts by Former Prisoners who Worked in the Gestapo of Auschwitz. New York: Shengold Publishers, 1986.

Shviyetzer, A. D. "Sotsiolingvisticheskie osnovy teorii perevoda." Voprosi Yazikoznaniya 1985, Vol. 5.

Shweder, Richard A. "Relativism and Universalism." In: Companion to Moral Anthropology. Ed. D. Fassin. Chichester: Harvard University Press, 2012, pp. 85-102.

Siedlecki, Franciszek. "Przekłady z poezji rosyjskiej” [1936]. In: Pisma. Eds. F. Siedlecki, S. Żółkiewski, M. R. Mayenowa. Warsaw: PIW, 1989, pp. 663-675.

Siedlecki, Franciszek. In: Pisma. Ed. S. Żółkiewski, M. R. Mayenowa. Warsaw: PIW, 1989.

Skwarczyńska, Stefania. "Zagadnienie dramatu." Przegląd Filozoficzny 1949, Vol. 45, pp. 158-173; or in: S. Skwarczyńska, Studia i szkice literackie. Warsaw: PAX, 1953, pp. 95-121.

Skwarczyńska, Stefania. "Przekład i jego miejsce w literaturze i kulturze narodowej (Na przykładzie "Hamleta" w wersji Józefa Paszkowskiego)." In: O współczesnej kulturze literackiej. Eds. S. Żółkowski, M. Hopfinger. Vol. 1, Wrocław: Ossolineum 1973, pp. 287-330.

Sławek, Tadeusz. "Vita femina. Dekonstrukcja jako styl krytyki." In: Interpretacje i styl krytyki. Ed. W. Kalaga, T. Sławek. Katowice: Śląsk, 1988, pp. 141-168.

Sławek, Tadeusz. "Kalibanizm. Filozoficzne dylematy tłumaczenia." In: Przekład artystyczny. Ed. P. Fast. Vol. 1, Katowice: Śląsk, 1991, pp. 7-17.

Sławińska, Irena. Sceniczny gest poety. Kraków: Wydawnictwo Literackie, 1960.

Sławiński, Janusz. "Pozycja narratora w Nocach i dniach Marii Dąbrowskiej.” In: Pięćdziesiąt lat twórczości Marii Dąbrowskiej. Ed. E. Korzeniewska. Warsaw: PIW, 1963, pp. 82-99. 
Sławiński, Janusz. "O kategorii podmiotu lirycznego. Tezy referatu." In: Wiersz $i$ poezja. Ed. J. Trzynadlowski. Wrocław: Ossolineum, 1966, pp. 55-62.

Sławiński, Janusz. “O dzisiejszych normach czytania (znawców).” Teksty 1974, Vol. 3, pp. 9-32.

Sławiński, Janusz. "Semantyka wypowiedzi narracyjnej." In: Dzieło, język, tradycja. Warsaw: PWN, 1974, pp. 120-156.

Sławiński, Janusz. "Synchronia i diachronia w procesie historycznoliterackim." In: Dzieło. Język. Tradycja. Ed. J. Sławiński.Warsaw: IBL, 1974, pp. 11-38.

Sławiński, Janusz. "Myśli na temat: biografia pisarza jako jednostka procesu historycznoliterackiego." In: Biografia - geografia - kultura literacka. Ed. J. Ziomek, J. Sławiński. Wrocław: Ossolineum, 1975, pp. 9-24.

Smirnoff, Aleksandr, "Metodika literaturnovo perevoda". In: Literaturnaia encykłopiedija, vol. 8, Moscow: Kommunisticheskaia akademiia, 1934, pp. 526-531.

Snell-Hornby, Mary, ed. Übersetzungswissenschaft. Eine Neuorientierung. Tübingen: Narr, 1986.

Snell-Hornby, Mary, Jettmarová, Zuzana, Kaindl, Karl, eds. Translation as Intercultural Communication. Selected Papers from the EST Congress. Amsterdam-Philadelphia: John Benjamins, 1995.

Soliński. Wojciech. Przekład artystyczny a kultura literacka. Komunikacja $i$ metakomunikacja jezykowa. Wrocław: Wydawnictwo Uniwersytetu Wrocławskiego, 1987.

Souriau, Etienne. "Les grands problèmes de lésthétique théâtrale." Les Cours de Sorbonne. Paris: Centre de Documentation Universitaire, 1956.

Spitzer, Leo. "Zur Interpretation Christian Morgensternscher Gedichte." Euphorion 1921, Vol. 23, pp. 95-99.

Sprusiński, Michał. Między prawdą a zmyśleniem, Kraków: Wydawnictwo Literackie, 1978.

Stachura, Edward. Siekierezada, Warsaw: Czytelnik, 1975.

Stahl, Stephen Michael. "Psychotherapy as an Epigenetic 'Drug': Psychiatric Therapeutics Target Symptoms Linked to Malfunctioning Brain Circuits with Psychotherapy as Well as with Drugs." Journal of Clinical Pharmacy and Therapeutics 2011, Vol. 37, pp. 249-253.

Stepken, Angelika, ed. Ewa Partum 1965-2001. Karlsruhe: Badischer Kunstverein, 2001.

Stepken, Angelika. “Monograph.” Trans. I. Balfour. In: Ewa Partum 1965-2001. Ed. A. Stepken. Karlsruhe: Badischer Kunstverein, 2001, pp. 17-23.

Stern, Anatol. “Nad Majakowskim.” In: O sztuce tłumaczenia. Ed. M. Rusinek. Wrocław: Ossolineum, 1955, pp. 347-366. 
Sweatt, J. David. "Experience-Dependent Epigenetic Modifications in the Central Nervous System.” Biological Psychiatry 2009, Vol. 65(3), pp. 191-197.

Szczepan, Aleksandra. "Polski dyskurs posttraumatyczny. Literatura polska ostatnich lat wobec Holokaustu i tożsamości żydowskiej." In: Kultura po przejściach, osoby z przeszłością. Ed. R. Nycz. Kraków: Universitas, 2011, pp. 239-256.

Szmydtowa, Zofia. "Czynniki rodzime i obce w przekładzie literackim." In: O sztuce tłumaczenia. Ed. M. Rusinek. Wrocław: Ossolineum, 1955, pp. 111-126.

Szuman, Stefan. O kunszcie i istocie poezji lirycznej. Łódź: Poligrafika, 1948.

Szurek-Wisti, Maria. Miriam-tłumacz. Kraków: Kasa im. Mianowskiego, 1937.

Szymańska, Kasia, Heydel, Magda, eds. Literature from Literature. Essays on Translation by Edward Balcerzan and Stanisław Barańczak. Lausanne: sdvig press, 2018.

Szymczak, Mieczysław. "O tzw. nieprzekładalnych kategoriach językowych." In: Poetyka i stylistyka słowiańska. Ed. S. Skwarczyńska. Wrocław:1973, pp. 21-26.

Szymczukiewicz, Michał. "L'inteprétation communautaire dans l'armée. Etude de cas: missions polonaises de paix". Unpublished M.A. Thesis, University of Warsaw, 2005.

Święch, Jerzy. “Tłumaczenie a problemy historii literatury." In: $Z$ teorii i historii przekładu literackiego. Ed. J. Baluch. Kraków: Uniwersytet Jagielloński, 1974, pp. 7-24.

Święch, Jerzy. "Przekłady i autokomentarze." In: Wielojęzyczność literatury $i$ problemy przekładu literackiego. Ed. E. Balcerzan. Wrocław: Ossolineum, 1984, pp. 45-66.

Tabakowska, Elżbieta. "The Polish Translation of James Joyce's Ulisses and Some Underlying Problems." Zeszyty Naukowe UJ. Prace historycznoliterackie 1973, Vol. 24, pp. 141-156.

Tabakowska, Elżbieta. Cognitive Linguistics and the Poetics of Translation. Tübingen: Narr, 1993.

Tabakowska, Elżbieta. "Językoznawstwo kognitywne w teorii i praktyce przekładu: oleodruk i symfonia na dwa fortepiany." In: Między oryginałem a przekładem. Ed. J. Konieczna-Twardzikowa, U. Kropiwiec. Kraków: Universitas, 1995, pp. 31-41.

Tabakowska, Elżbieta. "Linguistic Expression of Perceptual Relationships: Iconicity as a Principle of Text Organization (A Case Study)." In: Form Miming Meaning, Ed. M. Nänny, O. Fischer. Amsterdam-Philadelphia: John Benjamins, 1999, pp. 409-422. 
Tabakowska, Elżbieta. Językoznawstwo kognitywne a poetyka przekładu. Trans. A. Pokojska, Kraków: Universitas, 2001.

Tabakowska, Elżbieta. "Między obrazem a tekstem, czyli o przekładzie intersemiotycznym." In: Między obrazem a tekstem. Ed. A. Kwiatkowska, J. Jarniewicz. Łódź: Wydawnictwo Uniwersytetu Łódzkiego, 2009, pp. 37-48.

Tabakowska, Elżbieta. In: Myśl językoznawcza z myśla o przekładzie. Wybór prac. Eds. P. de Bończa Bukowski, M. Heydel. Kraków: Wydawnictwo Uniwersytetu Jagiellońskiego, 2015.

Talmy, Leonard. "Figure and Ground in Complex Sentences." In: Universals of Human Language. Ed. J. H. Greenberg. Vol. 4, Stanford: Stanford University Press, 1978, pp. 627-649.

Tarnawski, Wit. O polskich przekładach dramatów Szekspira. Kraków: Polska Akademia Umiejętności, 1914.

The ICD-10 Classification of Mental and Behavioural Disorders, Diagnostic Criteria for Research. Geneva: WHO, F43.1.

Thomas, Roy. "United Nations Military Observer Interpreting in a Community Setting." In: The Critical Link: Interpreters in the Community. Eds. S. E. Carr, R. Roberts, A. Dufour, D. Steyn. Amsterdam-Philadelphia: John Benjamins, 1997, pp. 249-257.

Tippner, Anja. Alterität, Übersetzung und Kultur. Chechovs Prosa zwischen Rußland und Deutschland. Frankfurt a. M: Peter Lang, 1997.

Tomashevsky, Boris. "La nouvelle école d'histoire litteraire en Russie." Revue des Etudes Slaves 1928, Vol. VIII (3-4), pp. 226-240.

Toury, Gideon. "Interlanguage and Its Manifestations in Translation." Meta 1979, Vol. 24(2), pp. 223-284.

Toury, Gideon. “Translation. A Cultural-Semiotic Perspective." In: Encyclopedic Dictionary of Semiotics. Ed. T. A. Sebeok. Vol. 2, Berlin-New York-Amsterdam: de Gruyter, 1986, pp. 111-124.

Tryuk, Małgorzata. L'interprétation communautaire. Des normes et des rôles dans l'interprétation. Warsaw: TEPIS, 2004.

Tryuk, Małgorzata. Przekład ustny środowiskowy. Warsaw: PWN, 2006.

Tryuk, Małgorzata. “You Say Nothing; I Will Interpret': Interpreting in the Auschwitz-Birkenau Concentration Camp." In: Translation and Opposition. Ed. D. Asimakoulas, M. Rogers. Bristol-Buffalo-Toronto: Multilingual Matters, 2011, pp. 223-243.

Tryuk, Małgorzata. Ty nic nie mów, ja będę tłumaczył. O etyce $w$ tłumaczeniu ustnym. Warsaw: Wydawnictwo UW, 2012.

Tulli, Magdalena. Włoskie szpilki. Warsaw: Nisza, 2011. 
Tsiv'yan, Tatiana. "K nekotorym voprosam postroeniya yazyka etiketa." In: Trudy po znakovym sistemam. Tartu: Tartuskij Gosudarstvennyj Universitet, 1965, pp. 144-149.

Tuwim, Julian. "Czterowiersz na warsztacie." In: Pegaz dęba, czyli panopticum poetyckie, Warsaw: Czytelnik, 1950, pp. 191-209.

Tuwim, Julian. "Traduttore - traditore." In: Pisarze polscy o sztuce przekładu 1440-2005. Antologia, Eds. E. Balcerzan, E. Rajewska. Poznań: Wydawnictwo Poznańskie, 2007, pp. 151-167.

Tynianov, Yuri. The Problem of Verse Language [1924]. Ed. and trans. M. Sosa, B. L. Harvey. Ann Arbor: Ardis, 1981.

Tynyanov, Yuri. “On the Composition of Eugene Onegin.” Trans. S. S. Hoisington. In: Russian Views of Pushkin's "Eugene Onegin". Ed. S. S. Hoisington. Bloomington: Indiana UP, 1988, pp. 71-90.

Tytler, Alexander Fraser. On the Principles of Translation [1791]. London: Everyman's Library Edition, 1907.

Unger, Thorsen, Schultze, Brigitte, Turk, Horst, eds. Differente Lachkulturen? Fremde Komik und ihre Übersetzung. Tübingen: Narr,1995.

Ushakov, Dmitry N., ed. Tolkoviy Slovar' Russkogo Jazyka. Moscow: State Publishing House of Foreign and National Dictionaries, 1935-1940.

Valéry, Paul. "Variations on the Eclogues." Trans. D. Folliot. In: Theories of Translation: An Anthology of Essays from Dryden to Derrida. Eds. J. Biguenet, R. Schulte. Chicago: University of Chicago Press, 1992, pp. 113-126.

Venuti, Lawrence. The Translator's Invisibility. A History of Translation, 2nd ed., London-New York: Routledge, 2008.

Vinogradov, Viktor. Leksicheskie voprosy perevoda khudozhestvennoy prozy. Moscow: Izdatel'stvo Moskovskogo Universiteta, 1978.

Wachtel, Michael. Russian Symbolism and Literary Tradition: Goethe, Novalis, and the Poetics of Vyacheslav Ivanov. Madison: University of Wisconsin Press, 1994.

Wadensjö, Cecilia. Interpreting as Interaction. London-New York: Longman, 1998.

Wanner, Adrian. Baudelaire in Russia. Gainesville: University Press of Florida, 1996.

Wanner, Adrian. Russian Minimalism: From the Prose Poem to the Anti-Story. Illinois: Northwestern University Press, 2003.

Watten, Barett. The Constructivist Moment. From Material Text to Cultural Poetics. Middletown: Wesleyan University Press, 2003. 
Wawrzycka, Jolanta. “The Reception of James Joyce in Poland.” In: The Reception of James Joyce, vol. 1: Germany, Northern and East Central Europe. Eds. G. Lernout. W. van Mierlo. London-New York: Continuum, 2004, pp. 219-229.

Ważyk, Adam. "O pracy nad Onieginem." In: O sztuce tłumaczenia. Ed. M. Rusinek. Wrocław: Ossolineum, 1955, pp. 377-381.

Ważyk, Adam. Kwestia gustu. Warsaw: PIW, 1966.

Ważyk, Adam. "Przygody i doświadczenia." In: Przekład artystyczny. O sztuce tłumaczenia księga druga. Ed. S. Pollak. Wrocław: Ossolineum, 1975, pp. 323-346.

Ważyk, Adam. Wybór przekładów. Warsaw: Czytelnik, 1979.

Wende, Waltraud. "Sehtexte - oder: Vom Körper der Sprache." In: Über den Umgang mit der Schrift. Ed. W. Wende. Würzburg: Königshausen\& Neumann, 2002, pp. 302-335.

White, John J. "Forms of Restricted Iconicity in Modern Avant-Garde Poetry." In: Insistent Images. Eds. E. Tabakowska, Ch. Ljungberg, O. Fischer. AmsterdamPhiladelphia: John Benjamins, 2005, pp. 129-154.

Wiegand, Chriss. "Role of the Interpreter in the Healing of a Nation: An Emotional View." In : The Critical Link 2: Interpreters in the Community. Eds. R. Roberts, S. E. Carr, D. Abraham, A. Dufour. Amsterdam-Philadelphia: John Benjamins, 2000, pp. 207-218.

Wierzbicka, Anna. "Przekładalność a elementarne jednostki semantyczne." Przeglad Humanistyczny 1978, Vol. 2, pp. 53-78.

Wierzbicka, Anna. "Semantics and the Interpretation of Cultures: The Meaning of 'Alternate Generations' Devices in Australian Languages.” Man 1986, Vol. 21, pp. 34-49.

Wierzbicka, Anna. Semantics, Culture and Cognition. New York: Oxford University Press, 1992.

Wierzbicka, Anna. "Anglo Scripts Against 'Putting Pressure' on Other People and Their Linguistic Manifestations." In: Ethnopragmatics: Understanding Discourse in Cultural Context. Ed. C. Goddard. Berlin: de Gruyter, 2006, pp. 31-63.

Wierzbicka, Anna. English: Meaning and Culture. New York: Oxford University Press, 2006.

Wierzbicka, Anna. Experience, Evidence and Sense: The Hidden Cultural Legacy of English. New York: Oxford University Press, 2010.

Wierzbicka, Anna. “Arguing in Russian: Why Solzhenitsyn's Fictional Arguments Defy Translation." Russian Journal of Communication 2011, Vol. 4(1/2), pp. 8-37. 
Wierzbicka, Anna. "The Common Language of All People: The Innate Language of Thought." Problemy peredachi informatsii/ Problems of Information Transmission 2011, Vol. 47(4), pp. 380-99.

Wierzbicka, Anna. “Translability and the Scripting of Other Peoples' Souls." The Australian Journal of Anthropology 2013, Vol. 24, pp. 1-21.

Wierzbicka, Anna. Imprisoned in English. Oxford: Oxford University Press, 2013.

Wierzewski, Wojciech. "Ekranizacje rodzimej klasyki literatury w powojennej twórczości filmowej." In: Film polski wobec innych sztuk. Eds. A. Helman, A. Madej. Katowice: Uniwersytet Śląski, 1979, pp. 24-43.

Wirpsza, Witold. "Parę aktualnych czynników współczesnego przekładu poetyckiego.” Poezja 1976, Vol. 6, pp. 32-33.

Wojtanowska, Weronika. Język kluczem do kultury. Anna Wierzbicka i naturalny metajezzyk semantyczny. Wrocław: Exante, 2016.

Wojtasiewicz, Olgierd. Wstęp do teorii tłumaczenia. Wrocław: Ossolineum, 1957.

Woźnicka, Zofia. Problemy kreacji i reprodukcji w filmie. Wrocław: Ossolineum, 1983.

Wysłouch, Seweryna. Problematyka symultanizmu $w$ prozie. Poznań: Wydawnictwo Naukowe UAM, 1981.

Wysłouch, Seweryna. "Adaptacja filmowa jako przekład intersemiotyczny." In: Literatura a sztuki wizualne. Warsaw: PWN, 1994.

Yehuda, Rachel. "Current Status of Cortisol Findings in Post-Traumatic Stress Disorder." Psychiatric Clinics of North America 2002, Vol. 25, pp. 341-368.

Yehuda, Rachel, Bell, Amanda, Bierer, Linda M., Schmeidler, James "Maternal, Not Paternal, PTSD Is Related to Increased Risk for PTSD in Offspring of Holocaust Survivors." Journal of Psychiatric Research 2008, Vol. 42(13), pp. $1,104-1,111$.

Yehuda, Rachel, Bierer, Linda M., “Transgenerational Transmission of Cortisol and PTSD Risk." Progress in Brain Research 2008, Vol. 167, pp. 121-135.

Yehuda, Rachel, Bierer, Linda M., "The Relevance of Epigenetics to PTSD: Implications for the DSM-V." Journal of Traumatic Stress 2009, Vol. 22(5), pp. 427-434.

Yehuda, Rachel, Cai, Guiqing, Golier, Julia A., Sarapas, Casey, Galea, Sandro, Ising, Marcus, Rein, Theo, Schmeidler, James, Müller-Myhsok, Bertram, Holsboer, Florian, Buxbaum, Joseph D. "Gene Expression Patterns Associated with Posttraumatic Stress Disorder Following Exposure to the World Trade Center Attacks." Biological Psychiatry 2009, Vol. 66(7), pp. 708-711.

Yehuda, Rachel, Engel, Stephanie M., Brand, Sarah R., Seckl, Jonathan, Marcus, Sue M., Berkowitz, Gertrud S., "Transgenerational Effects of Posttraumatic 
Stress Disorder in Babies of Mothers Exposed to the World Trade Center Attacks during Pregnancy." The Journal of Clinical Endocrinology \& Metabolism 2005, Vol. 90(7), pp. 4,115-4,118.

Yehuda, Rachel, Schmeidler, James, Labinsky, Ellen, Bell, Amanda, Morris, Adam, Zemelman, Shelly, Grossman, Robert A., "Ten-Year Follow-Up Study of PTSD Diagnosis, Symptom Severity and Psychosocial Indices in Aging Holocaust Survivors." Acta Psychiatrica Scandinavica 2009, Vol. 119(1), pp. 25-34.

Zagroba, Boguś, ed. “Siekierezada." Filmowy Serwis Prasowy 1986, Vol. 18-19, p. 14.

Ziętarska, Jadwiga. Sztuka przekładu w pogladach literackich polskiego Oświecenia.Wrocław: Ossolineum,1969.

Ziomek, Jerzy. Staff i Kochanowski. Próba zastosowania teorii informacji w badaniach nad przekładem. Poznań: UAM,1965.

Ziomek, Jerzy. "Kto mówi?” Teksty 1975, Vol. 8, pp. 45-55.

Ziomek, Jerzy. "Przekład - rozumienie - interpretacja." In: Zagadnienia literaturoznawcze interpretacji. Eds. J. Sławiński, J. Święch.Wrocław: Ossolineum, 1979, pp. 43-71; or in: J. Ziomek, Powinowactwa literatury. Studia i szkice. Warsaw: PWN, 1980, pp. 159-200.

Ziomek, Jerzy. "Powinowactwa przez fabułę." In: Powinowactwa literatury. Studia i szkice. Warsaw: PWN, 1980, pp. 7-101.

Znamierowski, Czesław. Oceny i normy. Warsaw: PWN, 1957.

Zurbrugg, Nicholas, ed. Art, Performance, Media: 31 Interviews. Minneapolis: University of Minnesota Press, 2004.

Żeromski, Stefan. Projekt Akademii Literatury Polskiej. Wyd. 2. Warsaw-Kraków: Wydawnictwo J. Mortkowicza, 1925.

Żółkoś, Monika. “Tworzenie pamięci. O powieściach autobiograficznych Ewy Kuryluk.” In: Kultura po przejściach, osoby z przeszłością. Ed. R. Nycz. Krakow: Universitas, 2011, pp. 271-282. 


\section{Index}

A

Abraham Diana 326, 396

Abramowicz Mieczysław 323

Adamczyk-Garbowska Monika 34, 298, 371

Alargow see Jakobson Roman

Albrecht Jörn 304, 371

Alpher Barry 159, 162, 371

Amos Flora Ross 121, 390

Amyot Jacques 132, 373

Antczak Jerzy 266, 273-275, 382

Appignanesi Lisa 312

Apter Emily 43

Aragon Louis 349

Aristophanes 390

Arnold Matthew 218

Attridge Derek 323

Aubry Dominique 121, 371

B

Bachmann-Medick Doris 301, 371

Bąk Wojciech 111

Baker Mona 327, 345, 371

Bakhtin Michail 347, 374

Balcerzan Edward 6, 7, 9, 10, 15, 22-24, 29, 31, 32, 34, 35, 105, 108, $122,142,184,185,191,193,196$, $202,205,215,242,244,247,264$, $267,276,285,360,361,371,372$, 393, 395

Baldensperger Fernand 133, 372

Baltaziński/Balasiński Józef 332, 334

Baluch Jacek 24, 372, 393

Banaszkiewicz Władysław 263, 372

Barańczak Stanisław 6, 7, 9, 22, 24, 25, 31, 34-36, 190, 215, 372, 393

Barańska Jadwiga 266

Barbaro Maria de 316
Barkhudarov Leonid S. 197, 372

Bart Andrzej 323

Barthes Roland 23, 254, 255, 268, 272, 317, 372

Bartmiński Jerzy 28, 373

Bartoszyński Kazimierz 193, 373

Bassnett Susan 43, 323, 366, 367, 373

Baudelaire Charles 127, 130, 194, 356, 395

Baworowski Władysław 332-334, 337-340, 342

Bechczyc-Rudnicka Maria 69

Belewski Leonard 332

Bellanger Justin 132, 373

Belmont Leo 211

Benjamin Andrew 308, 309, 373

Benjamin Walter 30, 43, 174, 175, 193, 311, 373

Béranger Pierre-Jean de 129, 136

Bereza Henryk 283, 373

Bergson Henri 135

Bernstein Charles 360, 376

Biedka Łukasz 316

Bielik-Robson Agata 309, 310, 373

Bieńczyk Marek 323

Bierer Linda M. 322, 397

Biernat of Lublin 106

Bilczewski Tomasz 5, 8, 9, 43, 44, 307, 308, 373

Bińczycki Jerzy 266

Blignères Auguste de 132, 373

Block Jerzy 277

Boas Franz 157, 373

Bogusławski Andrzej 21

Bogusławski Stanisław 79, 373

Bogusławski Wojciech 142

Bojarska Katarzyna 307, 311, 373 
Bolecki Włodzimierz 361, 372

Bollas Christopher 308, 324, 373

Bomba Jacek 316

Bończa Bukowski Piotr de 6, 7, 13, $38,42,373,394$

Booker M. Keith 347, 374

Borowy Wacław 14, 59, 132, 133, 138, 374

Bouissac Paul 271, 374

Bowen David 325, 374

Bowen Margareta 325, 374

Boy-Żeleński Tadeusz 14, 59, 347, 349, 374

Brandstaetter Roman 198, 207, 374

Breza Tadeusz 267

Bridges Robert 217, 218, 220, 222

Briusov Valery 115

Broch Karl 329, 330

Brock Sebastian Paul 362, 374

Brodzki Bella 323, 374

Brower Reuben A. 122, 187, 198, 208, 377, 382

Brzękowski Jan 349

Brzeski Kazimierz 334

Brzostowska-Tereszkiewicz

Tamara 5, 8, 9, 45, 343, 365, 369, 374

Budny Szymon 201

Bühler Karl 89, 90

Bułakowska Jadwiga 208, 389

Buttler Danuta 21, 374

Byron George Gordon 127, 195

C

Cage John 352, 354

Cała Alina 299, 374

Calderon de la Barca Pedro 131, 199, 387

Camus Albert 352

Carr Silvana E. 326, 394, 396

Cary Edmond 121, 122, 139, 374

Castiglione Baldassare 130
Cazamian Louis 173

Celińska Stanisława 266

Cervantes de Saavedra Miguel 243

Chałasiński Józef 123, 124, 375

Chamberlain Lori 308, 375

Chesterman Andrew 360, 366, 375

Christidis

Anastassios-Fivos 362, 374

Chwalewik Witold 133, 141

Cicero 67, 172

Cienciała Stanisław 338

Cohen Gustave 140, 375

Collin Richard 148, 151, 375

Corneille Pierre 252, 253

Corness Patrick 343, 385

Cortazar Julio 239

Cougno Hella 331

Coutrat, Louis 147, 375

Crane Ronald Salmon 173

Croce Benedetto 14, 135, 175

Cronin Michael 328, 339, 340, 341, 375

Cuddon John A. 288, 375

Cynka Bronisław 334

Czaplak Ewa 316

Czartoryski Adam Kazimierz 207

Czermińska Malgorzata 171, 237, 389

Czerniawski Adam 232, 233

\section{D}

D'Andrade Roy 160

Darbelnet Jean 19, 117, 184, 185

Davies Norman 39, 291-296, 375

Dąbrowska Maria 15, 265, 273, 275, 340, 375

Dąbrowski Bartosz 317, 375

Dąmbska-Prokop Urszula 41, 375

Dedecius Karl 172, 173, 197, 198, 235, 236, 244, 376

Delavenay Emile 122, 376

Demjanjuk Ivan 325, 387 
Democritus 88

Demosthenes 67

Derrida Jacques 42, 43, 206, 251, 253, 260, 261, 318, 376, 386, 395

Dichter Wilhelm 312

Diderot Denis 14, 173, 188

Dijk Teun Adrianus van 171

Dixon Richard M. Watson 220

Dmochowski Franciszek

Ksawery 243

Dobrowolski Władysław J. 69

Dolet Etienne 131

Domagalska-Kurdziel Ewa 316

Dominik Małgorzata 316

Doroszewski Witold 27, 376

Dreschner Horst W. 301, 376

Dróżdż Stanisław 10, 349, 362, 368, 376

Drucker Johanna 360, 376

Drzazga Alojzy 333

Drzewicka Anna 25, 376

Dufour Aideen 326, 394, 396

Duns Scotus 219, 220, 222

Durišin Dionýz 133, 376

Dworkin Craig 353, 354, 376, 386

Dygat Stanisław 267, 268

Dylewski Klaus 330

Dziamski Grzegorz 347, 376

E

Eades Diana 151, 155, 376

Eagleton Terry 351, 377

Eco Umberto 148, 270, 377

Eichmann Adolf 325

Eisenstein Sergey 356

Eliot Thomas Stearns 135

Elkin Adolphus Peter 161, 377

Elsas Christoph 304, 377

Elzenberg Henryk 59

Engels Fryderyk 136

Enkvist Nils E. 193, 377

Escarpit Robert 121, 377
Etkind Jefim (Efim) G. 22, 25, 118, 122, 203, 377

Evans Nicholas 156, 157, 160, 162, 165,377

F

Fang Achilles 197, 198, 208, 377, 388

Fanon Frantz 124, 377

Faryno Jerzy 216

Fast Piotr 10, 41, 42, 365, 374, 392

Faulkner William 118

Fedorov Andrei V. 17, 122, 377

Felman Shoshana 324, 377

Fire Andrew Z. 320

Fischer Olga 291, 359, 394, 396

Fornelski Piotr 302, 377

Fowler Roger 378

Fraser Alexander 74, 132, 395

Freud Sigmund 261, 308-311, 313, 314,378

Fritzsch Karl 333, 337-339

Frycz Modrzewski Andrzej 125

G

Gadamer Hans-Georg 170, 172

Gaiba Francesca 325, 378

Galus/Kalus Franciszek 332

Gappmayr Heinz 349-351, 369

Gardner William H. 219, 221

Garlicki Boleslaw 183

Gątarski Julian 316

Gawroński Alfred 180, 181

Geertz Clifford 28, 143, 144, 148, $150,165,166,378$

Genette Gérard 345, 378

Gierulanka Danuta 168

Głowiński Michał 31, 105, 122, 200, 239, 365, 371, 378

Gnedov Vasilisk 357

Goddard Cliff 144, 149, 150, 152, 154, 159-161, 166, 378-380, 383, 396 
Godfrey Tony 344, 379

Goethe Johann Wolfgang von 133, 174, 190, 199, 248, 352, 356, 372, $379,387,395$

Gogol Nikolai 139

Goldsmith Kenneth 353, 354, 376, 386

Gombrowicz Witold 42, 276, 279

Gomringer Eugen 351, 385

Gomulicki Juliusz Wiktor 245, 379

Górnicki Łukasz 106, 130, 131, 238, 389

Grace Patricia 323

Greenberg Joseph H. 295, 394

Greniewski Henryk 75, 79, 373, 379

Grimbert Philippe 317, 318, 379

Grosbart Zygmunt 26, 31, 379

Grossman Edith 143, 379

Grucza Franciszek 29, 379

Grzegorczyk Piotr 191, 379

Guillén Nicolás 81

Gumilov Nikolai 244

Gunia Anna 327, 328, 379

Gwóźdź Andrzej 263, 379

Gyde Hansen 360, 375

$\mathbf{H}$

Halle Morris 18,114

Hanka Václav 364

Hantz Stanisław 334

Harkins Jean 161, 380

Harvey Brent L. 356, 395

Has Wojciech 267

Haugh Michael 150, 379

Hauser Arnold 263, 380

Heath J.G. 159, 162, 371

Hegel Georg Wilhelm

Friedrich 260, 261

Heidegger Martin 259, 260, 380

Heine Heinrich 129, 136

Hejwowski Krzysztof 41, 380
Helman Alicja 263, 264, 269, 270, 380, 397

Helsztyński Stanislaw 133, 138, 380

Hemar Marian 361, 380

Hendrykowski Marek 31, 264, 267,380

Hercus Luise 155, 380

Hermans Theo 345, 380

Hertz Paweł 201, 238, 380

Heydel Magda 6, 7, 13, 24, 38, 42, $373,374,393,394$

Hiatt Lester 154, 380

Hieronymus St. 172, 173

Hirsch Eric D. 204, 381

Hirsch Marianne 316, 317, 339, 381

Hjelmslev Louis 21

Hoffman Eva 33, 312-315, 317, 322, 381,382

Hofstadter Albert 259

Hoisington Sona S. 365, 395

Hölderlin Friedrich 200

Holmes James 355, 381

Homer 252

Hopfinger Maryla 10, 26, 39, 211, 263, 264, 267, 268, 381, 391

Hopkins Gerard Manley 7, 35, 215, 217-222, 224-234

Horace 172, 173, 199, 387

Horâlek Karel 26, 134, 135, 381

Höss Rudolf 327, 333

Housman Alfred Edward 354-357

Humboldt Wilhelm von 174

Husserl Edmund 89

Hymes, Dell H. 144, 157, 160, 373, 390

\section{I}

Iampolski Mikhail 356, 381

Ihimaera Witi 323

Ihnatowicz Janusz A. 227, 230-232

Ingarden Roman 5, 7, 9, 14, 15, 18, $19,85,122,242,246,381$ 
Ivanov Vyacheslav 215, 356, 395

Iwaszkiewicz Jarosław 15, 115, 138, $139,141,192$

Izdebski Ryszard 316

J

Jackiewicz Aleksander 263, 382 Jakobson Roman O. (Alargov) 19, $21,25,35,39,114,118,122,187$, $208,235,359,363,382,385$

Janicki Jan 337

Janion Maria 263, 277, 382

Jankowski Zygmunt 340

Jasieński Bruno 23, 117, 119, 185, 202, 267, 371

Jastrun Mieczysław 199, 200, 382

Jędrzejewski Sławomir 167

Jesus Christ 183

Jettmarová Zuzana 301, 343, 385,392

Joyce James 27, 248, 346, 347, 374, 393, 396

K

Kachru Braj 149, 159, 374, 382

Kafka Franz 352

Kaindl Klaus 301, 392

Kalaga Wojciech 32, 391

Kamieńska Anna 200, 207, 382

Kamińska Marta 316

Kant Immanuel 100

Karawacka Maria 337

Karcz Danuta 273, 382

Karolak Wojciech 277

Karski Gabriel 202, 382

Karwacki Janusz 329, 330, 382

Karwowska Bożena 312, 382

Kashkin Ivan 115

Kazanecki Waldemar 266

Kearney Richard 311, 390

Keesing Roger 165, 383

Keff Bożena 323
Kellerman Natan P.F. 316, 383

Kelly-Holmes Helen 301, 304, 390

Kędziora Zygmunt 340

Kępiński Antoni 316, 321, 383

Khan Masud 320, 383

Kibirov Timur 354-357, 365, 366, 383

Kijowski Andrzej (Dedal) 285, 383

Klarsfeld Beate 318

Klaudy Kinga 300, 383

Kleiner Juliusz 131, 383

Kleist Heinrich von 100

Klemensiewicz Zenon 7, 9, 19-21, $59,122,175,369,383$

Kloepfer Rolf 174

Kłodziński Stanisław 316

Kmita Jerzy 19, 122, 168, 383

Knight Emily 161, 383

Knight Max 360, 361, 369, 387

Kochanowski Jan 21, 106, 117, 122,398

Kochanowski Piotr 130, 131, 389

Koj Leon 374

Koller Werner 170

Komissarov Vilen N. 205, 300, 383

Konieczna-Twardzikowa Jadwiga 10, 38, 302, 394

Konopka Feliks 352, 379

Konwicki Tadeusz 42

Kończal Ludwik 337

Koptilov Victor 315, 185, 383

Kornhauser Julian 24

Korzeniewska Ewa 273, 389, 392

Korzeniowski Apollo 260, 376

Kossack Oliver 346, 387

Kostyrko Krzysztof 124, 383

Kowalski Stefan 272, 384

Kowzan Tadeusz 128, 383

Kozak Jolanta 41, 383

Koźmian Stanisław Egbert 211

Krasicki Ignacy 244

Kraskowska Ewa 361, 372 
Kraszewski Józef Ignacy 103

Kret Józef 335, 338

Król Henryk 333, 334

Kruchonykh Aleksey 118

Krylov Ivan 33, 238, 241

Krzemień Teresa 378

Krzyzanowski Julian 133, 384

Książek-Konicka

Hanna 270-272, 384

Kuhiwczak Piotr 323, 384

Kumaniecki Kazimierz 202, 384

Kuncewiczowa Maria 208, 384

Kurecka Maria 194, 196, 198, 199, 384

Kuryluk Ewa 317, 319, 323, 384, 398

L

LaCapra Dominick 317

Lachman Gerard 330, 331

Laffay Albert 272, 384

Lagus Stanisław 336

Lakoff George 37

Langacker Ronald W. 37, 38, 288, 289, 291, 294, 295, 384

Lange Nicholas de 287, 296, 376, 384

Laub Dori 324, 377

Lebiedzinski Henryk 36, 384

Lefevere André 32, 367, 373, 384

Legeżyńska Anna 5, 8, 9, 31-34, $235,284,304,305,384$

Leibniz Gottfried Wilhelm 144, 146, 147,375

Lem Stanisław 42

Lenin Vladimir I. 136

Lernout Geert 346, 396

Leski Kazimierz 169

Leszczyński Witold 277-280, 282, 283, 385

Leśniak Roman 316

Levi Primo 323, 328, 329, 339, 341, 381,385
Levin Yuri D. 121, 385

LeVine Robert A. 160

Levi-Strauss Claude 123, 385

Levý Jiři 20, 343, 359, 385

Lewicki Bolesław W. 263, 386

Lewicki Roman 8, 9, 36, 37, 297, 303, 385

Liede Alexander 359, 385

Ligocka Roma 318, 385

Linschinger Josef 351, 385

Lipszyc Adam 43, 310, 385

Ljungberg Christina 359, 396

Locke John 143, 385

Loffredo Eugenia 344, 385, 391

Lorenczyk Alois 330

Loth Stanisław 266

Lotman Yuri 113, 268, 273, 385

Lovitt William 260, 380

Loyola Ignatius, St. 219

Lubimov Yuri 115

Ludskanov Alexander 169

Lukszyn Yuri 41, 386

Ławrynowicz Marek 352, 386

Łobodowski Józef 192, 386

Łukaszewicz Jerzy 277

Łukawiecki Eugen/Łukasz 332

M

Mac Low Jackson 357-359, 386

Macedo Gabriela 345, 387

Mach Anna 317, 386

Machula Kurt 332, 335

Maciąg Włodzimierz 275

Madej Alina 263, 280, 380, 397

Majakowski Włodzimierz 9, 33, 203, 384, 393

Majchrzak Krzysztof 277

Makarewicz Zbigniew 10, 361-364, 368, 369

Malinowski Bronisław 7, 10, 15-17, $37,47,123,143,386,390$

Mallarmé Stéphane 200, 209 
Malmberg Bertil 180, 181

Malmkjær Kirsten 360, 375

Mandelbaum David 158, 390

Mann Thomas 101, 194

Maranda Michael 353, 354, 386

Marciszewski Witold 176

Marcjan Maria 263, 386

Markiewicz Henryk 177

Markiewka Tomasz 365, 374

Markovits Hermine (Herma) 339

Markowski Michał Paweł 43, 386

Marx Karl 136

Martes Carolina 344, 386

Mathews Timothy 323, 384, 388

Matlakowski Władysław 133, 141

Matuszewski Ryszard 274, 386

Mayenowa Maria Renata 14, 174, 386, 391

McGowan P. O. 321,386

Mello Craig C. 320

Mérimée Prospér 139

Merlan Francesca 159, 162, 371, 377

Merwin William Stanley 192

Metz Christian 265, 269, 270, 271, 349, 387

Micewicz Teresa 171

Mickiewicz Adam 110, 125, 127, 212, 356, 390

Międzyrzecki Artur 202, 203, 387

Mierlo Wim van 346, 396

Milewski Tadeusz 131, 387

Miller Claude 317

Miłosz Czesław 111, 192, 194, 199, 207, 312, 382, 387

Minier Marta 345, 387

Mitarski Jan 316

Młodożeniec Stanisław 349

Modzelewska Natalia 244, 387

Moore Bruce 151, 387

Morgenstern Christian 359-361, $369,387,392$

Morhange-Bégué Claude 323
Morris Ruth 325, 387

Morstin Ludwik Hieronim 199, 202, 387

Mounin Georges 113, 121-123, 126, $139,371,376,387$

$\mathbf{N}$

Nabakowski Gislind 346, 350-352, 387

Nänny Max 291, 394

Napiórkowski Zbigniew 277

Naumow Aleksander 169

Nawrot Roman 335

Nekrasov Nikolay 239, 241, 248

Neruda Pablo 115, 192

Nerval Gérard de 194, 203

Newman John Henry 218

Nida Eugene 19, 21, 122, 388

Nietzsche Friedrich 42, 251-258, 260-262, 388

Niewęgłowski Mieczysław 170

Nikitin Evgenij 167

Norwid Cyprian Kamil 125, 195, 217

Novalis 173, 356, 395

Nowosielski Kazimierz 279, 388

Nycz Ryszard 9, 44, 317, 375, 386, 393, 398

O

Oberlander Tim F. 321, 388

Obinkaram Echewa T. 323

Ogden Charles Kay 16, 386

Ogibenin Boris 112, 388

Okladnikova A.V. 300, 388

Okopień-Sławinska Aleksandra 33, 105, 237, 378, 388

Olbrychski Daniel 277

Ollendorf Heinrich Gottfried 48

Orlik Jakub 337

Orłowski Władysław 263, 267, 268, $276,284,388$ 
Ortega y Gasset Jose 196

Orwid Maria 316, 321, 388

Osadnik Wacław M. 40, 388

Osiński Ludwik 196, 207

Ostachowicz Igor 323

Ostrowski Krystyn 132

Otwinowski Stefan 275

$\mathbf{P}$

Pach Joseph 331

Paczuła Tadeusz 332

Pak Ludwik 277

Pammachius, St. 172

Panwitz Rudolf 174

Papierz Maria 237, 389

Parandowski Jan 10, 131, 388

Parbeci Ghazar 173

Parker Jan 323, 384, 388

Partum Ewa 10, 46, 345-352, 368, 369, 376, 386, 387, 389, 393

Pasternak Borys 139

Paszkowski Józef 127, 138-141, 211, 391

Pater Walter 218

Patmore Coventry 220

Paziński Piotr 323

Pelc Jerzy 177, 374

Pereira Margarida E. 345, 387

Perteghella Manuela 344, 385, 391

Pieczka Franciszek 277

Pieszczoch Nikodem 337

Pietrkiewicz Jerzy 234

Pietruszewski Kazimierz 316

Pilař Jiři 208, 389

Pilecki Witold 331

Piorunowa Aniela 263, 382

Pisarska Alicja 41, 389

Pisarska Justyna 365, 374

Plato 88

Plesnar Łukasz A. 269, 270, 389

Poe Edgar Allan 127

Pollak Roman 130, 389
Pollak Seweryn 17, 18, 25, 173, 191, 204, 244, 382, 384, 387, 389, 396

Popovič Anton 24, 171, 210, 237, 239, 240, 245, 249, 345, 389

Pound Ezra 135

Poźmiński Jerzy 332

Pragłowska Maria Renata 265, 387

Pretnar Tone 189

Prokop Jan 172, 197, 235, 376

Prot Katarzyna 316

Proust Marcel 10, 14, 68, 347-351, 353, 366, 368, 369

Prus Bolesław 103, 284

Przerwa-Tetmajer Kazimierz 68

Przyboś Julian 119, 276, 349, 389

Pszczołowska Lucylla 356, 390

Pushkin Alexander 9, 33, 356, 384,390

Q

Quinn Naomi 160

Quirk Randolph 149, 382

R

Rablin Andrzej 334

Radcliffe-Brown Alfred R. 158, 159, 161, 390

Rajewska Ewa 15, 32, 191, 395

Rakoczy Marta 16, 390

Redliński Edward 276-280, 388, 390

Reiss Katharina 176

Rej Mikołaj 106

Richards Ivor Armstrong 16, 386

Ricoeur Paul 167, 311, 312, 390

Rilke Rainer Maria 200

Roberts Roda 326, 394, 396

Rosner Halina 19

Rossels Vladimir M. 108, 190

Rottenberg Anda 323

Rozanova Olga 118

Rozenzveig Victor 122, 168, 169, 390 
Rumsey Alan 159, 371

Rusinek Michał 9, 18, 19, 122, 175, 191, 246, 377, 379, 380-384, 387, 388, 390, 393, 396

Ruskin John 218

Ruszczycówna Janina 263, 380

Rychlik Czesław 333

Ryevzin Isaak 116, 122, 168, 390

Ryn Zdzisław 316

S

Salinger Jerome 108, 109, 377

Salska-Kaca Mirosława 263, 386

Samoylov David 117

Sandauer Artur 115, 192, 204, 240, 390

Sapir Edward 144, 157, 158, 390

Satanowski Jerzy 277, 283

Sawkiewicz Wanda 338

Schäffner Christina 301, 304, 390

Schlegel August Wilhelm 127, 130, 139, 142

Schleiermacher Friedrich 30, 169,174

Schneider Klaus P. 150, 379

Schröder Friedrich Ludwig 142

Schwab Gabriele 308, 318, 320, 323, 390

Schwerner Armand 343, 364, 365,391

Schwitters Kurt 349

Scott Clive 344, 347-349, 366, 367, 391

Sebald Winifried Georg 310, 312, 385

Segal Dimitri 112, 391

Seniuk Anna 277

Setkiewicz Piotr 342

Shakespeare William 25, 43, 109, $110,127,129,130,132,133,138$, $139,141,190,211,374,380,391$ Shelley Lore 329-331, 339, 391
Shusterovich R. 357

Shviyetzer, Alexander D. 305, 391

Shweder, Richard A. 153, 160, 391

Siedlecki Franciszek 14, 15, 17, 242, 386, 391

Siemaszkiewicz Eugenia 203, 377

Sienkiewicz Henryk 125

Sienkiewicz Joanna 277

Simbierowicz Zygmunt 167

Sito Jerzy S. 139-142, 190, 228, 229, 231, 234, 391

Skibicki Stanisław 331, 332

Skibińska Elżbieta 42

Skłodowski Józef 141

Skowron Egbert 332

Skwarczyńska Stefania 7, 10, 26, 27, $31,121,139,211,379,391,393$

Sławek Tadeusz 8, 10, 42, 43, 251, 391, 392

Sławińska Irena 139, 392

Sławiński Janusz 105, 193, 197, 206, 236, 237, 239, 242, 245, 265, 273, $373,378,388,389,392,398$

Słomczyński Maciej 246, 248, 346

Słowacki Juliusz 131, 383

Smirnoff Alexandr 17, 20, 392

Smith Robertson 261

Snell-Hornby Mary 301, 304, 392

Soliński Wojciech 33, 392

Sophocles 199

Sosa Michael 356, 395

Souriau Étienne 140, 392

Spiegelman Art 307, 317, 318, 373

Spitzer Leo 359, 360, 392

Sprusiński Michał 277, 392

Stachura Edward 277, 280-283, 373, 392

Staff Leopold 15, 21, 111, 117, 122, 398

Stahl Stephen Michael 322, 392

Steiner George 308 
Stepken Angelika 10, 346, 349, 350, 352, 353, 368, 386, 387, 393

Stern Anatol 204, 393

Stetnik Joseph 330

Steyn Dini 394

Stopa Roman 183

Störig Hans Joachim 169, 174

Stransky Karel 336

Strasburger Karol 266

Sweatt J. David 321, 393

Święch Jerzy 7, 10, 24, 31, 32, 191, 206, 393, 398

Szafiański Andrzej 267

Szapiro Jerzy 79, 373

Szaszkiewicz Maciej 316

Szegidewicz Jakub Jan

(Sehyd Jakub) 336

Szelburg-Zarembina Ewa 81

Szewc Piotr 323

Szleyenowa Zofia 81

Szmydtowa Zofia 128, 134, 393

Szpilman Władysław 323

Szulc Aleksander 180

Szuman Stefan 17, 18, 393

Szwajca Krzysztof 316, 388

Szymczak Mieczysław 27, 393

Szymczukiewicz Michal 326, 393

Szymusik Adam 316

T

Tabakowska Elżbieta 5, 8, 10, 27, 37-40, 287, 288, 291, 292, 296, $359,375,393,394,396$

Tacitus 100

Talmy Leonard 295, 394

Tarnawski Władysław 132, 133, 138, 141, 394

Tasso Torquato 130, 131, 379

Teutsch Anna 316

Thomas of Aquinas, St. 219

Thomas Roy 326, 394

Tippner Anja 301, 304, 394
Tolstoy Leo 105

Tomashevsky Boris 128, 129, 136, 394

Tomaszkiewicz Teresa 41, 389

Toporov Wladimir 215, 382

Toury Gideon 34, 206, 359, 394

Treger Bartosz 316

Tretiak Andrzej 133, 141

Tryuk Małgorzata 5, 8, 10, 45, 325, 326, 341, 394, 395

Trzynadlowski Jan 245, 263, 386, 392

Tsiv'yan Tatiana 112, 395

Tukumba Maggie 162, 377

Tulli Magdalena 312, 319, 323, 395

Turk Horst 301, 395

Turner Mark 37

Tuszyńska Agata 323

Tuwim Irena 298

Tuwim Julian 15, 69, 189, 194, 197, 212, 239, 241, 243, 245, 379, 395

Twardowski Kazimierz 89

Tynianov Yuri 26, 355, 356, 360, 364, 395

Tytler Alexander Fraser 74, 132, 395

U

Unger Thorsten 301,395

Urbańska Dorota 356, 390

Ushakov Dmitry N. 74, 395

Uyemov Avenìr İvanovič 170

Uyemova Yekaterina Andreevna 170

V

Valéry Paul 206, 395

Venuti Lawrence 308, 309, 373, 375, 395

Vinay Jean Paul 19, 117, 184, 185

Vinogradov Viktor 304, 395

Vivaldi Antonio 277, 283 
Volin B.M. 74

Voltaire 132

W

Wachtel Michael 356, 395

Wadensjö Cecilia 341, 395

Walsh Michael 151, 376

Wanner Adrian 356, 357, 395, 396

Watten Barrett 358, 396

Wawrzycka Jolanta 5, 104, 346, 396

Ważyk Adam 194, 196, 198-200, 203, 208, 209, 211, 396

Weiermair Peter 351, 385

Wende Waltraud 349, 396

Whorf Benjamin Lee 112, 113

Widdowson Henry G. 149, 382

Wiegand Chriss 326, 396

Wierzbicka Anna 5, 7, 10, 15, 21, $27,28,143-145,149,150,156$, $160,161,165,378,379,380$, 396, 397

Wierzewski Wojciech 268, 397

Wiesiołek Zdzisław 333

Wilk Alfred 340

Wilkins David P. 161, 380

Wirpsza Witold 194, 207, 397

Witczak Witold 263, 372

Witkiewicz Stanislaw Ignacy (Witkacy) 276

Witkowski Marek 374

Wojtasiewicz Olgierd A. 7, 11, 15, 19-21, 25, 37, 41, 73, 122, 170, $175,176,397$

Woźnicka Zofia 272, 397
Wujek Jakub 111

Wysłouch Seweryna 8, 11, 40, 263, 397

Wyspiański Stanisław 125

Y

Yallop Colin 151, 376

Yehuda Rachel 322, 397, 398

Z

Zadęcki Jerzy 316

Zagórska Aniela 211

Zagórska Maria 173

Zagórski Jerzy 189

Zagroba Bogdan 280, 398

Zając Kazimierz 332, 334

Zamenhof Ludwik 172

Zdebik Jan 333

Zegadłowicz Emil 248

Ziętarska Jadwiga 195, 398

Zimetbaum Mala 331

Zimmerer Katarzyna 316, 388

Ziomek Jerzy 7, 11, 21, 22, 29-31, $35,117,118,122,167,197,206$, $243,265,266,276,285,392,398$

Znamierowski Czesław 211, 398

Zurbrugg Nicholas 358, 398

Żentara Edward 277

Żentara Magdalena 277

Żeromski Stefan 13, 14, 46, 103, 125, 398

Żółkiewski Stefan 10, 14, 26, 211, 386, 391

Żółkoś Monika 317, 398 



\section{Cross-Roads \\ Studies in Culture, Literary Theory, and History}

Edited by Ryszard Nycz

Vol. 1 Małgorzata Budzowska: Phaedra - Ethics of Emotions in the Tragedies of Euripides, Seneca and Racine. Translated by Adriana Grzelak-Krzymianowska. 2012.

Vol. 2 Andrzej Zawadzki: Literature and Weak Thought. 2013.

Vol. 3 Maria Janion: Hero, Conspiracy, and Death: The Jewish Lectures. Translated by Alex Shannon. 2014.

Vol. 4 Grzegorz Grochowski / Ryszard Nycz (eds.): From Modern Theory to a Poetics of Experience. Polish Studies in Literary History and Theory. 2014.

Vol. 5 Anna Nasilowska (ed.): Wisława Szymborska's poetry. Choice of Essays. Translated by Karolina Krasuska and Jedrzej Burszta. 2015.

Vol. 6 Zdzisław Łapiński (ed.): "Miłosz Like the World". Poet in the Eyes of Polish Literary Critics. Translated by Grzegorz Czemiel. 2015.

Vol. 7 Włodzimierz Bolecki: $A$ World Apart by Gustaw Herling. Translated by Agnieszka Kołakowska. 2015.

Vol. 8 Jakub Momro: Literature of Consciousness. Samuel Beckett - Subject - Negativity. Translated by Jan Pytalski and Cain Elliott. 2015.

Vol. 9 Katarzyna Majbroda: Clifford Geertz's Interpretive Anthropology. Between Text, Experience and Theory. 2016.

Vol. 10 Michał Głowiński: Myths in Disguise. 2018.

Vol. 11 Mikołaj Golubiewski: The Persona of Czesław Miłosz. Authorial Poetics, Critical Debates, Reception Games. 2018.

Vol. 12 Adam Dziadek: Somatic Criticism Project. 2018.

Vol. 13 Piotr Sobolczyk: The Worldview, the Trope, and the Critic. Critical Discourses on Miron Białoszewski. 2018.

Vol. 14 Małgorzata Czerminska: The Autobiographical Triangle. Witness, Confession, Challenge. 2019.

Vol. 15 Krzysztof Trybuś: Romantic Memory. Studies from the Past and Present. 2019.

Vol. 16 Piotr de Bończa Bukowski / Magda Heydel (eds.): Polish Translation Studies in Action. Concepts - Methodologies - Applications. A Reader. 2019.

Vol. 17 Tamara Brzostowska-Tereszkiewicz / Magdalena Rembowska-Płuciennik / Beata Śniecikowska (eds.): Understanding Misunderstanding. Vol.1: Cross-Cultural Translation. 2019.

Vol. 18 Tamara Brzostowska-Tereszkiewicz / Magdalena Rembowska-Płuciennik / Beata Śniecikowska (eds.): Understanding Misunderstanding. Vol. 2: Artistic Practices. 2019.

Vol. 19 Wojciech Ligęza: World under Revision. The Poetry of Wisława Szymborska. 2019.

www.peterlang.com 
